UNIVERSIDADE DE SÃO PAULO

ESCOLA DE COMUNICAÇÕES E ARTES

EDSON PEREIRA DA COSTA JÚNIOR

\title{
A figura humana no cinema: matéria, desejo e comunidade
}


EDSON PEREIRA DA COSTA JÚNIOR

\title{
A figura humana no cinema: matéria, desejo e comunidade
}

\author{
Versão Corrigida \\ (Versão original disponível na Biblioteca da ECA/USP)
}

Tese apresentada à Escola de Comunicações e Artes da Universidade de São Paulo para obtenção do título de Doutor pelo Programa de Pós-Graduação em Meios e Processos Audiovisuais.

Área de concentração: História, Teoria e Crítica.

Orientador: Prof. Dr. Cristian da Silva Borges. 
Autorizo a reprodução e divulgação total ou parcial deste trabalho, por qualquer meio convencional ou eletrônico, para fins de estudo e pesquisa, desde que citada a fonte.

Catalogação na Publicação Serviço de Biblioteca e Documentação

Escola de Comunicações e Artes da Universidade de São Paulo Dados inseridos pelo(a) autor(a)

Costa Júnior, Edson Pereira da

A figura humana no cinema: matéria, desejo e comunidade / Edson Pereira da Costa Júnior. -- São Paulo: E. P. Costa Júnior, 2018.

297 p.: il.

Tese (Doutorado) - Programa de Pós-Graduação em Meios e Processos Audiovisuais - Escola de Comunicações e Artes / Universidade de São Paulo.

Orientador: Cristian da Silva Borges

Bibliografia

1. Figura humana 2. Cinema contemporâneo 3. Matéria 4.

Desejo 5. Comunidade I. Borges, Cristian da Silva II. Título.

CDD 21. ed. -791.43

Elaborado por Sarah Lorenzon Ferreira - CRB-8/6888 


\section{Folha de aprovação}

Edson Pereira da Costa Júnior

\section{A figura humana no cinema: matéria, desejo e comunidade}

Tese apresentada à Escola de Comunicações e Artes da Universidade de São Paulo para obtenção do título de Doutor pelo Programa de Pós-Graduação em Meios e Processos Audiovisuais.

Aprovado em:

Banca examinadora

Prof. Dr.

Instituição:

Assinatura

Prof. Dr.

Instituição:

Assinatura

Prof. Dr.

Instituição:

Assinatura

Prof. Dr.

Instituição:

Assinatura

Prof. Dr.

Instituição:

Assinatura 


\section{RESUMO}

O corpo no cinema está associado a uma ausência. A imagem apresenta um ser humano filmado em outro espaço, outro tempo. O contraste evidente é com o teatro, a dança e a performance, artes nas quais o espectador geralmente está diante de um corpo físico. Surge, então, um questionamento: seria possível, e em que termos, falar de uma materialidade da figura humana cinematográfica? A tese esboça uma resposta ao investigar os modos de presença do corpo, com ênfase em sua forma plástica, seu desejo e sua dimensão coletiva. $\mathrm{O}$ debate tem como eixo filmes de Philippe Grandrieux, Tsai Ming-liang, João Pedro Rodrigues, Claire Denis e Pedro Costa. A obra destes realizadores é discutida em cotejo com um heterogêneo repertório iconográfico, sobretudo fílmico e pictórico. A hipótese defendida é a de que a gênese, o significado e a pregnância da figura humana são dependentes de um tipo de circularidade manifesta na imagem cinematográfica, seja por sua natureza plástica, seja pela rede de interação entre corpos, seres inanimados e espaços.

Palavras-chave: Figura humana; cinema contemporâneo; matéria; desejo; comunidade. 


\begin{abstract}
The body in cinema refers to an absence. The image presents a human being filmed in another time, another place. The difference is remarkable in the face of theater, dance and performance, arts in which the spectator is usually in the presence of a physical body. The question that arises is: how it would be possible to speak of a materiality of the cinematographic human figure? In order to answer this question, the thesis investigates modes of body's presence, highlighting its plastic shape, desires and collective dimension. The debate is made from films of Philippe Grandrieux, Tsai Ming-liang, João Pedro Rodrigues, Claire Denis and Pedro Costa. The work of these directors is discussed in comparison with an iconographic repertory, especially film and pictorial. The hypothesis defended is that the genesis, meaning and impregnation of the human figure are dependent on a kind of circularity manifest in the cinematographic image by the plasticity or by the interaction between bodies, inanimate beings and spaces.
\end{abstract}

Key words: Human figure; contemporary cinema; matter; desire; community. 


\section{AGRADECIMENTOS}

À Fundação de Amparo à Pesquisa do Estado de São Paulo (Processo 2014/09365-4), em convênio com a CAPES, pelas bolsas de estudo, no Brasil e na França, que permitiram uma dedicação integral à pesquisa durante os quatro anos de doutorado.

Ao meu orientador, Cristian da Silva Borges, pelo diálogo, pelo suporte dado para a obtenção da bolsa e por respeitar os caminhos que escolhi para a tese.

Ao Philippe Dubois, pelo acolhimento na Université Sorbonne Nouvelle - Paris 3, pelas indicações de leitura e pelo entusiasmo com a pesquisa.

Ao Mateus Araújo Silva e à Sônia Salzstein, cujos generosos comentários e sugestões no exame de qualificação foram essenciais para redefinir os rumos da tese.

À Tainah Negreiros, pela fraternidade, pela leitura e pelas trocas.

Ao Vitor Zan e à Naara Fontinele, pela amizade e por gentilmente aceitarem ler uma parte do texto.

Aos queridos Patrícia Costa Vaz e Eduardo Affonso, pelo cuidado diário. Ao Leonardo Freire, pelos convites e almoços. À Rhaíssa Monteiro Pinto e ao Raul Parreira Maciel, pelas noites brancas. À Tatiana Monassa e aos demais companheiros da Association Braquage, Sébastien Ronceray, Francesca Veneziano e Miquel Escudero, pelo aprendizado e pela cinefilia. À Paula Nogueira Ramos, pelo incentivo e pelo afeto na reta final. Aos amigos Pedro Faissol, Andréa Scansani, Maria Inês Dieuzeide, Wiliam Pianco, Li-Chen Kuo, Isabella Bellinger, Bianca Mitteregger, Natália Vaz, Claudia Frosali, Luiz Carlos Oliveira Júnior, Maria Chiaretti, Calac Nogueira, Lívia Lima, João Vitor Leal, Alexandre Wahrhaftig, Filipe Brito, Luce Mignot, Ana Carolina Roman, Lucas Baptista, Izabel Melo, Christophe Lecarpentier e Vivian Bortolotti, pela ajuda, pelos encontros e pelas partilhas.

À Clarissa Poty, que acompanhou o início deste e de outros projetos.

Aos meus pais, Edson e Maria, e ao meu irmão, Anderson, pela confiança e pelo apoio incondicionais. 


\section{Sumário}

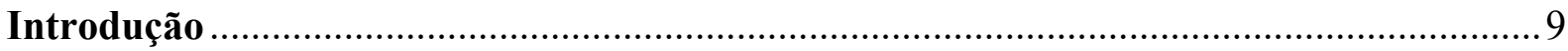

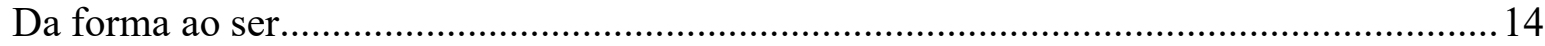

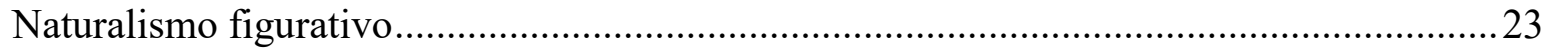

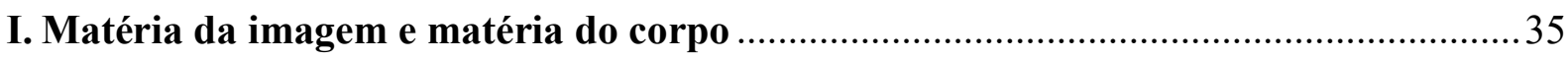

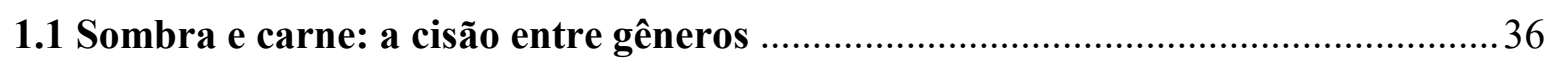

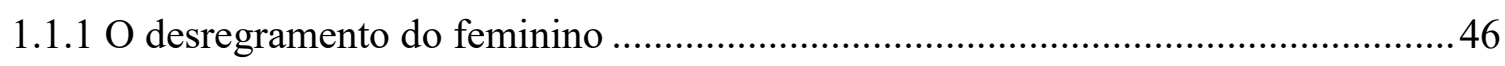

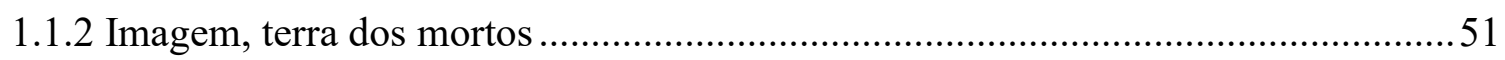

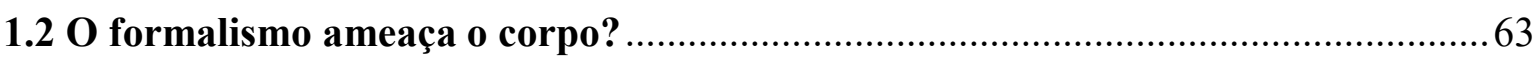

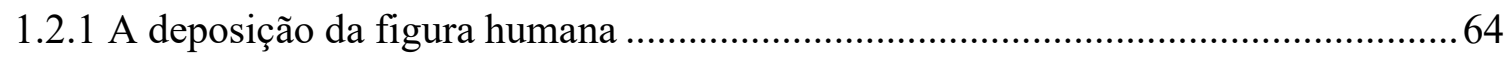

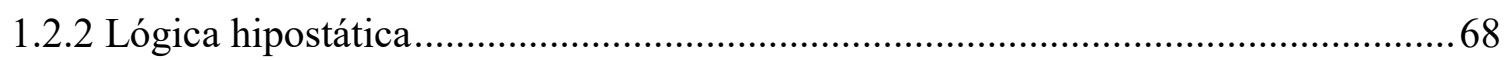

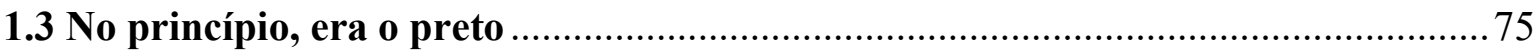

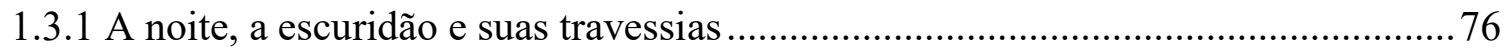

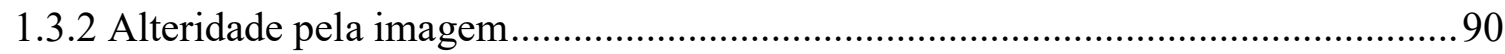

1.4 A presença em face dos limites da representação .................................................94

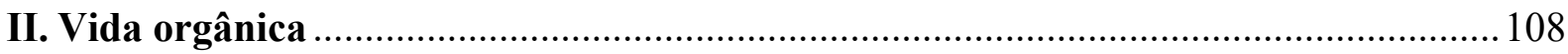

2.1 Estar sobre a terra: o homem que caminha ....................................................... 110

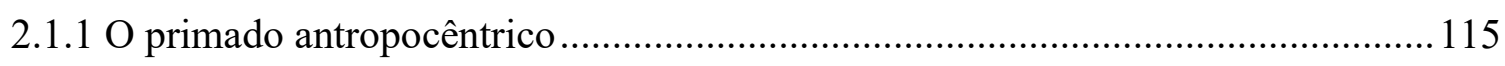

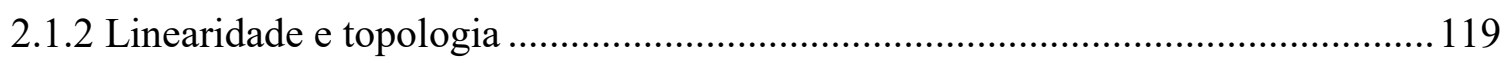

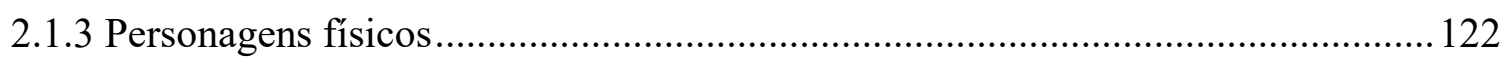

2.1.4 Performance: a política do ato reflexivo e processual ........................................ 128

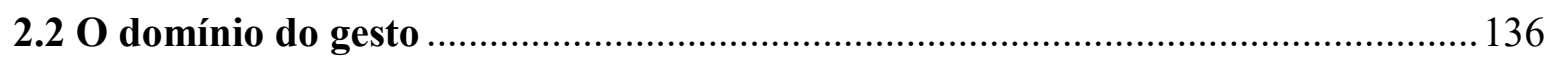

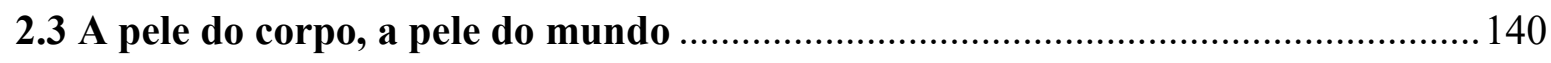

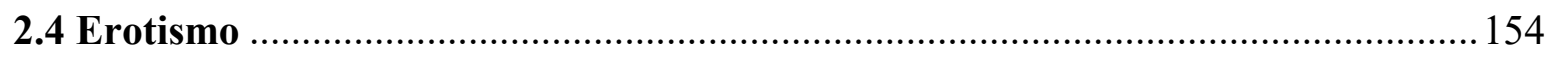

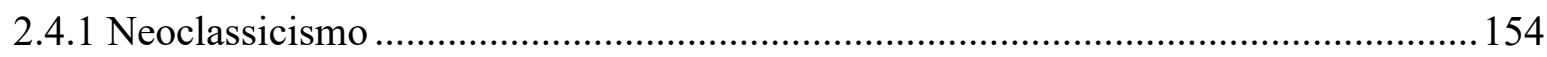

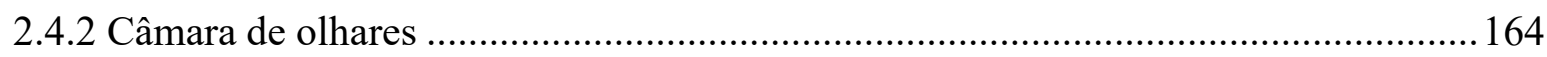

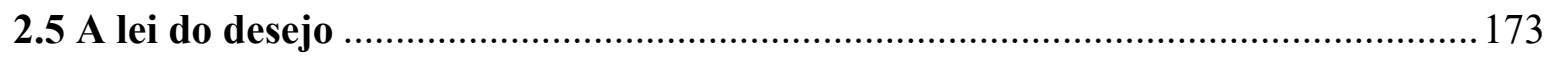

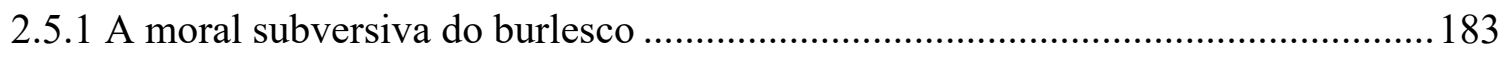

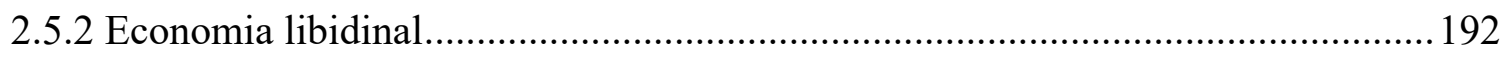




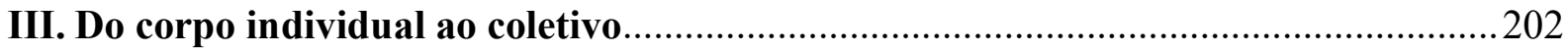

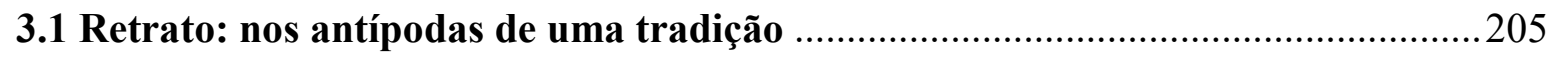

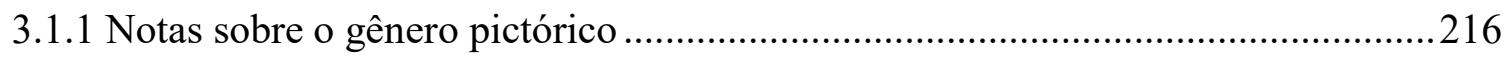

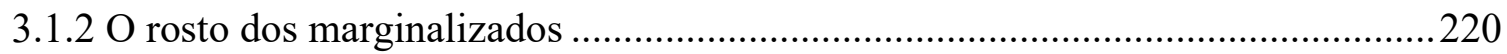

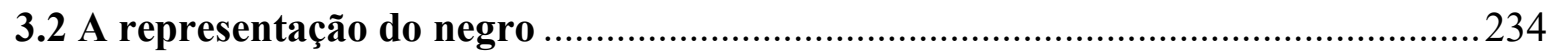

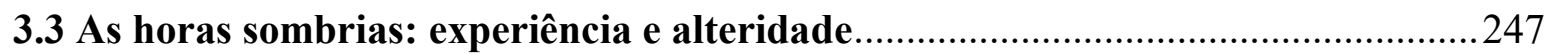

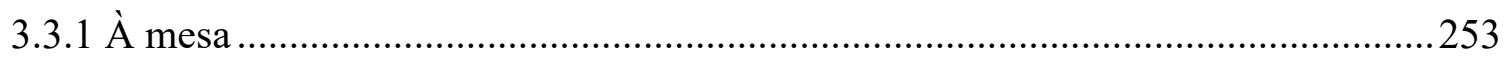

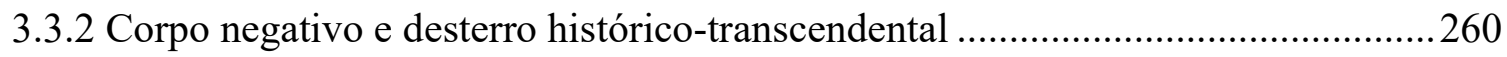

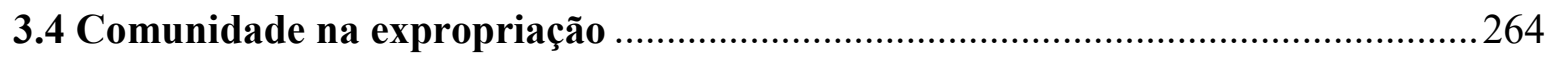

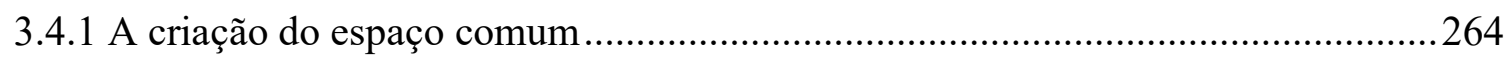

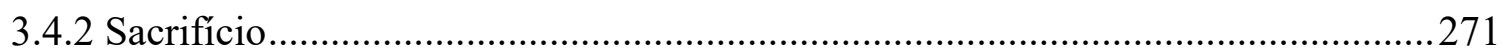

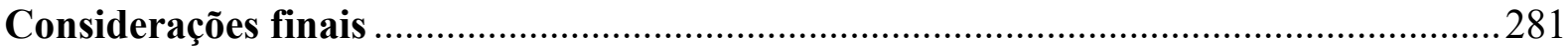

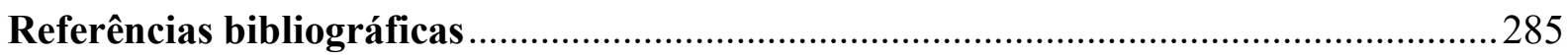





\section{Introdução}

Temas muito vastos são convidativos na mesma medida em que reservam hostilidades. Quem se dedica a investigá-los acredita guiá-los quando na verdade está a ser conduzido. Muitas vezes, percorre longas distâncias sem necessariamente avançar. Em um caso como em outro a prudência é valiosa e pode servir como ponto de apoio, mas nem sempre evita o pior: perder de vista a medida do problema que se deseja superar. Unidade sensível do ser humano no mundo, o corpo impõe ao seu intérprete essa forma de resistência. Sua associação a campos epistemológicos diversos expõe a malha difusa que o envolve. Tentar compreendê-lo é reconhecer a imensidão que o ultrapassa e ao mesmo tempo o define. ${ }^{1}$

O tema de nosso trabalho, a presença da figura humana no cinema, que trocando em miúdos podemos entender como os modos de constituir e notabilizar o corpo na imagem, situa-se sob um tal horizonte cuja vastidão é obstrutiva ao olhar. A razão não é difícil de compreender. O estudo do corpo no cinema se desenha de modo tentacular e tem uma tradição longeva, mesmo que não propriamente sistematizada. Dos anos 1920, com autores como Béla Balázs, até as diferentes perspectivas conceituais contemporâneas, o percurso é longo e permeado por descontinuidades. O fio que percorre uma extremidade a outra não é dos mais claros. A mudança do olhar acadêmico ou da crítica cinematográfica acompanha as transformações históricas do corpo, e a elas tenta responder.

Uma das muitas rupturas que separam as análises de Balázs de pontos de vista mais atuais pode ser encontrada entre as décadas de 1960 e 1970. Como se sabe, o período abrigou mutações políticas que evidenciaram a relação do corpo com as mais diferentes formas de poder. Assim, grupos sociais marginalizados reconheceram no corpo tanto o que porta

\footnotetext{
${ }^{1}$ Não é raro encontrar pesquisas, nos mais diferentes domínios do saber, que delineiem seus respectivos itinerários a partir das dificuldades surgidas na abordagem de enquadrar o corpo humano dentro de programas conceituais. Um exemplo é o de Judith Butler, que reconhece como determinadas bases filosóficas acabam por tornar o corpo uma abstração, dificultando o seu enraizamento no mundo concreto. Ver Judith Butler, Ces corps qui comptent: de la matérialité et des limites discursives du "sexe", Paris: Amsterdam, 2009. Em outros casos, há trabalhos que tentam traçar um método de abordagem, mas, tão logo iniciam a análise, o abandonam. Nos estudos de cinema, pensamos particularmente no caso de Nicole Brenez, cujo suposto método de análise da figura humana cinematográfica é prontamente esquecido durante suas análises fílmicas, pautadas nos mais diferentes critérios, alguns em contradição com o que havia delimitado previamente. Ver Nicole Brenez, De la figure en général et du corps en particulier: l'invention figurative au cinéma, Bruxelas: De Boeck Université, 1998.
} 
consigo as marcas de diferentes opressões como também a potência de suas lutas. ${ }^{2}$ No bojo do período, a revolução sexual impulsionou mudanças progressistas que vinham se esboçando no Ocidente desde o início do século XX. O recuo de normatizações culturais permitiu a libertação do desejo, o maior direito ao prazer (fora da moral conjugal) e a recusa de uma sexualidade sob pressão. ${ }^{3}$

O cinema feito a partir da década de 1960 e o seu modo de representar o corpo foram marcadamente influenciados por essas transformações, como se vê nos filmes de Chantal Akerman, Pier Paolo Pasolini, Andy Warhol, Rainer Werner Fassbinder, entre tantos outros realizadores. Somente alguns anos depois, os efeitos foram sentidos nas pesquisas acadêmicas. Hoje eles são patentes: atualmente, não é possível, ou certamente é mais difícil, discutir um procedimento cinematográfico, como o close, tal como Balázs fizera no início do século XX, orientando-se exclusivamente por um viés formal, desconsiderando a identidade do corpo em cena: mulher, homem, negro, branco, pardo, homossexual, heterossexual, e assim por diante. $\mathrm{O}$ avanço dos estudos de gênero, étnico-raciais, pós-coloniais, entre tantos outros matizaram a análise fílmica com um viés político.

Ao mesmo tempo que no cinema o corpo tem uma cor, um gênero, uma raça, uma condição histórico-social, ele continua a ser apresentado como uma forma plástica, conformado aos desígnios da imagem cinematográfica, aos postulados estéticos, e não somente éticos, dos realizadores. Em nossa tentativa de estudar a presença da figura humana cinematográfica, alimentamo-nos de ambos os campos aventados. Grosso modo, advindos de domínios inseparáveis, forma e conteúdo. Encontrar um equilíbrio em meio à miríade derivada desses dois polos não é dos exercícios mais simples. Nossa pesquisa certamente adquiriu um viés tendencioso. Ela muitas vezes opta por principiar na plasticidade do corpo, nas potencialidades estéticas da figura humana, para só então tentar compreender o que elas permitem restituir e compreender do mundo real. Se esse é o horizonte mais justo com os filmes analisados e com os debates por eles propostos, é um julgamento que nos escapa. Em todo caso, a tentativa foi a de manter a permanência de múltiplas perspectivas, ainda que admitindo uma desproporção. A posologia, o equilíbrio, dizíamos, não é dos mais fáceis. O campo é vasto. Contemplar nuances distintas tem o seu preço.

A seara que se abre a respeito do nosso tema se desenha como um emaranhado ainda mais intrincado quando se pensa que a figura humana cinematográfica, com a consciência ou

\footnotetext{
${ }^{2}$ Ver Jean-Jacques Courtine, Decifrar o corpo, Petrópolis: Vozes, 2013.

3 Ver Anne-Marie Sohn. "O corpo sexuado", in Alain Corbin; Jean-Jacques Courtine; Georges Vigarello (org.). História do corpo: 3. As mutações do olhar. O século XX, Petrópolis: Vozes, 2011.
} 
não dos realizadores, é constituída sob a herança da representação de corpos pertencentes a outras épocas, a outras artes. Falar isso não é remeter exclusivamente à afamada natureza impura do cinema, constituída pelo profícuo diálogo com outras tradições artísticas. ${ }^{4}$ Trata-se também de tentar reaver a espessura e desdobrar as múltiplas temporalidades da imagem cinematográfica a partir das correspondências com um repertório iconográfico evocado diretamente pelo artista, ou indiretamente recomposto pelo analista. Em outras palavras, o corpo representado num filme: onde já o vimos? Como os seus gestos e a sua representação dialogam com os de outros corpos no cinema, na pintura, na fotografias e em outras artes plásticas? Engana-se quem enxergar nisso a sombra do que se acredita ser um método warburgiano, ${ }^{5}$ ou um interesse puramente formal.

Ao longo da tese, a linha diretriz das comparações entre a representação do corpo no cinema e nas outras artes, sobretudo na pintura ocidental, é tentar transformar a analogia numa ferramenta que revela o significado e reconecta a figura humana com um campo epistemológico ou histórico. ${ }^{6} \mathrm{O}$ viés comparatista tenta apontar um sentido que, por outros meios, é velado ou mesmo inacessível. Trazer à luz as tramas subterrâneas que ligam duas imagens permite delinear um museu imaginário, fazer um mapeamento de aparições de motivos iconográficos e debates que, a despeito das diferentes condições histórico-sociais de seus contextos de produção, expõem coincidências e reincidências. Como não poderia deixar de ser, revelam também as dissonâncias. $\mathrm{O}$ recurso à analogia demarca as similaridades, mas também expõe as diferenças. Nesse sentido, nosso trabalho compreende a imagem plástica, seja de qual natureza for, como uma ferramenta hermenêutica, interpretativa.

A inclinação para um método comparatista traz seus benefícios, mas também tem suas desvantagens. Uma vez que a análise da figura humana em um determinado filme desvela feixes que a conectam a corpos representados em outras obras, é de se imaginar os efeitos para a estrutura da tese, sobretudo o de uma escrita que peca pela sua recorrente descontinuidade. Dado que as comparações são heterogêneas, provindas tanto do que os filmes evocam como de nossa cultura visual, é possível que nalguns momentos a tese venha a

\footnotetext{
${ }^{4}$ Ver André Bazin, "Por um mito do cinema impuro - defesa da adaptação", in $O$ que é o cinema?, São Paulo: Cosac Naify, 2014.

${ }^{5}$ Jorge Coli, entre outros historiadores da arte, posiciona-se contra uma tendência à conversão dos estudos de Warburg em teoria ou método analítico, posto que não havia sistematicidade e tampouco um princípio norteador fixo no modo com que o autor alemão estudava a continuidade e metamorfoses das formas em épocas e culturas diversas, a partir do famigerado Pathosformel. Ver Jorge Coli, O corpo da liberdade, São Paulo: Cosac Naify, 2010.

6 "Pois a analogia é precisamente apenas a faculdade de variar as imagens, combiná-las, fazer coexistir a parte de uma com a parte da outra e perceber, voluntariamente ou não, a ligação de suas estruturas". Paul Valéry, "Introdução ao método de Leonardo da Vinci", in João Alexandre Barbosa (org.), Variedades/Paul Valéry, São Paulo: Iluminuras, 2011, p. 145.
} 
ter a aparência de um dédalo, um labirinto. O leitor precisa ser paciente com esses desvios, ou pelo menos acreditar que eles não serão feitos à toa ou por capricho. Ao fim de cada descontinuidade, espera-se iluminar aspectos formais e conteudísticos das imagens e do filme que serviram de matriz. Para evitar a ruptura da estrutura, às vezes somos forçados a adotar uma prosa mais acadêmica, tentando insinuar ou mesmo expondo diretamente o movimento do pensamento. Assim, acreditamos minorar os desvios, arrefecer as descontinuidades e, finalmente, aclimatar o olhar do leitor.

A proposta de debater a presença da figura humana no cinema surgiu a partir de filmes das décadas de 1970 e 1980, especialmente da obra de John Cassavetes. O histrionismo, os improvisos atorais e a encenação aberta ao que era criado em cena nos causavam uma forte sensação de pregnância. No limite, falando em termos estritamente pessoais, tínhamos a impressão de compartilhar o mesmo espaço-tempo dos corpos representados, como se estivéssemos no teatro e não no cinema. Visto que a filmografia de Cassavetes já foi demasiado estudada pela crítica e pela pesquisa acadêmica, direcionamos o nosso olhar para filmes contemporâneos que, por outras vias, causavam-nos uma similar sensação a partir do relevo dado aos estados e afetos da figura humana como elementos condutores do drama. Ora, que tratamento conferido à representação dos corpos forjaria as condições necessárias para sua materialização na tela? Não estaríamos no domínio aporético ao tentar discutir a presença num meio que lida com a projeção de seres que existiram em outro espaço, outro tempo logo, uma arte das ausências? Qual seria o trabalho formal - de semelhança e dessemelhança, de transparência e opacidade - efetuado na passagem do corpo orgânico do mundo real ao ser cristalizado na imagem? Indo além: ao esculpir, estruturar ou figurar o modelo que a câmera tem diante de si, dotando-o de uma natureza visual, quais enunciados o cinema contemporâneo forja a respeito do corpo representado? Em outras palavras: o que os modos de presença permitiriam revelar sobre o significado dado à figura humana?

Guiado por estas questões, o corpus do trabalho se concentra em obras do final da década de 1990 e início dos anos 2000, realizadas por: Philippe Grandrieux, Tsai Ming-liang, João Pedro Rodrigues, Claire Denis e Pedro Costa. Constituindo o nervo axial da tese, seus filmes, pelo teor comparatista já mencionado, remetem-nos a obras de realizadores como Georges Méliès, Charlie Chaplin, Buster Keaton, John Ford, Jean Epstein, Georges Franju, Jacques Tati, Carolee Schneemann, Jorge Sanjinés, Peter Watkins, Jonathan Glazer, Larry Clark, Affonso Uchoa, Wang Bing, entre outros. ${ }^{7}$ No campo da pintura, debatemos os filmes

\footnotetext{
${ }^{7}$ Da constelação que se forma, é pouca a presença do cinema brasileiro, restrita a uma breve análise de um filme de Affonso Uchoa. A ausência não decorre de uma falta de inventividade ou de interesse da produção nacional
} 
em comparação com quadros de artistas como Michelangelo da Caravaggio, Diego Velázquez, Pablo Picasso, Paul Cézanne e Lucian Freud.

Atualmente, há um número considerável de pesquisas debruçadas sobre as particularidades da figura humana nos realizadores que compõem nosso corpus principal, analisando-as, em especial, pelo viés das sensações. São estudos que, como quaisquer outros, estão sujeitos a problemas. Identificamos pelos menos dois, que esperamos contornar com a nossa tese. O primeiro é uma análise fílmica orientada e no pior dos casos normatizada por teorias prévias, especialmente por Gilles Deleuze. ${ }^{8}$ Nesses casos, há pouco espaço para o que as imagens e os sons revelam por si mesmos. O segundo é a recorrência de abordagens estruturadas dentro de um bloco único, que, sob o pretexto de reunir os filmes sob um monismo conceitual, perde as singularidades de cada obra.

Frente às duas vias, nossa tese tenta responder com uma proposta de análise imanente, ancorando-se na descrição do que está visível na imagem para somente então tentar pensá-las em cotejo, e não sob a tutela, de uma teoria. Nas vezes em que recorremos a um repertório teórico, a tentativa foi a de evitar seguir um autor como quem se enclausura numa igreja. A transversalidade das referências que subsidiam o trabalho tentou respeitar tanto as exigências dos objetos como também se esquivar das limitações de um epigonismo intelectual - o que não eliminou as afinidades com determinados autores. Essa mesma transversalidade serviu de alternativa para o que mencionamos como um monismo conceitual. Recorrendo a debates diversos para entender a presença do corpo no cinema contemporâneo buscamos respeitar as

pela representação do corpo. O contrário talvez seja mais verdadeiro. Pensemos em alguns casos. O escracho da nudez nas pornochanchadas na década 1970. A insubmissão da figura feminina em seu total deboche diante do que tenta constrangê-la no Cinema Marginal, como as personagens de Helena Ignez nos filmes de Rogério Sganzerla. Corpos cujas deambulações se transformam em princípio motriz e existencial na obra de Ozualdo Candeias. A figura humana dentro de um quadro social e histórico, seja como camponês (pré-1964), seja como burguês industrial (pós golpe militar), numa extensa lista de filmes do Cinema Novo. O cinema contemporâneo e a desordem causada pelo desejo sexual em Nova Dubai (2014), de Gustavo Vinagre, ou o universo queer em Doce Amianto (2013), de Guto Parente e Uirá dos Reis. Alinhavando uma parte desses temas e desbravando outros numa chave muito singular, o cinema da última década de Júlio Bressane. É um mapa incompleto, imaginário e apenas ilustrativo das possibilidades que uma análise dos modos de presença da figura humana cinematográfica poderia encontrar no cinema nacional. $\mathrm{O}$ recorte por uma produção internacional foi menos um desinteresse ou um não reconhecimento da produção brasileira do que uma maior dificuldade em lidar com esta última dado o nosso restrito repertório para discuti-la quando do início do doutorado. À época de definição do corpus, filmes estrangeiros nos pareceram mais operatórios para discutir os diálogo entre cinema e pintura na figuração do corpo - debate que estava no centro de interesse da tese. No mais, consideradas as particularidades históricas e sociais que envolvem diretamente o cinema brasileiro, talvez fosse difícil trazê-lo para o debate que empreendemos sem ser direcionado para questões ainda mais amplas que a da presença do corpo. Nada disso, contudo, impede um estudo futuro.

${ }^{8}$ Entre os exemplos de uma estrita filiação ao aporte deleuziano, podemos citar os textos "La forme et l'informe : de la dissolution du corps à l'écran", de Martine Beugnet, e "Images-sans-Organes / Récit-sans-Télos: Carlos Reygadas et Gus van Sant", de Jérôme Game, ambos publicados em: Jérôme Game (org.), Images des corps/corps des images au cinéma, Lyon: Ens Éditions, 2010. 
singularidades dos diferentes filmes analisados, embora tentando manter uma coesão dentro do nosso tema.

Antes de apresentarmos a estrutura dos capítulos, esta Introdução continua por mais dois tópicos, talvez os mais áridos e morosos do trabalho. "Da forma ao ser" explica a nossa predileção pela expressão figura humana ao invés de corpo. A partir de uma visada sobre a história semântica de figura, tentamos entender também os desdobramentos do termo nos estudos cinematográficos. "Naturalismo figurativo" tece uma linha imaginária em que remontamos uma pequena história da figuração do corpo na pintura e no cinema ocidentais, tendo em vista a tentativa de intensificar sua materialidade a partir dos graus de analogia com o corpo real. Vistas as dificuldades em seguir com modelo similar, lançamos a questão: como falar da presença da figura humana no cinema sem recorrer à noção de verossimilhança?

\section{Da forma ao ser}

Figura, corpo, homem. Em geral, no campo das artes, essas palavras são utilizadas com sentidos próximos, senão similares. Um debate sobre os modos de presença da figura humana no cinema contemporâneo, contudo, muito ganharia com uma maior clareza sobre cada termo, em especial porque o primeiro remete a um conceito com trajetória semântica longa, heterogênea e singular na cultura ocidental. Nas próximas páginas tentaremos um breve exercício de diferenciação pautado no mapeamento dos vários sentidos de figura. Ao seu fim, será delineada uma fronteira diante de corpo e homem.

Quem orienta o expediente proposto é o filólogo alemão Erich Auerbach, autor de um ensaio que recompõe a história das aparições e dos significados da noção de figura, desde textos da Antiguidade latina até a Idade Média. ${ }^{9}$ De raiz comum com fingere, figulus, fictor e effigies, o termo foi inicialmente utilizado no latim para designar forma plástica, o aspecto de algo enformado a partir de determinado molde. Correspondia em certa medida ao que os gregos denominavam por skēmə, palavra utilizada no vocabulário filosófico e retórico para o modelo puramente perceptivo, diferentemente de morphē e eidos, relativos à forma ou à ideia que enforma a matéria. Como se vê, existe aí uma distinção, que Auerbach sinaliza: "Em termos estritos, forma significa 'molde' - no francês 'moule' - e estava ligada à figura como a forma vazia ao modelo plástico que sai dela". ${ }^{10}$ Temos, então: de um lado, o que plasma, do

\footnotetext{
${ }^{9}$ Citaremos sempre a mesma obra: Erich Auerbach, Figuras, São Paulo: Editora Ática, 1997. Ao longo das páginas seguintes, as observações sobre o autor foram subsidiadas por Modesto Carone, "Um roteiro do conceito de figura", Ibid.

${ }^{10}$ Ibid., p. 15.
} 
outro, o resultante deste processo. Com a helenização da cultura romana no último século antes de Cristo, o autor alerta para a expansão do significado original de figura, quando é apagada a linha divisória que antes existia diante de forma. A partir de então, os dois termos não cessam de trocar suas posições ao longo da história.

Auerbach elenca uma série de autores que contribuíram para matizar o sentido de figura. Nome central neste quadro é o do poeta e filósofo latino Lucrécio, cujos textos expõem a tensão existente na transição da forma original para sua imitação, do modelo para a cópia. A figura, que remete ao que foi produzido a partir de uma fonte, torna-se variante de "cópia" e também de simulacra, imaginas, effigies. Em decorrência disso, recebe, pela primeira vez, o sentido de visão de sonho, fantasma e ficção. Lucrécio ainda emprega a palavra para falar das "estruturas que se desgarram das coisas como películas (membranas) e flutuam no ar", ${ }^{11}$ ou seja, como eidola, espíritos, simulacros dotados de natureza fantasmagórica.

Ecos do sentido proposto por Lucrécio ressoam em poetas futuros, como Ovídio, para quem figura tem o sentido de uma forma mutável, de uma cópia marcada pela condição móvel, multiforme e ilusória, reforçando a noção de algo cuja semelhança é enganosa. Há aí a desconfiança diante da aparência, da duplicidade, de algo que se aproxima mais do material que habita os sonhos que do próprio real.

Se a variante criada por Lucrécio segue um caminho próprio nos séculos vindouros, incluindo aí seus registros no campo da literatura e da Estética, um outro uso dado pelo poeta teria cessado. Trata-se da tradução de figurae por "átomos". Em correspondência com a cosmogonia de Demócrito e Epicuro, Lucrécio considera que os átomos, cuja agremiação, movimento e propriedades fariam nascer as coisas do mundo, seriam materiais com formatos infinitamente diversos, sendo por isso frequentemente denominados de formas e figurae (figuras). "Os numerosos átomos estão em movimento constante; movem-se no vazio, combinam-se e repelem uns aos outros: uma dança de figuras". ${ }^{12}$ Está contida nesta acepção a ideia de aspecto movente e de variação infinita comumente associadas a figura. ${ }^{13}$

\footnotetext{
${ }^{11}$ Ibid., p. 17.

12 Ibid., p. 18.

${ }^{13}$ Sobre este aspecto, ver: Philippe Dubois, "La question des Figures à travers les champs du savoir: Le savoir de la lexicologie: note sur Figura d'Erich Auerbach", in François Aubral; Dominique Chateau (org.), Figure, figural, Paris: L'Harmattan, 1999, pp. 11-24. Conforme Dubois, a ideia de movimento rivaliza e ao mesmo tempo complementa aquela de fixação, também utilizada para figura quando se trata da fixação presente na ordem da arte (estátua, retrato, efígie) ou na ordem da linguagem (a organização de um sistema instituído por figuras matemáticas, retóricas, entre outras). Movimento e fixação compõem um dos quatro eixos dialéticos esboçados pelos autor a partir dos usos semânticos de figura. Os outros três são: índice e ícone; invenção e codificação; artifício e verdade.
} 
Interessa-nos, por fim, uma última aparição de figura, oriunda de Tertualiano, na Idade Média, e referente à relação estabelecida entre duas realidades, uma sendo a prefiguração da outra. $\mathrm{O}$ alicerce é a ideia de que a primeira, a figura, seria uma espécie de sombra ou imagem (umbra ou imago) que precisaria de um preenchimento fornecido pela segunda e designado de veritas (verdade), através do qual alcançaria sua realização plena. ${ }^{14}$

Como se vê, a última acepção de figura em muito lembra o princípio no qual Jean Douchet, entre outros autores, baseia-se para sublinhar a natureza espectral da imagem cinematográfica. ${ }^{15} \mathrm{Em}$ ambos os casos, encontra-se em primeiro plano a tensão existente entre a imagem, tomada como uma forma que copia outra e, por isso, precisa ser preenchida, passando por um tipo de encarnação para recobrar seu devido valor e deixar o limbo dos eflúvios.

Grosso modo, o cinema narrativo clássico soluciona o problema do invólucro vazio da imagem corporal a partir da dramatis personae/personagem, noção cujo papel é justamente o de atribuir uma camada imaginária que irá encarnar a figura, dar-lhe verossimilhança por meio de natureza psicológica e de comportamentos com significação dentro do universo ficcional. Algumas obras dificilmente permitem similar preenchimento. É o caso de parte considerável dos filmes contemporâneos analisados na tese. À primeira vista, neles a figura humana foi esvaziada de um sentido evidente, numa inversão do paradigma clássiconarrativo: se neste último a natureza dramática favorecia a encarnação da figura pelo personagem, no contemporâneo existe uma subtração, um processo que parece ser o de um esvaziamento da imagem do corpo. O papel dentro de uma trama - quando esta existe - não é claro, a causa de suas ações é imprecisa e sua natureza se ergue numa zona de opacidade. Será necessário encontrar o substrato e o significado da figura humana em um campo externo ou paralelo, ainda que por vezes complementar, ao do drama.

A figura enquanto ser que carece de encarnação remete não precisamente ao sentido, mas à dinâmica do termo tal como designado por Tertuliano. Esta compreensão, junto com os demais significados aqui ligeiramente apresentados com base nos ensaios de Auebarch,

\footnotetext{
${ }^{14}$ Esta noção foi utilizada para um tipo de interpretação segundo a qual pessoas ou acontecimentos do Velho Testamento eram profecias do Novo Testamento. Assim, por exemplo, Moisés seria uma figura de Cristo, dado que suas ações e a estrutura dos acontecimentos em que é apresentado profetizariam aspectos da vida de Cristo. Ainda sobre esta acepção de figura, Auerbach faz uma ressalva importante: "tanto sombra quanto verdade são abstratas apenas em referência ao significado, a princípio ocultado para ser revelado em seguida; são concretas em referência às coisas ou pessoas que aparecem como veículos do significado. Moisés não se torna menos histórico e real porque é umbra ou figura de Cristo; e Cristo, o preenchimento, não é uma ideia abstrata, mas uma realidade histórica." Erich Auerbach, Op.cit., p. 31.

15 Jean Douchet, "L'ombre portée de la réalité", in Jacques Aumont (org.), L'invention de la figure humaine, Paris: Cinémathèque française, 1995, pp. 247-258. Voltaremos a esse debate no Capítulo 1, ao lidar com o cinema de Philippe Grandrieux.
} 
orienta a escolha pela expressão figura humana. Seu emprego designará tanto o sentido de forma plástica, remetendo à própria aparência sensível, visual, que se faz do corpo ao longo de um filme, como também ao processo de enformar uma matéria determinada, aos elementos que compõem a feitura daquela imagem. Mais do que uma mera cópia ou imitação do ser real, expõem-se as dimensões de invenção formal e significação daí decorrentes.

Ao longo da tese, figura corresponde ainda às propriedades moventes e fluidas que Lucrécio lhe concedeu. Ecos dessa definição serão sentidos principalmente no Capítulo 1, diante de alguns filmes que investem sobre a hipertrofia da imagem. O trabalho sobre a epiderme da película, sobre cada átimo, corpúsculo e mínimas figuras (mesmo que não figurativas) nelas presente, permite compor e decompor o corpo a partir das variações de movimento, luz, sombra e de outros componentes visuais. Nos capítulos posteriores, a proximidade com um regime "realista" aproxima corpo e figura, de maneira que os termos serão usados quase como sinônimos - salvo quando for sinalizado no próprio texto.

A fórmula figura humana responde a uma vontade de compreender o ator, ou pelo menos o seu corpo, como matéria visual modulável, mais do que propriamente se dirigir à análise dos modos de interpretação. A história e a teoria do cinema apresentam tentativas próximas sob outras designações. O formalista russo Boris Kazanski, por exemplo, propunha ao cinema reabilitar a noção de modelo tal qual na pintura. O objetivo era pensar o ator submetido às exigências do diretor. Kazanski considerava que o essencial do intérprete era simplesmente a "pose", a faculdade de assumir uma ou outra posição, de executar um movimento pedido, similar a um modelo. ${ }^{16}$ Dentro de sua própria poética, o realizador francês Robert Bresson também recorreu ao mesmo termo. Como lembra Aumont, o sentido que Bresson deu à palavra, referia-se $\mathrm{a}$ :

[...] Uma convenção de linguagem estabelecida, aquela da pintura de cavalete, especialmente a do retrato, pela qual o modelo é um corpo real (humano ou não, animal ou não) que se encontra realmente diante do olho do pintor, e cuja obra propõe figurar. [...] O modelo bressoniano não é um ator, não tanto porque ele não "interpreta" ou interpreta "mal", mas porque seu papel não é construir um personagem. O modelo deve se esforçar ao contrário pela não construção, pela ausência de construção, ele deve a cada instante visar permanecer na ausência do visado, na brancura expressiva, na disponibilidade, não deve ser nada além de imagem ou melhor, fonte de imagem: ele deve deixar emanar de si, sem o saber e sobretudo sem querer sabê-lo, as potências que o cineasta detectou e que se encarregará de captar e figurar (isto quer dizer, precisamente, de produzir pela montagem: a manipulação, como se vê, não está ausente). ${ }^{17}$

\footnotetext{
${ }^{16}$ Citado em: Jacqueline Nacache, $O$ ator de cinema, Lisboa: Texto e grafia, 2012.

${ }^{17}$ Jacques Aumont, De l'esthétique au présent, Bruxelas: De Boeck, 1998b, p. 26.
} 
Para além da noção de modelo, nosso diálogo maior é com autores que também retomaram o vocábulo figura. Aproximando-se e às vezes se distanciando dos sentidos que entram em cena na história semântica traçada por Auerbach, o termo fez suas incursões nos estudos de cinema, especialmente na França. Possivelmente os casos mais significativos ou pelo menos mais conhecidos sejam os de Jacques Aumont, ${ }^{18}$ Philippe Dubois, ${ }^{19}$ Nicole Brenez ${ }^{20}$ e Luc Vancheri. ${ }^{21}$ São autores que recorreram ao já amplo repertório da palavra e, seguindo a tendência diagnosticada por Auerbach, expandiram-no mais uma vez. Também visitaram a noção cunhada por Jean-François Lyotard de figural, ${ }^{22}$ seja para incorporá-la com mudanças (como fazem Dubois, Brenez e Vancheri), seja para efetuar ressalvas críticas (como Aumont). Fora da França, Adrian Martin também se detém sobre o termo lyotardiano. ${ }^{23}$

O uso de figura e figural no cinema recebe um verniz próprio de acordo com quem o emprega. Reconhecendo isso, limitar-nos-emos a uma brevíssima menção às zonas de contato entre as discussões daquele autores e o uso que realizaremos da expressão figura humana. Quanto ao figural, trata-se de um conceito que a princípio assumia uma posição ínfima no projeto de pesquisa. $\mathrm{Na}$ tese, acabou por desaparecer. A ele ficará reservado, neste momento, um comentário sobre sua natureza e um recuo diante de seu uso.

Comecemos por Aumont e Brenez. ${ }^{24}$ Salvo a menção incontornável a Auerbach, os autores recorrem a repertórios teóricos distintos em seus estudos sobre a figura. Chegam, porém, a uma proposição similar. Retomam o termo para demarcar suas respectivas defesas da imagem cinematográfica enquanto meio capaz de refletir sobre o mundo independentemente da narrativa, da história contada pelo filme ou mesmo da articulação com um repertório exterior (cultural, histórico, ideológico etc.). Ao compreendê-la como figura, Aumont e Brenez explicitam a existência de um trabalho formal, de uma manipulação material e plástica que dota a imagem de um poder de simbolização capaz de traduzir um pensamento. A dimensão de feitura, tácita na pintura e em outras artes plásticas, parece ter de

\footnotetext{
${ }^{18}$ Aumont, A quoi pensent les films?, Paris: Nouvelles Éditions Séguier, 1996; Aumont, 1998a.

${ }^{19}$ Philippe Dubois, in François Aubral, Dominique Chateau (org.), Op.cit.; Dubois, "La tempête et la matièretemps, ou le sublime et le figural dans l'œuvre de Jean Epstein", in Jacques Aumont (org.), Jean Epstein, Paris: Éditions de la Cinémathèque Française, 1998, pp. 267-324.

${ }^{20}$ Op.cit.

${ }^{21}$ Luc Vancheri, Les pensées figurales de l'image, Paris: Armand Colin, 2011.

22 Jean-François Lyotard, Discours, figure, Paris: Klincksieck, 1985. O neologismo surge pela primeira vez em Merleau-Ponty, de acordo com: François Aubral, "Variations figurales", in Fraçois Aubral, Dominique Chateau, Op.cit., pp.197-244.

${ }^{23}$ Cf. Adrian Martin, Last day every day, Nova York: Punctum Books, 2012.

${ }^{24}$ Jacques Aumont, 1996; Nicole Brenez, 1998.
} 
ser lembrada no cinema a fim de se afastar o fantasma do automatismo técnico e, por conseguinte, do entendimento da imagem como uma duplicação ou cópia do referente real.

Nos termos expostos, Aumont defende a atenção a ser dedicada pela análise fílmica aos problemas criados pelas e nas imagens. De modo talvez demasiado sucinto para o escopo do problema a que se dirige, o autor empreende um debate cuja fórmula motriz e final é "a imagem pensa". ${ }^{25}$ Dito de outro modo, a imagem é capaz de apresentar processos mentais que, sem ela, não teriam forma, de manifestar fenômenos de natureza invisíveis, de transportar elementos de simbolização ou já simbolizados, não sem antes rearranjá-los, transformando-os. A força que autorizaria e a imbuiria dessas propriedades, por meio das quais inventa um sentido, seria justamente a força da figura.

Deixaremos para os mais versados julgar a validade ou a improcedência do percurso estabelecido por Aumont. O que dele conseguimos aproveitar diretamente é a observação a respeito da possibilidade de uma análise das figuras que, em lugar de se ater ao todo de um filme, visando o trabalho narrativo e representativo que se constrói em sua duração integral, atém-se aos detalhes perceptíveis em "cada objeto, cada região da imagem, cada momento de seu fluxo". ${ }^{26} \mathrm{O}$ objeto da proposta são os motivos, ${ }^{27}$ as mínimas frações analíticas que se repetem ou variam numa obra. São elementos estruturais que podem tanto colaborar para o tema do filme como para a organização de um pensamento que é erigido pela imagem. Ao longo da tese, o foco paira então por certas passagens específicas dos filmes, de cenas ou mesmo de planos.

Em diálogo não anunciado, mas identificável com Aumont, Brenez defende um tipo de análise fílmica - ora chamada de estética, ora de figurativa, ora de figural - cujo objetivo é o de considerar as imagens como atos críticos, desdobrando delas suas próprias forças, atentando para as questões que colocam. Segundo a autora, o método é tributário daquele que o historiador de arte Hubert Damisch teria traçado para a pintura. A proposta consiste em pensar a imagem "na relação de conhecimento e não de expressão, de analogia e não de desdobramento, de trabalho e não de substituição - que mantém com o real". ${ }^{28} \mathrm{O}$ cinema, como a pintura, não refletiria as coisas segundo os acordos visuais que a visão humana mantém com o real, pois a figuração realiza um movimento de deslocamento no interior de um filme entre os seus elementos plásticos e as categorias da experiência comum. Como

\footnotetext{
${ }^{25}$ Aumont, 1996, p. 50.

${ }^{26}$ Ibid., p. 163.

${ }^{27} \mathrm{Ibid}$. Segundo o autor, os motivos são entendidos no sentido próximo ao que se usa na música, em que designam a menor unidade melódico-rítmica.

${ }^{28}$ Hubert Damisch citado por Nicole Brenez, Op.cit., p. 11.
} 
exemplo, Brenez fala do modo de representar o corpo humano, em que a silhueta, os personagens, a efígie, o corpo, a figura e o fundo, colocam-se em circulação nos filmes. Se no real existe uma equivalência entre corpo, indivíduo e pessoa, o cinema burla esta lógica: a silhueta pode não fornecer um corpo, uma figura pode se distribuir em vários personagens, um personagem pode existir sem pessoa, um corpo, sem suporte, e assim por diante.

Para Brenez, de maneira próxima a Aumont e aos usos discutidos por Auerbach, a figura opera o movimento de uma coisa (o referente real) em direção a outra (sua forma plástica). $\mathrm{O}$ resultado do deslocamento é um trabalho de semelhança ou dessemelhança. No segundo caso, em vez de uma relação de similitude, de mise en accord, a figura gera uma quebra, uma ruptura, impedindo a relação de conformidade, arruinando os laços que aproximariam o original e a cópia.

A concepção de dessemelhança, segundo a qual a figura pode perder seus contornos, dissociar-se completamente do caráter representativo/figurativo para engendrar formas nem sempre claras, revogando a subordinação a um regime de legibilidade e inteligibilidade, está na base do que Lyotard denominou "figural". Situando sua reflexão inicialmente na fenomenologia, da qual posteriormente se distancia, e fincando raízes definitivas nos processos do inconsciente freudiano, em especial no trabalho do sonho (Traumarbeit), Lyotard localiza seu pensamento numa tradição de desconstrução do logocentrismo. Recorrendo às pinturas de Picasso, Cézanne, Klee e à poesia de Mallarmé, entre outros artistas, o autor toma partido de obras capazes de ultrapassar o discurso da significação, de uma ordem imposta pela linguagem verbal pautada no sentido. ${ }^{29}$

Como a entonação expressiva da voz na ópera pode primar sobre o discurso, como a linha de uma pintura dispõe de energia plástica além da significação articulada, Lyotard encontra no figural o momento em que a forma não se deixa conter por sua evidência ou previsibilidade, quando é submetida a um tipo de desfiguração (no original freudiano: Entstellung). Violenta-se a linguagem (seja verbal, seja plástica) para propor uma potência sensível. O autor encontra essa mesma operação no trabalho do sonho freudiano. Pelas operações de condensação, deslocamento, figurabilidade e elaboração secundária, os sonhos criam imagens compósitas, incompletas, fragmentárias e, sobretudo, distorcidas. À frente deste trabalho, está a censura. Por trás dele, como impulso a ser combatido, velado ou suprimido, o desejo. ${ }^{30}$

\footnotetext{
${ }^{29}$ Jean-François Lyotard, Op.cit.

${ }^{30}$ Ibid.; Cf. Sigmund Freud, A interpretação dos sonhos, Rio de Janeiro: Imago Ed., 2001.
} 
A reflexão que Lyotard empreende ao longo das quase 400 páginas de seu livro alça um voo bem mais alto do que o nosso resumo sugere. Sua influência também vai além dos nomes já citados na teoria do cinema, alcançando historiadores e teóricos do campo das artes visuais cuja base epistemológica tangencia o figural e os processos do inconsciente. ${ }^{31}$ Feitas as ressalvas, faremos uma última menção ao figural. O conceito não será retomado ao longo da tese, mas parece-nos justo explicitar pelo menos uma das formas com que foi incorporado aos estudos de cinema. Seguiremos para isso a análise que Dubois faz do curta Le Tempestaire (1947), do realizador e poeta francês Jean Epstein.

Uma das cenas do filme mostra a noite que cai sobre a Belle-Île-Mer. A ventania ruidosa varre furiosamente os lugares, as ondas do mar se agitam, as nuvens se deslocam no céu e, finalmente, a tempestade estoura. A situação somente se apazigua quando o "tempesteiro", uma espécie de bruxo da ilha que parece deter poderes mágicos sobre o clima inclemente, toma em mãos sua bola de cristal, onde se vê a tempestade. Ele assopra o objeto, produzindo outro vento, outra força que se choca com a do temporal e o faz arrefecer até acabar completamente. Ao fim da colisão entre natureza e homem, a bola de cristal cai das mãos do velho e se despedaça no chão. Na análise da cena, Dubois atenta para os efeitos de velocidade (o progressivo ralentar da película, a aceleração e a reversão temporal) desencadeados a partir da colisão entre as forças contrárias. No momento em que o mar, o vento e os demais elementos da tempestade, sob o efeito do "sopro" do bruxo, ralentam quase até a imobilidade, haveria para o autor um tensão acumulada (talvez a responsável por explodir a bola de cristal) que responderia pelo figural. ${ }^{32}$

O conceito é empregado para designar o princípio que "faz a ligação das formas aparentemente heterogêneas, mas que pertencem às mesmas redes subterrâneas do visual, revelando as profundas relações constitutivas deste inconsciente do visível". ${ }^{33}$ Em outras palavras, a noção é interpretada em relação à excitação de movimentos e à turbulência que provoca a metamorfose das matérias, decompondo fisicamente os elementos de uma imagem para depois recompô-los sob novas formas. Referindo-se aos esboços e desenhos que Leonardo da Vinci fez de tempestades, tornados e outras formas de violência da natureza, Dubois discorre sobre o figural produzido a partir da potência que "destrói os limites da mimese, suprimindo ou desfigurando toda forma de habitação ou de dado humano,

\footnotetext{
${ }^{31}$ Um caso emblemático é o de Didi-Huberman que, em sua defesa por formas mais heterodoxas de interpelar as imagens (de pintura, cinema, fotografia, vídeo etc.), faz uso frequente do trabalho do sonho, do figural, da desfiguração, entre outros procedimentos e conceitos que flertam diretamente com uma base freudiana. Ver, por exemplo: Georges Didi-Huberman, Diante da imagem, São Paulo: Editora 34, 2013.

${ }^{32}$ Philippe Dubois, 1998.

${ }^{33}$ Ibid., p. 287.
} 
instaurando um universo de pura força onde se torna impossível distinguir o mar em fúria do céu transtornado". 34

Além de sua própria interpretação do figural, Dubois tenta traçar uma metodologia de análise que em alguns pontos antecipa a realizada em nossa tese. Para o estudo de uma figura (naquele caso, a da tempestade), o autor recorre a uma abordagem em três níveis: 1. do figurado, que remete ao Saber, e convoca um conhecimento fora da obra: iconográfico, histórico e teórico, de textos e imagens que se tem a respeito do tema retratado; 2. do figurativo, que remete ao Ver (também ao Ouvir, acrescentamos), referente ao que se inscreve na superfície da obra, na figuração, e pode ser pensado no sentido e na forma que uma figura desempenha no interior do filme; 3. do figural, próprio às dimensões do sensível e do inteligível, pois é revelado pela própria matéria da obra. ${ }^{35}$

Em nossa pesquisa, os dois primeiros aspectos recebem primazia: de um lado, o repertório iconográfico, histórico e teórico que envolve os regimes de presença da figura humana; de outro, a análise da figuração do corpo dentro da dinâmica de um filme, de uma cena ou somente de um plano. Pelo menos a princípio, o último, a análise imanente, a interpretação dos dados sensíveis da obra, puxa e nos orienta em direção ao primeiro, o conhecimento exterior que subsidiará o exercício hermenêutico sem, porém, tornar-se uma chave interpretativa. A essas duas vias, somam-se mais três: a análise dos motivos, há pouco comentada com base em Aumont; uma abordagem interdisciplinar envolvendo o cinema, a pintura e mais pontualmente a dança; o entendimento de que o cinema contemporâneo pode ser interpretado à luz de filmes de outras épocas, de modo que o passado é constantemente retomado e por isso fecundo para o entendimento do presente. A orientação metodológica de nossa tese se finca nestes critérios. Orientação, diga-se, não implica na supressão absoluta de outros meios de análise. Dada a heterogeneidade do corpus, alguns critérios estabelecidos podem ser mais ou menos válidos de acordo com os filmes. Se a melhor metodologia é aquela que o objeto solicita, vale equilibrar a diretriz escolhida com outros aspectos que possam contribuir para tornar mais profícuo o contato com os filmes, não perdendo de vista as bases e objetivos principais.

Pensar a representação do homem a partir da figura humana, atravessando os dípticos semelhança e dessemelhança, transparência e opacidade, bem como a polissemia inerente à figura, permite antever a diferença implícita que existe em nossa tese entre figura e corpo. Se

\footnotetext{
${ }^{34}$ Ibid., p. 284. Ao falar da pintura de Francis Bacon, Deleuze recorre ao figural em sentido similar. Ver Gilles Deleuze, Francis Bacon: Lógica da sensação, Rio de Janeiro: Jorge Zahar, 2007.

${ }^{35}$ Philippe Dubois, 1998.
} 
ainda não ficou claro, o último só existe a partir de uma construção, é matéria resultante da modelação que se efetua na e a partir da figura. Dirigir-se à figuração do corpo no cinema é o primeiro passo para tentar entender qual a representação que se faz do homem. O corpo, pois, é a sua unidade material mais imediata e sensível. Já o homem, como sabemos, é uma ideia que foi transformada ao longo da história. Nossa defesa aqui é que o cinema tanto se aproveitou desse repertório como ajudou a construí-lo.

\section{Naturalismo figurativo}

Tentaremos, agora, uma primeira aproximação com os modos de pregnância do corpo representado numa imagem. Trata-se de um terreno de envergadura vasta e sem balizas seguras. Antes do primeiro passo a ser dado e da definição do roteiro a ser seguido, realizaremos um mapeamento, não extensivo, mas pontual, sobre o que já se sabe: nas artes visuais, em especial na pintura, por vezes atribui-se a presença tendo em vista a "verossimilhança", ${ }^{36} \mathrm{o}$ alto grau de analogia, os efeitos de realidade ou de real existentes entre o referente e a sua representação plástica. ${ }^{37}$ Associa-se a solidez de um corpo à figuração a partir de códigos naturalistas que ambicionem restituir na imagem a sua percepção no mundo real. ${ }^{38}$ Poder-se-ia mesmo traçar uma esquemática linha evolutiva dos regimes de representação da figura humana cujo norte seria o desejo de torná-la visivelmente semelhante a um corpo verdadeiro. Nas próximas páginas, esboçaremos algumas das particularidades dessa perspectiva no âmbito da pintura para, depois, pensá-la no cinema. A finalidade não é adotar uma linha temerária e em última instância arbitrária, mas dela decalcar uma via alternativa para o tema.

\footnotetext{
${ }^{36}$ Sabemos que o termo não é unívoco ou semanticamente intemporal. No teatro, por exemplo, Franklin de Matos sublinha pelo menos dois sentidos: o primeiro de matriz aristotélica, retomado e reinterpretado por italianos e franceses no teatro desde o século XVI, e grosso modo pautado no verossímil como o possível ou o impossível capaz de persuadir; o segundo advindo de Diderot (inspirado por Aristóteles) e inserido dentro do fenômeno de cotidianização geral da literatura e da arte no século XVIII, cuja ênfase se detém no jogo de compensações entre o comum e o incomum, no balanço entre o prosaico e o maravilhoso, no qual a verdade da natureza é mantida pelo apreço às circunstâncias e aos assuntos triviais diretamente enraizados na realidade de um público - diferentemente da tradição clássica francesa, no qual os temas teatrais eram restritos ao espaço e ao cotidiano da corte. O sentido que aqui empregamos é devedor desse reconhecimento na obra de arte do que pertence ao universo material e cotidiano do espectador. Ver: Franklin Matos, O filósofo e o comediante: ensaios sobre literatura e filosofia na Ilustração, Belo Horizonte: UFMG, 2001.

${ }^{37} \mathrm{O}$ primeiro, entendido como o catálogo de regras representativas que permite evocar a percepção natural, submetido tanto a procedimentos estéticos como às condições históricas que codificam a imagem e a tornam mais ou menos verossímil de acordo com o seu lugar de produção/difusão. O segundo relativo ao julgamento de existência do espectador sobre as figuras da representação, uma tal confiança a ponto de atribuir-lhes um referente no real. A propósito, ver a recapitulação de Aumont do artigo escrito por Jean-Pierre Oudart a respeito de tais efeitos: Jacques Aumont, A imagem, Campinas, SP: Papirus, 1993.

${ }^{38}$ Por exemplo, em: Nadeije Laneyrye-Dagen, L'invention du corps, Paris: Flammarion, 1997.
} 
O ponto de partida para uma imaginária história da figura humana, segundo a evolução dos seus graus de verossimilhança, seria um dos mitos de nascimento da arte no Ocidente, narrado por Plínio, o Velho, no qual uma jovem de Corinto contorna com carvão a sombra do amante, projetada na parede pela luz de uma vela. Seu gesto almejava conservar pela linha e pela figura a presença residual do amado antes de sua partida para uma longa viagem, da qual nunca regressaria. A representação artística teria sua origem nesse ato de circunscrever a sombra humana e assim fazer perdurar um vestígio do ser, subtraindo-o do fluxo contínuo e transformador do tempo presente para enregelá-lo no universo duradouro da imagem. Reinterpretado com outras variantes a depender do momento histórico a ser convocado, esse episódio inaugura uma perspectiva teleológica que avança em direção a outros meios figurativos, entre os quais a pintura e o cinema. A passagem de um a outro seria marcada pelo aperfeiçoamento de um programa de produção de presença, de criação de uma imagem especular cujo grau de analogia com o real seria progressivamente aprimorado.

Nesse itinerário imaginário, o papel da pintura seria o de conquistar ou pelo menos o de inventar o corpo, encontrando os meios para insuflá-lo de vida e assim afastá-lo do parco esboço vestigial produzido pela jovem de Corinto, cuja remota semelhança com o referente restringia-se aos contornos. Se tomarmos como referência o discurso oficial ou dominante da história da arte ocidental europeia - por isso mesmo assumindo seu reducionismo diante de outras perspectivas -, reparamos que a concreção de uma figura semelhante ao ser real foi correlata às vicissitudes técnicas e estéticas de pelo menos dois momentos particulares da Idade Moderna.

O primeiro remete aproximadamente ao final do século XIV, na curva entre a Idade Média e o Renascimento, quando a base da representação do espaço na pintura passou a ser fincada em uma nova concepção de homem e do mundo. ${ }^{39}$ A despeito de sua influência, os

\footnotetext{
${ }^{39}$ Ainda que estabeleçamos essa breve distinção entre a pintura da Idade Média e a do Renascimento, estamos cientes, conforme Burke propõe, apoiado em investigadores medievalistas, das redes de continuidade existentes entre estes dois momentos da história ocidental. As correspondências compreendem desde aspectos relativos ao comportamento, às crenças e às ideias das duas sociedades, até a existência de "renascimentos" no seio da Idade Média, quando uma combinação de feitos artísticos e literários culminou no reavivar do interesse pela educação clássica. Ver: Peter Burke, O renascimento, $2^{\mathrm{a}}$ edição, Lisboa: Edições texto e grafia, 2014. Com base em Francastel, também não ignoramos que ao conceber o espaço plástico a partir de um cubo figurativo orientado pela perspectiva linear, por um sistema de compartimentação dos planos que possibilitava a extensão e a profundidade da cena, o Renascimento italiano se valeu não apenas das leis físicas aptas a criar uma figuração rente ao mundo real, mas de um repertório de códigos visuais composto por acessórios simbólicos e mesmo míticos. Parte deste repertório foi tomado de empréstimo da tradição teatral e não da interpretação direta da natureza. Por fim, na linha de Burke e de Francastel, sabemos do caráter heterogêneo e dificilmente preciso do Renascimento em decorrência da variedade de estilos e técnicas que o coabitaram, incluindo aí a convivência de métodos tradicionais de figuração com as novas descobertas do Quattrocento. Mesmo com tais ressalvas, reconhecemos a singularidade de determinados artistas do Renascimento italiano em comparação com pintores da Idade Média no que concerne a lidar com o visível e particularmente com a figura humana como uma forma
} 
dogmas da Igreja, segundo os quais o meio terreno era uma representação concreta do pensamento de Deus, rivalizavam e em certa medida cediam paulatinamente a outro sistema de pensamento cuja matriz é a ideia do mundo como realidade em si, dotado de caráter semidivino. Ali, a figura de Deus mantinha-se seminal para justificar a criação e o equilíbrio do universo, mas a natureza passava a ser entendida como submetida às leis da física, portanto, suscetível aos investimentos do cálculo e da razão humana. Ao recrudescimento da consciência de autonomia do homem em face do que antes era submetido ao dogma cristão, também crescia a importância dada a uma educação humanista. ${ }^{40}$ Pelo menos a partir do século XIV, isso ganhou expressão sensível na pintura europeia com a entronização da figura humana, colocada no centro do teatro do mundo representado na tela. Retomar-se-iam os ideais greco-latinos e em particular sua tradição antropomórfica. ${ }^{41}$

A escolha de pontos de vista inusitados capazes de criar a impressão de relevo, ${ }^{42} \mathrm{o}$ aperfeiçoamento da perspectiva por Giotto, a presença da sombra projetada em Masaccio, os estudos sobre anatomia de Leonardo da Vinci, entre outras propostas compuseram um amplo repertório calcado na representação de formas visíveis segundo a natureza, devedora especialmente da física e da matemática. ${ }^{43}$ A produção de imagens verossímeis do ser humano e de suas grandes ações dentro de uma história e mais especificamente de uma cena estava diretamente sujeita a esse programa. ${ }^{44}$ Distanciando-se dos moldes medievais, ${ }^{45}$ o corpo representado passou a ser colocado dentro de uma nova articulação que o ancorava no espaço

sólida, matéria que deveria ter peso e se manter presa ao espaço figurativo, numa representação ilusionista do real. Pierre Francastel, Pintura e sociedade, São Paulo: Martins Fontes, 1990.

40 Burke (Op.cit.), amparando-se em Leonardo Bruno, explica que a educação humanista era baseada em cinco disciplinas: Gramática, Retórica, Poesia, Ética e História. A ideia fundamental era de que os homens se distinguiam dos animais pela fala e pela capacidade de discernir o bem do mal, de modo que as principais matérias eram referentes à linguagem (Gramática e Retórica) e à Ética. A História e a Poesia eram consideras como ética aplicada, pois ensinavam os estudantes a seguir bons exemplos e a evitar os maus.

${ }^{41}$ Pierre Francastel, 1990.

42 A exemplo do afresco pintado no óculo da Camera degli Sposi, em 1474, ou de Assunção da virgem, de 1456, na capela Ovetari. Ambos de Andrea Mantegna.

${ }^{43}$ Além de motivações simbólicas. Cf.: Erwin Panofsky, La Pprspective comme forme symbolique et autres essais, Paris: Minuit, 1975. Ainda nesse sentido, mas particularmente sobre os códigos de figuração do corpo: Erwin Panofsky, "L'histoire de la théorie des proportions humaines, conçue comme un miroir de l'histoire des styles". in L'œuvre d'art et ses significations: essais sur les “arts visuels", Paris: Gallimard, 1969.

${ }^{44}$ Notadamente, os escritos de Alberti nos quais o autor reflete sobre a história como verdadeira finalidade da pintura. Ver Leon Battista Alberti, Da pintura, $2^{\text {a }}$ Edição, tradução de Antonio da Silveira Mendonça, Campinas: Unicamp, 1999.

45 “'...] a pintura medieval cristã não se apresenta como um simulacro. Ela remete a uma pessoa ausente, ao próprio Deus, a um santo, ou a simples mortais que vivem ou viveram em outro tempo ou em outro lugar; ela não busca restituir a exata réplica de um ser [...] O cristianismo se preocupa com a alma e não com o corpo; ele concebe o futuro dos justos no além não como uma réplica eterna da vida sobre a terra, mas como o paraíso das almas finalmente separadas de seus corpos. A esse princípio fundamental logo é agregado o medo de que a imagem, muito semelhante ao real, dê lugar a um culto idólatra. Para evitar o risco de uma confusão entre sua obra e a realidade, a pintura cultiva as convenções que mostram que a primeira é pura simulação e não presença real." Nadeije Laneyrye-Dagen. Op.cit., p. 8. 
figurado, fincando seus pés no chão, dotando-o de uma solidez visual, de um peso físico no mundo representado. ${ }^{46}$

O afresco Adão e Eva expulsos do paraíso (1425, Fig. 2), de Masaccio, é exemplar desta valorização da "materialidade" - sutil se comparada ao que estava por vir com as figuras lenhosas de Michelangelo e com o "naturalismo" de Caravaggio, radical diante do que a precedia nos séculos anteriores - que deveria marcar o modulado da figura humana. Na obra, as referências religiosas, extraterrenas e no limite abstratas resumem-se ao anjo no céu e à silhueta do portal do Paraíso. A atenção maior é voltada para a caminhada dos dois corpos nus. Adão com a cabeça reclinada e o rosto mergulhado entre as mãos, Eva com o semblante visivelmente marcado pelo sofrimento, numa figuração expressiva das paixões. Ambos representados a partir do desespero e do encarnado macilento que salienta sua passagem para a condição eminentemente humana, terrena. A caminhada é em direção ao Tempo Histórico dos seres vivos e, fatalmente, em direção à morte. Desnudando Adão e Eva, Masaccio "construía uma imagem do corpo, em particular do masculino, cuja anatomia se igualava, pela primeira vez na pintura, àquela das esculturas de Donatello" e, ao mesmo tempo, apresentava um motivo que seria dominante, a partir de então, na pintura renascentista: a representação do movimento. ${ }^{47}$

\footnotetext{
${ }^{46}$ Em vez de imagens, o espectador deveria ter a impressão de estar diante das coisas em si mesmas. Ver Giorgio Vasari, The lives of the artists, Nova York: Oxford University Press, 1991.

${ }^{47}$ Daniel Arasse, "La meilleure façon de marcher. Introduction à une histoire de la marche", in Daniel Arasse, Lionel Bourg, Thierry Davila, Patricia Falguières; Maurice Fréchuret [et. al.], Les figures de la marche, Paris: Réunion des musées nationaux, 2000, p. 36.
} 
Fig. $1^{48}$

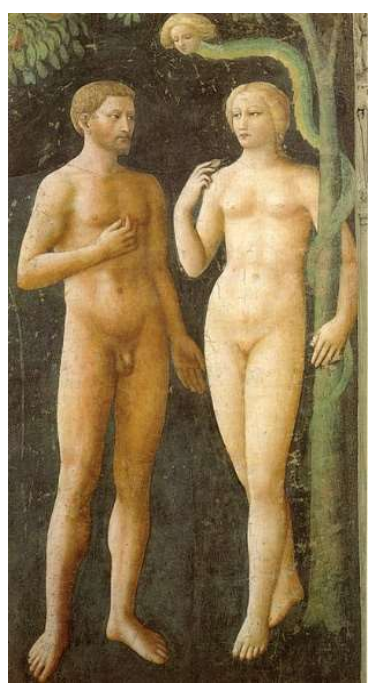

Fig. 2

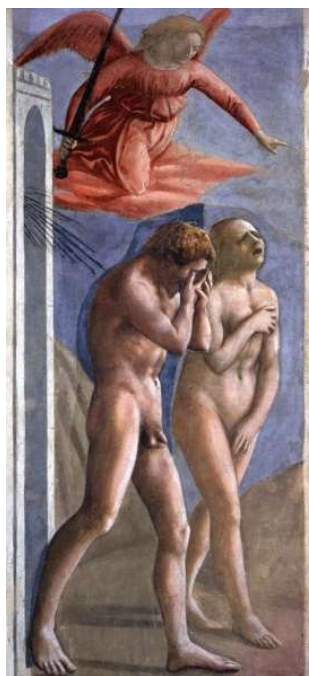

A maior corporeidade indicada pela gestualidade e também pelo encarnado mais protuberante da figura humana no século XV é acentuada pelo futuro uso do empasto, das camadas de tinta que borravam e fluidificavam o então contorno esquematizado pelo desenho, definido pela linha. Antes do que se veria com Rubens no século XVII e com Delacroix no século XVIII, emergiu na pintura veneziana do século XVI uma nova representação do encarnado. Nomes como Ticiano passaram a formá-lo com uma pasta pigmentar vibrante, gordurosa, capaz de simular o tecido humano. Em lugar da precisão do traçado, utilizavam-se pinceladas mais grossas e às vezes o próprio dedo para criar um empasto que tornava proeminente a massa, constituindo uma figura mais palpável, mais material. ${ }^{49} \mathrm{O}$ tratamento possibilitava um revestimento vibrante, um tipo de movimento a povoar as telas, independentemente do corpo estar em repouso, como se tudo fosse revestido pela ilusão de vida. $^{50}$

$\mathrm{O}$ segundo momento ao qual nos referimos concerne à pintura holandesa do século XVII. Em correspondência com os estudos de Hooke, Bacon e Comenius a respeito da possibilidade de um saber científico fincado na experiência empírica, particularmente na observação visual, desenvolveu-se ali um programa cuja produção e compreensão das imagens pictóricas era balizada pela vocação cartográfica da representação, pelo desejo dos pintores de captar sobre a tela toda uma gama de conhecimentos e de informações sobre o

\footnotetext{
${ }^{48}$ A sombra projetada, o peso imposto sobre os corpos durante a caminhada e a articulação das figuras de Masaccio com o mundo (Fig.2) ficam mais claros quando comparamos seu afresco ao de Masolino da Panicale (Fig.1), cujas figuras assumem uma pose hierática, a fisionomia não revela pathos evidente e o encarnado é mais leve, tornando-as etéreas e distantes do espaço.

${ }^{49}$ Nadeije Laneyrye-Dagen. Op.cit.

${ }^{50}$ Voltaremos a isso nos tópicos: $O$ desregramento do feminino (Cap. I) e Câmara de olhares (Cap. II).
} 
mundo. ${ }^{51}$ A consumação desse modelo não se deu pelo crivo da matemática e da história (representação de uma cena), como na arte italiana, mas pelo viés empírico (descrição da realidade visível), pela atenta observação experimental das aparências sensíveis. Já não se tratava da tela como janela, mas como mapa que agrega sobre sua superfície um conjunto de pontos de vista pelos quais se apresentam os múltiplos e parciais aspectos do que é representado. Tal projeto se desenvolveu em paralelo com a confiança setentrional em instrumentos e aparelhos intermediários, como a câmera escura e os dispositivos ópticos de Kepler, capazes de representar minuciosamente a natureza. Entre outros efeitos para a figuração do corpo, reconhece-se ali a predileção tanto pela pintura de gênero, com a representação da vida cotidiana, até a confiança na tradição pictórica dos retratos (individuais e de grupo), justamente o meio de figurar a identidade de cada pessoa, de buscar não uma verdade geral ou comum, mas a sua singularidade, o conjunto de signos que refletiam desde a posição social aos traços psíquicos. ${ }^{52}$

Diferentemente da pintura ocidental europeia, o cinema nem passou por um momento de secularização em que a arte deixa os valores transcendentais e espiritualmente elevados para aos poucos se aproximar da esfera terrena, e muito menos precisou da mestria do artista para alcançar a semelhança do visível. As primeiras manifestações do cinematógrafo, a partir de 1894-5, são matizadas por outras características. Ao apropriar-se de formas de cultura populares da Idade Média, como o circo, o carnaval, a pantomima, a prestidigitação e a feira de atrações, os primeiros filmes já apresentavam a figura humana com os "pés fincados ao chão", movimentando-se despudoradamente no interior do quadro, sem qualquer decoro ou vestígio de pertencimento a uma ordem outra que não a do mundo em sua dimensão mais profana. ${ }^{53}$ A ligação com estes espetáculos populares, em vez de formas eruditas (teatro, ópera e literatura) dos séculos XVIII e XIX, foi determinante para que os primeiros filmes criassem um universo paralelo ao da cultura oficial, pautado na inversão de valores morais, e também distante de qualquer elevação abstrata. ${ }^{54}$ Universo imanente, rente ao plano material e não raro carnal - como no caso de uma das especialidades da época: a pornografia.

Poderíamos evocar aqui a tão apregoada natureza indicial resultante do automatismo técnico herdado da fotografia, capaz de restituir por si mesma e ainda que parcialmente a aparência do mundo. Mas a verdadeira dimensão dos efeitos de realidade do cinema, ou senão

\footnotetext{
${ }^{51}$ Alpers desvela em diferentes níveis as correspondências entre as propostas destes autores e a tradição pictórica setentrional. Ver Svetlana Alpers, L'art de dépeindre, Paris: Gallimard, 1990.

52 Ibid.; Tzvetan Todorov, Éloge du quotidien, Paris: Société nouvelle Adam Biro, 1993.

${ }^{53}$ Flávia Cesarino Costa, O primeiro cinema, São Paulo: Scritta, 1995; Arlindo Machado, Pré-cinemas e póscinemas, 6 a edição, Campinas, SP: Papirus, 2011.

${ }^{54}$ Arlindo Machado, Op.cit.
} 
a sua interpretação mais poética, encontraremos no conhecido depoimento de Méliès ao assistir $A$ refeição do bebê (Le repas de bébé, 1895), dos irmãos Lumière. Enquanto a ação se desenrolava no primeiro plano, o que deteve sua atenção foi o que passava no fundo da imagem, algo que dificilmente despertaria o interesse particular de um espectador hoje: as folhas das árvores se moviam. É dessa pequena e banal observação que Aumont parte para situar a capacidade do cinematógrafo tanto de tornar palpáveis e presentes os fenômenos da atmosfera, seja o ar, seja a água, seja o mais fugidio deles, a luz, como de insuflá-los de movimento e consequentemente de tempo. ${ }^{55}$ A premência e a sistematização desses efeitos de realidade seria uma das mudanças em relação à tradição pictórica ocidental.

Mas e o corpo representado? Ainda que houvesse um déficit de realismo pelas imagens em preto e branco e pela ausência de voz, já não era necessário preocupar-se com a composição do seu encarnado, com técnicas que o provessem de uma similaridade visual. O que então motivaria o comportamento e a organização no espaço das figuras? Como tornar presente essa efígie que, pela primeira vez na história que aqui traçamos, incorporava o movimento?

No período predominantemente não-narrativo do primeiro cinema, de 1894-5 a aproximadamente 1907, era rara a existência de histórias desfilando ao longo dos filmes e, por conseguinte, de personagens com motivações psicológicas que encarnassem os corpos representados. Segundo a noção de cinema de atrações, inspirada nos escritos de Eisenstein, o princípio dos filmetes daquele período era a apresentação de uma ação válida por si mesma, fora de um universo ficcional ou documental, capaz de solicitar a curiosidade do espectador, promover o choque visual e propiciar prazer pelo próprio espetáculo que criava. ${ }^{56} \mathrm{O}$ descolamento e a independência diante de um todo diegético coerente era tal que a atração às vezes se resumia ao próprio maquinário envolvido na projeção de um filme e não necessariamente ao que era representado na tela. ${ }^{57}$ Ainda que percebamos em filmes como Viagem à lua (Le voyage dans la lune, 1902, de Georges Méliès) a coexistência de narração e de atrações, era raro àquela época o imperativo e o uso sistemático da primeira, de tal maneira que a ação das figuras nem sempre era submetida à rígida semantização dos aspectos sintáticos, à significação dentro de um universo fictício.

\footnotetext{
55 Jaques Aumont, L'oeil interminable, Toulouse: Séguier, 1989.

56 Tom Gunning, "The cinema of attractions: early film, its spectator and the avant-garde", in Thomas Elsaesser (org.), Early cinema, Londres: BIF, 1990.

57 Por exemplo, o caráter espetacular conferido ao uso das mudanças de velocidade e ao close, elementos que ainda não tinham sido incorporados à gramática narrativa e apenas existiam tendo em vista o efeito criado, tal como em As Seen Through a Telescope (1900) e Grandma's Reading Glass (1900), ambos de George Albert Smith. Ver Tom Gunning, Op.cit.
} 
Um exemplo mais concreto da última observação encontraremos seja nos filmes de William K.L. Dickson feitos para o estúdio de Thomas Edison (Fig. 3), seja na produção dos irmãos Skladanowsky, ambos centrados na apresentação de performances realizadas em espaços fechados, geralmente filmados contra um fundo negro, sublinhando o movimento da figura humana de maneira similar às cronofotografias de Muybridge. Sem outro elemento capaz de desviar a atenção do espectador, o interesse ali se detinha na mecanicidade dos atos, desde o registro de simples movimentos motores de cada um dos membros até a caminhada e a dança. Mais que apreender o mundo, encenado ou não, como faziam os filmes da Companhia Lumière, a atenção era direcionada aos corpos treinados, ao trabalho dos músculos e às gradações do movimento. ${ }^{58}$

Fig. 3 Fotogramas de Carmencita (1894, William Kennedy-Laurie Dickson)

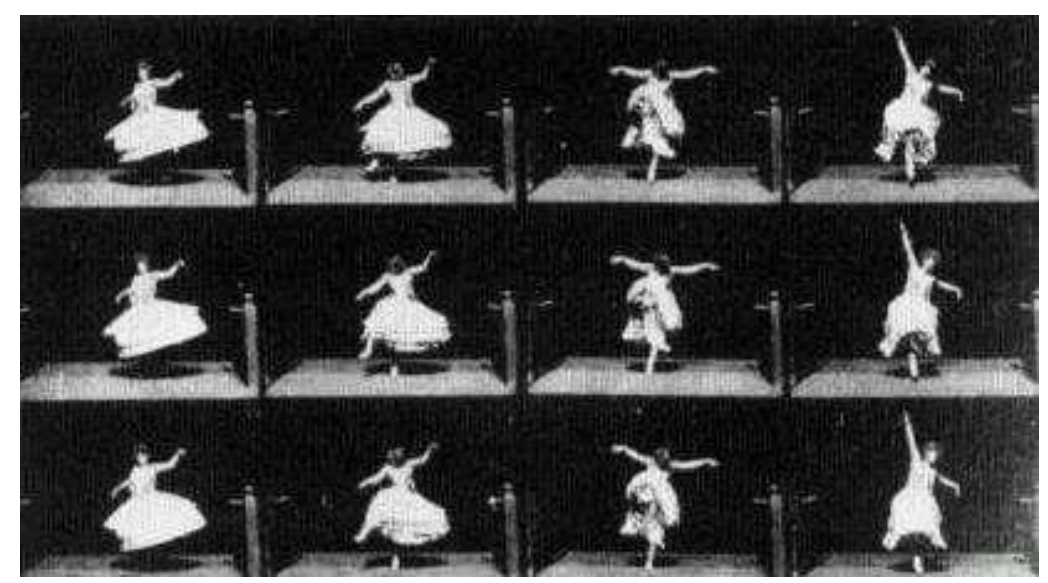

O que nos interessa aqui ao fazer esta sumária recapitulação do primeiro cinema é pensar a passagem de um modo de figuração cujo regramento sobre o corpo é menos codificado para outro caracterizado pela inserção da figura no sistema da decupagem clássica, em meados de 1914-1915, quando assume o papel dentro de uma trama. O momento de inflexão - menos esquemático e claro do que aqui propomos - é acompanhado de um maior diálogo com a dramaturgia teatral. A dinâmica espetacular das atrações é substituída pela encarnação da figura a partir da já mencionada dramatis personae, noção referente à resposta

\footnotetext{
58 Entre os atos filmados, era frequente a aparição da dança serpentina. A modulação de formas pelo fremir convulsivo dos tecidos no ar, como sabemos, despertou o interesse de pensadores e artistas simbolistas pelo nome mais popular deste gênero de dança: Loie Fuller. Em razão do demasiado apelo cinemático, eles acreditavam que o movimento era capaz de anular as formas sólidas, de dissolver o corpo em uma mudança contínua, dissociando a figura do real e a transformando em pura existência cinética. Ver Tom Gunning, "Body, light, eletricity and the origins of cinema", in Richard Allen, Malcolm Turvey (org.), Camera obscura, camera lucide, Amsterdã: Amsterdam University Press, 2003, p. 75-90.
} 
extrospectiva do ator às demandas advindas de um cosmo fictício, de um ordenamento lógico que compõe a história e a ação em que está inserido. $\mathrm{O}$ cinema silencioso narrativo, de realizadores como D. W. Griffith, assimilou e remodelou conforme as especificidades do cinematógrafo um vocabulário gestual advindo principalmente do teatro, na expressão das paixões a partir da pantomima, e posteriormente de noções culturalmente específicas sobre a mimese da vida cotidiana. ${ }^{59}$

O futuro advento do som e das cores demarcaria um passo a mais rumo à concreção do naturalismo figurativo cinematográfico e de seu universo verossímil. Se até então o fantasma gorkiano do "reino de sombras" pairava sobre as imagens cinéreas e silenciosas, ${ }^{60}$ o registro direto do som e das cores contribuiriam sobremaneira para a promoção de novos modos de realismo prontamente integrados ao paradigma clássico de representação, sob o signo da metáfora albertiana da tela (originalmente a pictórica, mas nesse caso a cinematográfica) como janela transparente e aberta para o mundo.

Mas, repetimos a pergunta, que posição ocuparia a figura dentro dessa linha evolutiva? É certo que o desenvolvimento dos meios tecnológicos permitiu uma maior naturalidade do corpo figurado na tela. Recordemos que a baixa qualidade das películas do primeiro cinema por vezes exigia uma disposição atoral histriônica a fim de que a figura não se confundisse com o fundo. ${ }^{61}$ A concepção do plano como unidade capaz de conter o desenvolvimento de uma ação completa, com a câmera afastada e o ponto de vista fixo, tinha por consequência direta a perda das feições dos atores - o que também era compensado pelas interpretações espalhafatosas. ${ }^{62}$ Além disso, alguns filmes não articulavam firmemente a figura ao espaço porque a baixa qualidade da película não permitia aos corpos explorar o eixo óptico da

\footnotetext{
${ }^{59}$ Ver a passagem do código histriônico para o da verossimilhança, em: Roberta E. Pearson, Eloquent gestures, Berkeley: University of California Press, 1992.

60 "Ontem à noite, eu estava no Reino das Sombras. Se vocês pudessem somente representar a estranheza desse mundo, um mundo sem cor, sem som. Tudo aqui - a terra, a água e o ar, as árvores, as pessoas - tudo é feito de um cinza monótono. Raios de sol cinzentos num céu cinzento, olhos cinzentos num rosto cinzento, folhas de árvores que são cinzentas como a cinza. Não a vida, mas a sombra da vida. Não o movimento da vida, mas uma espécie de espectro mudo." Máximo Gorki, "No país dos espectros", in Jérôme Prieur. O espectador noturno. Os escritores e o cinema. Rio de Janeiro: Nova Fronteira, 1995, pp. 28-31.

${ }^{61}$ Ao comentar o cinema de Méliès, Lenk reconhece o risco da imobilidade dos corpos: "[os atores não devem] ficar imóveis, ou podem fundir-se com o cenário, daí recorrer-se a gesticulações entretanto ordenadas. Pois na tela as personagens ficam 'como numa grande fotografia, prensadas umas sobre as outras', e se não representarem cada um de uma vez, é grande o risco de confusão entre personagens principais e secundárias." Citado em: Jacqueline Nacache, Op.cit, p. 16.

${ }^{62}$ A predominância do plano geral e a consequente distância entre a objetiva e os atores, portanto, contribuía para a despersonalização parcial das figuras. Em Viagem à lua, por exemplo, para além do cientista principal que planeja a excursão espacial, os demais integrantes da expedição não são individualizados. Sem grandes contribuições para a execução da viagem, restritos a fazer companhia ao idealizador, sem uma face que os defina, eles assumem função no limite decorativa, respondendo por uma massa agitada que contribui para gerar movimento no plano e ajudar na composição, não participando diretamente da breve linha narrativa.
} 
perspectiva e caminhar até o fundo do plano sem perder a nitidez. Tais singularidades do primeiro cinema foram progressivamente contornadas com o aprimoramento técnico e flanqueadas pelas transformações estéticas. ${ }^{63}$ Depois desse processo, poderíamos falar em uma maior verossimilhança visual da figura diante do corpo real?

Até aqui, parece-nos que o som e a cor marcam o esgotamento de uma perspectiva linear e evolucionista que almeja identificar no progredir da história técnica do cinema um aperfeiçoamento dos graus de analogia frente ao corpo real. Procurá-los exclusivamente em termos de naturalismo figurativo talvez seja pouco frutífero em um meio que pelo menos desde a depuração da decupagem clássica aprendeu a fragmentar a figura humana para, assim como fez com o espaço, reintegrá-la à continuidade metonímica de origem dramáticonarrativa. ${ }^{64}$ Já não nos encontramos no domínio da pintura, na qual a semelhança da figura precisou ser conquistada às custas de interditos religiosos e à luz de técnicas, querelas, pesquisas e tratados. O corpo, em si, é figurativamente dado no cinema pela indicialidade (de)composto e recomposto pela montagem. Onde então procurar uma encarnação que potencialize a sua presença, que encarne a figura e lhe forneça um substrato, sua matéria?

Evocamos mais cedo a noção de personagem, mas ela seria suficiente ou mesmo única? Caso deixemos o padrão de representação clássico ou uma visão restritiva e homogeneizante dele, deparamos com um polimorfismo, uma miríade de figurações do corpo que não necessariamente está amparada em um naturalismo visual e/ou dramático, mas ainda assim encontra seus próprios meios de encarnar, de preencher o envelope visual da figura e conferir-

\footnotetext{
${ }^{63}$ Nesse sentido, vale recordar a "conquista" do espaço no gênero mais popular entre 1903 e 1906, os filmes de perseguição, nos quais na maior parte do tempo tudo consiste em mostrar como a figura atravessa a imagem em suas mais diferentes direções, em como o corpo desbrava e ao mesmo tempo ajuda a expandir o espaço, exigindo novos planos que possam acolhê-lo em seu constante deslocamento. A exemplo de: Stop thief! (1901, de James Williamson), Desperate poaching affray (1903, de William Haggar) e Personal (1904, de Wallace McCutcheon). Voltaremos a essa relação com os filmes de perseguição no Capítulo 2 da tese. Para além disso, também é possível citar as mudanças possibilitadas pelo close-up, que permitia atuações mais moderadas, pautadas nas micro expressões. Sobre este último ponto, ver: Béla Balázs, "The spirit of film”, in Erica Carter (ed.), Early film theory, Nova York: Berghahn Books, 2010.

64 "O homem do século XX e XXI não pode mais ter o mesmo olhar sobre si mesmo que o homem da Renascença, do humanismo, que se pensava em sua globalidade tanto no teatro como na pintura, e evidentemente na literatura. A literatura adora jogar com os detalhes, sublinhar o piscar de um olho ou o movimento de nervosismo de uma mão, mas estes sinais são feitos sempre em relação à ideia de conjunto, enquanto que o cinema põe desde o princípio na representação do ser humano a questão de sua fragmentação". Ver Jean Douchet, "Le visage comme révélation, le geste comme signe, le corps découpé comme figure, le corps plein comme opacité", in Jacques Aumont (org.), 1995, pp. 115. Dado o caráter genérico dessa afirmação, podese pensá-la como mais ou menos válida a depender do filme ao qual se enderece. A título de exemplo, durante os chase films, o corte de um plano a outro só era efetuado depois que todos os corpos deixavam o campo, justamente a fim de preservar a unidade corporal. Já no cinema clássico, a decomposição do corpo pelo plano fechado é trabalhada dentro de uma lógica de recomposição a partir da decupagem clássica, podendo ser comparada justamente com o que Douchet falou sobre a literatura. Um filme experimental como Erogeny (1976), de James Broughton, composto integralmente por planos detalhes de dois corpos, parece se adequar mais ao comentário.
} 
lhe um sentido a partir de modos particulares de existência. Como poderíamos defini-los? Estaríamos em busca de formas que corroboram, diferem ou rivalizam com a noção de personagem? Afinal, não seria necessário abandonar o papel da figura dentro de um cosmo fictício, da moldura da fábula, para aceder a um tipo de verdade, de presença do corpo representado - em si mesma, sem necessariamente responder a leis exteriores de um universo ficcional? Nesse ponto, as questões se avolumam, ganham contornos pouco precisos e dificilmente seriam respondidas tendo em vista unicamente a perspectiva imaginária que propusemos de uma progressão dos graus de analogia. Nossa tese propõe outro caminho, menos genérico e cronologicamente impositivo: refletir sobre a presença da figura não mais a partir de uma via teleológica, de uma estrutura preexistente, mas decalcada diretamente dos filmes. Esse tipo de escolha nos apresentou três vias: a plasticidade, o desejo e a comunidade.

Tendo em vista os regimes de representação a serem analisados, a tese foi estruturada em três capítulos. O primeiro tem como centro a análise de Sombra (Sombre, 1998), de Grandrieux. Submetendo o protagonista a uma série de deformações plásticas, o filme nos apresentou um desafio: como forjar uma presença quando a figura humana é a todo instante ameaçada de desaparecer na escuridão? Uma questão paralela se esboçou a partir da representação do corpo feminino, inelutavelmente associado a uma sensualidade protuberante. Reconhecemos aí uma fratura entre os gêneros tanto no nível figurativo, pela representação umbrática do masculino e carnal do feminino, como também pela violência envolvendo o protagonista e as mulheres com quem se relaciona. Tentamos compreender as duas problemáticas (diluição da figura e clivagem entre gêneros) a partir do tratamento crepuscular dado ao espaço pictórico, comum em Sombra e na maior parte da obra de Grandrieux. A análise dos filmes do realizador aconteceu em cotejo: mais detidamente, com as teorias e os filmes da vanguarda francesa da década de 1920, a partir de nomes como Élie Faure, Ricciotto Canudo e Jean Epstein; mais brevemente, com a realizadora experimental norte-americana Carolee Schneemann. Fora do cinema, efetuamos um exercício comparativo com a pintura, sobretudo obras de Picasso e Cézanne.

O segundo capítulo foi conduzido por O rio (He-Liu, 1997) e Adeus, Dragon Inn (Goodbye, Dragon Inn, 2003), de Ming-liang, O fantasma (2000), de Rodrigues, e Bom trabalho (Beau travail, 1999) de Denis. Discutimos inicialmente um regime de figuração fincado na exacerbação de gestos cotidianos, como a caminhada. A ênfase em 
comportamentos que nem sempre promovem um andamento ou uma mudança da linha dramática foi pensada a partir de uma inclinação para ações reflexivas e processuais. Essa análise sobre a fisicalidade do corpo compreendeu ainda o papel da pele na mediação entre o mundo e a subjetividade da figura humana. Ao final do capítulo, defendemos como os filmes de Ming-liang, Rodrigues e Denis estão envolvidos por uma economia libidinal que reorienta o corpo para além das normatividades que tentam censurá-lo. Tais propostas foram refletidas em comparação com dois gêneros laboratoriais para a fisicalidade da figura humana: os filmes de perseguição e o cinema burlesco do início do século XX. Em complemento, efetuamos um brevíssimo diálogo com noções advindas da dança e da performance, além de recorrer a pintores que lidam com a carnalidade, como Lucian Freud.

O terceiro capítulo usou como fio condutor No quarto da Vanda (2000), seguido dos outros dois filmes da trilogia das Fontainhas, Ossos (1997) e Juventude em marcha (2006), de Pedro Costa. Principiando na atenção dada ao rosto da figura humana, debatemos as possíveis convergências entre o plano cinematográfico e o gênero retratístico - segundo suas raízes pictóricas. O retrato no cinema de Costa, e mais pontualmente em filmes de Bing e Uchoa, foi pensado como um mecanismo ético que se afasta da lógica narrativa em prol de uma particular visibilidade do corpo dos oprimidos. Em No quarto da Vanda, indivíduos marginalizados social e historicamente, incluindo imigrantes cabo-verdianos que residem em Portugal. Dessa atenção ao sujeito em sua dimensão social, discutimos as diferentes estratégias pelas quais se figura o corpo coletivo, o da comunidade. 


\section{Matéria da imagem e matéria do corpo}

Desde o mito de Plínio, um dos níveis mais distantes de similaridade da imagem em relação ao modelo representado, um dos estados mais primitivos e talvez deficitários da figuração artística é correspondente à sombra. ${ }^{65}$ Os contornos por vezes fluidos e a escuridão que a constituem velam os detalhes, dificultam o seu escrutínio e a sua apreensão pelo olhar. A silhueta criada pela obstrução da luz sobre um corpo incorpora o estigma de uma cópia vacilante, de um esboço que simultaneamente evoca o ser que o originou e, pela dessemelhança, dele se afasta. A forma potencialmente anamórfica e projetiva sugere uma figura volúvel, vaporosa, sob o risco constante de desaparecer, de se tornar imaterial.

O cinema soube bem acolher e tirar proveito dessas propriedades. Ao longo de sua história, a sombra parece ter abandonado a parede sobre a qual a jovem de Corinto a fixou para se esgueirar, projetar-se sobre outras superfícies, outros meios, outras imagens, pelo menos desde a famosa silhueta que sobe as escadarias em Nosferatu (Nosferatu, Eine Symphonie des Grauens, 1922, de F.W. Murnau). Não haveria nessa figuração do corpo uma forma de materialidade, um modo de presença? Ou isso seria recusar a longeva tradição pictórica que relegou a sombra a uma cópia deficitária? Se sim ou se não, o que algo de natureza tão furtiva revela sobre a figura humana? Como constrói e recupera a relação de um corpo com o mundo e com outros seres? E ainda: o que a sombra permite compreender sobre as propriedades específicas do cinema ao representar um corpo?

As questões surgiram ao longo dos filmes analisados por este capítulo. Elas esboçam uma problemática ainda mais ampla, que encontraremos no primeiro longa-metragem de Philippe Grandrieux, Sombra (Sombre, 1998). ${ }^{66}$ O filme é pontuado por elementos que concernem diretamente à figuração do corpo a partir de uma série de investidas contra a sua bela forma, escolhas que agridem a sua integridade visual e física, diluindo-o ou mesmo suprimindo-o da imagem. É no seio desta aparente violação ao primado da figura humana que se estabelece um regime à primeira vista contraditório, posto que em busca de uma restituição

\footnotetext{
${ }^{65}$ Ver a Introdução, tópico Naturalismo figurativo, páginas 23 e 24.

${ }^{66}$ A tradução mais fiel ao título original diz respeito ao que recebe pouca luz, ao obscuro ou ao sombrio.
} 
da corporeidade e consequentemente de presença justamente onde não há mais um corpo visível.

A análise do esvaecimento visual da figura humana no filme de Grandrieux constituirá a espinha dorsal a partir da qual tentaremos desdobrar uma rede tentacular e sinuosa composta por motivos e por debates, advindos de obras fílmicas e pictóricas diversas, que auxiliem a subsidiar nosso argumento sobre um singular modo de existência do corpo representado.

\subsection{Sombra e carne: a cisão entre gêneros}

A cena inicial de Sombra demarca a imersão no universo tenebroso que impregnará tanto este primeiro longa-metragem de Grandrieux como de um modo geral todo o seu cinema. Ali, um automóvel se desloca por uma estrada situada na encosta de uma montanha. A câmera segue o veículo à distância, em sua retaguarda, filmando-o como um elemento menor diante da paisagem, cuja amplitude domina o quadro. Além da diferença de escala e da consequente imponência da natureza, o que chama a atenção é o baixo contraste, a carência de reentrâncias e saliências entre o primeiro plano e o fundo da imagem. A impressão de uniformidade se deve entre outras razões à interposição das nuvens entre o sol e o espaço, o que produz uma cortina brumosa e nívea, espécie de difusor natural que impede a incidência direta dos raios solares. O resultado é uma iluminação homogênea, sutil, produtora de sombras pouco demarcadas quando não inexistentes. O efeito de achatamento que daí advém é acentuado quando o automóvel (e consequentemente a câmera) faz um giro de quase $180^{\circ}$, defrontando-se contra o sol e imergindo toda a paisagem no contraluz. O espaço perde ainda mais sua tridimensionalidade: convertido em sombra, regride ao estado de projeção umbrátil, numa inversão do mito de Plínio. Com o progredir da sequência, a iluminação se torna mais crepuscular, submetendo as formas ao negrume, até que a fronteira entre as figuras e o fundo, o céu e a terra, seja diluída e a imagem mergulhe quase que inteiramente numa noite densa e total (Fig. 4-5). 
Fig. 4

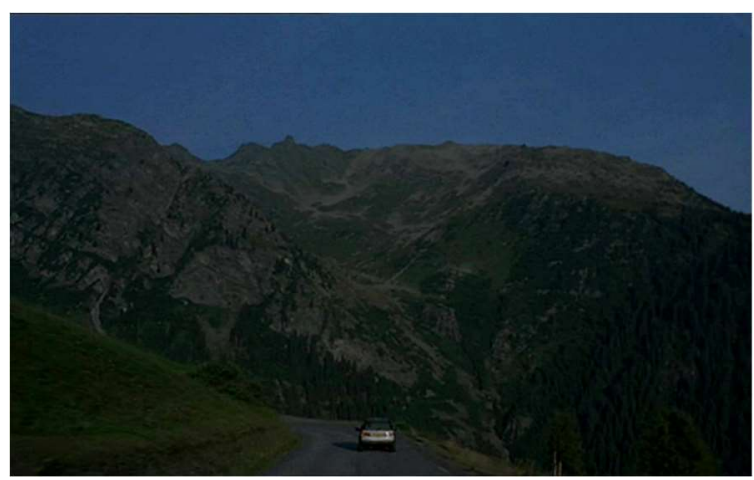

Fig. 5

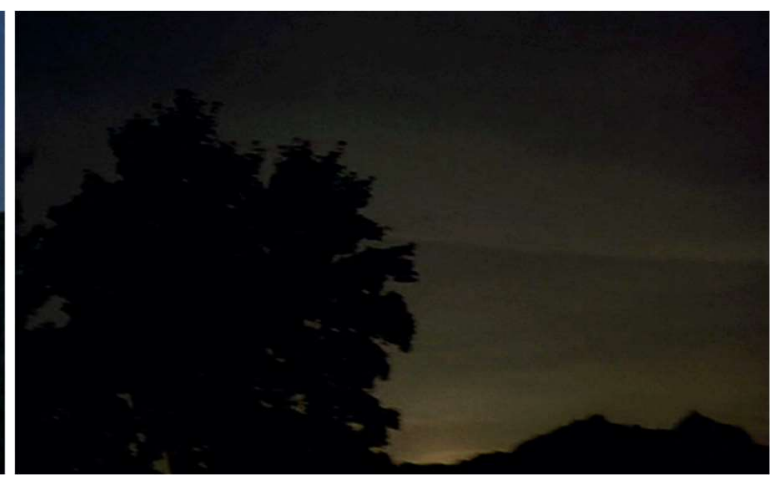

A luz crepuscular que submerge na escuridão a paisagem da primeira sequência de Sombra antecipa duas tendências complementares do filme. Inicialmente, a ameaça sofrida pelo personagem principal, Jean, um serial killer, de perder os seus traços constitutivos, ter o seu insumo carnal subtraído pelo negrume, e ser transformado em um ser sem corporeidade, espectro negro que vaga pelo mundo. Em segundo lugar, o risco do monocromo, da dissolução não apenas da figura humana mas de toda a imagem numa camada homogênea e pouco diferenciada.

A primeira aparição de Jean anuncia desde então o sinal desse estigma. Em plano médio, divisa-se seu rosto com muita dificuldade num quarto escuro. Sem uma luz pontual que dramatize e evidencie algo no espaço, ou mesmo de uma difusa que revele uniformemente o conjunto da composição, o que se tem é a refletância mínima na epiderme do corpo e na superfície do espaço e dos objetos, que aparecem no limite da visibilidade. Com roupa escura, o personagem facilmente se converte em silhueta negra que mimetiza a negrura do quarto. Em contraste, no mesmo aposento identificamos outra presença, a de sua vítima: uma mulher despida, cuja brancura da pele e a opulência das carnes - tal como uma figura feminina de Rubens - acabam se tornando um ponto de referência no espaço. Enquanto ela se impõe pela carnalidade, Jean parece se diluir, incorporando-se não mais ao espaço do mundo figurado, mas à superfície da imagem, ficando a meio caminho entre a presença no universo diegético e a existência enquanto figura de outra ordem. Como veremos ao longo do filme, a desigualdade da mise en scène direcionada à figura masculina e à feminina corrobora diretamente a natureza híbrida de Jean, ao mesmo tempo em que demarca uma cisão entre gêneros, capital para o nosso debate.

A disparidade descrita é demarcada pelas escolhas de figuração do corpo. De um lado, a vítima tem o rosto geralmente oculto pelos cabelos, pelo desfoque, pelo enquadramento e pela escuridão. A face, que poderia lhe conferir uma identidade, é confiscada. Sua figura somente 
existe ali pela exposição do corpo enquanto carnalidade e massa que serão ora exploradas pelo toque brusco e reticente de Jean, ora pela câmera que passeia pelas formas femininas com uma tal proximidade que dificulta a precisão dos contornos visuais em benefício de uma aparente tatilidade. De outro lado, Jean é apresentado inicialmente pelo rosto e pelo olhar. Quando não, se faz presente visualmente como sombra. A mesma lógica se repete no segundo assassinato, só que desta vez o que suprime a identidade da mulher são os olhos vendados. A notoriedade do seu corpo nu fica a cargo de uma luz que entra pela janela e se espalha pela cama sobre a qual está deitada. Jean aparece em contraluz, como silhueta, novamente em disparidade com o peso carnal da mulher.

Sabemos que, pelo menos desde a Antiguidade clássica, a cultura ocidental conferiu ao rosto e à voz não só um dos critérios de diferenciação entre o ser humano e os demais animais, mas igualmente o meio privilegiado de relação entre os indivíduos - e ainda de ascensão à ordem do inteligível por meio da beleza. ${ }^{67}$ Por que então conceder a Jean o rosto e às vítimas exclusivamente o corpo? Uma pista advém da parcial isomorfia visual entre as duas sequências. Em ambas, o protagonista não consuma o ato sexual e, antes de assassinar as mulheres, repete o gesto de colocá-las de pernas abertas, de frente para si, enquanto as contempla (Fig. 6-7). O enquadramento é o mesmo: Jean em primeiro plano, na forma de silhueta, com a cabeça e parte do corpo a obstruir a visão do sexo das mulheres, situadas ao fundo. Tanto a disposição das figuras como a forte contraposição entre o protagonista, reduzido à forma de sombra impotente, e as mulheres, em toda a sua receptividade e presença corporal, separam Jean das vítimas, relegando-o a um espaço à parte que lhe nega a consumação do ato sexual e lhe reserva à escopofilia, como se uma tela se interpusesse entre o sujeito e o objeto do olhar e do desejo - talvez não por acaso o protagonista conhece a segunda vítima num peep show.

\footnotetext{
${ }^{67}$ Frontisi-Ducroux discute a importância dada ao rosto na cultura ocidental, desde a civilização grega, como meio privilegiado de relação dos indivíduos, lugar de emissão dos signos e revelador dos sentimentos, do pensamento e do modo de ser. Em decorrência desse estatuto, o rosto era por vezes assumido como equivalente ao indivíduo. Ver Françoise Frontisi-Ducroux, Du masque au visage, Paris: Flammarion, 2012. Retomaremos o tema no Capítulo 3, ao discutir o retrato no cinema.
} 
Fig. 6

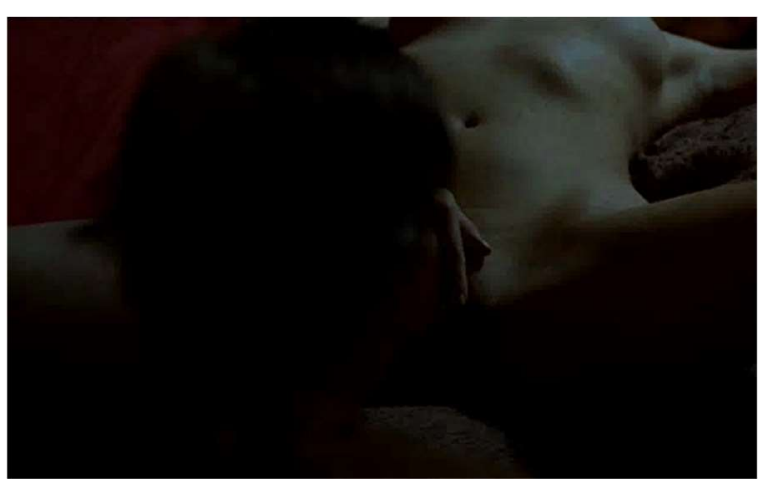

Fig. 7

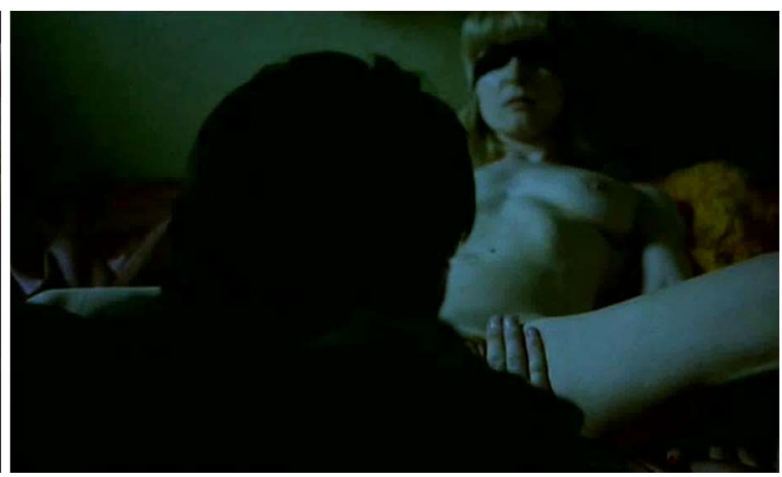

Podemos, a princípio, pensar a oposição entre masculino e feminino nos termos de um reflexo cultural da ordem patriarcal, conforme um célebre artigo de Laura Mulvey. ${ }^{68}$ Revisto criticamente pela própria autora e amiúde pela teoria feminista, o texto se baseia na psicanálise freudiana para identificar no cinema narrativo clássico um modo de representação da mulher concebido a fim de alimentar a pulsão voyeurista do espectador masculino. Caso desloquemos essa afirmação para o nível diegético do filme de Grandrieux, as duas vítimas (Fig. 6-7) assumiriam o papel simbólico da ausência fálica, do complexo de castração. Elas estariam limitadas à condição passiva frente ao olhar masculino, expostas a um tipo de prazer visual no limite obsessivo, dado que a satisfação sexual de Jean aparentemente só pode advir - nos termos de Mulvey - da observação, objetivação e do controle do outro. Ora, até faz sentido pensar o filme pelo viés de uma disposição escopofílica, já aquiescer a uma passividade da figura feminina é forçado porquanto há uma clara consciência das mulheres em face do olhar que tenta objetivá-las. Sua performance é uma resposta direta a ele. Perder esse ponto de vista é ver a relação pela metade. O jogo é duplo.

Fig. 8

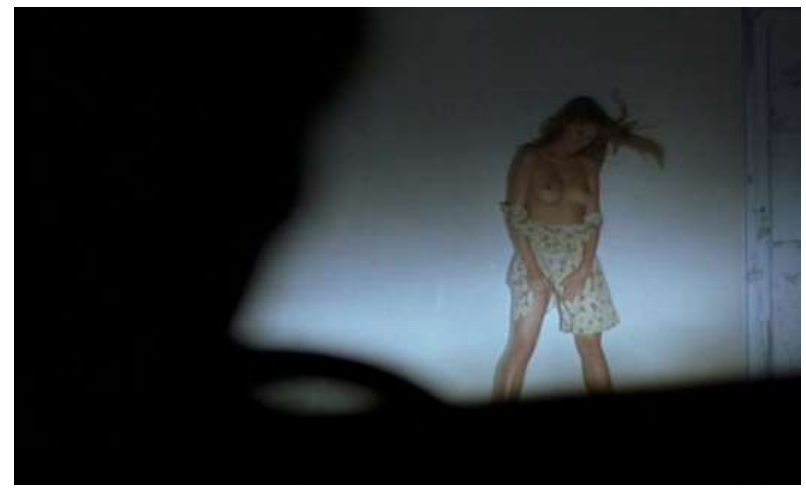

${ }^{68}$ Laura Mulvey, "Prazer visual e cinema narrativo", in Ismail Xavier (org.). A experiência do cinema, Rio de Janeiro: Edições Graal; Embrafilme, 1983, p. 437-453. 
Contribui para o estatuto descrito uma terceira cena (Fig. 8). Embora com outra composição, novamente um dos planos repete a disposição espacial dos corpos: a silhueta de Jean a observar uma possível vítima, ao fundo da imagem, que dança para ele. O que nas sequências anteriores se restringia a uma separação pela impossibilidade de consumação do ato sexual, aqui se torna uma distância marcadamente física, pois o carro funciona como aparelho escopofílico que separa homem e mulher (sujeito do olhar e o seu aparente objeto), ecoando tanto a estrutura do peep show como a do dispositivo cinematográfico. Voltaremos a essa relação entre sexualidade e escopofilia mais tarde. Por enquanto, continuemos a pensar o papel atribuído à figuração da sombra.

O contraste figurativo entre homens e mulheres no filme de Grandrieux mantém um estrito eco visual com duas telas pintadas por Picasso no ano de 1953: A sombra e $A$ sombra sobre a mulher (Fig. 9-10). Elas retratam, respectivamente, uma silhueta preta e uma translúcida que se projetam no cômodo em que a figura feminina, nua, está deitada. Na primeira delas a sombra aparenta assumir a condição de voyeur, tal como no filme de Grandrieux, pois o corpo feminino se recolhe exatamente no lugar onde aconteceria o contato entre as duas figuras, evitando que a forma negra o alcance, demarcando a separação e o consequente isolamento do sujeito. Ele está duplamente ausente da imagem: fora de campo (ainda que sugerido pela sua extensão umbrátil) e rejeitado pelo único corpo que ali habita. Parcialmente semelhante, a segunda tela perturba essa lógica em razão do contato direto entre a silhueta negra e o corpo feminino. A interseção acontece numa região marcadamente erógena, entre os seios e o início das pernas, que apresenta uma pigmentação avermelhada, ardente, indicando que ali, apesar dos mundos que separam os dois seres, é possível reaver um tipo de comunhão. ${ }^{69}$ É justamente o oposto do que acontece com o personagem de Grandrieux.

\footnotetext{
${ }^{69}$ Como se sabe a partir de uma entrevista de Picasso dada a David Duncan, as duas pinturas foram feitas no ano em que Françoise Gilot deixou o artista, sendo impregnadas por um conteúdo biográfico. Nelas se vê o antigo quarto do casal. A entrevista com Duncan é mencionada por Leo Steinberg, "Picasso: observando o sono", in Outros critérios, São Paulo: Cosac Naify, 2008.
} 
Fig. 9

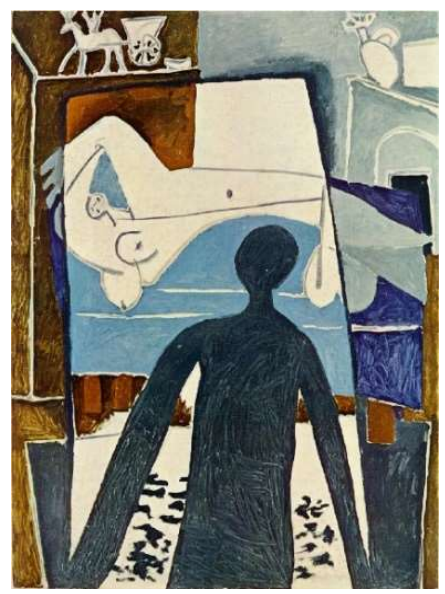

Fig. 10

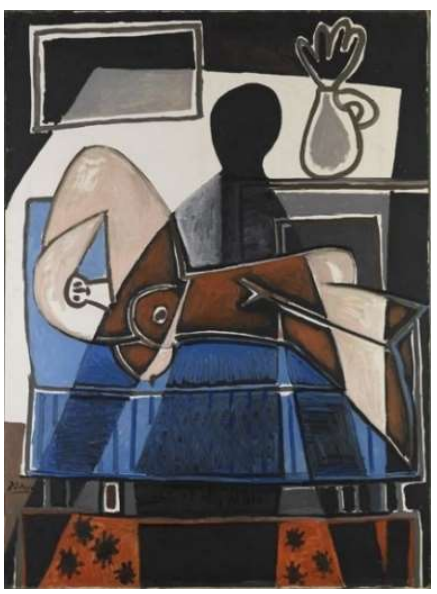

Ainda em Picasso, nas aquarelas Contemplação e Nu dormindo (Fig. 11-12), ambas de 1904, encontraremos o mesmo princípio compositivo. Embora a figura masculina seja dotada de uma corporeidade, continuam a ser empregadas estratégias visuais capazes de criar uma fratura, dois mundos separados a habitar uma mesma imagem. Um jogo de oposições desdobra a cisão entre gêneros: sono e vigília, leveza e rigidez, obliquidade e verticalidade, luz e sombra.

Fig. 11

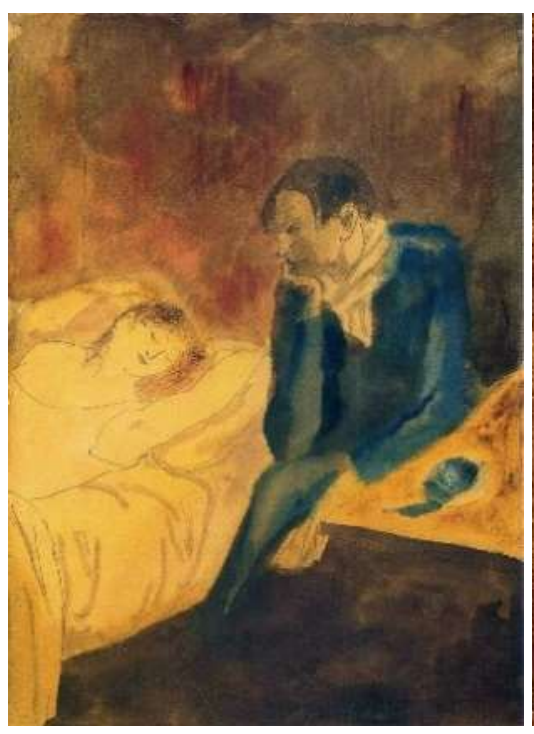

Fig. 12

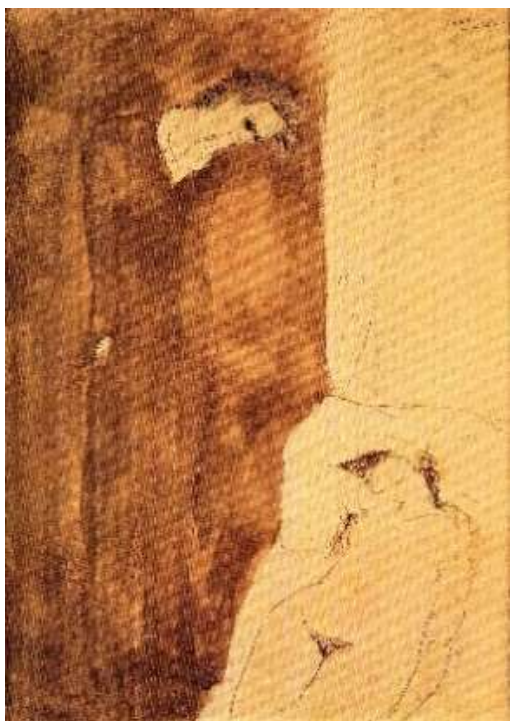

O cinema igualmente figurou a não reconciliação entre homem e mulher. Poderíamos alinhavar um grupo bastante heterogêneo, composto por Classe operária (Moonlighting, 1982, de Jerzy Skolimowski, Fig. 13), Amateur (1994, de Hal Hartley, Fig. 14), Blackout (1997, de Abel Ferrara, Fig. 15) e A prisioneira (La Captive, 2000, de Chantal Akerman, Fig. 16), em que homens contemplam a figura da mulher amada em diferentes 
suportes - fotografia, vídeo ou filme em película. Guardadas as devidas particularidades das telas de Picasso e desses filmes, todos recorrem a dispositivos de clivagem figurativa em razão dos quais a imagem feminina, mesmo que aparentemente próxima, encontra-se num espaço e num estado - de plenitude, graça ou indiferença - inalcançável pelo homem, ao qual resta o exílio do olhar. ${ }^{70}$

Fig. 13

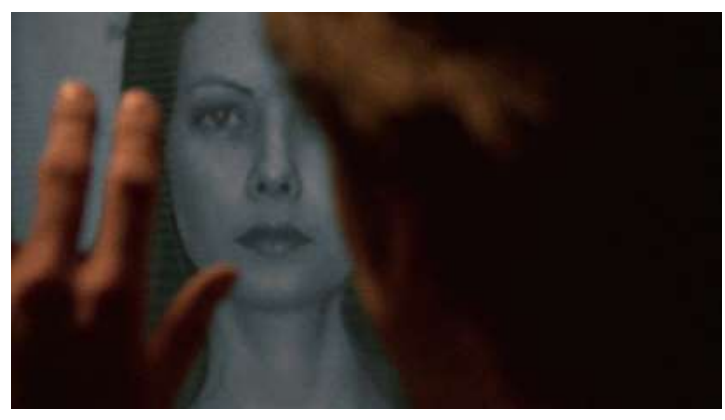

Fig. 15

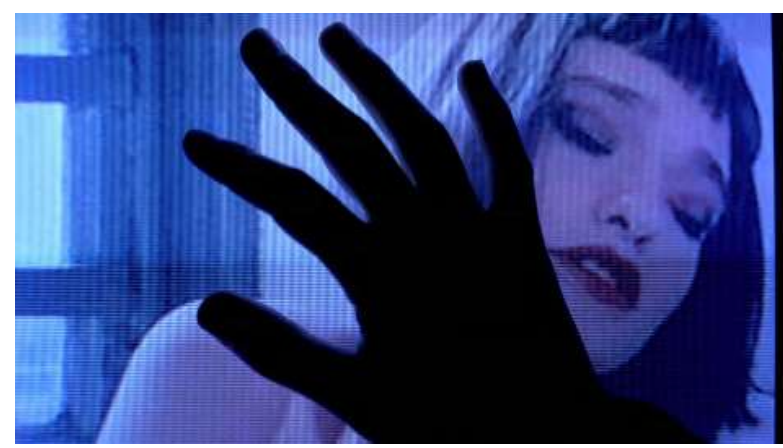

Fig. 14

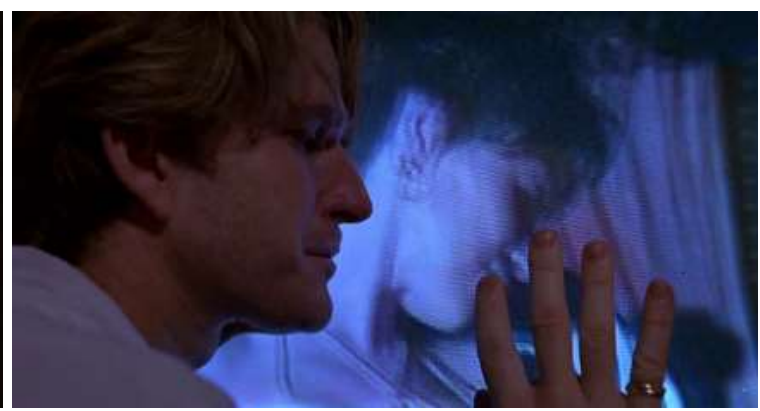

Fig. 16

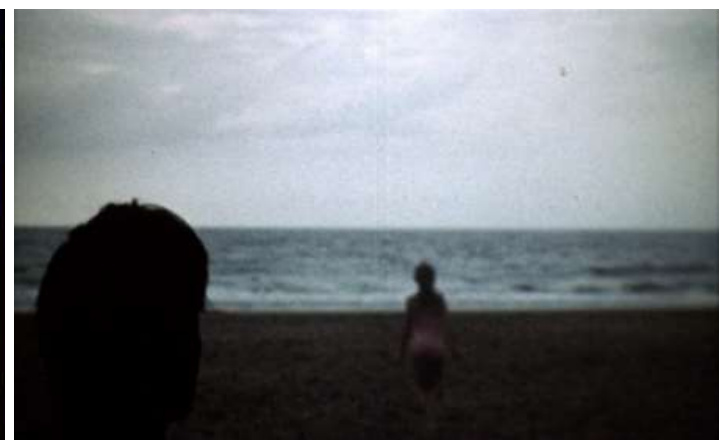

Nesse grupo de filmes, a contemplação alimenta a perda ou o distanciamento do outro, transformando sua imagem menos em rememoração do vivido do que em lembrança de sua intangibilidade. Não é por outra razão que neles acompanhamos momentos em que os personagens assumem uma cruzada órfica sintetizada pelo gesto da mão de tocar a imagem, tentando assim colmatar o abismo que separa inelutavelmente os seres. Sombra partilha dessa alienação do sujeito frente ao objeto de desejo. Mas enquanto nos filmes de Skolimowski, Ferrara, Hartley e Akerman a figura feminina surge em suportes imagéticos e assume uma natureza quase etérea e idealizada, em Grandrieux a ela é dedicada uma presença sobretudo carnal, uma fisicalidade que se contrapõe à natureza do protagonista. Além da clivagem entre gêneros, o que nos parece estar em jogo é o diálogo entre sombra e corpo, que reverbera em outros dípticos antitéticos e complementares: espectral e carnal, imagem e ser, e finalmente morte e vida.

\footnotetext{
${ }^{70} \mathrm{O}$ comentário foi inspirado pelo texto "Picasso: observando o sono", de Leo Steinberg, Op.cit.
} 
Se o mito de Plínio sugere um primeiro nível de interação entre esses polos, é em $A$ Divina Comédia (1304-1321), de Dante Alighieri, que encontraremos a sua cristalização. Ali, mesmo depois de mortos, portanto mesmo na ausência de seus corpos físicos, os seres continuam a viver na forma de sombras. Dito de outro modo, de imagens. Segundo Hans Belting, há um parentesco com culturas antigas nas quais um medium visual assume, por meio de um ritual, a encarnação de seres que já não possuem vínculo com o mundo terreno. ${ }^{71}$ Suplanta-se a disposição memorialística das imagens a fim de dar aos mortos um meio real, ainda que extremamente particular, de existência. Especificamente em Dante, é pela sombra que a alma assume outra vida em relação à realidade empírica, adquirindo um corpo fictício e virtual que pressupõe e invoca o real, embora dele se distancie ontologicamente por não partilhar de uma natureza material. ${ }^{72}$ A disparidade física entre um e outro é constatada quando Dante encontra Virgílio e outros que habitam o inferno. Nesse momento, percebe que apesar da existência visual, da aparência de corpos, está diante de figuras diáfanas: ao serem iluminadas pela luz, elas não projetam sombras; são almas visíveis, espectros a habitar o outro mundo.

Possuir uma sombra se torna, em Dante, um fator de vida, a linha que distingue os vivos dos mortos, os seres opacos dos translúcidos, aqueles que projetam e aqueles que são sombras. $^{73}$ Sua ausência, inversamente, demarca a aproximação com a morte ou o pertencimento a outro estatuto ontológico. Por razões distintas, encontraremos esse mesmo modelo de pensamento e de representação nas artes egípcia e medieval. A matriz da primeira estava baseada na representação de seres pertencentes não mais ao reino ordinário dos vivos mas ao além-mundo, a um espaço só acessível após a morte do corpo físico. À falta de escorço, às figuras retratadas de perfil e dispostas em um espaço sem profundidade no qual se deslocavam de um lado a outro, jamais em direção ao fundo, incorpora-se a ausência de sombra.

A arte bizantina se vale de outras escolhas formais que igualmente obstruem a semelhança entre a imagem e o referente real. Tanto o receio do culto idólatra da imagem, que em sua vertente mais radical daria origem às manifestações iconoclastas, como o desejo de fazer da pintura a evocação de uma ordem sagrada, resultam em estratégias de diferenciação entre a imagem figurada e o mundo terreno, entre o idealizado e o real. Em meio às escolhas,

\footnotetext{
${ }^{71}$ Hans Belting, Pour une anthropologie des images, Paris: Gallimard, 2004.

72 Ibid.; Cf. Victor I. Stoichita. Breve história da sombra, Lisboa: KKYM, 2016.

${ }^{73}$ Distinção que encontramos de modo quase literal na famosa cena da dança das sombras de $\operatorname{Vampyr}(1930)$, de Carl Theodor Dreyer: sem um corpo ao qual estejam vinculadas ou que as encarnem, elas existem por si mesmas, pertencendo a outro mundo.
} 
a ausência da sombra. A presença desta última poderia contribuir para a inserção dos corpos na representação de um espaço em três dimensões, não mais achatado. Igualmente, seria o sinal do pertencimento da figura à condição imanente. Como visto mais cedo, desde a Idade Média até meados do século XV, sob a influência dos dogmas da Igreja, que preconizavam a valorização da alma em detrimento do corpo, dos assuntos celestiais em oposição aos terrenos, a arte abdicava da representação dos seres segundo as leis da óptica. ${ }^{74}$ Desconsiderava-se, entre outras coisas, a sombra: nas telas daquele período, quando a figura intercepta a fonte de luz não deixa em torno de si silhueta ou qualquer rastro indicando que seu corpo opaco é iluminado. A sombra projetada é, pois, um indicativo da exposição às leis física que operam sobre os vivos, sinônimo do que é terreno, material. ${ }^{75}$ Em razão disso, só é reabilitada com o recrudescimento da consciência do ser humano como ser pertencente a uma realidade - ainda que parcialmente - secularizada.

Dificilmente se encontra a sombra projetada no filme de Grandrieux. Sua ausência pode ser justificada pela predominância ora de uma iluminação ambiente e sutil, sem contrastes, como a descrita a respeito da primeira cena, ora pela penumbra espessa que invade os espaços e visualmente transforma os seres em espectros. Relacionar exclusivamente tal ausência à subordinação de Jean a outra ordem talvez seja temerário, na medida em que ficaria difícil precisar se durante a realização do filme essa omissão foi uma decisão ou, o que é muito provável, consequência natural do tipo de iluminação. Por outro lado, não se pode ignorar que a raridade da sombra projetada é flanqueada pela sistemática figuração de Jean enquanto silhueta negra (Fig. 17-19) e igualmente por outros procedimentos figurativos cujos efeitos tendem a sublimar a presença corpórea do personagem, aproximando-o das criaturas de Dante - autor, aliás, diretamente referenciado por Grandrieux em A vida nova (La vie nouvelle, 2012), título homônimo de uma de suas obras.

Fig. 17

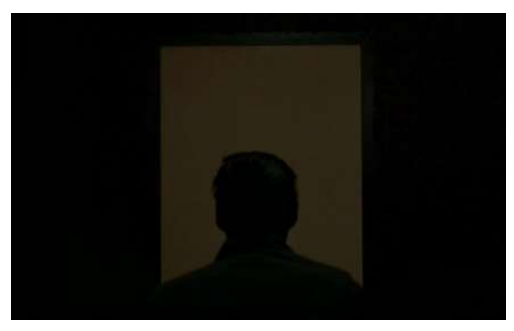

Fig. 18

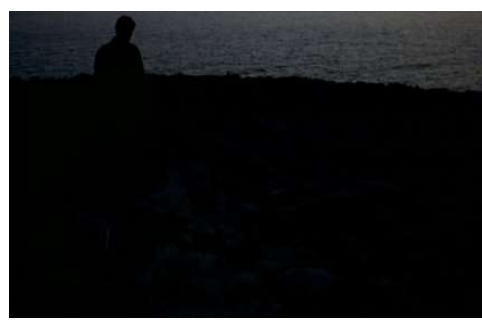

Fig. 19

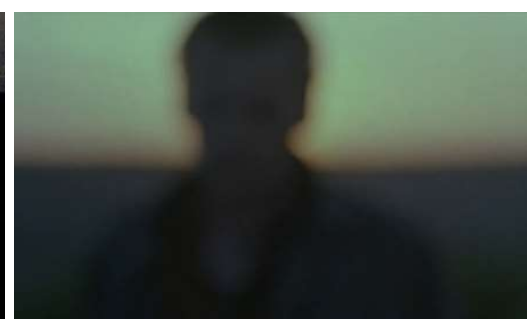

\footnotetext{
${ }^{74}$ Ainda que a óptica medieval estudasse com interesse a projeção das sombras, o estatuto (onto)lógico das imagens do período é, a princípio, o de uma entidade que se deseja isenta de corporeidade. Ver Victor I. Stoichita, 2016.

${ }^{75}$ Nadeije Laneyrie-Dagen. Op.cit.
} 
A figura fantasmagórica do protagonista é igualmente devedora da paleta de cores frias, situadas no espectro entre o azul e o violeta, com uma combinação de tons equivalentes, de mesmo valor cromático e de intensidade próximas. A consequência é o aspecto tonal do filme. Em cenas com desfoque ou com perda dos contornos figurativos - em razão de movimentos da câmera, do que é filmado, da aproximação excessiva (em todo caso, menor que a distância focal) da objetiva ou simplesmente pelo ajuste do foco -, Sombra sugere vagamente uma fotografia monocromática. No negrume e nos momentos parcamente iluminados, essas escolhas contribuem para a indistinção entre as figuras e o meio em que se encontram, para a perda de volumes e consequentemente para a assimilação ao espaço pictórico. Os demais personagens são em maior ou em menor grau afetados por esse tratamento. Jean, porém, é a principal vítima da pouca diferenciação em relação à superfície da imagem. O contraste maior nesse caso corresponde, como já sinalizado, à diferenciação entre os gêneros.

Acompanhemos mais um exemplo, dessa vez pautado em outras nuances pictóricas e igualmente no movimento dos corpos, referente ao momento em que o protagonista entra numa boate onde depara com uma stripper, uma vítima em potencial. Na sequência, Jean encontra-se na maior parte do tempo integrado à turva escuridão, imiscuído aos tons azulados e pretos, visível apenas pelas intermitências da luz bruxuleante, ou desfocado e achatado junto à superfície da imagem. Durante a perambulação pelo espaço, sua figura será contraposta à de uma das dançarinas. Enquanto o protagonista sofre diferentes efeitos de supressão, a mulher será progressivamente evidenciada na imagem. Ela aparece inicialmente num plano de curtíssima duração, como forma escura e pouco distinta do restante do espaço. Posteriormente, pela sombra projetada na superfície de um dos muros. Por fim, seu corpo é visualmente revelado, ganhando volume diante do negrume azulado da imagem ao ser iluminado pela intermitência de tons amarelos e vermelhos, quando a câmera se aproxima e a perscruta, deixando-se conduzir pelo movimento erótico da dança e pela protuberância da carne. Enquanto isso, a montagem acelerada de fragmentos do seu corpo intensifica o ritmo e a potência da cena. Os graves da música eletrônica, a cintilação das luzes e cores, e a interação entre corpo e câmera criam um frenesi do qual parece redundar a imponência física da dançarina.

$\mathrm{O}$ que se desenrola nessa sequência é o processo que dá origem às clivagens comentadas anteriormente. Desta vez, principalmente graças à contraposição das cores quentes e frias como modos de destacar a figura do fundo da imagem, mas também à relação de proximidade entre o movimento erótico da dança e a câmera, em contraposição à 
caminhada solitária de Jean. A figura feminina é desbastada do espaço escuro como uma escultura é talhada a partir do mármore (Fig. 20-23). Presencia-se a própria encarnação plástica da dançarina, que inicia com sua aparição informe, passa pelo momento em que sua figura bloqueia a luz e projeta a sombra, como um ser material, e finalmente culmina no seu devir físico, que será explorado pela câmera, pela montagem e posteriormente pelo olhar de Jean. Em contraste, ao longo da sequência: sombra e corpo, masculino e feminino.

Fig. 20-21
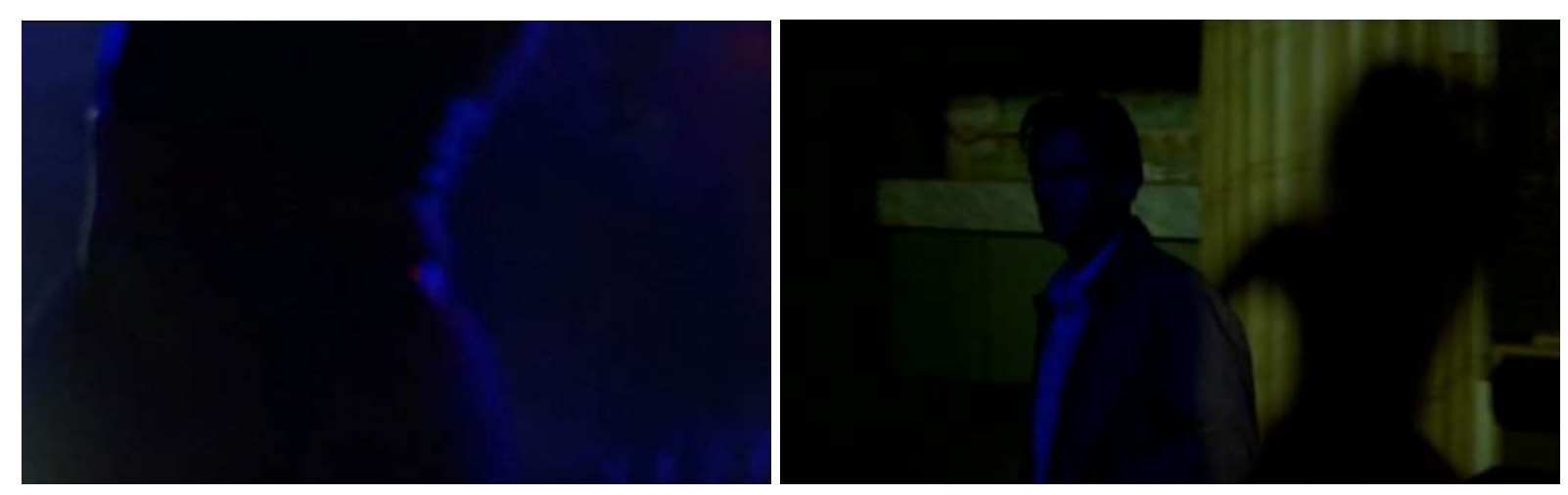

Fig. 22-23
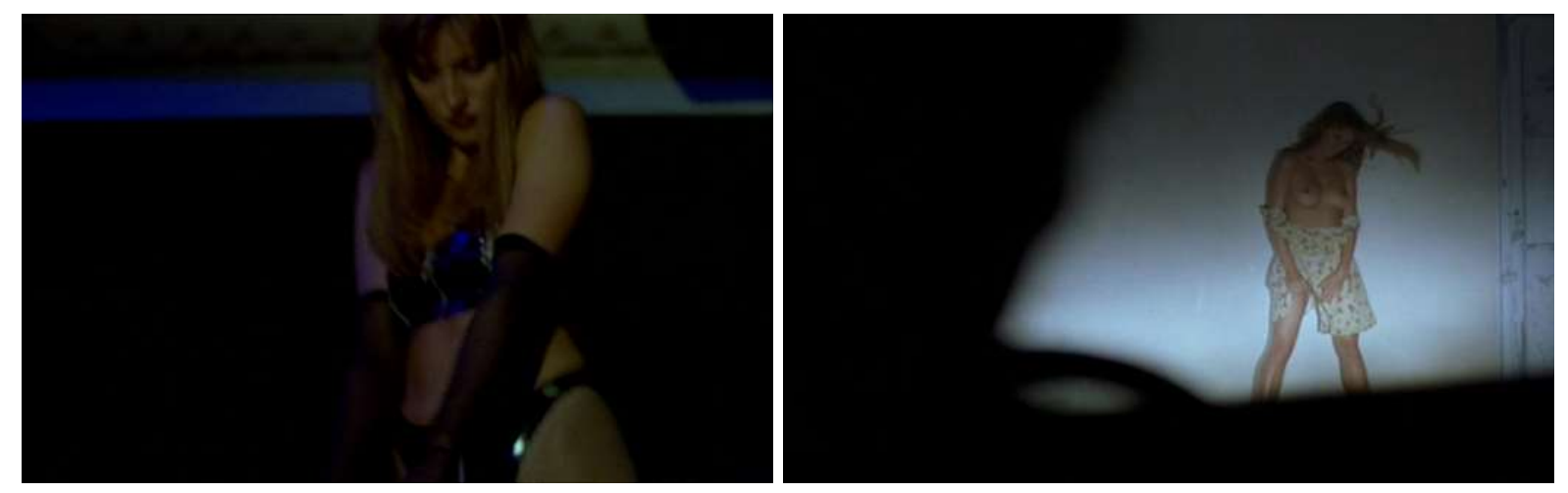

\subsubsection{O desregramento do feminino}

Ao longo de Sombra, a representação do corpo das mulheres porta consigo outras nuances para além da evidente oposição estabelecida diante de Jean. Nesse sentido, a sequência da boate é reveladora.

Decorrente da interação do corpo com as luzes e as cores quentes, a presença da dançarina é ali intensificada pelo movimento, especificamente pela dança. Não será a única vez que esses elementos se associam no cinema de Grandrieux. Num filme posterior, $A$ vida nova, a cena se repete: o protagonista Seymour perambula por uma boate quando é arrebatado 
pela dança de uma das strippers. O seu estado, a princípio de curiosidade e excitação escopofílica, muda bruscamente. Na cena seguinte, ele aparece envolto pela escuridão, com um olhar absorto frente à contemplação da figura feminina tal como se preso a uma visão onírica da qual é incapaz de usufruir de maneira ativa, deixando-se conduzir por um estado de absorção. Os únicos elementos que se distinguem no espaço são o rosto de Seymour, partes do corpo da dançarina e, depois, a aparição de Melania, personagem surgida no negrume como uma espécie de miragem. A dança da stripper é o que dispara a excitação e, posteriormente, o estado sonial do personagem. A vida nova e Sombra vinculam assim a carnalidade da mulher a um erotismo criado a partir do movimento - intensificado pela potência dos graves da música tecno. Caso cotejemos esse indício com uma curta e sugestiva observação de Baudelaire sobre a dança como aquilo que faz a matéria ao mesmo tempo graciosa e terrível, aquilo que a embeleza e a anima, a questão nos dois filmes aparenta ser a da capacidade desse movimento corporal de promover a força que dá vida à figura feminina e paralelamente a modela dentro de uma lógica, a do desregramento. ${ }^{76}$

Ao observar a cena da encarnação visual da dançarina em Sombra, reparamos como a câmera e a montagem se deixam ser conduzidas pelo movimento e pela música. O que agora gostaríamos de indicar é o modo pelo qual essa condição reflete e intensifica um excesso atrelado à figura feminina, uma dificuldade de agenciamento de sua forma, um transbordamento de sua matéria. O filme é pontuado por uma rede de constrangimentos que tenta controlar o corpo da mulher. O primeiro e mais evidente é o gesto assassino de Jean, cuja incapacidade frente à presença física e carnal das vítimas, o fracasso em usufruir do desejo e consumar o ato sexual, converte a pulsão libidinal em uma pulsão de morte, criando uma existência que depende da eliminação do outro, figurativamente mostrado pelo signo da disjunção. Afora essa disposição, e certamente a ela vinculada, a própria mise en scène forja a dificuldade de plasmar uma pulsão que a excede. A montagem da cena da dançarina pulveriza o corpo em pequenos fragmentos, com clara preferência por zonas erógenas. A curta duração e o encadeamento de planos com o mesmo movimento, em rápidas repetições, criam uma disposição espiralar, vertiginosa, dificultando a reconstituição da figura da dançarina em uma forma precisa e delineada. O flou e a intermitência luminosa tornam a sua imagem ainda mais difusa. A matéria não é conformada, ou, se quisermos fazer referência à querela pictórica entre cor e desenho, entre háptico e óptico, o movimento conservativo da linha não produz

\footnotetext{
76 “A dança pode revelar tudo de misterioso que é velado na música, tendo ainda o mérito de ser humana e palpável. A dança é a poesia com os braços e as pernas, é a matéria, graciosa e terrível, animada, embelezada pelo movimento". Charles Baudelaire, La Fanfarlo, Paris: Boucher, 2002, p. 27.
} 
uma estrutura definida, assimilável e clara que agencie a percepção do corpo no espaço inteligível. ${ }^{77}$

Se concordarmos com Paul Valéry que a dança é uma espécie de gestão do movimento que não necessariamente o conduz a uma evolução determinada, a uma causa a ser alcançada, a um ato a ser concluído, encadeando uma série de movimentos que têm neles próprios um fim, ${ }^{78}$ é o movimento da figura em consonância e ressonância com a câmera, a montagem e a música que irá dissipar, fazer transbordar a presença da dançarina em uma figura difusa, percebida, mas não dominada, não enformada. Na descrição do que chamamos de encarnação visual da dançarina, subsistia uma lógica escultórica: a mise en scène destaca do azulado tonal da boate um corpo, tal como um escultor retira a figura do mármore. Caso desejemos continuar com essa analogia, poderíamos dizer que, enquanto uma escultura clássica circunscreve o movimento e impõe limites por meio dos quais o gesto mais intenso não se expande, mas retorna e se concentra na própria obra, numa contenção de forças pelo hieratismo, ${ }^{79}$ em Sombra a sinergia entre a música e os movimentos do corpo e do aparato (câmera e montagem) investe a figura humana de opulência carnal e de sensualidade, insuflaa de um vigor inaudito que se expande para além do corpo, ressoando nas configurações plásticas da imagem. É a dimensão sensível (som e movimento) que faz pela dançarina do filme de Grandrieux o que a primazia do colorido fez pelo modelado da figura humana na pintura europeia. O gesto do cineasta, ou o da mise en scène, equipara-se e redobra o do protagonista no malogro em moldar, plasmar o feminino. Mas, afinal, qula o significado de uma tal figuração do corpo da mulher? A qual tradição poderíamos vinculá-la?

Um primeiro ponto a observar é o alinhamento do debate entretido em Sombra com a clivagem figurativa entre gêneros recorrente na história da arte ocidental europeia, veiculada, por exemplo no impressionismo francês, quando a tradição do nu feminino se afasta parcialmente da tentativa de figurar o corpo enquanto vetor de uma beleza ideal e por isso desencarnada, por vezes transcendente, para nele resgatar uma espécie de potência sensual. ${ }^{80}$

\footnotetext{
${ }^{77}$ Um debate feito pela revista francesa Cahiers du Cinéma se aproveitou da querela entre desenho e cor na história da arte como analogia para distinguir a mise en scène de uma estética do fluxo no cinema contemporâneo, incluindo filmes de Grandrieux. Voltaremos pontualmente a essa questão no Capítulo 2.

${ }^{78}$ Paul Valéry. Degas, dança, desenho, São Paulo: Cosac Naify, 2003.

${ }^{79}$ Rainer Maria Rilke. Auguste Rodin, São Paulo: Nova Alexandria, 2003.

${ }^{80}$ No que toca à distinção entre gêneros, pode-se recordar também da exclusão do corpo feminino em artistas que representavam a figura humana a partir do cânone das proporções, no século XV. A ausência era justificada por alguns autores, como Cennini, pelas hipotéticas medidas imperfeitas, não agenciáveis a um esquematismo geométrico. ${ }^{80}$ Essa ideia misógina de uma inferioridade do corpo feminino, marcante entre os séculos XV e XVII, era explicada por um argumento teológico: no cristianismo, a alusão à mulher como ser criado a partir da costela de Adão e por isso tratada como criatura secundária, sempre na qualidade de reflexo imperfeito de um projeto divino. A reabilitação estética do corpo feminino aconteceria com Durer, pela publicação Quatro livros
} 
Nas dançarinas pintadas por Degas, por exemplo, isso acontece pela conversão do corpo feminino em espetáculo a ser consumido pelo olhar masculino, num processo de monetarização e objetificação sexual. Na série de bailarinas do pintor (Ballet, vu d'une loge, 1884, por exemplo), tal como em Sombra, a natureza fragmentária da visão expõe a decomposição do corpo em zonas erógenas bem como enuncia a presença de um olhar que o reveste de sexualidade. ${ }^{81}$

Para além das bailarinas de Degas, é possível resgatar o tema das banhistas, que, conforme Tamar Garb, contribuiu diretamente para a exploração da sensualidade da figura feminina pelos expoentes daquela geração. ${ }^{82}$ Uma das telas analisadas pela autora é Torse de jeune fille au soleil (1875, Fig. 24), de Pierre-Auguste Renoir. Retomando o padrão de fantasias arcádicas do final do século XIX e de seu mundo mítico, o corpo feminino de uma ninfa aparece intimamente misturado à água e às folhagens. A tela evoca uma textura pictórica em que a carne, a vegetação, o cabelo e o tecido fornecem uma superfície, um travesseiro macio e aveludado sobre o qual o observador urbano da Paris do século XIX poderia repousar o seu olhar. Se a cobertura da metade inferior do corpo pelo tecido é reminiscência do drapeado clássico e permite traçar uma linhagem de protótipos presentes desde a Alta Renascença ao século XIX, outros aspectos derivam da perspectiva cultural e histórica sobre o corpo feminino. Particularmente para Renoir, a evocação da mulher nua na paisagem idílica estava associada à tentativa de deslindar parcialmente seu corpo de signos e de artifícios da civilização, promovendo o retorno a uma feminilidade pré-moderna, "natural" - ainda que, ironicamente, corresponda a uma concepção de natureza e de feminino marcadamente cultural. Garb identifica em outras obras e igualmente em publicidades referentes aos Salões de Paris, a reprodução desse padrão que tende a alinhar o feminino ao mundo natural e a uma espécie de inspiração, de musa capaz de fazer aflorar a sensibilidade e o gesto criativo dos pintores. ${ }^{83}$

das proporções humanas, e posteriormente com Rubens, cuja obra propiciaria um ideal de beleza a partir da carnalidade da mulher. O pintor flamengo, aliás, foi uma inspiração para os nus de mulheres com formas arredondadas, vistas de costas ou inclinadas sobre o próprio ventre, em Watteau e Boucher, no século XVIII; e no século XIX, dos corpos opulentos de Courbet. Ver: Cennino Cennini, "O livro da arte", in Jacqueline Lichtenstein, A pintura - Vol.6: A figura humana, São Paulo: Editora 34, 2004, p. 23; Nadeije Laneyrye-Dagen. Op.cit. A respeito da relação entre a figura feminina e as formas circulares, consultar: Peter Paul Rubens, "Teoria da figura humana, considerada em seus princípios, seja em repouso ou em movimento", in Jacqueline Lichtenstein, Op.cit.

${ }^{81}$ Tamar Garb, The body in time: figures of femininity in late 19th century France, Seattle: University of Washington Press, 2008.

82 Tamar Garb, "Painterly plenitude: Pierre-Auguste Renoir's Fantasy of the Feminine”, in Bodies of modernity, Londres: Thames and Hudson, 1998, pp. 144-177.

${ }^{83}$ Tamar Garb, "Visuality and sexuality in Cézanne's Late Bathers", The Oxford Art Journal, Vol. 19, No. 2, 1996, pp. 46-60. 
Fig. 24

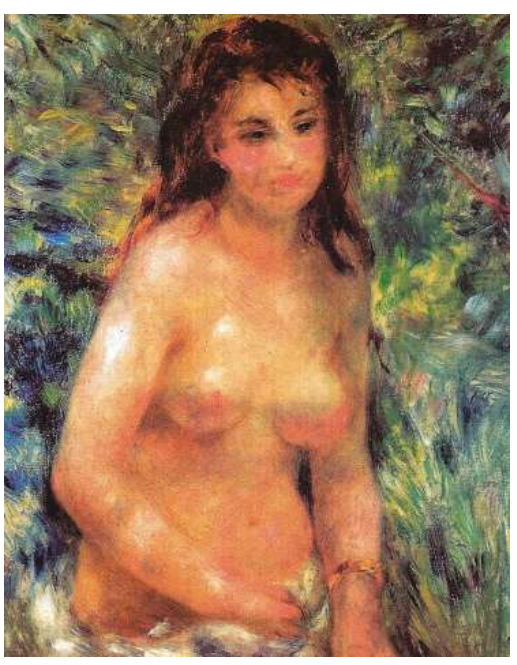

Fig. 25

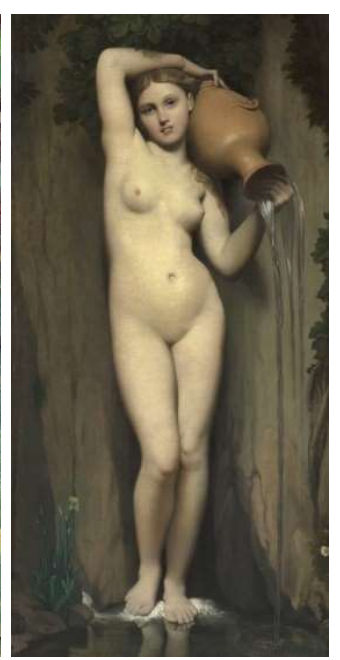

Ainda sobre a tela de Renoir, a segunda questão a ser sublinhada é a presença sensual da figura. Parte disso, como Garb salienta, vem do tratamento da pele enquanto superfície desigual, fluida, diretamente exposta e matizada pela natureza que a circunda. $\mathrm{O}$ aspecto tátil é salientado pela interação do corpo com os efeitos da atmosfera; o modulado constituído pelo rebatimento entre a carne e a dança fervilhante das cores e das luzes, originado pela presença da figura no meio, face às vicissitudes do tempo e do espaço. A possível dimensão espiritual ou hipoteticamente imortal, reservada ao nu marmóreo e acadêmico de uma tela como $A$ fonte (La source, 1856, Fig. 25), de Ingres, por exemplo, cede à corporeidade resultante do encontro com a (da presença na) natureza e da exposição da mulher enquanto objeto erótico, vulnerável, em parte despojado dos atributos da civilização, emoldurado pela fantasia de um nu "natural" destinado ao olhar. A beleza perdura, mas o etéreo se torna poroso ao tempo e o corpo ao agora de sua sensualidade carnal.

O filme de Grandrieux e as telas de Degas e Renoir apresentam estratégias que associam e, por vezes, reduzem a figura feminina a seu erotismo. Quer seja a fantasia de um "nu natural" nos impressionistas, quer seja um personagem apartado do que deseja, recorre-se a um esquema binário: o corpo da mulher, matizado pela sensualidade, sujeito ao olhar masculino (dos pintores, de Jean, de Grandrieux). Assim, as obras mencionadas aproximamse de um discurso e de uma figuração tradicionalmente identificados pela teoria feminista. Trata-se da tendência a se pensar o corpo carnal como sendo unicamente o feminino, vinculando as mulheres à matéria (seja ela inerte, morta, fecunda, imortal ou procriadora), enquanto ao homem é reservada a posição daquele que assume o domínio racional: 
A origem da associação clássica da feminilidade com a materialidade pode ser vinculada a uma série de etimologias que ligam a matéria aos termos mater ou matrix (o útero) e que a associam então à problemática da reprodução. A concepção clássica da matéria como lugar de geração ou de origem se torna particularmente reveladora desde que a análise do que é um objeto e do que ele significa exige considerar o princípio de sua geração. Desde que a matéria não esteja explicitamente associada à reprodução, ela é mais geralmente definida como um princípio de geração ou de causalidade. ${ }^{84}$

Algumas autoras feministas retomam criticamente a história da filosofia a fim de identificar as marcas desse discurso, em específico, e o de uma economia falogocêntrica, em geral. Importante fonte para esse debate são as análises, retomadas por Butler, de Luce Irigaray sobre a cosmogonia das formas em Timeu de Platão, na qual a autora identifica o feminino como um termo não completamente inteligível, apresentado sob a égide de uma catacrese, assumindo o papel de um tipo de superfície especular que existe como lugar de inscrição do ato de significação masculino. ${ }^{85}$ Corolário a essa conjuntura, a criação de uma falsa imagem do feminino, um reflexo que interessa menos pelo que é do que propriamente como meio de perpetuação e imposição do lugar do outro. Escondido, recalcado por essa imagem, por esse duplo, estaria um feminino não tematizável, privado virtualmente de forma inteligível.

Não objetivamos levar à risca a análise de Irigaray, que muito grosseiramente resumimos, como chave interpretativa para o filme de Grandrieux, mas supomos que ela reforça o que expusemos mais cedo a respeito de uma das manifestações da clivagem figurativa entre gêneros ser a representação das mulheres a partir de um duplo itinerário: uma presença restrita ao erotismo e, paralelamente, ações, diegéticas e na forma fílmica, pautadas no controle deste excesso carnal. ${ }^{86}$

\subsubsection{Imagem, terra dos mortos}

A figuração de Jean na forma de sombra e, em consequência, sua constante integração à superfície da imagem cinematográfica, pela qual sua natureza visual é esvaecida, ganha um sentido a mais quando a relacionamos com a ideia de uma presença feminina a ser reiteradamente coagida posto que difícil de ser enformada. Ecoando o que antes foi escrito a respeito de Dante, o recurso à sombra seria o sinal de ausência ou perda parcial do corpo; o

\footnotetext{
${ }^{84}$ Judith Butler, Op. cit.

${ }^{85}$ Ver a leitura crítica feita por Butler (Op.cit.) sobre Irigaray.

${ }^{86} \mathrm{O}$ que, vale pontuar, ganha outras nuances com o aparecimento de Claire, personagem que perturba essa economia normativa e impositiva do masculino sobre o feminino, assumindo um papel ativo sobre Jean e também permanecendo imune à sua violência.
} 
percurso de Jean consiste, desse modo, numa espécie de peregrinação vampírica a fim de prover-se da matéria carnal (feminina) que lhe falta. Isso não implica em tomar o personagem por uma criatura exclusivamente fantástica, sem corporeidade, mas de reconhecer que ao longo do filme são empregadas estratégias figurativas que sinalizam uma espécie de debilidade, de perda de substancialidade a partir da contraposição entre gêneros. Ao passo que a figura masculina possui uma existência fugidia, composta de matéria visualmente vaporosa, o corpo feminino é ancorado no espaço pelo fremir dos movimentos e pela densidade da presença sensual.

O trajeto de Jean, em seu constante deslocamento, dirigindo-se de um lugar a outro, incapaz de fixar-se em um espaço, numa incessante busca por algo não definido narrativamente, alheio às relações sociais (mesmo quando parece se apaixonar por Claire), aproximam seu itinerário ao de um ser que vaga pelo limbo, por um mundo ao qual ele já não mais pertence. Seu percurso é pontuado por assassinatos, o que leva a pensar na natureza vampírica do protagonista, na necessidade de se apropriar da vida das mulheres, tal como um duplo impalpável sem força vital própria e por isso subordinado ao insumo de outrem.

A partir dessas suspeitas, somos direcionados a dois caminhos, a duas vias de entendimento possíveis sobre a sombra e o sentido desse tipo de figuração para o significado do corpo representado. Uma a associa a uma espécie de perversão (metaforicamente, ela revela a realidade oculta e vil do sujeito), a outra a encara a partir de um déficit (perda de volume da figura, ausência de corporeidade, espectralização).

No que concerne à perversão, a sombra seria a manifestação plástica da natureza tenebrosa de Jean. Talvez por isso, antes de matar suas primeiras vítimas, seu corpo é apresentado na forma de uma silhueta negra, numa antecipação da crueldade que está por vir. A transfiguração, parece-nos, traz consigo a carga simbólica do preto, que entre outras fontes deriva do cristianismo. Conforme Pastoureau, desde o Gênesis bíblico, o preto é imbuído de estatuto negativo. ${ }^{87}$ Cor primordial, quando a Terra ainda não tem forma e nela só existe o vazio: tudo está mergulhado na escuridão até que Deus diga, "Fiat lux", e assim a luz dissipa as trevas e cria as condições para a vida. Desde então, o preto amarga a ligação com o mortífero e o vazio. Cor do caos originário, da noite perigosa, maléfica e especialmente da morte, sendo frequentemente associada ao erro e ao sofrimento. Já nos primórdios do cristianismo é também a cor do Inferno (juntamente com o vermelho) e do Diabo. Este último, cujas primeiras aparições pictóricas acontecem a partir do século VI, revela um traço

\footnotetext{
${ }^{87}$ Michel Pastoureau, Black: the history of a color, Nova Jérsia: Princeton University Press, 2008.
} 
marcante na arte românica, em meados do século XI: é sempre o "elemento mais saturado da imagem, aquele que, cromaticamente, é mais denso. É um meio de valorizar e de evocar a opacidade sufocante das trevas, que se opõe ao caráter translúcido da luz e de tudo o que é divino". 88

A natureza umbrática que Jean assume em determinados momentos recupera parcial e muito livremente o simbolismo negativo do preto. Do mesmo modo, o filme não é isento das marcas de uma teologia cristã da luz. A virgem por quem o personagem se apaixona, chamase Claire (Clara, em português). O nome não é acidental. À exceção da sequência do lago, a ela é dedicado o único plano de iluminação solar direta no filme. Enquanto está sentada no banco do automóvel dirigido por Jean, um raio de luz entra pela janela, irradia sobre seu rosto e rebate discretamente no protagonista. Se na pintura ocidental o azul foi a cor destinada ao manto e à indumentária da Virgem Maria, predominantemente entre os séculos XII e a arte barroca, ${ }^{89}$ Grandrieux também nos apresenta uma virgem vestida de azul, mas que é coberta, ainda que por poucos segundos, por um manto de luz. A cena parece indicar a interferência benéfica que Claire desencadeia em Jean, visto que ao conhecê-la ele interrompe os assassinatos - mas como toda luz deste filme, entretanto, Claire não passa de um lampejo, uma réstia de sol incapaz de afugentar a escuridão, e os homicídios não tardarão a retornar.

A polarização entre sombra e luz não é tão maniqueísta quanto o nosso relato parece sugerir. Claire e Jean não encarnam, respectivamente, a Santa e o Diabo, mas, como já mencionamos, são impregnados pelo simbolismo cristão entre o claro e o escuro, a luz e as trevas. Tal binarismo remete a um diretor que Grandrieux geralmente menciona como influência importante para seu cinema, F.W. Murnau. ${ }^{90}$ Adotando um tratamento mais sistemático e menos dúbio da luz e da sombra, não é raro que no cineasta alemão a transfiguração dos seres em sombra e a presença na escuridão designem o maléfico ou remetam à morte. Em oposição, a luz porta a resignação, a reconciliação entre os seres e deles com o mundo: ao final de Aurora (Sunrise: a song of two humans, 1927, Fig. 26), a imagem resplandecente do casal de protagonistas, plenamente felizes, sendo sobreposta pelo fulgor matinal e redentor que primeiramente entra pela janela e depois ocupa todo o plano; na derradeira cena de Nosferatu, a luz também entra pela janela para extirpar de vez a presença maligna do vampiro. Essas duas sequências se passam em cômodos fechados. O ingresso da luz, além de dissipar as trevas, é a comunicação entre o interior e o exterior, entre os

\footnotetext{
${ }^{88}$ Ibid., p. 54.

${ }^{89}$ Michel Pastoureau, Bleu: histoire d'une couleur, Paris : Éditions du Seuil, 2000.

${ }^{90}$ Cloe Masotta, "La plástica del deseo: entrevista a Philippe Grandrieux", in Transit, março de 2010. Disponível em: <http://cinentransit.com/entrevista-a-philippe-grandrieux/>. Acesso em: 2 outubro de 2015.
} 
personagens e um mundo que os acolhe e os reintegra a uma ordem reconciliatória. Mas talvez o maior emblema de tamanha polaridade, em Murnau, seja a sequência final de Fausto (Faust, 1926) que, como na inicial, apresenta o combate entre o Anjo, encarnação pictórica da luz, e o Diabo, representado pela escuridão, na forma de silhueta.

Fig. 26

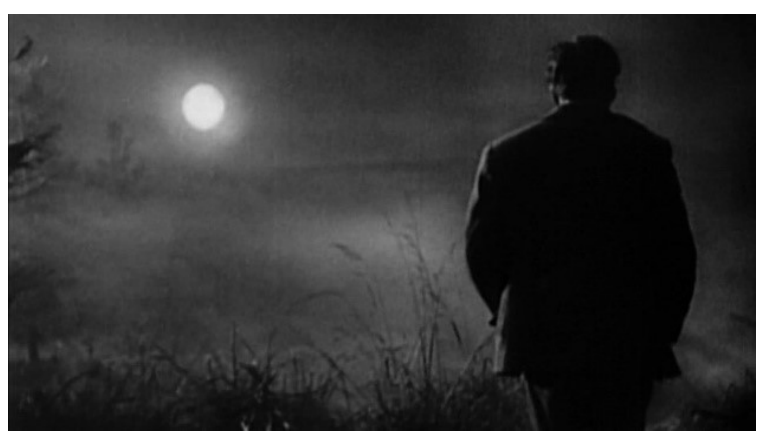

Fig. 27

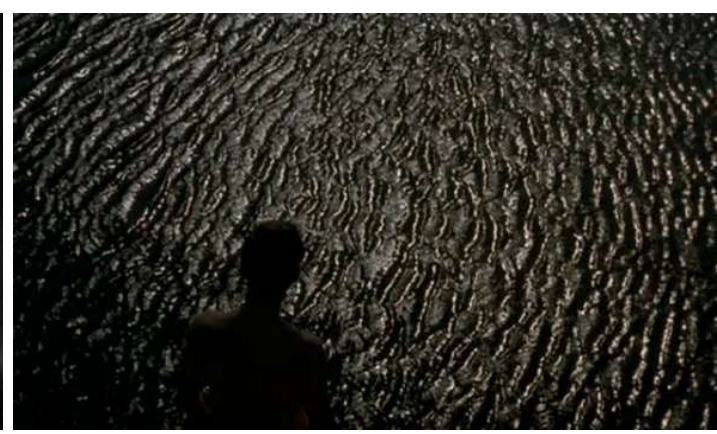

Não só o cristianismo, mas a literatura romântica, desde os seus primórdios, recupera a associação entre o preto e a perversão. Ali, o tema do duplo encontra na sombra o seu meio de expressão. Ela aparece como extensão do eu, sósia, imagem noturna que desvela os contornos sinistros do que o seu protótipo oculta, sinalizando o Outro, indicando a duplicidade que perturba a consciência. Isso antecipa a noção, presente na arte moderna, e em especial no surrealismo, de que cada homem abrigaria em si um hóspede desconhecido, tal como escreve Breton. ${ }^{91}$ À primeira vista, não seria difícil aproximar Jean desse quadro de referências, principalmente se considerarmos sua reiterada consternação (arrependimento?) diante dos próprios atos, o que fica mais patente com a chegada de Claire. Por outro lado, além desse aparente resquício de culpa, o filme não dá sinais de outra personalidade, nada se contrapõe ao lado sombrio do protagonista: se não o encerra dentro de uma chave maniqueísta de vilania, também não o redime. Cria-se uma ambiguidade que é resultante menos do agrupamento de polaridades que da ausência delas, de um esvaziamento de referências. Dentro desse quadro, a sombra seria o signo da opacidade, devendo ser lida pelo que visualmente é: matéria de contornos pouco precisos, fluidos, e cujo interior é insondável ao olhar (Fig. 27).

Do primeiro sentido atribuído à sombra, vinculado à noção de perversão, cabe retermos a associação com um universo mortífero - que remete à discussão pregressa sobre Dante e às artes egípcia e medieval -, e a ideia de opacidade de sentido. Esse último ponto, aliás, é no filme de Grandrieux uma das razões que torna difícil buscarmos uma encarnação da figura

\footnotetext{
${ }^{91}$ Eliane Robert Moraes, O corpo impossível, São Paulo: Iluminuras, 2012.
} 
humana pautada majoritariamente no conjunto de indícios e de ações que a associem a um personagem com papel claro dentro de um universo fictício.

A segunda via, a sombra como revelação de um déficit corporal, manifesta-se no vampirismo de Jean, em sua peregrinação como figura que busca um substrato para o corpo vinculado à figura feminina. Sombra reivindica, sob esse aspecto, uma filiação àquilo que poderíamos designar como uma espécie de "síndrome de Nosferatu". Trata-se de uma tendência que atravessa a história do cinema e convida ao debate sobre a presença da figura humana, uma vez que põe em evidência a força vital do corpo representado, buscando reconhecer o que o anima e o que o ameaça. Tal síndrome, recorrente em gêneros como o terror, corresponde à figuração de corpos no limiar da vida, vivendo em um espaço intersticial, esvaziados parcialmente de sua energia essencial, por vezes de sua matéria, seja ela física ou de outra natureza. A evidenciação desse estado acontece por meio de um regime de reflexividade que associa a existência e a debilidade da figura humana diretamente às propriedades do medium e, assinaladamente, às da imagem cinematográfica. Representar o corpo a partir da sombra seria um dos recursos a estabelecer uma ponte entre a figura e o dispositivo - na esteira do que Belting reconheceu como "teoria da imagem" ou mesmo "teoria artística" de Dante, fincada na associação e analogia entre a sombra e a própria natureza da imagem como formas vestigiais de outro ser. Como agora tentaremos mostrar, através de outros exemplos, alheios ao filme de Grandrieux, esvaziar o modulado, reduzir a carne visual a uma massa escura, a uma silhueta, ou mesmo a um corpo diáfano, corresponderia a uma menção autorreflexiva e, em termos semânticos, é frequentemente associada à condição de miséria material e moral, ou mesmo a um tipo de ameaça à integridade física e existencial do corpo.

No cinema clássico, John Ford foi sensível à questão de que tratamos. Em As vinhas da ira (The Grapes of Wrath, 1940), a crise no sistema de arrendamento das terras faz com que os pequenos agricultores sejam expulsos dos lugares que habitam há várias gerações e dos quais tiram o seu meio de subsistência. A mise en scène pronuncia a condição miserável a que serão relegados ao mostrar a "conversão" dos personagens em sombras. Numa das sequências a família do personagem Muley vê a casa em que moravam sendo demolida. Um plano conjunto os mostra imobilizados, incrédulos diante do que observam. Então, um travelling parte de suas figuras perplexas, desce até o chão, onde suas sombras estão projetadas sobre o solo, e depois continua num movimento lateral até enquadrar o trator destruindo a casa e desaparecendo no horizonte. O próximo plano repete o enquadramento dos personagens 
enregelados a olhar o fora de campo e novamente a câmera refaz o movimento em direção ao chão, passando dos corpos para as suas sombras (Fig. 28-30).

Nessa sequência, a silhueta negra cria uma extensão da figura humana sobre o espaço, indicando o elo vital que existe entre os personagens e o território onde nasceram, trabalharam e esperavam morrer. ${ }^{92}$ Ao mesmo tempo, a sombra é o sinal da mudança de condição social, da retirada do que é mais caro para a vida daquela família, denotando a miserabilidade a que serão condenados: sem moradia, perambulando escondidos pelas antigas terras e a dormir na estrada e em lugares abandonados, vivendo às escuras, sob a luz tremeluzente de velas, sob a ameaça de desaparecem na treva, como sombras. "Sou apenas um velho fantasma num cemitério. É tudo o que sou no mundo", diz Muley.

Fig. 28-30
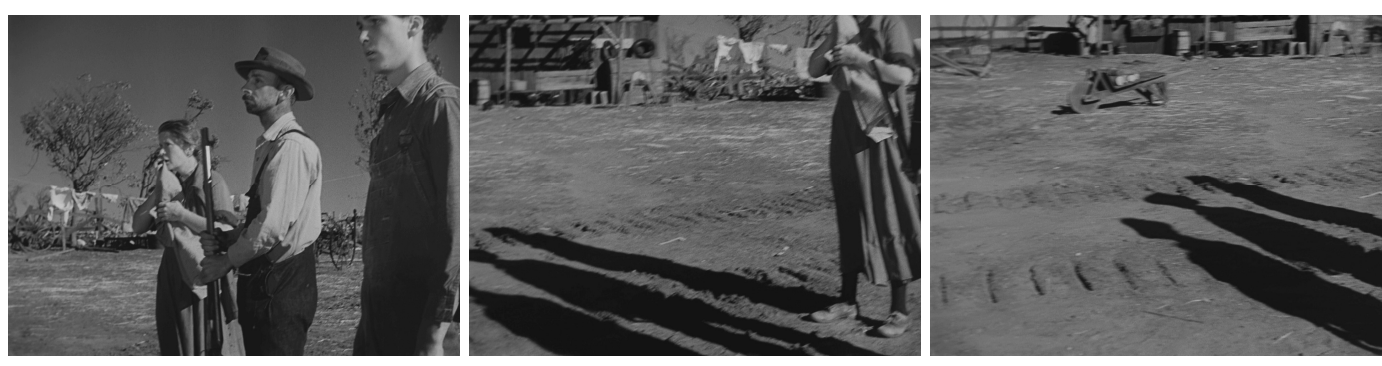

Igualmente relacionada à condição sub-humana ocasionada pela pobreza material, mas com outra força expressiva, veremos a marcha efetuada por um exército de sombras, de mortos-vivos esfomeados a preencher o plano final de Trovão distante (Ashani Sanket, 1973), de Satyajit Ray (Fig. 31-32). O filme se passa durante a Segunda Guerra Mundial, precisamente nas proximidades do evento que ficou conhecido como "A Fome de Bengala de 1943”, quando milhões morreram na Índia de desnutrição, entre outros motivos, pela política de exportação e de distribuição de alimentos produzidos no país, conduzida pelo Império Britânico. O plano que comentamos mostra uma caminhada que acontece do fundo em direção ao primeiro plano da imagem ou, se quisermos, do filme para o público, numa possível interpelação entre o problema social e o espectador. A transfiguração dos corpos em sombra e por conseguinte dos indivíduos em massa indistinta, amorfa, sem rosto, parece precisar o momento em que o flagelo da fome, progressivamente a espreitar o filme, ganha proporções endêmicas na região e condena a população à peregrinação errante na forma de criaturas sem identidade.

\footnotetext{
${ }^{92}$ Quando recebe a notícia de que precisa abandar o lugar onde vive, o personagem Muley, diz: "E alguns de nós morreram aqui [nessa terra]. É isso que a faz nossa: nascer nela, trabalhar nela e morrer nela.”
} 
Fig. 31-32
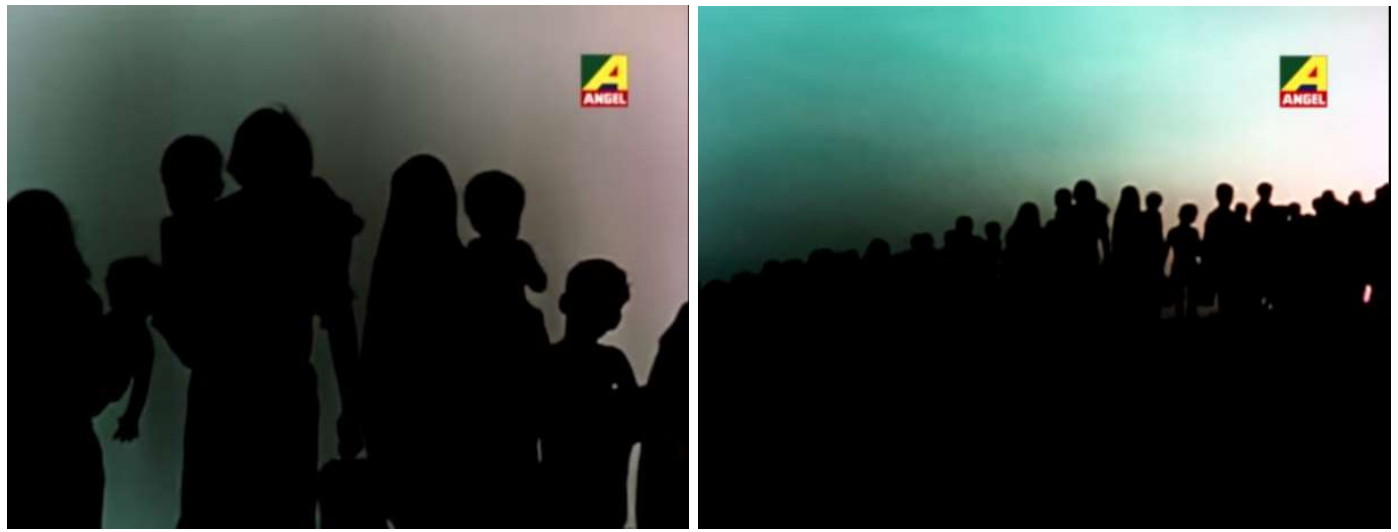

Como analistas, a partir de uma suposição espectatorial induzida pela imagem, ${ }^{93}$ podemos distinguir ou deduzir algum nível de reflexividade nas obras de Ford e Ray, referente à primazia dada à figuração do corpo como elemento pictórico da imagem, mas, mais que evidenciar a natureza do medium cinematográfico, a finalidade da sombra é a de um elemento notadamente narrativo. O filme de Grandrieux é diferente na medida em que a figuração umbrática do corpo se dá em paralelo a outras escolhas que sensibilizam a presença do dispositivo, como o que já mencionamos sobre a predisposição monocromática ou senão tonal do filme, que submete a figura humana às dinâmicas e ao espaço achatado da imagem, esvaziando parcialmente a representação tridimensional e a relação entre os seres em cena. Simultaneamente, a imagem representa um universo e faz alusão a si mesma enquanto medium opaco, revelando suas propriedades. Além disso, há uma dupla menção ao dispositivo cinematográfico. Uma indireta (último quadro da Fig. 8) e outra direta (a cena que se passa dentro de uma sala cinema, no início do filme).

$\mathrm{O}$ alinhamento do filme de Grandrieux à hipotética síndrome de Nosferatu talvez se aproxime mais de momentos pontuais de obras como A queda da casa de Usher (La chute de la maison Usher, 1928), de Jean Epstein, Os beijos de emergência (Les baisers de secours, 1989), de Philippe Garrel, ou ainda de Rumpelstilzchen (1989), de Jurgen Reble. Nessas obras as remissões diretas ao dispositivo cinematográfico evidenciam uma troca, uma circularidade entre a natureza do corpo representado e a matéria imagética.

\footnotetext{
93 Fazemos remissão aqui à distinção proposta por Emmanuel Siety ao discutir filmes nos quais os próprios atributos da imagem no âmbito diegético sinalizam diretamente o estatuto material da imagem, revelando sua opacidade e sua qualidade de medium mais do que o que elas representam, em oposição a obras nas quais o espectador, munido de seus afetos, ideias e por vezes valendo-se do seu papel de enunciador e analista parte de pistas deixadas pelos filmes para refazer o percurso que os levaria a identificar tal qualidade da imagem. A distinção equivaleria, nos termos do autor, respectivamente, a "ficções de imagem icônica" e "ficções de imagem". Ver Emmanuel Siety, Ficctions d'images Rennes: Presses universitaires de Rennes, 2009.
} 
A queda da casa de Usher tematiza diretamente a imagem enquanto meio que se nutre da matéria de outro ser: ao ter seu retrato pintado pelo marido, a personagem de Madeleine Usher perde progressivamente sua robustez, tornando-se débil e letárgica. A vitalidade é tragada pelo medium pictórico e a transposição de vida do modelo para a sua imagem é figurada no filme pela estratificação, pela sobreimpressão que torna visível os feixes de alma a abandonar Madeleine à medida que seu marido avança na feitura e depuração do retrato (Fig. 33-34). A cena parece ilustrar diretamente a "teoria dos espectros" relatada por Nadar:

Segundo Balzac, cada corpo na natureza é composto de séries de espectros em camadas sobrepostas ao infinito, folheadas em películas infinitesimais [...] E, é claro, cada operação daguerreana, cada fotografia vem surpreender, destacar e reter aplicando-se nela uma das camadas do corpo revelado. Daí, para o tal corpo, e a cada operação repetida, a perda evidente de um de seus espectros, isto é, de parte de sua essência constitutiva. ${ }^{94}$

A queda da casa de Usher não mostra as ações fotográfica e cinematográfica sobre o corpo, mas a pictórica. Ainda assim, a figuração da transferência da energia vital do modelo para o seu duplo imagético é diretamente resultante da manipulação do espaço cinematográfico. O efeito dispositivo se dá pelo potencial autorreflexivo da sobreimpressão, capaz de revelar o que o cinema "geralmente dissimula: sua operação fundamental que consiste em fundir no movimento [...] dois fotogramas distintos e fixos que ela liga em conjunto", sinalizando tanto a feitura de um filme quanto o seu mecanismo de projeção. ${ }^{95}$ Para além disso, a estratificação da figura pela sua passagem à imagem remete muito mais ao aspecto indicial oriundo do automatismo cinematográfico, pelo qual o ente deixa impresso na película um traço ou, para usar os termos de Balzac, uma de suas camadas espectrais.

Fig. 33-34
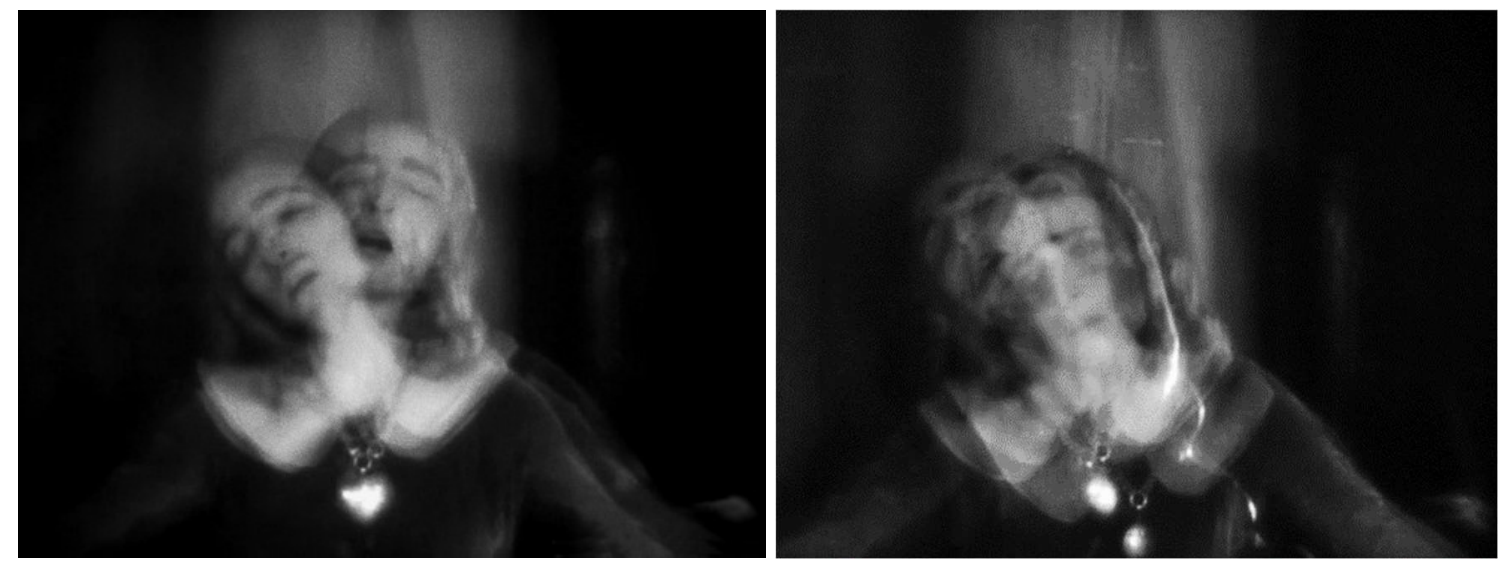

\footnotetext{
${ }^{94}$ Citado em: Philippe Dubois, O ato fotográfico e outros ensaios, Campinas, SP: Papirus, 2008, p. 227.

${ }^{95}$ Marc Vernet, Figures de l'absence, Paris: L’Étoile, 1988, p. 65.
} 
Como o filme de Epstein, mas por outras razões, Os beijos de emergência é explícito em sua inflexão reflexiva. Desde o princípio a obra gira em torno de Mathieu, um realizador interpretado pelo próprio Garrel, que escreve um filme autobiográfico no qual será encenada a relação com sua mulher, Jeanne, interpretada pela então esposa de Garrel à época, Brigitte Sy. O casal entra em crise uma vez que Mathieu convida uma terceira personagem, Minouchette, para interpretar Jeanne que, a partir de então, sente o risco de perder a sua posição, sendo substituída não apenas na obra a ser realizada mas na própria realidade (diegética). Nesse jogo de espelhamentos entre cinema e vida, uma das cenas mostra o primeiro contato entre Jeanne e Minouchette, isto é, do referente real com o ator que irá interpretá-lo, do corpo com a figura que lhe servirá de presença na imagem do filme a ser feito. O que está em jogo é a perda ou senão a transferência da identidade de Jeanne para a de sua intérprete, o risco de um vampirismo de um corpo por outro. Essa ameaça de usurpação será indicada no momento em que, durante a discussão com Minouchette, Jeanne fica diante de uma janela e ali corre o risco de ser siderada em razão da superexposição. A luz que vem do exterior e ilumina o espaço borra os contornos e fragiliza a sua figura, que fica a um passo de desaparecer na brancura da imagem (Fig. 35). O mesmo acontecerá com Minouchette ao se aproximar da janela. Discutese para decidir quem vai encarnar uma personagem em um filme como quem trava uma luta para existir. A película expõe esse drama que é próprio ao aspecto autobiográfico da obra de Garrel, segundo o qual filmar é uma condição de existência, estar num filme é viver, e atuar no filme de quem se ama é estar vivo em seu coração. Não existe a sombra entendida como forma escura originada pela interrupção da luz sobre um corpo opaco, mas a relação que se estabelece entre as figuras em cena emula o efeito de um ser que se origina como extensão, às custas, na dependência de outro.

Fig. 35

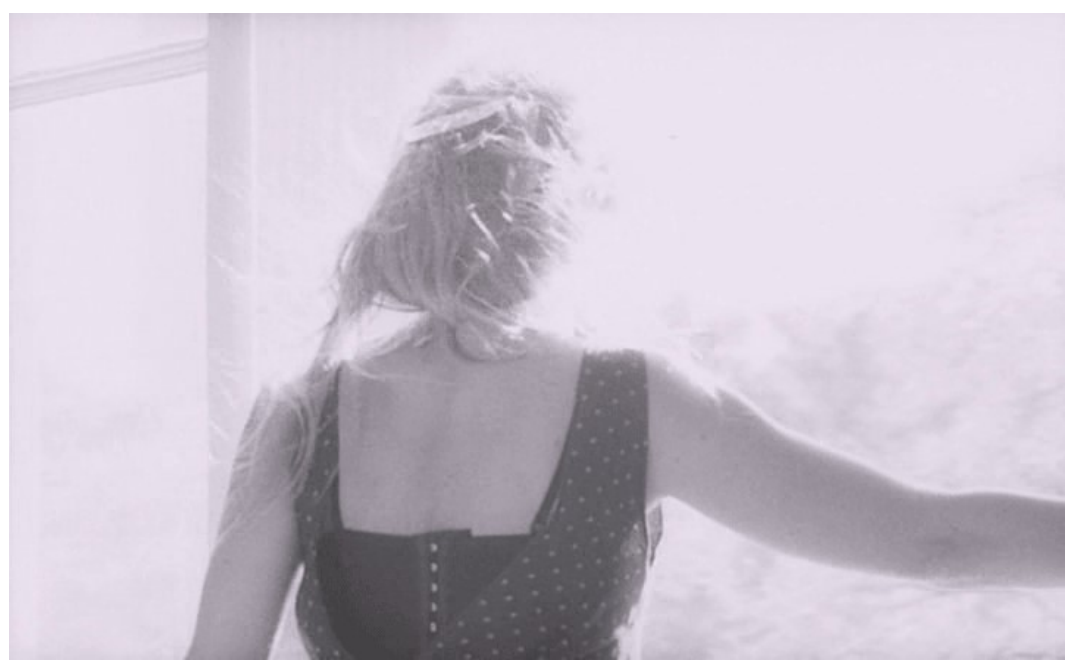


Por fim, ilustração direta do que na falta de outro termo se propõe sob a égide de uma “síndrome de Nosferatu”, Rumpelstilzchen (Fig. 36-37), de Jürgen Reble. Uma de suas cenas retoma uma sequência do filme de Murnau em que o vampiro ataca uma vítima. Reble põe em evidência a relação entre o conteúdo figurado e a natureza física da película: quando Nosferatu se debruça sobre o corpo humano para se alimentar, a decomposição pelicular resultante de um processo de manipulação química feito pelo realizador torna o suporte da imagem instável. A emulsão sofre uma corrosão que altera as cores, evidencia a granulação, acentua os contrastes e, por fim, solariza a imagem e desfigura o conteúdo representativo. $\mathrm{O}$ vampiro se curva em direção à vítima, mas quem sofre o ataque é a própria película cinematográfica, o corpo da imagem, tratada como organismo vivo - tema de boa parte do cinema de Reble. Nosferatu desencadeia a solarização, da qual é simultaneamente vítima enquanto elemento visual, tornando-se vampiro e ser vampirizado, algoz e vítima, figura e própria metáfora da imagem cinematográfica. A sequência assume um tom de reflexividade paroxística, um circuito de retroalimentação em que as posições de Nosferatu e da imagem são assimiláveis e intercambiáveis. É o vampiro que suga a imagem, ou é a imagem que absorve a sua (quase) vida?

Fig. 36-37
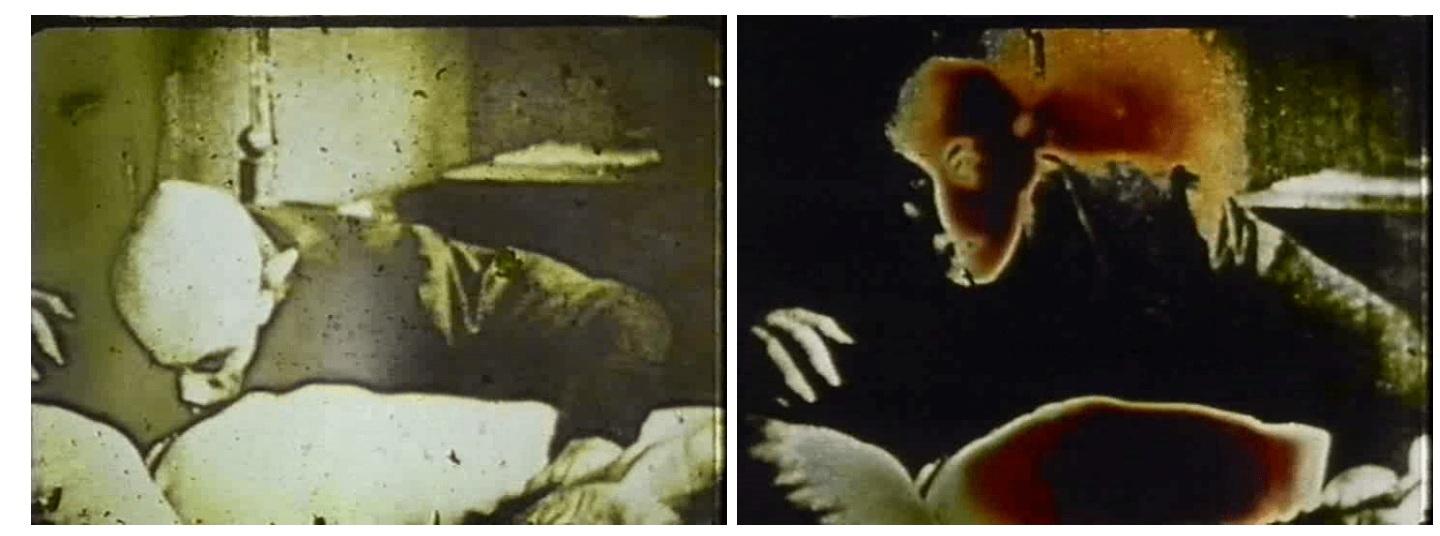

O filme de Grandrieux está a meio caminho entre o que se apresentou, por um lado, em Ford/Ray e, por outro, em Epstein/Garrel/Reble. A figuração do corpo na forma de sombra pode responder a uma demanda da diegese, o que foi sinalizado pelo sentido de perversão e opacidade, porém ela igualmente reverbera nas correspondências entre o personagem e a natureza da imagem, sendo o vetor de comunicação entre ambas. A ameaça à integridade do corpo se deve tanto à natureza extrema das experiências de Jean, assombradas pela morte, quanto, num nível mais metafórico, ao que antes se comentou sobre o seu percurso solitário 
por lugares aos quais não pertence, numa espécie de limbo, remetendo-o a uma ordem espectral.

No que tange à enunciação do dispositivo, é emblemática a cena de crianças numa sala de cinema, logo no início de Sombra, posterior à sequência de abertura (Fig. 4-5). O filme ao qual assistem nunca é mostrado, permanecendo fora de campo. Tampouco há uma explicação diegética inequívoca para a existência da sequência. O contracampo é virtual: ele só se dá a ver pelo que podemos deduzir do olhar, dos jogos fisionômicos e dos gritos das crianças. A emergência da cena logo após a sequência inicial poderia sugerir que o filme ao qual nós, enquanto espectadores, assistimos é na verdade o mesmo que as crianças veem. Suas reações e gritos - "Atrás de você!" - se adequariam muito bem a Sombra, como um metacomentário. Não sendo este o caso, é certo pelo menos que a cena estabelece uma relação direta com o aparato cinematográfico. A tal traço reflexivo se junta o que anteriormente se discutiu sobre a imersão e a quase integração entre a figura de Jean e a superfície do plano, e também a respeito dos diferentes níveis de analogia entre sua sombra e a imagem cinematográfica. Ambas compartilham uma instabilidade fundadora, um sentido de incompletude, uma necessidade de serem preenchidas a partir da abertura para outro ser. A posição do filme de Grandrieux em relação à síndrome de Nosferatu, junto aos outros filmes há pouco mencionados, viria da conjunção desses elementos.

A correspondência entre o corpo figurado enquanto silhueta preta e a imagem cinematográfica permite ainda resgatar um sentido atrelado à sombra no pensamento ocidental desde a Antiguidade Clássica, conforme nos explica Stoichita:

Dir-se-ia que, no pensamento platônico, assistimos a uma certa vacilação (simultaneamente funcional e terminológica) entre o modelo da sombra e do reflexo especular. A sombra representa o estágio mais distante relativamente à verdade. $\mathrm{Na}$ alegoria da caverna, ela era necessária na medida em que Platão precisava de um polo que se opusesse de modo absoluto à luz do Sol. Desde esse momento e posteriormente, a sombra ver-se-á imbuída de uma negatividade fundamental que, durante todo o seu percurso pela história da representação ocidental, jamais a abandonará por completo. Para Platão, a sombra é não somente "aparência" como também aparência gerada por uma censura da luz. ${ }^{96}$

O autor vai bem mais a fundo em sua análise da sombra e de seu papel na teoria da mimese platônica. Sem adentrar nas particularidades desse exercício hermenêutico, o que interessa é reter, da citação destacada, a sombra como o grau mais distante da verdade, um

\footnotetext{
${ }^{96}$ Stoichita, 2016, p. 26.
} 
duplo, puro ser de aparência. Segundo Stoichita, essa propriedade negativa, deficitária, está na base tanto da representação cognitiva ocidental, pelo mito da caverna de Platão, como na da representação artística, pelo mito de Plínio. Alcançar a arte (encarnando a figura) e o conhecimento (deixando o mundo das aparências) verdadeiros dependeria da possibilidade de superar o estágio da sombra, da projeção originária.

Deparamos com ecos platônicos ou ao menos uma extensão da ideia de incompletude da figura/sombra/reflexo num comentário de Jean Douchet ao fazer referência à natureza vampírica da imagem cinematográfica, baseada no processo negativo-positivo da fotografia: impressa primeiramente na película negativa através da luz, a imagem preserva, na película positiva, um traço da realidade. ${ }^{97}$ Por mais que possa se assemelhar ao referente real, a cópia produzida apresenta um caráter ilusório, sendo nada mais do que uma aparência destituída de ser e essência. A imagem carregaria consigo fardo similar ao de um vampiro, criatura que metaforiza a ideia de incompletude, um corpo vazio, macilento, que sobrevive à custa da energia de outros seres. Por tal perspectiva, a imagem cinematográfica seria uma cópia que carece de encarnação para recobrar o seu devido valor e assim deixar o limbo dos eflúvios. A própria natureza do dispositivo cinematográfico, ancorada na projeção incorpórea da luz sobre uma tela, reforça esse estatuto de um meio forjado sobre uma falta de corporeidade, de solidez - embora saibamos que, apesar de incorpórea aos olhos humanos, a luz é uma matéria como qualquer outra. Analogamente, não estamos distantes do que se discutiu a respeito da natureza espectral do protagonista de Sombra. Convertido pela iluminação e pelo tratamento da imagem em silhueta negra, ser bidimensional e sem carnalidade, Jean busca vítimas que o saciem, um insumo diretamente vinculado à corporeidade das mulheres que encontra.

Ora, mas como ir além dessa síndrome de Nosferatu que impregna a existência da figura humana no filme de Grandrieux? Reconhecido o alinhamento de Sombra a um quadro que associa a debilidade da existência corporal, bem como experiências radicais e limítrofes, à instabilidade do suporte cinematográfico, o que existe além? Estaríamos diante de uma negação do elemento humano ao encará-lo como forma plástica, silhueta informe e débil, no limite de desaparecer da imagem e ceder lugar à escuridão, ao risco do monocromo? O que se esboça é um tipo de presença ou, contrariamente, de imaterialidade, aerificação, esvaecimento visual/físico da figura humana?

\footnotetext{
${ }^{97}$ Jean Douchet, in Jacques Aumont, 1995b.
} 


\section{$1.2 \mathrm{O}$ formalismo ameaça o corpo?}

Diante das questões postas, somos lançados em direção a um debate que pontuou a arte moderna realizada entre o final do século XIX e início do XX, acusada por alguns e enaltecida por outros em razão de se afastar do conteúdo figurativo, da representação dos dramas humanos para se debruçar sobre as propriedades específicas do medium. Se outras formas de arte ditas "primitivas" ou mesmo não ocidentais costumeiramente abdicavam de um espaço figurativo tridimensional pautado numa forma naturalista e antropomórfica de representação, essa renúncia dentro da história oficial da arte europeia teria recebido evidência a partir do movimento impressionista. Em lugar do paradigma naturalista, ganha primazia a pincelada, as cores, a tinta, os rastros referentes à presença do artista na obra e pelas demais forças elementares do meio pictórico, tudo o que realça a tela como objeto tangível e material do mundo e menos como lugar de representação de um microcosmo figurativo fictício, reles "imitação" da natureza. A arte, alguns acreditavam, caminhava para o reconhecimento de seus próprios valores.

Muita tinta já foi gasta a respeito da ruptura desencadeada por meio das vanguardas, desde a arte moderna até a contemporânea. Obras como as de Francastel, Schapiro, Steinberg, entre outros, dedicaram-se a discutir a emergência de um novo estilo, quer seja por um viés materialista-histórico, quer seja por um viés estético. ${ }^{98} \mathrm{O}$ que orienta nossa alusão a tais transformações existentes no âmbito das artes visuais a partir do século XIX é analisar como o debate que empreendemos a partir do filme de Grandrieux remete a tal problemática a partir do momento em que recorre à sombra e aos demais procedimentos que achatam o espaço da imagem e obstruem ou desfiguram o seu conteúdo figurativo. A fim de compreender essa disposição do filme, realizaremos uma breve visada teórica e retrospectiva, nomeadamente em direção aos discursos pronunciados por alguns dos teóricos da vanguarda francesa dos anos 1910 e 1920. Neles encontraremos tanto um parcial alinhamento com o debate ao qual referenciamos no âmbito das artes visuais, como também formulações que nos auxiliam a matizar essa hipotética oposição, encontrada em Sombra, entre a figuração do corpo humano e a manipulação das dinâmicas da imagem.

O foco de interesse são os escritos de Élie Faure e Ricciotto Canudo, assim como a produção teórica e fílmica de Jean Epstein, frente às quais identificamos uma proposta de organização da estrutura fílmica em prol do que esses autores consideravam como as qualidades técnicas e expressivas do meio. Entrevemos a partir deles um modelo de figuração

\footnotetext{
${ }^{98}$ Pierre Francastel, 1990; Meyer Schapiro, A arte moderna, São Paulo: EDUSP, 2010; Leo Steinberg, Op.cit.
} 
que tenta reaver a dimensão presencial do corpo pela distorção do regime naturalista e realista de representação. Esse programa a respeito da figura humana não é declarado nos textos, só existe virtualmente, como por uma espécie de negação: o corpo só está presente nos discursos de Faure, Canudo e Epstein ora por uma exclusão pronunciada, ora pela indiferença. Nossa passagem por seus textos tentará justamente procurar identificar o que há de propositivo nessa denegação, de presença onde se quer ausência, de corpo onde só parece haver um delírio hipertrófico da imagem.

Amparar-nos-emos nas interseções entre os postulados estéticos de Faure, Canudo e Epstein sem, contudo, ignorar as notáveis diferenças que mantêm entre si. Ao recapitulá-los, buscando entender o que está por trás da linha de pensamento, a expectativa é escapar do risco de associar a atenção à materialidade e ao experimentalismo sobre os elementos fílmicos à ideia, ao mito de autonomização da arte. Ficará mais claro como a figuração do corpo no filme de Grandrieux por um lado se alinha a esse debate que o cinema partilhou com a pintura e, por outro, o desenvolve dentro de chave própria.

\subsubsection{A deposição da figura humana}

Uma possível porta de entrada para as proposições da vanguarda francesa é compreender seu princípio formalista, senão essencialista. A pedra angular a sustentar suas bases é a busca de um sistema de valores, por vezes um único critério, pelo qual uma obra de arte é legitimada. Trata-se de estabelecer uma qualidade estética em prol da qual se minimiza o tema, as intenções e mesmo a cultura ou a iconografia que envolve uma obra, esvaziando-a do seu conteúdo narrativo e simbólico. Privilegia-se como critério valorativo a adequação a uma rede de referências previamente estabelecida e intimamente alinhada à hipotética área de competência, à essência de cada arte. Tal programa foi comum na produção crítica de diferentes meios artísticos do final do século XIX e meados do século XX, incluindo desde os textos de Baudelaire exaltando os arabescos visuais em detrimento do tema, nas telas de Delacroix, passando por membros da vanguarda cinematográfica e indo desembocar futuramente no mito greenberguiano e em seus herdeiros.

O essencialismo assume contornos específicos a depender do autor e de seu respectivo programa. No cinema, Canudo reuniu suas reflexões em torno do drama visual; ${ }^{99}$ já Faure

\footnotetext{
${ }^{99}$ A expressão designava um tipo de drama "concebido na luz, executado com todas as fontes cientificamente possíveis e com todos os jogos esteticamente concebíveis" (p. 66). Nele, "os seres só aparecem como concentrações móveis de luzes, como figura humana" (p. 66). Se o pintor tinha à disposição o desenho e a cor, o instrumento do écraniste (cineasta) era o próprio fulgor ritmado que se desprendia dos seres filmados. A
} 
cunhou a noção de cineplástica. ${ }^{100}$ Ambos os termos sinalizavam um interesse comum pela expressividade do meio cinematográfico a partir da agitação das formas visíveis, da arquitetura em movimento desenhada na tela pela exaltação da potência rítmica criada por linhas, volumes, luzes e mesmo pela figura humana - vista como um elemento plástico em decorrência de sua gestualidade. ${ }^{101}$ Além da ênfase dada à forma visual, eram frequentes as comparações entre cinema e música. Esta última teria alcançado a autonomização de seus elementos constituintes, o domínio do seu próprio material para além do realismo ilusionista. ${ }^{102}$ Era esse o horizonte vislumbrado para o cinema, o de uma expressividade e um drama oriundos exclusivamente do que, acreditava-se, compunha a materialidade do seu medium: as dinâmicas rítmicas da imagem.

A atenção dada mais cedo aos aspectos pictóricos de Sombra na análise da representação dos corpos masculino e feminino levou em consideração justamente uma tendência a ancorar o drama nas qualidades sensíveis do medium, em correspondência com os princípios essencialistas. A forma fílmica é articulada menos pelo diálogo e pela psicologia dos personagens, e mais por uma vocação plástica calcada na relação entre figura humana, movimentação da câmera, luz e escuridão, cores, montagem - em paralelo à experimentação sonora.

O que nos trouxe até os formalistas do início do século XX, contudo, não foi reconhecer o alinhamento com noções presentes num discurso essencialista, mas como isso reverbera na aparente imaterialidade do corpo de Jean. Evocar aquela geração de teóricos/artistas para tentar compreender tal aspecto tem uma razão simples: uma das principais vítimas do essencialismo artístico foi justamente a figura humana. ${ }^{103}$ No cinema, o corpo representado

qualidade mais poderosa do corpo não era a fala, mas a expressão visual decorrente da ação. Pelo movimento, dever-se-ia desprender o sopro vital das figuras e se descortinar o drama calcado no ritmo. Os desejos, sentimentos, choques, triunfos e demais matizes da vida encontravam sua expressão cinematográfica através da agitação nas imagens. Essa e as demais remissões a Canudo foram extraídas dos seus textos publicados na coletânea organizada por Jean-Paul Morel, L'usine aux images, Paris: Arte Éditions, 1995. Apesar de italiano, Canudo entra neste tópico por ser um membro ativo e espécie de mentor da vanguarda francesa.

${ }^{100}$ A cineplástica é muito mais uma noção do que propriamente um conceito. Com seu estilo lírico de escrita, Faure não busca um rigor científico na definição e muito menos um desejo de aplicabilidade para o termo. Ver Élie Faure, Função do cinema e das outras artes, Lisboa: Texto \& Grafia, 2010.

101 Principalmente nas comédias do primeiro cinema e em Charlie Chaplin. Tanto Faure como Canudo encontravam em Carlitos a difícil harmonia entre a instância atoral e a essência cinematográfica.

102 A recorrência de metáforas musicais nos autores nos parece em consonância com um instinto identificado (ou interpretado) por Greenberg nas vanguardas do século XX, o de uma autopreservação da arte, a proteção de seus valores e o afastamento de ideias que poderiam contaminá-la com lutas ideológicas exteriores. "Em razão de sua natureza 'absoluta', da distância que a separa da imitação, de sua absorção quase completa na própria qualidade física do seu meio", de comunicar algo pela sensação imediata, a música teria se tornado um método de arte pautado na pureza das formas. Clement Greenberg, "Rumo a um mais novo Laocoonte", in Glória Ferreira, Cecília Cotrim (orgs.), Clement Greenberg e o debate crítico, Rio de Janeiro: Jorge Zahar, 2001, p. 52.

${ }^{103} \mathrm{O}$ foco aqui são os formalistas franceses da década de 1910 e 1920, mas encontraremos ideias similares em textos da vanguarda norte-americana a respeito de um cinema materialista e sua exclusão dos códigos não- 
porta consigo a lembrança que os membros da vanguarda francesa se esforçavam a todo custo para esquecer: a presença do ator, logo, a herança teatral.

Ainda que em seus textos não tenha levado adiante o primado formal a ponto de defender um cinema eminentemente "abstrato", livre da matriz figurativa e pautado exclusivamente nos valores rítmicos da imagem, Faure, por exemplo, considerou a possibilidade de suprimir dos filmes a figura humana, ou "cinemimo", como ele a denominava. Independentemente da existência do ator, o cinema já havia adquirido os recursos necessários para explorar o drama do movimento precipitado no tempo, por isso no futuro poderia prescindir da imagem do homem. Nestas condições, o vislumbre do porvir reservava uma "arte cineplástica plena, que não será mais do que uma arquitetura ideal e da qual o cinemimo [...] vai desaparecer", pois o realizador poderá se expressar exclusivamente pelo que se constrói e se desconstrói na imagem a partir das mudanças de tons e padrões. ${ }^{104}$ Quanto a Canudo, não houve um discurso aberto sobre a supressão do corpo figurado, mas seus textos prognosticam e revelam pontualmente a predileção por um horizonte no qual o cinema deveria alcançar sua depuração, elaborar a imagem a partir de suas formas e não de uma representação naturalista do mundo real fincada no ator. ${ }^{105}$

A hipótese inicial sugerida por nossa linha de raciocínio, que esboçou uma relação entre Sombra e a vanguarda francesa, seria encarar os procedimentos que vaporizam a figura de Jean a partir de um viés negativo: um desdobramento da natureza espectral da imagem cinematográfica, um ser que em lugar de superar a projeção original, encarnando, torna-se refém de sua condição imaterial, destituído de peso no mundo. Esse ponto de vista redundaria

cinematográficos, o que também daria margem para pensar uma hipotética secundarização ou exclusão da figura humana. Cf: Peter Wollen, “'Ontology' and 'Materialism' in Film”, in Screen, vol. 17, n. 1, março de 1976, pp. 7-25; Malcolm Le Grice, "Material, Materiality, Materialism [1978]", in Experimental Cinema in the Digital Age, Londres: BFI, 2001.

104 Élie Faure, 2010, p. 36. Caso a figura humana fosse preterida, os escritos do autor sugestivamente apontam que a cineplástica poderia encontrar na natureza o seu insumo. De modo próximo a Dulac e a Epstein, também entusiastas do que se extraía do meio natural, o autor comenta a potência dos filmes em reabilitar todas as faces da vida universal, incluindo as menos acessíveis ao olho humano, como os movimentos ondulatórios imperceptíveis dos gestos animal e vegetal, ou ainda a solidariedade entre o ritmo cósmico e os infinitesimais, em suas vibrações moleculares. ${ }^{104}$ No lugar do homem, então, poderiam entrar em cena as formas em movimento retiradas da natureza e transformadas em potência rítmica na imagem. Por meio dessa transferência, seria possível apreender o rosto do mundo, suas constelações universais e seus destinos. O cinema seria a máquina capaz de revelar o invisível no visível da natureza, alcançando o coração dos homens pelo que extrai do universo exterior, numa dinâmica inesgotável entre tecnicismo e afetividade também comum aos textos de Epstein e Dulac. Consultar Xavier, 1978.

${ }^{105} \mathrm{O}$ italiano acreditava que as variações luminosas e os demais valores da imagem eram capazes de fixar todo o sentimento e toda a sensação da alma e dos corpos. "Pouco a pouco o cinema alcançará seu objetivo. O estudo da mise en valeur das luzes, das proporções de objetos diferenciados pelos planos" (grifo do autor). Canudo, Op.cit., p. 42. Outra possibilidade era secundarizar a figura humana pela autonomia expressiva do espaço, seja a partir da captação da força da natureza, seja pela ambiência criada, seja pela ambiência plástica. São dados como exemplo: Atlântida (L'Atlantide, 1921), de Jacques Feyder, O gabinete do doutor Caligari (Das Cabinet des Dr. Caligari, 1920), de Robert Wine, e Febre (Fièvre, 1921), de Louis Delluc. 
numa perspectiva eminentemente formalista, segundo a qual a figura de Jean corresponderia a um componente plástico da imagem, à transformação em pura forma manipulável, ornamento visual que reivindica não uma filiação aos homens representados no espaço tridimensional, mas à superfície da imagem cinematográfica. A predileção seria, portanto, pelo corpo do cinema, mais que pela constituição do corpo em referência a um ser real e às condições sociais frente ao mundo material. A figura seria apresentada por tudo o que a separa da imagem de um ser humano: sombra, formas distorcidas pelo movimento, flou e apagamento na escuridão.

Seguir por tal caminho ecoaria a percepção, devedora de autores como Greenberg, segundo a qual o abandono da forma naturalista e antropomórfica de representação em favor das marcas no espaço pictórico, de tudo o que enfatiza os gestos do artista e a opacidade do medium, corresponde à autonomização da arte, ao reconhecimento dos valores que a constituem. ${ }^{106}$ A criação de um microcosmo figurativo fictício e a "imitação" da natureza seriam então suplantados pelo investimento nas propriedades específicas do cinema. Assim, o tratamento da figura humana de Jean enquanto um ser semelhante ao homem real ficaria inviabilizado pela própria imagem cinematográfica - plana, sem odor, destituída da presença real -, sendo por isso desbancado por uma figuração do corpo segundo valores específicos do cinema. Por fim, corroboraria a ideia de uma figura essencialmente cinematográfica, mais do que propriamente um corpo, a rarefação do drama, que impede a encarnação da imagem de Jean em um personagem, em uma dramatis personae portadora de psicologia, história, objetivos e ações determinados. Resta, para todos os efeitos, a sua figura. ${ }^{107}$ Até onde poderíamos acreditar nessa hipótese?

\footnotetext{
${ }^{106}$ Clement Greenberg, Arte e cultura: ensaios críticos, São Paulo: Cosac Naify, 2013; Clement Greenberg, 2001.

${ }^{107}$ Essa primeira hipótese ecoa o parecer de autores do início do século XX, como Ortega y Gasset. O autor espanhol alude justamente ao processo de desrealização das artes plásticas (mas também musicais) do século XX a partir da redução de algumas obras a elementos estritamente ou primordialmente estéticos (cores e linhas organizadas não necessariamente de modo representativo). Ortega y Gasset vê no afastamento da figuração do mundo segundo códigos visuais ilusionistas ou segundo formas complexas dependentes de formas já ordenadas na natureza uma progressiva eliminação dos elementos humanos, pois o objeto da arte deixaria de ser a figura, as paixões e o destino humano para se concentrar sobre uma estrita fruição estética. A reação do autor poderia ser sintetizada num axioma: "estilizar é deformar o real, desrealizar. Estilização implica desumanização. E viceversa... O realismo, ao contrário, convida o artista a seguir docilmente a forma das coisas, convida-o a não ter estilo". ${ }^{107}$ José Ortega y Gasset, A desumanização da arte, São Paulo: Cortez, 2008, p. 47. Mais que um dualismo, Ortega y Gasset via um antagonismo, duas operações excludentes: ver o mundo, a partir de uma arte representativa-ilusionista-humanista, ou ver a obra e o estilo e correr o risco de uma desantropomorfização pela desfiguração das formas humanas, pela ausência da imagem do corpo na tela e, por fim, pela incompreensão que um público pouco versado em arte teria, dado que já não dispunha da história e de dramas para se ancorar.
} 


\subsubsection{Lógica hipostática}

Pelo que apresentamos até o momento, a figura humana dentro da agenda essencialista, e no filme de Grandrieux, seria representada como elemento secundário restrito a viabilizar um programa formal. Esta suspeita, que forjou nossa primeira hipótese, será recusada a partir de agora em razão de um segundo desdobramento sugerido pelos autores da vanguarda francesa. Se por um lado eles depunham ou secundarizavam a imagem do corpo, por outro, tentaram restituir a presença humana de um modo singular. Com Grandrieux, não será diferente.

No que toca ao nosso tema, a principal contribuição dos formalistas do início do século XX é o princípio de hipóstase, pelo qual as propriedades imagéticas tinham a capacidade de dar concretude visual a estados subjetivos da figura humana. Para Canudo, por exemplo, as deformações, os flous parciais e, em suma, as mudanças plásticas fariam do cinema o meio ideal para desenvolver a "faculdade extraordinária e aguda de representar o imaterial" (grifo do autor). ${ }^{108}$ As dinâmicas visuais precipitariam no espaço figurado os sentimentos dos personagens. O crítico defendia uma estilização cujo apanágio era a deformação imposta pelo meio cinematográfico como modo de restituir algo do ente real à luz do olhar do realizador. Afastava-se, pelo menos em teoria, de um cinema que imitasse os seres por meio de um alto grau de analogia ou de semelhança, numa suposta reprodução transparente da exterioridade, da aparência do modelo/objeto. A proposição de Canudo, como também veremos em Grandrieux, é figurar o corpo pelo hiato que a imagem cria diante do seu referente. O coeficiente de deformação do meio cinematográfico permitiria às formas visíveis representarem o que pertence ao reino do incorpóreo, do imaterial, do que não tem corpo na ordem do visível: as faculdades perceptivas e sensoriais do ser humano.

A concreção de um estado interior na superfície da imagem também era essencial para Epstein. Mais do que uma deformação, poderíamos pensá-la nos textos e nos filmes do realizador a partir do valor aditivo do cinema: pelo que o aparato e, especificamente, o domínio técnico permitem revelar e extrair do mundo, ${ }^{109}$ numa espécie de clarividência

\footnotetext{
108 Ricciotto Canudo, Op.cit., p. 101. O teatro, por sua vez, apenas poderia representar as imagens do subconsciente pela palavra, pelos figurinos e pelo tratamento luminoso, mantendo-se atado a ferramentas do mundo concreto.

${ }^{109}$ Neste sentido, convém recobrar uma diferença essencial entre Canudo (Op.cit.) e Epstein. O primeiro, em pelo menos dois textos - "Defendons le cinematografe" e "Le septieme art et son esthétique: La tâche de l'Écraniste" - critica os realizadores que se contentam com a tirania da técnica, reservando-se ao seu domínio e deixando em segundo plano o primordial: os princípios do espírito, a sensibilidade que deveria coordenar a mão artística, tal qual acontecia com os pintores e escultores. Epstein, ainda que claramente compartilhe deste entusiasmo artesanal/autoral sobre os cineastas, atribui valor essencial ao controle do aparato. Para o autor, o
} 
assegurada pelo e específica do medium. ${ }^{110}$ Os efeitos desta propriedade são percebidos tanto no âmbito epistemológico, com uma articulação fílmica capaz de transcender o espaço euclidiano e de apreender o mundo por um sistema outro que não o racionalista, como na nova modelação do corpo filmado. Iremos enfocar esta última tendo em vista a função desempenhada pelo close up. Pautado na aproximação focal a tal ponto de desvelar o que em outras condições permanece indistinto ou inacessível, o primeiro plano do rosto acaba por encarnar metaforicamente a ideia de aditamento. Ao mesmo tempo, permite apresentar como a hipóstase se realiza cinematograficamente.

O close assume em Epstein a função de radiografia dos seres, de acesso ao lado mais íntimo e verdadeiro dos atores, tal como se desvelasse o envelope carnal para apresentar diretamente os dramas interiores. O cinema funcionaria como revelador, arte espírita na qual o ator abandonaria sua feição ilusionista e a representação de uma personagem para viver, ser noção de autenticidade e recusa de técnicas de interpretação também comuns a Louis Delluc, Canudo e Abel Gance. ${ }^{111} \mathrm{O}$ primeiro plano sobre o rosto transmuta a figura humana e permite que o espectador gravite por alguns segundos em torno de um sorriso ou de outros traços fisionômicos que adquirem retórica particular. ${ }^{112}$ Já não se trata do que se cria a partir da figura e de seu gesto, mas da modulação do corpo pelo intermédio da forma que cristaliza essa expressividade. Assim, a monumentalidade do rosto na tela permite divisar os movimentos infinitesimais e as contrações musculares da fisionomia, transformada em paisagem. Com os sentimentos dos personagens dispersos nas reentrâncias, saliências e texturas da pele filmada em close, a tragédia do cinema passa a ser anatômica. Em vez da palavra e de uma divisão em atos, tudo poderia ser visto no rosto, palco do movimento interior e psicológico. ${ }^{113}$ Abstração de Epstein? Não quando recobramos um dos seus mais célebres e líricos filmes, Coração fiel (Coeur fidèle, 1923).

ponto fraco de Louis Delluc como cineasta, por exemplo, advinha do desinteresse pelo manejo técnico, o que resultava em obras cuja matéria visual era pouco trabalhada e que por isso adquiriam aspecto de inacabamento, de uma realização feita ao acaso. Ver Jean Epstein, Écrits sur le cinéma 1: 1921-1947, Paris: Seghers, 1974.

${ }^{110}$ Como Xavier (1978) e Aumont (1998) já evidenciaram, esse tipo de adição ou de revelação propiciado por intermédio do cinema foi compartilhado por outros teóricos dos anos 1920, incluindo Vertov e Balázs. Vimos que o pensamento de Canudo segue no mesmo sentido. No mais, as propriedades que descrevemos certamente estão relacionadas com a noção de fotogenia. Por considerá-la bastante fugidia, e merecedora de um exame mais detido, optaremos por não discuti-la ao longo da tese.

${ }^{111}$ Ismail Xavier, 1978.

112 Jean Epstein, 1974.

113 Jean Epstein, La essencia del cine, Buenos Aires: Galatea Nueva Vision, 1957. 
Fig. 38-39
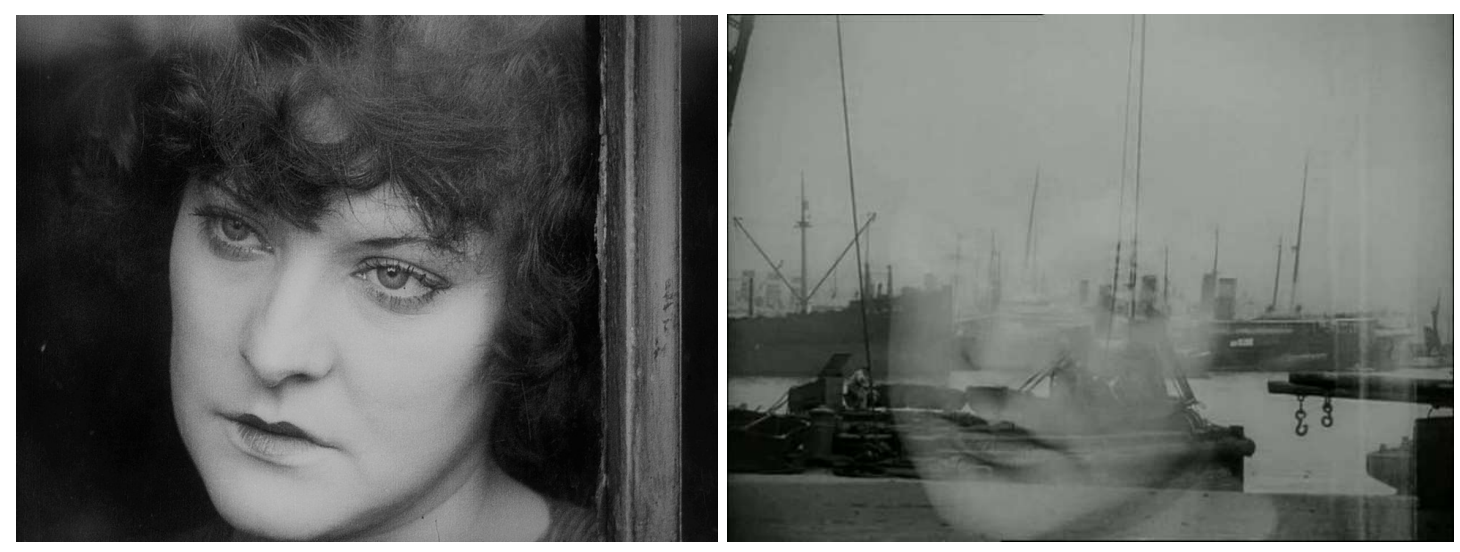

Logo no início da película, a personagem Marie (Gina Manès) se recosta na janela do bar em que trabalha e olha para o horizonte (Fig. 38-39). O plano seguinte, em close up, carrega parte da mística defendida por Epstein em seus textos. Sobre o fundo negro e com uma expressão pétrea, Marie é ladeada pela moldura da janela e, diante de seu rosto, sobre o vidro, flutuam os reflexos do mundo exterior desfocados. Para além da sensação de enclausuramento sugerida pela superfície vítrea e pela moldura, a isolar a figura do espaço extramuros, a composição do plano realça o olhar distante, a mirar o fora de campo.

A próxima imagem, que inicialmente aparenta ser um raccord de olhar, é o preâmbulo de uma sequência de planos de diferentes lugares e pontos de vista que, ao fim, retorna para o rosto de Marie. O desfile de visões estabelece outro regime na narrativa: cria um fluxo de pensamento visual que percorre a zona portuária e evidencia o estado da personagem, seu alheamento diante do cotidiano do bar. Acompanhamos uma espécie de flânerie espiritual em que somos conduzidos pelo próprio íntimo da figura, num passeio irrealizável em termos realistas - o corpo permanece imóvel -, mas tornado possível pelo cinema, que modula a sensação em deslocamento por um espaço misto, tanto mental como físico. O olhar contribui para o esvaziamento da presença da personagem e atua como o disparador dos seus pensamentos e/ou de sua memória (talvez os espaços sejam lembranças de outros dias), de um contracampo imaginário. Antes mesmo deste desfile de imagens interiores, o close nos coloca diante do reflexo do vidro, no qual pululam massas informes, indistinguíveis, como flous, nimbos, matérias vaporosas que contrastam com a fixidez do rosto, tal como evanescências flutuando sobre um fundo rochoso. Já a própria composição do close, portanto, coloca em comunicação esses dois vetores distintos, o impalpável e o concreto, antecipando o que se desenrolará a seguir, quando pela sequência de planos o filme dá forma, modula visualmente 
a sensação que escapa do interior da figura, do invólucro fechado e firme do corpo filmado para ganhar a tela.

O efeito desencadeado pelo close vai além da dimensão espacial: na sequência, desconhecemos também a duração exata, pois não se trata do tempo mensurável da física einsteiniana, e sim de um tempo que deve muito mais a Bergson, impregnado pelas oscilações interiores, subjetividade e consciência. Entre o close inicial e o final, a permanência de Marie frente à janela pode ter durado meros segundos ou a eternidade de um dia. O rosto na tela sugere essa elasticidade ou mesmo compressão da duração de acordo com os humores. O que possibilita isso? À primeira vista, a expressão fisionômica é poderosa em si mesma, o olhar distante sugere as afecções, bem como a cisão entre a mente (em movimento) e o corpo (estático) que se dará ao longo da sequência. Mas para além dessa potência natural do olhar e do rosto, para além desse viés ativo primário que emana da figura, há pouca contribuição da corporeidade. Marie permanece imóvel durante o close, tal como um modelo que espera enquanto o cineasta tenta extrair-lhe a essência que irá imprimir na imagem fílmica. É menos a figura por si mesma do que a ação do realizador de esculpir sua matéria a fim de acrescerlhe potência visual.

A primeira etapa deste filtro que contribui para a retórica do corpo diz respeito à presença, no close, de um motivo recorrente na história da pintura ocidental: a janela. A superfície vítrea que inicialmente demarca a separação entre Marie e o exterior do bar nos coloca diante de pelo menos duas tradições referentes a tal dispositivo óptico: a da imersão do olhar e a do caráter autorreflexivo.

No primeiro dos casos, está em jogo um mecanismo comum à cultura Renascentista, a veduta, essa abertura criada a partir do recorte no espaço representado: no interior de uma cena geralmente hermética, os pintores inseriam, a partir de portas, janelas ou quaisquer outras bordas, frestas pelas quais se descortinava um espaço extensivo, projetivo. Ao tornar acessível e penetrável ao espírito humano a vastidão infinita do mundo, a veduta está em consonância com outras técnicas utilizadas para a balizagem em profundidade do espaço, bem como com a significação social e simbólica deste último para a cultura do Renascimento italiano. ${ }^{114}$

Em comparação com esta visada, o que a sequência analisada de Epstein nos coloca é uma janela que, dentro do espaço inicialmente fechado e limitado do bar, instaura um valor expansivo, a abertura para um lugar outro. Se na pintura renascentista a veduta acabava por

\footnotetext{
${ }^{114}$ Pierre Francastel, 1990.
} 
funcionar além do nível ilusionista, pois não necessariamente obedecia à unidade de escala e nem à identidade com o ângulo de visão do espaço no qual estava inserida, a veduta epsteiniana opera igualmente segundo uma clivagem. Já não se trata apenas de descontinuidade visual, mas da própria natureza da representação: a passagem do close para a sequência demarca a mudança do universo concreto para o mental, do ambiente exterior para a sensação interior, do tempo de duração realista para o tempo subjetivo. A janela atua como medium, dispositivo intermediário pelo qual se esboça uma nova realidade em que o que se vê do outro lado já não é o resultado do olhar objetivo ou neutro, mas o mundo filtrado por uma tela que imprime à imagem uma distorção ou desrealização.

A sequência iniciada e fechada com o close de Marie em Coração fiel se vale inicialmente da janela como membrana capaz de efetuar a cesura entre dois mundos. Ela é a primeira etapa, a porta de entrada para a representação plástica do estado imaginário. A continuidade desse processo de revelação é dada a partir da manipulação do tempo, com as imagens ralentadas, e do espaço, com a multiplicação de planos que inicialmente deveriam corresponder a um único ponto de vista (o da personagem). O efeito é a criação de um contracampo imaginário, que não responde a um olhar, mas a um estado - do contrário, e se não quisermos apelar para nenhum olho de Sirius transcendental, a quem corresponderia este ponto de vista ubíquo, que atravessa/fluidifica os espaços? Na sequência, temos, portanto, um processo constituído por três etapas, uma progressão que se inicia com o close, passa pela janela e por fim desemboca na recriação do espaço-tempo.

A estrutura que descrevemos exemplifica a operação aditiva que anteriormente destacamos como fulcral para a teoria e o cinema de Epstein. Na sua base, está a possibilidade de substituir o discurso verbal por um pensamento visual e assim aumentar o poder de significação das imagens no domínio das ideias e em relação à realidade psíquica. A efetuação disso acontece ao "multiplicar os virtuosismos fotográficos, os truques, as sobreimpressões, as buscas de ângulos e de iluminação capazes de outorgar a uma pessoa ou a um cenário ou a um acessório, uma expressão moral particular". ${ }^{115}$ Com isso, o autor acredita levar ao espectador, em cada plano, as oscilações da alma, seja a do realizador, seja a dos personagens.

Em se tratando da figura humana, a nova dinâmica cinematográfica proposta por Epstein é conformada no artifício do close, matriz do deslocamento entre as esferas imanente e metafísica. Se o primeiro cinema tinha como critério de julgamento a ação, e o bom argumento era medido pelo excesso de movimento superficial (perseguições, tumultos,

115 Jean Epstein, 1975, p. 66. 
cavalgadas), o que está em pauta nos filmes de vanguarda é outro tipo de movimento, não tanto físico e dramático, mas espiritual. ${ }^{116} \mathrm{~A}$ imobilidade de Marie durante o close é o sinal desta condição. A gestualidade e outras possíveis dinâmicas corporais são arrefecidas. Em lugar do corpo ou ainda da palavra, é o realce do rosto dado pelo close, em conjugação com a janela, a montagem e a modulação não ilusionista do espaço-tempo, que acresce às imagens o valor subjetivo. "A ação cinematográfica deixa de ser uma soma de gesticulações que respondem a aventuras superficiais e passa a ser um movimento que traduz uma evolução psicológica". ${ }^{117}$ É este movimento estruturado a partir das potencialidades do meio (desde os elementos cênicos e as escolhas da decupagem até, como veremos mais à frente, a interferência direta na imagem) que dá forma ao drama interior da figura.

O distanciamento do naturalismo à custa do desaparecimento e da desfiguração da figura humana, ou mesmo da ressonância entre corpo e espaço plástico, como vimos em Canudo e em Epstein, permite dar uma resposta negativa à pergunta que iniciou o tópico. $\mathrm{O}$ formalismo não necessariamente implica o afastamento dos valores humanos em benefício de um discurso exclusivamente meta-artístico, como pode sugerir o lado essencialista dos discursos da vanguarda francesa. Pelo menos, e esse é o caso de Grandrieux, quando a estilização consegue alinhar a perspectiva formalista com uma representação da figura e dos valores humanos. Ou, ainda, a possibilidade de trabalhar a materialidade do meio, chamar a atenção para os valores estéticos, sem perder de vista a relação com o mundo. ${ }^{118}$

$\mathrm{Na}$ linha do que esboçamos, poder-se-ia convocar, a título de complemento, o aporte fenomenológico de Merleau-Ponty sobre a pintura de Cézanne, pelo qual reconhece, nas distorções do modelo naturalista de representação, o desejo de dar concreção visual ao mundo apreendido pelos sentidos. A pintura não separaria "as coisas fixas que nos aparecem ao olhar de sua maneira fugaz de aparecer", ${ }^{119}$ ou seja, não faria distinção entre a aparência das coisas e como elas tocam o pintor, consciência que as apreende. As visões e os sons do mundo vão encontrar forma pelo crivo da experiência do sujeito, em correspondência com seus impulsos interiores. A tela não resulta, então, de uma objetividade do olhar e nem exclusivamente das convenções de modos de representação, mas da complexa interação entre o mundo das

\footnotetext{
${ }^{116}$ Ibid. A separação entre dois tipos de movimentos é igualmente presente nos escritos de Germaine Dulac. A autora distinguia a agitação, os deslocamentos puramente mecânicos, de um tipo de movimento dirigido pelo pensamento, capaz de provocar a emoção e revelar a própria essência do universo. A respeito, consultar: Ismail Xavier, 1978.

117 Jean Epstein, 1957, p. 114.

${ }^{118}$ Similar harmonia é discutida no texto "Sobre a Humanidade na Pintura Abstrata", em Meyer Schapiro, 2010.

${ }^{119}$ Maurice Merleau-Ponty, Sens et non-sens, Paris: Les Éditions Nagel, 1966, p. 20.
} 
sensações físicas, o das projeções psíquicas e o dos códigos artísticos. ${ }^{120}$ Nessa operação de expressão, o objetivo do pintor seria o de restituir algo da presença do objeto que apreende, por outra via que não a da exatidão das formas segundo critérios naturalistas - eles próprios carregados de convenções e artifícios que maculam uma hipotética representação fiel do mundo. $^{121}$

Assim como o viés fenomenológico, contribui para dissipar o aparente antagonismo entre a presença da figura humana e o formalismo que obstrue sua semelhança frente ao homem real, uma abordagem que demonstre como esses polos interagem numa obra. É o caso de um dos textos de Steinberg sobre Picasso. Entre outros temas, o crítico explora o poder formal como condição para a brutalidade e a carga erótica das obras do artista feitas entre 1907 e 1908. Atendo-se ao desenho Mulher em Pé (1907), observa a ambivalência das linhas: o traçado impede apreender o ângulo exato em que a mulher é mostrada, sugerindo que ela está disposta tanto de frente como de costas para o espectador. A despeito da bidimensionalidade da imagem, sem indicações de volume, como sombra e superposições, Picasso tentaria recriar a ideia de corpo, de algo mais denso do que a silhueta figurada. Isso passaria pela produção da visibilidade dupla, da ambiguidade frente-dorso, de uma forma vista de ambos os lados. O procedimento é sucinto, mas suficiente para evocar algo da corporeidade da figura, impedindo sua total submissão ao aspecto planar do papel. Contudo, é ao falar de Les Demoiselles d'Avignon (1907) que Steinberg integra a proposta formalista ao peso das figuras. A partir da descrição das sugestões espaciais, o autor demonstra como a pintura estabelece um conflito entre compressão e expansão, resultando numa profundidade sob pressão que carrega a tela com a presença dos corpos, ao mesmo tempo em que projeta o quadro em direção ao espectador. Concentrando-se na figura agachada à direita, percebe como a impudência desavergonhada da pose, longe do desinteresse erótico ao qual o nu foi correlato na arte ocidental, juntamente à visualidade alternada, provocada pela frontalidade agressiva do rosto e pelo corpo visto inteiramente de trás - numa estratégia similar à de $A$ mulher em pé -, implicam no envolvimento espacial de um observador, que vê a figura de todos os lados.

Em sua presença absoluta, as prostituas sinistras de Picasso encenam uma aterradora dessublimação da arte. O quadro quebra o triplo feitiço

\footnotetext{
${ }^{120}$ A leitura do texto de Merleau-Ponty foi auxiliada e complementada por: Tamar Garb, 1996.

121 Steinberg, em sua desconstrução da polaridade proposta por Greenberg entre arte pré-moderna e a arte moderna, baseada na materialidade do meio, discute como uma pintura a princípio pautada no "ilusionismo" igualmente cultiva artifícios que suspendem o aparente realismo. Leo Steinberg, Op.cit.
} 
da tradição - idealização, distância emocional e perspectiva de foco fixo -, a tradição do ilusionismo que conduz o espectador-voyeur inobservado a seu assento privilegiado. ${ }^{122}$

A menção que fazemos a Merleau-Ponty e a Steinberg resgata apenas um ligeiro extrato de suas reflexões, omitindo o percurso dos autores para alcançá-las. Todavia, acreditamos que seja suficiente para apresentar de que modo as desfigurações do corpo representado podem servir menos para anular sua presença do que para matizar a obra com a percepção e as sensações do artista (em Grandrieux, as dos corpos em cena) na apreensão do mundo, exigindo, portanto, esquemas formais que restituam a materialidade por outra via que não a da imagem integral do corpo.

\subsection{No princípio, era o preto}

Basta lembrar que Rembrandt jamais tratou a luz de outro modo, que a obscuridade é o seu hábito, que a sombra é a forma ordinária de sua poética, seu meio usual de expressão dramática, e que, em seus retratos, em seus interiores, em suas lendas, em suas anedotas, em suas paisagens, em suas águas-fortes, assim como em sua pintura, é geralmente com a noite que ele faz o dia.

Eugène Fromentin ${ }^{123}$

Anteriormente, destacamos duas ameaças ao primado da figura humana no filme de Grandrieux: a transformação dos corpos em sombra e o devir monocromático da imagem. Ora, uma das lições tiradas da visada sobre a vanguarda dos anos 1920 é que a diluição das formas visuais não necessariamente implica em um esvaziamento, perda ou negação do que é figurado na imagem, mas talvez sugira a criação de uma ordem incapaz de ser expressa a partir do regime figurativo naturalista. Caras a Canudo e a Epstein, a subjetivação da imagem e a crença no seu poder revelador, a partir de um princípio hipostático, são também pontos centrais na poética de Grandrieux. A suspeita a ser apresentada nas próximas páginas é a de que o negrume de Sombra converte o espaço plástico em placa sensível, meio que acolhe uma presença da figura humana criada pela circularidade da imagem. Investigar a economia envolvida nessa operação nos conduz à função do espaço preto enquanto matriz figurativa do corpo no cinema, tema longevo que remete inicialmente às cronofotografias de Étienne Jules

\footnotetext{
122 Ibid., p. 218.

${ }^{123}$ Eugène Fromentin, Les maîtres d'autrefois, Belgique-Hollande, $8^{\mathrm{a}}$ edição, Paris: Plon, 1896, p. 329.
} 
Marey, sedimenta-se nos filmes de Méliès e continua até o cinema contemporâneo, seja na obra de Grandrieux, seja na de realizadores como Pedro Costa e Jonathan Glazer.

Seguiremos no encalço das questões propostas a partir de Sombra, verificando sua ocorrência tanto em obras (fílmicas e visuais) de outros artistas como também buscando compreendê-las à luz da filmografia de Grandrieux. Ao tornar mais amplo o escopo de abordagem, esperamos inserir o tema do esvaecimento visual da figura humana dentro de um corpus mais amplo, evidenciando sua reincidência e em corolário sua importância como problemática. Ao mesmo tempo, será possível refletir tanto sobre as bases gerais - a transversalidade do tema frente à heterogeneidade de suas aparições - como sobre as particularidades em um filme ou filmografia.

\subsubsection{A noite, a escuridão e suas travessias}

O negrume no filme de Grandrieux se situa a meio caminho entre a carga simbólica da noite e a herança da escuridão artificial, dispositivo desenvolvido no início e consolidado ao final do século XIX a partir da tela preta (black screen, écran noir) e dos teatros negros (black theaters). Presente em fantasmagorias e outros espetáculos de magia, cinema, teatro, fotografias amadoras e profissionais, a tela escura foi essencial para conformar o corpo humano dentro dos parâmetros de uma cultura visual moderna, em especial o de sua decomposição. Suas aparições nos diferentes meios citados podem ser arranjadas em torno de dois eixos comuns. No que concerne à criação de imagens, uma estrutura amparada no tripé fundo negro, medium e tela. Quanto aos seus efeitos, a qualidade da escuridão como lugar de produção do visível. ${ }^{124}$

O arranjo básico das atrações com a black screen, fossem elas amparadas em mídias ópticas ou não, depende do jogo entre visibilidade e invisibilidade criado pelo contraste entre os elementos revestidos de preto, portanto mimetizados ao fundo, e os postos em evidência por tecidos brancos e pela iluminação. A oposição visual é central nas performances da Black Art, que em meados da década de 1880 punha em cena atores com roupas escuras, ocultos pelo fundo preto, a manipular objetos do palco como se os mesmos se movessem sozinhos. Pelo mesmo artifício, forjavam o desmembramento de partes do corpo, incluindo os números

\footnotetext{
${ }^{124}$ Noam M. Elcott, Artificial darkness, Chicago: University of Chicago Press, 2016.
} 
de decapitação, anos mais tarde recuperados por Méliès e outros diretores do primeiro cinema. ${ }^{125}$

A mesma polarização criada pelas telas pretas amparou as cronofotografias de Marey (Fig. 40-41), mas com finalidade oposta à da Black Art. O negrume já não portava o apagamento ou permeabilidade das fronteiras entre a ficção e a realidade, corpo real e sua figura dilacerada. Produzia-se ao invés disso uma imagem com finalidades científicas, na qual a figura humana era despersonalizada, disciplinada em benefício do que se exibia, pelo menos a princípio, objetivamente. A subjetividade do elemento humano declina tanto no âmbito da criação, pelo automatismo técnico, como no do produto final. Nas cronofotografias o corpo é convertido em objeto do olhar, matéria anatômica: pose, musculatura e movimento. Sua fisicalidade é isolada na virtualidade de um "não lugar", de um espaço tragado pelo preto. Como dotá-lo de significado ao separá-lo de outros seres e privá-lo de um espaço? Descolada de um mundo, a figura, de perfil, habita uma superfície rasa, imagem bidimensional mesmo a nível representativo. O dispositivo óptico das cronofotografias aliena, enquadra e registra um corpo que no limite poderíamos chamar de desencarnado, forma limitada ao seu envelope carnal e à sua motricidade. Conforme Daston e Galison (1992), Marey foi um pioneiro do novo modelo de pesquisa científica de meados do século XIX e início do XX, pautado na objetividade mecânica, particularmente em uma "objetividade a-perspectiva", referente à eliminação das idiossincrasias de um indivíduo ou de um grupo em benefício da comunicabilidade e do conhecimento que dele é possível extrair para a comunidade científica. $^{126}$

\footnotetext{
${ }^{125}$ Desde o final do século XIX, na arte europeia e em particular na França, foi recorrente a representação da decapitação presente no tema bíblico de Salomé. Dedicaram-se ao episódio: nas artes visuais, nomes como Henri Regnauld, Gustave Moreau, Pierre Puvis de Chavannes, Aubrey Beardsley e Gustav Klimt; na literatura, Mario Praz, Oscar Wilde, Jean Lorrain, Mallarmé e Flaubert. A persistência do tema no imaginário da época estava vinculada à perda de unidade do corpo, debate que vinha desde o final do século XVIII e marcaria o entre guerras, no século XX, quando as metamorfoses da figura humana subvertem os princípios do antropomorfismo. Ver: Eliane Robert Moraes, Op.cit.

${ }^{126}$ Diferentemente de outros tipos de objetividade, a objetividade a-perspectiva preza justamente por transcender os pontos de vista nacionais e/ou restritos a demais fronteiras individuais e sociais a fim de alcançar um maior comunicabilidade junto ao campo científico - ainda que, em um caso extremo, seja preciso sacrificar a profundidade ou um conhecimento mais acurado em razão dessa demanda. Ver: Lorraine Daston, "Objectivity and the Escape from Perspective", in Social Studies of Science, vol. 22, n. 4, novembro, 1992.
} 
Fig. 40-41
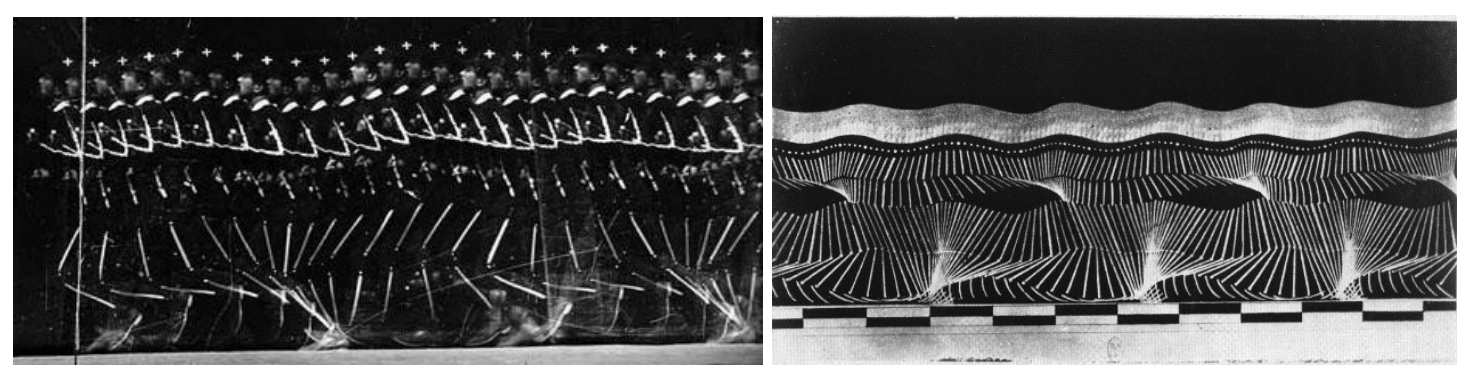

A experiência de Marey ao reunir numa mesma fotografia imagens sucessivas de diferentes posições de seres vivos durante o movimento de locomoção produzia um efeito singular. A captação de posições intermediárias do movimento, bem como o seu método gráfico, resultante da aplicação de uma mancha clara numa figura pintada ou vestida de preto (o contraste do qual anteriormente falávamos), permitia a captação de linhas, ao invés de volumes. ${ }^{127}$ Onde havia o corpo físico, sobram os traços fugidios de sua passagem espaçotemporal, dispersos no fundo negro. A despersonalização e, no limite, a desencarnação do corpo acontecem pela sua conversão em figura geométrica. O predicado científico que subsumia ou que Marey buscava com o seu método era o de inscrever sobre a imagem a dinâmica do movimento, o fenômeno em si mesmo. A apreensão deste era subordinada à recusa em restituir a aparência do visível ou ao desejo de depurá-lo até preservar exclusivamente a inscrição do movimento ali presente. Como na equação proposta por Michaud: em vez de representar o corpo figurando o movimento, Marey representa o movimento em favor de um eclipse do corpo, transformado em suporte evanescente. ${ }^{128}$ Diante da visibilidade excedente da figura, buscavam-se meios para reduzir sua superfície visível, conjurar sua presença, neutralizá-la a fim de capturar exclusivamente a força cinética que ela veicula. Essencial para essa tarefa de eliminação das aparas e registro objetivo do fenômeno, o fundo preto. ${ }^{129}$

À primeira vista, nada mais distante do cientificismo das cronofotografias de Marey que a natureza fantástica do cinema de Méliès. ${ }^{130}$ Um seria diametralmente oposto ao outro? Em que pesem a particularidade de seus programas, ambos utilizam a tela escura para engendrar a

\footnotetext{
127 Annateresa Fabris, “A captação do movimento: do instantâneo ao fotodinamismo”, in Ars, v.2, n.4, São Paulo, 2004, p. 50-77.

128 Philippe-Alain Michaud, Sur le film, Paris: Éditions Macula, 2016.

129 Como se sabe, o resultado do método gráfico das cronofotografias de Marey acaba por situá-las entre a ciência e a arte, o que torna discutível a possível "objetividade" de suas imagens.

${ }^{130}$ Pelo menos, no âmbito das motivações, das finalidades que orientavam Marey. Deixando-as de lado, poderse-ia muito bem argumentar que o resultado final de suas cronofotografias se aproxima igualmente de um universo artístico ou fantástico.
} 
figura humana ou, em outras palavras, ameaçar sua integridade figurativa. Em lugar de traços e formas geométricas extraídos e destacados de uma figura em movimento, em vias de desaparição, os filmes de Méliès jogavam com os limites da corporeidade a partir das variações de escalas e sistemáticas amputações, em especial a decapitação. A tela preta, herdada da Black Art e de outros espetáculos dos séculos XIX e XX, reaparece na base das trucagens. A escuridão artificial facilitava sobrepor duas imagens e disfarçar a disjunção entre ambas, incrementando a famosa parada da câmera (arrêt de caméra). Assim, em filmes como O homem com a cabeça de borracha (L'homme à la tête de caoutchouc, 1901, Fig. 42), o fundo negro é a região do cenário que acolhe a imagem superposta: a cabeça de Méliès, filmada contra uma black screen. Em Le mélomane (Fig. 43), o mesmo procedimento é utilizado para as cabeças lançadas nas partituras musicais. A decapitação do corpo do maestro, por sua vez, é feita por meio de um capuz preto. São muitos os exemplos ao longo da obra de Méliès nos quais a escuridão artificial e as diferentes manifestações do preto amparam os modos de figuração do corpo, promovendo o divórcio entre natureza e imagem. Na fratura entre dois regimes de figuração, a tela negra é o espaço intersticial onde tudo será possível ao corpo, inclusive transgredir as leis que regem vida e morte.

Fig. 42

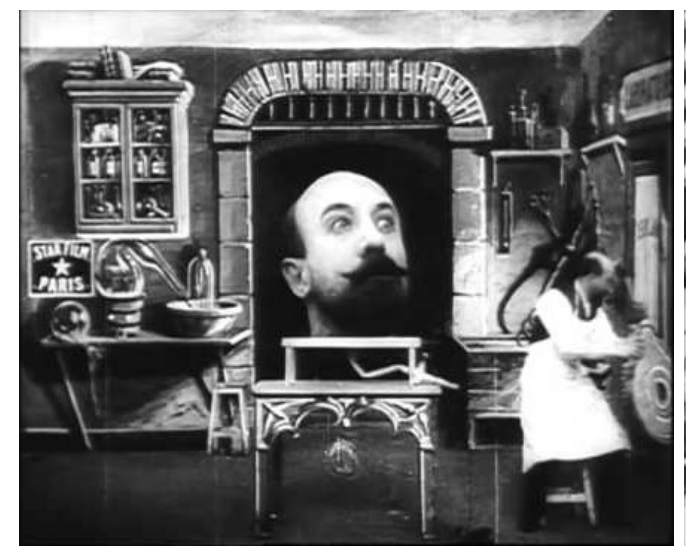

Fig. 43

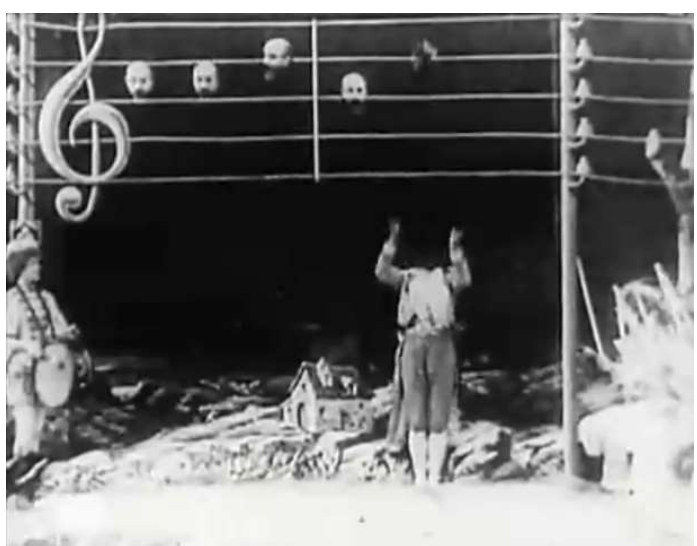

Munidos da sucinta menção ao papel da tela escura para Marey e Méliès, e antes de retomarmos os filmes de Grandrieux, podemos fazer uma pequena escala em outros realizadores do cinema contemporâneo dedicados a explorar as potencialidades da matéria negra do espaço, tornada elemento matricial para a gênese da figura humana e igualmente para o sentido a ela conferida.

Um caso a ser evocado são os filmes do português Pedro Costa. Em No quarto da Vanda e em Juventude em Marcha, não estamos no domínio da escuridão artificial, mas as massas escuras espreitam o interior das residências e as ruelas do bairro das Fontainhas, em 
Lisboa. Nesses ambientes com pouca luminosidade ou com luz pontual, os imigrantes caboverdianos por vezes se imiscuem à escuridão. É desse modo que por vezes encontramos o personagem Ventura em vias de desaparecer no plano, sendo filmado em contraluz ou com a figura circunscrita e tragada pelas sombras (Fig. 44-45). A escuridão não é tanto o artifício de gênese e modulação da imagem do corpo. A função que assume parece próxima àquela dos filmes de Jacques Tourneur, diretor que Costa evoca frequentemente em entrevistas como fonte de influência. Ali, a sombra espacial é o lugar do mistério, o domínio no qual a razão treme diante do irreal: ela acolhe consigo os mortos-vivos (A morta viva, I walked with a zombie, 1943), a metamorfose dos seres (Sangue de pantera, Cat People, 1942; Homem Leopardo, Leopard Man, 1943), as figuras em transe, imersas em rituais vodu (A morta viva), e finalmente o pacto com outros mundos (Noite do demônio, Curse of the demon, 1957).

Fig. 44-45
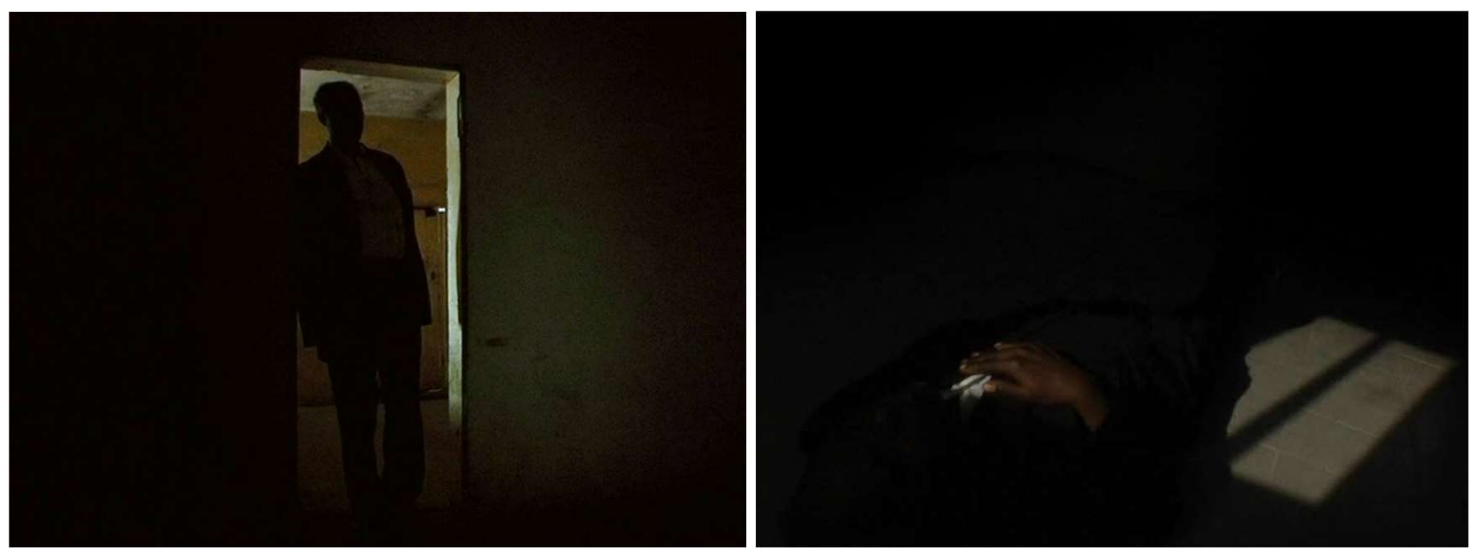

Os espaços escuros de No quarto de Vanda e de Juventude em Marcha aureolam a figura humana e seus dramas firmemente ancorados no mundo real com uma ambiência de estranhamento, como se se infiltrasse no seio das experiências mais violentas e materiais (a droga, no primeiro; a miséria em ambos) algo do irreal tourneuriano. A sombra, como outros elementos do cinema de Costa, contorna o documental com expressividade pictórica, e insufla nos espaços reais a dimensão do imponderável e de uma tragédia iminente. A figura humana, dissemos, não é criada por essa escuridão, mas dela se nutre semanticamente: a penumbra que assola os espaços assume uma função metafórica, aludindo à condição dos imigrantes caboverdianos, entre o país natal e Portugal, entre a memória do passado e a ameaça ao presente (acompanhamos o processo de destruição do bairro em que moram e a realocação dos moradores para outra região de Lisboa). A muito custo, a figura humana surge visível na imagem, assim como aos olhos do Estado. O preto é ali o signo da incerteza e da ameaça 
invisível que ronda os espaços, um limbo dentro dos planos, o confinamento dentro de uma condição social miserável, o (não) lugar dos exilados.

Deixando a austeridade e olhar social do cinema de Costa, reconhecemos na ficção de Glazer, Sob a pele (Under the skin, 2014), outra relação entre a imagem do corpo e a escuridão. Ambientado sob uma Escócia brumosa, com cenas noturnas e crepusculares, ou sob a luz difusa e sutil dos dias nublados, o filme incorpora ao visual soturno um suspense que se desenvolve sobre um fio delgado: uma mulher de quem temos vagas informações dirige uma vã por vários pontos de uma cidade, parando desconhecidos para pedir informações. Feito o primeiro contato, ela inicia um flerte e os convida para acompanhá-la. O destino são sempre endereços cujo acesso se dá por meio de passagens tenebrosas, portas que abrem para quartos escuros, com uma escuridão impenetrável: é preciso que os homens atravessem o coração das trevas para saciar o desejo com a desconhecida. Uma vez cruzada a linha da sombra, ambos entram num espaço hermético, onde a noite se torna escuridão artificial. ${ }^{131}$ Chegando ali, os corpos, nitidamente visíveis pelo contraste com o preto, caminham sobre uma espécie de espelho d'água. A mulher começa se despir, enquanto os homens a seguem. A cada passo, e sem perceberem, eles afundam na matéria escura e densa que está sob seus pés (Fig. 46). A armadilha se repete de modo sistêmico ao longo do filme, ganhando ares de um ritual. Ao imergirem, os homens adentram outro espaço, aparentemente mais grosso, mais sólido, como um líquido pastoso - pelo menos a tal ponto de dificultar os seus movimentos. Sob uma luz azulada que os torna pálidos, os corpos masculinos parecem envelhecer rapidamente ou pelo menos passar por um processo de degeneração física. Ao final, são subitamente esvaziados da matéria carnal e óssea. Sobra a epiderme a flutuar na profundidade de um universo abissal (Fig. 47). A carne, os órgãos internos, o sangue e toda a vida que reside sob a pele escoam por uma grande vala cujo destino não nos é precisado.

\footnotetext{
${ }^{131} \mathrm{O}$ realizador explica em entrevista que concebeu o quarto escuro por meio de um jogo de espelhos, de trucagens de prestidigitação (herança da Black Art?) baseadas em efeitos mecânicos misturados a efeitos ópticos, posteriormente retrabalhados na pós-produção. Ver a entrevista de Jonathan Glazer concedida a Frédéric Strauss, "Under the skin: Scarlett est envoûtante, comme son personnage", in Télérama, 23/06/2014. Disponível em: http://www.telerama.fr/cinema/jonathan-glazer-under-the-skin-scarlett-est-envoutante-comme-sonpersonnage, 114007.php. Acesso em: 02/08/2017.
} 
Fig. 46-47
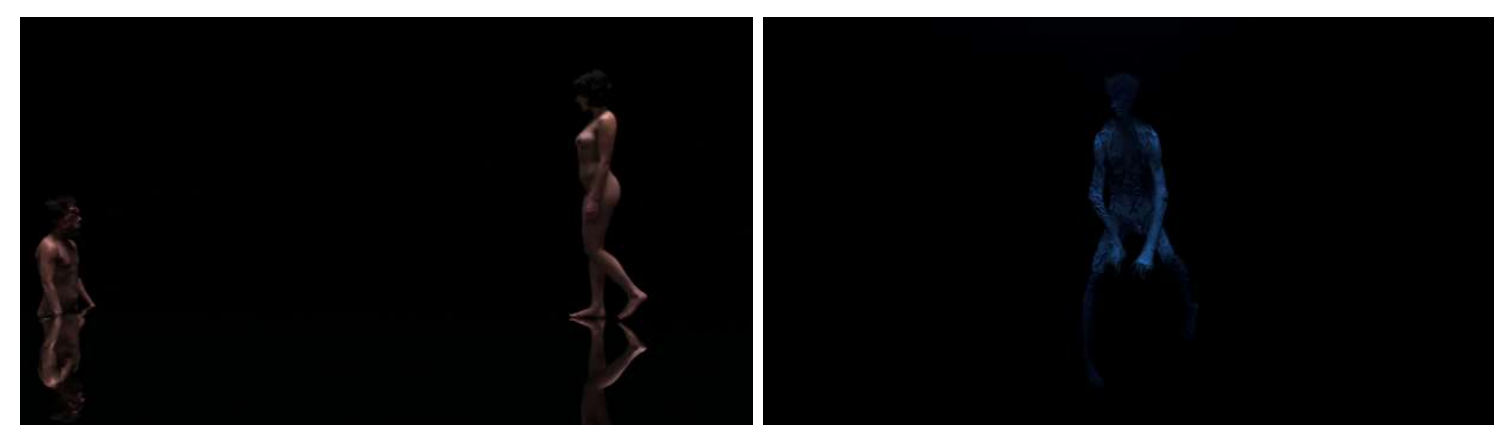

Nas cenas de escuridão artificial, a já sucinta mise en scène é reduzida a duas figuras se despindo em um espaço obliterado pelo preto. Os diálogos findam. Sob a ausência da fala e sob o ruído da trilha musical, os personagens são achatados tal como o fundo: nada existe para além dos seus corpos e do desejo (unidirecional) que liga um ao outro. A rasura da imagem se transforma em espaço do desejo, ou pelo menos engendra o lugar em que ele se torna absoluto na cena, demarcando a figura enquanto aparência, envelope, exterioridade corporal. Elogio da superfície, logo, da pele - todo o filme é assombrado pelo desejo que se produz sobre e pelo segredo que reside sob esse véu.

A etapa final do ritual é justamente o esvaziamento de tudo o que há para além da epiderme. Entre o primeiro e o segundo momento desse processo, entre a relação sexual não consumada e a figura eviscerada, um deslocamento, uma lógica de compensação: a troca deixa de ser entre dois corpos para se efetuar entre a figura e a matéria negra da imagem. Dito isso, voltemos ao cinema de Grandrieux.

O primeiro ponto a sublinhar sobre os seus filmes é o distanciamento em relação ao que aqui apresentamos sobre a Black Art, as cronofotografias de Marey, os filmes de Méliès e Glazer. Nestes, o fundo preto engendra o visível a partir do contraste entre figura e fundo. Mesmo quando há o esvaecimento do corpo, o objetivo é fazer sobressair algo na imagem, como o grafismo das cronofotografias de Marey. Noutros casos, como em Costa, o que fica em evidência é menos a figura que o significado a ela atribuído pela mise en scène. À primeira vista, a obra de Grandrieux segue em outra direção. Em Sombra, La vie nouvelle, Un lac e White epilepsy, o espaço ensombrado absorve o que está em campo. A imagem é ligeiramente enturvecida. A aparência é a de que existe um véu preto, parcialmente opaco, parcialmente translúcido, disposto entre o olhar do espectador e o conteúdo figurado. Esse filtro, espécie de cortina, está presente em todos os filmes mencionados com intensidades variadas. Graças a ele, a figura e o fundo, os corpos e a imagem estão em vias de tornarem-se um só, de uma comunhão total. 
Ao encobrir a visibilidade mesmo que parcialmente a partir do negrume, o efeito inicial é o esboroamento das fronteiras espaciais, dos limites físicos. Em uma das cenas de Sombra, o protagonista sai com duas garotas que conheceu em uma boate e as leva de carro para outro lugar. A localização não é precisada. Claire, que estava no quarto de hotel, próxima à casa noturna, emerge paulatinamente da escuridão ao lado do carro de Jean, materializando-se a partir da noite. Ela caminha do fundo da imagem, sem contornos nítidos, até o primeiro plano, quando entra em foco. Não se sabe e nem teria qualquer importância para a interpretação do filme saber como ela chegou até ali. Importa, porém, sublinhar um ponto: o salto da personagem de um lugar a outro, logo, a sutura entre espaços, a possibilidade de uma travessia mediada pelo próprio tecido da noite. Consequência direta dessa propriedade, uma espécie de profundidade do plano escuro. Diferentemente do que apontamos anteriormente, o aspecto tonal e túrbido da imagem em Sombra não se resume a um achatamento do espaço figurado. O preto é também uma zona a tal ponto abissal que o olhar nada discerne, sua invisibilidade é patente. Justamente por isso, dele tudo se espera: o visível é uma virtualidade. A figura humana pode tanto mergulhar como também emergir dali, ir de um lugar a outro, deslocando-se dentro do campo escuro cuja opacidade é sinal de infinidade, não somente de rasura.

Para além dos efeitos sobre o espaço físico, o preto sinaliza a entrada no universo das sensações corporais. Na sequência já mencionada de La vie nouvelle, quando o olhar do protagonista para a dançarina produz um entorpecimento, quando a contemplação se torna uma espécie de inanição, a mudança de um estado a outro é demarcada pela entrada na escuridão (Fig. 48-49). Do espaço onde as dançarinas se exibem, o próximo plano mostra partes do corpo da stripper e o rosto do protagonista em close a flutuar em um ambiente sem bordas, objetos e demais referenciais. Pouco se vê. Inicia-se uma mudança no regime de representação, pois o plano reverbera a sensação de entorpecimento do protagonista. A cena nos recorda o close no rosto de Marie, durante a sequência analisada anteriormente em Coração Fiel (Fig. 38-39), de Epstein. Lá, a janela assumia a função de elemento projetivo, capaz de descortinar e expandir o mundo figurado, tanto em termos de uma profundidade do espaço, a exemplo do Renascimento, como de abertura para (clivagem diante de) outra dimensão, a interior/subjetiva. Em Grandrieux, os dispositivos ópticos já não são necessários. O delírio do personagem acontece sob o endosso da escuridão. 
Fig. 48-49
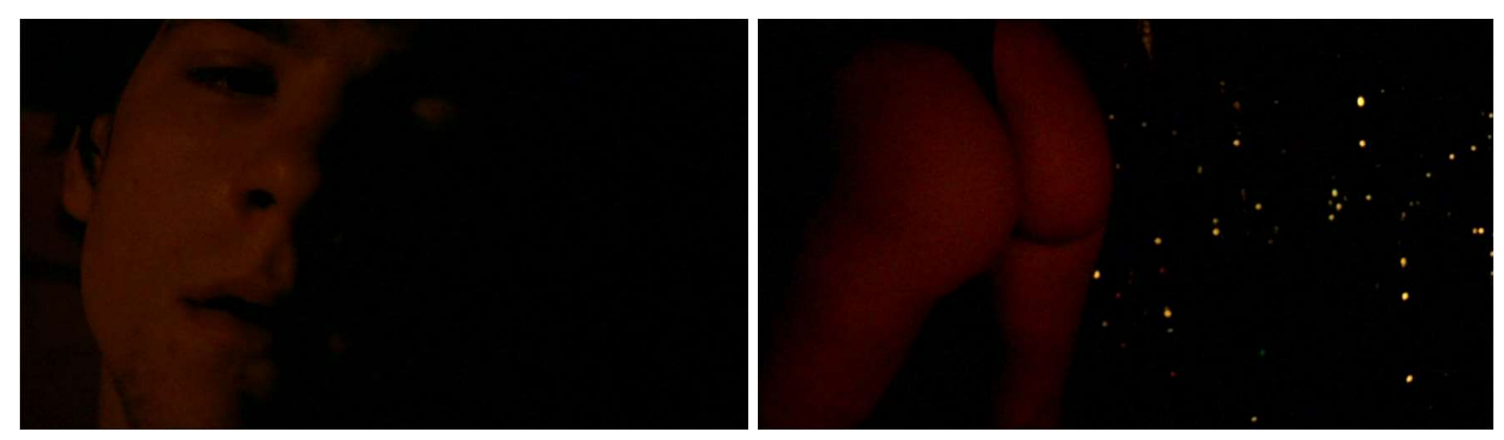

Função similar reaparece em uma das últimas cenas do mesmo filme, quando Seymour, desfocado, caminha em direção ao fundo do campo até ser absorvido pelo preto. No plano seguinte, inicia-se outro regime figurativo. O personagem adentra um espaço ocupado por outros seres. São corpos humanos, mas que filmados por Grandrieux com uma câmera térmica adquirem feições monstruosas, numa curta incursão do filme pela teratologia (Fig. 50-51). As criaturas - e Seymour se torna uma delas - têm a epiderme branca, com variações pontuais de preto, similar ao efeito de uma imagem em negativo. A íris indistinta e o globo ocular vazio impede o reconhecimento pelos olhos, janela da alma. Qual subjetividade, que idiossincrasia dar a cada uma delas? A princípio, há uma espécie de homogeneização, de diluição do caráter individual em um comportamento coletivo orgânico: as criaturas deambulam na direção na escuridão sob duas pernas ou movimentando-se de quatro. Ora gritam e se agridem com mordidas. Os corpos agem sem um objetivo, desprovidos de uma racionalização e imersos em ações bestiais.

\section{Fig. 50-51}
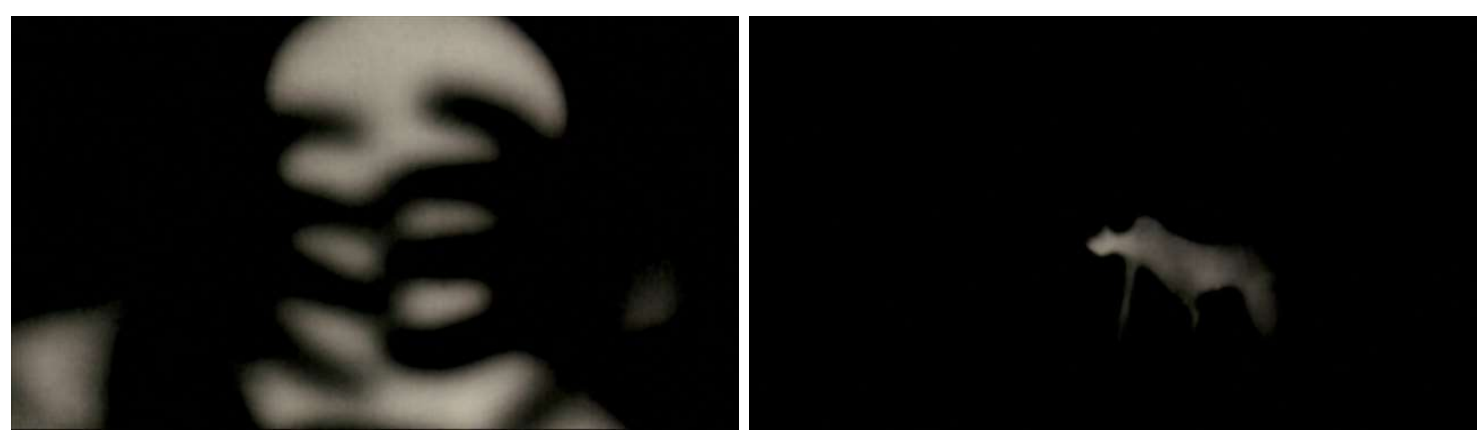

Ao longo da sequência, os desfoques momentâneos diluem os contornos das figuras. As formas brancas que constituem o modelado se imiscuem formando massas informes, em metamorfose. Pelo procedimento, curtos instantes de uma efetiva hibridização entre as figuras 
e os seus respectivos gêneros (masculino e feminino), a diluição das clivagens numa equivalência entre os seres, incluindo os reinos humano e animal.

A qualidade do preto - seja o da noite, seja o da escuridão artificial - enquanto um espaço de travessia se aproxima de certos motivos da pintura ocidental europeia cujo papel é o de estreitar a distâncias entre duas formas de vida. Pensamos, em particular, na obra de Caravaggio, cujas telas não cessam de promover o cruzamento entre polaridades, em especial os domínios do sagrado e profano, do realismo e do idealismo. Pelo menos duas estratégias permitem ao pintor efetuar esse projeto: a existência de seres de natureza híbrida e a criação de uma zona de permeabilidade. ${ }^{132}$ Detenhamo-nos sobre a última a fim de compreender o seu funcionamento e assim encontrar referências para a figuração do corpo em Grandrieux.

A remissão a Caravaggio, como não é difícil pressupor, é fértil na medida em que o pintor se serve do tenebrismo tanto para esculpir os corpos como para hibridizar domínios opostos. Max Milner repara que em A Vocação de São Mateus (1599-1600, Fig, 52), na segunda zona de sombra, situada na parte inferior do quadro, surgem Cristo e São Pedro. ${ }^{133}$ Emergindo progressivamente da negrura, mas sem se distinguir do fundo preto, as figuras permanecem entre dois espaços: nem em frente e nem atrás do cenário. Elas estão a tal ponto conformadas pela escuridão que passam a habitá-la, permanecendo num interregno, dentro e fora do quadro. Em outras telas, as trevas se tornam o meio comum que fixa os corpos no meio terreno mas os aureola com a espiritualidade, criando afinidades inesperadas entre o mundo material e as aspirações místicas. Ao turvar ou tornar ausente os elementos arquitetônicos ou naturais que permitissem uma localização da cena representada em um espaço próprio, preciso, o preto corroboraria para a permeabilidade entre realidades. Enquanto nas primeiras telas mencionadas o estatuto híbrido do anjo é condicionado aos limites do quadro, à nuvem e à sombra, em $A$ Vocação de São Mateus é a escuridão quem faz as vezes de figura de transição, reino intersticial entre as esferas do sagrado e do profano.

\footnotetext{
132 A primeira das estratégias é constatável pela figura angélica, criatura cujo estatuto ontológico é excepcional na obra de Caravaggio. Como repara Stoichita, ela porta consigo o signo de um aparente paradoxo: sua presença marca a manifestação do divino e do transcendental no seio de uma obra afamada pelo naturalismo, por ser um "espelho da realidade". O seu acolhimento implica, portanto, soluções de representação que permitam a coexistência de duas realidades distintas no seio de uma mesma imagem. Victor I. Stoichita, Figures de la transgression, Genebra: Droz, 2013, p. 75.

${ }^{133}$ Max Milner, L'envers du visible: essai sur l'ombre, Paris: Éditions du seuil, 2005.
} 


\section{Fig. 52}

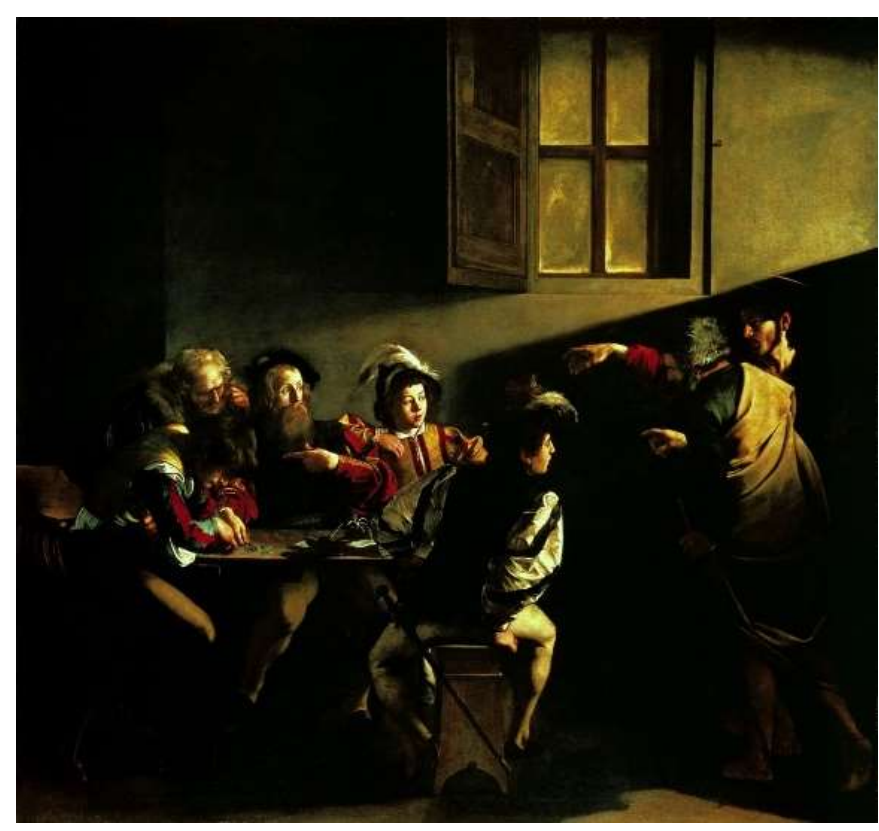

Como na obra de Caravaggio, em Grandrieux quem assume o lugar de membrana, intermediário, figura de travessia entre dois espaços, dois estados, dois mundos, dois tempos, às vezes dois seres, é a escuridão. Diferentemente de Epstein, já dissemos, as janelas não são mais necessárias. $\mathrm{O}$ mesmo vale para as portas e outros dispositivos de cesura. ${ }^{134} \mathrm{O}$ negrume se torna espaço privilegiado de exceção, tornando-se incubador de toda sorte de passagens. A figuração do corpo e o tipo de presença da figura humana são indissociáveis desse tipo de permeabilidade criada no plano.

Uma obra mais recente de Grandrieux, White Epilepsy (2012) permite esboçar as diferentes gradações do debate. O filme é a primeira parte de uma trilogia sobre a ansiedade. Ao longo de sua duração, dois corpos nus interagem na escuridão de uma floresta. Não há um drama conduzindo suas ações e tampouco diálogos: eles permanecem quase que inteiramente parados durante alguns minutos ou executam movimentos lentos. As ações não têm sentido claro, não possuem as intenções deduzíveis de uma trama. As figuras assumem poses, aproximam-se, tocam-se, deambulam, ficam uma sobre a outra e às vezes parecem se violentar. Parecem, pois nada é explícito, temos apenas indícios, como no plano em que a mulher pressiona com as mãos as costas do homem, enquanto ele contorce a face e abre a boca para gritar. Mas nenhum som é emitido, nada acontece além da mudança de postura do corpo, que cede lentamente à força que sobre ele se impõe. $O$ ato é reduzido à sua dimensão

134 Sobre a função da porta como elemento de passagem, meio de sutura, ver Jean-Louis Leutrat, Vie des fantômes: le fantastique au cinéma, Paris: Cahiers du Cinéma, L’Étoile, 1995. 
física, existe em sua natureza puramente mecânica e presencial. As tentativas de situar as figuras dentro de esquemas e de uma ordem inteligível que permitam interpretá-las fraquejam ainda mais em razão do enquadramento vertical. Se a escuridão está em vias de tudo devorar, os limites reduzidos do quadro também confiscam a porção territorial e visível. A possibilidade de expansão fica a cargo do som, com ruídos do vento, de insetos e de animais. A todo instante, irrompe a respiração e o grunhido gutural de um ser que não se revela. Talvez por não identificarmos a fonte sonora, talvez pela ausência de pontos de referência nessa densa cortina de escuridão, tais ruídos portam uma ameaça. Ou eles viriam dos dois corpos? Afinal, tudo é direcionado a eles, seja pela supressão espacial que os coloca no centro da cena, seja pela duração às vezes longa dos planos - alguns superiores a cinco minutos.

Um princípio da paisagem noturna é válido para White Epilepsy e os demais filmes de Grandrieux aqui analisados, o de indistinção: sua qualidade de espaço homogêneo que suspende os detalhes e as nuances identitárias, aspirando os seres numa densidade que os despersonaliza - similar ao que vimos em Marey pela tela preta.

As silhuetas, muito frequentemente, adquirem na noite um aspecto fantasmático, com contornos obscuros, sobretudo quando de costas, posto que se obstrui o rosto, fonte de luz, a fim de preservar somente a presença do corpo. Os humanos acabam então, eles também, como os gatos, ${ }^{135}$ a se assemelhar a tal ponto de só revelar a espécie a que pertencem. Os homens, e não as identidades, presenças vivas prestes a se fundir à noite [...] Se não é mais possível personalizá-los, resta a nós [...] a possibilidade de os associálos a atos [...] Se a noite os torna não identificáveis, ela contudo não oculta a razão de estarem lá, num momento em que tudo pode acontecer, num lugar que não impede a visão, mas a confronta à difícil tarefa da indiferenciação. Nós não sabemos quem são, mas sabemos o que fazem. ${ }^{136}$

Com encenação modesta, resumida ao que se cria a partir da relação entre espaço enegrecido, enquadramento, som e movimentação das figuras, Grandrieux nos lança, enquanto espectadores, num universo de total estranhamento, de nebulosidade dos signos. Resta-nos a contemplação dos corpos, de sua epiderme fracamente reluzente, de seus movimentos desconhecidos, potentes em si mesmos mas semanticamente opacos. Esvaziamse as demais informações para que o corpo se imponha por sua materialidade, para que exista exclusivamente a partir de sua presença. Ao mesmo tempo, esta renúncia de redes de referência lança as figuras num reino de incertezas e de potencialidades. Entre elas, a de que aqueles corpos não necessariamente correspondem a uma entidade humana. A dinâmica entre

\footnotetext{
${ }^{135}$ Referência à famosa frase de Hegel: “À noite, todos os gatos são cinzas”.

${ }^{136}$ Georges Banu, Nocturnes: peindre la nuit, jouer dans le noir, Cahors: Biro, 2005, pp. 34-35.
} 
imagem e som deixa um vasto campo de ambiguidades pelas possibilidades de associação dos ruídos animalescos com as figuras. De modo similar, as formas corporais esculpidas pela escuridão e pelo quadro vertical passam por metamorfoses, perdem, ainda que sutilmente, a semelhança direta com a imagem do ser humano. E quanto mais as duas figuras interagem, mais elas parecem formar um único corpo, trocar os membros, compor e decompor sua estrutura visual. Estabelece-se, assim, um ambiente de circularidade.

A noite em White epilepsy, como também era a escuridão na sequência da câmera térmica de La vie nouvelle, é o espaço que poderia ser o do caos primordial, anterior à criação das formas, à designação dos seres e ao nome das coisas. Como lembra Pastoureau, em diferentes mitologias e religiões, o preto foi indissociável da simbologia de florestas, cavernas e outros espaços da natureza que parecem se comunicar com as entranhas da terra, recintos de nascimento ou de metamorfose, receptáculos de energia, espaços sagrados. ${ }^{137}$ Se White epilepsy e o trecho de La vie nouvelle estão em estrita conformidade com esse simbolismo, não podemos precisar, mas o que constatamos nas imagens e nos sons é a potência do negro, da sombra, em fabricar um universo maleável, agenciar um espaço de permeabilidade, onde os limites sucumbem à fusão e transmutação das formas.

Fig. 53-54 Paul Cézanne, Les grandes baigneuses (1906)

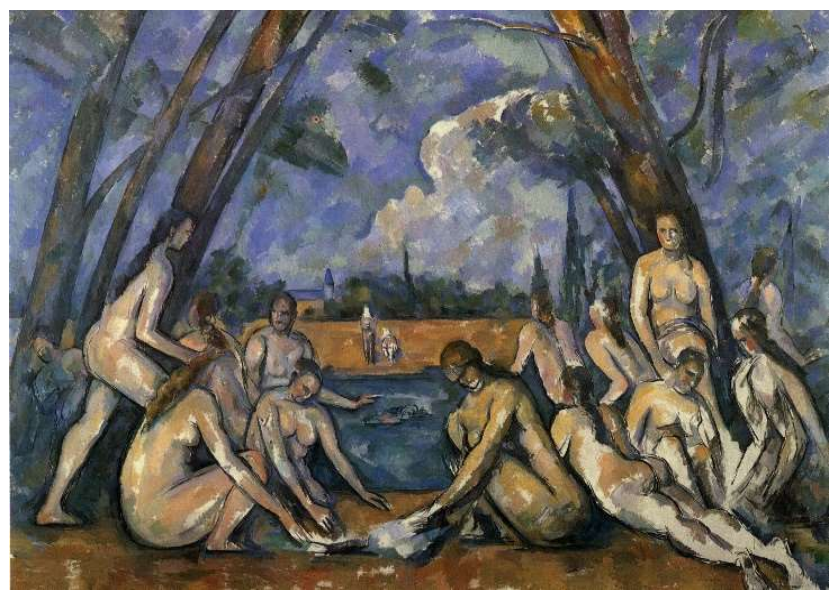

Fig. 55 White Epilepsy

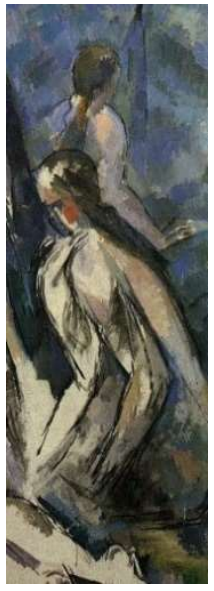

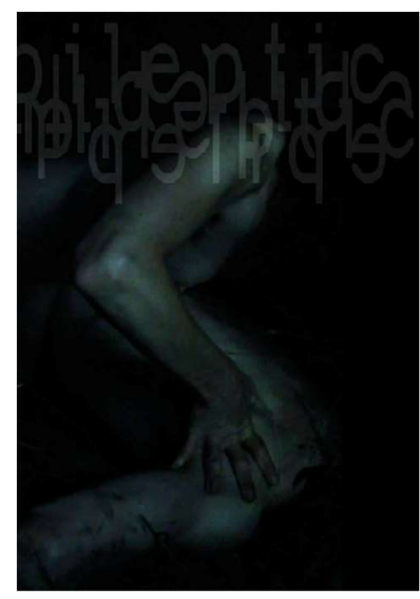

Anteriormente, mencionamos o preto como elemento de passagem em Caravaggio. Ali, ainda que por vezes as figuras estejam parcialmente impregnadas pelas sombras espaciais, há uma preservação do conteúdo figurativo e mesmo a evidenciação do corpo por meio do contraste entre claro e escuro. Talvez o tipo de fluidez encontrada entre corpos e dos corpos com o espaço pictórico, nos filmes de Grandrieux, remeta muito mais a alguns expoentes da

\footnotetext{
${ }^{137}$ Michel Pastoureau, 2008.
} 
pintura moderna. Cézanne é um nome importante para esse tema, em especial nas últimas pinturas de banhistas. Na análise das telas que compõe essa fase da obra do pintor, Tamar Garb observa que os corpos se fundem uns nos outros. ${ }^{138}$ Em Les grandes baigneuses (1906, Fig, 53-54), o ombro da figura agachada, no lado inferior direito da tela, pode corresponder às nádegas da mulher que está em pé, ao fundo da paisagem. Nenhuma das duas possui a integridade dos membros: a que está acocorada não tem mãos, a que está erguida não tem pés. Do lado esquerdo da tela, a mão da figura levantada se funde com a cabeça encolhida da mulher sentada, enquanto o ombro é o elemento de passagem, de conexão com a pincelada do céu ao fundo. A imprecisão e a incoerência das extremidades, assim como a circularidade entre as figuras e das figuras e o espaço, repetem-se ao longo da pintura.

Nem os limites do corpo, nem os traços anatômicos de suas partes, são sagrados aqui. As nádegas rimam com seios e joelhos, criando analogias de forma e de estrutura. Mãos se fundem com pés, cabeças e folhagens, destruindo a especificidade de cada um. ${ }^{139}$

O tratamento dado às figuras masculinas em Groupe de baigneurs (1895) também apresenta os corpos por meio de um campo de sensações que funde figura e fundo, expondo o corpo à profusão de tinta e criando uma equivalência entre o rosto e a folhagem, entre a estrutura sólida e o espaço circundante. A figura humana, como as árvores, se torna questão de sensação - como o pintor percebe e representa o mundo. Com as genitálias indistintas, assumindo as mesmas poses das banhistas, os corpos masculinos adquirem um aspecto andrógino. As mulheres de Les grandes baigneuses também não trazem signos de feminilidade. Nos dois casos, os corpos são lábeis em suas delineações e ambíguos em sua identidade sexual. As figuras e a paisagem são submetidas a um modo de olhar em que a fluidez da pintura constrói uma sexualidade fluida, em que a projeção imaginativa de uma tela de sensações minora as diferenças. A sexualidade aparece além de suas margens convencionais e estruturas normativas. ${ }^{140}$

O que gostaríamos de guardar dessa breve passagem por Cézanne é a ideia de uma correspondência entre os seres e o mundo, tratados pictoricamente como em constante negociação, numa fluidez que impregna o espaço e promove a circularidade entre os seus elementos. Vimos disposição similar na cena da câmera térmica de La vie nouvelle e em

\footnotetext{
138 Tamar Garb, 1996.

${ }^{139}$ Ibid., p. 52.

${ }^{140}$ Ibid. Garb não defende uma igualdade absoluta entre a representação de homens e mulheres nas telas de banhistas. A subversão dos meios tradicionais de se figurar a corporeidade desloca, mas não elimina, a diferença sexual, que estaria inscrita em outro lugar que não no próprio corpo das figuras.
} 
White epilepsy. Embora neste último não haja o mesmo nível de desfiguração e fusão dos corpos à escuridão, com as metamorfoses e o intercâmbio entre as figuras, a possibilidade de um corpo individualizado cede a um corpo híbrido que só existe no embate entre a figura e o negrume da tela, disperso na superfície da imagem cinematográfica, transformada em espaço de trocas - como em Sob a pele.

O percurso pelos filmes de Grandrieux e por determinadas obras pictóricas reafirma a singularidade da relação entre a figura humana e a escuridão, já sinalizada sucintamente pela remissão às cronofotografias de Marey e aos filmes de Méliès, Glazer e Costa. Sombra recobra parte do que foi discutido. Neste filme crepuscular, os momentos de maior integração de corpos no espaço ensombrado são os de experiências limites, extremas: nas cenas de embate físico ou de erotismo entre Jean e suas vítimas. Supomos que a parcial diluição do corpo no campo escuro responde igualmente ao que há pouco descrevemos como uma lógica da circularidade. Mas, diferentemente de La vie nouvelle e White epilepsy, o efeito em Sombra não é o de uma hibridização entre os corpos.

\subsubsection{Alteridade pela imagem}

Vimos que existe um impedimento do desejo de Jean, convertido em pulsão destrutiva, nos homicídios de mulheres. Sua transfiguração em sombra seria o sinal de clivagem, de segregação em relação à corporeidade das vítimas. Por esse ângulo, apontamos mais cedo a aparente conformidade do filme ao texto de Laura Mulvey, a uma possível lógica escopofílica na qual o homem é colocado na posição de sujeito do olhar enquanto a imagem da mulher existe a fim de, conscientemente, alimentar sua pulsão voyeurista. Existiria, portanto, uma impossibilidade do Outro resultante da fratura na relação entre dois seres. Aqui, vale questionar ou senão nuançar tal argumento. Embora determinadas cenas (Fig. 6-8) estejam em conformidade com a ideia de uma obstrução do desejo de Jean e de sua compensação por uma disposição escopofílica, essa condição não recobre integralmente a relação entre os corpos masculinos e femininos. $\mathrm{O}$ desequilíbrio entre os gêneros pautado em uma série de rupturas figurativas, das quais as principais são entre sombra e carne, sujeito e objeto do olhar, é compensado, ou senão minimizado, pelo preto que enubla e se projeta sobre o campo. Por meio dele seria forjada a travessia irrealizável, fazendo da sombra (espacial) meio, ${ }^{141}$ território favorável a um tipo de comunicação, à troca das sensações que emanam dos corpos,

\footnotetext{
${ }^{141}$ Ainda que não a desenvolva plenamente, Aumont discute a sombra como meio, um espaço de potencialidade. Cf. Jacques Aumont, Le montreur d'ombre: essai sur le cinéma, Paris: VRIN, 2012.
} 
mesmo que isso se dê modo não consensual - novamente, podemos evocar o diálogo com o filme de Glazer, no qual a amputação da relação sexual é compensada por outra espécie de troca corporal cuja base é o preto pictórico.

Se a escuridão é o espaço da virtualidade, onde tudo é possível, a passagem de um espaço físico a outro, de um estado a outro, da formação e deformação dos seres, ela também é o lugar privilegiado para abrigar o que neste filme ganha uma dimensão particular: a difícil relação entre os corpos. A alteridade até então impossível, visto que o Outro é sempre uma ameaça ou uma vítima, é esboçada pela imagem convertida em antro das sensações, única forma de negociação e sociabilidade da figura humana. A parcial horizontalidade entre os seres só existe no abandono ou diluição da forma humana, pela redução das diferenças figurativas, sejam elas relativas à aparência, ao gênero ou à natureza, a fim de um nivelamento pela intensidade da experiência física que reverbera na opacidade da imagem. Sombra dá início ao processo de circularidade interna do plano, que ganha contornos mais firmes nas cenas comentadas de La vie nouvelle e White epilepsy de hibridização dos corpos.

$\mathrm{O}$ que tratamos aqui nos termos de uma alteridade pela imagem é comum a determinados autores do cinema experimental, em especial aquele produzido pela vanguarda norte-americana dos anos 1960 e 1970. Uma geração composta por Barbara Rubin, Andy Warhol, Carolee Schneemann e Stan Brakhage realizou obras em que o medium cinematográfico atua como extensão da sexualidade e da sensualidade da figura humana, valendo-se de uma permeabilidade do plano similar àquela que aqui tentamos bosquejar a respeito de Grandrieux. Essa afirmação é particularmente válida para os filmes de Schneemann em que a autora faz da relação sexual o meio propulsor da circularidade da imagem e da gênese figurativa dos corpos. Malgrado esse ponto de partida comum, a dessemelhança diante do programa de Grandrieux ganha evidência quando cotejamos Fuses (1965) com Sombra. No abismo entre as duas obras, reconhecemos dois efeitos opostos de programas igualmente radicados na circularidade.

Insatisfeita com Cat's cradle (1959), de Brakhage, em razão do que considerou um tratamento patriarcal de sua sexualidade e de sua vida afetiva com Jammes Tenney, Schneemann decide realizar um filme sobre sua relação com o marido. Seu objetivo era retratar a intimidade de um casal heterossexual igualitário, sem enregelá-lo dentro de formas idealizadas e normatizadas de gênero e sexualidade. Com um processo de filmagem e de edição que durou entre 1964 e 1967, Fuses é composto por cenas de Schneemann e James transando - exibindo, sem pudor, pênis, vagina, a penetração e o sexo oral - com planos do ambiente caseiro e de paisagens. O suporte pelicular é pintado, submetido a colagens, 
sobreimpressões, riscado, tingido e mergulhado em ácido. Como resultado, um acúmulo frenético de fragmentos de corpos, textura, cor e luz desfila pela imagem (Fig. 56-57). As manchas cromáticas, a cintilação luminosa e as reações da película desintegram as figuras, permitem que transcendam suas fronteiras e se fundem, entre si e com a própria imagem. ${ }^{142} \mathrm{~A}$ função do negrume espacial em Grandrieux aqui é substituída pela intervenção sobre o celuloide, que funciona como extensão do fluxo sensorial e alusão às demais trocas corporais e afetivas do casal.

Fig. 56-57
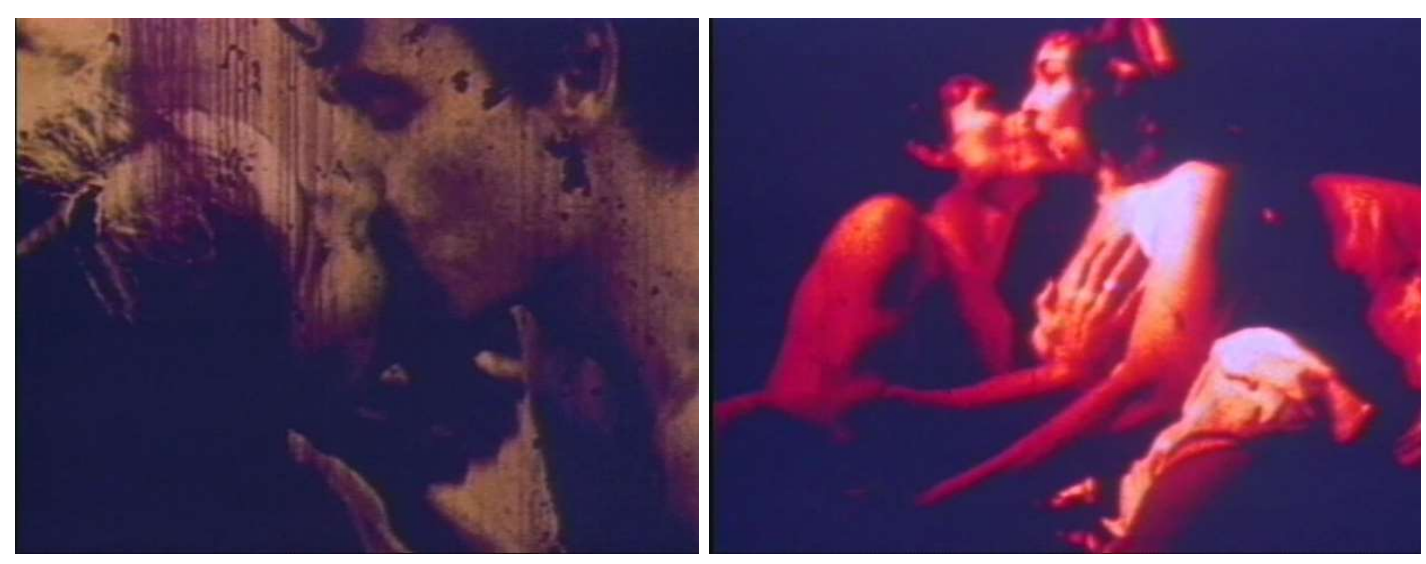

A tentativa de uma circularidade passa não apenas pela diluição figurativa em um mesmo tecido imagético. Segundo Ara Osterweil, Schneemann realiza uma edição pautada em equivalências, em escolhas aparentemente banais: ao mostrar a genitália masculina, sucedê-la ou sobrepô-la à feminina, e vice-versa. Tal reciprocidade se aplica também ao sexo oral e à dinâmica do casal, de um modo geral, pois tudo implica a presença de Schneemann e Tenney, impedindo que um corpo priorize sobre o outro. São opções que a princípio poderiam sufocar o filme dentro de uma estrutura rígida, formatada, mas a possível sistematicidade perde-se no frenesi visual, ainda que seu efeito de horizontalidade seja mantido. Por fim, com o mesmo espírito, Schneemann desafia o tabu de filmar a frontalidade do órgão masculino, que aparece por diferentes ângulos e em diferentes estados de intumescência. "O prazer extrapola os limites do quadro. Não se pode falar em submissão ou objetificação quando amantes dissolvem tão completa e generosamente as fronteiras entre si”. ${ }^{143}$

Fuses e Sombra, não é difícil constatar, trabalham dentro de regimes distintos de representação. Grosso modo, o primeiro é mais documental, lida com a manipulação direta do

\footnotetext{
${ }^{142}$ A descrição das operações materiais e dos seus resultados sobre a película foi retirada de Ara Osterweil, Flesh cinema: the corporeal turn in American avant-garde film, Manchester: Manchester University Press, 2014.

${ }^{143}$ Ibid., p. 161.
} 
suporte pelicular e, em certa medida, com a frontalidade da relação sexual; o outro é fíccional, com a modulação plástica respeitando a integridade do suporte imagético, associando a sensualidade das figuras ao sexo e, ao mesmo tempo, à sua impossibilidade. Diferenças à parte, ambos partilham do desejo de transformar a imagem em extensão das sensações que os corpos em cena experimentam. Pensando essa correspondência e frente à proposta de Schneemann em fazer da carne em elemento de igualdade, de permuta e integração, torna-se mais transparente um dos traços da alteridade fabricada em Sombra. O negrume pictórico que situa os corpos dentro de um ambiente de parcial diluição imagética das formas, favorável à circularidade sensorial, abdica de uma possível comunhão ou igualdade entre os seres pautada no consenso, na negociação e no afeto. Formas de conciliação sociais são preteridas em benefício de uma alteridade que só se resolve pelo recuo a um lado primitivo e pela ameaça à integridade física.

Das inúmeras acepções que poderiam conferir à figura o estatuto de humana, Sombra e os demais filmes de Grandrieux já discutidos recuam claramente diante de uma delas. Nas recorrentes cenas de violência e de erotismo, a figura humana já não é representada pelas suas qualidades morais ou pelo pensamento lógico e racional. Estes valores, geralmente associados à superioridade do homem diante de outros seres (em especial, os animais), ${ }^{144}$ são refutados. A obra de Grandrieux localiza o corpo dentro de outra ordem, aquela da primazia das sensações sobre a razão. Junto a isso, é mister pontuar que a constante violência em seus filmes explicita o risco da morte, portanto, da efemeridade. Neste sentido, a figura humana é duplamente "rebaixada": não é superior aos animais e, a todo instante, destaca-se sua natureza imanente, sua qualidade de ser mortal, terreno, pensado a partir do que limita sua existência.

Diante das primeiras conclusões sobre a forma de existência da figura humana, convém tentar entender a razão para associar sua aparente imanência a um regime de parcial invisibilidade ou de deformação, que em vez de apresentar a concretude e a existência bruta da figura humana, a vaporiza visualmente. Essa é a problemática que nos motiva desde o comentário sobre a cena de abertura de Sombra, quando verificamos o risco que acomete o decorrer do filme e a própria obra de Grandrieux: a dissolução da figura humana e do espaço em geral numa camada homogênea e pouco diferenciada. Chegando a este ponto da análise, em que identificamos um ambiente de circularidade das sensações, podemos finalmente retomar o paradoxo da existência de uma corporeidade onde não há mais um corpo (completamente) visível.

\footnotetext{
${ }^{144}$ Aristóteles, por exemplo, tentava definir o ser humano a partir do logos. Ver o debate sobre o autor em Francis Wolff, Nossa humanidade, São Paulo: Editora Unesp, 2012.
} 


\subsection{A presença em face dos limites da representação}

Desde as desfigurações em Sombra, passando pela cena teratológica de $A$ vida nova, e finalmente alcançando a junção entre dois corpos de natureza desconhecida em White epilepsy, o cinema de Grandrieux propõe uma determinada permeabilidade e circularidade dos elementos na imagem a partir da escuridão e de seus jogos entre visibilidade e invisibilidade. Mas, afinal, o que desencadearia a fluidez da imagem e o estado informe, por vezes evanescente, da figura humana?

Uma das cenas de Sombra nos ajuda a refletir. Jean e Claire estão dentro de um automóvel. O destino é incerto e o momento turbulento: antes o protagonista havia tentado violentar a moça. $\mathrm{Na}$ impossibilidade de consumar o ato sexual, ele a arrastou consigo. Quando estão no veículo, escutamos o ruído do motor a acelerar. O pouco que se vê na imagem são as respectivas silhuetas e o asfalto desfocado, com as luzes da cidade pululando disformes. Jean entorna uma garrafa com bebida alcóolica e a entrega a Claire: "Beba!". Inicia-se um frenesi: a trilha musical dispara com Hot Nines, de Alan Vega, enquanto desfilam imagens desfocadas do asfalto e, por fim, um close de Claire (Fig. 60). Seu rosto não é visível: aparece em contraluz, filmado por uma câmera trepidante, num desvario cinético (Fig. 61). Mesmo as formas visuais da figura começam a se dissipar pelo excesso de movimento e pelo desfoque. Os fios de cabelo alvoroçados pelo vento resultam numa figura em vias de se formar ou de se desfazer completamente.

Fig. 58-59
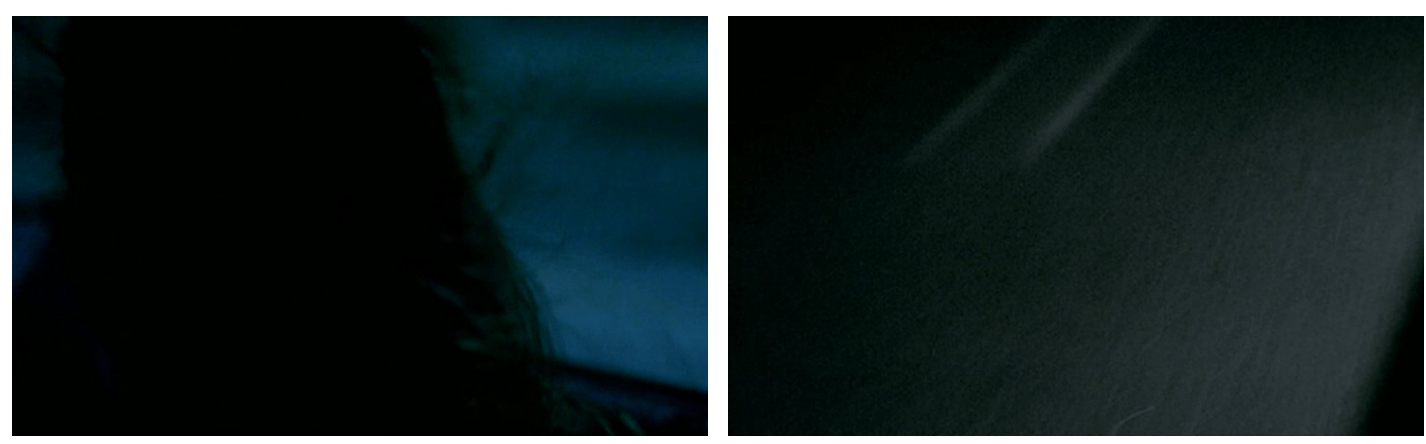
Fig. 60-61
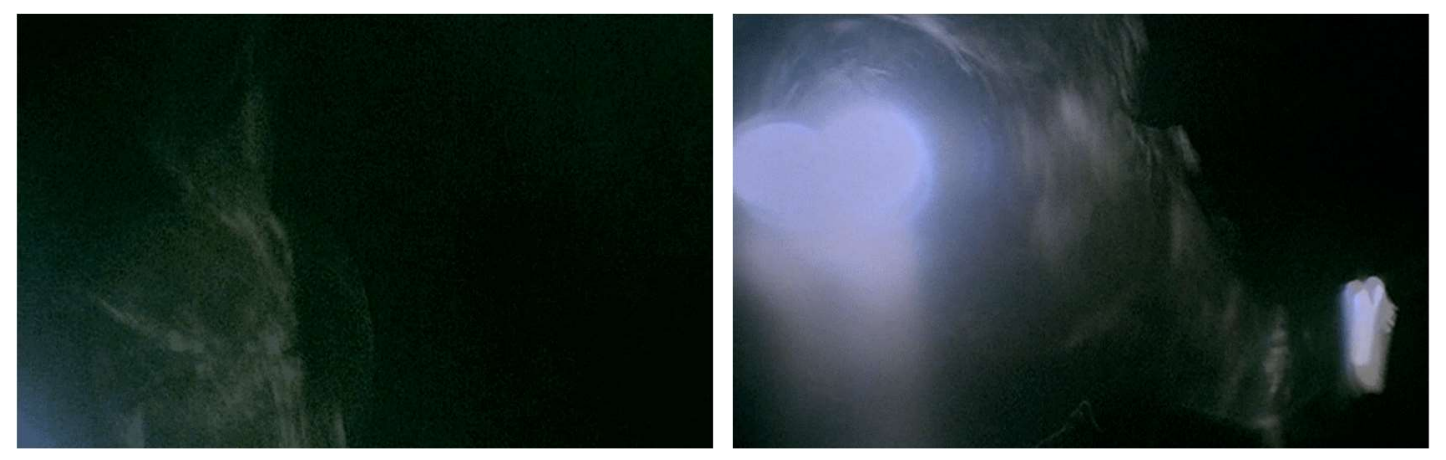

Automóvel, velocidade e embriaguez. A composição ternária que ancora a cena nos remete, mais uma vez, a Epstein, cineasta de quem Grandrieux é tributário. Os três elementos subsidiam um dos topos mais intrigantes do pensamento epsteiniano: a lógica do fluido. Trata-se de uma expressão por meio da qual o autor manifestou o que considerava ser a vocação do cinema para disseminar uma representação do mundo fincada na mobilidade e, por isso, capaz de reabilitar o devir, a mudança e o fluxo como aspectos essenciais do ser. Esse entendimento segue na contramão do culto do elemento sólido, das construções resistentes, das medidas indeformáveis e das configurações imutáveis. O cinema é visto como arauto da maleabilidade do universo, da fluidificação de seus elementos e da transmutação das formas da natureza. ${ }^{145}$ Grandrieux nos parece em consenso direto com essas ideias. Uma breve compreensão delas permite lançar uma luz sobre a questão das deformidades visuais da figura humana em seu cinema.

Sabemos do descompasso de Epstein como teórico e como realizador. ${ }^{146}$ A lógica do fluido evidencia a diferença: a tenacidade com que defende os aspectos metamórficos da matéria nos textos nos faz imaginar toda sorte de experimentalismos visuais ao longo de sua obra. Mas as coisas não são bem assim. O cineasta Epstein é comedido. A fluidez das formas está presente em sua filmografia em passagens pontuais. Geralmente, pela variação da temporalidade da imagem, por meio do retardamento, da aceleração e da reversão. Em Le tempestaire, por exemplo, a manipulação do tempo é o que permite modelar e transformar os

\footnotetext{
145 Jean Epstein, 1975.

${ }^{146}$ Como Aumont distingue, as produções fílmica e teórica de Epstein possuem pelo menos duas fases distintas. A primeira concerne aos anos 1920, quando o impulso modernista e em consonância com traços de movimentos como o construtivismo e o futurismo se deixa entrever pelo culto do autor à eletricidade, mecanicidade e velocidade. O período também coincide com a década mais experimental do seu cinema e com reflexões teóricas diretamente vinculadas a procedimentos técnicos e à linguagem fílmica. Este quadro muda na produção mais tardia, pois os textos publicados depois da Segunda Guerra Mundial, em L'intelligence d'une machine, Esprit de cinéma e no póstumo Alcool et cinéma constituem um momento de inflexão no qual a teoria "se desenvolve no abstrato, sem empiria, como discussão de fenômenos gerais e categorias a priori consideradas em si mesmas, em sua possibilidade ou sua virtualidade". Assim, o tom filosófico dificilmente se articula com o trabalho prático. Jacques Aumont, "Cinégénie, ou la machine à re-monter le temps.”, in Jacques Aumont, 1998, pp. 87-108.
} 
fenômenos da natureza. O gradual ralentar de determinadas sequências solidifica as águas do mar, demarcando a passagem visual de um estado a outro da matéria, do líquido ao sólido. A figura humana, porém, parece incólume a esse tipo de tratamento. A imagem corporal no cinema de Epstein é no limite realista, sem grandes deformações que possibilitem sua transmutação em outro ser. As operações sobre o tempo em nada ou pouco lhe afetam.

Com muita dificuldade é possível pensar o corpo representado sob os efeitos da lógica do fluido. Mais do que pelas variações temporais, será a partir de procedimentos realizados sobre o espaço na e da imagem a engendrar uma ligeira instabilidade e transformação de sua matéria. Essa dinâmica se expõe com clareza em excertos de $O$ espelho de três faces ( $L a$ glace a trois faces, 1927), Le lion de mogols (1924) e Six et demi, onze (1927). Uma cena se repete nos três, e é ela que nos liga ao cinema de Grandrieux: um passeio de automóvel que gradualmente se torna pretexto para um estado de excitação da figura humana.

Fig. 62

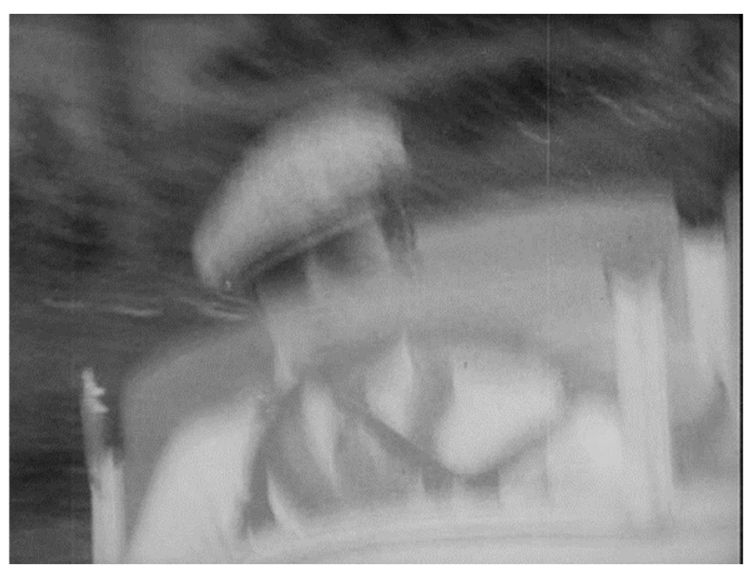

Fig. 63

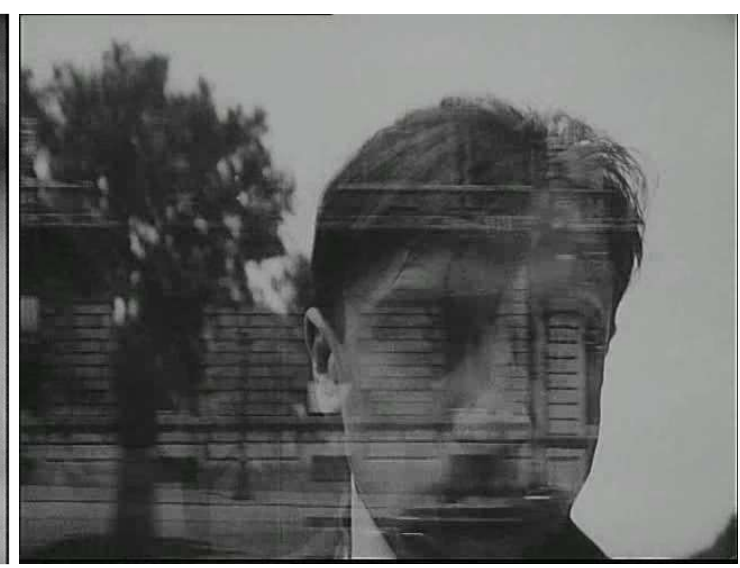

Em $O$ espelho de três faces (Fig. 62), a rápida sucessão de planos e a deformação do espaço pela velocidade são associadas ao torpor do personagem, numa espécie de culto futurista ao automóvel e ao movimento febril, articulação entre tecnologia e afetividade. Le lion de mogols (Fig. 63), por sua vez, cria uma sobreposição de planos que tentará conformar visualmente a embriaguez da figura e a velocidade, fazendo da materialidade da imagem uma extensão sensório-psicológica do corpo representado. Por fim, Six et demi, onze mostra o protagonista, Jean, acompanhado de Marie. Eles passeiam de automóvel numa estrada às margens do mar. A mulher faz um carinho na nuca do companheiro e logo em seguida repousa sua mão sobre a dele. A plasticidade acompanha o grau de intimidade entre o casal: depois do gesto afetuoso, o plano do carro na estrada é sobreposto a um close de Jean e Marie, e à imagem do mar. A figura humana e a natureza, os elementos sólidos e os fluidos se 
interpenetram. A sequência continua com um beijo, disparador de outra transformação: a água passa a dominar o plano, como se os rostos mergulhassem numa paisagem imaginária. Há um corte e a cena termina com o mar (Fig. 67). A imagem é transformada em sismógrafo a medir e a modelar o domínio afetivo. Do carinho inicial ao beijo, o universo se desfaz.

Fig. 64-65
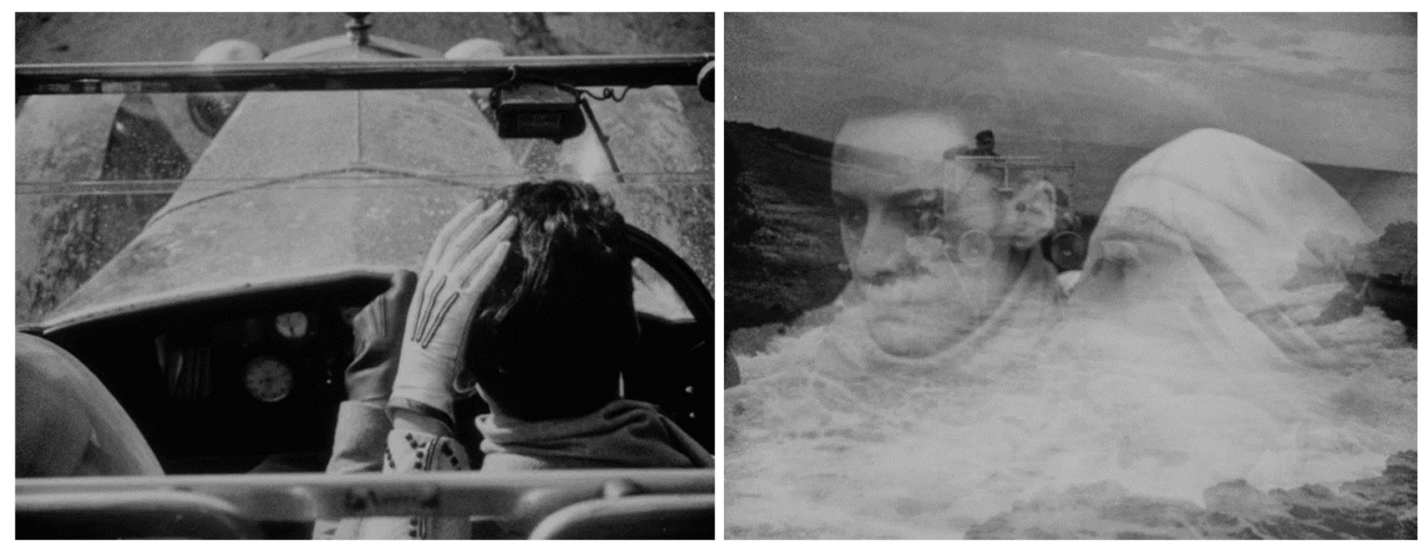

Fig. 66-67
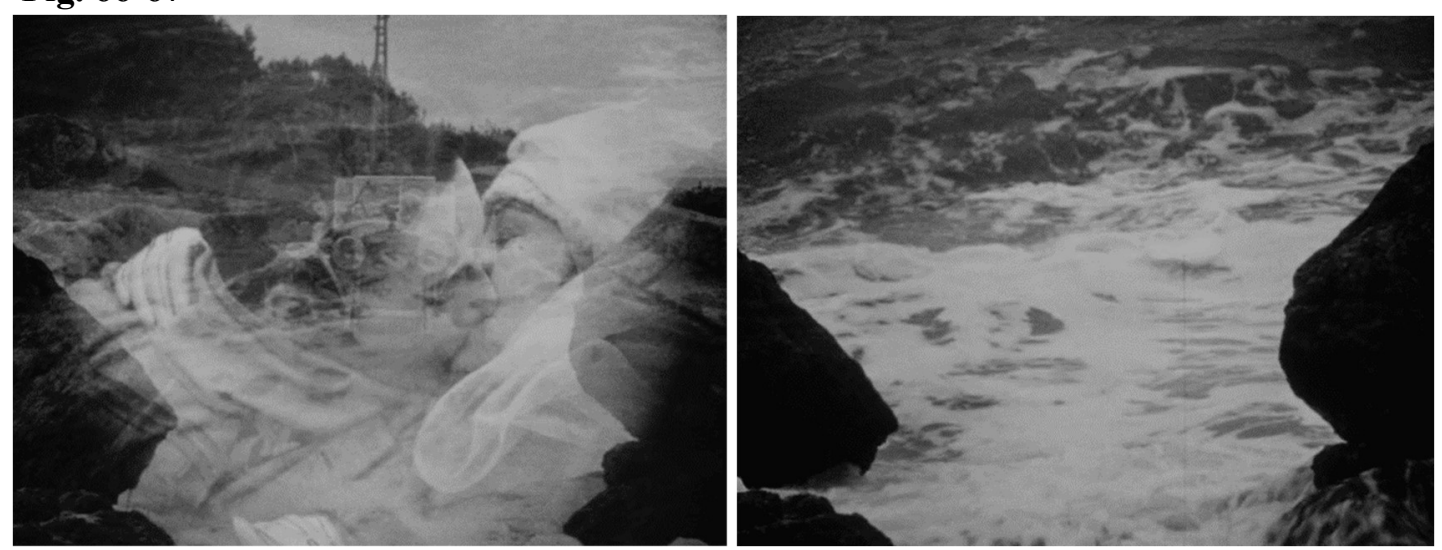

A cena do automóvel em Sombra se alicerça sobre um programa similar ao de $O$ espelho de três faces, Le lion des mogols e Six et demi, onze. Os filmes de Epstein relacionam a lógica do fluido à velocidade, ao álcool, ao sonho e à afeição entre os corpos, em suma, ao que afrouxa os limites ditados pela razão. ${ }^{147}$ Grandrieux também faz da imagem o suporte, a

\footnotetext{
${ }^{147}$ Alguns textos de Epstein se alicerçam sobre uma crítica ao ideal racionalista, que principia com a avaliação negativa que o autor faz da valorização do pensamento verbal no Ocidente: a passagem da realidade concreta para uma estrutura inteligível formada por palavras ocorreria à custa de uma abstração em que a realidade sensível é progressivamente substituída pelo esquematismo lógico. Este último estaria mais em acordo com a sintaxe gramatical do que propriamente com a experiência defronte o mundo. A consequência desse cenário é um tipo de educação que contribui para a redução da vida a teoremas e a cálculos que servem diretamente às estruturas sociais e econômicas modernas. Nesta guinada materialista-histórica pontual dos escritos epsteinianos, o autor menciona a nivelação e a conformação do homem a padrões de racionalidade que contaminam desde os meios de produção, com a divisão do trabalho e a vigilância cada vez mais rigorosa das fábricas sobre o nível de atenção do operário, a fim de satisfazer as metas previstas; até a esfera do consumo e da vida social, na qual os gastos e o usufruto do tempo e do espaço são igualmente calculados. O enquadramento das práticas humanas
} 
prótese que irá refletir o estado de excitação da figura humana, bem como a transformação de suas formas. Em ambos, o corpo, sobretudo pelo close, é representado em situações que possibilitam visões feéricas da natureza e dos seres pautadas no desvelamento de novos mundos (áudio) visuais e em estados de êxtase.

O cinema de Epstein e Grandrieux se alinha a uma verdadeira tradição, nos domínios da literatura e das artes visuais, sobre a conformação de fenômenos a tal ponto pujantes, violentos e caóticos que sua narrativa ou figuração se estruturam sobre estratégias de exceção. Ao reconhecer a potência que se desprende e é própria à matéria, portanto, ao reconhecer a impossibilidade de enregelá-la em limites rígidos e fixos, escolhe-se uma forma lábil, que suplante o caráter amorfo sem contudo suprimir a disposição informe. ${ }^{148}$ Recordamos dos desenhos de Da Vinci resultantes das pesquisas do pintor em torno de cataclismos, tempestades e outros fenômenos naturais submissos a forças que alteram as formas e produzem uma sucessão de metamorfoses. São obras cuja figuração é marcada por uma impossibilidade (Fig. 68-69), pois o objetivo era representar uma espécie de potência incorpórea e invisível. ${ }^{149} \mathrm{O}$ artista recorria a traços fluidos e nebulosos para evocar um cenário em que: "Decompostas pela tempestade, as coisas não são nada além de matéria em suspensão, sem figura ou identidade. Elas parecem retornar ao caos, passar pelos limbos de onde sairão talvez novos corpos". ${ }^{150}$ Como em Epstein e Grandrieux, trata-se de fenômenos cuja intensidade (força) e propriedade (natureza) impedem ou dificultam o acabamento em uma forma rígida. Como fazer da imagem uma representação sensível do que tem natureza imaterial e intensidade não agenciável? A pergunta nos acompanha discretamente desde o princípio deste capítulo, quando falávamos sobre a dificuldade de modular a sensualidade da figura feminina em Sombra.

dentro dessa composição, que inicia na linguagem verbal e culmina no social, ocorreria à custa do cerceamento, da supressão da imaginação e de outras formas de pensamento pré ou paralógicas. Epstein frequentemente recorre a analogias entre o cinema e estados nos quais o ser humano abandona as imposições do comportamento racional, da superestrutura verbal, caso do alcoolismo e do sonho. Consultar "Finalid del cine", em Jean Epstein, 1957. A versão original do texto, "Finalité du cinéma", foi publicada na edição de fevereiro de 1949 da revista Mercure de France, n ${ }^{\circ} 1026$.

$148 \mathrm{O}$ século XVI, sensível às gêneses e metamorfoses, recuperou cosmogonias e o episódio do Gênesis como pilares históricos do embate entra a força de ordenamento e o caos da matéria. Escapando do idealismo racional e das formas geométricas e harmoniosas do Quattrocento, um pensamento naturista impregnado pelo animismo e vitalismo floresceu naquele período, priorizando uma concepção metamórfica do mundo, o movimento e a energia mais do que o rigor da forma. Michel Jeanneret, Perpetuum mobile, Genebra: Droz, 2016.

149 "Eu digo que a força é uma violência, uma vertigem espiritual, uma potência invisível, que, por uma violência acidental exterior, é produzida pelo movimento, introduzida e infundida nos corpos que ela altera, dotando de uma atividade maravilhosamente poderosa. Ela obriga toda coisa criada a mudar de forma e de lugar". Leonardo da Vinci, in Joséphin Péladan (org.), Les Manuscrits de Léonard de Vinci. Paris: E.Sansot, 1910, p. 138.

${ }^{150}$ Michel Jeanneret, Op.cit., p. 86. 
Fig. 68

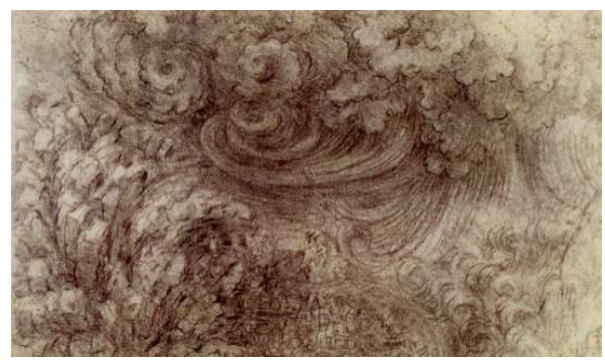

Fig. 69

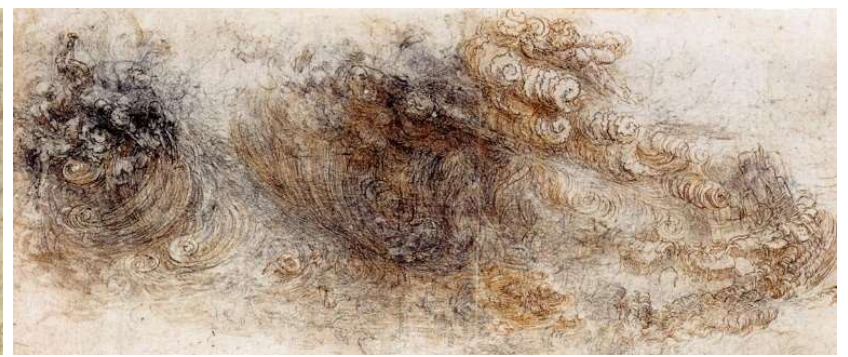

A força em Da Vinci tinha uma origem física e remetia aos fenômenos naturais. Em Grandrieux, inicialmente, corresponde a uma violência perceptiva, uma mutabilidade e deformação do universo a partir de como a figura humana é impetuosamente afetada pelo que a circunda. Assim, numa das vezes em que Jean, mais uma vez, dirige o carro, o contracampo do seu olhar mostra os lugares pelos quais passa em travelling, desfocados pela objetiva e alterados pela velocidade. Com a progressão da cena, a montagem cria um ritmo vertiginoso pela sobreposição e aceleração de imagens de gravetos, ramos, mato e flores filmadas em movimento (Fig. 70). Junto a isso, breves momentos da própria película desfilando pela tela sem conteúdo figurativo (Fig. 71), num procedimento que lembra os dos filmes de Brakhage.

Fig. 70

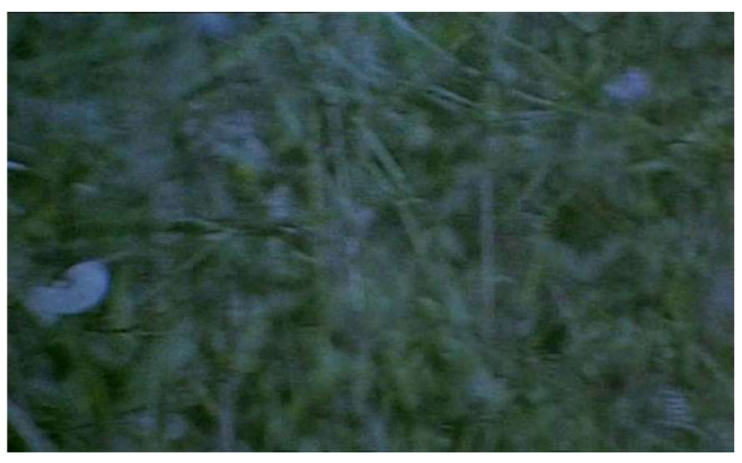

Fig. 71

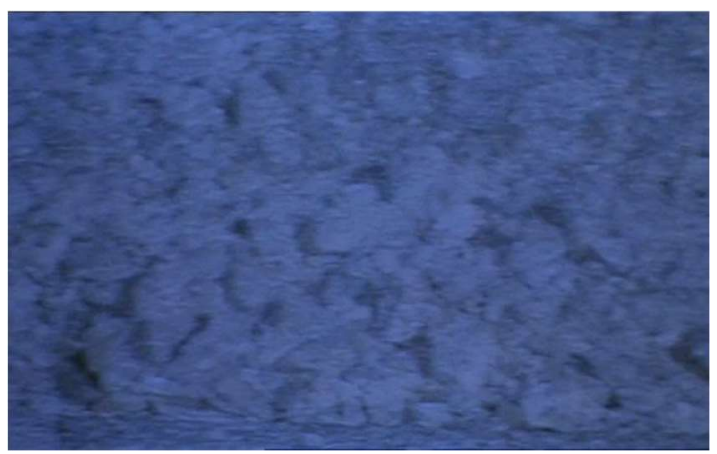

Insistimos anteriormente na figuração de Jean como sombra sendo o sinal do apartamento diante das mulheres que desejava, mas igualmente a alusão a um ser que vaga por um espaço límbico, sem lugar na terra. Nos momentos de maior experimentalismo, de hipertrofia visual e sonora, o filme de Grandrieux talvez ensaie apresentar as nuances e as formas que compõem este outro mundo vivenciado por Jean. Já não importa tanto o respeito a um naturalismo figurativo no modo de representação dos corpos, uma vez que tudo está impregnado pela percepção do protagonista, pela brutalidade com que recebe e experimenta sensorialmente o seu entorno. 
Imagine um olho não governado pelas leis fabricadas da perspectiva, um olho livre dos preconceitos da lógica da composição, um olho que não responde aos nomes que a tudo se dá, mas que deve conhecer cada objeto encontrado na vida através da aventura da percepção. Quantas cores há num gramado para o bebê que engatinha, ainda não consciente do "verde"? Quantos arco-íris pode a luz criar para um olho desprovido de tutela? Que consciência das variações do espectro de ondas pode ter tal olho? Imagine um mundo animado por objetos incompreensíveis e brilhando com uma variedade infinita de movimentos e gradações de cor. Imagine um mundo antes de "no princípio era o verbo". ${ }^{151}$

A citação é de um conhecido texto de Brakhage. Acreditamos que o filme de Grandrieux leva à risca sua proposta, tomando-a quase como um modelo de cosmogonia. Nos dois realizadores parece haver uma herança comum àquela que envolvia os desenhos de $\mathrm{Da}$ Vinci e a lógica do fluido de Epstein: uma concepção animista segunda a qual mesmo os seres aparentemente inanimados são vivos e dotados de uma alma. O mundo é tratado como um animal, organismo em que todo objeto é capaz de sensibilidade e de movimento. Uma substância difusa, una e universal, permitiria a comunicação entre os seres naturais, animando-os, conferindo um espírito vivo que no limite implica a alteração de suas formas. ${ }^{152}$ Em Grandrieux, essa substância não é uma entidade metafísica, mas extremamente imanente, o corpo de Jean. Há, porém, uma particularidade da obra do francês que o diferencia dos demais artistas aludidos até aqui.

As passagens de circularidade e parcial metamorfose das formas visíveis nos filmes de Grandrieux são imbuídas, dissemos, de uma violência perceptiva. Assim como expoentes da vanguarda francesa das décadas de 1910 e 1920, e do cinema experimental norte-americano dos anos 1960 e 1970, a obra de Grandrieux tenta buscar meios de figurar o que já não mais pertence ou o que jamais pertenceu ao domínio da visibilidade: o que o corpo sente. Dito isso, a particularidade do realizador de Sombra é a causa mais frequente dessa sensação: a dor e o sofrimento. Seus filmes desconhecem a representação da figura humana sem a agressão ao corpo, sem expô-lo a um tipo de violência física. Algo de terrífico se insinua tanto no que diz respeito ao universo interior como ao que está à flor da pele de seus personagens. A existência e a relação entre os seres são diretamente vinculadas ao que os oprime. O ponto nevrálgico de seu cinema é a brutalidade da experiência corporal. Fazer-se presente só é possível a partir de

151 Stan Brakhage, "Metáforas da visão", in Ismail Xavier (org.), A experiência no cinema, Rio de Janeiro: Edições Graal: Embrafilme, 1983, p. 341.

${ }^{152} \mathrm{O}$ animismo é descrito aqui segundo Jeanneret, ao debater Da Vinci e outros artistas do século XVI como Du Bartas e Giordano Bruno. Michel Jeanneret, Op.cit. A respeito de Epstein, lembramos que o autor discutiu com frequência a vocação animista do cinema, como no artigo: "Le cinematografe vu de 1'Etna", in Jean Epstein, 1974. 
uma série de privações: a do espaço, pelo negrume; a do Outro, pela incomunicabilidade; a do prazer, pela castração sexual; a da vida, pelo temor e pela proximidade da morte.

As violências perceptiva e física respondem pela força que deforma, hibridiza ou suprime a figura humana nos filmes mencionados de Grandrieux. A condição paradoxal do seu cinema é tornar o corpo material pela ameaça física e visual que sofre (Fig. 72-75). A presença não depende mais do encarnado e da precisão indicial da imagem cinematográfica, mas se dá por meio da dispersão no campo de tudo o que é relativo à figura humana, contaminando o filme com sua existência fracionada, evocada por percepções e sensações turbulentas que matizam a imagem. São comuns os momentos de Sombra em que escutamos a respiração dos personagens, os gemidos de sofrimento das mulheres agredidas, os ruídos do embate físico, enquanto, na imagem, é difícil ancorar os indícios sonoros em uma forma precisa. Corpo sem órgãos, matéria informe, imagem sem visibilidade. A expressão "figura humana" corre o risco de imprecisão, afinal, a forma plástica está em vias de desaparecer.

Fig. 72-73
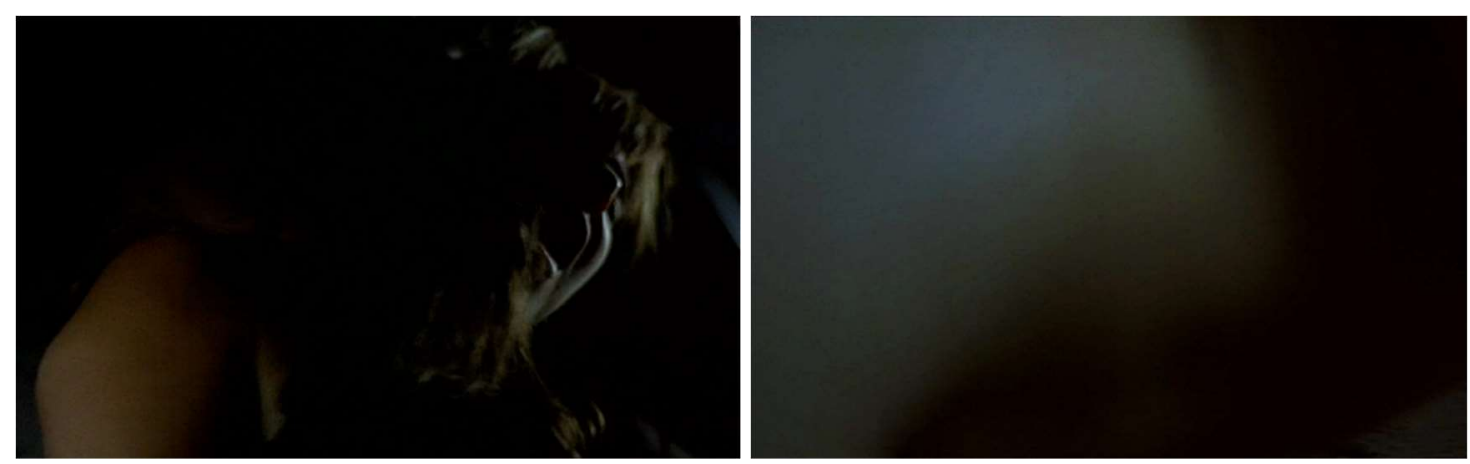

Fig.74-75
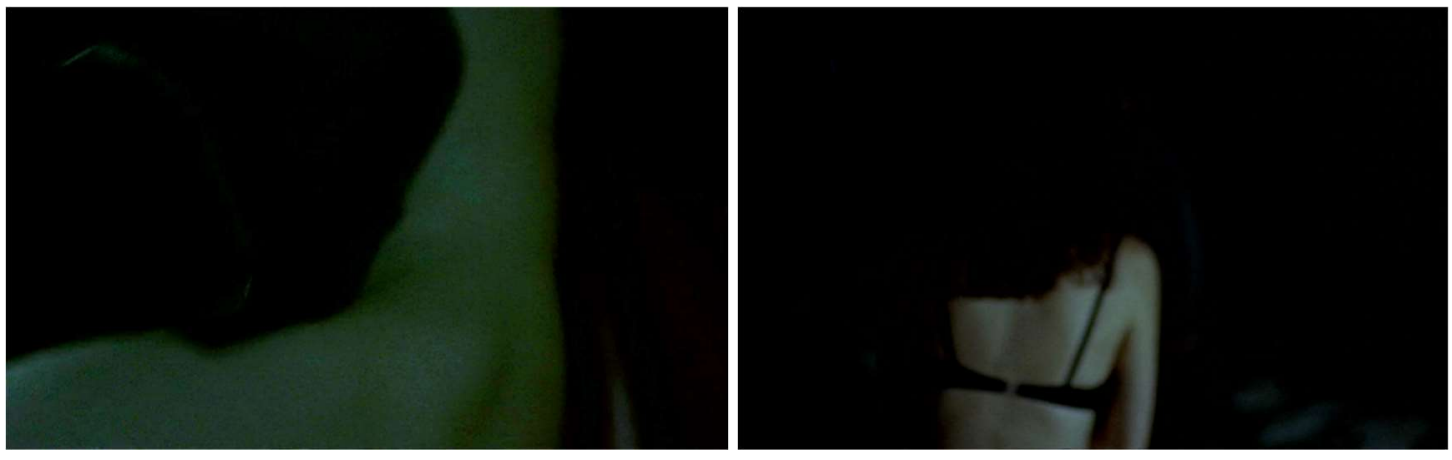

O momento paroxístico desta representação do corpo a partir de uma ambiência de circularidade e dispersão dos elementos visuais e sonoros, causados por uma força violenta, envolve a escuridão. $\mathrm{O}$ preto pictórico tensiona a imagem até o seu limite, até a quase abstração. As experiências limiares não podem ser modeladas dentro de uma forma plástica 
precisa, reforçando a impossibilidade de uma plena associação entre a imagem e o fenômeno sensório. Com exceção da cena do lago em Sombra, as sequências de agressão são envelopadas por um manto escuro. O preto é o que ambienta a opressão e o sofrimento, mas também o espaço que costumeiramente acolhe uma perspectiva animista, o novo mundo plástico criado pelas percepções e sensações.

Desde o momento em que a figura humana se torna uma matéria em constante negociação com o espaço e com os outros corpos, suscetível a metamorfoses, desfigurações, parcial supressão e demais violações contra a sua presença visual, parece-nos claro que ela não constitui uma forma consumada. Dito de outro modo, o seu constante devir é sinônimo de inacabamento.

O modo de figurar o corpo em Sombra difere do desmembramento que mesmo um cinema de decupagem clássica está habituado a fazer, no qual a fragmentação é compensada pela reconstituição metonímica - pois um plano fechado de um braço, cabeça ou qualquer outro membro reenvia diretamente a um personagem ou à integridade de um corpo. A razão para decompor a figura em diferentes planos passa geralmente por uma economia do visível, de direcionamento do olhar e acentuação do que é colocado em cena. Ainda que seja dividido, o que se visa é agregar ao corpo uma melhor visualidade, ideia que, como sabemos balizou os debates sobre o close na década de 1920, nos ensaios de Balázs, por exemplo. A singularidade do programa formal em Grandrieux é a de obnubilar a figura humana, transformando o corpo em suporte. Pela paisagem noturna e outros procedimentos listados ao longo desse capítulo (da conversão em sombra às demais desfigurações), a forma inteligível, a plena figuração do corpo e a referência a um personagem dramático são ainda que parcial e momentaneamente erodidas. Diante da imagem opaca, do esvaziamento de motivações, sobram a experiência física e perceptiva.

Por vezes, o processo metamórfico ao qual o corpo é submetido depende de procedimentos razoavelmente simples no cinema de Grandrieux. Além do desfoque promovido pela proximidade da câmera, o realizador se vale de diferentes possiblidades de esboroamento dos contornos a partir do enquadramento e do negrume, o que vimos em White Epilepsy, A vida nova e Sombra. Esse ponto em particular pode ser pensado em paralelo à noção de baixo materialismo proposta por Georges Bataille, reconhecível em determinadas fotografias (Fig. 77 e 79) das revistas Documents, dirigida pelo filósofo entre 1929 e 1930, e Minotaure, nos anos 1930, na qual também participou. 
Fig. 76 A vida nova, Grandrieux

Fig. 77 Anatomias, Man Ray
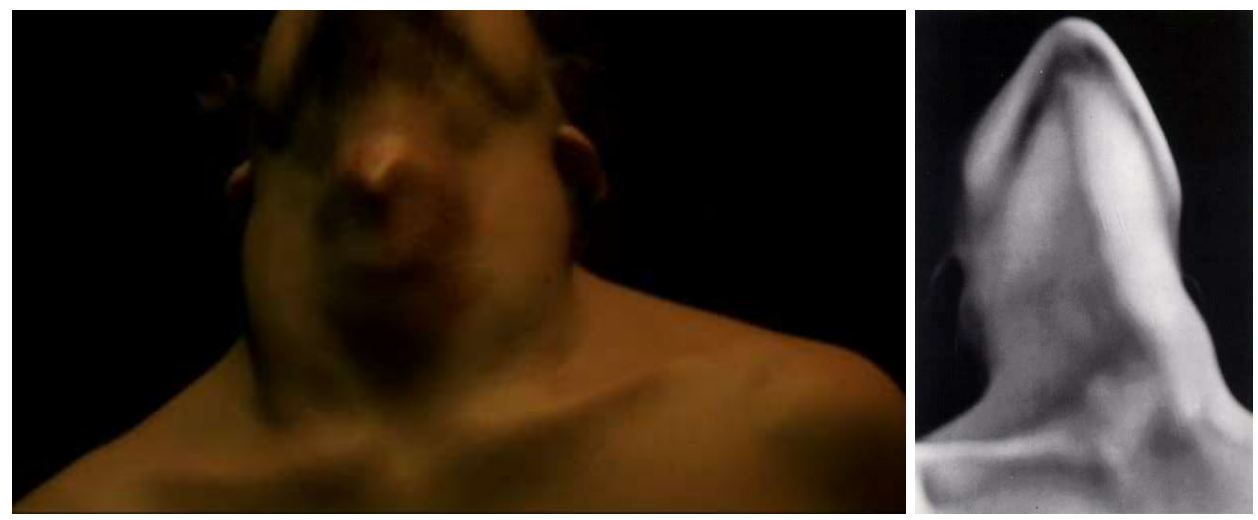

Fig. 78 White epilepsy, Grandrieux $\quad$ Fig. 79 Nu inclinado para frente, Man Ray
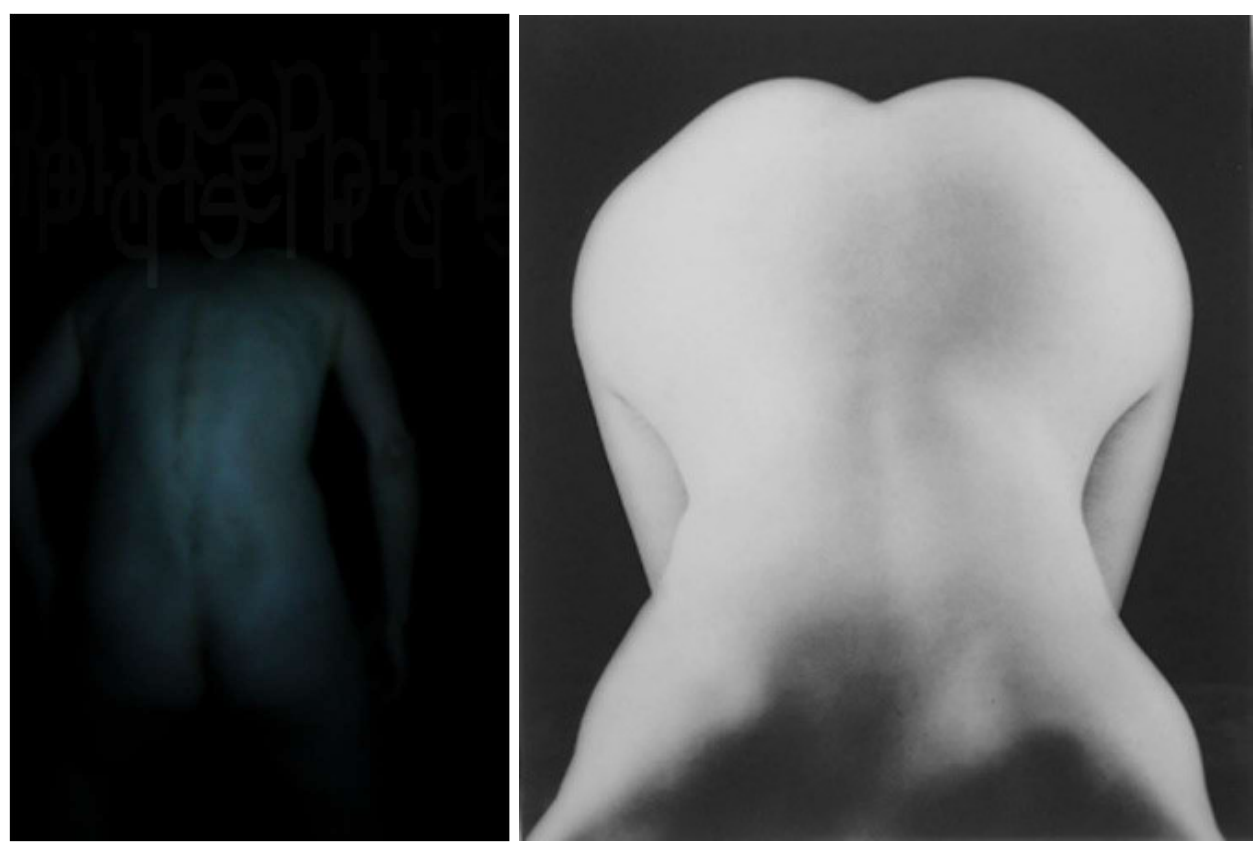

Conforme Yve-Alain Bois e Rosalind Krauss, uma das operações comuns aos fotógrafos associados àquelas duas revistas era a de rotacionar a figura humana de tal maneira a promover, pela mudança do eixo vertical para o horizontal, a transformação do "todo do corpo em parte, o alto (a Gestalt) em baixo (o órgão sexual), o humano em animal". ${ }^{153}$ A partir dessas simples e eficazes ações, Brassaï, em suas fotografias de nus para o primeiro número da Minotaure, conseguia transfigurar o torso feminino em falo, ou metamorfosear os seios e as costelas na imagem de uma besta. Mesma estratégia é empregada por Man Ray em Anatomias (1930, Fig. 77), onde a cabeça virada para trás, vista de baixo, substitui o rosto pela zona entre o início do pescoço erétil e a parte inferior e distendida do queixo. A fragmentação da figura humana em Brassai e Man Ray iria em contramão ao ideal

\footnotetext{
${ }^{153}$ Yve-Alain Bois, Rosalind Krauss, L'informe: mode d'emploi, Paris: Centre Georges Pompidou, 1996.
} 
civilizatório que inicia com a passagem do eixo horizontal para o vertical, com o homem sobre duas pernas, e cuja última escala é o seu progresso rumo à educação e à razão. A parcialização do corpo pela obstrução de sua bela forma corroboraria o abandono das categorias fixas, seja a de gênero, seja a de ser, criando uma migração visual e semântica no modo de interpretar da figura humana.

As escolhas dos fotógrafos, como também as de Grandrieux, aproximam-se da noção de informe, palavra que até o momento empregamos segundo seu uso corriqueiro - o que não tem forma própria ou definida, ou cuja forma é um esboço, não está completa. O termo tem outro sentido no Dictionnaire critique da Documents. ${ }^{154}$ A curta descrição feita por Bataille conserva uma zona de ambiguidade que dificulta a consensualidade. ${ }^{155}$ Frente a isso, interpretá-lo-emos segundo Krauss e Bois, para quem o informe não designa um tema, conceito ou coisa em si mesma, mas sim uma operação de deslizamento e alteração da rede de leituras, da estrutura que assimila um objeto. O desvio conduzido pelo informe afetaria as qualificações da matéria. Para Bataille, essa mudança de rota engendrada pelo informe reenviaria a um baixo materialismo capaz de liberar a matéria de enquadramentos ontológicos, desclassificando-a e desierarquizando-a, pondo em evidência a coisa em si mesma, extirpando-a de amarras conceituais e do que mais a pressupõe dentro de uma aparência fixa, de antemão prefigurada.

A maioria dos materialistas, embora tenha desejado eliminar toda entidade espiritual, chegou a descrever uma ordem de coisas que relações hierárquicas caracterizam como especificamente idealista. Esses materialistas situaram a matéria morta no cume de uma hierarquia convencional dos fatos de ordem diversa, sem se dar conta de que cediam assim à obsessão de uma forma 'ideal' da matéria, de uma forma que se aproximaria mais que qualquer outra do que a matéria 'deveria ser'. Com efeito, a matéria morta, a ideia pura e Deus respondem da mesma maneira, isto é, perfeitamente, tão grosseiramente quanto o aluno dócil em classe, a uma questão que não pode ser proposta senão por filósofos idealistas, a questão da essência das coisas, exatamente da 'ideia' pela qual as coisas se tornariam inteligíveis. [...] É o momento, desde que a palavra materialismo é empregada, de designar a interpretação direta, excluindo todo idealismo, dos fenômenos brutos [...]. ${ }^{156}$

\footnotetext{
154 “Um dicionário começaria a partir do momento em que ele não daria mais o sentido, mas tarefas às palavras. Assim, informe não é apenas um adjetivo tendo um determinado sentido, mas um termo que serve para desclassificar [...]. O que ele designa não tem seus direitos em sentido algum e se faz esmagar em toda parte como uma aranha ou um verme. Seria preciso, com efeito, para que os homens acadêmicos ficassem contentes, que o universo tomasse forma. Toda a filosofia possui esse objetivo: trata-se de dar uma vestimenta [no original, redingote] ao que existe, uma vestimenta matemática. Por outro lado, afirmar que o universo não se assemelha a nada e que é completamente informe, quer dizer que o universo é algo como uma aranha ou um escarro. Georges Bataille, Documents, Paris: Éditions Gallimard, 1968, pp. 177-178.

${ }^{155}$ Caso da diferença de interpretação da noção de informe entre Didi-Huberman e Krauss/Bois, exposta em: Yve-Alain Bois, Rosalind Krauss, Op.cit.

${ }^{156}$ Georges Bataille, Op.cit., pp. 182-183.
} 
Uma aproximação com o baixo materialismo seria pontual ao longo da cinematografia de Grandrieux, e aconteceria justamente pelo que comentamos sobre a parcial erosão das qualidades dramáticas e simbólicas relacionadas às figuras humanas. Em Sombra, ao longo das cenas de agressão, o drama, econômico em sua condução e justificativa sobre as motivações de Jean, esvazia-se ainda mais para dar primazia a suas experiências. O mesmo acontecerá em relação às personagens de $A$ vida nova, filme cujo "inacabamento" criado a partir do excesso de opacidade favorece a conversão das personagens (drama) a corpos (massa, matéria presente) que não necessariamente são dotados de forma humana. Dissociase, então, a figura e o corpo humanos. A primeira existe para tentar dar natureza sensível, visual (mesmo que por vezes pela parcial invisibilidade ou desfiguração da forma humana) ao que se vivencia, sem necessariamente recorrer à exposição do corpo.

Sombra e $A$ vida nova acolhem de modo pendular, intermitente, a inversão do eixo vertical para o horizontal. À submissão das figuras à magra linha dramática, os respectivos filmes, em suas passagens mais experimentais, abandonam o drama e mergulham no domínio perceptivo-sensorial a partir das dinâmicas plásticas da imagem. O vai e vem entre um regime e outro de figuração do corpo é constante. Na filmografia de Grandrieux, o exemplo mais apropriado, ou talvez mais aproximado de um baixo materialismo batailliano se verifica em White Epilepsy (2012). Visto o que comentamos anteriormente, em toda a sua duração, o filme cria, pelo enquadramento, negrume, mudança de velocidade, disposição das figuras e gestualidade, uma ambiência de nebulosidade dos signos - isto é, o informe - a obstruir a rede de leitura dentro de um quadro convencional, estimulando toda sorte de suspeitas e desvios, incluindo o de que a figura humana foi comutada por outro ser ou consubstanciada a outros corpos e ao espaço, transformada em algo que visualmente perde seu referente transparente no mundo.

Dado o exposto até aqui, o que seria determinante para a figura humana ser o que é? Qual seria o seu substrato, o predicado de sua presença no mundo, a sua matéria? Caso retomemos a noção de um materialismo cujo objetivo é definir as propriedades ontológicas de um ser, investigar a sua origem, reconheceremos que essas questões podem conduzir a dois eixos distintos: um buscando compreender as unidades que formam o corpo (a matéria); o outro, a pletora de formas que ele pode adquirir a partir da combinação e da recombinação dos diferentes elementos que o constituem (modos de presença). É necessário então refinar o problema a fim de separar: 1. O que compõe a figura humana cinematográfica; 2. Como os filmes de Grandrieux se valem de sua matéria para forjar uma presença singular. Definir o 
primeiro ponto exigiria uma trajetória fortemente ancorada nos entrecruzamentos entre uma história técnica do dispositivo cinematográfico e uma história estética do corpo representado. Essa empreitada monumental ainda está para ser escrita e nem de longe é a que aqui humildemente propomos. Ao se ater a Sombra, realizando sua análise num exercício comparativo com obras pictóricas e fílmicas, o capítulo cuidou mais de reconhecer uma manifestação específica da figura humana, isto é, como ela, enquanto matéria já formada se faz presente. Ora, a razão de ter começado a tese a partir do exemplo de Grandrieux diz respeito justamente a uma dupla aproximação entre os dois eixos que agora procuramos distinguir.

Por um lado, o corpo representado (modo de presença) regride à condição de corpo em formação (ao estado em que as unidades que estão em vias de compô-lo). Tendo isso em vista, apresentamos a figura humana enquanto sombra, desdobramento de uma das propriedades gerais - a totalidade delas, já dissemos, resta a ser descoberta - da figura humana no cinema: duplo de um outro ser, forma carente de um preenchimento, de uma encarnação. $\mathrm{O}$ estatuto de sombra remete ainda ao mito de Plínio e à representação primeva conferida ao ser humano no domínio das artes ocidentais. Enfim, a silhueta preta a se destacar do manto da noite, assim como outras formas deficitárias em relação ao referente real, colocam-nos diante de um corpo que partilha das mesmas propriedades pictóricas do fundo, da plasticidade da imagem, precisando ser desbastado a todo momento ou mesmo correndo risco de imergir na matéria que lhe dá substrato.

Por outro lado, a figura humana é rebaixada às condições sensoriais mínimas de existência, ao momento anterior a um enquadramento lógico, cultural ou social, submetida a uma figuração informe (nos termos bataillianos) que embaralha a sua interpretação dentro de quadros rígidos. Desse modo, da figura permanece o corpo carnal. Do corpo carnal sobram os instintos naturais e a sensorialidade: a existência a partir da violência do que sente, da intensidade das experiências - que reverberam nas metamorfoses e hibridizações.

As duas vias mencionadas, portanto, associam a presença da figura humana a dois tipos de matéria: a da imagem cinematográfica, pela obstrução de (e invectiva contra) um espaço figurativo que tenta mimetizar o real, enfatizando-o enquanto imagem/medium; e a do corpo carnal, pela opacidade das possíveis redes de leitura calcadas numa lógica que o transcenda ou que o enquadre, priorizando o lado animal e a experiência perceptiva/sensorial. O regime de representação da figura humana se ergue portanto sobre um duplo movimento de retorno às origens, à matéria da imagem e à do corpo, imersos num perpétuo intercâmbio, numa circularidade do plano. Já não estamos diante da distinção entre um cineasta que acredita na 
imagem e um cineasta que acredita na realidade, ${ }^{157}$ mas de um realizador - como também poderíamos falar de Carolee Schneemann em Fuses, Epstein nas cenas de êxtase pela velocidade ou pelo álcool, como de outros nomes do experimental -, cujo foco é restituir algo da experiência sensual do corpo e, no limite, do real, pelas propriedades plásticas do medium, pelo drama visual. Cria-se, assim, uma economia figurativa em que a intensidade da vivência, seja a da figura humana, seja a da relação do seu corpo com o Outro ou com o mundo, exige a diluição no espaço da imagem, uma presença fracionada do sujeito. As formas fixas são incapazes de agenciar a intensidade e a natureza das experiências. A precisão visual da figura é deposta não para excluir o ser humano, mas justamente para tentar contornar a ontologia da imagem fotográfica, em sua mumificação do referente real, e dar-lhe uma vida pautada no déficit de analogia frente ao real. Propõe-se um "animismo" pela hipertrofia visual do que é figurado. Em lugar do eterno retorno do referente, da reprodução do corpo humano, a sua evocação e a da intensidade de sua experiência pela expressividade e inacabamento da imagem.

${ }^{157}$ Cf.: André Bazin, “A evolução da linguagem cinematográfica”, in André Bazin, Op.cit. 


\section{Vida orgânica}

No centro de uma paisagem de pântanos e dunas na costa de Ópalo, um homem e uma mulher entram em cena depois de atravessarem alguns arbustos. Acompanhados por um travelling horizontal, eles caminham enviezadamente em direção ao fora de campo, passam de perfil em frente à câmera e continuam rumo ao fundo da imagem, quando viram à esquerda e desaparecem na vegetação, num movimento diametralmente oposto ao do início da cena (Fig. 80-83). Esse plano sequência compreende a entrada e a saída de campo dos personagens, a permanência efêmera de dois seres em oposição à solidez e à amplitude do mundo que os circunda.

Ao longo de Fora de Satã (Hors Satan, 2011, de Bruno Dumont), outros planossequência irão repetir, com mudanças de luz, paisagens e percursos, essa configuração em que a figura humana caminha em silêncio de uma extremidade a outra da paisagem visível até sair de campo. O tempo escorre tal como o vento que sopra ao longo de todo o filme, sem interrupção ou grandes variações, pois o ritmo é ditado pela caminhada compassada dos corpos e pelos movimentos orgânicos da câmera a acompanhá-los. As paisagens, valorizadas pelo formato scope, ganham premência face à figura humana e aos seus dramas, resguardando no interior de sua amplitude o berço de um mistério: os milagres do filme são associados a uma força presente na natureza, apreendida em planos gerais que anunciam a vastidão do espaço na mesma medida em que velam seus segredos.

Fig. 80-81
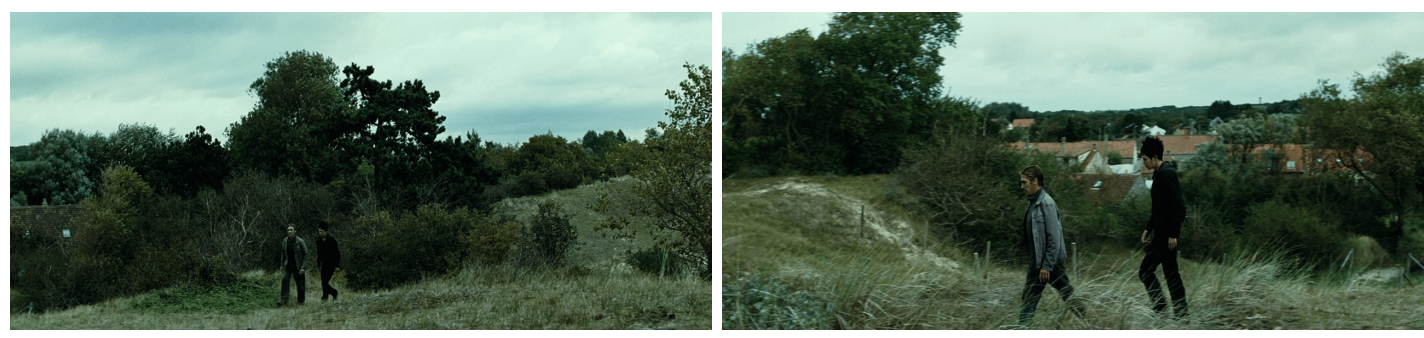
Fig. 82-83
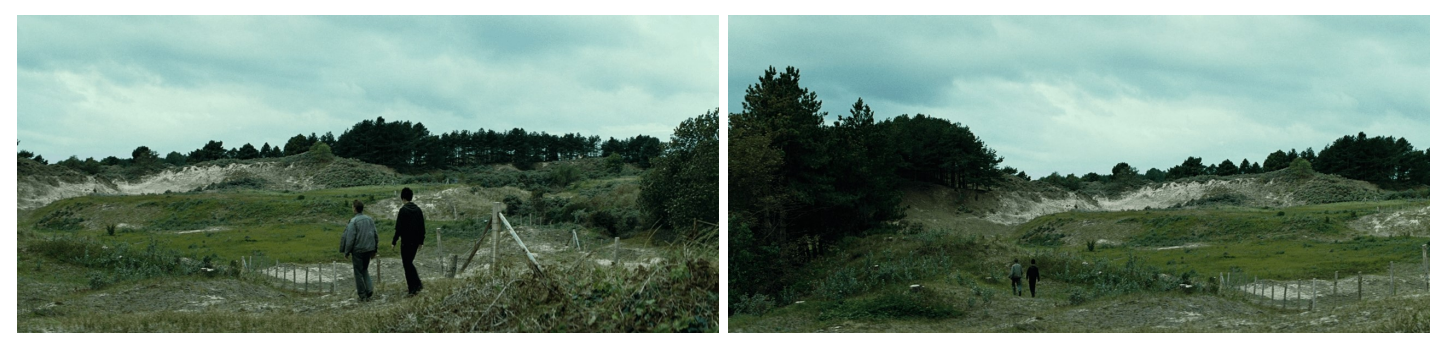

Na cena descrita, como nas demais caminhadas de Fora de Satã, a figura humana é mostrada pela permanência na duração dilatada e pela travessia por imensos espaços. Quando se distancia no horizonte, o som evidencia a sua presença pelos ruídos da relva pisoteada e pela respiração dos corpos, por vezes ofegantes em razão do esforço físico. Realça-se a presença física dos personagens. A despeito da visibilidade comprometida pelo afastamento dos corpos, o som forja a sensação de proximidade, de circunvizinhança. O sutil relevo da corporeidade rivaliza com a imponência visual (a paisagem) e audível (o vento) da natureza, sinal, como os milagres e rituais, da existência de uma ordem superior. Ainda que reforcem a fisicalidade do corpo representado, as caminhadas parecem responder à relação íntima e de subsunção dos personagens em face do fundo místico e grandiloquente da paisagem.

O filme de Bruno Dumont não é uma exceção geracional. O cinema contemporâneo resgata com frequência e a seu próprio modo a banal ação que Rodin cristalizou com sua escultura $O$ homem que caminha (L’homme qui marche, 1906). O domínio já não é o mesmo de expoentes do cinema moderno, como os da Nouvelle Vague, com as longas andanças urbanas estimuladas pelos equipamentos mais leves e pela saída dos grandes estúdios. Nada dos passeios tagarelas de dois personagens como pretexto para reflexões pessoais e filosóficas, como em Éric Rohmer. Algo, talvez, das caminhadas existencialistas dos filmes de Michelangelo Antonioni. Seja como for, a equação partilhada por alguns realizadores contemporâneos tem como fórmula minimalista figuras que se deslocam silenciosamente sobre a integridade ou a ampla extensão de um território durante planos de longa duração. As variantes e a significação mudam, como não poderia deixar de ser, conforme o realizador e a obra. No emaranhado de singularidades, algumas questões permitem bosquejar uma identidade na diferença.

No cenário descrito, qual seria o regime de figuração, o modo de existência a se depreender de um corpo representado a partir de algo tão banal quanto o caminhar? Por que escolher o seu desenrolar na longa duração de um plano quando haveria a possibilidade de encurtá-lo por uma elipse, por um atalho que conduzisse a figura humana diretamente ao seu 
destino final? Ainda é cedo, mas desde já é possível pôr em questão a natureza do movimento corporal: a caminhada, como a do filme de Dumont, é um mero movimento motivado por um objetivo externo, geralmente um espaço a ser alcançado, ou ela porta em si mesma um desígnio que independe de onde se almeja chegar? O deslocamento pertence à categoria do ato ou do gesto? São dois comportamentos cujas correspondências geralmente os sentencia ao uso indiscriminado, mas que merecem ser discutidos e singularizados à luz de determinados filmes contemporâneos. Para além dessa distinção, cabe ainda perguntar quais seriam as particularidades de uma agenda cujo corpo é representado pela prevalência do ato/gesto e por uma mise en scène límpida em termos visuais, com planos gerais e de longa duração. Se há algum tipo de obstrução na composição e significação da figura, parece ser outra que a analisada na obra de Grandrieux, tributária da investida contra a visualidade do corpo pela exploração plástica da matéria (preta) da imagem. Seria o caso de um naturalismo figurativo, de um regime que tenta intensificar os graus de analogia entre o corpo representado e o seu referente real?

O presente capítulo será atravessado por essas questões. Dessa vez, o eixo a propor e a mediar o debate será composto por obras de três cineastas contemporâneos: Tsai Ming-liang, João Pedro Rodrigues e Claire Denis. O interesse comum pela fisicalidade do corpo, quer seja pela caminhada, quer seja por outros meios, permite uma visada conjunta sobre momentos pontuais das obras dos três. Como no capítulo anterior, a análise das cenas será amparada a partir do cotejo com obras plásticas, mas dessa vez incorporar-se-á, por uma demanda do próprio corpus, referências advindas da performance e da dança.

\subsection{Estar sobre a terra: o homem que caminha}

Dizíamos que o motivo da caminhada presente em Rodin - e em outros artistas do século XX - é programaticamente reiterado no cinema contemporâneo, mas conforme o estilo e as obsessões de cada diretor. Nos filmes do taiwanês Tsai Ming-liang, as imponentes paisagens naturais de Dumont são substituídas por sítios urbanos e às vezes por corredores e outros espaços que se descortinam em profundidade retilínea e abrupta. São como túneis, gargantas alongadas dentro das quais as figuras caminham em direção ao espectador como quem chega de uma longa viagem, ou se afastam, rumo ao fundo da imagem, como quem parte para outra terra. $\mathrm{O}$ ir e vir se dá em planos de longa duração e geralmente com uma câmera fixa, o que acentua a permanência dos corpos no tempo e no espaço, o enraizamento deles no presente do ato. À diferença de Fora de Satã, porém, nem sempre o movimento da 
marcha reverbera para além da figura humana. Mesmo quando o espaço é sublinhado, o é menos em si mesmo, por autonomia ou transcendência, do que como meio de evidenciar a figura humana ou por ela ser secretado. Raramente em segundo plano, o corpo é o elemento centrífugo, de onde tudo parte, e centrípeto, para onde tudo retorna.

O rio $(\mathrm{He}-\mathrm{Liu}, 1997)$ parece antecipar as coordenadas desse programa pautado na figura humana como o suporte sensível sobre o qual se desenvolvem os rarefeitos eventos, acidentes e linhas dramáticas. Logo no início, uma equipe de cinema tenta em vão filmar uma cena na qual um boneco flutua nas águas de um rio, provavelmente simulando o cadáver de um corpo. Diante do insucesso, convidam o personagem Hsiao-Kang para tomar o lugar do manequim. Duas permutas se seguem: a de um ator pelo boneco, presumida, e posteriormente a do boneco pelo figurante, vista (Fig. 84). A substituição não é mera casualidade. A partir dela se estabelece uma passagem cujos indícios serão percebidos apenas depois da gravação da cena, quando Hsiao-Kang passa a sentir um mal estar no pescoço. Algo se infiltrou em seu organismo durante o mergulho? Sem causa definida, a dor piora progressivamente até o momento em que o personagem perde o controle do próprio corpo e passa a sofrer espasmos. Refém de forças que não consegue administrar, submetido a uma série de tratamentos, de acupuntura a rituais budistas, passando de mão em mão a fim de descobrir a cura, ele incorpora o estigma da marionete, essa réplica destituída do controle dos próprios movimentos e subsumida à vontade de outros para funcionar. O mergulho no rio - e a água, veremos, é o elemento essencial para Ming-liang - demarca o momento de transição, de passagem, de uma ligeira e embrionária transferência de identidade, ou permeabilidade, entre o corpo humano e os objeto inanimados. Essa, veremos, é uma das marcas dos demais filmes analisados no capítulo.

Fig. 84

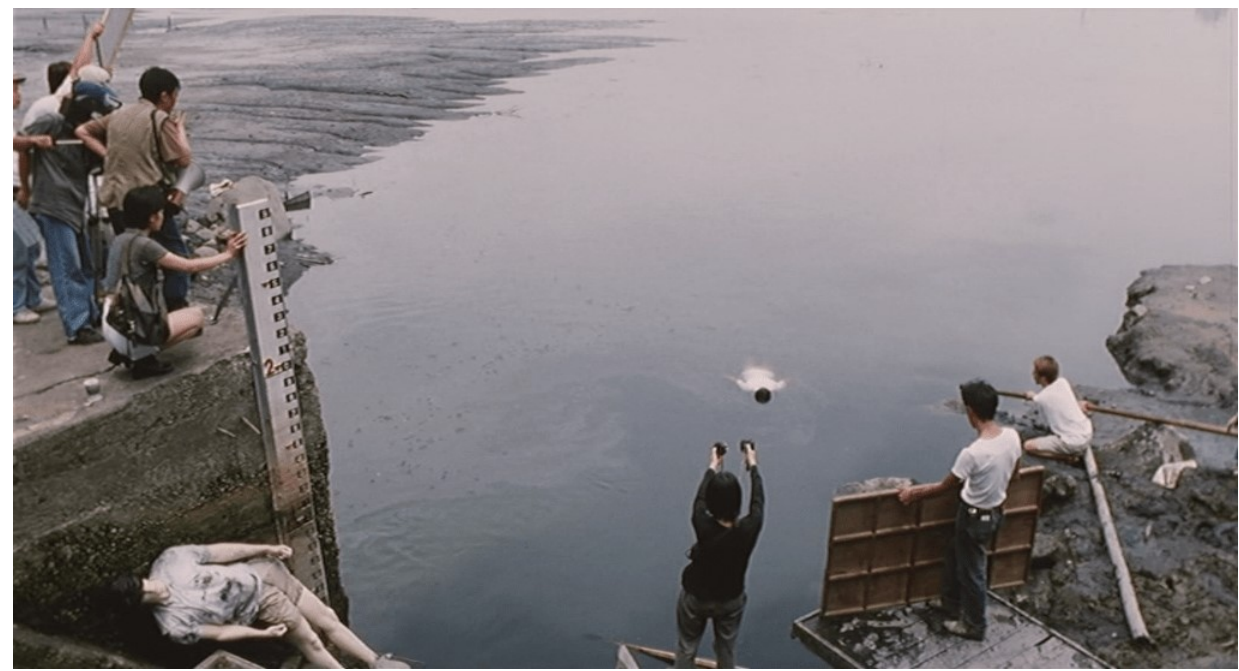


Será recorrente em outros filmes do realizador o corpo enquanto entidade incompleta, jamais autossuficiente, por vezes descoordenada, como uma engrenagem em mau funcionamento, numa procura incessante pelo que irá regular o seu interior e supri-la com o que/com quem lhe falta - tal como se na dependência do fio pela qual o títere coordena o centro de gravidade do movimento da marionete, dotando-a da alma, dando vida ao simulacro. ${ }^{158}$ Em razão dessas características - vale o parêntese, a ser retomado ao longo do capítulo - o cinema de Ming-liang irá tangenciar com frequência o burlesco, gênero em que os corpos são postos em cena justamente a partir de um desajuste interno e de uma inconformidade com o ambiente em que ocupam. Afinal, haveria um cinema do corpo sem submeter sua figura a um tipo de crise, sem questionar o que seria o seu hipotético estado natural?

Fig. 85-86

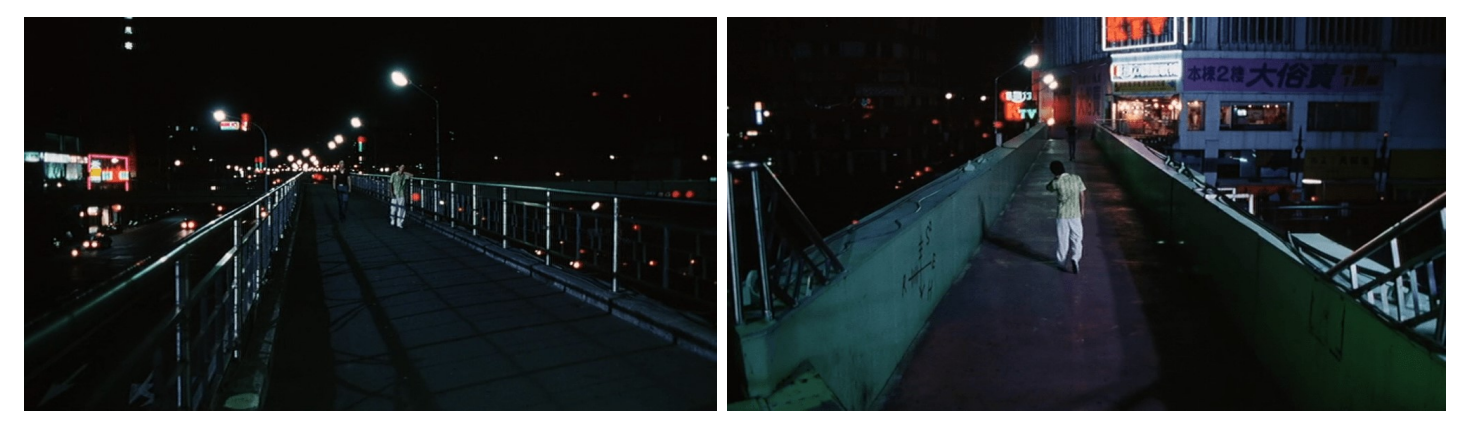

Em meio a espasmos musculares, o protagonista de $O$ Rio irá compor o itinerário repetido pelos demais personagens de Ming-liang, deambulando em silêncio por longos espaços, do início ao fim dos planos. Numa dessas sequências (Fig. 85-86), Hsiao-Kang caminha sobre uma passarela à noite. Ali aparece um rapaz que cenas antes estava numa sauna a masturbar o pai de Hsiao-Kang, interpretado por Miao Tian. Durante a caminhada, nenhum contato se estabelece entre os dois, além de alguns olhares. Eles seguem, cada um em seu ritmo, até o fim da passarela. Embora não haja comunicação efetiva, saberemos mais à frente que o encontro é menos casual do que parece. Algumas cenas depois, Hsaio-Kang estará na mesma posição do rapaz: na sauna, a transar com o próprio pai, num incesto parcialmente encoberto pela escuridão. Assim, o plano da passarela, mais do que enfatizar a condição física de Hsiao-Kang, mostrando o desenrolar de sua tortuosa caminhada por uma temporalidade dilatada, põe em cena um cruzamento. O deslocamento de dois corpos esboça

${ }^{158}$ Cf.: Heinrich von Kleist, Sur le théâtre de marionnette, Paris: Editions Millet et une nuits, 1998. 
uma sutil linha dramática: duas figuras, duas histórias, duas trajetórias pelo espaço que acercam-se sem se cruzar, sem tangenciar-se, mas que mantém entre si uma correspondência. A ação física se torna um pretexto para expor uma pequena história de corpos que partilham um destino comum; que se cruzam, mas se mantêm ilhados, orbitando em seus próprios percursos, alienados um do outro. É pouco, mas é preciso ter em mente que nos filmes a serem analisados ao longo do capítulo o corpo é representado por uma disposição coreográfica que, se em outras cinematografias é secundária, aqui é primordial, mesmo em seu minimalismo. Nesse caso, como na maioria das caminhadas, o lugar a ser alcançado tem pouca importância frente ao que se sugere e ao que se desvela sobre a condição da figura humana e suas relações sociais e afetivas.

Em O fantasma, do português João Pedro Rodrigues, contemporâneo de Ming-liang, e cuja atenção também é voltada aos corpos masculinos, à homossexualidade e às performances físicas dos atores, a marcha e a corrida desempenham uma função similar. O filme, repleto de deambulações, faz do itinerário sobre o espaço um dos modos de modelar e significar a imagem do corpo, aproveitando-se do movimento dentro de um quadro corriqueiro, mas simultaneamente como meio de explicitar o que se vivencia.

Fig. 87-88
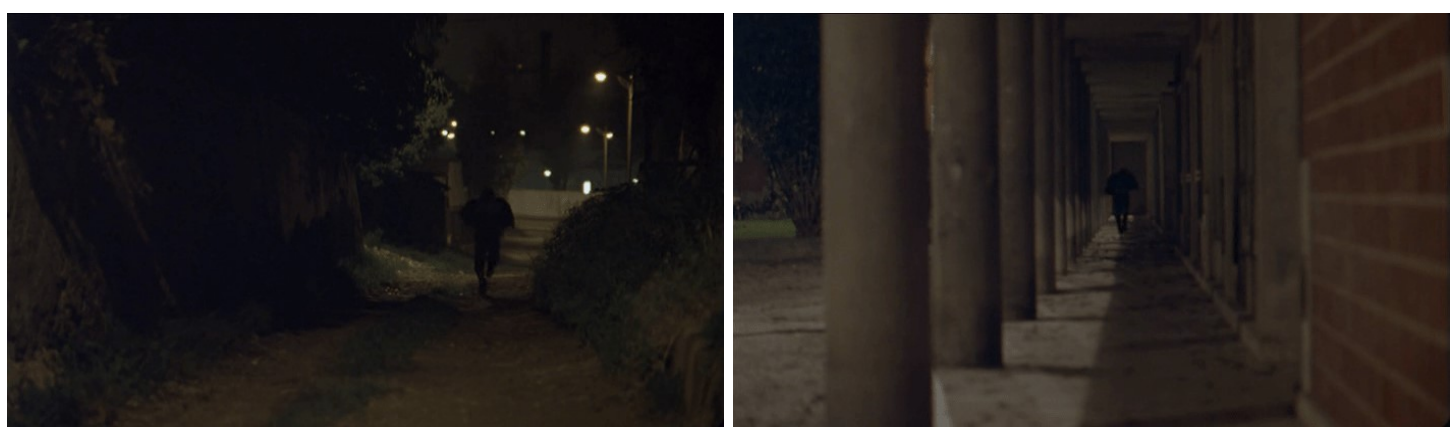

Os momentos de tensão e êxtase acabam por reverberar no deslocamento da figura humana, como se a resposta mais plausível aos dilemas da trama fosse o maior perímetro percorrido do espaço. Nessas ocasiões, como em Ming-liang, os planos abertos são frequentes e, por vezes, também se desdobram na profundidade de campo. Pode-se conjecturar sobre a razão e os efeitos dessa decupagem na sequência em que o protagonista é algemado ao tentar invadir uma casa. Com as mãos atadas, ele desata a correr por lugares abertos ou profundos (Fig. 87-88). Na diegese, a reação parece lógica: fugir para buscar uma forma de se libertar. A sequência, porém, termina sem mostrar como ele se livrou das algemas - há uma elipse e o filme continua em outra cena, já com o rapaz livre. Tudo parece se resolver pelo 
deslocamento e pelo dispêndio de energia corporal. A busca por uma resolução para o problema é menor se comparada a como se explora as sensações da figura humana a partir do seu comportamento físico. A algema existe quase como pretexto capaz de submeter o protagonista a tal circunstância. Para que esta se confirme, é preciso ainda um outro elemento: a expansão do espaço.

Nas cenas comentadas de $O$ fantasma é a figura humana a desbravar e a exigir a amplitude espacial, promovendo a dilatação do universo visível, por vezes implicando em um travelling que a acompanhe e desvele o que há fora de campo. Quanto maior a projeção no espaço, maior o acento sobre o desenrolar contínuo das ações, a interação com o entorno e a expressividade do corpo. É necessário recompor até onde for possível a teia que liga uma figura ao espaço-tempo em que ela está, privilegiando sua permanência no mundo físico. Somente assim será possível inferir algo sobre os personagens. Mais do que isso, o que se percebe é a representação do corpo a "ordenar" a encenação, dos movimentos de câmera à duração do plano. A mise en scène não conforma, mas acolhe e responde ao programa gestual da figura humana.

Recobrando Ming-liang, percebemos, num filme posterior a $O$ rio, Adeus, Dragon Inn (Goodbye, Dragon Inn, 2003), que novamente a dimensão física entra em evidência. Dessa vez, a partir de uma personagem manca de uma das pernas. Funcionária do cinema que dá título ao filme, ela aparece em diferentes cenas a caminhar por corredores (Fig. 89-90) e a subir escadas. Durante seus percursos, nenhum evento com peso dramático acontece. Os planos se estendem por minutos e a única ação a se desenrolar é a passagem, sem grandes surpresas, da figura de um lado a outro do espaço. Se não é o caso de uma novidade a surgir, possivelmente é o de uma varredura criada pela redundância: nos planos-sequência, cada passo dado ajuda a compor o itinerário que irá mapear, topografar a sala de cinema Dragon Inn, numa imersão pelo seus cômodos abandonados, assombrados por espectadores que rondam os cantos escuros tal qual fantasmas, num constante ensaio de afeto e flerte jamais consumados, como se já não pudessem se relacionar e estivessem destinados a deambular por um universo de desejos recalcados. A funcionária do museu igualmente marcha. Sua condição física é ressaltada na mesma medida que a sentimental, pois descobrimos que nessa última noite de abertura do cinema seu longo itinerário silencioso é a busca e a tentativa de encontro com o projecionista. 
Fig. 89-90
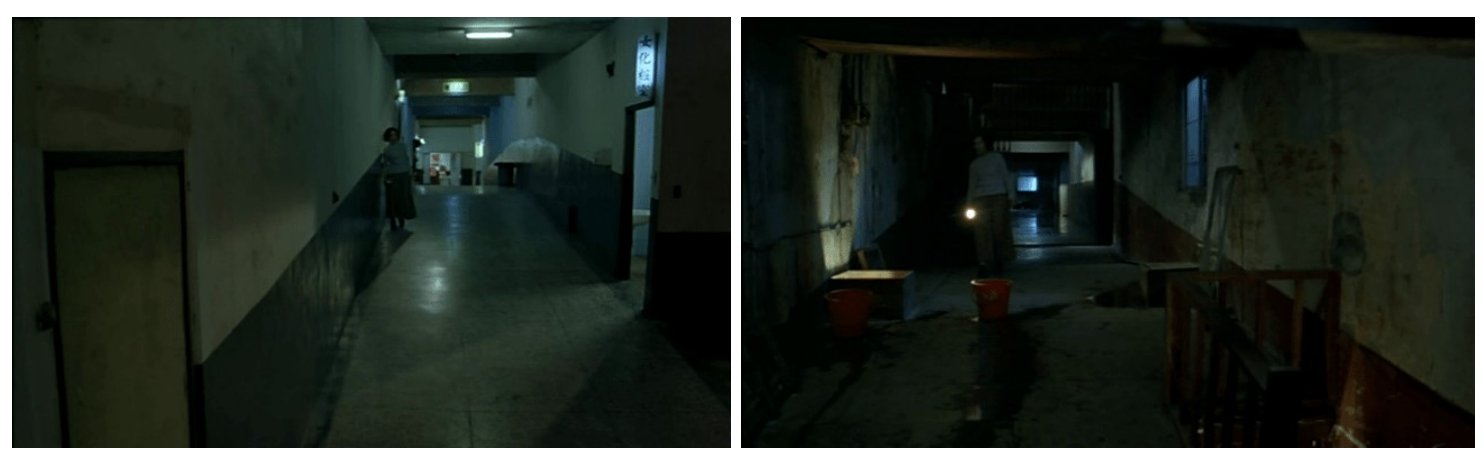

A fala, os discursos, o peso das ações dentro de um quadro moral, simbólico ou narrativo são rarefeitos - ainda que não obliterados. Adeus, Dragon Inn não abandona a história, mas a confia às ações mais elementares das figuras humanas. Além de deambulações, a narrativa é formada por olhares e por corpos que fumam, mastigam e urinam. São atos que não vem para ancorar as figuras dentro de uma naturalidade comportamental, como pontuações entre eventos dramáticos, mas que constituem por si mesmos a fábula. A marcha da funcionária e dos espectadores pelos corredores amplos e vazios porta consigo o estigma da solidão e, em um caso como no outro, é o que permite ao espectador o tempo para repousar o olhar sobre o abandono e as condições deterioradas do Dragon Inn.

Nos exemplos apresentados, a caminhada poderia ser pensada à luz daquela realizada pela figura humana em dois gêneros existentes desde o início do século XX: os filmes de perseguição (chase films) e o burlesco. Quais seriam os traços particulares a revestir e a definir a imagem do corpo nessas formas cinematográficas? Um pequeno interlúdio por elas talvez ajude a recuperar as semelhanças para posteriormente sinalizar as diferenças frente ao cinema contemporâneo, logo, as respectivas singularidades na figuração do corpo e de suas ações. Abordaremos três pontos: a dilatação no espaço-tempo, a linearidade e os personagens físicos.

\subsubsection{O primado antropocêntrico}

O vértice inicial a motivar nossa comparação é o papel central destinado à figura humana a partir de sua maior permanência no espaço e no tempo. O ponto já foi mencionado, mas agora é possível aprofundá-lo ao retomar a lógica estrutural dos chase films. Recobremos as características gerais do gênero.

Obra inaugural dos filmes de perseguição, The miller and the sweep (1897, de George Albert Smith), contém a linha geral que se repete incessantemente, com variações mínimas, 
ao longo dos anos seguintes. Com apenas um plano, o enredo se divide em dois momentos: uma situação estável e posteriormente o aparecimento do elemento perturbador que irá provocar a perseguição. Stop thief! (1901), Desperate Poaching Affray (1903), Personal (1904, de Wallace McCutcheon), Tom, Tom, the Piper's son (1905, de Billy Bitzer), mantêm a mesma dinâmica de seu predecessor. Podemos equacioná-la sumariamente por: ação (qualquer que seja) e reação (perseguição). A principal diferença em relação ao filme de Smith se deve à existência da montagem. A história passa a se descortinar como ação sequenciada ao longo de planos, com linearização da narrativa. ${ }^{159}$

A respeito da figura humana, a maior conquista do gênero foi possivelmente a organização fílmica condicionada ao movimento imposto pelo corpo. O cubo cênico dos filmes de tomada única, em seu potencial centrípeto, não dita mais o espaço que os atores têm à disposição. Será a figura humana quem irá criar e delimitar a extensão territorial conforme a direção da marcha ou da corrida. Posto que ainda não havia movimentação da câmera, a sucessão de planos era a única forma de acompanhar o itinerário e os desdobramentos da perseguição. Desbravava-se o espaço para seguir os corpos em cena, tal como se comentou mais cedo em O fantasma. Outra particularidade, evidenciada em Personal (Fig. 91-94), é a realização do corte somente depois da saída de campo de todos os personagens. Tentava-se preservar a integridade corporal a qualquer custo, como se a edição ameaçasse desmembrar a figura, destruí-la e impedir que aparecesse no plano seguinte. Assim, aguardava-se a partida dos corpos em cena a fim de prosseguir para a próxima imagem. Os filmes que seguem essa lógica sugerem que a continuidade narrativa "depende menos de técnicas particulares de filmagem, como a edição analítica, do que da representação da corporeidade: o corpo ou os corpos em movimento se tornam o corpo abstrato do filme". ${ }^{160}$ A figura humana é a medida básica, o bloco de construção essencial para a estrutura, “o script móvel da inteligibilidade por meio da qual os espectadores aprendem a seguir as histórias do primeiro cinema". ${ }^{161}$

\footnotetext{
159 Apesar da continuidade da ação ao longo do filme, há uma clara descontinuidade de um plano a outro, pois os filmes ainda não continham raccord de movimento. Também eram frequentes as quebras de eixo, o que promovia certa autonomia dos quadros, sua qualidade de "mundo em si". Noel Burch, La lucarne de l'infini, Paris: Nathan, 1991.

${ }^{160}$ Jonathan Auerbach, Body shots: Early cinema's incarnations, Berkeley: University of California Press, 2007, p. 103. O comentário é direcionado a Personal.

${ }^{161}$ Ibid., p. 103.
} 
Fig. 91-94
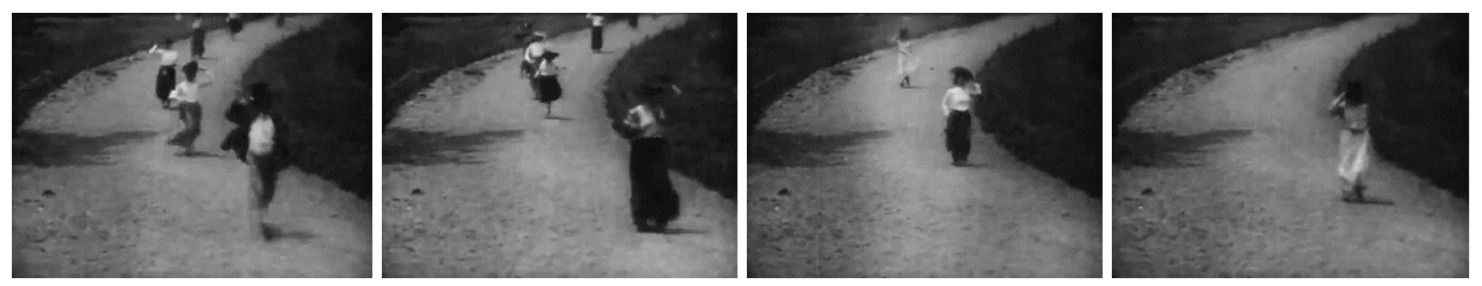

O cinema burlesco primitivo igualmente tentou preservar a visibilidade da figura humana, colocando a decupagem a serviço das ações corporais. No início de sua obra, quando ainda trabalhava para a Keystone Cops, de Mack Senett, Chaplin percebeu que os montadores de seus filmes cortavam as gags antes que fossem concluídas. Aprendeu então a boicotar o procedimento ainda durante as filmagens: dilatando os gestos de seus personagens, evitava a interrupção das cenas. Caso tentassem cortá-las antes do término, isso comprometeria a continuidade com o plano seguinte. Chaplin garantia então o desenrolar integral do que era encenado e uma maior duração da tomada. Evitava as censuras e as mutilações dos filmes ao mesmo tempo em que assegurava a unidade gestual. A preservação da figura humana em detrimento da montagem foi comum a outros expoentes do burlesco, incluindo Buster Keaton. Como alguns autores assinalam, essa economia da forma e do tempo que privilegiava o gesto e a instância atoral antecipou a sensibilidade estética do cinema moderno, fascinando desde nomes da Nouvelle Vague francesa, como realizadores orientais, incluindo Nagisa Oshima. ${ }^{162}$

À luz das considerações sobre os chase films e o burlesco do início do século XX, podemos repensar as caminhadas do cinema contemporâneo. Não é o possível receio da montagem desmembrar a imagem do corpo em cena a justificar a escolha de Ming-liang, Rodrigues e mesmo Dumont por dilatar a presença da figura no espaço e no tempo. Muitos anos já se passaram e o espectador é seguramente familiarizado com o dispositivo cinematográfico e com todo tipo de descontinuidade a ele subjacente. A lógica do cinema contemporâneo talvez se aproxime mais da consciência de Chaplin em preservar a unidade gestual. Se for esse o caso, ainda reside a dúvida: por quê?

As caminhadas em planos de longa-duração podem a princípio ser pensadas em conformidade com a noção baziniana de montagem proibida. ${ }^{163}$ Direcionado a uma série de filmes, incluindo os burlescos de Chaplin e Keaton, o argumento era o de que o corte no plano deveria ser interdito sempre que uma ruptura arriscasse transformar a realidade em mera representação imaginária. $\mathrm{O}$ respeito à duração do plano e à unidade espacial durante o

\footnotetext{
${ }^{162}$ Manuel Garin, El gag visual: de Buster Keaton a Super Mario, Madrid: Cátedra, 2014.

163 André Bazin, Op.cit.
} 
desenrolar de um determinado evento garantia a veracidade do que era encenado. Ora, pensando especificamente nos filmes de Ming-liang, a banalidade das caminhadas é tal que montá-las em um ou mais planos dificilmente colocaria em dúvida a realidade do acontecimento. Por outro lado, também é verdade que se o recurso à montagem não deslegitimaria a natureza do ato, se não impediria o espectador de acreditar na sua realização, a permanência da figura na longa duração do plano pode muito bem reforçar a verossimilhança. Sendo assim, a defesa de Bazin da interdição da montagem quando o essencial de um acontecimento depende da presença simultânea de dois ou mais fatores, de sua contiguidade física, tem sua parcial valência aqui. Pelo menos, como ponto de partida.

O impedimento do corte nas cenas descritas mais cedo de Ming-liang garante a forte correspondência entre: a figura humana, o tempo e o espaço. Mais que a mera coexistência, o importante é o tipo de relação criada entre os três elementos. Na duração dilatada, a figura humana se faz presente, pois somente nela a caminhada se desvencilha do mero ato para adquirir ares de gesto, evidenciando a condição e a história do corpo, sejam elas física, afetiva ou social. É preciso vivenciar e se deslocar na morosidade da duração, como se numa perpétua via-crúcis, para que algo possa ser depreendido da figura humana. Entre outras razões, porque os personagens de Ming-liang pouco falam. O tempo, e mais precisamente a continuidade da ação no tempo, é o que segreda o que a palavra, em sua raridade, oculta. Sem instantes e eventos decisivos, a presença corporal se faz pelo acúmulo residual de cada movimento e de cada gesto numa longa linha temporal, logo, por capitalização de seus estados e sensações.

Em segundo lugar, é preciso pensar a permanência no espaço. A travessia de lugares vastos e profundos acontece de modo similar à proposição estimada por alguns artistas modernos do século XX sobre a dimensão existencial da caminhada, considerada uma topografia da experiência dos corpos mais do que a de um lugar. Em meio à diversidade de trabalhos, Tal-Coat, Germaine Richier, Jean Dubuffet, Alberto Giacometti, Auguste Rodin, Antoni Tàpies, Francis Bacon entre tantos outros lidaram em uma ou outra obra com o deslocamento do corpo num espaço, transformando a caminhada em insígnia primária de estar e habitar o mundo. Recordemos por exemplo das figuras macérrimas de Giacometti, com suas proporções minguadas e as superfícies ásperas. A massa corporal de $O$ homem que caminha (L’homme qui marche, 1960) é tão rarefeita que a banal ação do corpo de se sustentar e se locomover é muito, ou pelo menos parece ser tudo o que dele se pode esperar. Caminhar acentua sua presença, afirma a densidade de sua delgada matéria em relação a um espaço. Algo similar se encontra na lenta marcha da personagem manca em Adeus, Dragon Inn, ou do 
protagonista de $O$ rio, com a sua desconhecida doença no pescoço. Dados os distúrbios físicos, a caminhada deixa de ser uma ação corriqueira para se tornar um exercício moroso e pesado que lembra ao espectador todo o esforço nela presente, tornando patentes a motricidade e a natureza física do corpo.

A caminhada exige uma energia em prol de uma ação, um ímpeto para romper com o aspecto inanimado, um esforço que atesta e por isso afirma o corpo. Parte do grupo de artistas plásticos listados anteriormente vivenciou o âmago dos trágicos acontecimentos históricos que marcaram o século XX, incluindo a Segunda Guerra Mundial. A caminhada de suas figuras era então, por si só, um ato de resistência e às vezes o forte testemunho de um corpo que se ergue a despeito das perturbações do mundo. ${ }^{164}$ Já os personagens de Ming-liang apresentados estão distantes e às vezes, mas nem sempre, parecem alheios a um estado das coisas (a uma política) exterior aos seus dramas pessoais, cuja própria natureza nem sempre é clara. Mesmo nessas condições suas caminhadas partilham algo dos expoentes da arte moderna: a travessia por espaços profundos reforça a permanência e a densidade dos corpos ao mesmo tempo em que constitui um impulso, um sinal de força e de vitalidade. Frente às dificuldades de comunicação e ao mal estar que vivem, diante das condições desfavoráveis da figura humana (manca, dolorida, doente, sem motivações), caminhar é um ato de obstinação e também de insubmissão. Locomover-se é a lembrança da vida que apesar de tudo habita o corpo.

\subsubsection{Linearidade e topologia}

O primado da figura humana, tanto nos filmes de perseguição como nos contemporâneos citados, envolve uma espécie de depuração do plano. No caso dos chase films, desenhava-se o movimento da figura humana no espaço, transformando-a no epicentro da representação, em vetor de um deslocamento que carregava algo de uma gratuidade, mas que igualmente permitia esboçar um traçado na imagem, reforçando a geometria do plano a fim de direcionar a sua leitura por parte do espectador. Demarcava-se ali o início do processo de narrativização cujo objetivo era o de aparar as arestas e eliminar tudo o que sobrava no plano para assim dar centralidade ao corpo representado, refinando a mise en scène em torno de sua locomoção. ${ }^{165}$

\footnotetext{
${ }^{164}$ Maurice Fréchuret, "Le pied arpenteur", in Daniel Arasse, Lionel Bourg, Thierry Davila, Patricia Falguières [et. al.], Op.cit., pp. 157-224.

${ }_{165}$ As transformações advindas com o gênero de perseguição não acontecerem de maneira linear. Como afirma Machado, em meados de 1905, conviviam os filmes "baseados no enquadramento frontal e aberto, cuja ação
} 
Naquele gênero, seguir a movimentação é acompanhar um cursor (a imagem do corpo) que dá coerência à sequência de planos por meio da continuidade, possibilitando sua organização em princípio, meio e fim. A forma de dispor a ação é similar àquela que Rodin reparou na tela Peregrinação à ilha de Cítara (Pèlerinage à l'île de Cythère 1717, Fig. 9596), de Antoine Watteau, na qual a sequência começa a partir do homem e da mulher no primeiro plano à direita da imagem e se desenvolve ao longo da tela até alcançar o fundo do quadro, no canto esquerdo. ${ }^{166}$

\section{Fig. 95-96}
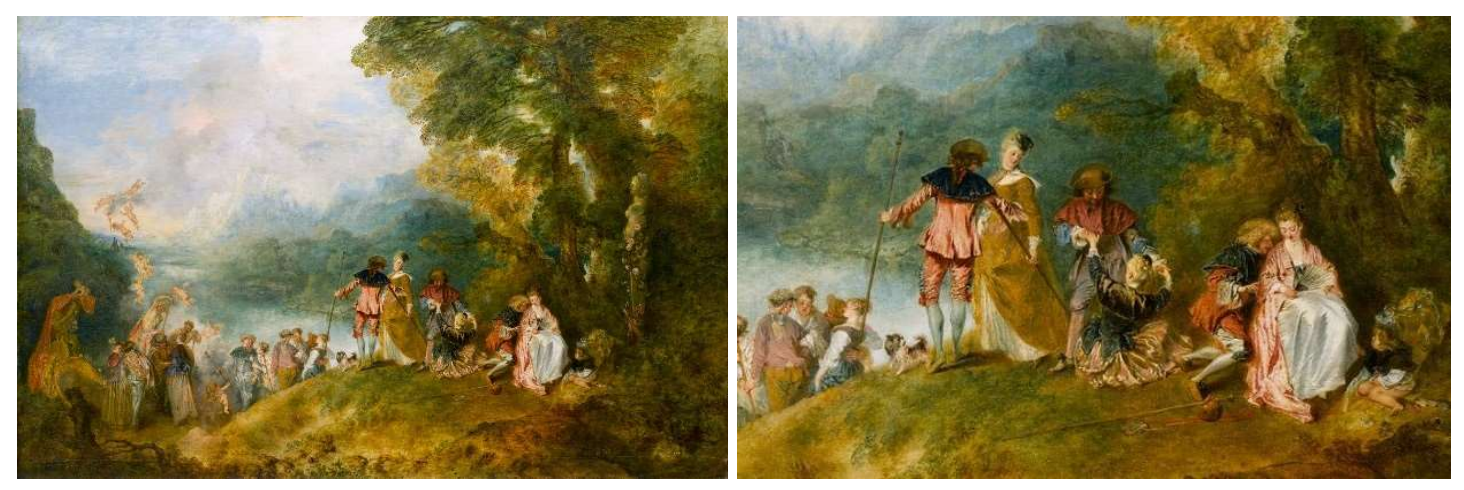

Segundo o escultor, pela disposição das figuras no espaço acompanharíamos desde o flerte inicial até o passeio em direção à embarcação. O detalhe é que os personagens aos quais Rodin se refere não formam um, mas vários casais. Cada um é representado com roupas e aparência distintas - apesar de haver similaridades/espelhamentos nos tipos e cores das vestimentas, cabelos e traços físicos. Com essa composição, a tela mostraria a dupla em tempos e ações distintos que se desdobrariam no decorrer da mesma imagem, orientando o olhar pela linearidade pautada nas posições ao longo do espaço.

Os filmes de perseguição realizam o mesmo trabalho de, visualmente, traçar a linha pela qual o espectador pode seguir tanto o movimento no interior do plano quanto de um plano a outro - quebras de eixo à parte. Correndo, a figura abole as distâncias entre o horizonte pelo qual passou e aquele que está à sua frente, sendo o elemento de cesura entre a imagem anterior e a seguinte. A figura humana e suas ações são enquadradas em uma engrenagem,

inteira se esgota num único quadro ou numa colagem de quadros autônomos separados pelos intertítulos, em que o cavalheiro da plateia faz uma 'leitura' paratática da imagem e a abundância de trucagens lhe faz tromper l'oeil evadir o espírito, cujo modelo é dado pela obra de Méliès, e aqueles que começam a decompor a ação numa cadeia sintagmática, produzindo uma ilusão de contiguidade por meio, principalmente, da introdução do conceito de montagem, em que passam a dominar as tendências do naturalismo e do voyeurismo, esticando a duração para mais uma bobina, cujo modelo acabado será dado um pouco mais tarde pela obra de Griffith". Arlindo Machado, Op.cit., p. 93-94.

${ }^{166}$ Auguste Rodin, L'Art: entretiens réunis par Paul Gsell, Paris: Bernard Grasse, 1911. 
tornam-se o elemento motriz necessário para a organização narrativa funcionar, para a decomposição da ação num eixo sintagmático. A composição visual também é rarefeita, reduzindo os elementos em campo aos protagonistas da perseguição.

No cotejo com a linearidade dos chase films, pode-se também creditar ao deslocamento da figura humana em Ming-liang a criação de uma, ainda que mínima, trajetória a conduzir o olhar do espectador. O espaço é depurado a fim de fortalecer a atenção sobre um elemento único no interior do plano. Mas as correspondências param por aí. O deslocamento não implica na continuidade sintagmática, em nível estrutural da montagem, e tampouco a ele pode ser atribuída uma causalidade narrativa. Há, pelo contrário, um processo de parcial atomização de cada plano, reforçando a sua unidade, a sua completude, a densidade em si mesmo. As sequências de caminhada raramente respondem a uma montagem linear. Por outro lado, delas é possível ramificar uma série de feixes que irão ligar a aparente mecanicidade do ato às pistas que se têm sobre os personagens, sobre a linha dramática ou sobre uma ideia geral a perpassar o filme. É o caso do encontro banal entre os dois rapazes na passarela de $O$ rio, ou do percurso da personagem manca em Adeus, Dragon Inn.

A maior das dissonâncias entre os exemplos analisados nos filmes de perseguição e no cinema contemporâneo, em se tratando especificamente da ênfase dada ao deslocamento da figura humana, talvez diga respeito à possibilidade de uma varredura do olhar dentro do plano. A presença do corpo nos filmes de Ming-liang até pode servir de guia dentro do campo, mas em razão da longa duração e igualmente do percurso monocórdico, sem variações da caminhada, sem grandes eventos - em contraposição à corrida pontuada pelas gags nas perseguições -, facilita-se o vagar do olhar espectatorial, a possibilidade de uma leitura topológica. ${ }^{167}$ A expressão foi cunhada em referência a filmes do primeiro cinema em que a composição do plano não obedecia a uma hierarquização. Com a predominância de planos gerais, com múltiplas figuras em cena, repleta por uma miríade de signos disponíveis quase como um enxame dentro dos limites do quadro, em toda a sua simultaneidade, sem imponente

\footnotetext{
167 A expressão foi elaborada por Burch (Op.cit.). Algumas década depois, ao comentá-la, Machado (Op.cit.) optou por usar expressão que considerava mais adequada: "leitura paratática". O sentido é o mesmo, denomina a ausência de desinências ou de índices de hierarquização, isolamento ou linearidade, no olhar sobre as imagens. Como Machado sinaliza, e Burch também já o fizera, essa noção de "confusão" do quadro faz parte do olhar de espectadores contemporâneos. O público da época, além de ver o mesmo filme várias vezes seguidas e ter conhecimento sobre as histórias encenadas, poderia não ter problemas em passear o olhar livre e erraticamente sobre a superfície da imagem, sem a necessidade de uma centralização. Esta centralização, como sabemos, só se tornaria costume com o aperfeiçoamento da narrativa e da mise en scène. A despeito disso, deve-se reforçar como os primeiros filmes, incluindo também os mais elementares de Lumière, encontravam meios de estruturar a informação. A desordem não reinava. Ainda na falta da narrativa, tais obras organizavam-se por relações de simetria, de linhas diagonais, coerência espacial, entre outros modos. O que aqui se aponta são momentos de dispersão que dinamitam essa ainda frágil estrutura.
} 
organização e isolamento do essencial, sem separação entre significante e não significante, abdicava-se de um direcionamento pela mise en scène. $\mathrm{O}$ espectador dos primeiros filmes podia então percorrer a imagem livremente e dela extrair suas próprias associações.

As sequências analisadas em Ming-liang guardam algo dessa abertura a um olhar topológico ou paratático, mas não por um atulhamento da imagem. $\mathrm{O}$ excesso do primeiro cinema dá lugar a uma depuração: em Adeus, Dragon Inn, O rio, assim como em O fantasma, resta a figura e a arquitetura do espaço, os estados do corpo e o do mundo, em suas constantes negociações, mínimas que pareçam ser. A caminhada é o que reconecta um a outro, e igualmente o espectador à pregnância, à densidade de cada plano, em sua já comentada inteireza.

\subsubsection{Personagens físicos}

Sobre o cinema silencioso burlesco das primeiras décadas do século $\mathrm{XX}$, as correspondências com os filmes contemporâneos de Ming-liang, mas também os de Rodrigues e de Claire Denis, desdobram-se em vários âmbitos que ao longo do capítulo serão evocados. Nesse momento o que interessa tratar é o revestimento da dramatis personae a partir das aptidões físicas do ator. O burlesco evidencia um quadro em que o personagem já não é uma instância superior passível de ser interpretada por diferentes atores, mas uma criação inerente às condições físicas, à gestualidade e mesmo à anatomia de um corpo. $\mathrm{O}$ desafio de cada cômico é então o de conquistar uma visualidade própria, uma constelação de gestos e atos que componham sua figura. "São as gags que vestem os personagens narrativamente, não o inverso, de modo que o storytelling é mais uma hipótese que uma meta: a grande meta, a única meta é consolidar o personagem até que se torne inconfundível, universal". ${ }^{168}$

Seguindo a linha indicada, os personagens de Charlie Chaplin, Buster Keaton, Harry Llyod, Harry Langdon entre outros nomes do gênero são produzidos a partir de suas respectivas performances gestuais. $\mathrm{O}$ ato mais simples, como a caminhada, é o suficiente para diferenciá-los. André Martin, referindo-se ao conjunto da obra de Chaplin, descreve sua movimentação conduzida por contrações musculares e uma diretriz descontínua: a figura se mantém num vibrato perpétuo fundado sobre a atividade muscular instável, que abala o centro

\footnotetext{
${ }^{168}$ Manuel Garin, Op.cit., p. 239.
} 
de gravidade, sacodindo os membros e o corpo num histrionismo em cascata. ${ }^{169}$ O estilo corporal exclui o esforço contínuo e se desenvolve por descargas nervosas.

Fig. 97-98

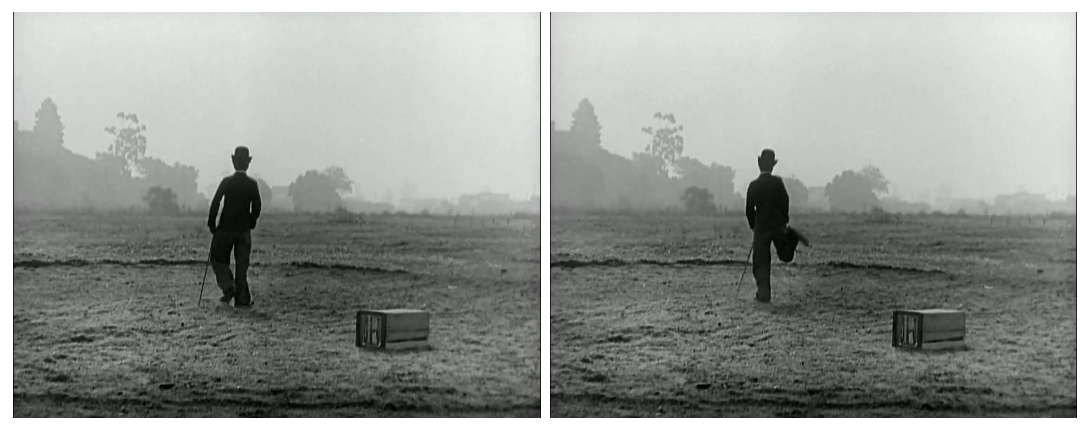

Fig. 99-100

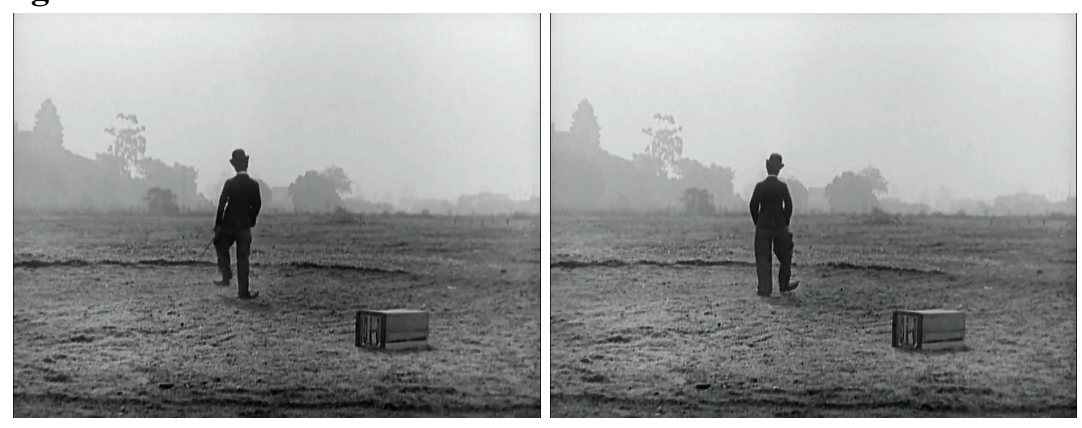

Nas caminhadas de $O$ Circo (The circus, 1928, Fig. 97-100), por exemplo, observamos Chaplin a dobrar a articulação do joelho para depois esticar a perna ao máximo, como se chutasse o ar - silhueta que atravessa, marca e define sua figura ao longo da obra. Quando se agita, como na cena em que engole por infortúnio a pílula destinada a um cavalo, sua figura entra numa convulsão pela qual o cômico segmenta o corpo em quatro partes que se movem independentemente umas das outras: pernas, tronco, braços e cabeça. A imagem é a de uma criatura em que cada movimento é interrompido logo após começar para, em seguida, dar lugar a outro que, igualmente, cessará, e assim por diante. Essa plasticidade fervilhante presente tanto no andar como na corrida, herdeira da agitação incessante dos filmes de Mack Senett, deve-se à motricidade sincopada, e é potencializada pela instabilidade do visual: calças largas, sapatos grandes e o chapéu, que sempre teima em cair. A descontinuidade não passou despercebida por Fernand Léger, que representou Chaplin em Balé mecânico (Ballet Mécanique, 1924) a partir de um boneco articulado por partes intercambiáveis, que se reorganizam num jogo rítmico, compondo e decompondo a figura.

\footnotetext{
${ }^{169}$ André Martin, “Le mécano de la pantomime”, Cahiers du cinéma, n. 86, agosto, 1958, pp. 18-30.
} 
Curioso reparar que apesar dos planos gerais e dos cortes na montagem feitos somente após a conclusão de um gesto, típicos do cinema burlesco, sempre a realçar, como veremos mais tarde, a relação entre a figura humana e os mundos objetal e social, a performance de Chaplin sugere uma espécie de descontinuidade corporal. A movimentação veloz, compartimentada, com cada membro agindo sob o aparente efeito de uma disjunção, remetenos à própria representação da figura humana na modernidade, condicionada à fragmentação e à mutilação. Em meio às suas heterogêneas significações para a cultura visual, que referenciamos pelo menos desde as decapitações existentes na Black Art e posteriormente herdadas por Méliès, ${ }^{170}$ a ideia de um corpo em pedaços está em consenso com o sentido social, psicológico e mesmo metafísico da experiência de choque na modernidade, ${ }^{171} \mathrm{com}$ as céleres transformações produzidas pelo capitalismo no início do século XIX, em especial a perda de solidez e a transitoriedade das condições de vida. ${ }^{172}$ Enquanto filmes contemporâneos aos de Chaplin como as "Sinfonias da cidade" exploravam as descontinuidades no nível da montagem cinematográfica e das sobreimpressões, aqui ela é sugerida - ou por nós interpretada - pelo próprio dinamismo do movimento corporal, incluindo a caminhada.

Longe do nervosismo crepitante, do arrepio cinético de Chaplin, o estilo corporal de Keaton não salta aos olhos, aproxima-se da elegância e da discrição da comédia teatral, aquela da qual Max Linder não quis jamais se distanciar. ${ }^{173}$ A articulação desequilibrada de Chaplin, com seu alto gasto energético, é substituída em Keaton pela destreza econômica, mecânica, por meio da qual sua figura pode, subitamente, passar da imobilidade à corrida, da corrida à estatismo, ou ainda mudar a direção da locomoção em plena continuidade do movimento, sem esforço aparente. Comum aos demais nomes do burlesco, a perseguição será apropriada como motivo frequente e igualmente irá compor os traços matriciais de sua figura.

Sete oportunidades (Seven chances, 1928), verdadeira homenagem aos chase films e especialmente a Personal, é talvez o caso mais emblemático dessa herança, pois a matriz do enredo permanece, apesar de ser mais nuançado e complexo narrativamente. No filme, o personagem de Keaton é caracterizado de duas formas. Primeiramente, como James Shannon, o herdeiro de uma fortuna - à qual só terá direito caso se case até as $19 \mathrm{~h}$ do seu aniversário de 27 anos. Em segundo lugar, pelas qualidades físicas que demonstra quando foge de suas

\footnotetext{
${ }^{170}$ Consultar o Capítulo 1, no tópico No princípio, era o preto.

${ }^{171}$ Cf. Walter Benjamin, Magia e técnica, arte e política, São Paulo: Brasiliense, 1994.

${ }^{172}$ A importância da perda de solidez, presente em Marx, e da efemeridade, em Baudelaire, para uma estética do fragmento na modernidade é discutida por Linda Nochlin, The body in Pieces, Nova York: Thames \& Hudson, 1994.

173 André Martin, Op.cit.
} 
pretendentes: a velocidade atingida, a qualidade dos saltos e a destreza acrobática. Tudo o que fora apresentado sobre seu personagem dramático parece ser deixado de lado na sequência da fuga: Keaton dispara a correr, atravessando a terra, o ar e a água, bem como quaisquer obstáculos que tenha à frente num fluxo contínuo e irrefreável. Dado o automatismo dos gestos e das respostas corporais, a mecanicidade do ato veste seu personagem.

Fig. 101-102

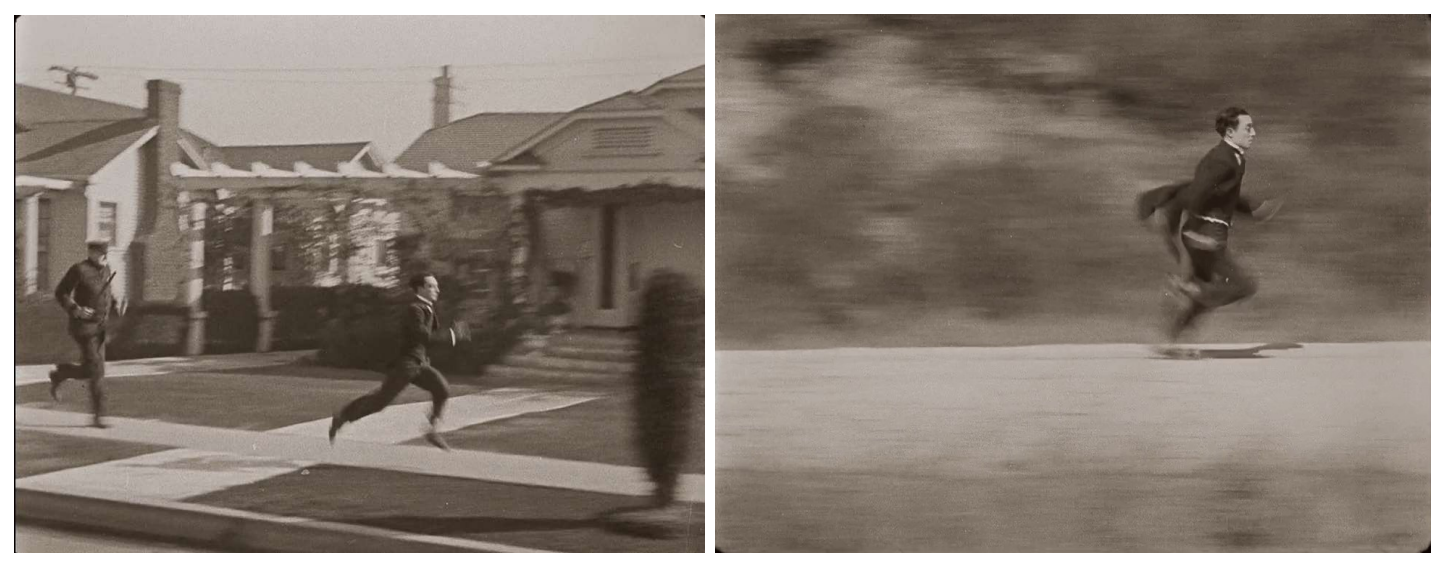

Atravessando o quadro fílmico de um lado a outro, impulsionado em direção ao seu destino final, a figura keatoniana é criada pela obstinada e infatigável varredura topográfica (Fig. 101-102). Quando esta última lhe é vetada ou impossível de ser realizada, entrará em crise. É o que acontece em Marinheiro de encomenda (Steamboat Bill Jr, 1928). Diante da destruição ocasionada pelo temporal, seu personagem fica desnorteado e, o que é raro na filmografia do ator, com movimentos titubeantes. O típico automatismo é obstruído, lançando o corpo diante do que até então parecia inimaginável ou certamente desnecessário: a ação ponderada, em lugar da resposta imediata. A ausência de um espaço a desbravar o mais longe possível corresponde à negação da força motriz de Keaton. A continuidade do movimento que existia nos chase films é transformada em traço identitário.

A forma com que cada expoente do burlesco lida com a perseguição, bem como seus respectivos modos de caminhar ou correr, delineia os aspectos essenciais, revela um traço de sua personalidade, define seus personagens. É justamente isso que se mencionou anteriormente sobre a caracterização ser condicionada à performance: o que o ator faz em um filme se repete ao longo de sua filmografia, como se de uma obra a outra a real alteração fosse a exposição do mesmo personagem a tramas e a gags distintas.

Para além da constituição de uma figura corpórea, ou de um personagem físico, o corpo representado será o responsável por engendrar uma forma particular de expressão e mesmo de 
narração de uma história. Existe um consenso com o que Romano diz a propósito da mímica, no que toca a "uma narrativa gestual organizada sintaticamente (por oposições entre atitude/movimento, velocidade/lentidão, movimentos bruscos/movimentos delicados etc.) ao invés de semanticamente [...]”, condicionada ao virtuosismo técnico dos corpos e à configuração de seus movimentos. ${ }^{174} \mathrm{O}$ drama se alicerça pelo universo físico, e a figura sobre a proeza corporal.

No cotejo com o burlesco, o cinema contemporâneo resgata acento similar sobre o gesto e as disposições físicas enquanto meios de encarnar uma figura. Esse modo particular de representar o corpo já não se encontra alinhado integralmente aos padrões de atuação costumeiramente codificados por sistemas como o naturalismo, o realismo épico, a abstração (caso da escola de Bauhaus) ou mesmo do simbolismo. Efetivamente, há uma maior proximidade com o naturalismo, posto que tanto as ações de Chaplin e Keaton como as dos personagens de João Pedro Rodrigues e de Tsai Ming-liang correspondem a uma fusão entre o ator e as motivações de sua figura (vagas que sejam nos filmes dos dois últimos). A caracterização é pautada na criação do interior e do exterior do personagem a fim de reconstituir um ser confrontado a uma situação hipoteticamente real/verossímil. Apesar disso, vale observar que nos momentos em que a fisicalidade é mais preponderante, a conformação à dramatis personae acaba sofrendo um processo de distanciamento à sua matriz dentro do drama. Distancia-se não para negá-la, mas para reivindicá-la em outras condições: o corpo reclama para si a posição de núcleo, o corpo é o drama.

No burlesco, pelo menos dos filmes mencionados, ${ }^{175}$ há uma linha dramática que é posta desde o início, quando são apresentados as aspirações, o lugar de origem, a classe social e uma série de outros indícios que irão compor o personagem. Em determinados momentos,

\footnotetext{
${ }^{174}$ Lúcia Romano, O teatro do corpo manifesto, São Paulo: Perspectiva, 2013, p. 46.

175 É preciso ter cuidado com as generalizações e possíveis abstrações. Citamos nomes de realizadores, mas é preciso lembrar que cada um traz consigo um percurso heterogêneo. A respeito de Chaplin, sabe-se que a partir de 1916 deliberadamente introduziu pathos em suas gags a tal ponto que o efeito cômico calcado na fisicalidade se tornou indissociável da expressão sentimental e, por conseguinte, da dramática (Garin, Op.cit.). Na fase correspondente a esse período, caso de $O$ circo, a natureza corporal é inserida dentro de uma demanda dramática, mas em determinados momentos dela se distancia para ter valor em si mesma. Se tudo está condicionado à performance física do personagem de Carlitos, desde a entrada no circo às investidas amorosas em relação à bailarina, há cenas em que as ações adquirem uma autonomia. É o caso do momento em que Chaplin sobe na corda bamba - retomando o número que o tornou conhecido no music hall e de certa maneira perpassa a maioria dos seus filmes silenciosos, o do equilíbrio. Nada desta ação será aproveitada diretamente pela trama. Suspenso no ar, Chaplin igualmente suspende o seu gesto. Ir de um lado a outro da corda não é chegar a um objetivo e tampouco irá influenciar sua permanência no circo ou conquistar a bailarina. Cria-se um espaço neutro em que conta a destreza de manter-se equilibrado, apesar das adversidades cumulativas que literalmente ilustram esta gag como o caminho mais distante para ir de um ponto a outro. Conta a performance, a forma de administrar o peso da figura e consequentemente sua existência material - além, claro, do riso. O momento intersticial, criado a partir de uma demanda dramática (conquistar a bailarina), acaba por ser impelido a outra direção: a do acento sobre o que pode ser criado e recriado pelo corpo.
} 
esses vetores serão pontuados por outro acento, o físico. Há um equilíbrio entre o lado psicológico e o acrobático, sendo que o primeiro é muitas vezes sujeito ao segundo, ao drama corporal. Já no caso de O fantasma, de $O$ rio, e de Adeus, Dragon Inn aqueles primeiros indícios serão rarefeitos. As ações físicas são por vezes a única pista sobre os corpos.

Patrice Pavis observa um quadro similar ao analisar conjuntamente as transformações de uma representação clássica para formas de enunciação modernas, tomando conjuntamente a literatura, o teatro e o cinema. ${ }^{176}$ A respeito do último, o autor contrapõe o personagem dos filmes clássicos hollywoodianos dos anos 1940 e 1950 a outros modelos. Uma estética fundada sobre o paradigma da transparência, como era o caso, exige que a representação das ações aconteça sem obstáculos à verossimilhança e à narrativa, mantendo uma forte coerência entre o que é feito, as características dos personagens e suas falas. Os atores não devem obstruir o entendimento, mas propiciar a clareza da fábula, aproveitando-se das regras dramáticas e dos meios expressivos corporais (olhares, atitudes, silêncios e falas). Em contraposição, Pavis elenca outros modos de compor a dramatis personae. É dado como exemplo A morte de Molière (La mort de Molière, 1994), de Bob Wilson, em que os personagens já não possuem uma identidade psicológica, restringindo-se a reações puramente fisiológicas (tossir, sangrar, chorar, beber, morrer) ou a cruzamentos com excertos de textos em voz off, palavras desconectadas. Um personagem ao mesmo tempo físico e textual; a figura do ator sendo um recipiente que preenche discursos diversos de narradores desconhecidos. Em lugar de um efeito mimético pelo qual a corporeidade e o indivíduo coincidem, dando a ilusão de que o corpo falando produz um texto, ou de um efeito de construção, pela intersecção entre a interpretação do ator, o personagem (constituído de uma rede de características) e o texto, produz-se um efeito de desconstrução. Este põe em questão a união natural entre o ator e o personagem ou entre o personagem e o texto, abolindo as correspondências entre o corpo que enuncia, o sujeito de enunciação e os enunciados textuais e visuais.

O cinema contemporâneo também recusa o personagem de matriz clássica, mas por outras vias que não as sugeridas por Pavis. A lógica é muito mais a de uma rarefação propiciada pela falta de um estofo explícito dos personagens e o drama em que estão inseridos. Muitas vezes isso pode passar por assignificância ou suspensão da inteligibilidade em prol da desordem sensorial, como se ali já não existisse mais um personagem - no sentido restrito de vetor e agente do drama. Frente a essa suspeita, o texto de Pavis é generoso no

\footnotetext{
${ }^{176}$ Patrice Pavis. "Le personnage romanesque, théâtral, filmique", in Iris: Revue de Théorie de l'image et du son: Le personnage au cinéma, n. 24, Outono, 1997, pp. 171-184.
} 
sentido de colocar o espectador no papel de um trapeiro que irá coletar as mínimas ações dos corpos para então buscar uma unidade, ou às vezes uma fratura, mas sempre uma espécie de reconhecimento, de significado a ser extraído da figura.

No cinema contemporâneo, a restrição ao ato é o que encarna e não o que achata e diminui a envergadura do personagem. Diferencia-se, nesse sentido, de uma das lógicas pela qual já se tentou rascunhar o corpo pornográfico enquanto "corpo oco em razão das carências da narrativa e da pobreza dos papeis que ela suscita, pois antes de tudo a pornografia o reduz ao ato pelo qual ele é corpo", ${ }^{177}$ limitando-o "aos atributos que o designam e às atribuições que o motivam", ${ }^{178}$ a tal ponto de perder a lembrança de um mundo que o concederia uma história. A encenação em Ming-liang parte de uma base similar, mas para atingir um resultado oposto: preenche-se a figura por meio de um parcial esvaziamento narrativo e do comportamento dos personagens, compondo a retórica corporal na sua aparente falta de comunicabilidade e de significado, por ações físicas mais do que simbólicas ou claramente dramáticas. Um cinema cujo solo é a mecânica gestual.

\subsubsection{Performance: a política do ato reflexivo e processual}

Deixando as comparações com os chase films e o burlesco de lado, podemos avançar em nossa análise sobre a locomoção. Talvez o passo mais radical da reiterada cruzada das figuras humanas por exteriores ou por interiores urbanos no cinema de Ming-liang seja Jornada ao Oeste (Journey to the West, 2014), que faz parte da série Walker, composta por curtas do realizador sobre caminhadas. O filme mostra uma performance do ator Lee KangSheng inspirada nas viagens do monge budista chinês Xuanzang, que durante a Dinastia Ming percorreu milhares de quilômetros sozinho e a pé em uma longa viagem à Índia a fim de estudar o budismo e coletar textos sagrados. ${ }^{179}$

\footnotetext{
${ }^{177}$ Luc Vancheri, "Le nu, le cru et le monstrueux: les trois manières du corps pornographique", in Admiranda, n. 4, 1998, p. 31 .

178 Ibid., p. 31.

179 Uma comparação com a cultura ocidental talvez seja arriscada. Ainda assim, é possível pontuar que a representação da caminhada é comumente associada aos grandes temas religiosos do Ocidente (fuga do Egito, a marcha dos reis mágicos, a travessia do deserto, a caminhada de Adão e Eva expulsos do Paraíso, a chegada de Cristo em Jerusalém, sua marcha sobre as águas, etc.) e à figura dos profetas. Estes últimos fazem da caminhada um gesto de humildade, mas também o de percorrer o espaço em direção a um lugar, geralmente santo, que implica dolorosas provações e um difícil esforço que será recompensado, seja com a mestria do espaço, seja com sua passagem a um tempo eterno ou pelo menos além do profano. Num contexto secularizado, o "profeta" às vezes é a figura de um peregrino que, pela sua caminhada, abandona um mundo antigo e serve de guia em relação a um novo, como Gustave Courbet em seu autorretrato La rencontre ou Bonjour Monsieur Courbet (1854). Ver: Maurice Fréchuret, "Un siècle d'arpenteurs, les figures de la marche”, in Daniel Arasse, Lionel Bourg, Thierry Davila, Patricia Falguières; Maurice Fréchuret [et. al.], Op.cit., pp. 9-34.
} 
A caminhada, discutimos, vinha se insinuando na obra de Ming-liang como um ato que a despeito da simplicidade é capaz de encarnar a figura humana, compensar os parcos diálogos entre os personagens pela movimentação mais simples e aparentemente destituída de retórica, depurando, canalizando a mise en scène sobre o comportamento do corpo. Mas enquanto nos demais filmes isso se restringia a cenas específicas, em Jornada ao Oeste é o alicerce único e absoluto. A estrutura é, plano a plano, amparada sobre a peregrinação ralentada de um monge pelas ruas de Marselha, em seu esforço por decompor física e milimetricamente cada etapa do caminhar, realizando o inverso da Gradiva: Ao invés de uma estátua suscetível de retornar à vida, um corpo cuja morosidade pétrea do movimento se arrisca a enregelá-lo sob a forma de uma figura de cera.

O monge experimenta uma luta interna contra a naturalidade do passo, expondo lentamente o corpo à força da gravidade. Todo um universo se anuncia a partir da figura e de sua caminhada. Um universo paralelo, edificado sobre o evidente contraste com o ir e vir dos outros corpos: a figura do monge em vias de se imobilizar em comparação aos demais passantes; estes, de assumirem um ritmo acelerado em comparação ao sacerdote. O corpo representado na duração do plano se torna manifesto de outra percepção, apreensão e vivência do tempo do mundo.

A peregrinação do monge leva a refletir sobre um programa diferente daquele que conhecemos no Ocidente desde o final do século XIX. Este período, sabemos, foi caracterizado pelos choques físicos e perceptivos do ambiente urbano, por uma série de fragmentações da percepção provocadas pela hiperestimulação sensorial. A sobrecarga de informações e de transformações num ritmo acelerado interferiam fisiológica e psicologicamente no indivíduo dos grandes centros urbanos, transformando os fundamentos de suas respostas e apreensões sensoriais diante do que vivenciava - por exemplo, pela separação entre a sensação e a cognição. ${ }^{180}$

Mais do que simplesmente apontar para o alcance das mudanças tecnológicas, demográficas e econômicas do capitalismo avançado, Simmel, Kracauer e Benjamin enfatizaram os modos pelos quais essas mudanças transformaram a estrutura da experiência. A modernidade implicou um mundo fenomenal - especificamente urbano - que era marcadamente mais rápido, caótico, fragmentado e desorientador do que as fases anteriores da cultura humana. Em meio à turbulência sem precedentes do tráfego, barulho, painéis, sinais de trânsito, multidões que se acotovelam, vitrines e anúncios da cidade grande, o indivíduo defrontou-se com uma nova intensidade de

\footnotetext{
${ }^{180}$ Leo Charney, "Num instante: o cinema e a filosofia da modernidade", in Leo Charney, Vanessa Schwartz (org.), O cinema e a invenção da vida moderna, São Paulo: Cosac Naify, 2004, pp. 317-336.
} 
estimulação sensorial. A metrópole sujeitou o indivíduo a um bombardeio de impressões, choques e sobressaltos. O ritmo de vida também se tornou mais frenético, acelerado pelas novas formas de transporte rápido, pelos horários prementes do capitalismo moderno e pela velocidade sempre acelerada da linha de montagem. ${ }^{181}$

As mudanças na experiência sensorial e na atenção coincidiram com a nova temporalidade imposta pela celeridade dos processos econômicos e pelo fluxo dos valores de troca, com a mercantilização pautada na circulação, na contingencialidade e na obsolescência de bens (produto, imagem e informação). ${ }^{182}$ A peregrinação do monge de Jornada ao Oeste parece estabelecer um contraponto diante dessa conjuntura iniciada com a modernidade, mas herdada e intensificada na contemporaneidade. $\mathrm{O}$ instrumento que o filme se vale para isso é a locomoção do corpo.

Fig. 103-104
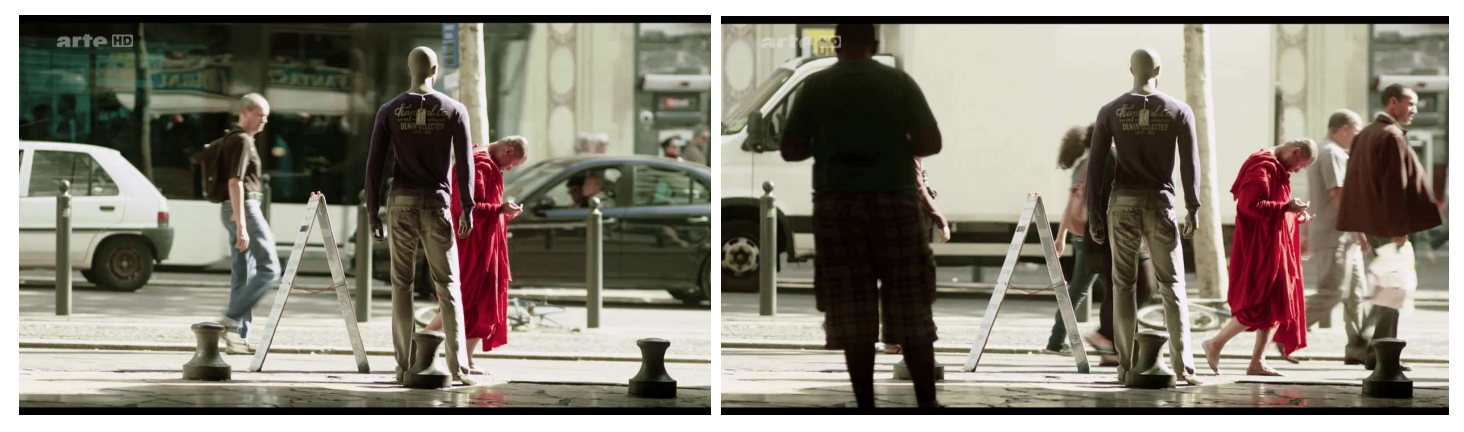

A marcha e a corrida estiveram no centro dos modos de representação visual da figura humana na modernidade desde pelo menos Marey. Em suas cronofotografias, vimos no primeiro capítulo, a ênfase recaía sobre os diferentes estágios do movimento a partir da decomposição do instante, com a estratificação da figura humana em vários espectros, cada um correspondendo a uma fração do seu deslocamento diante de uma tela escura que obliterava o mundo, isolando e evidenciando o corpo dentro de uma redoma. O resultado final fixava e condensava os fragmentos do tempo numa imagem compósita, numa montagem

\footnotetext{
${ }^{181}$ Ben Singer, "Modernidade, hiperestímulo e o início do sensacionalismo popular", in Leo Charney, Vanessa Schwartz (org.), Op.cit., p. 96.

182 "Parte da lógica cultural do capitalismo exige que aceitemos como natural a mudança rápida da nossa atenção de uma coisa para outra. O capital, como troca e circulação aceleradas, necessariamente produz esse tipo de adaptabilidade perceptiva humana e torna-se uma regime de atenção e distração recíprocas”. Jonathan Crary, "A visão que se desprende: Manet e o observador atento no fim do século XIX”, in Leo Charney, Vanessa Schwartz (org.), Op.cit., p. 69. Em outra obra, Crary, na esteira de Foucault, comenta como pelo menos desde as descobertas fisiológicas do século XIX formaram a base para um conhecimento que posteriormente seria utilizado pela economia e pelas tecnologias emergentes de controle e sujeição a fim de adequar o indivíduo às exigências produtivas. Ver Jonathan Crary, Técnicas do observador, Rio de Janeiro: Contraponto, 2012.
} 
(forma axial da modernidade ocidental). ${ }^{183}$ Em Jornada ao Oeste, a caminhada se faz dentro de um quadro extensivo, pela projeção num espaço-tempo dilatado. A ação se alonga e ocupa um fluxo temporal que escoa demoradamente, numa continuidade harmoniosa: se Marey decompunha, separava cada instante a partir dos mínimos avanços, da diferença de cada posição do corpo no tempo, Ming-liang faz do movimento da figura humana o elemento que reagrupa em vez de disjungir o tecido do tempo. A marcha ralentada do monge dificulta a distinção entre o início e o fim de cada passo. Por vezes, já não se sabe se a figura humana está se movimentando ou atada a um contínuo pré-movimento - atitude em relação ao peso e à gravidade que existe antes de se iniciar o movimento propriamente dito, quando os músculos se articulam para evitar a instabilidade que o deslocamento provoca, mantendo o equilíbrio do corpo no espaço, e determinando a qualidade, a cor e a expressividade da ação. ${ }^{184}$ A zona indistinta ocupada pela figura obstrui a possível ênfase no instante, o destaque a um interstício temporal que se separaria dos demais. Forja-se em lugar disso uma continuidade indivisa ou pelo menos fluida. O corpo é o disparador de uma dimensão temporal paralela - em conjunto com o plano de longa duração -, de uma segunda linha que se desdobra simultaneamente àquela vivenciada pelos outros seres em campo.

A caminhada em Jornada ao Oeste é, portanto, a ferramenta pela qual se investe contra a fragmentação perceptivo-sensorial e se reestabelece outra condição de percepção do mundo. A sensação não se dissocia da cognoscibilidade, não é mais vivenciada na forma de um instante intenso e descontínuo da experiência dificilmente sedimentado como memória do sujeito. Atuando em sentido contrário, a caminhada é a urdidura da temporalidade e da atenção, o meio pelo qual o corpo da figura tenta reestabelecer uma experiência com o tempo para além do fugaz e do presente sensório, fazendo o agora durar e se dilatar o máximo possível, organizando a experiência subjetiva (a do performer, a do público no seu entorno, e a do espectador do filme) de modo plácido e contemplativo.

Uma outra suspeita que se alimenta a partir dos planos filmados no centro comercial é a de que a temporalidade criada pela performance, fruída pelos passantes de Marselha e pelos espectadores do filme, também confronta aquela dos processos econômicos. A suspeita, é verdade, pode fraquejar pela ausência de uma base sólida. Em todo caso, num dos planos de Jornada ao Oeste a composição pictórica inclui o anúncio de uma imobiliária sobre alugueis de espaços, um caixa eletrônico, um manequim (vimos mais cedo, a metáfora a assombrar a

\footnotetext{
${ }^{183}$ Linda Nochlin, 1994.

${ }^{184}$ Hubert Godard, "Gesto e percepção", in R. Pereira, S. Soter (org.), Lições de dança, Rio de Janeiro: UniverCidade, v. 3, 1999.
} 
imagem do corpo em Ming-liang) e o ir e vir de transeuntes, consumidores, carros e ônibus. Os limites do quadro encerram, assim, um conjunto de signos mercadológicos comumente associado aos elementos que a imprensa do final do século XIX utilizava para representar os primeiros centros urbanos (em especial, os transportes e o ir e vir dos cidadãos). Forjaria a marcha do monge uma duração e relação com o espaço também oposta à da circularidade e a da efemeridade que medeia as relações comerciais? Deixaremos a questão.

Durante a exposição sobre a teoria e os filmes de Jean Epstein, evidenciamos a confiança que o autor, bem como outros da vanguarda francesa do início do século XX, depositava sobre as potencialidades do medium em acessar uma dimensão do mundo sensível inalcançável por outras vias. Os procedimentos sobre a temporalidade da imagem e mesmo recursos mais simples como o close contribuíam para o valor aditivo do cinema. Em Jornada ao Oeste, o tempo é igualmente modulado, mas sem o acesso a um recurso externo e imperativo ao mundo apreendido, sem a manipulação direta e incisiva do medium. É a figura humana quem lhe dá forma, fazendo do corpo o instrumento a transformar a duração. Respeitando-se a circunstância da tomada, a caminhada (a dança?) monacal insere o elemento intrusivo, vindo do Oriente, por meio do qual se inscreve uma nova temporalidade ao mesmo tempo em que se reinventa, reelabora-se o real. Este último se mantém, mas no seu seio se insinua uma brecha, um elemento provocativo e crítico aos seus alicerces.

A caminhada de Jornada ao Oeste já não é da mesma natureza das comentadas a partir de $O$ rio e Adeus, Dragon Inn. Estas últimas acontecem no espaço urbano real, mas são emolduradas - por hastes delgadas, sutis, é verdade - dentro de uma ficção. A série Walker é em sua maior parte formulada como uma performance. Em lugar da dimensão cênica, de um universo fictício, há o mundo real, com pessoas que passam na rua ao lado do monge. A vida se aproxima da arte, e o espontâneo do estético, a partir da ritualização de uma ação diante do olhar de espectadores.

O que propicia o encontro entre essas duas esferas é o próprio trabalho do ator, do performer. O comportamento de Lee Kang-Sheng como monge é independente de uma conjuntura representativa. A teatralidade é criada pela investidura do corpo no espaço, ao ostentar o ato/o processo que se desempenha. ${ }^{185}$ Não há mais necessidade de um todo ficcional que ampare um cosmo, de uma história ou de um drama no qual o ator se insira e na qual encarne um personagem, respondendo a uma demanda externa. A performance lida mais com a extrojeção, com o que se cria a partir do corpo, e menos com a introjeção, com a

\footnotetext{
${ }^{185}$ Cf. Josette Féral, Além dos limites: teoria e prática do teatro, São Paulo: Perspectiva, 2015.
} 
demanda que ele recebe a fim de participar de um universo no qual imperam leis próprias e um nexo interno dos elementos, uma moldura ficcional, uma realidade "encenada" separada da do mundo real. O performer partilha do "aqui-agora" do espectador, a fronteira que separa a encenação do público é permeabilizada por uma presença não só física (como já era no teatro), mas também cênica. Noutras palavras, o universo criado se constrói em presença, mas principalmente em interação com o público. ${ }^{186}$

A performance de Lee Kang-Sheng diante dos espectadores marselheses e turistas se ajusta às condições descritas. Não custa pontuar, porém, que Jornada ao Oeste, por ser um filme (instalação?), acaba por ter subtraída parte da potencialidade presencial ali produzida: não é nem uma performance audiovisual, criada exclusivamente diante e com espectadores, nem o mero registro de uma performance atoral. Trata-se de uma forma híbrida. O trabalho de Lee Kang-Sheng é conformado a uma mise en scène, pensado de acordo com um claro sistema de decupagem que compreende desde os pontos de vista por vezes oblíquos da câmera, com forte conotação sobre a cena, até a montagem. Em sua concepção, o filme incorpora traços da performance. Em sua forma final, submete a potência desta a um formato fílmico, tentando preservá-la pelos planos de longa duração e a ela acrescentando o peso da montagem, pela sua "geografia criativa" 187 capaz de multiplicar os lugares pelos quais o monge atravessa, ampliando a peregrinação para além dos limites do condicionamento físico do performer.

O que aqui se descreve são modos de entronizar a figura humana em cena e contribuir para a sua presença física, pois a performance faz do corpo um material significante que é ao mesmo tempo o agente e o suporte do que realiza. Sua ação é realizada segundo dois objetivos: sobre o mundo e sobre si mesmo. ${ }^{188}$ No primeiro caso, já aventamos, a passagem do monge abre uma brecha sobre o real e interfere diretamente no cotidiano da cidade e de seus habitantes/visitantes, na contramão de pontos cardeais da vida urbana existentes desde a modernidade. No bojo da caminhada, portanto, erige-se a dimensão política da arte. Não se trata de um filme militante em que o discurso verbal, a montagem ou o drama desvelam as relações e os meios de produção de uma situação história e social com o objetivo de esclarecer o espectador e, assim, sugerir uma mudança direcionada e radical. Jornada ao

\footnotetext{
186 A respeito da performance e de sua dimensão de presença, mais do que de representação de um universo fictício, consultamos: Hans-Thies Lehmann, O teatro pós-dramático, São Paulo: Cosac Naify, 2007; Renato Cohen, Performance como linguagem, São Paulo: Perspectiva, 2007; Jorge Glusberg, A arte da performance, São Paulo: Perspectiva, 2013.

${ }^{187}$ Recordando a expressão de Lev Kuleshov.

188 Soulier distingue quatro tipos de ação na performance e na dança (sobre o mundo e em direção ao mundo, sobre si e em direção a si). Noé Soulier, Actions, Mouvements, Gestes, Pantin: Centre national de la danse, 2016.
} 
Oeste apela, sim, para uma retórica corporal - menos pujante por ser difusa? - que sugere "a redisposição dos objetos e das imagens que formam o mundo comum já dado, ou a criação de situações adequadas para modificar nossos olhares e nossas atitudes" em relação a um ambiente coletivo. ${ }^{189}$ A potência política do caminhar é então aquela de sugerir uma reconfiguração das formas de se relacionar com o espaço e com o tempo a partir da transformação da experiência sensível.

Em outro sentido, a performance é direcionada ao suporte que a efetua. A figura humana do monge passa por uma constante tensão uma vez que o seu sucesso depende de um cuidadoso esforço físico por parte de Lee Kang-Sheng de frear a naturalidade, de transformar a motricidade num exercício árduo e expor cada etapa do passo à força da gravidade. Existe uma reflexividade em razão desse agir sobre si mesmo. Ao mesmo tempo, desponta um caráter semi-processual, similar ao das corridas dos filmes de perseguição - em que o sentido do deslocamento, as gags, está no progredir e não na conclusão da ação. No filme de Mingliang, como nas cenas comentadas dos filmes de Bruno Dumont e de João Pedro Rodrigues, o destino a alcançar é a consequência lógica de uma ação, mas importa menos do que o ato em si e do que é revelado durante sua encenação - a relação com o espaço em Dumont, o estado dos corpos em Ming-liang e Rodrigues. O deslocamento encontra no próprio desenrolar sua justificativa e seu sentido. Diminui-se o hipotético peso que um objetivo a ser alcançado poderia ter. ${ }^{190}$ A longa duração dos planos e a profundidade de campo são solicitadas para filiar os corpos ao mundo e igualmente para acentuar o aspecto processual das ações.

Ao submeter o suporte corporal a uma nova condição, fazendo-o experimentar os seus limites, redescobrir o seu potencial expressivo, Jornada ao Oeste se filia a uma problemática vigorosamente examinada na história do cinema, a da figura humana que experimenta formas de motricidade impróprias e atípicas aos homens, ou mesmo próprias a outros seres. Como observa Michel Chion, uma das mais comuns é aquela presente no cinema de ação dos anos 1980, em que robôs, monstros e androides reelaboram o caminhar, valendo-se exclusivamente disso para compor um personagem. ${ }^{191} \mathrm{O}$ autor cita alguns exemplos baseados na ideia de uma outra espécie, extraterrestre, animal, robótica, mutante ou qualquer outra que penetra ou precisa se misturar ao corpo humano: Schwarzenegger em O Exterminador do Futuro (The

\footnotetext{
${ }^{189} \mathrm{O}$ trecho corresponde a um fragmento de Jacques Rancière ao falar sobre os cruzamentos entre arte e política na contemporaneidade, em "A estética como Política", in Devires, v. 7, n.2, 2010, p. 18, jul/dez, 2010.

190 Pode-se lembrar aqui da brevíssima distinção feita por Arendt quando demarca o sentido, sempre contido na própria coisa, só podendo existir enquanto durar uma atividade, e o objetivo, que começaria a aparecer quando a atividade que o produziu chega a seu fim. Ver Hannah Arendt, $O$ que é política?, Rio de Janeiro: Bertrand Brasil, 1993.

${ }^{191}$ Michel Chion, “L'homme qui marche”, in Jacques Aumont, 1995, p. 36-51.
} 
terminator, 1984, de James Cameron), Jeff Bridges em Starman - O homem das estrelas (Starman, 1984, de John Carpenter), Kyle McLachlan em O escondido (The Hidden, 1987, de Jack Sholder), Jeff Goldblum em A Mosca (The fly, 1986, de David Cronenberg). Tais atores criariam uma gestualidade, especialmente a partir da caminhada, capaz de dar a impressão de alguém que experimenta um corpo humano e tenta entender como ele funciona.

$O$ Rio é assomado por esse quadro em que o corpo da figura humana guarda algo de extraordinário, desconhecido e involuntário, portando consigo uma condição ou um elemento em razão do qual é impelido a agir fora da naturalidade ou de um determinado código comportamental. Jornada ao Oeste, como também uma série de outros filmes a serem discutidos neste capítulo partilham da mesma condição em que a motricidade, a pele, o gesto, o rosto e tudo o que compõe o envelope carnal será redescoberto, seja para procurar o que nele há de pueril, seja para investigar o que nele há de pujante. O corpo não é dado de antemão, mas constantemente sondado a fim de revelar o que o constitui e quais são suas potencialidades, quais figuras (sociais, sexuais, anatômicas, políticas, simbólicas) é possível dele extrair.

$\mathrm{Na}$ direção apontada, o cinema contemporâneo, como também já acontecera com outros gêneros laboratoriais para a figuração do corpo, como o burlesco, tangencia as danças moderna e contemporânea em suas buscas por técnicas e processos que permitam revisitar e reorientar a arquitetura corporal, tornando visíveis outros corpos - no caso da dança, sabemos, aqueles negligenciados pelos cânones da estética clássica. ${ }^{192}$ Assim, o envelope carnal é entendido como tecido ilimitado que contém em si suas próprias mutações de sentido. Pelo menor movimento, como se viu aqui a partir da caminhada, pode-se perceber a presença de outro corpo e consequentemente de novas formas dele se relacionar com o seu interior e o seu exterior, com outros seres e com o espaço. Como nas danças moderna e contemporânea, reinventa-se o corpo pelo desvio, tentando reencontrá-lo ou criá-lo fora dos modelos previstos, pela reorganização de sua anatomia e de suas funções elementares, como nos casos de Trisha Brown e Yvonne Rainer. ${ }^{193}$

\footnotetext{
${ }^{192}$ Sobre a continuidade estabelecida entre a dança moderna e a contemporânea no que tange à descoberta de novas funções, sentidos e potencialidades dos corpos, ver Laurence Louppe, "Le corps comme poéthique", in Christine Macel, Emma Lavigne (ed.), Danser sa vie: écrits sur la danse, Paris: Centre Pompidou, 2011, pp. 211230. Nossas remissões feitas à dança devem aos debates e à bibliografia do curso "A Dança como Cinema, o Cinema como Dança", ministrado por Cristian da Silva Borges na Escola de Comunicações e Artes da USP, em 2014.

${ }^{193}$ Há pontos que podem diferenciar as escolas moderna e contemporânea, como a relação que esta última estabelece com as novas mídias, e mesmo a sua adoção de uma dramaturgia do fragmento pela qual seria possível reconhecer a presença de um efeito cinema na dança. Consultar Paulo Caldas, "Poéticas do Movimento: Interfaces", in Eduardo Bonito, Paulo Caldas, Regina Levy (Orgs), A dança na tela. Dança em Foco, vol. 4. Rio de Janeiro: Contra Capa Livraria/Oi Futuro, 2009.
} 
Será a partir dessa constante dinâmica de sondagem e de descobertas sobre a corporeidade, isto é, a partir de seus atos reflexivos, voltados inicialmente para a própria figura para depois serem direcionados ao mundo, que será criada uma retórica do corpo. As dinâmicas da imagem vistas no primeiro capítulo ficam em segundo plano e só raramente vem auxiliar algo cuja matriz é o comportamento, o ato, o gesto. Pela ação reflexiva, a figura humana adquire ou retoma um potencial político que de outro modo talvez fosse inacessível. A ação do corpo, mesmo a que se supõe ser a mais banal, como a motricidade, se torna então exigência necessária antes da figura defrontar e ressignificar o mundo que a envolve.

\subsection{0 domínio do gesto}

Até aqui se optou por um uso correspondente entre o ato e o gesto corporais. O descuido proposital se deu inicialmente pela dificuldade de encontrar uma literatura que estabelecesse de modo preciso e consensual as fronteiras entre os dois domínios, mas também porque os filmes contemporâneos analisados, diferentemente de alguns expoentes do clássico e mesmo do moderno, parecem diluir um termo em outro.

A princípio, ato e gesto partem de uma origem comum, o movimento do corpo, mas onde determinadas obras artísticas possibilitariam identificar duas trajetórias distintas em seus percursos e motivações, as cenas de deambulação de Ming-liang e Rodrigues articulam as possíveis especificidades em uma mesma direção: a conversão de quase toda disposição corporal em gesto. Afirmar isso, claro, só é possível ao ter um mínimo ainda que não definitivo parâmetro de dissociação entre os dois termos. A seguir, três autores nos auxiliam a estabelecê-los. Em si mesmas, suas definições não são as mais elucidativas para o corpus analisado. Porém, pensadas conjuntamente, e também em diálogo com o que se viu até aqui, apontam um caminho possível.

De início, a dúvida: o que vem a ser um gesto? Roland Barthes se pôs a mesma pergunta e arriscou uma resposta mais sucinta do que o tema possibilitaria. Seja como for, esboçou uma diferença: o ato tem natureza transitiva e objetiva pois busca um resultado, tenta alcançar algo, enquanto o gesto, seu complementar, é "uma soma indeterminada e inesgotável das razões, das pulsões, das preguiças que envolvem o ato em uma atmosfera (no sentido astronômico do termo)"; 194 nele não há a distinção entre causa e efeito, motivação e objetivo. O gesto nem almeja produzir uma informação, como a mensagem, e nem uma intelecção,

194 Roland Barthes, O óbvio e o obtuso: ensaios sobre fotografia, cinema, pintura, teatro e música, Rio de Janeiro: Editora Nova Fronteira, 1990, p. 146. 
como o signo, ficando com todo o restante. Não é muita coisa, mas parece se tratar de uma ação com tendência para a suspensão, ou pelo menos sem uma direção de atuação precisa, clara. Mais que uma suspensão, talvez uma ação difusa, opaca ou, para usar uma palavra cara ao universo barthesiano, obtusa.

Com similar proposta de desvencilhar o gesto do ato, há um curto ensaio de Agamben. ${ }^{195} \mathrm{O}$ autor parte de um comentário de Marco Terêncio Varrão para diferenciar fazer (facere), agir (agere), e uma terceira dimensão da ação, o gesto. O primeiro é descrito na forma de um meio que visa um fim, o segundo de um fim sem meios, enquanto o terceiro é caracterizado pela ação de assumir e de suportar algo. O gesto é pensado como uma ação subtraída à esfera da medialidade, pela qual se torna visível um meio como tal, sem um propósito a ser alcançado. A falta de um desígnio não impede o potencial para a comunicação. A particularidade é que nesse caso não se comunica um enunciado (Barthes segue na mesma direção), mas a própria comunicabilidade. O que isso quer dizer? A escrita do autor talvez não seja das mais generosas, mas o exemplo dado esclarece. Cita-se a dança como um gesto, pois ela é considerada "o suportar e a exibição do caráter medial dos movimentos corporais". ${ }^{196}$ Já havíamos chegado a esse ponto mais cedo ao analisar a performance em Jornada ao Oeste. $\mathrm{O}$ que está em evidência para Agamben, aparentemente, é a dimensão reflexiva, o relevo dado ao suporte de uma ação.

Por fim, uma terceira possibilidade de distinção é dada por Jean Galard. O autor tenta afastar ato e gesto a partir dos respectivos tratamentos que recebem, relegando ao segundo plano as intenções que os subtendem: a ação se resume ao ato não descrito, enquanto o gesto existe desde o momento em que desperta a atenção. Nada mais é que "o ato considerado na totalidade de seu desenrolar, percebido enquanto tal, observado, captado", sobretudo revelado, tornado perceptível em sua construção. ${ }^{197}$ A embrionária definição de Galard estabelece uma escala que aqui se tende a visualizar como gradativa. De um estado a outro da ação o que evolui é menos a finalidade do que as estratégias encontradas para evidenciá-las em seu desenrolar e consumação. Para isso, subentende-se um critério externo, a existência de uma instância enunciadora a definir um modo de apresentação diferente para o que na base - o movimento - é idêntico. Uma mesma ação pode tanto ser categorizada como ato quanto gesto, a depender das escolhas que orientam a sua apresentação.

\footnotetext{
195 Giorgio Agamben, "Notas sobre o gesto", in Artefilosofia, Ouro Preto, n. 4, p. 9-14, janeiro 2008.

196 Ibid., p.4.

197 Jean Galard, A beleza do gesto: Uma estética das condutas, São Paulo: Editora da Universidade de São Paulo, 2008, p. 27.
} 
Tomando ao pé da letra a descrição de Galard, a passagem do ato ao gesto no cinema poderia se dar muito bem pela continuidade do movimento em um mesmo plano, o que permitiria ver o desenvolvimento da ação em toda a sua integridade, como nos filmes de Ming-liang e Rodrigues. Esse argumento, contudo, exige ainda uma segunda condição para ganhar validade. Identificamo-la diante de um filme como $O$ cassino clandestino (Le tripot clandestin, 1905, Georges Méliès, Fig. 105-106). Ali, com plano fixo e tomada única, pessoas se divertem em um cassino quando são alertadas da chegada da polícia. Numa súbita metamorfose espacial que em muito lembra a casa "mágica" de Buster Keaton em $O$ espantalho (Scarecrow, 1920), o lugar é transformado em loja de roupas e cada jogador assume um papel social para despistar os tiras. Os limites do quadro são preenchidos por diversas figuras agindo em simultaneidade. À exceção das que recebem destaque pela posição que ocupam - o personagem que entra em cena para alertar sobre a chegada da polícia e o funcionário do cassino que fica no centro da mesa -, as demais agem simultaneamente e seus atos se dispersam sem qualquer relevo. A cena mais aberrante dessa desordem em que o ato não assume a dimensão de gesto é a entrada de vários policiais, quando o espaço é obstruído pela quantidade de figuras. Sob a luz apagada, elas atacam umas às outras sem que se saiba qual o ato principal, e quem é quem (fora o chefe, os demais policiais estão vestidos com o mesmo uniforme). A movimentação excessiva se torna a própria atração do filme. Mais importante: os atos são diluídos na algazarra, perdem a potência de sua singularidade.

\section{Fig. 105-106}
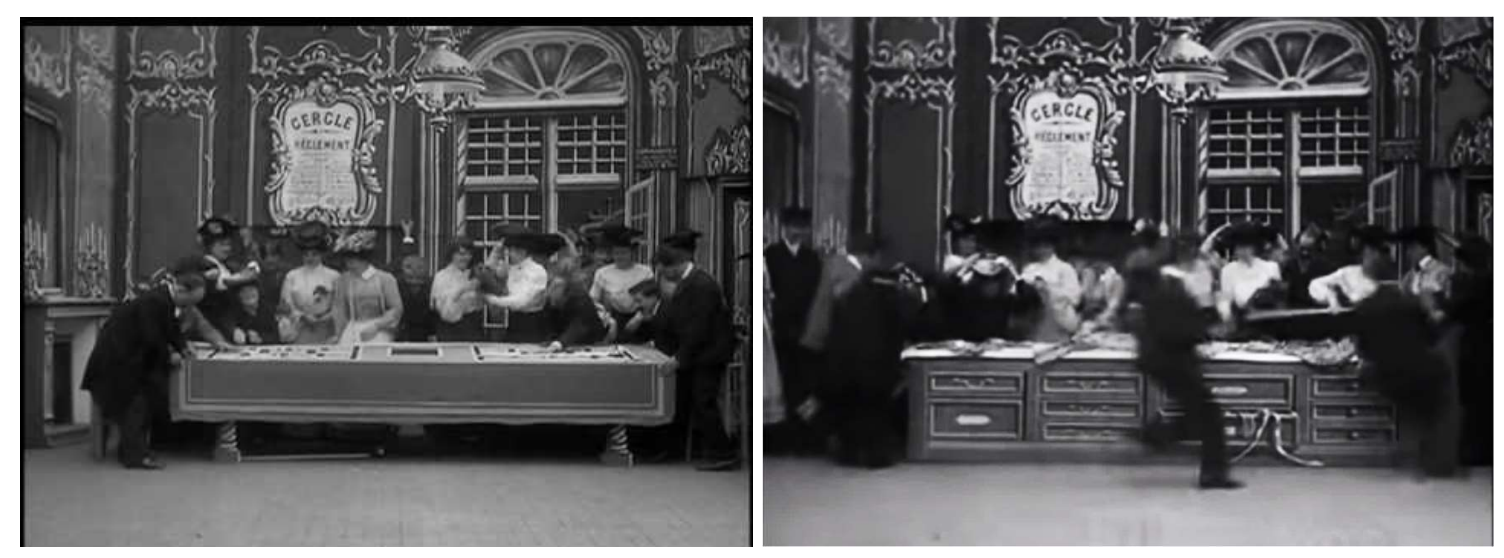

Assim, a continuidade da ação no plano, por si só, não configura necessariamente a condição para justificar a distinção entre o ato e o gesto no cinema - pensando-se em conformidade com os termos de Galard. Em se tratando especificamente dos filmes contemporâneos aqui analisados, exige-se além do plano de longa duração um segundo 
critério. A passagem de uma categoria a outra nas obras de Ming-liang e Rodrigues implica uma singular depuração da mise en scène em prol da figura humana. Nas cenas de caminhada/corrida de O rio, Adeus, Dragon Inn, Jornada ao Oeste e O fantasma, as figuras são dispostas individualmente em meio a paisagens ou a sítios urbanos, sem outras ações a desviar a atenção, de maneira a dar primazia ao principal agente na imagem, ao único elemento a se movimentar, o corpo. Tudo se resolveria aí se não houvesse um aspecto singular que age em sentido contrário à depuração, que macula o possível aspecto cristalino da imagem: a possibilidade, já comentada, de uma leitura topológica. Existe um afrouxamento da mise en scène pelo plano aberto e pelo não direcionamento do olhar. Os filmes de Mingliang e Rodrigues criam por meio disso uma relação ambígua com o espaço. A caminhada, não obstante submetida a um possível sentido a partir da comparação com o programa gestual dos personagens ao longo dos filmes, resguarda uma porção de assignificação, de pura fisicalidade. Parece que aí são contempladas tanto a intransitividade do gesto proposta por Barthes, ${ }^{198}$ ao realçar sua obtusidade, como também a mediação (o corpo tornado evidente), mencionada por Agamben. ${ }^{199}$ Constata-se ainda o realce sugerido por Galard, mas com uma ressalva: ele é potencializado pela depuração (rarefação da composição do plano e da ação) e ao mesmo tempo ameaçado pela opacidade (afinal, destaca-se o quê?).

A depuração das cenas de caminhada naqueles filmes está distante daquela de um cinema narrativo clássico, a do agenciamento e transparência do visível. ${ }^{200}$ Trata-se, sim, de eliminar as sobras na imagem, sem necessariamente dar uma clareza ao que nela restou. Já a opacidade talvez lembre aquela reconhecida por Bazin na gestualidade da figura humana no cinema moderno de Rossellini, cujos atores não exprimiam diretamente os sentimentos, mas eram solicitados a uma presença singular diante da câmera, numa tal mise en scène em que o lugar "respectivo dos personagens, seu modo de caminhar, os deslocamentos do cenário, os

\footnotetext{
198 R. Barthes, 1990.

199 G. Agamben, Op.cit.

200 Presente desde os primórdios do cinema narrativo, a transparência obedece ao princípio de que o "poder de tudo ver não teria sentido sem que, em certos momentos, apenas as coisas essenciais pudessem ser observadas". David Bordwell, Figuras traçadas na luz, Campinas: Papirus, 2008, p. 44. Ou mesmo aquele implícito na ideia de encenação como uma disposição e uma força capaz de amplificar e transfigurar o efeito dos gestos, do olhar e de cada movimento no quadro, discutido por Jacques Aumont, O cinema e a encenação, Lisboa: Texto e grafia, 2011. Complementar a essas concepções, o comentário de Mourlet, ao escrever sobre Raoul Walsh: "Não mostrar de uma cadeia de eventos senão o indispensável a seu desenvolvimento e sua compreensão; mostrá-lo de forma mais direta; sempre permanecer ligado ao centro. Construir, em outros termos, uma arquitetura cuja beleza global nasce da exatidão do papel atribuído a suas partes". Citado por Luiz Carlos Oliveira Jr, O cinema de fluxo e a mise en scène, Campinas: Papirus, 2013, p. 59.
} 
seus gestos têm muito mais importância que os sentimentos que se esboçam sobre o rosto e ainda mais sobre o que dizem". ${ }^{201}$

É dentro de um duplo regime (transparência e opacidade; economia dos meios e pouca clareza) que nos filmes de Ming-liang e de Rodrigues o gesto é constituído. Não faz mal pensar, uma última vez, no exemplo da caminhada. Em primeiro lugar, ela é um movimento ordinário que pouco revela e apenas acentua a presença num espaço-tempo. Em segundo, é o que de mais acentuado será dado a respeito das figuras, o meio pelo qual são realçadas na cena, a ação que excede a objetividade para traduzir ou revelar indícios do estado de um personagem ou mesmo da relação que ele estabelece com outros corpos e com o mundo. Assume-se tal destino na medida em que, no deserto de grandes ações, o menor movimento que a figura humana executa ascende a um patamar de evidência ao mesmo tempo em que guarda sua imprecisão. A caminhada porta consigo o desconhecido, exalta a corporeidade e por vezes manifesta o definitivo de cada personagem. Talvez esteja aí a passagem do ato ao gesto.

\subsection{A pele do corpo, a pele do mundo}

A importância dada ao corpo pelos filmes deste capítulo suplanta o movimento. Ela é ainda mais sutil e potente. Dar-se-á no nível da própria pele das figuras. Sutil porque, se o movimento mobiliza todo um trabalho de organização muscular necessário para garantir a estabilidade do equilíbrio do corpo no espaço, o que implica a ideia de uma ação, voluntária ou involuntária, a pele assume a sua função tátil mesmo na passividade. Não há necessidade de engajar um sistema de micro ou macro engrenagens, pois ainda que o corpo esteja estagnado, sua superfície é sensível aos estímulos externos. A potencialidade está tanto aí como também na zona de atuação. Enquanto o movimento tem natureza localizada, na medida em que é direcionado sobre algo (espaço, ser ou objeto), a pele é o órgão mais extenso. Ela envelopa a figura humana e transforma a integridade corporal em zona (ativa e passiva, ou ativa mesmo na passividade) de toque e apreensão de estímulos. ${ }^{202}$

\footnotetext{
${ }^{201}$ André Bazin, “Europa 51”, Op.cit., p. 57.

${ }^{202}$ Cf. Sarah Seija-Vergez (org.), La peau: un continent à explorer, Paris: Éditions Autrement, 2005.
} 
Fig. 107-108
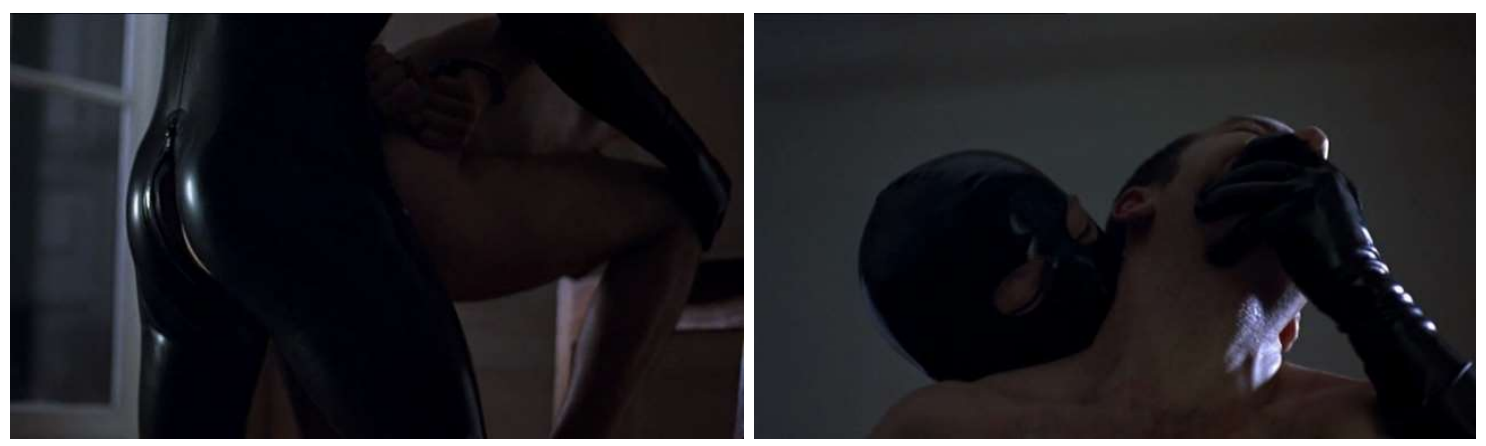

Em O fantasma, a epiderme é a principal mediação entre Sergio, um jovem gari em Lisboa, e o seu entorno. A importância dada ao órgão é sugerida desde o primeiro plano, quando o personagem, vestido com um traje preto de látex - fantasia rubber com aberturas nos olhos, na boca e no ânus (Fig. 107-108) - está transando com um homem. Cabe um parêntese: a mesma indumentária tem circulado em obras audiovisuais contemporâneas. Ela surge na série norte-americana American Horror Story (2011, de Ryan Murphy, Fig. 109) e nos filmes Apesar da noite (Malgré la nuit, de Philippe Grandrieux, 2016, Fig. 110) e Elle (2016, de Paul Verhoeven). Em cada aparição, o traje rubber é associado à identidade velada de personagens que cometem ou são vítimas de violência: o estupro em American horror story e Elle, a tortura em Apesar da noite. O prazer sadomasoquista é convertido em violação. O abuso acontece a partir de uma singular relação de domínio pautada em liberar ou coagir a pele, em agenciar o senciente. Cobrir a superfície do corpo com uma segunda camada, a de látex, limitando ou focalizando a zona de ação/recepção da pele é a condição de poder, de ver e não ser visto, tocar sem ser tocado, sentir o corpo do outro, mas privá-lo parcialmente do seu.

Fig. 109

Fig. 110
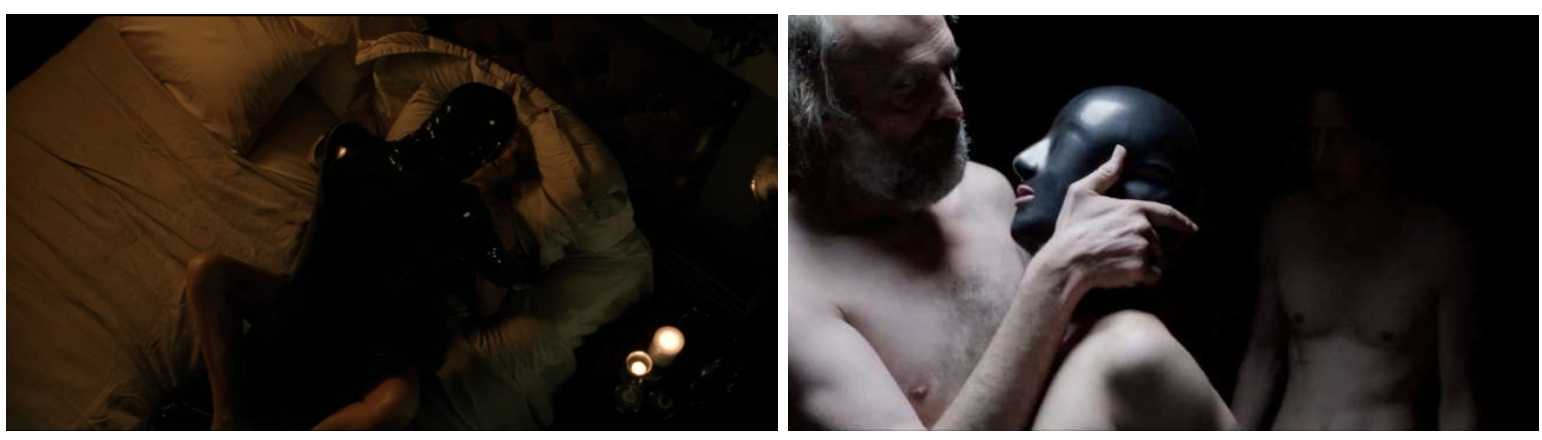

Mas o que nas obras referidas de Murphy, Grandrieux e Verhoeven estabelece a cisão e a imposição de uma figura sobre a outra, em O fantasma depende de um acordo tácito, pois 
Sergio e o parceiro se envolvem num jogo sodômico consentido, tal como se verá ao longo do filme de outras maneiras e com outras figuras, com corpos sem identidade na trama, presenças eróticas mais do que personagens dramáticos. A consensualidade entre os dois pode ser depreendida pela disposição de suas figuras em cena. Elas assumem uma espécie de combinação e espelhamento, como se fossem duas partes de um só corpo. No primeiro plano (Fig. 107), com as cabeças cortadas pelo quadro, a coxa nua aparenta ser a extensão fálica da figura preta, eixo vertical e central da imagem. No segundo (Fig. 108), o que falta a um é apresentado no outro, numa lógica de complementaridade: de um lado, um rosto com os olhos quase fora de campo e com a boca tapada, inclinado para a direita e para trás; de outro, uma cabeça encapuzada com os olhos em campo e com a boca parcialmente visível, enviesada para a esquerda e para frente. Independentemente de haver uma consensualidade pautada nas correspondências entre figuras, o que interessa ao comentar a cena é que desde então a pele é enfatizada. Sua importância cresce a partir do momento em que Sergio se apaixona por um rapaz e desde então sacia o seu desejo pelo toque. Mas isso é menos lógico do que parece.

Sem estabelecer uma comunicação efetiva ou uma mútua relação afetiva com o personagem visado, permanecendo em sua paixão platônica, Sergio procura outra via. Ele vai suprir a decalagem espaço-temporal do corpo desejado a partir de uma reconstituição tátil. Tudo começa durante um turno de serviço, quando revira a lixeira da casa do rapaz pelo qual se apaixonou. Ali encontra uma sunga puída e rasgada. Examina-a. Cheira-a repetidamente, supostamente experimentando ou fantasiando pelo olfato a presença do outro. Guarda consigo a peça e em outro momento a veste: reparando no corte, olhando para o espelho em diferentes posições, apalpando-se para perceber o volume do corpo, reparando em como a carne é modelada, sugerindo ao espectador a experiência do toque (Fig. 111-112).

Fig. 111-112
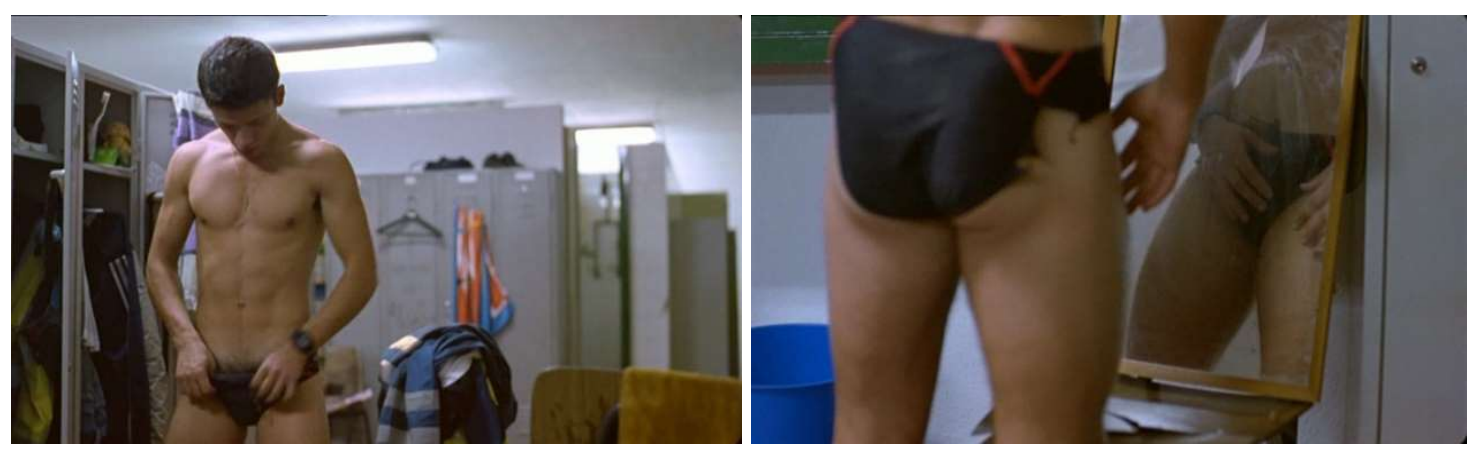

Mais à frente do filme, depois de dormir com um personagem desconhecido (de quem nada saberemos além das medidas corporais), Sergio veste a sunga, escala um telhado com 
pés e mãos, filmado, como é recorrente, pelo ponto de vista mais provocante possível, numa aberta pulsão escopofílica que Rodrigues não esconde, instiga (Fig. 113). No alto, o personagem abandona a posição horizontal de quadrupede e se ergue verticalmente (Fig. 114). Caso tomemos a passagem já aventada entre os dois eixos em Bataille, ${ }^{203}$ ou mesmo os conhecidos dizeres de Ovídio, ${ }^{204}$ o plano parece compreender a tensão que existe ao longo do filme entre dois lados. O selvagem, relacionado à pujança desmesurada e incontrolada dos impulsos sexuais, cujo limite é a aproximação com uma face animal. O racional, humano, associado à posição de uma figura que se eleva imponente, acima de um percurso conquistado, de um mundo dominado. A peça de roupa é o território limítrofe e poroso entre natureza e cultura, polos que em outras cenas serão sugeridos pela decupagem, que costumeiramente fratura as figuras em dois enquadramentos sequenciados, com um plano da cintura seguido por outro da cabeça, um do sexo e outro da mente (Fig. 116-117).

Fig. 113-115
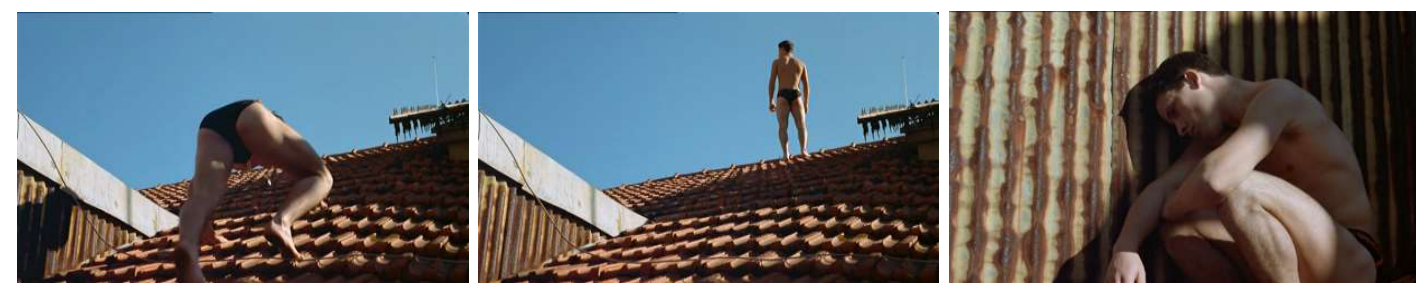

A composição pictórica do plano da escalada realça a polaridade insinuada pela disposição do corpo. A parte inferior, com um telhado de laranja terroso e estriado, ritmado pelas oscilações de luz e sombra, truncado pela presença de um triângulo com outro padrão geométrico, é oposta à imensidão de um céu cuja gradação suave de tons azul segue plena e fluida de um canto a outro da imagem, sugerindo uma imensidão que é o objeto do olhar do protagonista. Do telhado que implica um investimento corporal, físico, com mãos e pés, ao céu, que demanda unicamente o olhar. Do horizontal para o vertical. Um corte e o próximo plano mostra o resultado dessa sutil tensão visual do espaço e performática do corpo. Sergio aparece em crise, nem em pé, nem sobre os quatro membros, recostado na parede com um olhar desolado. Em toda a cena, a lembrança do homem desejado rente ao corpo, contígua à pele.

\footnotetext{
${ }^{203}$ Consultar o primeiro capítulo, no tópico A presença em face dos limites da representação.

204 "Ele fez o homem elevado, para que para o céu olhasse/ordenou, e às estrelas a face voltasse". Citado por F.W.J. Schelling, Filosofia da arte, São Paulo: Editora da Universidade de São Paulo, 2010, p. 243.
} 
Fig. 116-117
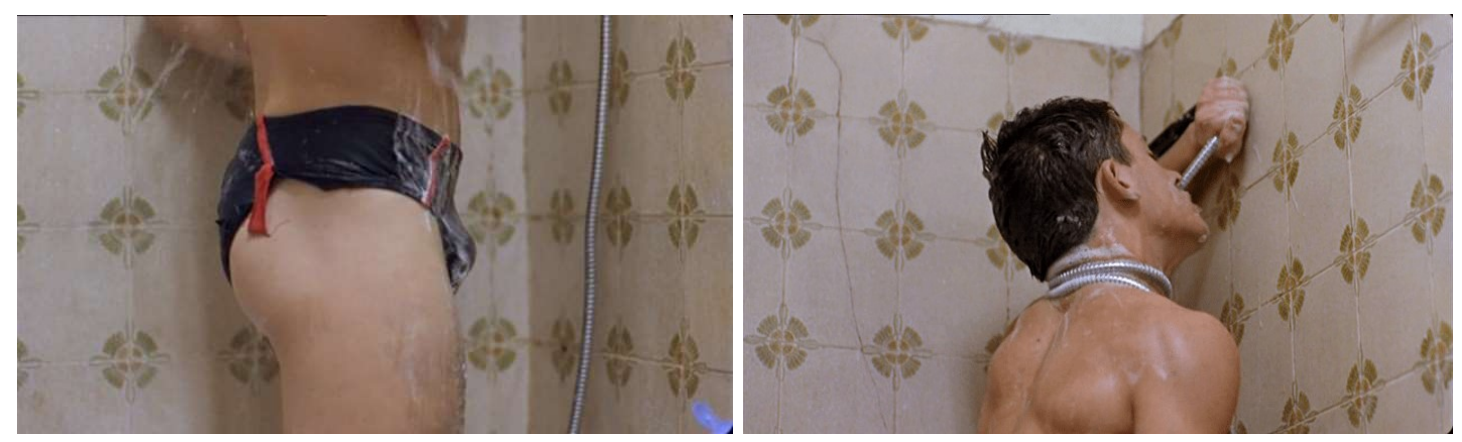

Uma mera peça de roupa como insígnia da lembrança e elemento disparador de uma tensão? Sim, e a próxima sequência dá uma natureza ainda mais pujante à crise. Nela, Sergio toma banho de chuveiro com a sunga. O primeiro plano é fechado na cintura do protagonista, enfatizando o gesto de ensaboar nádegas e o sexo, ato que logo se transforma em masturbação (Fig. 117). Na sequência, o personagem enforca-se com a ducha, interrompendo o fluxo de sangue para impulsionar o prazer. A crise da cena anterior é encarada pela exacerbação da pulsão sexual e conversão do desejo em gozo. Ao falar da corrida (Fig. 87-88) nesse filme, já se anunciava que as soluções para os conflitos precisam necessariamente resultar numa ação que culmine em dispêndio energético, físico, independentemente de haver qualquer consequência imediata para o drama. As coisas se dão em acúmulo. Tudo é uma questão de transbordamento, de romper com qualquer forma de contenção, mesmo aquela representada pela unidade corporal, o que fica claro no desfecho do filme.

O capítulo mais emblemático da mediação com o outro por meio da pele acontece quando Sergio visita a mesma piscina pública onde havia visto o rapaz que deseja. Ali, em outro momento, o observou nadar e, depois, no vestiário, trocou olhares não correspondidos. Ao invadir o prédio da piscina à noite, o personagem irá aos mesmos lugares em que o viu. Mas como o paradigma de $O$ fantasma não é o de acessar a realidade sensível pelo olhar, Sergio precisa ir além da mera observação nostálgica e melancólica dos espaços. Isso acontece quando se despe e mergulha na piscina. $\mathrm{Na}$ água, encontra uma posição confortável e flutua. A sunga passa a ser desnecessária na medida em que o próprio meio se converte na presença do outro, cujo acesso se dá pela pele. Para isso, despir-se, liberando a superfície corporal das contenções sensoriais impostas pela cobertura da roupa é o primeiro passo. O segundo é a disposição física: com braços e pernas abertos o personagem tanto se põe à disposição do olhar espectatorial como reforça uma total sujeição do corpo ao mundo. Um mundo, é verdade, particular e afetivo, o do outro. 
Fig. 118-119
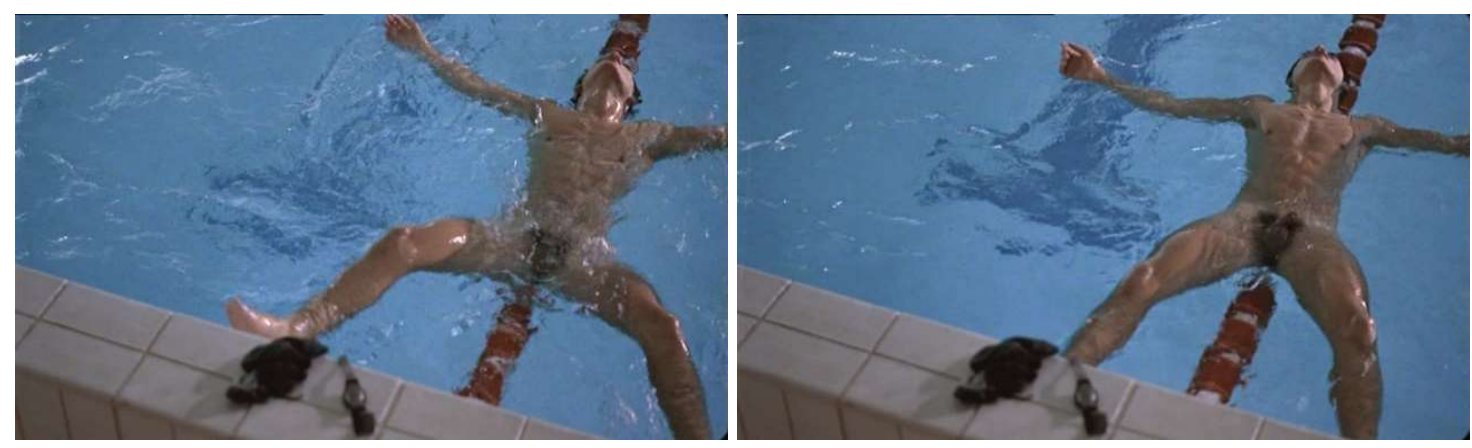

A cena da piscina revela o contato entre um corpo presente e outro ausente a partir de um medium partilhado a despeito da decalagem temporal. A figura humana sonda o entorno, friccionando o corpo contra a raia, experimentando a água, estabelecendo uma contiguidade tátil com o que a envolve. Isso culmina, figurativamente, numa espécie de integração. Quando o corpo flutua (Fig. 118-119), a composição do plano acaba por associar a figura de Sergio à raia, forjando a partir da sobreposição entre figura e objeto cênico a imagem de um alongamento da coluna vertebral do personagem. O corpo é apresentado enquanto matéria articulada, parte do ambiente. A sua pele é imantada à superfície espacial, à pele do mundo. Estamos distantes de um cinema que tenta restituir a presença corporal pelas distorções e esvaecimento do espaço figurativo, como visto em Grandrieux. Em Rodrigues, como também nos planos profundos de Ming-liang, a figura humana depende necessariamente do que se cria a partir da ancoragem palpável no universo concreto. O plano da piscina leva a um nível forte esse enraizamento, anunciado anteriormente a partir da atenção à caminhada. Cria-se um mutualismo tátil entre corpo e espaço. O intercâmbio entre agente e paciente é levado a um ponto em que um faz parte do outro, mas sem a anulação de suas respectivas identidades e principalmente sem recorrer a uma diluição da figura humana na imagem para sugerir qualquer tipo de circularidade entre os seus elementos. A circularidade aqui existe pelo que se toca, o que tem presença concreta e por isso é capaz de afetar o corpo sensivelmente.

Imiscuir-se ou lidar diretamente com o espaço é uma demanda interna do próprio filme de Rodrigues, no qual a presença e o modo de conhecimento da figura humana pertencem à ordem da sensação. Ao incumbir a pele da função de mediadora, passa a ser determinante a dimensão tátil. Para que algo afete os personagens e mesmo para que eles existam no filme, é necessário que em algum momento estabeleçam uma relação baseada no toque, como se fosse preciso sondar e confirmar a existência sólida de toda figura e objeto no espaço. Em razão disso, a economia figurativa é pautada na proximidade. Diferentemente da visão, capaz de 
perscrutar pela distância, o toque exige uma prospecção pela cercania, estar rente e diretamente, epidermicamente, envolvido com o seu objeto. No mesmo sentido, o contato físico, mesmo quando apreendido visualmente em um filme como O fantasma, é associado à ideia de um universo posto em relevo, transformado em matéria.

O tipo de presença tátil guarda uma segunda singularidade diferente daquela propiciada pela visão: estar ou não estar visível já não é sinônimo de ocupar um ambiente, como se vê na visita que Sergio faz aos lugares frequentados pelo rapaz que ama. Essa potência da pele em formular um modo particular de persistência do que está ausente faz lembrar aquela que Diderot descreve em seu romance Lettre sur les aveugles:

\begin{abstract}
Não conheço nada que demonstre melhor a realidade do sentido interno que esta frágil faculdade em nós, mas forte naqueles que nasceram cegos, de sentir ou de se lembrar da sensação dos corpos, mesmo quando eles estão ausentes e não os afetam mais. Nós não podemos fazer compreender a um cego como a imaginação nos esboça os objetos ausentes como se eles estivessem presentes; mas nós podemos muito bem reconhecer em nós a faculdade de sentir na extremidade de um dedo um corpo que ali já não está mais, tal como ela se dá em um cego. Para isso, aproxime o indicador contra o polegar; feche os olhos; separe seus dedos; examine imediatamente depois da separação o que se passem em você, e me diga se a sensação não dura muito tempo depois que a compressão cessou. ${ }^{205}$
\end{abstract}

Mais à frente, o autor diz que os cegos portariam a alma na ponta dos dedos. Dali viriam suas principais sensações e todos os seus conhecimentos. A imaginação compreenderia então a faculdade de se lembrar de combinar as sensações de coisas palpáveis. Ora, em O fantasma os personagens não são cegos. Pelo contrário, são dotados de uma visão acurada, principalmente para o flerte. A correspondência com o comentário de Diderot está na possibilidade de uma "epistemologia" fundada sobre o toque, um empirismo corporal elevado ao seu nível extremo, com a diferença de que a "alma" não estaria restrita aos dedos, mas disposta por toda a epiderme do corpo.

A pele enquanto órgão de conhecimento porta ainda um atributo que impele e justifica a pequena jornada de Sergio à piscina e aos demais espaços da lembrança: ela é dotada de uma pregnância e durabilidade das percepções e sensações, fazendo perdurar o que inicialmente seria efêmero, estendendo a permanência de um corpo numa temporalidade indefinida ou em todo caso mais longa do que aquela restrita à presença física, numa memória da sensação.

\footnotetext{
${ }^{205}$ Denis Diderot, Lettre sur les aveugles - à l'usage de ceux qui voient, Paris: Gallimard, 2015, p. 34.
} 
Fig. 120-121
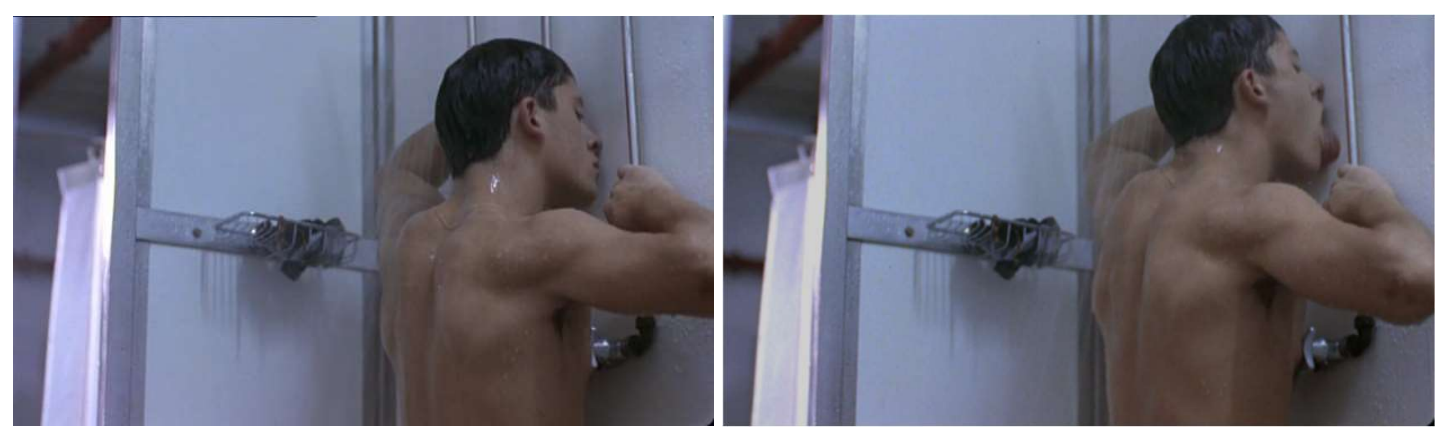

A continuidade da cena vai reforçar a capacidade de prolongar o sensível, independentemente do referente, convertendo a passagem de um ser em duração e pregnância no espaço. Da piscina, Sergio vai até o vestiário, onde toma uma ducha (Fig. 120-121). Dessa vez, o desejo de presentificação encontra um modo distinto de concreção. A mera partilha do meio não é suficiente. O plano da piscina parecia marcar uma certa placidez do personagem em ser envelopado pela mesma água em que o outro esteve. Agora, vivificar, experimentar a intensidade da lembrança exige uma ação. Se a alma está mesmo na ponta dos dedos ou da superfície do corpo, o possível exercício mnemônico é substituído por um programa tátil: o protagonista desliza o rosto sobre a parede, a cheira e depois a lambe tentando reaver pelos sentidos o gosto e o resíduo de um ser que ali passou.

Superfície abrangente e capaz de potencializar a experiência sensorial e perceptiva do corpo, a pele tem nessa natureza extrassensível também sua fragilidade. Membrana entre o interior e o exterior, é ela quem preserva a carne, reveste e guarda o organismo. Penetrá-la é atentar contra uma ordem biológica cujo bom funcionamento depende de sua intocabilidade, de um segredo que deve permanecer fechado pela cobertura cutânea. Em Sob a pele, viu-se no primeiro capítulo, Glazer faz da escuridão o artifício de comunicação osmótica entre o interior da figura humana e a profundidade opaca da imagem, capaz de atravessar sem contudo violar o tecido epidérmico. Na única vez em que a pele é diretamente atacada, numa cena de abuso sexual, ela é esgarçada com violência (Fig. 123). Sob sua cobertura, descobre-se uma criatura com a aparência de um manequim. Preta, destituída de expressão facial e de um olhar, a figura permanece aparentemente insondável. Pouco importa. A própria ação já havia mostrado tudo o que é necessário entender: atacar a superfície do corpo é violar o mais íntimo do ser. Não existe isolamento, mas uma comunicação entre o interior e o exterior. 
Fig. 122-123
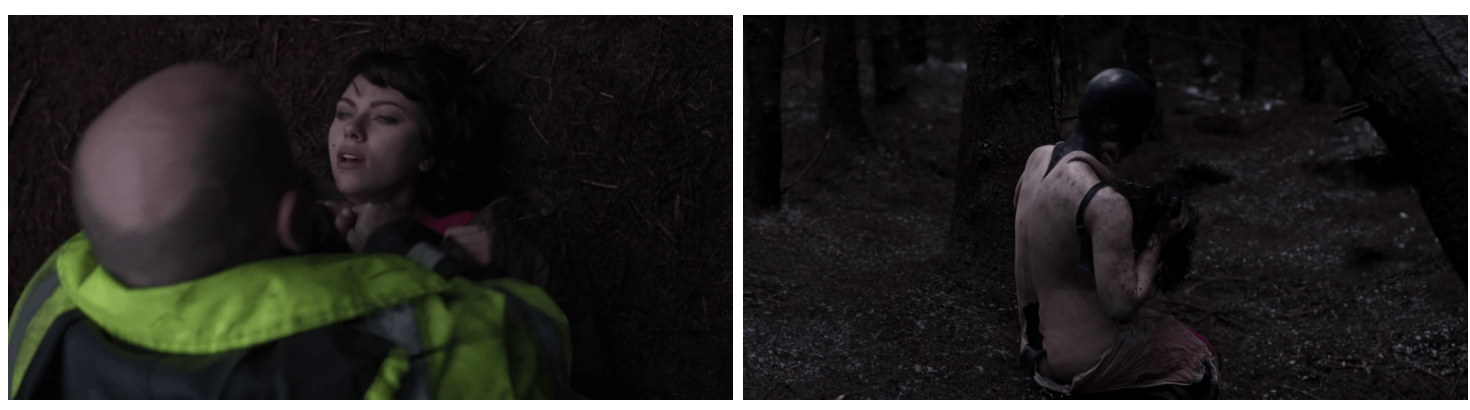

Em Bom trabalho, não há elemento de transição que se aproxime da "black screen" do filme de Glazer. A pele quando afrontada é sempre diretamente, expondo a vulnerabilidade de corpos masculinos cuja figuração dentro de um programa de beleza e erotismo parecia reservar-lhes uma supremacia hercúlea e maciça. Claire Denis desvela amiúde a tensão entre a virilidade física dos soldados de uma base militar da Legião Francesa, em Djibuti, durante seus treinamentos, e a exposição de seus corpos ao calor e às paisagens desérticas, entre a debilidade orgânica e a solidez mineral do relevo.

Pelos planos que exaltam a destreza e o vigor dos militares em exercícios no solo e no mar, pela disciplina gestual nas atividades diárias de passar e secar as roupas, pela exuberância da musculatura e das peles em sua heterogeneidade racial, Bom trabalho poderia se passar por um catálogo de poses e comportamentos do corpo. O filme se estrutura sobre diferentes aspectos da figura humana: a relação com a gravidade e o equilíbrio (sentar-se, deitar-se, permanecer em pé, cambalear), diferentes tipos de locomoção (marchar, arrastar-se, nadar, saltar por entre obstáculos, dançar), a desenvoltura diante dos quatro meios (ar, água, terra, fogo) e a reação a diferentes matérias (humana, vegetal, mineral, luminescente). Essa "vocação" catalográfica é impregnada pelo erotismo e assombrada pelos limites do corpo delimitação do que a ele pertence e, em corolário, demarcação da fronteira que marca seu fim, sua negação, logo, sua morte.

No limbo vivenciado pelos soldados da Legião, distantes do próprio país, enclausurados na base e nos exercícios militares, sem uma convivência com a população local (são vários os planos a apresentar a fratura entre nativos e militares), a pele expõe a face escondida, a fragilidade que reside no âmago da pujança e do vigor físicos. Sobre sua superfície, o lembrete de que, a despeito da beleza, o Olimpo é só um sonho para os corpos mortais, homens feridos interna e externamente. Assim, o soldado Sentain, cuja bravura exortada provoca um mal estar (ciúmes e desejo) com o sargento Galoup, cai ao chão e é socorrido pelos demais por conta de um simples pé ferido; as mãos de um outro legionário sangram ao 
ser penalizado a cavar com uma pá o solo seco e pétreo; Sentain, novamente, desfalece e quase morre ao ser abandonado num inferno de sal, nas imediações do Lago Assal. O drama passa pela superfície do corpo: nas duas primeiras cenas, o sangue aflora (Fig. 124-125). Na terceira, os lábios descoloridos, o corpo desidratado e a pele, até então lustrosa pelo suor, aparece granulada e circundada pela textura rugosa do solo (Fig. 126-127). Dir-se-ia que ali está um moribundo, não fosse o gesto quase ingênuo de nessas condições tentar proteger-se do sol. A pele do mundo não se integra, como em O fantasma, mas é o sinal da precariedade do corpo, a marca de sua imanente e delicada matéria.

Fig. 124-125
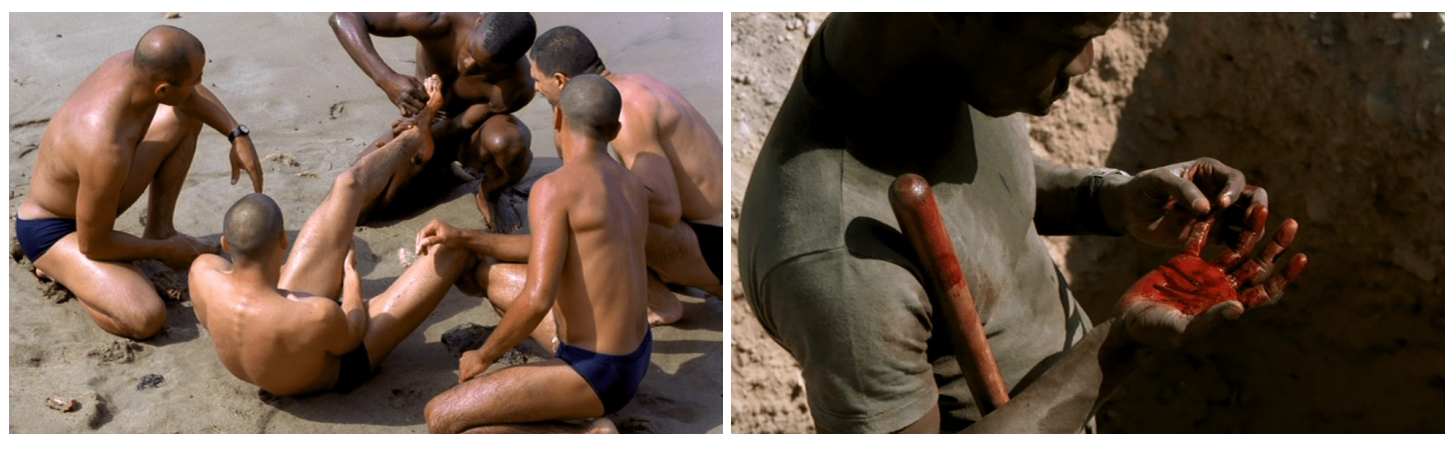

Fig. 126-127

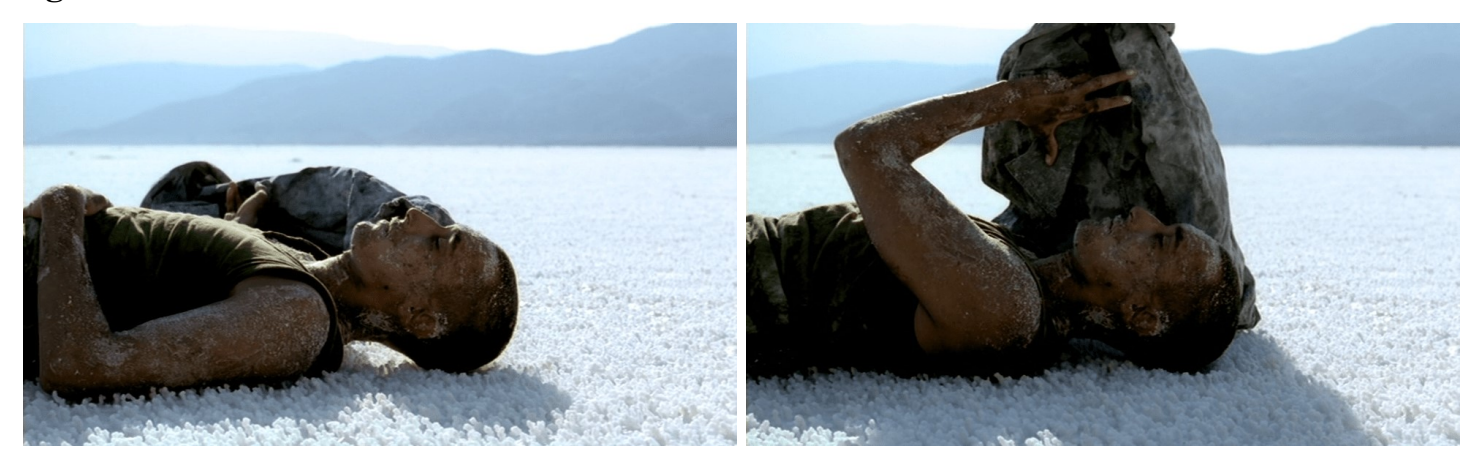

Em sua potencialidade ou pusilanimidade, a pele jamais é um fim em si mesma nos filmes de Rodrigues e Denis. Ela é a superfície que agencia uma comunicação. Mesmo quando está em evidência na diegese, evita-se apresentá-la a partir do close. Prioriza-se o plano geral ou o plano detalhe moderado. A encenação faz de tudo para localizar com clareza a figura humana no espaço, recusando um olhar microscópico sobre o tecido epidérmico, o que poderia resultar numa alienação do que está em cena. A pele passa longe de ser um fetiche ou obsessão, tal como se vê num filme como Erogeny (1976), de James Broughton.

Neste curta-metragem, exibem-se dois corpos em constante interação a partir de seus fragmentos, pedaços que jamais serão reconstituídos visual ou metonimicamente em uma 
unidade. Passeia-se sobre a pele tendo como guia as mãos que sobre ela deslizam ou partes que se tocam (Fig. 128-129). A voz off de Broughton convoca ao toque, à descoberta, discursa sobre as explorações que daí podem advir, numa elegia tátil. O close implode o todo. A interposição de telas pretas entre cada um dos planos aliena as partes. Perde-se a referência integral do corpo e da identidade, às vezes do gênero, em benefício de uma fragmentação detalhista que abstrai o espaço para fazer de cada porção visível um pequeno território, isolado de outros, e muitas vezes desconhecido, a ser sondado, tateado. A voz tenta sugerir uma geografia do corpo, descrevendo-o e qualificando-o a partir de metáforas espaciais: caminho, terreno, duna, serra, savana, península, arquipélago, paisagem, continente, planeta, universo. Não importa o quão grande a escala, a autossuficiência do que se cria a partir dos toques entre amantes em Erogeny busca uma encerramento, um fechamento para o exterior, fazendo do micro o macro, da parte o todo. Justamente, o antípoda do que se viu até aqui com Denis e Rodrigues: o da pele como abertura para o mundo.

\section{Fig. 128-129}
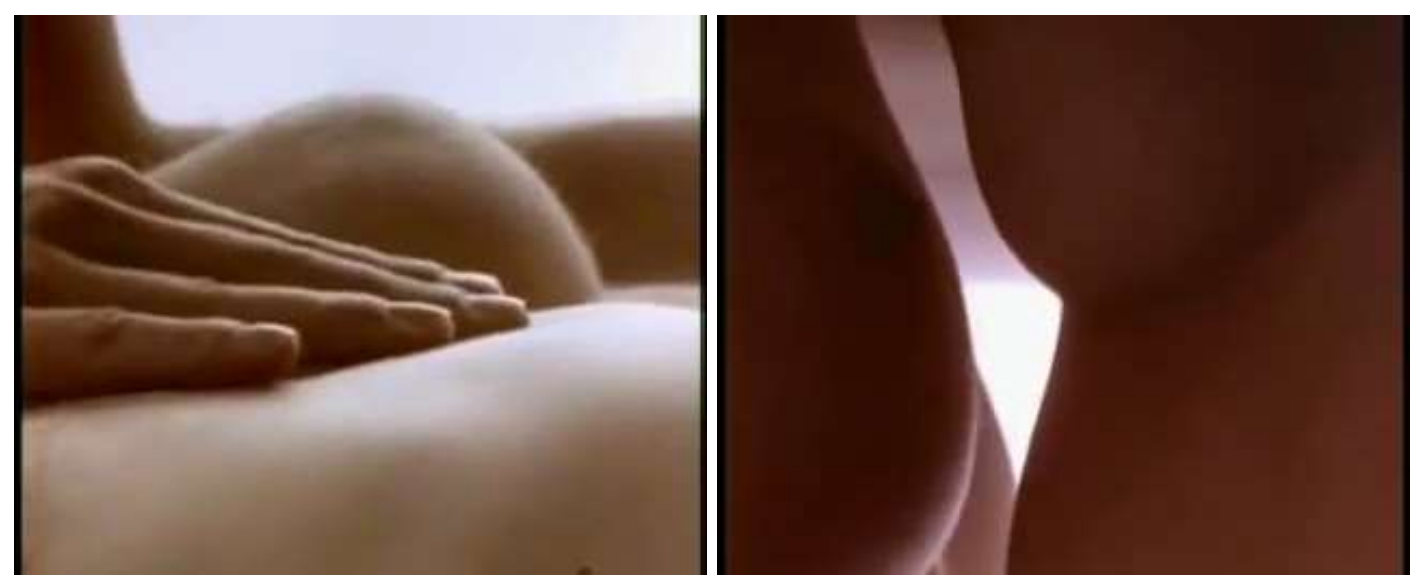

O momento paroxístico da pele em O fantasma é o desfecho do filme (Fig. 130-133), quando Sergio, em seu traje rubber, vai até a casa do rapaz que deseja e, lá, o amordaça e o algema a fim de levá-lo consigo. Abandonando o corpo na rua, desistindo do que quer que fosse fazer, ele inicia então uma pequena peregrinação que marca um ponto de inflexão na trajetória que vinha se desenvolvendo até aqui em relação ao processo de animalização e à própria figuração do corpo a partir da pele. Caminhando pelas ruas de Lisboa, espreitando-se pelas sombras, aproveitando-se da escuridão como lugar de permeabilidade de fronteiras, ${ }^{206}$ atravessando grades - outro motivo a reforçar a ideia de passagem entre territórios -, Sergio chega até o aterro sanitário da cidade. Lá passa a agir como um animal. Pelo menos, já não

\footnotetext{
${ }^{206}$ Ver Capítulo 1, tópico A noite, a escuridão e suas travessias.
} 
são traços de civilização ou racionais a orientar seu comportamento. Ele desloca-se ora encurvado, ora movimentando-se com mãos e pés no chão; chafurda no lixo; fricciona o corpo contra objetos com os quais se depara; devora restos de comida; e, ao beber a lama que encontra no caminho, prefere curvar-se com a cabeça em direção à poça que utilizar as próprias mãos.

A epifania de Sergio sugere uma metamorfose. O traje rubber deixa de ser fetiche sexual para sinalizar outra forma de representar o corpo. Se até aqui foi acentuada a função de balizar e mediar as relações vividas pela figura humana, no desfecho de O fantasma a pele demarca também a identidade. Ela faz parte do conjunto de traços físicos que singulariza um corpo. Justamente por isso, alterá-la, mesmo que por um revestimento, demarca uma passagem.

Fig. 130-131
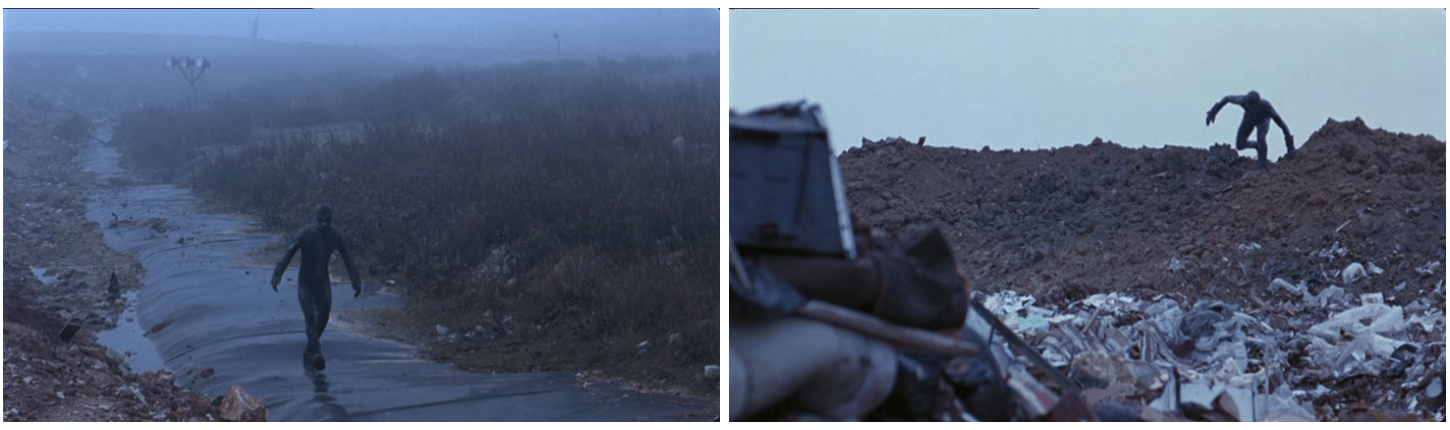

\section{Fig.132-133}
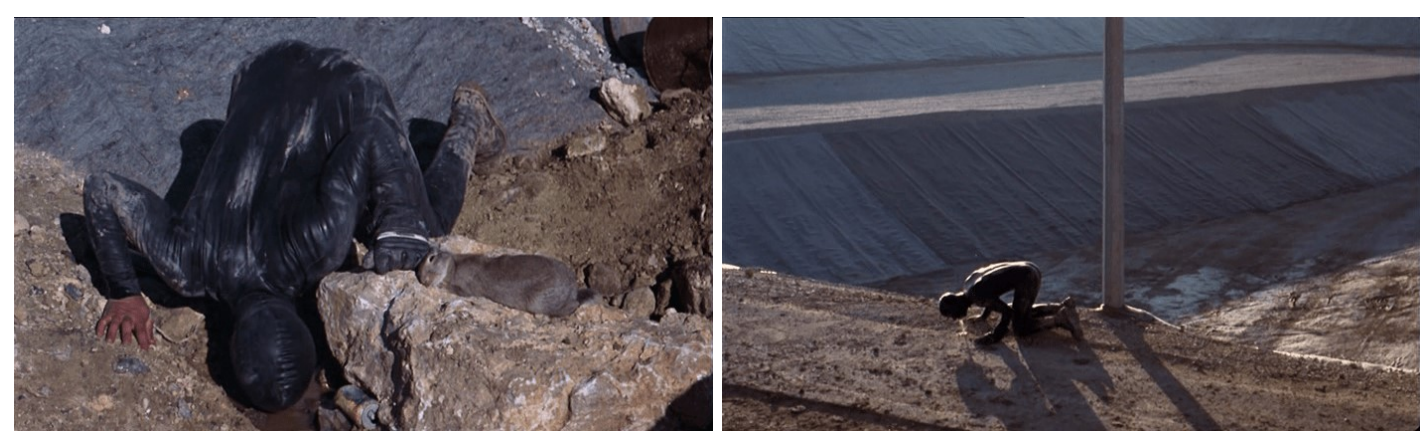

Desde o princípio do filme, há uma aproximação entre as ações de Sergio e as de um animal. Algo similar já se via no primeiro curta-metragem de Rodrigues, Parabéns (1997), quando um dos personagens se alimenta e mia como um gato. O fantasma parte da mesma situação. Já na segunda cena, o protagonista dá comida ao seu cachorro e, enquanto o observa, passa a imitá-lo, latindo e farejando o entorno (Fig. 134-135). O que nesse momento é uma brincadeira posteriormente será associado à sexualidade, quando Sergio lambe o rosto de 
Fátima antes de beijá-la e mesmo quando é flagrado ao tentar invadir uma casa. Nesse último caso, algemado diante do policial que o apanha, volta a agir como um cachorro, estabelecendo um jogo de dominação em que se coloca na posição de mascote sexual. A porta de entrada para esse processo de animalização é a tentativa de um regresso da figura humana a outro patamar de enquadramento no mundo. O ponto final, a exacerbação do desejo. $\mathrm{O}$ intermediário do processo, a transformação da pele.

\section{Fig. 134-135}
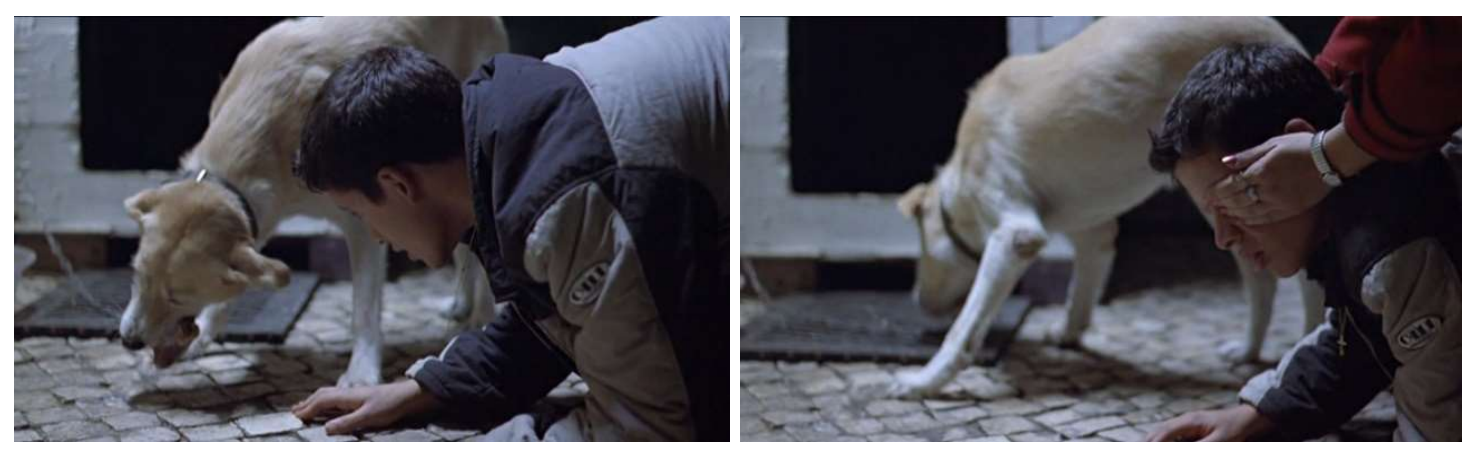

Uma das pedras angulares do conceito de "animismo", ou de uma ontologia anímica, em conformidade com o campo da antropologia, auxilia a pensar o processo vivenciado por Sergio. O campo é temerário. Ainda assim, merece ser entrevisto, mesmo que prevendo de antemão um recuo. Um dos alicerces daquela noção, dizíamos, é o de que entre homens, animais e vegetais existe uma contiguidade e uma identidade interna, um substrato ou essência espiritual que a todos é comum. Os limites categoriais entre os seres são suscetíveis a uma permeabilidade, pois existiria uma comunidade substancial de toda a matéria do mundo. Haveria uma extensão partilhada que permite falar em disposição humanista das plantas e dos animais, uma vez que "a alma da qual são dotados permite tanto comportarem-se segundo as normas sociais e os preceitos éticos dos humanos, como também estabelecerem com estes últimos e entre si relações de comunicação". ${ }^{207}$ O que estabeleceria a descontinuidade entre as diferentes espécies seria a fisicalidade. A diferença entre humanos e animais não se daria pela alma, mas pelo corpo, o real diferenciador ontológico. ${ }^{208}$ Dessa maneira, a forma, o envelope carnal, a pele estão entre os critérios cruciais de distinção entre os seres.

\footnotetext{
207 Philippe Descola, Par-delà nature et culture, Paris: Gallimard, 2005, p. 183. Entre os povos que amparam uma ontologia anímica, o autor cita os índios Candoshi e Arakmbut da Amazônia peruana, os Makuna da Amazônia colombiana, os Orokaiva da Nova Guiné, entre outros.

${ }^{208}$ Viveiros de Castro explica que o estatuto do humano para a tradição ocidental é intrinsecamente vinculado ao espírito, tomado como elemento diacrítico, o grande diferenciador que singulariza cada ser humano diante de seus semelhantes, mas também o que sobrepõe a humanidade aos animais e à matéria em geral. Em oposição, para outras cosmologias, como a ameríndia, são o corpo (entendido enquanto conjunto de maneiras ou modos de
} 
Uma outra constância das ontologias anímicas é a capacidade de metamorfose entre os seres que reconhecidamente são providos de uma interioridade idêntica. Os humanos poderiam se incorporar a um animal ou planta, tal como os animais e as plantas poderiam retirar a sua vestimenta (a pele) a fim de revelar sua alma objetivada no corpo de um homem. A exequibilidade e a frequência de cada metamorfose estão diretamente vinculadas às respectivas cosmogonias e a determinadas condições - a passagem do humano ao animal, por exemplo, é um atributo do poder de certos indivíduos como xamãs, feiticeiros, etc.

O brevíssimo passeio pela antropologia não deve gerar maus entendidos: o ponto de vista adotado em nossa análise não é antropológico e tampouco $O$ fantasma tem, em sua estrutura e em sua fábula, qualquer referência a uma mitologia anímica. $\mathrm{O}$ desvio por tal domínio só é profícuo admitindo-se que permite estabelecer dois eixos válidos para o filme de Rodrigues: uma identidade comum entre homem e animal, fundada numa série de comportamentos de Sergio; e uma evidente descontinuidade pautada nas respectivas pele e figura. É verdade que a fantasia rubber nem de longe será a ponte ou a associação definitiva entre os dois domínios, porém o seu uso é a explicitação de que o envelope corporal já não é suficiente para abrigar uma interioridade que agora se arrisca em estados de libido que ameaçam e transbordam sua figura. Tirania de Eros: sem zelo pela temperança, o personagem aceita os prazeres e o risco do desejo, fazendo do excesso uma prática comportamental e figurativa de si. $^{209}$

Dado que todo o filme é assombrado por uma paixão que subverte o comportamento de Sergio, estimulando-o a um universo tátil e movido pelo desejo, é natural que a pele, que o revestimento identitário mude para acolher essa nova forma. O ser se mostra na aparência, a superfície revela o interior. Como já havíamos sugerido, ao longo de O fantasma havia uma lógica de extravaso e conversão das energias em ato. Na sequência do aterro, o drama atinge um limite. O movimento projetado no espaço pela corrida, como em outras cenas, é

ser que constituem um habitus) e suas afecções que assumem a função de singularidade entre os seres. Ver Eduardo Viveiros de Castro, "Perspectivismo e multinaturalismo na América indígena", in O que nos faz pensar, n. 18 , setembro de 2004 .

209 Não faz mal recordar que, segundo defende Foucault, as raízes da sexualidade ocidental, situadas na Antiguidade grega e romana, são pautadas em um cuidado ético, numa hermenêutica de si ligada tanto aos modos de subjetivação como a um código comportamental, a um sistema prescritivo que é implícita ou explicitamente dado culturalmente. Embora não tente elidir o prazer enquanto fim da prática sexual, como faria o cristianismo, o pensamento clássico prezava por uma arte da temperança, um uso dos prazeres que evitasse que as práticas sexuais fossem além do necessário, que houvesse um equilíbrio entre o desejo e o prazer. Uma das razões era o reconhecimento de uma virtualidade hiperbólica na prática sexual, uma tendência ao transbordamento motivada pela própria energia que nela está envolvida: há uma força necessária, mas duvidosa pois pronta a ultrapassar os limites que lhe foram fixados. A moral antiga implicaria então um agenciamento dos prazeres e dos desejos, um trabalho sobre si pelo qual o indivíduo alcançaria a arte da temperança, uma economia conveniente ao seu usufruto do prazer. Ver Michel Foucault, Histoire de la sexualité II, Paris: Gallimard, 2013. 
insuficiente para lidar com a frustração da rejeição. Sem uma válvula de escape a partir do gesto, é o próprio corpo que sofre e é transformado pelo efeito do desejo. Em vez de um impacto sobre o seu exterior (o meio, os outros), é uma metamorfose a acolher e a moldar, pela reconfiguração epidérmica e pelos movimentos, a torrente afetiva e libidinal, o fracasso de todas as contenções.

\subsection{Erotismo}

A criação de uma espécie de horizontalidade entre humano e animal no filme de Rodrigues depende de um conjunto de ações externas a um parâmetro de conduta social. Embora haja uma tentativa de provocá-lo, embora o traje rubber sugira uma metamorfose, o corpo de Sergio continua com uma matriz referencial difícil de ser perdida pois a todo momento lembrada e enfatizada na encenação: a figura humana. Se por um lado a pele flexibiliza as fronteiras identitárias, por outro, ela é explorada em toda a sua sensualidade. Assim, o filme dialoga abertamente com o gênero do nu. Graças a isso, tanto forma um par com o contemporâneo Bom trabalho, como se insere numa tradição cinematográfica de representação do erotismo masculino. Entre as múltiplas variantes dessa tradição, deparamos com pelos menos duas: uma que sutilmente tangencia o ideal classicista de beleza das artes plásticas e exorta a pujança do corpo masculino; outra que flerta com um erotismo mais despudorado. Convém notar, ainda, como as especificidades da representação do corpo naqueles dois realizadores deve àquela do cinema narrativo clássico, mesmo que por contraposição.

\subsubsection{Neoclassicismo}

A fantasia de potência a partir das ações e da corporeidade masculinas existe nas artes plásticas desde pelo menos a estatuária da Antiguidade, cuja beleza estava em parentesco com a força física, como nas figuras de gesso dedicadas aos atletas. Mas, mais próximo do horizonte que se almeja lidar, são os corpos representados na arte europeia entre o final do século XVIII e início do XIX. Trata-se do neoclassicismo que aflora na Europa, tendo como referência nuclear David e o seu O juramente dos Horácios (Fig. 136). O quadro responde diretamente a um viés moralizante que surge na França desde o século XVII, refletindo numa arte cujo conteúdo e a forma são permeados por um fim ético e didático. A tela de David concentrava formalmente, a partir da concisão (clareza da ação, poucas figuras, gestos firmes, 
numa contenção winckelmanniana, sobriedade de cores etc.), uma imagem masculina de força moral e magnanimidade. Exaltava-se a virtude cívica e heroica das figuras, uma dignidade estóica cuja inspiração provinha da história, da literatura e da arte da Antiguidade, especialmente de Esparta e Roma. Por alcançar o sentimento patriótico, uma virtude moral a partir da austeridade, a tela se tornou marco estético e político do período - quatro anos antes da Tomada da Bastilha na Revolução Francesa. ${ }^{210}$

Fig. 136

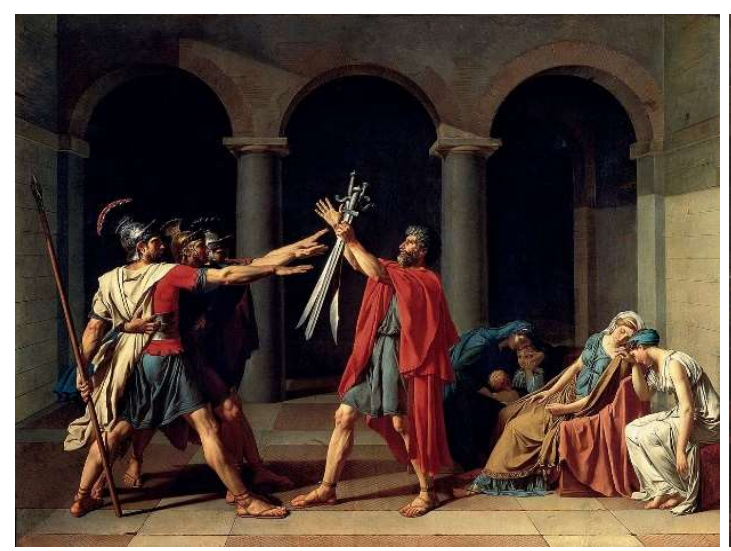

Fig. 137

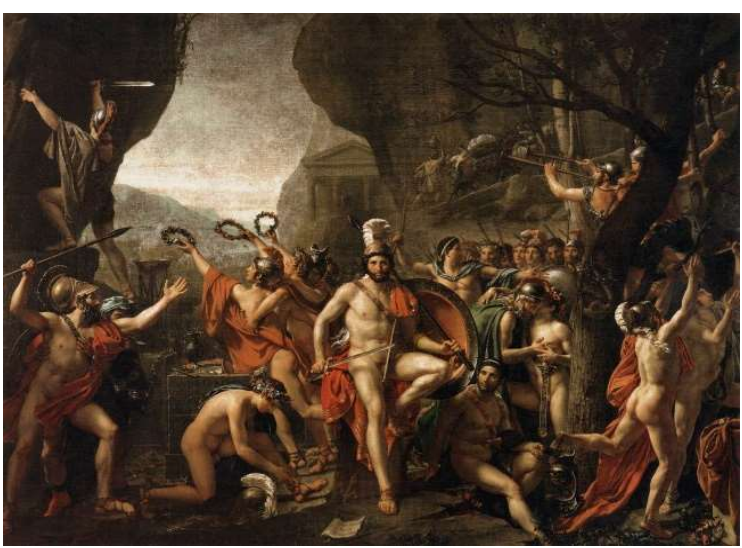

Mas não é $O$ juramento dos Horácios, bastião fulcral do neoclassicismo, e sim um quadro mais tardio e seguramente menos emblemático, Leônidas nas Termópilas (1814, Fig. 137), que aqui nos interessa. Diferentemente da opulência e da sensualidade febril das carnes femininas de um artista como Rubens, o que se vê na tela é a apresentação de corpos nus a partir de um estilo linear, na firme demarcação do contorno que envolve e organiza sensivelmente a figura masculina. Apesar da pletora de corpos representados na tela, eles são facilmente distinguíveis, em repouso ou em movimento. $\mathrm{O}$ olhar tanto identifica as poses isoladas como é capaz de seguir com clareza o encadeamento das ações. A cena é facilmente perscrutável pela total nitidez e fixidez dos seus elementos.

Para além da linearidade, o que está em evidência na tela de David é a conversão, ou a convivência entre o heroísmo patriótico e uma potência homoerótica. Essa última é salientada pela nudez, pelas poses que contraem e explicitam a musculatura, por objetos fálicos, como as espadas, sugestivamente evocando e por vezes se sobrepondo aos órgãos sexuais, mas também por uma série de gestos e toques entre os soldados. A guinada erótica da tela, que futuramente influenciaria e estaria em consenso com toda moda homoerótica na pintura

\footnotetext{
${ }^{210}$ Walter Friedlaender, De David a Delacroix, São Paulo: Cosac \& Naify, 2001.
} 
neoclássica, é comentada por Jorge Coli a partir de duas razões principais. ${ }^{211}$ De um lado, pela importância e o rigor conferidos à representação anatômica, que dentro do tema contemporâneo de enaltecimento de grandezas históricas, tinha por alvo privilegiado os corpos masculinos bem como seu específico erotismo. De outro, pela própria restauração neoclássica, isto é, pela recuperação e conversão em modelo de valores da Antiguidade, o que incluiu uma consciência das práticas homossexuais bem como a sua valorização teórica, cultural e mesmo comportamental.

Dentro da tendência aventada, floresce um culto singular à beleza. Para além de outras formas eróticas no neoclassicismo, como a valorização dos efebos, com seus corpos lisos e jovens, o que há na tela de David é a figuração de um universo masculino nutrido por grandes ações, por batalhas nas quais se destacam o heroísmo cívico, mas igualmente uma beleza viril. As mulheres, como já se via em $O$ juramento dos Horácios, em que apareciam no canto a lamentar pela partida dos guerreiros, eram excluídas desse programa ético e estético, de modo que se definia "um campo eminentemente masculino, onde a sexualidade entre homens é suscitada através de uma cultura da virilidade" ${ }^{212}$, abrindo espaço para "uma exploração para certa sensibilidade erótica que, embora recorrente desde sempre nas artes, lutava com procedimentos de ocultação". 213

Uma última escala, antes de retomarmos a representação erótica dos corpos masculinos no cinema contemporâneo, também diz respeito a um retorno do classicismo. Dessa vez, fora da pintura e do período em que nos situamos até momento. Trata-se do final do século XIX e início do XX, quando, dentro de uma cultura de fisiculturismo exposta em fotografias e gravuras publicadas em jornais e revistas franceses, ergueu-se um ideal de masculinidade. Sua inspiração era o protótipo físico e moral advindo da Antiguidade, principalmente de sua estatuária. Parece-nos que esse processo mantém suas afinidades com o do neoclassicismo pictórico, pois em ambos o retorno a uma cultura da Antiguidade tem por objetivo a retomada de um beleza física em concomitância a uma moral de virtuosidade e força. ${ }^{214}$

\footnotetext{
211 Jorge Coli, Op.cit.

212 Ibid. p. 59.

${ }^{213}$ Ibid. p. 59.

${ }^{214} \mathrm{Na}$ França da passagem do século XIX para o XX, o resgaste de imagens de atletas gregos aconteceu em um momento em que o país havia perdido a guerra franco-prussiana e no qual as transformações da modernidade redundavam numa deliquescência do corpo. Em publicações fisiculturistas, em ascensão no período, os efeitos nocivos do labor industrial, a superpopulação e o ar poluído das grandes cidades, os vícios urbanos (álcool, prostituição, maus hábitos alimentares), entre outros, eram considerados ameaças. Suas vítimas eram os corpos e, num nível mais amplo, o próprio país. A França, julgava-se, demonstrava baixo poderio bélico em razão da falta de virilidade e de vigor, da inaptidão física e moral do homem moderno para a vida militar. Nesse cenário, a estatuária grega fornecia um modelo de masculinidade que seria determinante para a sobrevivência da França. $\mathrm{O}$ resgate da cultura clássica propiciaria reavivar a beleza, a virtude, a saúde e a força dos franceses, protegendo a
} 
A noção de uma beleza viril inerente ao corpo masculino é largamente explorada no cinema contemporâneo. Dos filmes aqui analisados, Bom trabalho é o que leva a cabo uma proposta de figuração que dela se aproxima. O universo diegético, uma base militar onde os soldados são constantemente mostrados em exercícios físicos, em situações nas quais a bravura e o corpo são postos à prova, enseja uma ambiência que sutilmente relembra aquela aproveitada pela pintura neoclássica. A própria realizadora evoca a Antiguidade grega como uma referência, mesmo que indireta, durante as filmagens. ${ }^{215} \mathrm{O}$ exercício aqui não é o de tecer uma associação literal da figura humana no filme e no neoclassicismo - isso será, inclusive, problematizado -, mas realizar um cotejo, profícuo na medida em que permite identificar as nuances envolvidas no erotismo como modo de presença.

Numa das primeiras sequências Bom trabalho, os soldados aparecem numa sequência de treinamentos que exorta a resistência e a destreza. Parece não haver limite para corpos jovens que se arrastam sob trincheiras, escalam, pulam obstáculos e correm. A montagem encadeia um exercício atrás do outro, criando uma moviola em que os corpos vão e vem ininterruptamente, em todas as direções. Sem pausas na montagem, sem pausas no interior dos planos: nenhum dos soldados descansa, os corpos seguem firmes sem ofegar. Há qualquer coisa de maquínico e toda a sequência é uma demonstração de pleno vigor e de juventude. É no meio desse furor que o sargento Galoup aparece para demarcar um contraponto. Mais velho que os soldados, ele executa um dos treinamentos. Seus movimentos são vagarosos, duros e revelam o peso excessivo do corpo em relação à agilidade prévia dos rapazes. Interpretado por Denis Lavant, que algumas décadas antes movia-se com a leveza e impetuosidade da adolescência num longa de Leos Carax, Sangue ruim (Mauvais Sang, 1986), Galoup aparece no filme como um homem fora do lugar: dispensado do exército e considerado “inapto para a vida civil”. Mesmo na Legião, a mise en scène o desloca, criando uma inconformidade de sua figura com o espaço. Ele não tem lugar num microcosmo povoado por corpos jovens e viris.

\footnotetext{
raça e a pátria da ameaça e da degeneração expostos nos corpos modernos. Ver Tamar Garb, "Modelling the male body: physical culture, photography and the classical ideal", 1998.

${ }^{215}$ Recordamos de duas entrevistas dadas por Claire Denis. Numa delas, mencionou a beleza escultural dos corpos e rostos, a delicadeza dos traços que, mesmo um pouco, recorda os desenhos da Antiguidade. Ver: Claire Denis, "Corps d'armée": entrevista a Anne-Laure Chanel, in France culture, 8 de março, 2013. Programa de rádio. Em outra ocasião, a realizadora afirmou que, ao conversar com um ex-militar da Legião Francesa, percebeu o que significava ser legionário: "esta maneira que ele tinha de se sentar à mesa, de não beber álcool [...], de nos dizer: '-Vocês aí, humanos...' Um pouco como na mitologia grega, existe um mundo que separa os vivos e os mortos". Ver : Claire Denis, "Ce poids d'ici-bas": entrevista concedida a Jean-Philippe Renouard e Lise Wajeman, in Vacarme 14, 2 de janeiro, 2001.
} 
Logo após a execução morosa de um dos treinamentos, Galoup aparece num plano contraplongée, com uma das mãos apoiada sobre a perna, descansando o peso do corpo com certa elegância. Num sutil contraluz, vislumbra o horizonte com os olhos semicerrados e boca aberta, como quem se vê diante de um mistério. O contracampo revela o alvo do olhar, o soldado Sentain (Fig. 138-139). À parte o eixo, o enquadramento é idêntico ao de Galoup. Mas as dessemelhanças não poderiam ser maiores. Sentain está com o dorso nu e banhado em luz, exibindo o porte atlético e a musculatura, com punho fechado e um dos braços recostado, mas não repousado, sobre a coxa. O corpo se sustenta em pé sem amparo e dispensa, já se viu, o descanso. O legionário dirige a Galoup um olhar firme e agudo que - a diferença de patente entre os dois nos autoriza a dizer - também é provocador.

Ao escolher o mesmo enquadramento, evidencia-se o fator de diferenciação e também a matriz da mise en scène: a retórica corporal é estruturada pela ação mais simples, a figura em repouso, a pose, nada além do modo com que seu corpo ocupa um espaço, sua maneira de estar, de ser, antes mesmo da de agir no mundo. O close que acentua a exposição a partir do direcionamento do que se quer evidenciar é preterido em prol de um plano médio. O olhar e o rosto, reconhecidamente importantes para a figuração do corpo ocidental e especificamente no cinema, ${ }^{216}$ ajudam a compor a expressividade corporal, claro, mas nem de longe concentram a informação da cena. O que deve ser dito, tornado visível, o é pela integridade corporal. A linha mestra do drama, a rivalidade entre Galoup e Sentain, é dada desde então pela pose de dois corpos, oposição que secreta e sugere uma série de outras polaridades que ao longo do filme serão desenvolvidas.

\section{Fig. 138-139}
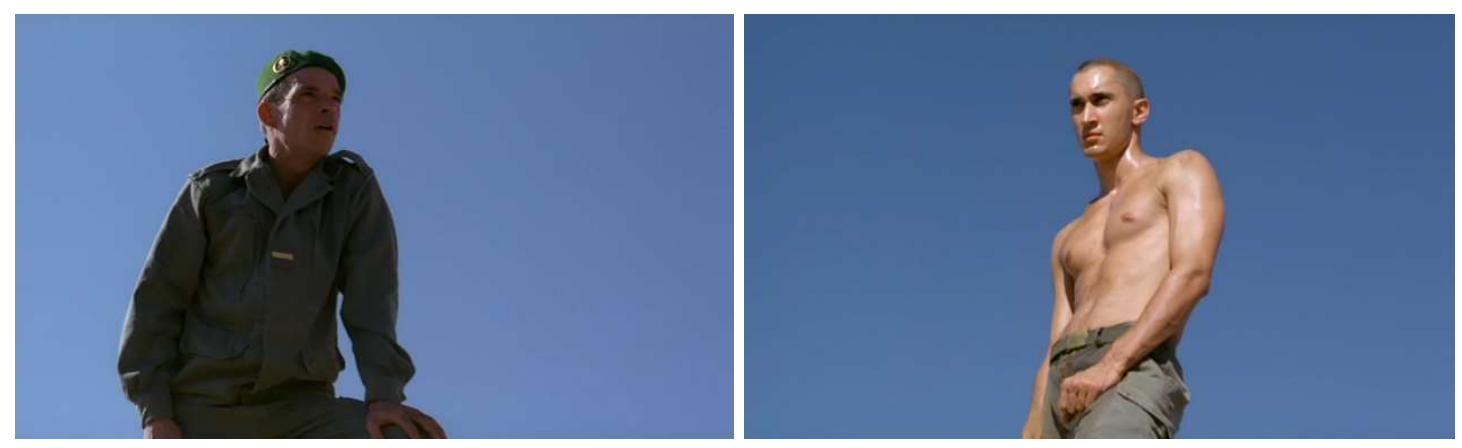

Aqui será feito um parêntese: nos anos 2000, a singular proposta formal do cinema contemporâneo, com suas narrativas rarefeitas e permeadas por um regime sensorial,

\footnotetext{
216 Ver no primeiro capítulo a remissão a Epstein; e, no terceiro, o debate sobre os retratos pictórico e cinematográfico.
} 
estimulou a crítica e posteriormente os estudos acadêmicos de cinema a buscar novos instrumentos conceituais de análise que possibilitassem a imersão nas estruturas motrizes daqueles filmes. Entre outros resultados, a empreitada culminou no que se convencionou chamar cinema de fluxo, definição criada por Stéphane Bouquet e debatida junto a outros em textos publicados no periódico francês Cahiers $d u$ cinéma. ${ }^{217} \mathrm{O}$ termo agrega um grupo de filmes, ${ }^{218}$ incluindo Bom trabalho e O fantasma, sob um denominador comum: a crise na "mise en scène, isto é, na possibilidade de uma ordem transcendente que vem enformar o real" a fim de construir um discurso dotado de sentido e de emoção. ${ }^{219}$ Prevalece em substituição ao controle imposto pela encenação, o fluxo indeterminado de imagens sem um firme princípio racional de organização interna do plano ou no nível da montagem. Procura-se intensificar nestes filmes ficcionais as zonas do real, priorizando suas potencialidades, seu "estatuto aleatório, indeterminado, movente". ${ }^{220}$ Nesta condição, importa mais a consistência das coisas representadas na tela do que o saber a propósito delas. Na falta de um traçado que as defina, os elementos no plano engendram uma confusão de matérias informes e ambíguas. Esvaziado de sua função de personagem, o corpo visível perderia seu significado dentro da trama dos eventos encenados. A oposição entre mise en scène e fluxo recupera por analogia a querela desenho e cor da pintura europeia.

A contenda de uma estética do fluxo e das rubricas a ela correlatas toca em pontos nodais do cinema contemporâneo, entre os quais a ambiguidade do real frente às sensações corpóreas como alternativa a outros modos de agenciamento da narrativa. Porém, detendo-se sobre a figuração do corpo especificamente, e não sobre a encenação em geral, embora as duas operações caminhem lado a lado, é difícil enquadrar Bom trabalho em um regime sensorial que resulte numa dificuldade de enformar as potências do real e da matéria do mundo, como se vê por exemplo nos pintores coloristas e como sugere a noção de fluxo. $\mathrm{O}$ filme de Denis é perpassado por uma dupla natureza que acreditamos extrapolar a dicotomia desenho e cor, mise en scène e desordem sensória (fluxo), controle e pujança do real, justamente por se valer de ambos os polos. A sequência dos exercícios físicos, descrita anteriormente, sinaliza um híbrido das duas tendências. À medida em que avançarmos no debate sobre o erotismo, isso ficará mais nítido. Por enquanto, continuemos a análise a partir

\footnotetext{
${ }^{217}$ Stéphane Bouquet, "Les flux sans visage", Cahiers du Cinéma, n.569, 2002a ; S. Bouquet, "Plan contre flux", Cahiers du Cinéma, n. 566, março, 2002b. Ainda sobre o tema, consultar Luiz Carlos Oliveira Jr, 2013.

${ }^{218}$ Nos textos de Bouquet (2002a, 2002b) são mencionados, entre outros filmes: Cinzas do passado (Dung Che Sai Duk, 1994, de Wong Kar-Wai), Flores de shanghai (Hai shang hua, 1998, de Hou Hisao-Hsien), Time and tide (Seunlau ngaklau, 2000, Tsui Hark).

${ }^{219}$ S. Bouquet, 2002b, p. 47.

${ }^{220}$ Ibid.
} 
de uma das primeiras cenas do filme. Nela acompanhamos um travelling diametralmente oposto àquele analisado no Capítulo 1, durante o comentário sobre As vinhas da ira, de John Ford (Fig. 28-30).

Fig. 140-142
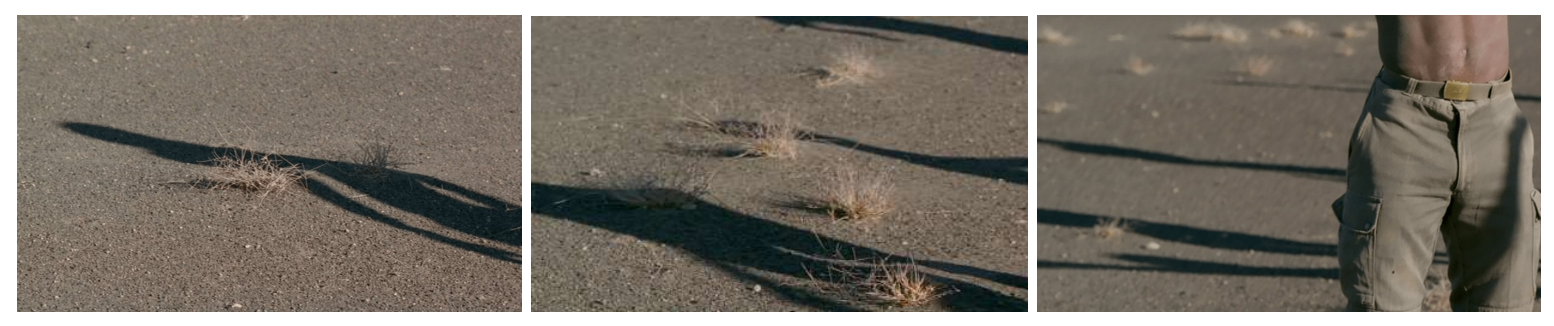

Fig. 143-145
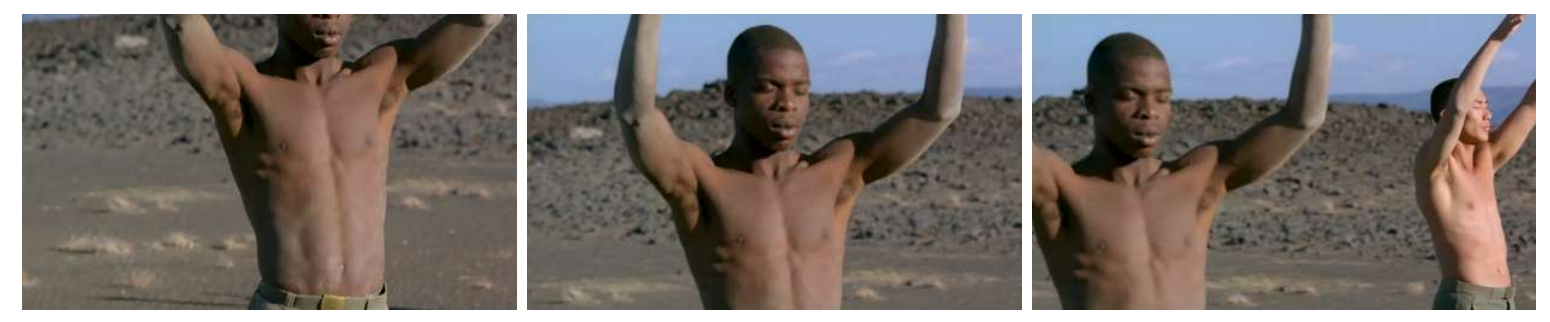

Em Ford, o travelling se movimentava da direita para a esquerda, enquadrando inicialmente as figuras e em seguida descendo até o solo, sobre o qual estavam projetadas suas sombras. A interpretação dada para esse movimento de câmera foi a figuração da miséria social. Com a perda do que era mais essencial, a propriedade da terra, os personagens eram figurativamente mostrados na condição de sombras, formas vazias, seres desprovidos de peso e lugar naquele mundo.

Em Bom trabalho, o fundo social está em segundo plano e a representação do corpo obedece a outras leis. Comparado ao filme de Ford, tudo é invertido, a começar pela direção do travelling, que inicia da esquerda para a direita. Da terra onde se veem projetadas as sombras delgadas e anamórficas (Fig.140-142), a câmera faz um lento movimento de ascensão. A inflexão do eixo horizontal para o vertical acontece pela figura de um dos soldados (Fig. 142-144). Ao alcançá-lo, a câmera segue verticalmente a estrutura corporal, das pernas, passando pelo torso musculoso até alcançar a altura da cabeça, quando então recobra o movimento horizontal e passa a mostrar os outros corpos em cena (Fig. 145). Das sombras para o corpo carnal, o movimento da diretora de fotografia Agnès Godard parece realizar uma encarnação visual, estipulando desde então a tendência do filme de insuflar de vida a matéria, de animar a figura humana a partir do vigor e da promoção de seus valores físicos, do que lhes sugere uma corporeidade maciça. Enquanto os personagens de Ford 
pareciam se diluir sobre a terra em razão da pobreza material ao qual eram relegados com a desapropriação de suas posses, os soldados de Denis brotam do solo rochoso com os braços levantados para o alto, numa manifestação de força e continuidade entre as matérias mineral e humana. Com os corpos enrijecidos, eles são figurados como formas encorpadas, indestrutíveis, impressão alimentada durante o vigor ininterrupto dos treinamentos.

Nessa sequência de encarnação, como também naquela que culmina com o campocontracampo entre Galoup e Sentain (Fig. 138-139), e ao longo de todo o filme, a composição da figura humana tangencia mesmo que sutilmente a de um corpo clássico, principalmente por dois aspectos que funcionam como uma balança em que um polo regula o outro, mantendo constante equilíbrio: força e placidez.

A força, já foi dito, percorre a maior parte das cenas de treinamento. A peculiaridade em sua representação é a sobriedade. Por mais intensos que sejam os treinamentos e as condições ambiente de Djibuti, a mise en scène preserva a placidez das ações a partir da disciplina, com os corpos dos soldados movimentando-se coordenadamente, mantendo-se firmes independentemente das atividades que fazem, sofrendo as agruras de temperatura e da aridez do relevo sem transparecer, numa contenção das emoções. A moral estoica que tanto se enaltecia na pintura neoclássica é reafirmada a cada vez que se malogra o corpo sem, contudo, resultar na expressão do sofrimento. Onde está a dor desses homens? Busca-se abolir o fraco e o individual daquele universo onde deve imperar uma força decalcada da coletividade. $\mathrm{O}$ rosto é uma máscara de pedra - como a dos personagens de Clint Eastwood. Do início ao fim, a fisionomia pouco revela. Dificilmente se veem as dores e as alegrias em seus rostos impassíveis. ${ }^{221}$ Não é ali, mas nos corpos que se deve buscar a expressão das paixões.

É por aquela mesma moral que as mulheres também não estão no núcleo do filme, como também não estavam no centro da ação em O juramento dos Horácios e nem em Leônidas nas Termópilas. Elas só aparecem em Bom trabalho como uma sensualidade outra, no lusco fusco das boates, criaturas da noite, enquanto o mundo dos homens é primordialmente solar. Definitivamente não se trata de um olhar misógino e estereotipado do feminino, mas de um esforço em figurar um universo de virilidade e de beleza culturalmente associadas ao masculino, sobretudo para mostrar que suas bases são mais delicadas ou mais ilusórias do que aparentam - como se já viu a partir da análise da pele. Um dos cernes do filme passa justamente pelo contraste entre a aparência externa e a vida interior dos corpos. Denis, já se viu, ergue fortalezas e deuses para depois evidenciar a sua queda ou a sua fragilidade. O

\footnotetext{
${ }^{221}$ Duas exceções: a euforia no aniversário de um dos legionários e a exaltação dos soldados numa festa em
} torno da fogueira. 
aparente neoclassicismo na figuração corporal é na verdade uma farsa que será a todo tempo tensionada até ser revelada ao final do filme.

Em sua origem no século XVIII e também em algumas de suas apropriações, como na cultura fisiculturista francesa da passagem do século XIX para o XX, o corpo neoclássico associava o discurso da força ao de um patriotismo. O que era visto pela solidez e pujança das figuras humanas remetia a uma moral cívica e patriótica mais ampla, alargando o domínio estético em direção ao político, como nas telas de David. Bom trabalho até pode ser vagamente associado a essa ideia, mas mais pelo universo da legião do que propriamente pela abordagem que dele se faz, pois qualquer traço de patriotismo aparece dentro de uma chave crítica. No mais, o interesse de Denis em figurar o corpo masculino em pontual correspondência com traços neoclássicos, segundo uma força plácida, contenção das paixões, parece-nos sugerir uma espécie de tensão própria ao drama ali encenado: a busca por uma sensualidade patente mas ao mesmo tempo circunspecta (ainda que jamais controlada), o acolhimento de uma disposição dionisíaca em formas apolíneas, a potência da sensação em equilíbrio com a disposição linear. Em outras palavras, a dinâmica da Legião Francesa, disciplina e sensualidade, lei e desejo.

Fig. 146

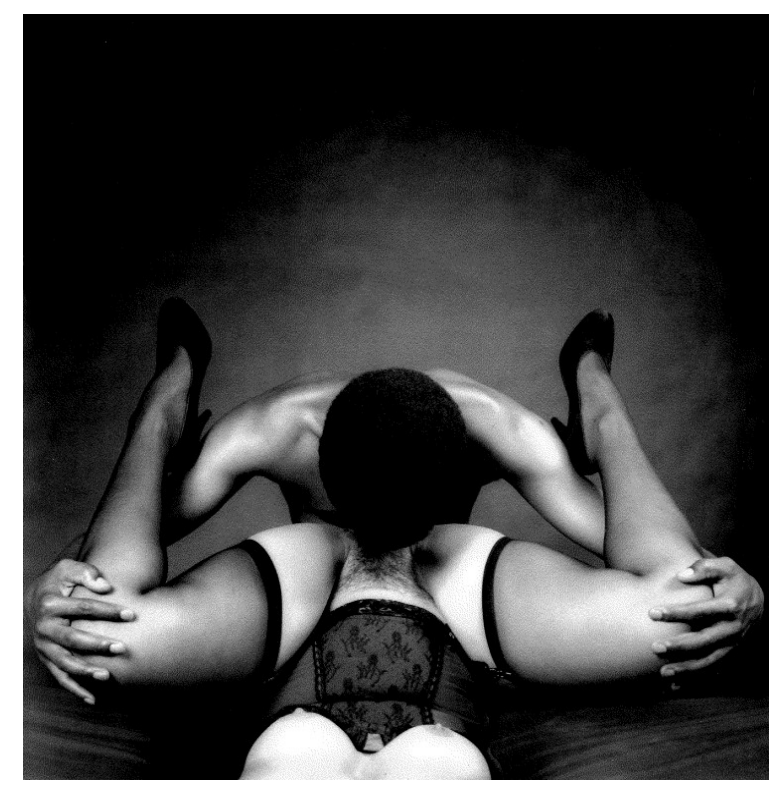

Uma tendência neoclassicista que vem para agenciar numa forma harmoniosa a potência erótica. A arte contemporânea também não se furta a essa equação. Fiquemos com um exemplo, as fotografias de Robert Mapplethorpe. A princípio, a estética lembra vagamente a do filme de Denis, no que diz respeito exclusivamente a buscar um equilíbrio entre forças 
aparentemente controversas. Em Marty e Veronica (Marty and Veronica, 1982, Fig. 146), uma cena explícita e potente de sexo oral é conformada dentro de uma rígida ordem pictórica. A imagem nos revela o risco do neoclassicismo: a estilização é tamanha que uma possível sensualidade do tema parece ser demasiadamente coagida e, por isso, perdida. O movimento dos corpos é completamente enregelado, não só pela fixidez da fotografia, mas pelas poses, em sua exímia disposição geométrica, e pelo forte contraste entre o claro e o escuro. A moldura estética teria refreado e resfriado completamente o desejo ali envolvido?

Fig. 147

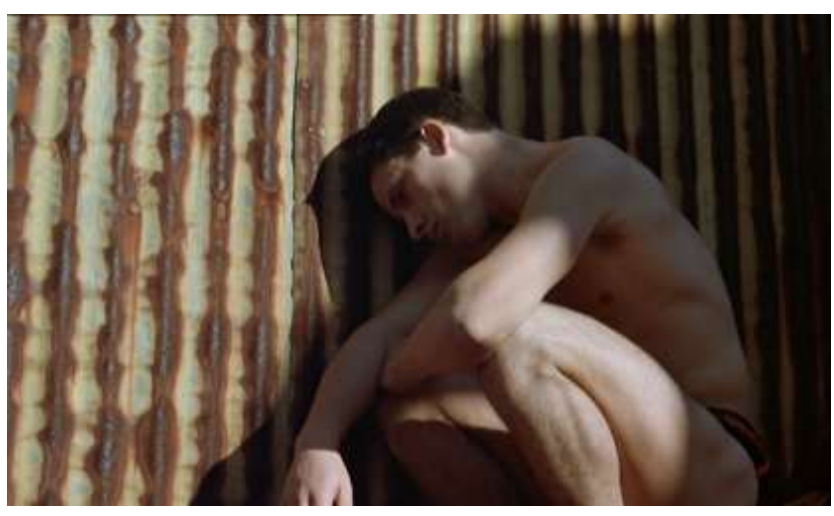

Fig. 148

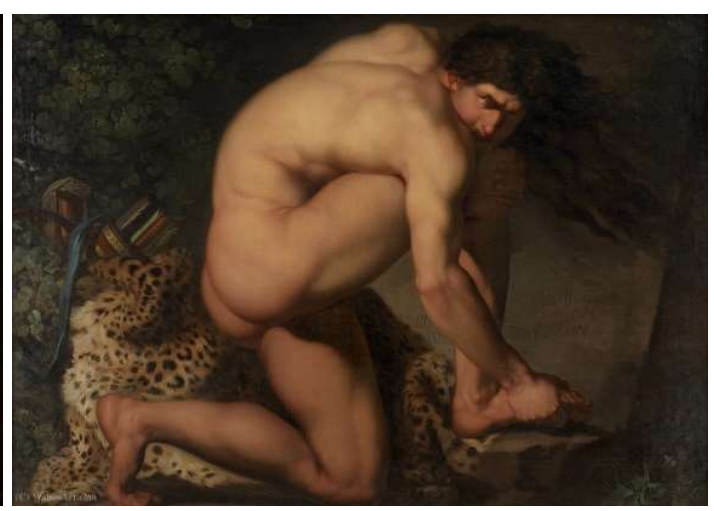

No caso de $O$ fantasma, um plano em específico também põe em cena a coação equilibrada de uma potência. É aquele em que Sergio está de sunga, agachado no telhado da casa (Fig. 147). Mesmo que a contenção seja temporária, ali a musculatura protuberante, sinal de força e vitalidade, está em contraste com a pose desamparada do corpo e a cabeça recostada sobre o muro. Comparado ao plano anterior, em que o personagem se erguia ereto sobre o telhado, acima do mundo, agora se vê a imagem de queda, de uma tristeza sóbria contida pelo corpo constrito. A tensão é equilibrada pela pose e recobra mesmo que indiretamente uma iconografia de homens gigantescos figurados tanto na pintura como no cinema a partir do sofrimento. Na história da arte ocidental europeia, isso começou desde pelo menos o paradigma laocoonteano, passou pelos gigantes contorcidos de Michelangelo e continuou na tradição neoclássica com figuras como a de Filocteto (1774-1775, Fig. 148), de Abildgaard, cujas dimensões atlantes rivalizam com os limites opressores do quadro. Nesses casos, a dor se torna uma justificativa para contorcer o corpo, evidenciar seu relevo e modular um drama pela robusta fisicalidade, numa dinâmica entre coação e descontrole, pathos e sobriedade. ${ }^{222}$

${ }^{222}$ Claro que a magnitude desse confronto nas artes pictóricas até o século XIX, que remontava aos grandes temas, é completamente secularizada nos períodos seguintes, e em especial num cinema como o que aqui se lida, voltado para o ordinário. Em segundo lugar, vale dizer que as figurações de corpos masculinos em sofrimento, às 


\subsubsection{Câmara de olhares}

Enquanto o neoclassicismo pictórico está alinhado a uma beleza pela elegância da pose e dos contornos harmoniosos, pelo primado do desenho, a "carnação" aqui proposta se alimenta de um repertório antinômico. ${ }^{223}$ A noção remete ao tratamento da pele da figura humana pelo colorido, quando o uso da tinta é capaz de criar o efeito tátil na pintura, traduzindo o vigor da carne através da modulação do empasto. A história é vasta e nossa breve menção à tradição pictórica não se preocupará em precisar uma data de início. Sabemos, porém, que a história de arte oficial europeia identifica que uma tal representação da figura humana recebe importância desde pelo menos o século XVI, alcançando, sob outros moldes, artistas contemporâneos. ${ }^{224}$ Ainda que tenhamos citado há pouco um plano de $O$ fantasma (Fig. 147) como associado ao erotismo neoclassicista, o filme nos parece em diálogo mais firme com os pintores que privilegiaram a carnalidade protuberante dos corpos.

Fig.149

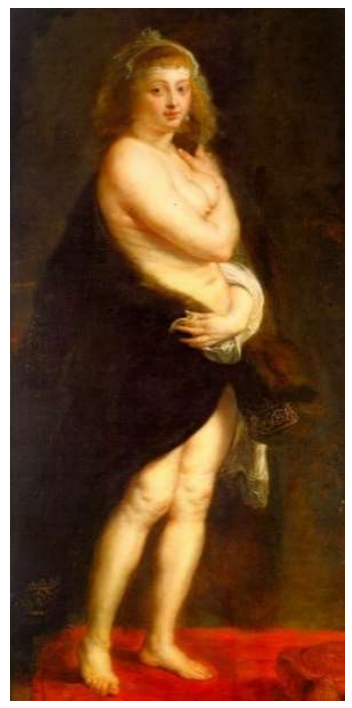

Fig. 150

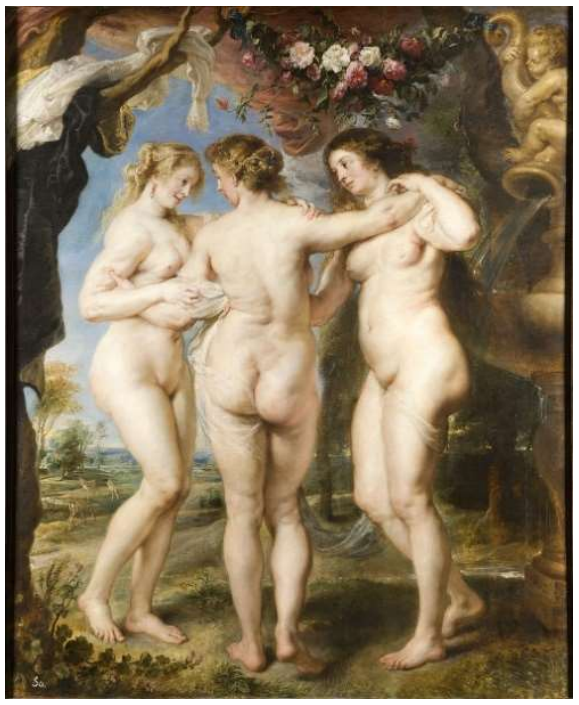

Fig. 151

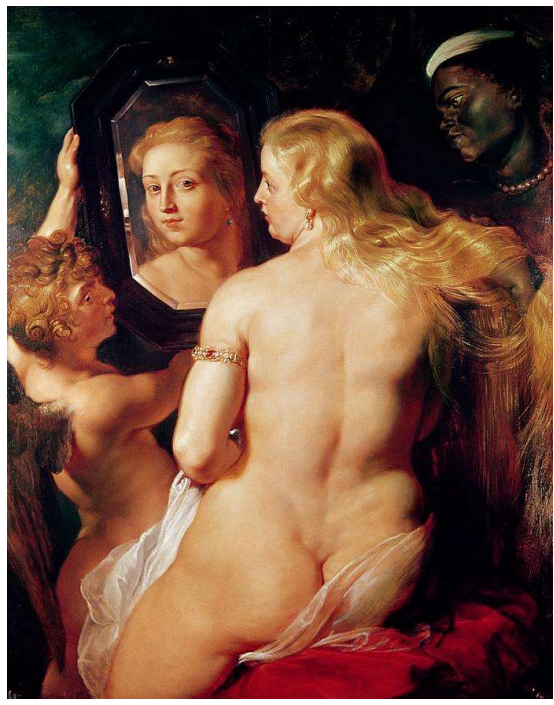

vezes, conduzem à tortura. Esta, para além da associação com a sobriedade de um corpo que a recebe com temperança, pode ser transformada em prazer e por isso mesmo resultar num programa erótico. A figuração de São Sebastião, com as flechas cravadas sobre o corpo evidenciadas na mesma medida em que os músculos tensionados é reconhecidamente um sinal dessa relação. Não por acaso o motivo aparece em uma das cenas de $O$ ornitólogo (2016), de Rodrigues, quando o protagonista é amarrado em um tronco, com uma toga branca e com uma pose, incluindo a disposição dos pés, que envolve um jogo de leveza e feminidade presente na iconografia do santo. Para além da alusão ao motivo, o importante é assinalar como a submissão da figura masculina ao sofrimento e às vezes à tortura flexibiliza a imagem ativa e onipotente vinculada à virilidade dos corpos, por vezes os feminizando ou os tornando vulneráveis, ao mesmo tempo em que cria um ambiência de sujeição ao prazer do olhar voyeurista. A respeito dos cruzamentos entre tortura e uma estética homoerótica, ver Richard Leppert, The Nude: The cultural rhetoric of the body in the art of western modernity, Boulder, Colorado: Westview Press, 2007.

${ }^{223} \mathrm{O}$ termo é utilizado por Arasse para discutir o erotismo carnal na pintura europeia a partir de artistas como Ticiano. Ver: Daniel Arasse, "A carne, a graça, o sublime”, in Alain Corbin, Jean-Jacques Courtine, Georges Vigarello (org.), História do corpo: 1. Da Renascença às Luzes, Petrópolis: Vozes, 2008, p. 535-620.

${ }^{224}$ Nadeije Laneyrie-Dagen, Op.cit. 
Um percurso bastante heterogêneo e genérico em sua linearidade salteada poderia remeter à carnação pictórica tendo como nomes iniciais: Ticiano, no período final de sua obra, quando utilizara a pasta pigmentar cremosa, vibrante e oleosa para tentar emular, mas também para propiciar uma carga erótica à pele do tecido humano; e Rubens, herdeiro desta potencialidade expressiva relativa à sensualidade das figuras, valendo-se tanto do pictórico como de temas e ações em suas telas que evocavam o toque e a pele (Vênus dentro do casaco de pele, Fig. 149; As três graças, 1636-1638, Fig. 150; A toalete de Vênus, 1636-1637, Fig. 151). ${ }^{225}$ Esta figuração do corpo com ênfase na opulência das carnes continuaria em obras como as de Watteau e Boucher (séc. XIX), e Courbet e Renoir (séc. XX), por exemplo. ${ }^{226}$ São pintores que evocavam a figura humana em contiguidade com o mundo. A pele dos corpos representados sugeria uma sensação de maciez ou aspereza, de rugosidade ou lisura. Essencial, portanto, a qualidade da superfície, a sensibilidade ao tipo de toque e à intensidade da pressão a que é exposta. Mais esclarecedor para a compreensão do erotismo no filme de Rodrigues, contudo, é um outro nome: Lucian Freud.

A comparação de alguns aspectos da obra do pintor alemão com O fantasma é frutífera na medida em que, além dos desdobramentos de uma figuração que põe em correspondência homens e animais a partir de um ângulo comum, há um interesse corolário em restituir um tipo de materialidade pautada na presença orgânica dos corpos. O encarnado pelo empasto continua sendo importante como já o era para os coloristas de séculos atrás, mas a sensualidade carnal adere uma deposição do estatuto da nudez diferente e mais próxima do que se vê em Rodrigues.

As telas Sunny Morning - Eight Legs (Fig. 152, detalhe da original) e Annabel and Rattler (Fig. 153) são pontos de apoio firmes no entendimento das escolhas mencionadas. Uma delas é retratar homens e animais a partir de uma série de horizontalidades: o estado, a posição, o lugar, às vezes a paleta de cores. Em Sunny Morning, o pintor faz do sono partilhado um tecido imaginário entre as duas espécies. Viradas na mesma direção, um corpo rente ao outro, as figuras são suspensas do tempo presente e de suas respectivas posições para habitar um mesmo mundo, respondendo a disjunção ontológica com uma continuidade onírica.

\footnotetext{
${ }^{225}$ Nadeije Laneyrie-Dagen, Op.cit.

${ }^{226}$ Sobre o último, ver o debate do Capítulo 1, no tópico O desregramento do feminino.
} 
Fig. 152

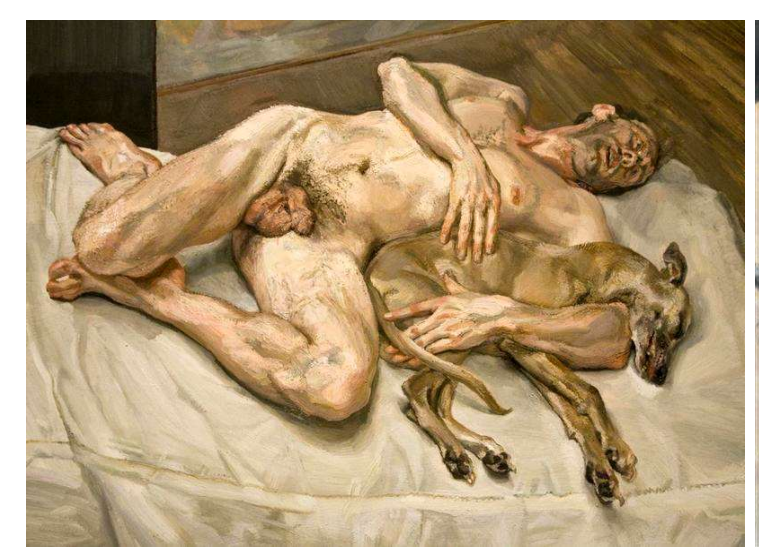

Fig. 153

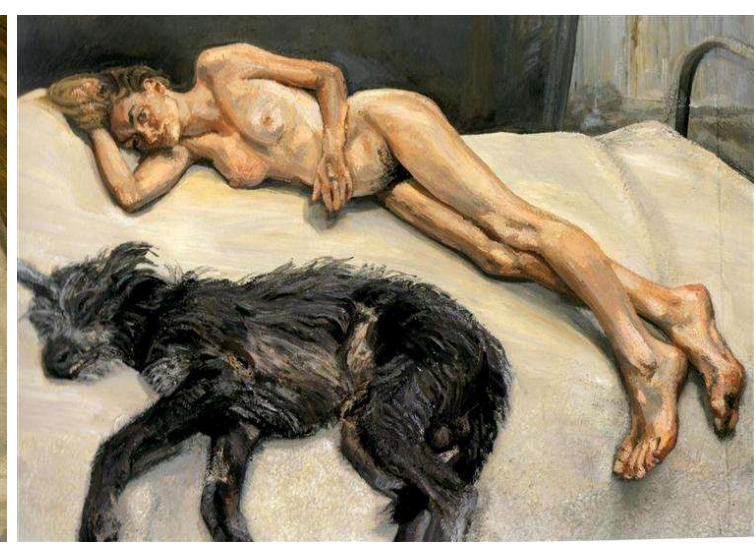

Os cachorros que aparecem nas duas telas, não é preciso dizer, nunca estão e jamais estiveram "nus", uma vez que a qualidade só existe como antônimo, na oposição a uma categoria cultural - "vestido" - naturalmente não endereçada a eles. Ao equiparar a figura humana aos animais, Freud tenta recobrar o nu não pelo seu viés negativo, mas como um estado em si mesmo, uma propriedade inerente ao aspecto orgânico, à materialidade mais simples do ser: estar no mundo. ${ }^{227}$ A partilha entre homem e animal é apenas um dos vértices dessa proposta.

Uma das condições para reaver o lado orgânico corporal na pintura foi a de afastar-se do $n u$ como categoria estética cuja execução é intrínseca a um programa de beleza, da submissão a uma série de normas que distanciam a figura do seu referente real e a aproximam de uma Ideia. O cânone das proporções, mesmo numa pintura já tributária da anatomia, operava de maneira a diluir, minimizar ou emoldurar os aspectos sensíveis do corpo e em especial os da carne dentro de uma dimensão idealizada.

Durante o impressionismo - viu-se no primeiro capítulo -, pintores como Renoir conseguiam conciliar os dois extremos, reavendo o liame entre a contingencialidade de uma verdade física do modelo e o eterno da beleza. No entanto, mais próximo da órbita freudiana está um contemporâneo e conterrâneo de Renoir, Gustave Caillebotte. O pintor transformou as convenções do $n u$ ao realizar uma descida do universo etéreo, liso e mítico para os campos rugosos do carnal, devolvendo o corpo a uma realidade bruta e mesmo desgraciosa em sua qualidade mundana. Vejamos a descrição de Garb para uma de suas telas, Nu sobre um sofá (Nu sur un canapé, 1882, Fig. 154):

227 Jean Clair, "Freud, biologiste", in Cécile Debray (org.), Lucian Freud: l'atelier. Paris: Centre Pompidou, 2010 . 
Fig. 154

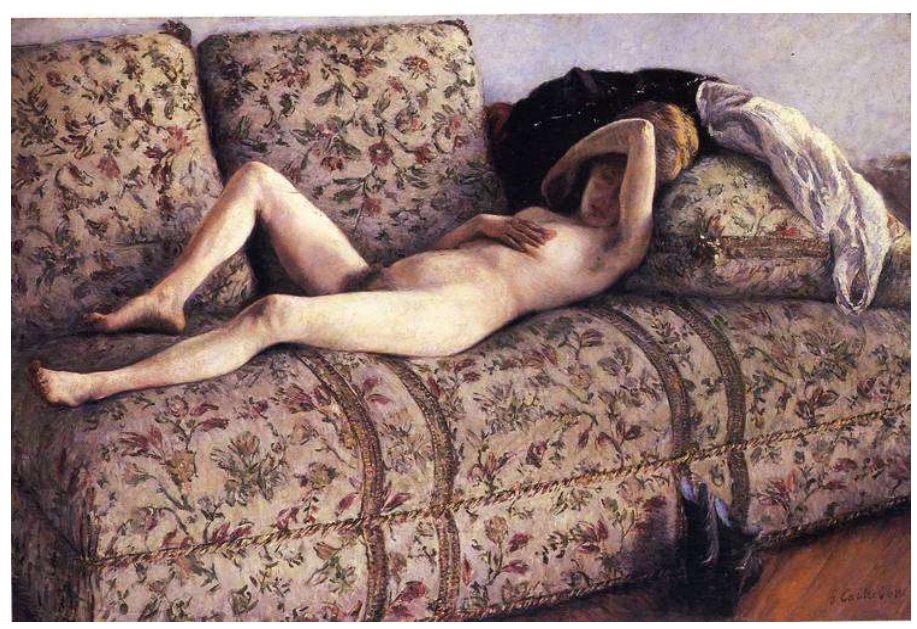

Fig. 155

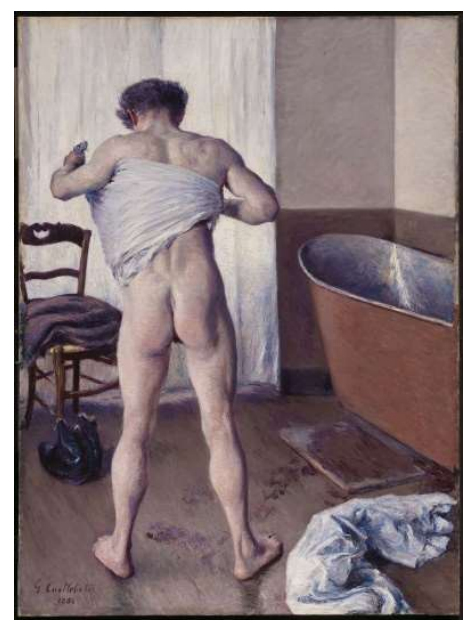

A modelo nua está caída indecorosamente em um grande sofá, seu corpo indolente portando os sinais da roupa íntima que ela há pouco removeu, seus pelos pubianos cobrindo extravagantemente seus órgãos genitais, sua mão sugestivamente repousada sobre o mamilo. A fisicalidade desta mulher é palpável. O encontro da carne e dos estofos, dos pelos e da parte interna da coxa, do braço e do rosto, são momentos táteis vivos em um mundo carnal. Mesmo as peças de roupas drapeadas descartadas e o vislumbre de tecido vermelho ardente na fenda do arco atrás do ombro da modelo parecem ressoar sua presença física. As mãos dela são ásperas e coradas, as solas de seus pés estão desgastadas e manchadas, os dedos dos pés apertados e esmagados como se tivessem sido aliviados das botas (colocadas de forma evidente no primeiro plano), que são ligeiramente apertadas. Não há uma ninfa ou deusa, nenhuma criatura etérea de outro mundo. Aqui, a figura feminina é desnudada de sua convenção: a pele lisa, a tez impecável, o corpo sem pelos e as proporções indefinidas de inúmeros nus de salão. O realismo produziu um nu para um quarto, que é o deste mundo: mundano, prático e inflexivelmente carnal. Enquanto a postura reclinada, o braço erguido e a disposição sonolenta lembram retratos neoclássicos do nu feminino $(O$ nascimento de Vênus, de Cabanel, é um bom e óbvio exemplo), o corpo não idealizado, a superfície tátil da superfície e o cenário cotidiano criam a imagem de uma contemporânea mulher sexualizada, escandalosamente disponível para escrutínio e sugestão. ${ }^{228}$

Similar enquadramento do nu feminino em um universo cotidiano havia sido realizado pela pintura de um contemporâneo, Alfred Stevens. A singularidade que Garb percebe na obra de Caillebotte em relação a de outros pintores da época foi ter se valido de uma figuração similar para o nu masculino, que até então continuava subsumido a uma estética de teor clássico ou neoclassicista, figurado a partir de ações e poses heroicas que idealizavam sua masculinidade viril. Com $O$ homem no banho (Homme au bain, 1884, Fig. 155), esse repertório arquetípico dá lugar a uma cena completamente ordinária de um homem que,

228 Tamar Garb, 1998, p. 25. 
mesmo mantendo uma musculatura enrijecida, pose ereta e pés firmes sobre o chão, restringe sua ação a enxugar-se. Dos guerreiros viris, do heroísmo cívico e erótico da pintura neoclássica, a tela de Caillebote conserva uma firmeza da carne e da pose, mas dentro de uma ação sem qualquer grandiosidade.

Freud surge alguns anos mais tarde na esteira de pintores como Corinth, Gwen John, Coldstrem, entre outros que como Caillebotte figuram o corpo nu a partir de uma veracidade que abdica da beleza para realçar aspectos crus e realistas. Mais que o nu enquanto gênero, ali aparecem seres despidos que portam consigo a imediatidade de um "corpo que acaba de deixar suas vestimentas sem preocupação com a beleza, a aparência, a harmonia ou o peso, eles são capturados por um olhar próximo do clínico e longe do estético". Um olhar, como Freud dizia ser o seu, de um "biologista". 229

A dessacralização do $n u$ passa também pela escolha dos modelos: homens e mulheres com corpos à sombra de um padrão de beleza artístico e social. Excessivamente magros ou gordos, disformes e por vezes monstruosos em suas formas, Freud tanto os retrata com fidelidade, como acentua o que neles parece fora de ordem. A oposição é clara diante da mítica história de Zêuxis de Heráclea, que escolheu cinco virgens de Crotona para retirar o que de mais belo havia em cada corpo para assim poder compor uma única figura. Em Freud, abandona-se a imitação de uma "pose" enquanto evocação e repetição de um modelo arquetípico. A posição dos corpos retratados geralmente mantém um certo desequilíbrio: membros curvados, dobrados, extensos ou ossudos demais, mãos que pendem sobre o dorso ou sobre o rosto, corpos desajeitados sobre a cama às vezes dormindo com a boca aberta (Fig. 152-153. Se existe beleza, ela não é a de um programa ideal, mas a da intimidade e da carnalidade protuberante.

O itinerário feito até o momento permite apresentar uma via singular para pensar a seguinte questão: como o cinema poderia sugerir o efeito de carnação que a pintura alcança a partir do empasto? A resposta mais óbvia, e por isso mesmo a se desconfiar, é a partir de uma encenação na qual a câmera está tão rente ao corpo que a figura humana cede ao flou e perde os contornos. Philippe Grandrieux, já foi debatido, recorre a esse artifício (entre outros) para criar uma disparidade entre o peso carnal da mulher e a presença umbrática do personagem masculino. Diferentemente dessa operação quase literal em suas consequências plásticas, o verniz erótico de $O$ fantasma nos apresenta outras, que identificamos a partir das 
características discutidas na obra de Caillebotte e de Freud: o espaço da intimidade, uma estética fetichista e o acento sobre a organicidade do corpo.

Inicialmente, o filme de Rodrigues se aproveita de um privilégio do olhar sobre a figura humana ao mostrá-la em lugares íntimos e em momentos de privacidade. Vê-se Sergio quando troca de roupa em um vestiário, no banho e na presença ociosa em seu quarto. Nos três espaços, o banal nunca existe completamente, pois está sempre sujeito a outro regime, o da exploração sensual da nudez e do desejo sexual do personagem. A conversão do cotidiano em erotismo está sujeita a duas condições. Uma é a decupagem em planos médios das partes do corpo, em especial da cintura e dos órgãos sexuais. Em geral, os enquadramentos não são nem tão fechados, a ponto de obstruir a unidade visual da figura, e nem tão abertos, a ponto de perdê-la de vista no espaço. Por vezes, vale observar, aproveita-se o próprio cenário para reenquadrar o corpo e orientar a atenção para o que interessa na cena (Fig. 157). Em segundo lugar, há uma "consciência" da figura diante do olhar. Nos momentos de parcial ou total nudez de Sergio, ele se dispõe frontalmente para a câmera ou se movimenta de modo a permitir que mesmo com o plano fixo seja possível ao espectador escrutar a sensualidade de sua figura. $\mathrm{O}$ corpo se oferece plenamente, contribuindo para uma estética fetichista (Fig. 118-119, Fig. 156-157).

Fig. 156-157
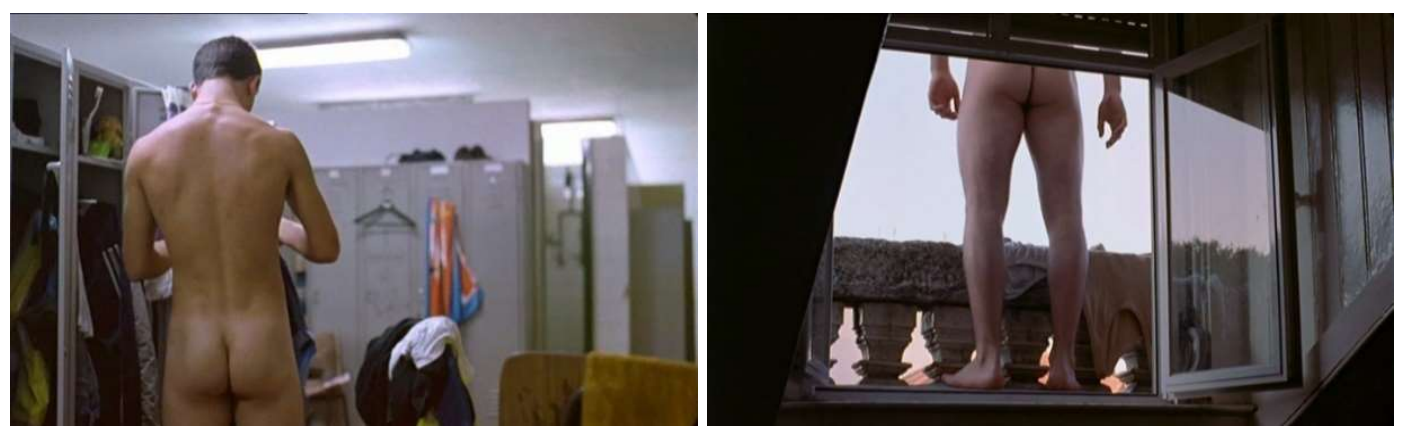

Em $O$ corpo de Afonso (2013), Rodrigues vai ainda mais longe nesse projeto. O ponto de partida é um teste de elenco para escolher um ator, mais precisamente um corpo capaz de representar o primeiro rei de Portugal, Dom Afonso Henriques. Vários candidatos leem documentos históricos sobre o monarca enquanto se despem, contam histórias pessoais e são sondados livre e despudoradamente pela câmera. Cria-se um dispositivo de permissibilidade do fetiche. Em certa medida, Bom trabalho, em sua figuração linear dos soldados, opera segundo a mesma lógica de engendrar uma ambiência capaz de documentar os corpos e ao mesmo tempo estimular o prazer escopofílico. A estética fetichista partilhada por esses filmes 
é antípoda à do cinema clássico hollywoodiano ao representar o corpo masculino. Comparemos.

Confortável e entusiasta na observação do nu e do erotismo femininos, o cinema mainstream hollywoodiano fez o oposto com a figuras dos homens. Deixando a sensualidade em segundo plano, preferiu figurá-lo a partir de sua virilidade, enaltecendo-o pelo senso de heroísmo e de onipotência. Não é difícil ilustrar esse argumento com um panteão de personagens, especialmente os de gêneros cinematográficos que submetem os corpos a atos de risco e por isso de bravura, como o western. Do ar experiente e consciente de John Wayne nos filmes de Ford ao olhar firme e severo de Randolph Scott nos de Budd Boetticher, por exemplo, é marcante o fascínio pela figura de super-homens que tudo podem dentro do drama, dispostos aos maiores sacrifícios pela honra, às vezes preferindo a coragem e aceitando o risco de sua costumeira companheira, a morte, ao bom senso e à vida.

Mulvey identificou em exemplares do cinema clássico uma fantasia narcisística em torno das figuras masculinas herdada de uma cultura patriarcal e que redundaria em mecanismos de controle sobre as mulheres em cena. ${ }^{230}$ Dentro da ampla fortuna de textos que surgiram em resposta e em complemento ao seu, seja pelo movimento feminista, seja dentro dos estudos queer, alguns se dedicaram a pensar as particularidades da figura masculina para além do quadro ali estabelecido. Steve Neale pertence a essa leva. Focalizando um cinema clássico heterossexual, o autor contesta sem abandonar completamente o argumento de Mulvey. ${ }^{231}$ Primeiramente, subsidiando-se em outros autores, elenca filmes que erodem a fortaleza masculina, afrontando sua autoridade e onipotência. Em seguida, identificando como um mesmo corpo representado por ações heroicas, que estimulam a identificação narcisística do público, pode paralelamente estimular uma fruição erótica. A figura masculina incorporaria então o mesmo destino apontado por Mulvey ao falar da feminina: ser “objetificada" pelo olhar (de um personagem, da câmera, do público) e transformada em presença sexual. $^{232}$

\footnotetext{
${ }^{230}$ Laura Mulvey, Op.cit.

${ }^{231}$ Steve Neale, "Masculinity as spectacle - Reflections on men and mainstream cinema", Screen, vol. 24, n. 6, novembro, 1983, pp. 2-17.

${ }^{232}$ A base do argumento vem de um artigo em que D.N. Rodowick argumenta: "Mulvey discute o personagem masculino como um objeto do olhar, mas nega a ele a função de objeto erótico. Pois Mulvey concebe o olhar como essencialmente ativo em suas intenções; a identificação com o protagonista masculino é considerada apenas de um ponto de vista que associa isso com um sentido de onipotência, de assumir o controle da narrativa. Ela não faz diferença entre a identificação e o objeto escolhido, pela qual o desejo sexual poderia ser conduzido em direção à figura masculina, nem considera a significação de autoridade na figura masculina do ponto de vista de uma economia do masoquismo". Steve Neale, Op.cit., p. 8.
} 
Nos filmes de Anthony Mann, ver-se-ia o desdobramento desse duplo regime. Seus filmes seriam estruturados em torno da contemplação da figura masculina, sendo a experiência do espectador a do prazer de ver a "existência" de um corpo ao andar, mover-se, passear e lutar em espaços, paisagens e numa história. Esse tipo de prazer estaria subsumido a um mecanismo de repressão exercido pelo redirecionamento do olhar para outros motivos dentro da cena, mas também por um projeto de recorrente mutilação dos corpos pelo sadismo. Ambas as propostas obstruiriam a contemplação masculina dentro de uma chave de erotismo e de desejo. Outro exemplo seria a presença de Rock Hudson nos melodramas de Douglas Sirk, igualmente figurado a partir de sua sensualidade. A repressão, porém, viria pela feminização dos seus personagens. A censura velada, em Mann ou Sirk, responderia a uma sociedade heterossexual e patriarcal em que “o corpo masculino não poderia ser explicitamente marcado como objeto erótico do olhar de outro homem" - presume-se, como alertava Mulvey, que o olhar espectatorial criado pelo cinema clássico é masculino.

$\mathrm{O}$ quadro mencionado responde por um mecanismo ambivalente. Cria-se uma tendência fetichista, de culto à beleza física do objeto de desejo (o corpo masculino) e, simultaneamente, buscam-se meios de censurá-la. ${ }^{233}$ Seria esse olhar sobre a figura dos homens, vitimado por operações de recalque no cinema hollywoodiano clássico, a encontrar uma reelaboração nos filmes de Rodrigues e Denis. Um cineasta gay e uma cineasta mulher, importante precisar. Seja no filme de um como no da outra, a subversão do cânone clássico acontece pela plena objetificação do corpo masculino e pelo adensamento das operações visuais (em especial o enquadramento e o ponto de vista) e performáticas (as poses, os gestos) a reforçar sua exposição. O cinema se torna câmara de olhares e de fetichização do corpo, sondagem do exterior que ora revela o interior, ora se contenta com a vida e o prazer sobre a superfície.

$\mathrm{O}$ erotismo naqueles diretores é baseado num pacto estabelecido com o espectador. Em O fantasma, o contrato depende da atenção dada à pele dos corpos em cena, mais do que à visão. No cinema, sabemos, o olhar de um personagem pode ser revelado integralmente, seja por um plano subjetivo, seja por outros meios da encenação que partilhem com o público o que é visto no universo diegético. Com a experiência tátil da figura humana, a situação é diferente. A pele permanece numa total inacessibilidade. Ela é restrita aos seus agente e paciente na imagem. A princípio, o espectador não pode fruí-la. Neste sentido, o filme de Rodrigues flerta com o cinema pornográfico. A atenção dada à pele e aos atritos entre os

\footnotetext{
${ }^{233}$ Haveria, segundo Mulvey, uma diferença entre fetichismo e voyeurismo. O último envolve o poder de subjugar sadicamente a partir de uma rede de acontecimentos pela qual se estabelece um controle do outro. Citada por S. Neale, Op.cit..
} 
corpos é comum a ambos. A diferença, porém, insinua-se pelo dispositivo do último, às vezes obcecado por tudo ver e tudo saber. O olhar panóptico da câmera pornográfica, com seus closes nos órgãos sexuais e a predileção por um repertório já codificado de atos, com o real saturado até a extenuação, ou até o seu inverso, corre o risco de resultar no controle da figura humana, com o menor detalhe a ser capturado. ${ }^{234}$ É neste ponto que o filme de Rodrigues parece seguir outra via.

O fetichismo visual de $O$ fantasma tenta preservar uma zona de inacessibilidade ao que está em cena. Em lugar de compensar a distância do espectador e saciar o seu desejo com uma visibilidade integral da sexualidade dos corpos, o filme alimenta a potência erótica da figura humana a partir de uma costumeira estratégia da história da arte ocidental: velar e desvelar o que é obsceno. ${ }^{235} \mathrm{O}$ principal efeito é um constante ir e vir entre o tátil (na diegese) e o intangível (pelo público), relação a partir da qual o espectador é instigado a fruir uma impossibilidade - o toque -, convidado a acessar o inacessível, sendo a todo instante estimulado a algo que tem consciência, mas que não pode apreender fisicamente. ${ }^{236} \mathrm{O}$ cruzamento com o cinema pornográfico existe em uma ou outra cena mais explícita, mas o filme de Rodrigues opta por um posologia. A dosagem entre o que é dado a ver e a enfatização da pele na figuração do corpo, especialmente o de Sergio, orienta esse processo. Põe-se em tensão o olhar fetichista, estabelecendo um ponto cego, uma defecção tátil, ao mesmo tempo em que se instiga a sua fruição imaginária.

\footnotetext{
${ }^{234}$ Yann Lardeau, "Le sexe froid", in Théories du cinéma, Quétigny: Petite anthologie des Cahiers du cinéma, 2004. Ainda que não seja esse o nosso papel aqui e nem o tema do trabalho, observamos que a visão excessivamente negativa do cinema pornográfico no texto de Lardeau, e no limite aérea, dado que dedica tanta ênfase ao gênero sem nem mesmo citar obras, parece se enquadrar num olhar enviesado e redutivo. Lardeau repete alguns dos argumentos que Susan Sontag aponta ao analisar as razões para a exclusão da pornografia pela alta cultura (no caso, a literatura), entre os quais a acusação de que não tem cuidado com o seu meio de expressão (uma das linhas condutoras do artigo de Lardeau) e de que tem uma intenção unívoca, presumidamente oposta à de uma "boa arte": a indução da excitação sexual. Ver Susan Sontag, "A imaginação pornográfica", in A vontade radical, São Paulo: Cia das Letras, 1987. A nossa alusão ao texto de Lardeau não partilha da condenação do cinema pornográfico feita pelo autor, mas do reconhecimento de uma tendência do gênero fundada na vontade de ver a todo custo, que em certa medida é oposta àquela de $O$ fantasma.

${ }_{235}$ Retomando a arte moderna e contemporânea, Ardenne comenta essa estratégia da alusão, ou mesmo de contenção, baseada numa prudência em mostrar, mais por razão e economia do que por pudor. No lugar da facilidade de explicitar o sexo bruto, opta-se por um princípio formal que refine a representação a tal ponto de despertar a ansiedade no espectador, incitando nele o desejo e a febre de ver, de acessar o que the é recusado. A estratégia seria calcada num princípio duplo: "De um lado, a vontade de preservar no espectador um potencial desejo. De outro, a escolha por uma economia simbólica que deliberadamente aumente o campo fantasmático e deixe o imaginário livre. A discrição, nesse caso, acontece não como uma brimade da imagem sexual, mas como uma das formas primordiais de revitalizá-la.". Ver Paul Ardenne, Op.cit., p. 294.

${ }^{236}$ Poder-se-ia contestar a afirmação sob o rótulo de genérica na medida em que estendível a qualquer filme: o toque não é um dos sentidos contemplados pelo cinema. Em resposta a isso, acreditamos que a singularidade de O fantasma como a de outros filmes contemporâneos que enfatizam a potencialidade da pele é a de desenhar um programa paroxístico em que o toque é a dimensão essencial dos personagens e, por isso mesmo, em que a defecção tátil do espectador, universalmente existente no cinema, é a todo instante explicitada pelo que acontece na diegese por um jogo de estímulos.
} 
A última tendência pela qual acreditamos haver uma predisposição à “carnação" é por uma espécie de animalidade da figura humana. Para além do que já se explorou sobre o tema anteriormente, cabe pontuar que a performance de Sergio, ao emular o comportamento de um animal, realça a corporeidade ao restringir seu personagem a um drama calcado exclusivamente sobre a libido e sobre as necessidades orgânicas. São as últimas que definem o protagonista na sequência final do filme, quando ele é apresentado exclusivamente pelo que remete à vida orgânica: movimentar-se sem direção, sentir frio e se esgueirar sobre o fogo, caçar para comer, beber água, vomitar, defecar. A figura é o corpo lembrado enquanto matéria física e biológica, restrito a tudo o que envolve sua vitalidade ou mais precisamente a sua sobrevivência. Se o filme é movido por um aberto domínio das paixões sobre a razão, a frustração amorosa e sexual do protagonista gera um curto circuito da dimensão volitiva. Da figura resta então um corpo limitado ao que lhe é puramente orgânico, numa deriva entre os domínios humano e animal que o relega à ausência de um lugar preciso no mundo. ${ }^{237}$

\subsection{A lei do desejo}

Don't be a body. John Maus

As análises dos filmes de Ming-liang, Rodrigues e Denis que capitanearam o percurso até aqui atentaram para os modos distintos com que a figura humana ganha soberania na encenação a partir do tripé gesto, pele e erotismo. De um a outro critério buscou-se esboçar um horizonte no qual o corpo se torna o epicentro da cena de tal maneira que os mínimos detalhes, às vezes seu simples estar no mundo, reivindicam uma retórica particular. Seja um

\footnotetext{
237 A título de curiosidade, lembremos, de modo sucinto e sem grandes pretensões, da distinção proposta por Hobbes sobre movimentos vitais e movimentos voluntários. Os primeiros seriam ligados ao que existe desde o nascimento e permanece até a morte: a circulação do sangue, o pulso, a respiração, a digestão, a nutrição, a excreção etc. Automáticos, não dependem das faculdades mentais, incluindo a imaginação. $\mathrm{O}$ segundo tipo, também chamado de movimento animal, é referente a "andar, falar, mover qualquer um dos nossos membros, da maneira como anteriormente ele foi imaginado em nossas mentes" (p.89). Dependeria, portanto, de um pensamento precedente. O centro da faculdade motriz do espírito, responsável por imprimir no corpo esse movimento voluntário, é o desejo. Motor primário da trama passional, vem dele o esforço em direção a algo, a trajetória de um sujeito rumo ao seu objeto. Na miríade de desejos disponíveis, o primordial para Hobbes, como se conclui pela própria necessidade de uma sociedade balizada pelo Estado, é o da conservação de si - entendida para além de uma sobrevivência, além de uma manutenção da vida biológica, pois compreende igualmente outros anseios como a felicidade, a alegria, a saúde etc. Vistas essas considerações, uma interpretação forçada poderia ver no comportamento de Sergio uma crise do movimento voluntário, em decorrência da frustração em alcançar o objeto desejado, restando apenas a conservação de si no sentido mais restritivo (portanto, não hobbesiano): a sobrevivência. Nesse caso, o personagem ficaria limitado ao que Hobbes considera de desejos inatos (fome, sede, sexualidade), que não necessariamente são vinculados com a experiência do sujeito. Conforme nos aponta Monzani, a diferença entre os desejos vinculados à experiência e os desejos inatos está no âmago da separação hobbesiana entre os domínios humano e animal. Nossa leitura e nossas citações a Hobbes são devedoras de Luiz Roberto Monzani, Desejo e prazer na idade moderna, Curitiba: Champagnat, 2011.
} 
ato mecânico aparentemente esvaziado de significado como a caminhada, seja a pose ou a figura em repouso exprimem e desvelam o personagem. No mesmo sentido, um tecido orgânico como a pele sugere uma epistemologia da sensação, um empirismo imoderado que orienta a comunicação com o universo e os outros seres. A figura humana deixa de ser a participante ativa para se tornar, ela própria, a incubadora, lugar de gestação e de execução do drama.

Arriscamos um breve comentário, na forma de interrogação, logo no início do capítulo: existiria um cinema do corpo sem necessariamente questioná-lo, sem expô-lo a um tipo de distúrbio, a uma desordem frente ao que seria o seu hipotético estado natural? Agora cabe precisar que em nosso corpus essa desordem tem uma origem: o Outro. Um ser amado, um ser desejado ou por vezes um ser que nem sequer está presente nos filmes e é apenas evocado pela sua ausência: o que se passa com o corpo da figura, seus afetos, tem uma causa fora dele. $^{238}$

O percurso feito no capítulo, do relevo dado ao corpo pelo gesto e pela pele ao relevo dada à carne pelo erotismo, já pressupunha que a sensualidade em cena é produto de uma malha de desejos diegéticos ora recalcados, ora mediados, ora febris em sua voracidade. É entre o apetite e a delectação nem sempre consumada que os distúrbios surgem e que os filmes aqui analisados se constituem como uma busca direta ou indireta a um objeto/ser querido, o caminho mais longo até o Outro. Estamos distantes de uma tentativa de alteridade pela imagem, em que se tenta reduzir uma série de diferenças entre os seres a partir de um nivelamento criado pelo investimento na matéria visual, como se viu no primeiro capítulo. Os

\footnotetext{
${ }^{238}$ Se se concordar com Spinoza, pode-se mencionar aqui a dependência dos afetos do corpo de causas que lhe são exteriores, que independem de sua essência. Sendo os afetos, conforme o autor, uma ideia pela qual se indica ou exprime "o estado do corpo ou de alguma de suas partes, estado que o próprio corpo ou alguma de suas partes tem porque sua potência de agir ou sua força de existir é aumentada ou diminuída, estimulada ou refreada" (SPINOZA, 2013, p. 152). Pelas imagens das coisas que nos afetam é possível representar os corpos exteriores como presentes a nós (ver a Proposição 27, da parte 3). Nas menções feitas a "afeto" ao longo do nosso texto, utilizaremos o termo livremente inspirado em tal natureza, mas sem fazer remissão - salvo quando for destacada essa intenção - à definição integral em Spinoza, cujos pormenores envolvem tanto a tentativa de delimitar sua força (a sujeição e a servidão humana a eles), quanto o seu domínio (a potência da razão para refreá-los e regulálos). Consultar Benedictus de Spinoza, Ética. Belo Horizonte: Autêntica, 2013. No mais, ao decidir por não fazer uso preciso do "afeto" em conformidade estrita com Spinoza, ignoramos, por exemplo a diferença entre afetos e afecções, apontada entre outros por Deleuze, em sua leitura de Spinoza: "Observou-se que, em regra geral, a afecção (affectio) se referia diretamente ao corpo, ao passo que o afeto (affectus) se referia ao espírito. Mas a verdadeira diferença não está aí. Ela existe entre a afecção do corpo e sua ideia que envolve a natureza do corpo exterior, por uma parte, e, por outro lado, o afeto que implica tanto para o corpo como para o espírito um aumento ou uma diminuição da potência de agir. A affectio remete a um estado do corpo afetado e implica a presença do corpo afetante, ao passado que o affectus remete à transição de um estado a outro, tendo em conta a variação correlativa dos corpos afetantes." Ver Gilles Delleuze, Espinosa: filosofia prática, São Paulo: Escuta, 2002 , p. 56. Se por um acaso essa distinção for levada em consideração, nosso texto trata de afetos e não de afeç̧̃es.
} 
filmes de Ming-liang, Rodrigues e Denis fazem do espaço na - e não $d a$ - imagem uma vasta e às vezes impenetrável vereda em direção ao Outro. Foquemos no interstício.

Nos filmes que analisamos, entre um corpo e outro, entre o desejo e sua consumação, engendram-se pelo menos três efeitos: uma caminhada pesarosa sob o signo da solidão; um princípio de entropia criado pelo extravaso desordenado e por isso violento da energia acumulada ao longo das sucessivas tentativas de alcançar o objeto de desejo; e, o que parece mais determinante em decorrência de sua força transformadora, a conversão dos seres, dos objetos e do universo a partir de uma economia libidinal. Antes ou na impossibilidade de ser transformada em prazer, ela contamina e transforma tudo com o desejo.

O último dos três efeitos será o foco maior de nossa atenção. Para compreendê-lo, voltaremos novamente ao cinema burlesco, que é impregnado pela mesma lógica de reestruturação do mundo. Naturalmente, não é o desejo sexual, mas outras razões a justificar essa transformação. Diferenças consideradas, compreender (mais uma vez) as leis do burlesco permite maior familiaridade com as operações feitas no cinema contemporâneo, em especial sobre o que há de subversivo no gesto. Por enquanto, discutamos os dois primeiros pontos.

Já foram dedicadas páginas suficientes à caminhada e ao peso existencial que ela concede às figuras humanas de Ming-liang, mas recapitulemos mais uma vez uma de suas qualidades: além de definir um significado ao corpo pelo ato mecânico, ela esboça uma procura muitas vezes frustrada em direção a outros personagens. Adeus, Dragon Inn é emblemático. O filme dispersa sobre o espaço uma série de corpos que tentam estabelecer um contato, mas que se desencontram nos labirintos do cinema Dragon Inn. Ou são por demais receosos para iniciar algo além de uma conversa desengonçada, ou jamais encontrarão uma mínima atenção aos seus desejos. A caminhada perde o sentido de cesura ou passagem, ${ }^{239} \mathrm{de}$ integrar dois extremos abolindo a distância entre o antes e o depois, o portador e o alvo do desejo. Em oposição, prolonga indefinidamente o afastamento, reforça uma ausência pelo investimento do corpo em um processo contraditório. Cada passo dado avança ao mesmo tempo em que parece recuar diante do que se objetiva alcançar.

O limite dessa progressão em que quanto mais a caminhada se dilata no tempo-espaço maior a distância entre os personagens é o movimento errante. Assim acontece com as figuras humanas no filme de Ming-liang. Uma busca a outra, mas independentemente das sucessivas tentativas de aproximação, parecem mais e mais distantes, pois nada conseguem consumar. Vista a intangibilidade do prazer e a impossibilidade de ser alcançada a fonte do impulso

\footnotetext{
${ }^{239}$ Maurice Fréchuret, 2000a.
} 
motriz dos corpos, as figuras são fadadas a um ir e vir sem finalidade. As deambulações ininterruptas parecem gestos de impotência e de falibilidade, pois expõem com frequência a frustração de conectar um corpo a outro. Às vezes, claro, simbolizam uma eterna esperança. Assim, em Adeus, Dragon Inn, um dos espectadores do cinema se mantém numa caminhada e numa troca de olhares perpétuas. Há um impulso que o move, como também é o caso da funcionária do cinema a procurar o projecionista. Mas, e os outros? Em geral, o filme é povoado de figuras que mal reagem aos investimentos e aos demais flertes, vagando com seus desejos recalcados, quiçá esquecidos, como autômatos.

A caminhada é apenas um dos motivos do cinema de Ming-liang a demarcar a parcial impossibilidade, a barreira intransponível até o Outro. Viva o amor (Vive l'amour, 1994), por exemplo, toma via alternativa, inclusive mais evidente. Numa das cenas, um casal está transando enquanto um jovem, Hsiao-Kang, está escondido sob a cama. Dos dois que se divertem sobre sua cabeça, o garoto sente atração pelo homem, de quem está duplamente separado: pelo próprio espaço, mas também pela decupagem que distribui Hsiao-kang e o casal em planos distintos. Apesar de afastado do objeto de desejo, ele frui imaginariamente o deleite alheio, com os olhos fechados. Ora, num cinema em que é tão importante a fisicalidade, nenhuma privação pode ser maior do que a do toque. Por isso mesmo, HsiaoKang se masturba enquanto o casal transa. Algumas horas depois, sai do esconderijo e vê o homem dormindo sozinho. Deita-se na cama ao seu lado e o observa (Fig. 158-159). Ameaça um toque e nada faz, afinal, a distância é o suplício e a própria condição entre os dois corpos em alguns filmes de Ming-liang. A inoperância da caminhada apenas reforçava isso.

Fig. 158-159
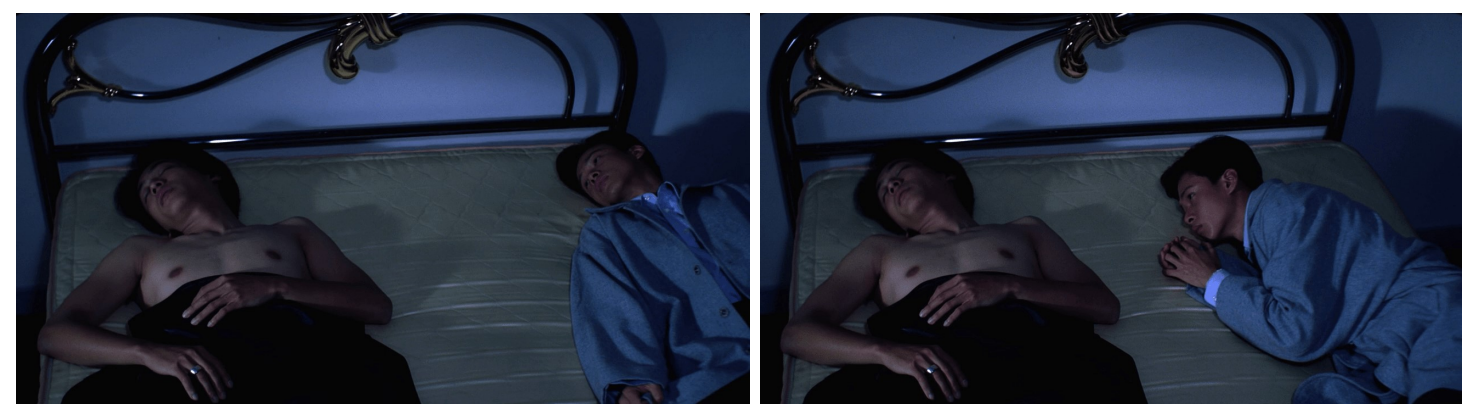

Mas para onde vai o desejo acumulado? Se os corpos são incapazes de alcançar o prazer, o impulso que os impele tampouco desaparece. Até pode ser transformado numa caminhada errante, como os zumbis de Adeus, Dragon Inn que já não sabem o que fazer com a energia acumulada e a eliminam lentamente - ou com ela convivem - num deslocamento 
sem fim. Também não é segredo que o desejo encontra uma vazão nos filmes de Ming-liang pela água que geralmente escoa ininterruptamente, desce pelo teto, transborda pelos cômodos, infiltra-se por todos os espaços. ${ }^{240}$ Adeus, Dragon Inn, O rio e O buraco (The Hole, 1998) são todos assomados, em um momento ou integralmente, por fortes chuvas ou por vazamentos, por uma força indomável, insensível a todas as barreiras que tentam contê-la. Estabelece-se uma espécie de dialética: o que o corpo guarda, o espaço expõe. O furor caudaloso é a válvula de escape do desejo, sexual ou não, que os corpos, por inabilidade ou malogro, não conseguem consumar. O impulso a movê-los rumo à mera comunicação, ao sexo e ao amor nunca é inteiramente recalcado. Enquanto os espectadores se cruzam pelos corredores do cinema em Adeus, Dragon Inn, num flerte latente que jamais conhecerá a luz, o cinema é inundado: goteiras por todos os lados, anseios por todos os poros. Enquanto pai e filho de $O$ rio estão na escuridão da sauna a praticar incesto, sob o véu da escuridão e do desconhecimento, o cômodo da casa da família que possuía um vazamento é completamente inundado. Enquanto os dois vizinhos de $O$ buraco, ela no andar de baixo e ele no apartamento de cima, vivem em seus respectivos universos, uma infiltração servirá como pretexto para fazer um buraco entre os dois imóveis, por onde se inicia a comunicação entre ambos, sugestivamente marcada por uma conotação sexual. O desejo é, portanto, figurado a partir de uma força incontida que transborda em todas as direções e estabelece uma espécie de contaminação. Corpos, objetos e espaço serão atravessados e amalgamados por uma mesma potência. Guardemos esse ponto.

Parece ser uma questão do cinema aqui tratado descobrir como canalizar o desejo. Só existe uma certeza nesse processo: não importa o suporte que o acolha, a fruição jamais acontecerá de maneira serena e ordenada. O impulso pelo Outro é transformado em elemento vital da figura humana e por isso mesmo potente e difícil de ser administrado. Seus efeitos são diversos. Há pouco vimos o que acontece com o espaço nos filmes de Ming-liang. Nos casos de Rodrigues e Denis, já não é o exterior, mas o próprio corpo a sofrer o tormento de uma pulsão que precisa ser extravasada. Ao se deter nesse ponto, retoma-se o que foi mencionado logo no início do capítulo: o cinema aqui discutido está numa constante busca por modos de revisitar e de reorientar a arquitetura corporal a fim de descobrir sobre sua superfície, por seus movimentos e por tudo o que o constitui novas figuras, sejam elas físicas, políticas, simbólicas ou de outra ordem. Desvia-se o corpo de sua naturalidade para adaptá-lo e para confrontá-lo às forças que o ameaçam.

\footnotetext{
${ }^{240}$ Jean-Pierre Rehm, Olivier Joyard, Danièle Rivière, Tsai Ming-liang, Paris: Éditions Dis Voir, 1999.
} 
Esse empreendimento reflexivo, sobre si mesmo, está no âmago da "metamorfose" de Sergio no final de $O$ fantasma, quando a mudança de pele e de comportamento acolhe o desejo não consumado. As relações sexuais do personagem, que pontuam todo o filme, no lugar da progressiva liberação de um impulso, operam segundo um contínuo acúmulo que será o motor da transformação final.

$O$ rio assume uma via similar, mas mais difusa. A doença de Hsaio-Kang não encontra nenhuma justificativa direta ao longo do filme, mas com um pouco de imaginação é possível entendê-la menos como uma enfermidade e mais como um sintoma. A pergunta seria: sintoma de quê? Efetivamente, a diegese pouco revela. Mas o pouco às vezes é muito. O que se sabe: a família do personagem é composta por três membros alienados em seus próprios universos. A mãe assiste a filmes pornôs escondida e às vezes encontra um amante a quem tudo interessa, menos o sexo; o pai frequenta saunas onde troca carícias e transa com desconhecidos; o filho faz sexo com uma amiga e, pouco antes do final, com o próprio pai, sem saber. A linha que atravessa e envolve sutilmente, comunicando os três personagens, as três ilhas, é o desejo sexual, a todo instante recalcado ou diante de interditos. O corpo de Hsaio-Kang acolheria essa energia acumulada e em constante tensão que perpassa o filme, sofrendo os seus efeitos? Isso só podemos supor.

Não é difícil encontrar pelo cinema contemporâneo exemplos de uma dinâmica entrópica disparada pelo desejo sexual. ${ }^{241}$ Uma obra mais recente que as demais aqui analisadas segue a mesma agenda, mas em lugar de concentrá-la em um elemento ou num momento em específico, subsidia a fábula sobre uma desordem generalizada, $O$ cheiro $d a$ gente (The smell of us, 2015), de Larry Clark. O filme mostra adolescentes que se reúnem no entorno do Musée de l'Art Moderne, em festas e em casa para se divertirem. A zona dos prazeres, como em outros filmes de Clark, é ampla em sua falta de limites: ela abrange dos jogos de videogame ao sexo e ao consumo de drogas, de um senso de inconsequência a um hedonismo inanido. E nebulosa em suas razões: a intensidade da experiência às vezes é uma resposta violenta e uma máscara involuntária à deformidade das relações familiares e sociais. Para além da natureza dos motivos, a imediata satisfação do desejo é o que move os jovens em suas jornadas de prazer. Mas onde está a entropia? Por todos os lugares: na montagem frenética de materiais heterogêneos (diferentes formatos de vídeo), nos temas (pedofilia, consumo de drogas e prostituição de adolescentes etc), no som estridente, na movimentação excessiva da câmera e dos personagens no interior do plano, em tudo o que dificulta a

\footnotetext{
${ }^{241}$ No cinema brasileiro, poderíamos pensar dentro dessa chave o curta Nova Dubai.
} 
conformação do visível e do audível em formas apreensíveis. Mas para ir além das evidências, o ideal é mudar a pergunta: como o desejo sexual, num universo de perversão e de exageros, ainda assim é capaz de resultar em uma potência que irá abalar, ameaçar as estruturas, ou mesmo revelar suas verdadeiras bases? A resposta é o que justifica a menção ao filme: pela representação do corpo.

\section{Fig. 160-161}
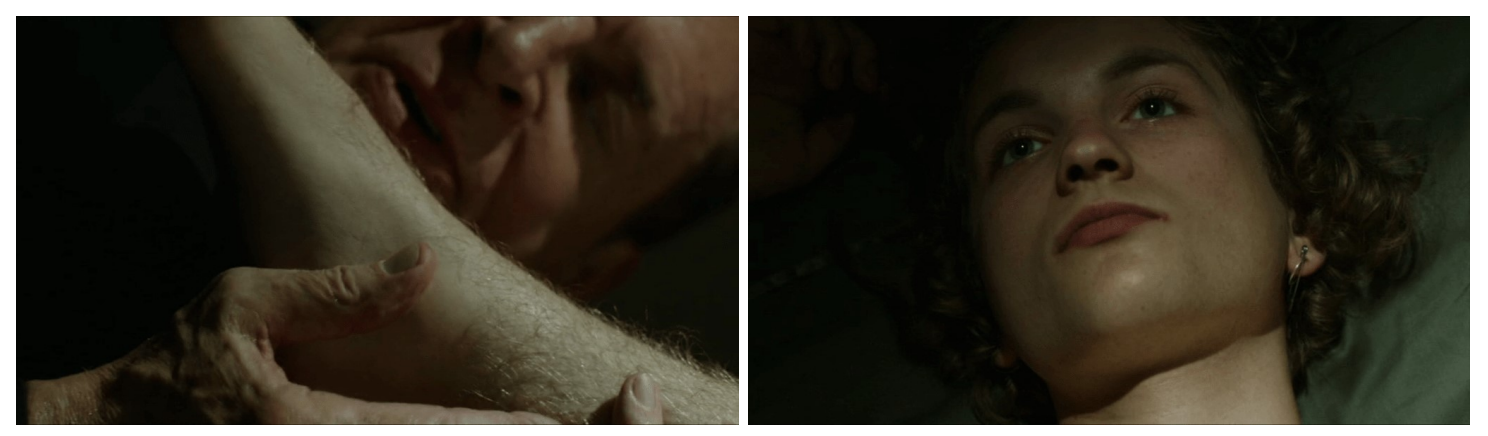

O maior sintoma de um estado das coisas em $O$ cheiro da gente é, no meio do caos, no olho da tempestade, a presença de um corpo jovem e delicado que sofre violentamente o efeito de tudo o que acontece, mas nada exprime. Em algumas cenas o personagem Matt encarna esse solilóquio silencioso: prostituindo-se com idosos e satisfazendo os mais diversos fetiches, incluindo a podolatria, ele é mostrado em closes durante as cenas de sexo, sem esboçar qualquer reação fisionômica, seja de prazer, seja de ojeriza (Fig. 160-161). Clark explora a excitação dos clientes e a reação mórbida do adolescente; a decrepitude física dos primeiros e o corpo efébico do segundo. A indiferença de Matt nessas relações de desequilíbrio nada tem de uma postura estoica já discutida em Bom trabalho. A supressão das paixões não vem enaltecer uma intrepidez, mas realçar um mal-estar. A apatia é o verdadeiro sinal de desordem numa encenação fundada sobre um festim sensorial, o ponto cego de um sistema. O close é o que resgata a experiência e impede sua banalização ou ocultamento. Concentrar-se sobre o rosto é encontrar uma âncora, um ponto fixo num universo que está em vias de se desmanchar a partir do que se acredita ser um deleite coletivo. A fisionomia cumpre o papel que em O fantasma era o da pele, resgatando a interioridade do latente para o patente. O semblante rígido de Matt mostra o que a intensidade dos prazeres esconde: a pulsão existente e celebrada no filme é oposta ao desejo, ou talvez a sua corrupção em sintoma. Pela rigidez do rosto a imagem do corpo instaura a verdadeira desordem em meio a uma mise en scène e a um universo caóticos. Como nos demais filmes analisados no capítulo, o que 
metaforicamente se chamou de entropia porta consigo uma espécie de revelação. Feito o parêntese, voltemos ao nosso corpus.

A dinâmica comentada tem sua importância em Bom trabalho. Até aqui o filme foi descrito dentro de um programa que deve à contenção de uma energia libidinosa e sensual a partir de uma beleza neoclássica, sobriedade dos movimentos, poses não afetadas, fisionomias impassíveis. O patético passava ao largo dos corpos representados por Denis. Mas o que aqui se omitiu foi a cena final, quando um processo similar ao de $O$ fantasma acontece. Trata-se também de uma "metamorfose", mas por outra via que já não envolve a pele, mas o movimento. A figura rompe com um programa edificado ao longo de todo o filme, um código comportamental esperado, um estado que dela se supunha ser o ideal.

O momento referido mostra o sargento Galoup, Denis Lavant, depois de ser dispensado da Legião Francesa. Ele aparece em seu quarto arrumando a cama de maneira impecável, reproduzindo uma precisão gestual para as tarefas domésticas comum à rotina militar. Ao terminar, senta-se na cama e pega um revólver. Deita-se e olha a arma. Põe-la de lado por um instante e depois a aproxima do corpo, sobre o ventre. O suicídio está à distância de um gesto. Contudo, segue-se um plano detalhe do peitoral e um movimento da câmera até o braço flexionado, no qual se vê uma das veias a pulsar: onde se esperava o morto, pulula a vida. Um corte e na próxima cena Galoup está numa boate, vestido de preto e com sapatos bicolores, a fumar um cigarro enquanto toca Rhythm of the Night, de Corona.

Fig. 162

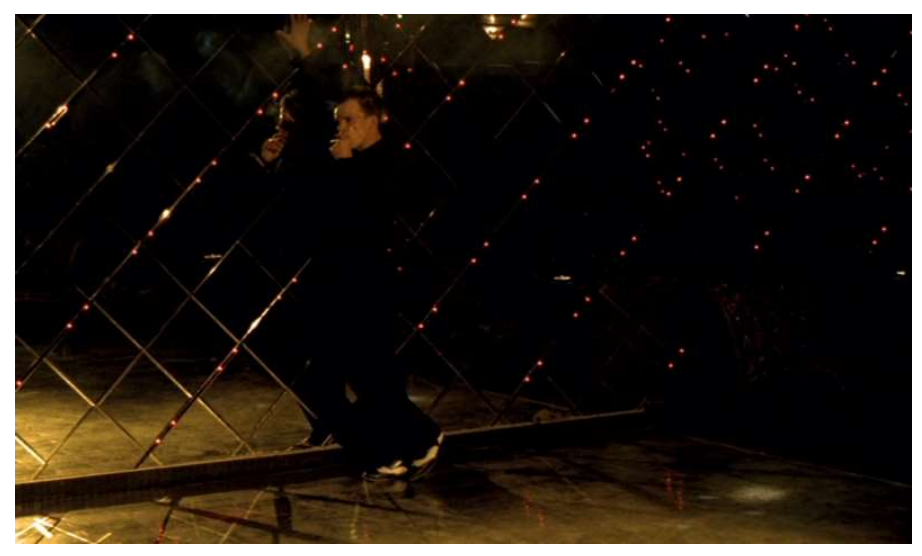

O rigor impassível continua a estampar o rosto de Galoup, mas o corpo não é o mesmo. Com os movimentos suavizados, mais femininos do que a Legião Francesa permitiria, ele caminha pela pista de dança sondando o ambiente com um ligeiro ar de desprezo. Para um momento, traga o cigarro e dá uma pirueta. Interrompe-a subitamente e pisa em falso, mas 
não cai. Agacha-se e movimenta um dos braços embalado pela música. Quando se levanta, contrapõe a rigidez do corpo com a leveza graciosa de um dos braços e de uma das pernas. Então caminha mais um pouco e progressivamente ensaia um movimento que culmina numa dança com os joelhos semidobrados, enquanto o dorso se vira ora para um lado, ora para o outro, lançando os braços para a esquerda para a direita. O corpo então toma impulso e salta no ar, girando em torno de si mesmo. Aterrissa, ensaia um movimento ainda mais forte, mas subitamente o interrompe, quase desliza e começa outra série. Não continuaremos a descrever a dança sob o risco de macular sua dimensão sensorial pela inaptidão da nossa escrita, mas também porque o que foi dito até aqui permite realçar seus dois traços essenciais: o desequilíbrio e a dialética entre liberação e refreamento, que termina com o fracasso do segundo.

Fig. 163-164
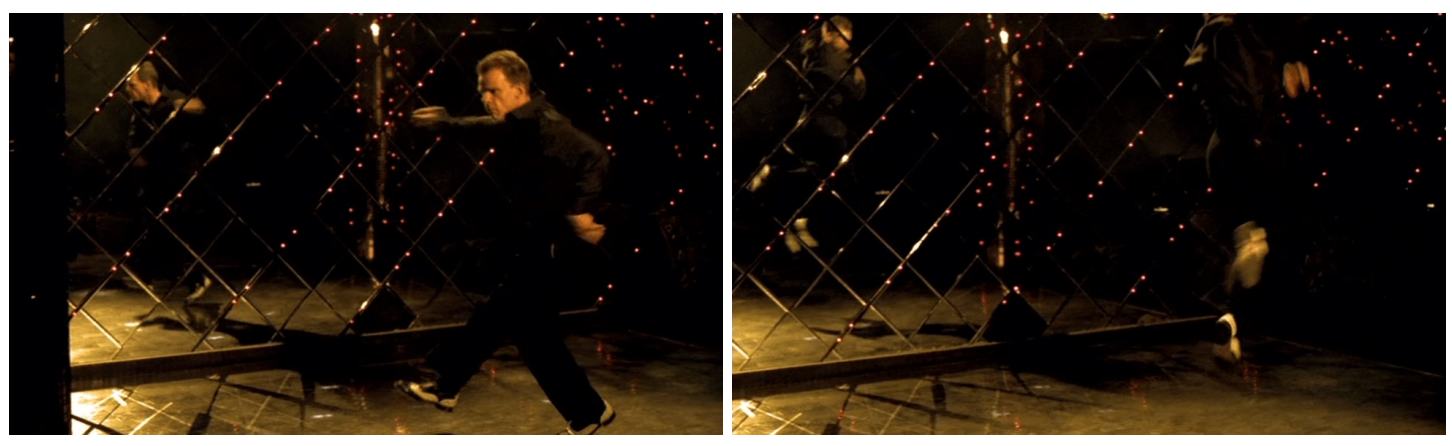

Fig. 165-166
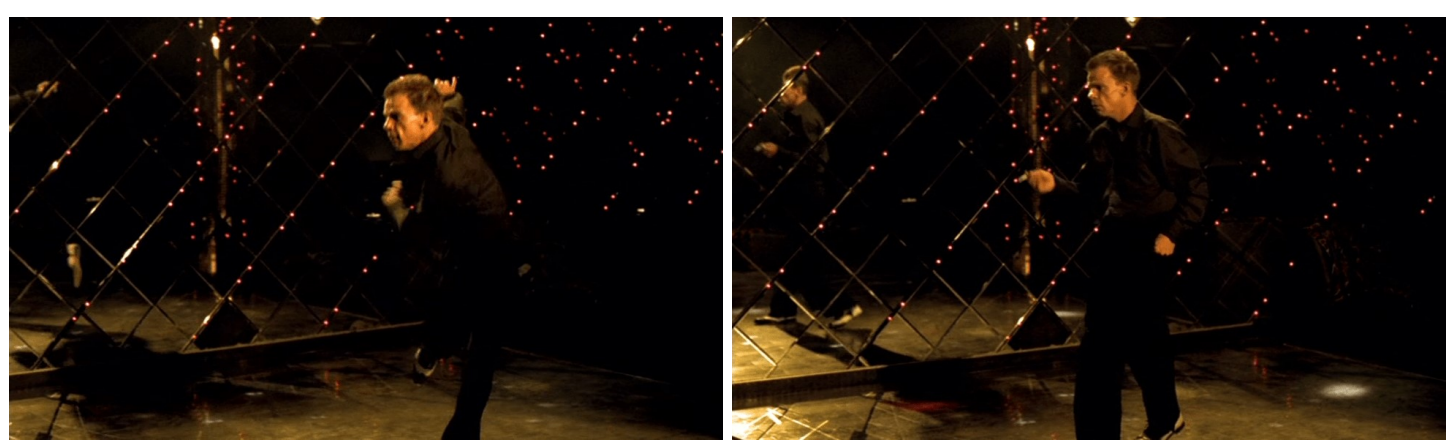

Se há um aprendizado que as artes do corpo como a dança não nos deixam esquecer é o da existência de movimentos para além daqueles que almejam um lugar ou objeto definidos. Sua evolução é indeterminada uma vez que causa e finalidade já não se encontram no universo tangível. A lei da economia de forças e do mínimo esforço que orienta um movimento com motivação definida já não funciona. No lugar da preservação de energia, uma segunda maneira de movimento tem a dissipação por objeto. Ao falar disso, Valéry nos dá o 
exemplo de um animal que está deitado e de repente se levanta, bufa e se movimenta. Não vai a lugar algum, não busca nenhuma coisa. ${ }^{242}$ Movimenta-se pelo movimento (como Sergio, ao final de $O$ fantasma). Haveria uma forma notável de ordenar ou organizar esse dispêndio de energia, a dança.

Ao retomar a distinção de Valery, não se quer constatar um truísmo: Galoup dança. Mas, sim, afirmar que a sequência final de Bom trabalho continua a evidenciar o que insistimos desde o primeiro tópico sobre a retórica fundamentada na performance física. Esta última faz do corpo da figura o lugar de entropia de um sistema elaborado sob a égide do neoclassicismo e dos próprios preceitos militares (um se alimenta do outro), sob a vigilância de uma sintropia gestual. A dança alterna um impulso por movimentos estridentes e exagerados e bruscas tentativas de interrompê-lo, de contê-lo numa sobriedade que, nesse momento, já não se sustenta. A dinâmica entre lei e desejo que viu-se até aqui é evidenciada pela forte dualidade coreográfica. Entre um polo e outro, Galoup ameaça cair. Caso não estejamos forçando o olho, o desequilíbrio ressoa a posição intermediária do personagem de nem permanecer completamente no rigor da disciplina e nem no desejo integral.

O que se descreveu até o momento sobre a sequência vale apenas para o início da performance. Ao final dela, o vestígio de sobriedade abandona inclusive o rosto, último bastião da contenção, última máscara a cair. A figura é completamente conduzida pela pulsão e a dança termina com movimentos espasmódicos, desmesurados: o corpo se contraindo e se expandindo, curvando-se para frente e lançando os membros e cabeça para trás, com os braços descrevendo aros nos ar em várias direções, enquanto os joelhos estão sempre em flexão e distensão. Pulando e rodopiando, Galoup se projeta contra as paredes e contra o solo. A performance, impregnada por pathos, remonta e ultrapassa o que foi dito mais cedo sobre a motricidade sincopada e a intensidade febril de Chaplin. ${ }^{243}$

A disposição reflexiva e processual da dança de Galoup deve ser entendida tanto pela liberação de uma energia que até então vinha sendo sutilmente contida no filme, portanto como uma certa passividade do corpo em recebê-la, mas também pelo seu lado ativo. Para além de explicitar um drama, a dança é uma resposta natural a uma aflição, ${ }^{244}$ tal como acontecia com outro personagem de Denis Lavant, Alex, em Sangue Mau. Ali, embalado por

\footnotetext{
242 Paul Valéry, 2013.

${ }^{243}$ Ver comentário sobre $O$ circo no Capítulo 2, em Personagens físicos.

${ }^{244}$ Para Paul Souriau, em qualquer tipo de exercício físico no qual se emprega muita energia, todas as funções do corpo se aceleram, o coração bate mais forte, a respiração aumenta de frequência e de profundidade, e se experimenta um sentimento de bem-estar similar à embriaguez. Assim como toda sensação muito viva provoca movimentos convulsivos, contrações musculares bruscas e violentas, mover-se, é a resposta natural do corpo às indisposições que afligem o ser. Dito de outro modo, o movimento até pode ser provocado pela dor, mas a ela serve de anestésico. Ver Paul Souriau, L'esthétique du mouvement, Paris: Elibron Classics, 2006.
} 
Modern love, de David Bowie, ele corria com o corpo vergado sobre si mesmo, socando-se, explicitando uma sensação penosa, tentando expulsar algo dentro de si. A coreografia violenta era uma reação ao sofrimento e uma tentativa de transformar o estado e o ânimo pelo jogo de ritmos e formas que o corpo realizava. Seja em Sangue mau, seja em Bom trabalho, a performance de Lavant corrobora o que Laban falava sobre o movimento na dança não se prestar à orientação no mundo exterior, mas aperfeiçoar a orientação do homem em seu mundo interior, onde os impulsos surgem e buscam uma válvula de escape. ${ }^{245}$

Reorientar o corpo é outra forma de dizer o que mais cedo tomávamos como um desvio. A entropia que vem desarranjar uma naturalidade da figura para então submetê-la a um regime imprevisto é uma resposta. A dança de Galoup está além de um simples artifício. Trata-se da performance de um sargento de meia-idade cujo desejo e o ciúme (a margem de ambiguidade é grande) por um soldado mais novo o fizeram ser dispensado do único lugar que o acolhia, logo, é também uma investida contra um código moral, militar, pautado numa masculinidade heterossexual e viril, que até então o subjugava. Com efeito, a investida é orientada por um modo de elaboração de si mesmo, uma forma de subjetivação que se revela pela estética da dança e cujo efeito é político. ${ }^{246}$ A figura humana assume pela primeira vez suas próprias rédeas e ocupa uma posição que até então lhe era impensável, subvertendo ou pelo menos acenando contra uma normatividade de gênero. A dança é o mais próximo da liberdade num filme em que desde o princípio, das poses ao movimento, regrou o corpo.

\subsubsection{A moral subversiva do burlesco}

Primazia da performance física e da gestualidade em relação à oralidade, acento sobre um universo tangível, movimento do corpo secretando e espacializando o drama. A despeito das distâncias, os paralelos entre o cinema burlesco silencioso e os filmes contemporâneos de Denis, Rodrigues e Ming-liang existem. Dessa vez, tentar-se-á estabelecer um último, pautado no que foi exposto há pouco sobre a violação de uma ordem. Com um adendo: mira-se sempre a reconstrução do universo segundo novos parâmetros.

Primeiramente, é necessário entender as leis que geralmente regem o mundo burlesco, com ênfase, não custa lembrar, na geração da década de 1920. Àquela época, já não era a magia das trucagens dos filmes de Méliès e tampouco os simplórios motivos cômicos dispostos num encadeamento sintagmático, como nos chase films, a coordenar as ações. A

\footnotetext{
${ }^{245}$ Rudolf Laban, Domínio do movimento. São Paulo: Summus, 1978.

${ }^{246}$ Os termos podem remeter a Michel Foucault, mas a correspondência não segue além do mero acaso.
} 
narrativa de teor naturalista que despontava na década de 1910 e encontraria seu acabamento em Griffth também não justifica o universo paralelo ali criado. O princípio sobre o qual se fundamenta o gênero encontra sua formulação na $\mathrm{gag}$.

A noção é ampla e carrega consigo uma série de desdobramentos, mas para conferir-lhe linhas gerais, pode-se dizer que implica a ruptura da ordem das coisas, o desvio capaz de fazer nascer novas trajetórias dentro da escala programada, o mais longo caminho para ir de um ponto a outro, perturbando todo tipo de desenvolvimento previsível pelo espectador. ${ }^{247}$ A gag opera por meio da cisão entre o esperado e o realizado, reorganizando a ação conforme novas combinações e, claro, almejando o riso a partir da surpresa ou da sabotagem.

Em seu ensaio sobre o riso, Bergson formula uma regra geral sobre a comédia no teatro que vai ao encontro dos mecanismos da gag no cinema burlesco: "obteremos um efeito cômico ao transpor a expressão natural de uma ideia para outra tonalidade". ${ }^{248}$ Os meios de realizar esta transposição são numerosos e variados, permitindo assumir uma ampla gama de graus. Funcionam pela interferência ora na magnitude, ora no valor das coisas. Podem ir, por exemplo, desde o exagero, quando as pequenas coisas se tornam grandes, até a degradação, quando o virtuoso é retratado como medíocre e vil. A transposição mais geral para Bergson, contudo, é aquela entre o real e o ideal: do que é com o que deveria ser.

A gag envolve um tipo de caráter performativo, imanente e, para além da finalidade cômica, é singular em sua maneira de criar imagens abertas ao lúdico, de instaurar uma nova ordem que profana as regras vigentes do jogo, reinventando a realidade ao mesmo tempo em que pode assumir a forma de questionamento sobre o sentido (histórico, político, social) dado até então, provocando o pensamento crítico. ${ }^{249}$ A figura humana do burlesco se aproveita desta licença poética criada pela gag e inerente ao próprio gênero para recorrer ao gesto como forma absoluta disposta em tempo próprio, suspenso, apta a recriar o mundo pela atitude mais banal.

O apreço pela fisicalidade é o motivador mesmo do fantástico, suficiente para que nos filmes burlescos sopre o mesmo vento que Baudelaire identificou no cômico absoluto: uma brisa maravilhosa que faz os personagens se moverem extraordinariamente, introduzindo-os à força numa nova existência. ${ }^{250}$ Uma brisa que se transforma em vertigem circulando no ar, permitindo aos seres lidar com os desastres e com o destino tumultuoso a partir da

\footnotetext{
${ }^{247}$ Emmanuel Dreux, Le cinema burlesque ou la subversion par le geste, Paris: L'Harmattan, 2007.

${ }^{248}$ Henri Bergson, O riso: ensaio sobre a significação do cômico, Rio de Janeiro: Zahar, 1983, p. 59.

${ }^{249}$ Manuel Garin, Op.cit.

${ }^{250}$ Charles Baudelaire, Escritos sobre a arte, São Paulo: Hedra, 2011.
} 
pantomima, essa ciência dos movimentos que para Baudelaire era a própria depuração da comédia, sua quintessência, o elemento cômico puro e concentrado pelo qual as farsas adquiriam uma realidade singular.

Postas estas linhas gerais, vejamos como o corpo adquire figuração única no gênero. A primeira delas é sua relação com o espaço. O cenário deixa de ser simplesmente um cenário a situar uma ação e uma ambiência com peso simbólico e dramático para se tornar um elemento ativo, passível de ser remodelado conforme a contínua interação com a figura humana. Em $O$ circo, quando Chaplin tenta escapar da polícia, sua fuga vai além de uma travessia indistinta do cenário, como nos chase films. Trata-se principalmente de ocupá-lo, de conhecer suas regras e por fim de dominá-lo para então tirar vantagem sobre o perseguidor. $\mathrm{Na}$ cena da mirror maze em um parque de diversões, os reflexos criados pelos espelhos permitem a Chaplin apossar-se figurativamente do espaço. O batedor de carteiras e logo em seguida o tira chegam ao lugar, mas ao depararem com a imagem do cômico desdobrada em inúmeras réplicas são incapazes de distinguir a cópia do referente (Fig. 167).

$\mathrm{Na}$ mesma perseguição, o personagem disfarça sua presença ao agir mecanicamente, equiparando-se a um dos bonecos do parque de diversões. A lógica implica a articulação e a adaptação ao espaço em que se encontra por meio das quais será possível dominar a situação. Ao mesmo tempo em que mantém o disfarce de autômato, aproveita para criar padrões de movimento pelos quais irá golpear o ladrão de carteiras que o perseguia (Fig. 168).

\section{Fig. 167-168}
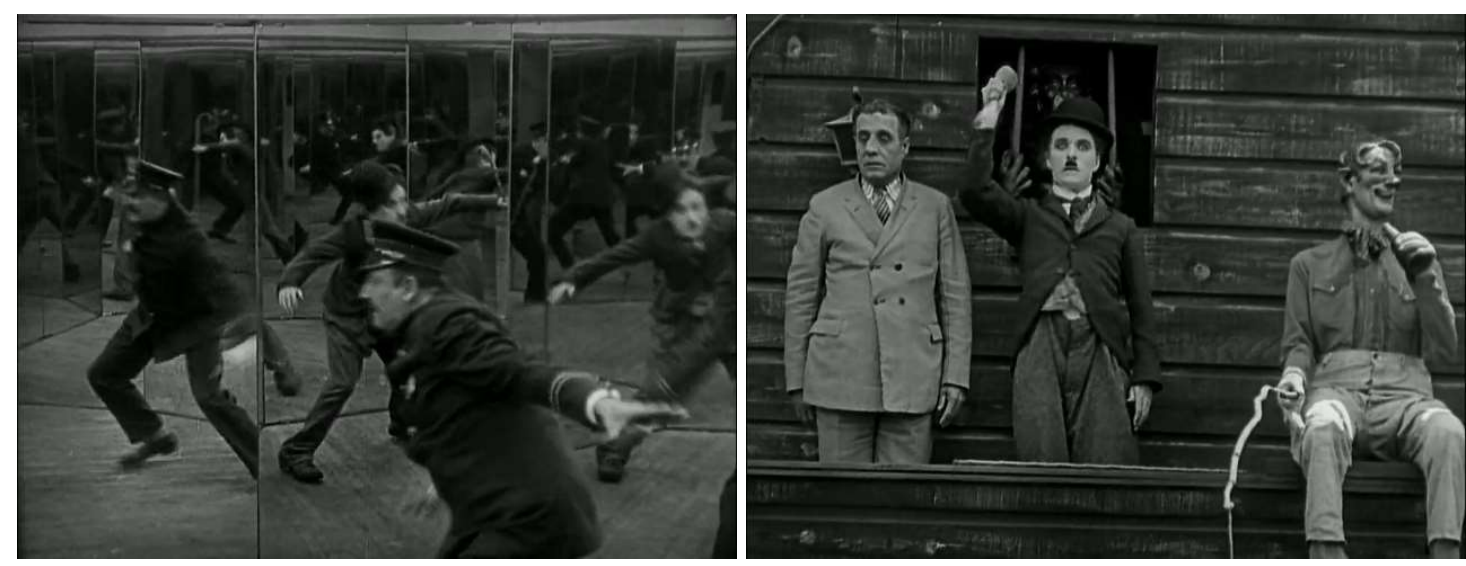

Tal como um imigrante que consegue adaptar-se a quaisquer condições, manipulando o que tem no entorno conforme seus interesses, fazendo emergir do caos um cosmo 
antropocêntrico em que é o coração de uma nova ordem, ${ }^{251}$ Chaplin submete o mundo ao seu gesto. Sua chegada ao circo, depois da perseguição, mostrará justamente isso. Fugindo do policial, ele entra no picadeiro em meio ao espetáculo encenado e, sem o interromper, recria-o a partir de sua presença. Ao chegar, sobe sem dificuldade na esteira em movimento onde os palhaços se apresentam e, ali, livra-se do guarda, que sem a mesma destreza tenta em vão adaptar-se à máquina. De modo similar, invade o número de mágica, domina suas regras e finalmente o rearranja segundo suas próprias conveniências. Carlitos intensifica a desordem até onde for possível para, ao fim, executar o gesto onipotente pelo qual tudo irá resolver, realizando por vezes o inexequível.

Ao ser convidado para trabalhar no circo, será ordenado a Chaplin que siga os sketches dados aos demais palhaços, predeterminados antes pelo diretor do espetáculo. Mas quando tenta ensaiar e seguir as regras, inverte toda a ordem a partir do improviso, desfaz o número para criar outro completamente distinto. A natureza de seu gesto é essencialmente subversiva. Diegeticamente, o sucesso que seu personagem faz ao entrar no circo vem justamente da espontaneidade, de burlar o esperado, cindir toda a lei distraidamente sem que perceba a potência de suas ações. Com a chegada ao circo, o filme reflexivamente explicita a diferença que reside entre o número encenado, roteirizado, e a liberdade criadora da gag, que só se constrói pela sabotagem, como um ato transformador, incapaz de ser previamente planejado. A reflexividade de $O$ circo está em ser um filme burlesco que tematiza o funcionamento da gag e mostra como a figura humana a opera e dela se nutre para fortalecer o alcance do gesto.

A figura chapliniana deve ser pensada não apenas pelo viés destrutivo, mas igualmente pelo cosmogônico. Seus gestos (re) significam, esvaziam os objetos do sentido original para descontextualizá-los e encarná-los sob outras designações, colocando-os em um novo sintagma. Diante de sua presença, o universo parece residir sob lógica similar ao readymade. Mas em vez de objetos ordinários elevados à categoria de obras de arte pela escolha do artista e não necessariamente pela anuência a critérios estéticos previamente determinados, como Marcel Duchamp preconizava, Chaplin depõe o significado culturalmente atribuído aos objetos e os lança num constante devir em que a ontologia é preservada, mas as determinações particulares alteradas. O mínimo contato que trava com um objeto desperta a dimensão lacunar das coisas, convoca as virtualidades da matéria.

Carlitos boêmio (One a.m, 1916) é todo calcado sobre esta dinâmica em que nada é o que parece e nenhum ser ou coisa é enregelado em formas fixas, mas fluido, intimamente

\footnotetext{
${ }^{251}$ Fabrice Revault D’Allones. “L'homme burlesque du cinéma (de Chaplin à Keaton et Langdon)”, in Jacques Aumont (org.), 1995, p. 53-73.
} 
dependente dos usos que dele se faz. No filme, os objetos inanimados de uma casa ganham vida com a chegada de Chaplin. A escada que leva ao primeiro andar se torna uma montanha tão íngreme que sua angulação às vezes beira os $90^{\circ}$, onde o solo é escorregadio, sem atrito, o caminho até o alto, sinuoso, e o cimo se abre para um despenhadeiro. Escalá-la exige as mesmas precauções que um alpinista deve tomar em seu exercício: aparelhar-se com bastões, piolet, corda de segurança, capacete e mochila. Ao atravessá-la, outros obstáculos aguardam Chaplin, tal como um relógio, cujo movimento pendular golpeia quem tenta passar e chegar até o corredor. O quarto da casa é o destino final que motiva esta micro odisseia em que, em vez de mil tormentos levados ao homem pelas mãos dos deuses, é o próprio mundo físico imanente contra o qual é preciso lutar. Quando finalmente alcança o cômodo, fatigado de tantas agruras, o que o espera é um penoso combate com sua cama, objeto indomável, que ora assume a forma de porta giratória, ora a de touro mecânico.

\section{Fig. 169-170}
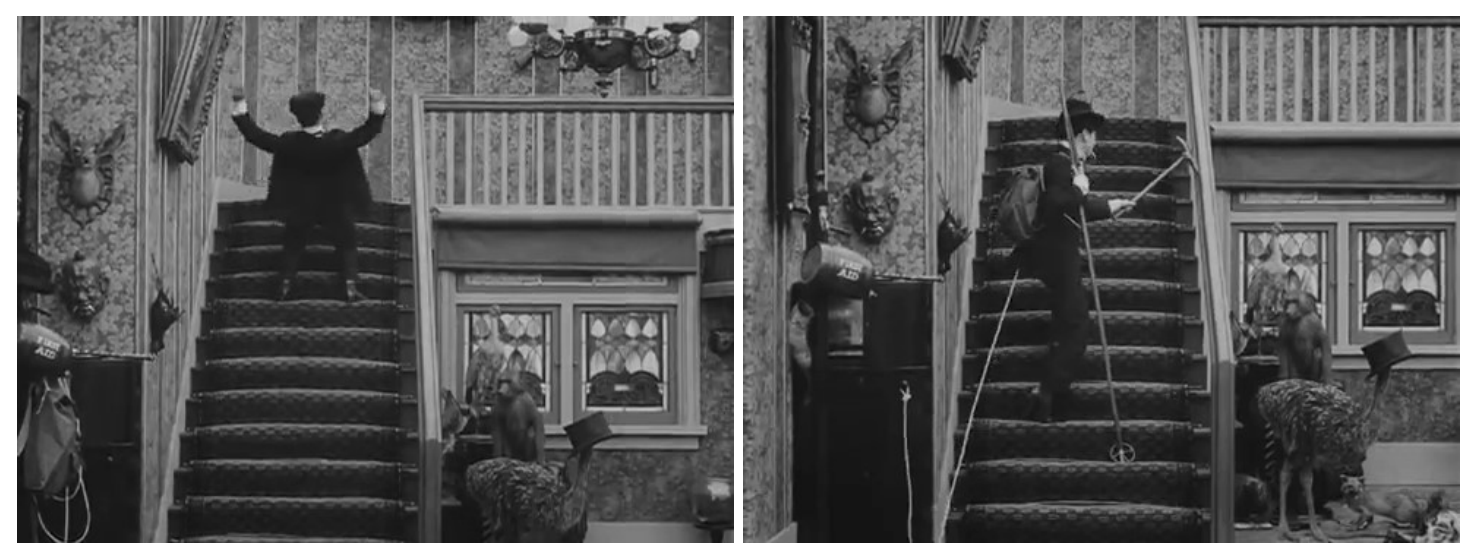

Descrevemos uma série de transformações fantásticas, mas, visivelmente, a casa e seus objetos continuam com um aspecto natural (Fig. 169-170). A vida que os insufla e cria as situações mencionadas é produzida unicamente pelos gestos da figura humana. $\mathrm{O}$ contato do corpo de Chaplin com o espaço e os seres inanimados parece despertar uma espécie de animismo. Não existe nenhuma montanha na casa, mas a postura que a figura assume ao subir a escada, inclinando-se como se sob o efeito da força da gravidade, gera a sensação visual de estar numa superfície mais íngreme do que realmente está. Trata-se nesse momento, como em outros, de recorrer a atitudes e a posições pelas quais se sugere o latente, o sub-reptício no interior do próprio visível.

Carlitos boêmio é um dos exemplos em que Chaplin, ao compor sua figura, seu "eu", não mensura a experiência real pela régua do espírito, mas constitui sua presença entre/a partir 
das coisas com as quais lida. A espessura do mundo é modulável, só surge do embate direto e do elo que se estabelece entre a figura e o seu entorno. Chaplin desenvolve ali um corpo fenomenal, no qual a fronteira edificada entre sujeito e objeto cede lugar ao nó górdio entre ambos. Cada gesto carrega em si um lado ativo, transformador da matéria, desbravador de sua natureza lacunar, e ao mesmo tempo passivo, aberto à ação das coisas sobre sua figura.

A possibilidade de extrair o subterrâneo preservando o realismo, de transfigurar o espaço e a matéria, operando a translação de sentido dos objetos, passa necessariamente pela embriaguez da figura, portanto, por sua percepção alterada. Um dos grandes méritos de Chaplin é representar esse fenômeno unicamente pelos movimentos. O estado é dado a ver pelo que fisicamente/visualmente o compõe. Sem planos subjetivos simulando o olhar, sem câmera em movimento mostrando o mundo a girar e, sobretudo, sem a voz embargada de um bêbado, sua condição é figurada pelo movimento e pelo contato com o espaço e os objetos. Só existe transcendência na imanência, a radicalidade da figura se dá no reino sensível, concretamente, por cada átimo do movimento corporal.

Não é difícil imaginar o porquê do alcance ilimitado do gesto de Chaplin - e dos cânones do burlesco, em geral - ter maravilhado os surrealistas na década de 1920. Nomes como Robert Desnos, Louis Aragon, Salvador Dalí e Paul Gilson escreveram a propósito da poesia devastadora dos seus filmes, e também dos de Langdon, Senett, irmãos Marx, entre outros. O burlesco aproximava-se das preocupações estéticas do surrealismo e de outras vanguardas artísticas pelo que há pouco comentamos a respeito de Chaplin: a criação de imagens insólitas, de um senso inédito para reinventar o universo no seio do próprio real. ${ }^{252}$

Se para Carlitos, tratava-se de assenhorar-se pelo gesto, em Keaton, além da fuga ou travessia contínua, é o funcionamento mecânico do corpo que assegura a sobrevivência e impede a catástrofe sempre iminente. ${ }^{253}$ A possibilidade de aliar o orgânico e o mecânico para lidar com o universo objetal permite a Keaton transformar a sua própria figura por via de uma dinâmica que faz do corpo um readymade apto a ser reaproveitado constantemente sob novas condições. Em Marinheiro por descuido, vê-se isso numa gag cuja simplicidade é tão grande quanto o seu alcance criativo para resolver um problema. O personagem de Keaton está na

\footnotetext{
252 “A fascinação dos surrealistas pelo cinema burlesco vem de que esta nova poesia emana justamente do prosaísmo de um corpo ou de uma silhueta, do concreto de um objeto, da banalidade mesma do décor. As desordens de todos os tipos, as imagens as mais insólitas, os encontros os mais fortuitos vistos pelos surrealistas nos filmes burlescos não separavam jamais do verismo da imagem, para fazer nascer o maravilhoso no próprio real, o inesperado no cotidiano, 'o estranhamento em plena familiaridade', para retomar uma expressão de Petr Král.” Emmanuel Dreux, Op.cit., p. 43.

253 Essa sobrevivência inclui o desafio à autoridade. Como nos filmes de Mack Senett, não é raro que a permanência no mundo dependa do confronto direto com a polícia, tal como veremos em Cops e Police (1916, Charlie Chaplin), entre tantos outros exemplos.
} 
praia, vestido com um escafandro e se dirige para um barco em alto mar, juntamente com Betsy O'Brien. Quando alcançam determinada profundidade, os dois se abraçam, Keaton cai de costas para a água e flutua. Betsy senta-se sobre ele e rema, aproveitando-o como um barco improvisado (Fig. 171). A prática é similar à de College (1927), quando, em meio a uma competição de canoagem, o personagem de Keaton percebe que acidentalmente quebrou a quilha da embarcação. Sua solução de reparo é amarrar o objeto nas costas e posicionar o próprio corpo na traseira da canoa, fazendo de sua figura uma prótese da canoa. A operação se repete também em $O$ enrascado (Cops, 1922), na cena em que Keaton faz de uma escada pendurada num muro uma gangorra e, depois, uma balança humana pela qual tentará se livrar dos policiais que o perseguem.

Fig. 171-172
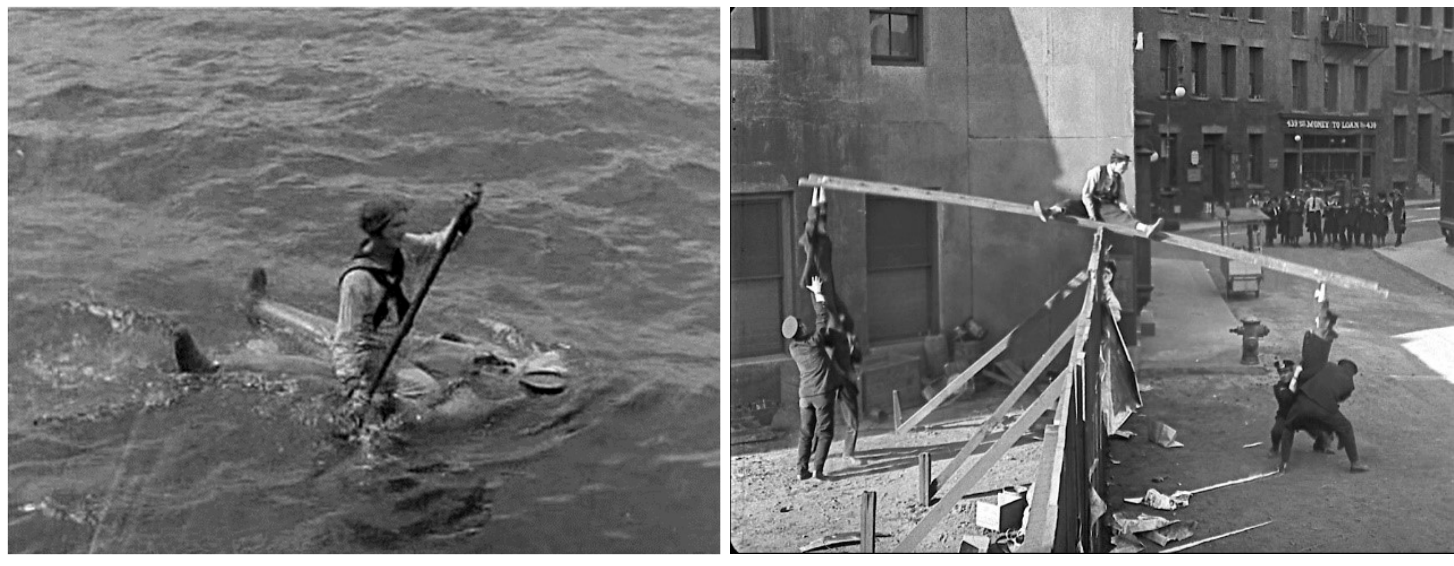

As soluções de Keaton para garantir sua adaptação ao estado de coisas em que se encontra têm como uma das pedras de toque a aproximação com o universo da mecânica, o que se dá em duas direções. Uma delas é pelo funcionamento aparentemente autômato (como em Ming-liang) do corpo, dada a sua obsessão em seguir em frente e mover-se como alguém inconsciente - impressão que logo se desfaz diante da volição e do objetivo a ser cumprido como motores de suas ações. Se Keaton é um autômato, o é com a consciência dos benefícios que daí advém. A segunda direção é pela simbiose ou dinâmica protética entre a figura humana, a máquina e os objetos, tendo por corolário a reconfiguração da corporeidade.

As fortunas literária e filosófica em torno da emergência do autômato no século XVIII delimitam a primazia do sujeito pensante sobre a máquina ou, contrariamente, provocam a crise na concepção antropocêntrica pela dificuldade de estabelecer firmes critérios de 
distinção entre orgânico e o mecânico. ${ }^{254}$ Enquanto isso, os filmes de Keaton aproximam os dois reinos não para questionar suas respectivas naturezas, mas para estabelecer a necessidade de coalisão por meio da qual é garantido o direito básico perseguido a todo custo pelo seu cinema - como também pelo de Chaplin: o de estar no mundo. A força obstinada que modula a figura keatoniana como um corte retilíneo pelo espaço-tempo faz parte da confrontação com o real que marca o burlesco. Está em jogo um realismo que nada tem a ver com o do cinema clássico, em seus mais diferentes gêneros, mas que é caracterizado pela experimentação permanente realizada no contato imediato com "a realidade do mundo, com os corpos físicos, seres e coisas; um efeito de proximidade com o real material, objetal, tangível"255. Esse contato é capaz de manter o estranhamento e a opacidade de um universo sempre a descobrir. Como se falou de O fantasma, opera-se também no burlesco um empirismo eminente. No caso deste último, explora-se uma tangibilidade que diverge da concepção de conhecimento segundo a qual a dimensão sensível é uma forma de distorção; e que converge em direção à própria experiência da modernidade, quando o sujeito é exposto a choques físicos e perceptivos do novo ambiente urbano.

O cinema de Keaton talvez antecipe, em certa medida, a viragem que aconteceria nos anos 1960 a partir de livros como Man Plus, de John McHale. A obra marca a passagem da visão das máquinas como extensão do corpo humano para a do corpo como extensão do maquínico, originando as bases para concepção de hipercorpo no qual os domínios entre orgânico e não orgânico, máquina e bios, desaparecem. ${ }^{256}$ Similaridades à parte, ante o que se discutiu, não é possível enquadrar Keaton integralmente nem do lado do hipercorpo e muito menos daquele, advindo da medicina cartesiana, que encara as próteses como meros suplemento de uma fraqueza ou doença. A questão é a de buscar todas as condições possíveis para assegurar seu bem estar. Isso implica desde o uso da técnica pelo corpo (a casa de Scarecrow, a engenhoca de Marinheiro por descuido, o sistema de cordas de Marinheiro por encomenda) até o da simbiose com os objetos/máquinas, modulando o corpo pela dinâmica ready-made (a integração entre figura e motocicleta necessária para atravessar inexoravelmente o espaço em Sherlock Jr; a criação de uma balança humana em $O$ enrascado; a figura a funcionar como canoa em Marinheiro por descuido; Keaton acoplado à

\footnotetext{
${ }^{254}$ Moraes cita a teoria dos animais-máquinas de Descartes, segundo a qual a diferença capital entre o homem e a máquina seria a linguagem, a fala e a expressão dos sentimentos, posto que qualidades exclusivas do espírito. Por tal pressuposto, a filosofia cartesiana "torna inconcebível a possibilidade de a máquina existir independente do entendimento que a constrói”. Assim, o pensamento clássico, firmando seu teor humanista, dá superioridade ao sujeito pensante em relação à engrenagem. Ver Eliane Robert Moraes, Op.cit., p. 96.

${ }^{255}$ Fabrice Revault D'Allones, Op.cit., p. 56.

${ }^{256}$ José Bragança de Miranda, Corpo e imagem, São Paulo: Annablume, 2011.
} 
quilha na embarcação de Marinheiro por encomenda). A simbiose operada entre a figura, a ciência e a técnica acontece sem riscos para a materialidade orgânica e segue na contramão da ideia do corpo como superfície passiva de inscrição de forças, pois a mecânica é justamente o meio de assegurar a vitória do homem, reverter em seu benefício os distúrbios naturais a partir do cálculo das forças envolvidas; sempre em correspondência com o gesto. É um encontro com o maquínico que assegura o caráter antropocêntrico, longe de violá-lo ou de ser motivado por qualquer obsolescência do homem.

O burlesco, mesmo o da geração do cinema silencioso, é um gênero amplo. Restringir univocamente o alvo de sua subversão seria perder de vista as particularidades de cada obra. Contudo, em se tratando de um universo objetal, a reconfiguração do mundo passa muitas vezes pela tentativa de lutar por um espaço para a figura humana no seio e em rivalidade com a sociedade industrial. Para avançar um pouco além dessa constatação, citemos e leiamos timidamente um conhecido trecho de Marx:

Com a valorização do mundo das coisas aumenta em proporção direta a desvalorização do mundo dos homens. O trabalho não produz somente mercadorias; ele produz a si mesmo e ao trabalhador como uma mercadoria, e isto na medida em que produz, de fato, mercadorias em geral.

Este fato nada mais exprime, senão: o objeto que o trabalho produz, o seu produto, se lhe defronta como um ser estranho, como um poder independente do produtor. O produto do trabalho é o trabalho que se fixou num objeto, fez-se coisal, é a objetivação do trabalho. A efetivação do trabalho é a sua objetivação. Esta efetivação do trabalho aparece ao estado nacional-econômico como desefetivazação do trabalhador, a objetivação como perda do objeto e servidão ao objeto, a apropriação como estranhamento, como alienação. ${ }^{257}$

$\mathrm{Na}$ sequência do texto, o autor põe em relação progressiva e ainda mais direta o trabalhador e o objeto que o produziu: quanto mais o primeiro se desgasta no trabalho, desprovendo-se de si próprio, em depauperamento de sua vida interior, tanto mais poderoso se torna o mundo dos objetos por ele criado. O investimento de sua força de trabalho e de sua própria vida são objetificados em um produto que não lhe pertence, que lhe é estranho. A alienação continua em outros níveis: "quanto mais o trabalhador produz, menos tem para consumir; que quanto mais valores cria, mais sem-valor e indigno ele se torna; quanto mais civilizado seu objeto, mais bárbaro o trabalhador". Desse modo, a progressão é orientada por

\footnotetext{
${ }^{257}$ Karl Marx, Manuscritos Econômicos-Filosóficos, São Paulo: Boitempo Editorial, 2004, p. 80. A lembrança desse texto de Marx devemos a sua citação, fulgurante, em um ensaio em que Salzstein realça o valor nos objetos na pintura de Matisse - artista, aliás, contemporâneo a Chaplin e a Keaton. Ver Sônia Salzstein, "Uma pintura de interiores", in Matisse, São Paulo: Cosac Naify, 2009.
} 
dois eixos que se afastam diametralmente, um respondendo ao outro: o investimento é acompanhado de uma alienação; quanto mais se engaja física e intelectualmente, mais se é privado do que foi investido. Ao trabalhador resta a expropriação, a deposição de si mesmo. Dentro da cadeia exposta, o produto concreto, a marca sensível do processo, e por isso mesmo o portador de um estranhamento e de uma hostilidade frente ao trabalhador, é o objeto.

O comentário sumário sobre Marx permite nuançar um pouco mais o trato dado aos objetos em Chaplin e Keaton. A aproximação entre o filósofo e os realizadores não é direta, naturalmente. Uma diferença rechaça desde o princípio um uso indevido: os filmes analisados ou citados sequer lidam com os trabalhadores industriais, a quem Marx situa no centro do processo de alienação em relação aos objetos. A remissão ao autor tem espaço mais singelo: depois dela é difícil não vislumbrar na pletora de signos industriais que ocupam os filmes de Chaplin e Keaton o primado do mundo objetal, a marca de uma civilização urbana em que o ser humano é a todo instante atravessado e ameaçado pelo mundo das coisas.

A soberania gestual de Chaplin e a dinâmica protética de Keaton são formas de lidar com o universo intrínseco àquela sociedade, mormente pela ressignificação dos objetos e pelo usufruto da mecânica. Carlitos emulando um boneco automático em $O$ Circo, defrontando o relógio e os demais objetos da casa em Carlitos boêmio; assim como Keaton em suas diferentes apropriações de uma lógica mecanicista e em sua dinâmica protética frente aos objetos (automóveis, motocicletas, escafandro, engrenagens etc.) que encontra pela frente: em todos os casos, os personagens reivindicam uma posição ativa e transformadora em face do que na sociedade industrial é uma das marcas da desvalorização e depauperamento do humano (e em particular do seu corpo), a cultura dos objetos. A moral subversiva passa então pela potencialização do corpo enquanto um meio capaz de enfrentar uma civilização industrial e capitalista, ainda que endereçando-se modestamente às miúdas peças que assinalam a sua existência, os objetos, e ainda que para desfrutar de algo muito pequeno, mas valioso: a sobrevivência no mundo moderno.

\subsubsection{Economia libidinal}

Mas por que fazer um desvio pelo cinema burlesco? Frente a um cinema calcado entre outras pedras no erotismo, as façanhas dos personagens de Chaplin e Keaton parecem pudicas demais, distantes demais. É verdade também que as leis regentes dos filmes contemporâneos aqui analisados não operam segundo o mecanismo da gag - salvo muito pontualmente em cenas específicas de Ming-liang. Entretanto, em ambos os casos os corpos são figurados a 
partir da imediatidade de um universo apresentado a tudo o que faz referência a sua tangibilidade, à superfície dos objetos, das paredes, da natureza, dos seres e dos corpos. Para além do que se chamou de uma pele do mundo, o que o burlesco e a gag permitem entrever é que a valorização da superfície acontece simultaneamente a um movimento que a coloca sob suspeita, que investe contra a sua aparência em prol de outro regime. No cinema contemporâneo, esse regime alternativo pode tanto ser a revelação de um universo mais real e profundo (o âmago) como, pelo contrário, resultar numa distorção, na criação de uma segunda ordem ainda mais ilusória que a primeira (um véu). Em todo caso, presume-se uma transformação cuja causa está diretamente vinculada ao lugar pleiteado pela figura humana.

A perturbação nos filmes de Denis e Rodrigues se dá pela marca que um corpo deixa em outro, isto é, pelo afeto. Essa primeira exposição ao que lhe é estranho e exterior desencadeia uma nova dinâmica ou intensifica uma já existente. Conhecer um rapaz é o gatilho para a obsessão de Sergio e o que intensifica o processo de animalização que passa; a chegada de Sentain inicia a crise de Galoup na Legião Francesa, que não é precisada se por ciúmes ou se por desejo sexual. Até que o próprio corpo dos personagens sofra os efeitos de um acúmulo pela metamorfose, no final dos respectivos filmes, pequenos eventos são sintomáticos do que está por vir, precipitando algo a atravessar os corpos, sejam eles humanos ou não.

Uma cena banal de $O$ fantasma revela o entreato, a existência dessa força anterior às transformações que estão por vir. Nela, Sergio e Fátima estão no intervalo do expediente de trabalho. Ela dirige um pequeno carro enquanto ele está na carroceria. Não estão indo para nenhum lugar. É apenas mais uma sequência de dispêndio de energia: o automóvel vai e vem pelo espaço descrevendo uma trajetória sinuosa, enquanto Sergio grita para que ela acelere mais. Simples brincadeira de adolescentes? Ali aparentemente se engendra um processo de contaminação entre matérias que continua na próxima cena, com Sergio e Fátima brincando com um objeto fálico, pressionando-o contra o corpo repetidamente. Ele inicia o jogo. Posteriormente, ela toma a peça para si e tenta fazer o mesmo movimento. Ao fim, ele se senta atrás dela e a ajuda a pressionar o objeto contra o corpo, numa frequência rítmica cada vez mais intensa. O ruído provocado pelo material sugere o atrito de dois corpos transando. Ora, em um filme que a todo momento evoca o sexo, a cena, com a presença fálica do objeto, a posição e o gesto conjunto do casal, é mais do que suficiente para sugerir que um jogo inicialmente inocente é progressivamente impregnado pela libido (Fig. 173-178). A suspeita não é absurda e nem pode ser descartada uma vez que logo após a brincadeira os dois vão para o chão, Sergio lambe o rosto de Fátima e a ação termina com o sexo: no próximo plano, 
os dois aparecem no quarto dele na manhã do dia seguinte, vestindo-se. As imagens da transa, a única heterossexual do filme, são eclipsadas pela elipse.

Fig. 173-175
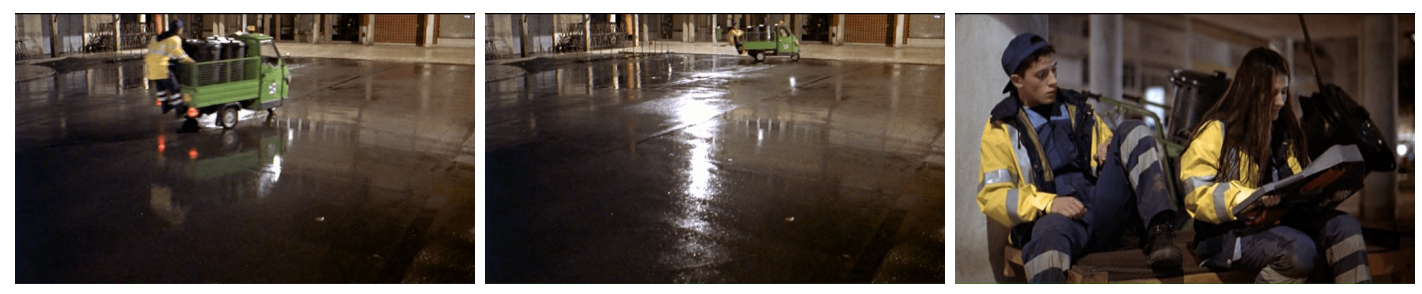

Fig. 176-178
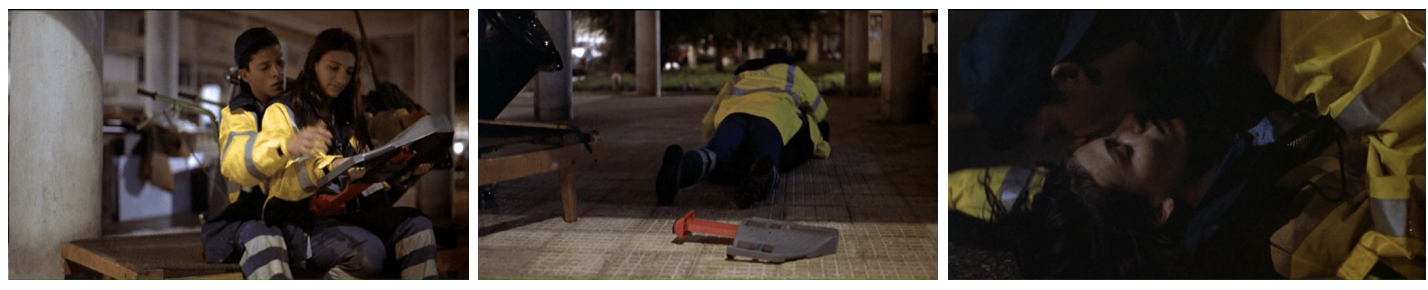

O ziguezague do carro no início da sequência sinaliza a existência de uma energia cuja modulação envolve conjuntamente o corpo das figuras e o automóvel, as matérias orgânica e inorgânica. A cena seguinte, com o objeto fálico, dá prosseguimento a essa espécie de comunicação entre os seres, indiferente a sua singular ontologia. Efetivamente, não se trata de uma total simetria. Mas em todo caso, apesar da constituição díspar de uma e de outra espécie, elas acolhem e partilham uma mesma energia, cuja identidade será revelada ao final da sequência. Mesma configuração se vê nas cenas em que Sergio faz carícias na motocicleta como se lidasse com um ser humano; ou nos momentos já comentados em que faz da ducha um objeto a contribuir para o seu prazer na masturbação; quando lambe as paredes, como se estivesse diante de quem por ali passou; quando o corpo se conjuga à raia da piscina, e assim por diante. Os espaços e os objetos já não são em si mesmos, mas o que o gesto deles consegue extrair. A sequência que inicia com o carro e termina com o sexo evidencia, portanto, o que está presente desde pelo menos a análise do programa tátil de O Fantasma: o filme é calcado em uma economia libidinal que atravessa e contamina indistintamente figuras, objetos e espaços convertendo-os em vetores pelos quais um impulso é capaz de ser transmitido de um ser ou de um reino a outro, em instrumentos de vazão ou de usufruto do desejo sexual dos personagens. Bom trabalho não é completamente estranho a essa lógica. 
Fig. 179-182
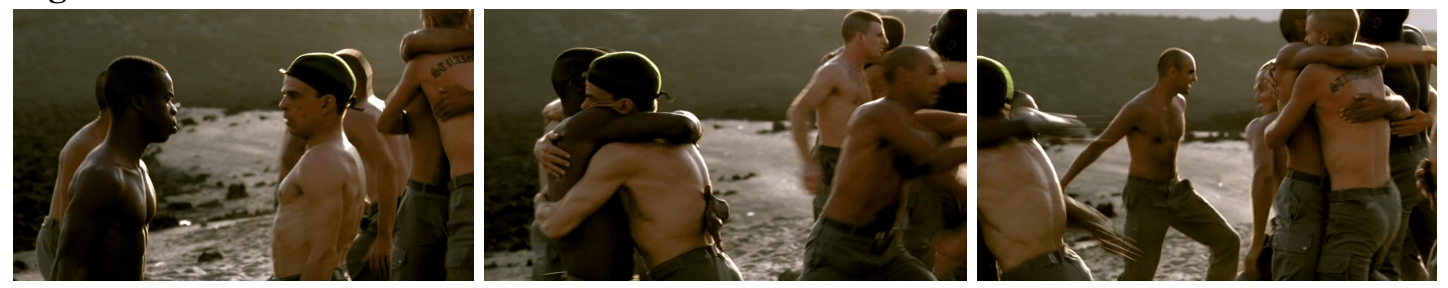

Fig. 182-184
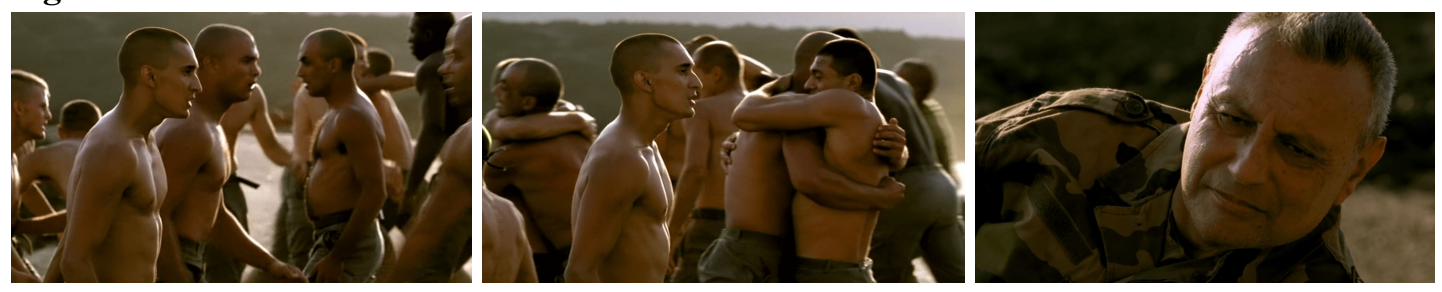

À explicitação de O Fantasma, o filme de Denis prefere a sutileza da ambiguidade. Os treinamentos da Legião são mostrados a partir de um olhar documental que se confunde com a pulsão escopofílica. Num dos exercícios, cada soldado está parado diante do outro, olhar fixo e postura rígida. Bruscamente, lançam-se em direção ao seu par e o abraçam com força, enquanto urram. Com o mesmo impulso, desenlaçam-se e voltam à posição inicial para mais uma vez repetir o gesto, numa performance que muito vagamente ecoa os abraços feitos e desfeitos de Café Muller (1978), de Pina Bausch. ${ }^{258}$ A encenação é conformada a partir de um plano sequência que desfila da esquerda para a direita e vai povoando a imagem com um enxame de corpos que se atraem e se repelem violentamente, enquanto se escuta o atrito de um contra o outro e enquanto uma luz poente reluz sobre suas epidermes, aureolando-as sutilmente. Como a simultaneidade entre cada par só existe por coincidência, o movimento fluido da câmera é tensionado pelos gestos assíncronos que instauram um ritmo fractal, com pequenas suspensões seguidas de choques sem frequência definida. $\mathrm{O}$ espaço é preenchido por uma continuidade disjuntiva e os corpos se aproximam e se afastam até os primeiros sinais do cansaço, sem contudo pararem.

Um mero treinamento militar é revestido de afetividade e sensualidade. A natureza dos gestos e particularmente o seu caráter cíclico desnaturalizam a dimensão marcial e a convertem em um ritual em que os corpos são livres para se amalgamar na mesma medida em que obrigados a se afastar, como se diante de um interdito prestes a ser violado para logo em seguida se regenerar. A coreografia desnuda a tensão sub-reptícia e libidinal que aflui sob cada um dos contatos entre os soldados e sob cada uma de suas aparições, explicitando o que a doutrina militar vela sob o código moral.

\footnotetext{
${ }^{258}$ Não custa lembrar que Claire Denis chamou um coreógrafo de dança contemporânea, Bernardo Montet, para conceber os exercícios dos legionários.
} 
Como em O Fantasma, o desejo sexual ronda os corpos e percorre os espaços desviando as menores ações em direção a outro domínio, ou nelas identificando a verdadeira força motriz. Diferentemente do filme de Rodrigues, a nova dimensão que se revela no seio das relações entre os corpos depende de um elemento externo, fora do núcleo que participa da ação: o olhar. O balé de corpos é endereçado a um sujeito diegético que irá corroborar a mudança de regime do treinamento, o comandante Bruno Forestier. No último plano da sequência (Fig. 184), seu olhar carrega ainda mais o treinamento com uma dimensão sensual, exacerbando o erotismo já presente na gestualidade dos soldados. Ainda que o personagem seja opaco e parcialmente insondável ao longo do filme, um ou outro diálogo, um ou outro olhar, mostra que tanto quanto Galoup, Forestier não é incólume à trama dos desejos. Está aí a base para a ressignificação do que inicialmente é um treinamento. O desvio de uma ordem para outra acontece por uma reação em cadeia, uma ordem dos afetos na qual um corpo marca o outro sucessivamente: primeiramente o de um soldado sobre o seu respectivo par, depois os dos pares entre si a partir da coreografia conjunta e, por fim, alinhavando e carregando ainda mais de afecção o que está em cena, deslocando-a de seu significado original, efetivando a dimensão do desejo, o olhar de Forestier.

Noutras sequências, e isso já foi sugerido, é o ponto de vista da câmera que converte os exercícios dos legionários em potência sensual, com a objetiva a perscrutar as curvas das figuras, seja enfatizando o volume corporal sob as roupas, seja direcionando a atenção para as partes desnudas, em especial as nádegas e as pernas. Em todo o filme, o olhar, da câmera ou dos personagens, estabelece um pacto malicioso frente aos corpos em cena. Dito isso, podemos caminhar rumo a um fechamento.

Vimos que o cinema burlesco de Chaplin e Keaton é capaz de reconfigurar o que estava no entorno da figura humana a partir da gag. Objetos são insuflados com vida, animados e instrumentalizados de acordo com as necessidades dos personagens, num livre devir da matéria que os constitui. O mesmo para o espaço, suscetível às modulações do gesto demiúrgico. O que é representado está num constante deslocamento pautado na virtualidade. Sob a aparência dos seres reside a potencialidade de seus novos usos e configurações; tudo em conformidade com uma estética realista. Ora, a figuração dos corpos nos filmes de Rodrigues e Denis envolve disposição similar em reestruturar a ordem na qual os personagens estão inseridos, para isso operando um deslocamento de expectativa, uma disfunção entre a aparência e a essência do que está em cena. Ou um redobramento das aparências? Em todo caso, como no burlesco, o desvio depende de uma investida da figura humana, um gesto capaz de refazer a rede - sem contudo estabelecer uma simetria - entre os seres orgânicos e os 
inorgânicos. O que se encontra entre a volição da figura e o objetivo a ser alcançado será contaminado e no limite subvertido; preservando-se, sempre, o realismo da imagem. $\mathrm{O}$ desejo faz as vezes de $g a g$.

Os programas dos dois cinemas são similares em termos de estrutura, dos pedestais sobre os quais edificam a posição ativa da figura humana no espaço que habita. As motivações, contudo, são radicais em suas diferenças. Elas não podem ser ignoradas: onde Chaplin e Keaton lutavam por um instinto de auto conservação, pela própria integridade física ameaçada face às engenhocas e às leis do mundo moderno, diante das autoridades, às vezes contra a miséria, os personagens de Denis, Rodrigues e Ming-Liang são mediados pelos desejos sexuais. O erotismo é o divisor de águas entre dois cinemas que valorizam plenamente a fisicalidade e a corporeidade da figura humana. Mas sigamos com o raciocínio: pode-se dizer que em um cinema como no outro a figura humana é movida por afetos, entendidos no sentido amplo do que marca um corpo aumentando ou diminuindo, estimulando ou refreando sua potência de agir. ${ }^{259}$ Os expoentes do burlesco certamente se beneficiam do lado positivo dessa relação. Mesmo o que os ameaça e os constrange os afeta positivamente uma vez que servirá como estímulo para encontrarem o meio, o gesto afirmativo de existência. Aqui as coisas se separam, porquanto o efeito dos afetos sobre os personagens de Denis, Rodrigues e Ming-liang os coloca sobre uma linha ambivalente em que seus gestos até são potencializados, mas já não se sabe se em prol de uma auto conservação ou de um delírio, de uma aparência criada em decorrência do objeto desejado, o Outro.

A sombra da dúvida é o que motivou o cuidado em exaltar a economia libidinal que subverte uma ordem dada nos filmes contemporâneos. Hesitamos sempre entre os seus efeitos: revelação do âmago das coisas ou o véu que aumenta o fosso entre a aparência e a coisa real? Quando Sergio visita os lugares pelos quais passou o homem desejado, tornando-o presente pelo toque, ou quando lida com humanos, animais, objetos e espaços por um ângulo comum, o seu corpo teria domínio de si mesmo ou seria subserviente a uma força externa? Quando Galoup deixa o rigor gestual da Legião para revelar um pathos estridente numa danceteria, ele abandona a razoabilidade em benefício da emoção? Ou, quando a mise en scène mostra que sob os exercícios dos legionários reside uma sensualidade e uma atração entre os militares, a imagem seria uma ilusão do desejo ou o sintoma de uma clarividência (quer seja da instância fílmica, quer seja de um personagem, quer seja do espectador)? Quando em $O$ rio e Adeus, Dragon Inn os personagens deambulam e são incapazes de uma

${ }^{259}$ Cf. B. Spinoza, Op.cit. 
comunicação efetiva, seriam eles vítimas de uma vontade de afeto e incapazes de gerir seus próprios sentimentos, permanecendo relegados a uma parcial passividade? Dito de outro modo: o que afeta a figura humana em tais situações a potencializa, a liberta, a conserva ou implica em uma servidão dos desejos? Existe uma relação consciente do que se vivencia ou se deve considerar que a obsessão pelo Outro é tal que "nada do que uma ideia falsa tem de positivo é suprimido pela presença do verdadeiro enquanto verdadeiro"? ${ }^{260}$ Sabe-se que a veemência e os efeitos dos afetos podem variar conforme uma ampla escala que envolve os cruzamentos de, pelo menos: presença, necessidade, possibilidade, temporalidade, tipo de objeto a afetar o corpo, relação com a imaginação etc. ${ }^{261}$ Como julgar a ação dos personagens a partir disso? Ora, paremos por aqui. Fazer uma avaliação em conformidade com esses critérios ou mesmo com outros não é primordial para uma análise dos modos de se conferir presença à figura humana no cinema. Importa sim saber que suas capacidades de ação foram sensivelmente ampliadas a ponto de subverterem os limites das normatividades ao qual estão submetidas. Um julgamento moral sobre o que os corpos possuem de subserviente ou de soberano em relação ao que os afeta foge ao nosso escopo. O fio tecido aqui encontra seu “fim” antes mesmo dessa avaliação. Retomá-lo-emos.

O libelo sobre os afetos, nomeadamente sobre o desejo, tem sua importância na medida em que permite suturar os componentes da figura humana elencados como essenciais ao longo das análises de Ming-Liang, Denis e Rodrigues, recompondo-os numa forma coesa. O gesto, a pele e o erotismo são reunidos pelo desejo e constituem um modo de presença da figura dependente do acento sobre a existência orgânica, física e carnal. Por orgânica, entenda-se a sua qualidade biológica, os movimentos involuntários que conferem vitalidade ao seu corpo, seu estar no mundo: respirar, alimentar-se, urinar, comer, defecar, entre outros. Algo similar mostramos no cinema de Grandrieux ao fazer referência ao trabalho do informe de esvaziar a figura de redes de leitura para acentuar a mera presença do corpo. Isso, porém, dependia de uma série de privações, em especial a do espaço. Em White Epilepsy desembaraçava-se a figura de tudo o que pudesse lhe reconectar com o mundo para então isolar e assim explicitar a matéria corporal.

Ming-liang, Denis e Rodrigues alcançam o aspecto biológico por outra via, que tudo muda: a figura humana só existe a partir do que a reconecta com o mundo fenomênico. A menção aos expoentes do burlesco tentou mostrar a correspondência entre dois programas

\footnotetext{
${ }^{260}$ Ibid., p. 159

${ }^{261}$ São parte dos critérios pelos quais Spinoza orienta suas proposições a respeito da natureza e da força dos afetos na segunda parte de seu livro. Ibid.
} 
diferentes de cinema entusiastas da natureza física, isto é, de uma presença forjada diretamente no contato com o que envolve a figura, quer seja orgânico ou inorgânico, humano, industrial, animal, vegetal ou mineral. O que está em campo na imagem é inevitavelmente criado, transformado, definido ou afetado pela ação e presença do corpo. Nada é por si mesmo ou a tal ponto rígido que sua configuração não possa ser transformada, pois o contato, entendido aqui como um atrito, uma tangência, é determinante para a sua existência. Outrossim, a figura é um corpo que se conta "entre as coisas, é uma delas, está preso no tecido do mundo, e sua coesão é a de uma coisa", ${ }^{262}$ isto é, presença decalcada da experiência com a textura do real, com a pele do mundo e mormente com a espessura do Outro. Dos planos de longa duração que permitem o desenrolar do gesto e seus desdobramentos ao acento sobre a pele a partir de um projeto tátil: a fisicalidade é uma dimensão constituinte. ${ }^{263}$ Corre-se o risco da repetição, mas vale insistir: o que conta não é ter um mero contato com os seres ou estar num espaço. Qualquer filme figurativo em certa medida faz isso e nem por isso partilha das preocupações aqui expostas. A linha cardeal é dar uma essencialidade a esses contatos e presença, insistir na mecanicidade gestual, persistir no confronto e na contaminação física entre as diferentes matérias, notabilizar o corpo por esses e não por outros artifícios.

O erotismo é o terceiro vértice do triângulo composto pelo orgânico e pela fisicalidade. De corpos constituídos entre os seres, os espaços e as coisas, o salto para uma ênfase dada à carnalidade não é muito grande. Revisitando motivos e momentos específicos da história da arte europeia identificaram-se estratégias que conferem uma carnação à figura humana cinematográfica pelo erotismo. Da relação com uma cultura neoclássica de exposição da figura masculina aos espaços de intimidade, de uma estética fetichista a um realce sobre a aparência "biológica", a guinada erótica transforma os filmes numa câmara de olhares, afrouxando qualquer pudor a fim de oferecer livre acesso à carne. Desde esse ponto foi

\footnotetext{
${ }^{262}$ Maurice Merleau-Ponty, O olho e o espírito, São Paulo: Cosac Naify, 2004, p.17.

263 As cenas de embate e sexo de Sombra, Uma vida nova e, um ou outro momento de White Epilepsy, naturalmente incluem uma fisicalidade, mas em sua qualidade de ponto de partida para uma experiência extrema (violência e sofrimento) do corpo a ser restituída pela plasticidade opaca da imagem. O toque é um disparador, mira um horizonte, um efeito limítrofe: plasmar a sensação, reconstituí-la pela fluidificação das formas. A fisicalidade não é algo a se experimentar gradual e profundamente. Ela existe, mas não é prioridade na figuração. A decupagem fragmentada das cenas de violência e sexo bem como a manipulação da imagem tornam evidente mais o gesto do realizador do que o dos corpos em cena; assim como o acento dado é sobre a pele da imagem ou do filme (The skin of the film, como o livro de Laura Marks), mais do que sobre o contato da epiderme corporal com o espaço e os seres. Em relação às cenas comentadas de Denis, Rodrigues e Ming-liang, a diferença é de gradação e ênfase mais do que natureza? Talvez. Não são cinemas antinômicos, mas com prioridades distintas a respeito da figura humana, logo, complementares em sua vontade de fornecer uma forte presença ao seu corpo. Lembrando também que, a depender da cena, um filme de Grandrieux poderia muito ser analisado neste capítulo. Mais difícil, é verdade, seria deslocar, mesmo a nível de cena, os filmes de Denis, Rodrigues e Ming-liang para o primeiro capítulo.
} 
possível entrever na maioria dos filmes analisados que as ações e a experiência corporais estavam subsumidas a um lógica libidinal marcada por uma particularidade: entre o desejo sexual e a sua nem sempre possível consumação, o corpo e os demais elementos em cena sofrem uma série de desarranjos e transformações por meio das quais são fortalecidos em sua potência de agir e de vivenciar suas experiências.

$\mathrm{Na}$ Introdução da tese foi comentado o que, na falta de uma expressão mais adequada, designou-se de naturalismo figurativo. Ali se gestou uma questão axial: tentar compreender como a figura se faz presente. Tendo em vista a facilidade de apresentar o corpo a partir de uma estética naturalista, quais seriam os meios levados em consideração para dar uma materialidade ao que é representado na imagem, para conferir-lhe uma presença? Viu-se em Grandrieux como era possível encontrar o corpo mesmo onde não havia sua figura ou onde ela era deformada. As cenas comentadas de Denis, Ming-liang e Rodrigues por sua vez, permitem retomar a questão por outro viés, mais próximo daquele do naturalismo figurativo, pois seus filmes também se valem de uma estética visual realista, em que a princípio a figura corresponde ao seu referente, ou seja, em que o corpo já está desde o princípio dado na imagem. Nesse sistema, como se demonstrou, os realizadores apresentam modos dar uma espessura, criam o correspondente a uma profundidade num meio bidimensional, forjam uma rugosidade onde há uma superfície lisa, dão densidade a uma imagem. ${ }^{264}$

Ter-se-ia alcançado uma completude, uma consumação da figura humana? Não. Os filmes de Rodrigues, Ming-liang e Denis complementam por outros meios o que se apresentava nos de Grandrieux a respeito da figuração de uma presença, mas padecem do mesmo mal. O solo monumental que criam a fim de dar uma solidez ao que vivencia o corpo e à sua imagem é sulcado e imperfeito pois estrutura-se sobre uma falha que a todo instante é contornada mas nunca resolvida, por isso mesmo sempre lembrada. O verniz revela o que deveria ocultar. Dilui-se o conteúdo figurado na imagem, atravessam-se longas distâncias, sondam-se os espaços, toca-se a pele do mundo, dança-se o desespero, faz-se de tudo, mas cada átimo das figuras porta consigo a ausência do Outro. A alteridade pela imagem no primeiro capítulo tentava construir uma ponte que minimizasse uma série de fraturas entre dois corpos. Agora, a gestualidade marcou a busca e o caminho mais distante de um ser a

\footnotetext{
${ }^{264}$ Para alguns autores, a luta contra a gravidade é o que afirma a presença da matéria do corpo e sua qualidade de ser vivo. Ver Paul Souriau, Op.cit. É nesse sentido também que Annie Suquet fala da dança: "Não só peso, afeto e movimento se fundem uns nos outros, mas o menor dos movimentos implica o indivíduo na sua totalidade funcional. Noutras palavras, a própria fibra do ser se vê atingida quando entra em jogo o peso." Ver Annie Suquet, "O corpo dançante: um laboratório da percepção", Jean-Jacques Courtine (et al.), 2011, p. 529. O burlesco reforça essa mesma ideia. Já foi muito comentado que para Chaplin, Keaton e outros expoentes do gênero a gravidade é a força contra a qual se luta para se provar a existência da figura.
} 
outro. Grandrieux, Rodrigues, Denis e Ming-liang constituem a presença do corpo pelos procedimentos que lhe são caros e também por uma travessia jamais concluída. A impotência volta a cada tentativa e na maioria das vezes parece reafirmar o mesmo destino. Insufla-se de vida o corpo pela dor, pelo sofrimento, pela pulsão e pelo desejo, mas quem se dirige ao umbral para ver o resultado dessa criação encontra apenas uma terra devastada no lugar em que deveria haver a imagem de um ser humano. 


\section{Do corpo individual ao coletivo}

De dentro de um cômodo vê-se em plano detalhe uma mão negra a abrir a tramela de uma porta sem grandes dificuldades. Nada seria mais natural, não fosse a ação acontecer do exterior para o interior. A encenação é sóbria: existe ali uma parede verde, manchada e desbotada, o alizar de madeira sujo e carcomido, e um pano grosso suspenso tal qual uma cortina frente à porta. $\mathrm{O}$ muro do lado esquerdo, o tecido do direito. A mão surge exatamente no centro (Fig. 185), acentuando a bipartição da imagem, a linha imaginária evocada pela zona limítrofe entre os dois domínios, o rígido e o maleável. Os pares continuam. Trata-se de uma dupla invasão. A do plano, pois o membro emerge do fora de campo, por detrás do que então era a superfície da imagem, violando sua rasura e insinuando ali a existência de um mundo para além do anunciado. A de um espaço físico, pois suspender a tramela de fora para dentro transgrede uma proteção, invade o que é privado, sugere uma visita não querida ou pelo menos uma presença não esperada. Quando a porta abre, o plano detalhe impede a identificação do sujeito e amplia o mistério. $\mathrm{O}$ enquadramento permanece fechado e o que se vê é o dorso de um corpo. Nenhum rosto. A figura nem entra no recinto, nem permanece fora. Fica parada na soleira, no entre dois (Fig. 186).

\section{Fig. 185-186}
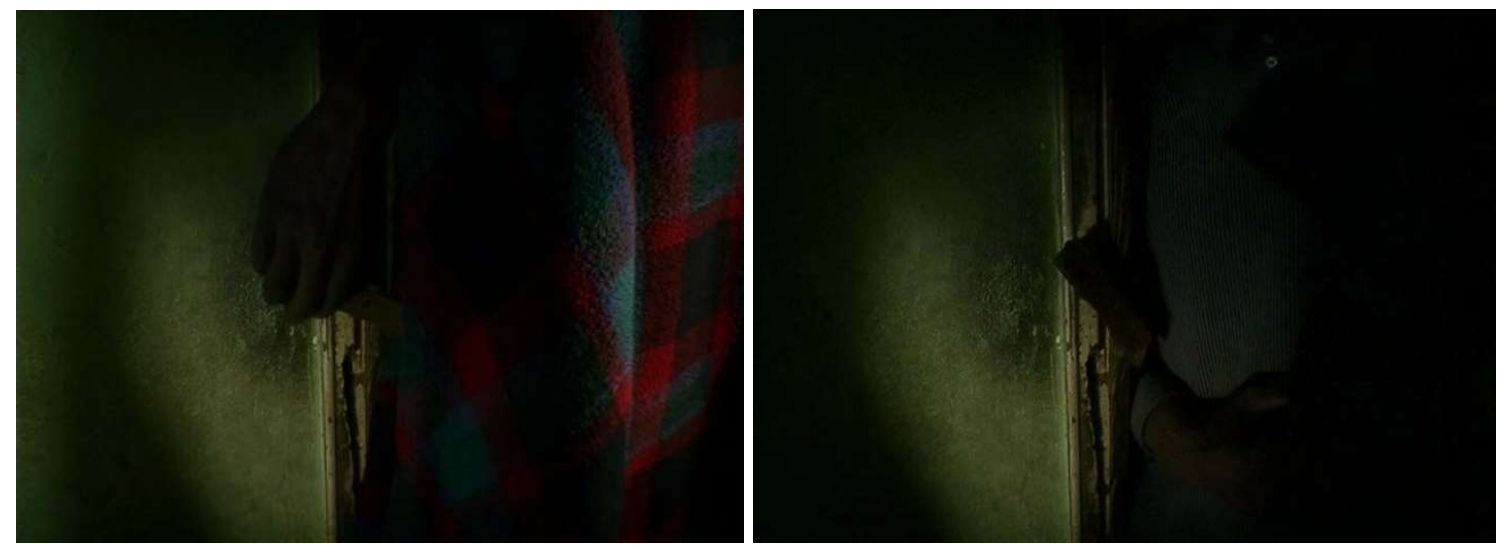
A cena é interrompida e somente alguns planos depois será retomada a fim de desvendar o segredo atrás da porta. Descobre-se que quem "forçou" a entrada é Nhurro, um morador do bairro das Fontainhas, em Lisboa. O cômodo onde a ação se passou é o que dá título ao filme No quarto da Vanda (2000), de Pedro Costa. Nhurro ali entrou para conversar com a vizinha Vanda e pedir abrigo por alguns dias. Ele acabou de ser desalojado. A favela das Fontainhas, cuja população é em sua maioria de imigrantes cabo-verdianos vivendo em condições precárias, de miséria social, está em processo de destruição por ordem da Câmara de Lisboa. Os moradores pouco a pouco deixam suas casas. Nhurro é um deles, Vanda também o será. Mas enquanto ela tem um teto, o amigo vem pedir ajuda. Uma elipse esconde o momento exato em que se encontram. Da porta aberta por um desconhecido salta-se diretamente para os dois no quarto dela (Fig. 187). Diferente do que a encenação sugeriu, a entrada foi parcialmente imprevista. Nhurro não anunciou a vinda, mas antes de entrar bateu na porta (com a educação que os pais lhe deram) e esperou o consentimento de Vanda. A única bronca que recebe pela chegada inesperada é que poderia tê-la encontrado "descomposta".

Fig. 187

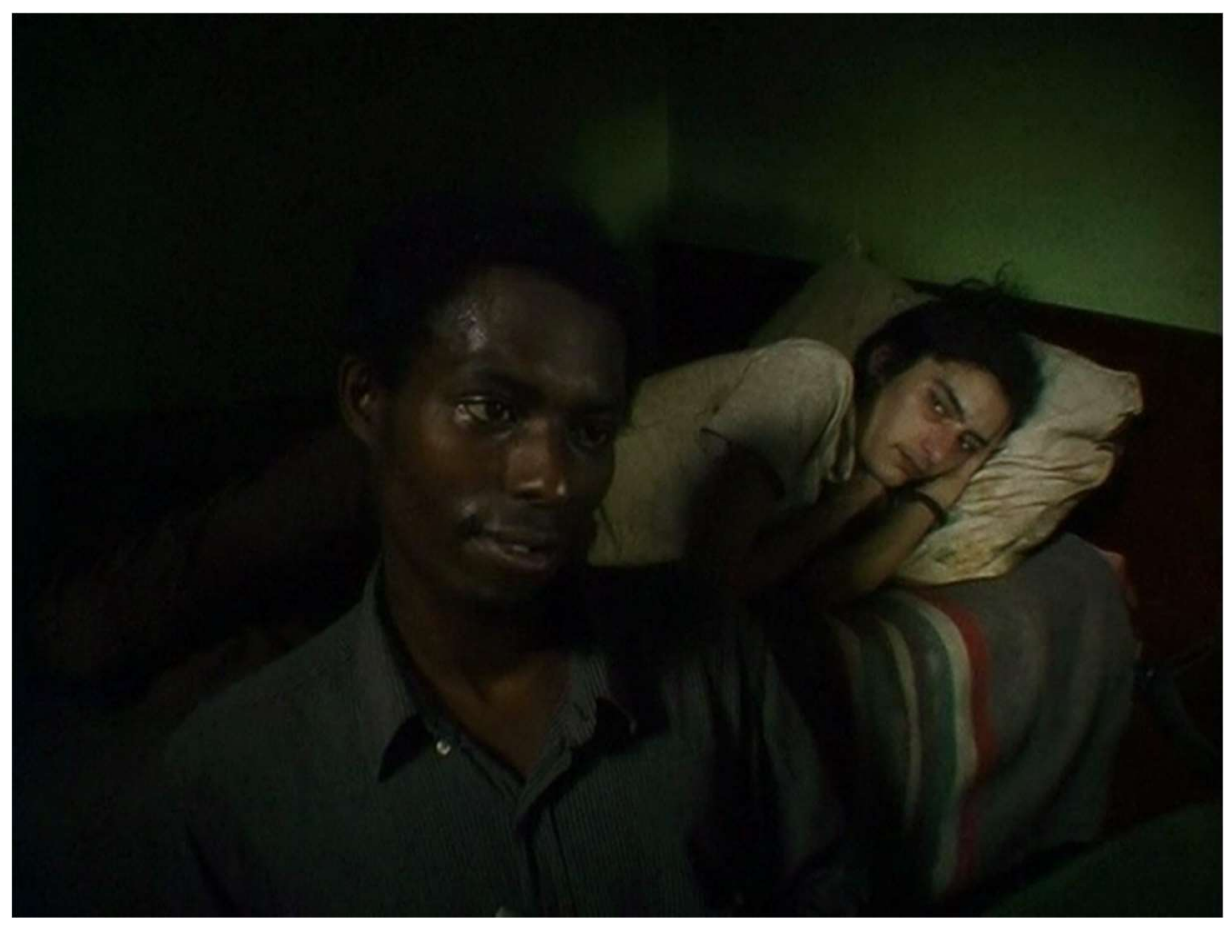

O início da cena, com a falsa invasão do recinto, e o seu desenrolar, com um diálogo de Nhurro e Vanda filmado em câmera fixa e em plano de longa duração, é uma súmula dos principais tópicos que serão abordados ao longo do capítulo. Mas o que teria de particular em dois momentos tão banais no modo de representar a imagem dos corpos? Afora a austeridade 
do plano da mão a abrir a porta e, em ambas as cenas, a iluminação noturnal, com sombras marcadas a ocupar e a devorar os cantos da imagem, a sequência é razoavelmente simples. Como nos filmes de Denis, Ming-liang e Rodrigues, a figura humana é desde o princípio dada visualmente. Como nos de Grandrieux, a escuridão é fulcral para a representação do corpo. Acaba aí o mistério? É muito cedo para conclusões. Tentaremos recompor a complexidade ou senão a singularidade dessa sequência para o nosso tema nas próximas páginas. A análise não será direta. $\mathrm{O}$ fragmento escolhido é apenas um ponto de referência que ora se fará mais presente, ora será esquecido e ora será retomado ao longo de um percurso a ser feito sobre rota esgarçada e numa condução pelas beiradas. Somente com o avançar, ou talvez na linha de chegada, reconstituir-se-á o mapa geral. A finalidade do exercício é descobrir como na sequência se insinua um tipo de presença da figura humana cuja real concreção só pode ser entrevista num arco maior, ao longo do filme.

Repetiremos a estratégia do primeiro capítulo, fazendo de um único filme a espinha dorsal da análise. No quarto da Vanda assume o posto, mas será ladeado por outras obras de Costa, em especial Ossos (1997) e Juventude em Marcha (2006), junto com os quais compõe uma trilogia a respeito dos moradores das Fontainhas. Paralelamente serão convocados filmes de outros realizadores e obras pictóricas que venham dialogar e construir um argumento por meio de uma inclinação comparatista.

Diferentemente da afasia ou dos raros diálogos nos filmes de Grandrieux, Rodrigues, Denis e Ming-liang, a figura humana em Costa não pode ser desvencilhada do que fala. A palavra é uma dimensão constituinte para o significado atribuído e para os modos de presença. Reconhecido isso, a gestualidade, a fisionomia, os enquadramentos, a relação com os espaços pictórico e físico, e os demais meios de figurar o corpo são tão ou mais importantes que nos filmes anteriormente analisados. A figura humana porta também sua singularidade e continua a ser central, embora por outra perspectiva que vem justamente complementar o que se trabalhou até o momento.

Uma segunda ressalva que a priori imprime um matiz diferente a este capítulo diante dos demais é que, a despeito das fragilidades das categorizações e da permeabilidade entre os gêneros cinematográficos, No quarto da Vanda assume uma inflexão documental. As pessoas em cena são de fato os moradores das Fontainhas interpretando ou vivenciando seu dia a dia no bairro e em suas casas. Isso por si só poderia conferir um maior efeito de presença aos seus corpos. Poderia, mas a preocupação aqui é de outra natureza e, acreditamos, a do filme também. Costa seguramente escolheu filmar os moradores por disposição a um tipo de realismo social capaz de conferir maior potência ao que se mostra, revelar a urgência e tornar 
patente ao espectador a situação das famílias das Fontainhas. ${ }^{265}$ Quanto a isso não há dúvidas. Tanto o filme como o que se sabe da relação do realizador e da equipe com os moradores do bairro corroboram o engajamento político e justificam a escolha por uma poética mais justa, mais direta frente ao problema social e à história daquelas pessoas. Em suma, frente a uma realidade concreta. Contudo, a entonação documental é necessária e ao mesmo tempo secundária. Mira-se algo de mais valor. O quê? A análise da representação dos corpos permitirá uma resposta. Até lá, ou mesmo aqui, como se vê pela sequência da chegada de Nhurro, vale pontuar o que talvez seja evidente: o filme é ancorado e permeado por uma série de estratégias de encenação, tal qual uma obra que comumente se associa a uma ficção. Do real para tela existiu um trabalho de figuração, de conformação audiovisual, escolhas que transformassem uma experiência em imagem/som e um corpo em figura - mesmo que para depois enviá-los de volta à potência da dimensão real. Se tais estratégias pertencem ao que se convencionou chamar de ficção ou documentário, isso pouco interessa a nós. O importante é a razão de empregá-las. Dito isso, a defesa é que o filme cria uma poética apta a acolher uma proposta ética diretamente relacionada ao olhar sobre a figura humana, ao modo de representá-la e de conferir-lhe presença.

\subsection{Retrato: nos antípodas de uma tradição}

Pour eux [les artistes] un visage humain est une manière de champ de bataille où des puissances adverses se livrent un combat sans fin, un combat sans décision. Ils ne sculptent pas l' " idée » de l'homme, ou quelque chose comme "l'archétype qui a dû inspirer le créateur ", mais une tête qui a été façonnée par la vie, prise dans un constant processus de remodelage par la vie, si bien que le Nouveau lutte avec l'Ancien, , par exemple l'orgueil avec la modestie, le savoir avec l'ignorance, le courage avec la lâcheté, la gaieté avec la mélancolie, etc. Un tel portrait restitue la vie même du visage, qui est un procès antagonique, un combat.

Bertolt Brecht, Observation de l'art et art de l'observation

\footnotetext{
${ }^{265}$ Recobramos a definição de Linda Nochlin ao se referir à arte moderna europeia do século XIX. Para a autora, o realismo social compreende o confronto com experiências concretas, costumes, eventos e aparências do tempo presente. $\mathrm{O}$ artista assume uma atitude zelosa na busca por uma imagerie apropriada, um espírito de urgência moral diante dos valores humanos e sociais envolvidos no tema que representa. A definição é voltada para o que antecipa e alicerça a poética de artistas como Courbet, Milllet e o outros. Mais do que definir critérios estéticos rígidos, Nochlin realça o engajamento com aspectos do presente da experiência moderna, em especial aqueles excluídos pela arte pregressa, como a labuta do pobre. Ver Linda Nochlin, Realism, Nova York: Penguin Books, 1984.
} 
O encontro de Vanda e Nhurro acontece depois de suas várias aparições ao longo de mais de duas horas de filme, sempre separados. Uma breve linha sobre cada um é necessária e ajudará a contextualizar a cena.

A primeira imagem de Vanda é na verdade um som: enquanto a tela ainda está escura, durante os créditos do filme, escuta-se o ruído feito ao tragar um cigarro de crack. O plano subsequente mostra ela e a irmã, Zita Duarte, sobre uma cama a conversar enquanto consomem a droga. A câmera fixa e a duração sem cortes são severas no que expõem. A magreza dos dois corpos, a ambiência escura do cômodo, os insetos, as tosses roucas de Vanda que em nada arrefecem seu ímpeto pela droga, e mesmo um detalhe como a tez suada não deixam dúvidas: ali se faz uma pequena incursão ao inferno. Imagem e som em nada tergiversam, mostram diretamente o evento e o estado dos corpos. A situação vai se repetir algumas vezes, com pequenas variações, quase sempre no mesmo cômodo e com a mesma desolação (Fig. 188).

\section{Fig. 188}

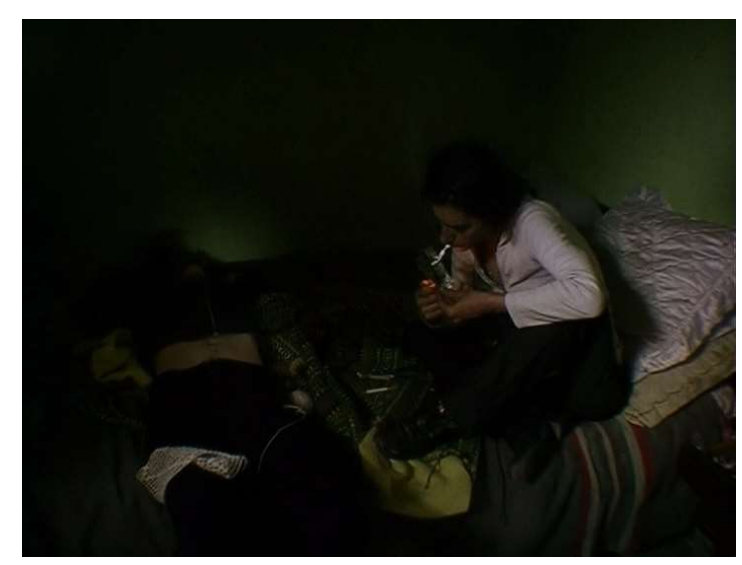

Fig. 189

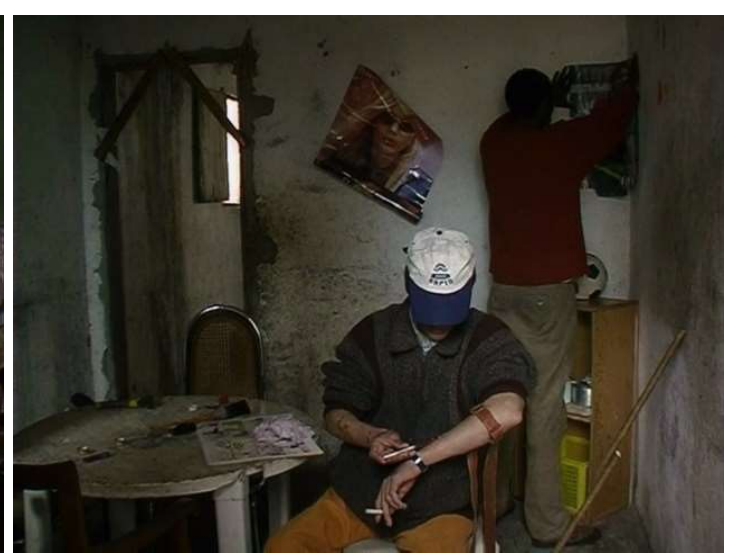

O cotidiano de Nhurro guarda suas semelhanças com o de Vanda. Ele está sempre em casa, dividido entre duas ações. A primeira é limpando e mudando a posição dos móveis. Nada mais há que uma cama, caixotes velhos, uma ou outra peça que recolhe na rua, objetos pelo chão e uma mesa. A tentativa de arrumar a casa é quase obsessiva pela reiteração dos gestos, mas também incongruente em seus resultados, pois nada realmente é alterado. A miséria perdura e o ambiente continua tão desalinhado quanto antes. Para além disso, Nhurro recebe os amigos, em especial Muletas e Russo, que vão até sua casa para juntos consumirem heroína. Nessas ocasiões, geralmente vedam portas e janelas e sob a luz de velas injetam a droga. Similar ao que acontece com Vanda, a escuridão vem dar o aval para o ritual. Noutras 
vezes, tudo é feito às claras e as imagens ganham uma naturalidade grotesca pela exposição do ato sem mediações (Fig. 189).

Apresentados Vanda e Nhurro, pode-se voltar para a cena da visita. Nela se encontram dois universos que até então a decupagem havia separado e que não se sabia qual o grau de relação. O momento é fraternal, de partilha e de tristeza entre amigos. Falam do passado, rememoram a relação com as respectivas mães e amargam o vício com a droga: escolheram aquela vida ou apenas seguiram um destino já traçado? ${ }^{266}$ Enquanto conversam, a disposição dos corpos permanece quase sempre a mesma. Nhurro está sentado ao lado da cama, em frente à câmera e de costas para Vanda. Ela, deitada e com o corpo parcialmente encoberto pela escuridão do quarto e pela figura do amigo. De ambos se vê o rosto e uma parte do dorso. Quando o diálogo inicia, continuam assim e pouco gesticulam. Ele mexe a cabeça e olha para todos os lados, enquanto ela se mantém quase sempre na mesma posição, às vezes também variando a direção do olhar e do corpo. Dessa composição, surge uma dúvida trivial: a intimidade entre os dois seria tal que uma conversa de mais de cinco minutos se dá mesmo sem uma troca de olhar, com Nhurro sempre de costas para Vanda?

Existe uma certa estranheza na cena que se torna mais patente quando se repara no comportamento de Nhurro. Durante sua fala há um sútil desconforto, seja pela ocasião de estar sendo filmado, seja pela própria timidez. Qual dos dois, é difícil precisar. O que chama a atenção é que ele tudo faz para desviar o olhar da câmera. Vez em quando cruza com o ponto de vista da objetiva, mas rapidamente se esquiva. Não é difícil deduzir que a pequena câmera DV está à frente e muito perto de Nhurro. Pelo que se vê nas demais cenas do filme, o quarto de Vanda parece ser pequeno, mas nesse momento em específico o enquadramento sugere uma proximidade da câmera em relação aos corpos maior do que a de costume. O motivo da escolha supomos ser o mesmo de manter os dois voltados para a objetiva, com Nhurro de costas para Vanda, embora às custas da maior naturalidade. Existe ali uma vontade de frontalidade. Mesmo um mínimo de aceno ou olhar entre os dois se torna dispensável, pois o espectador deve ser confrontado diretamente com os dois rostos, e nesse caso principalmente com o de Nhurro, que acabou de ser desalojado da casa. O relato dos dois é comovente, mas tanto como as palavras suas imagens precisam igualmente ser fixadas e, principalmente, devem encontrar uma forma de perdurar. Para isso, é preciso dar um rosto à experiência.

\footnotetext{
${ }^{266}$ Um dos trechos do diálogo:

"Vanda: - A vida que a gente quer é essa: a vida da droga.

Nhurro: - Não, não é a vida que a gente quer. Parece que é a vida que a gente é obrigado a ter.

Vanda: - Achas?

Nhurro - Acho que sim. Penso que é já um destino, um traço..."
} 
As descrições sobre as cenas separadas de Vanda e de Nhurro sugeriam desde então o ponto ao qual queremos chegar. No quarto da Vanda aproxima-se dos moradores das Fontainhas para ouvir suas narrativas na mesma medida em que atribui à câmera o papel de se endereçar ao envelope externo, às figuras estioladas pela pobreza e pela droga, a fim de arrancar dessa aparência algo sobre o que vivem e igualmente sobre quem são. A investida não busca respostas precisas e nem necessariamente o mundo interior e afetivo, mas reduzir a distância entre dois universos, o do filme e o do espectador. A hipótese é a de que essa vontade de frontalidade encontrará sua conformação a partir do retrato, evocado em uma dimensão que indiretamente herda e ao mesmo tempo transforma a tradição do gênero pictórico desenvolvido na Europa entre os séculos XV e XVII, notadamente nos Países Baixos e na Itália.

Desde pelo menos Casa de Lava (1994), ficção feita com os moradores de Ilha do Fogo em Cabo Verde e também com atores profissionais, existe uma predisposição do cinema de Costa em suspender temporariamente o fluxo narrativo para se deter demoradamente ou por vezes por poucos segundos sobre um rosto, apresentando-o de maneira mais ou menos solta dentro ou antes de uma cadeia lógica de eventos. Assim, lá pela metade do filme, o close de uma das moradoras da ilha (Clotilde Montron) de quem pouco se sabe surge entre duas cenas com a protagonista Mariana (Inês de Medeiros) aparentemente sem ter uma relação direta. Dura pouquíssimo tempo e nenhuma explicação é dada a respeito. A mesmíssima imagem já havia aparecido no início do filme (Fig. 192) em meio a uma série de outros closes de rostos imóveis e planos de figuras de costas que são mostrados posteriormente ao vulcão da ilha, embalados pelos sons agudos de um violino (Fig.190-198). Alguns desses "personagens" aparecem apenas aqui, outros estão em um ou outro momento do filme, em ações paralelas à trama principal.

Fig. 190-193
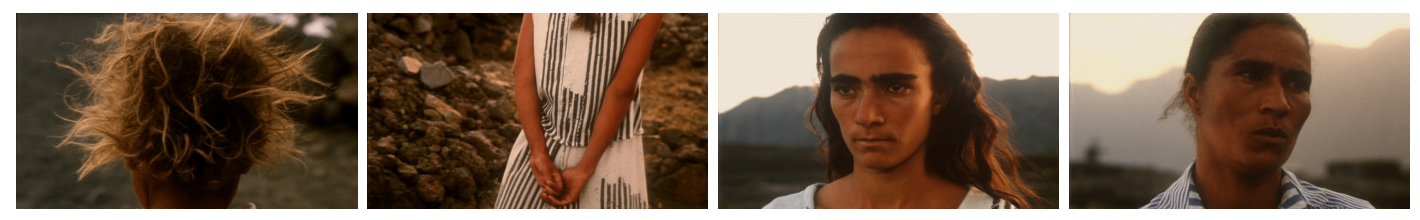

Fig. 194-197
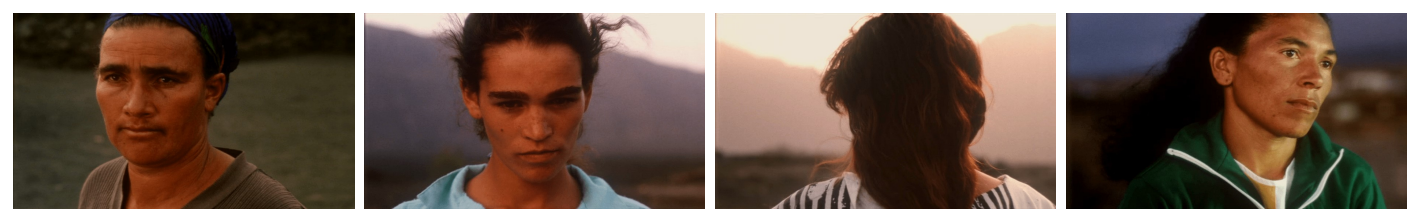
Fig. 198

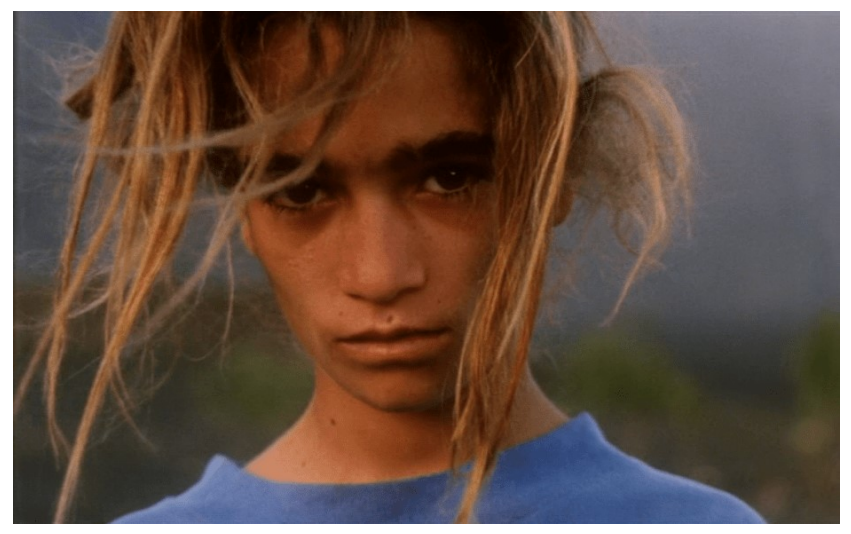

A sequência tem um lado facilmente presumível e outro um tanto enigmático. Não é difícil reparar que ela inicia com uma figura de costas, segue com rostos enviesados, num conjunto de linhas de força em franco desvio da objetiva, e acaba com um olhar frontal a encarar detidamente a câmera. Da face escondida, e portanto da identidade velada, passa-se primeiramente aos olhares furtivos. Se neles há uma timidez, está encoberta sob a firmeza dos rostos, resolutos e fixos diante do que detêm suas respectivas atenções, um mundo não partilhado com o espectador e com a instância da enunciação. Somente ao final desses jogos de negação categórica e de esquiva deliberada um rosto encara a câmera. Sua seriedade faz da possível cumplicidade da troca de olhares um enfrentamento.

Mais que os demais, o último plano do mosaico fisionômico revela uma aparente conformidade com o sentido etimológico de rosto na língua grega, o prosopon: "o que se apresenta à vista". A raiz da palavra pressupõe necessariamente a existência de um observador. O rosto existe uma vez que os traços de um indivíduo são dados a ver, logo, na relação direta entre duas ou mais pessoas. Origem do olhar, nele impera um princípio de reversibilidade pela relação do si com o outro: o que olha também é visto, e vice-versa. Por essa razão e porque é o local de emissão de signos, revelador direto dos sentimentos, dos pensamentos e das características de um indivíduo, portador de uma linguagem autônoma à das palavras, a da fisionomia e a dos olhos, o rosto é considerado o medium privilegiado das relações humanas. ${ }^{267}$ Pensada em correspondência com estes significados, a frontalidade da garota revela o pacto direto com o espectador. A figura humana devolve e assume a consciência do olhar que recebe. Junto a isso, ergue um muro em torno de si. Durante a sequência existe uma gravidade sugerida pelo som dos violinos que reverbera sobre as faces

\footnotetext{
${ }^{267}$ Cf. Françoise Frontisi-Ducroux, Op.cit.
} 
dela e das demais moradoras da ilha, ao mesmo tempo em que por estas é silenciada. O rosto tem uma linguagem, mas não se sabe o que diz.

Uma das mulheres surge três vezes (duas de costas e uma de frente) durante a sequência. É Clotilde Montron, a mesma cujo close retorna pela metade do filme. Algum fascínio ela exerceu sobre Costa. Não só pelo tratamento diferenciado, mas porque fotografias da moça também são reincidentes no caderno em que o realizador reuniu anotações, cartas, colagens e outros materiais quando viajou a Cabo Verde para filmar Casa de Lava. ${ }^{268}$ Numa das páginas, a imagem da atriz é colada junto à de Christiane (Edith Scob), a protagonista de Os olhos sem rosto (Les yeux sans visage, 1960), de Georges Franju. Ambas as mulheres estão de perfil, postas uma de frente para a outra (Fig. 199, canto inferior esquerdo). O que compartilham? No filme de Franju, Christiane teve a face desfigurada depois de um acidente de carro. O pai, cirurgião plástico, sequestra mulheres e tenta clandestinamente transplantar a pele de seus rostos para o da filha. Dada como morta, ela é mantida presa em casa, sempre com uma máscara a ocultar as cicatrizes. Sua figura dificilmente se aproxima da de Montron e das demais mulheres em close no início de Casa de Lava. Salvo pelo que permite refletir a respeito do rosto.

Fig. 199

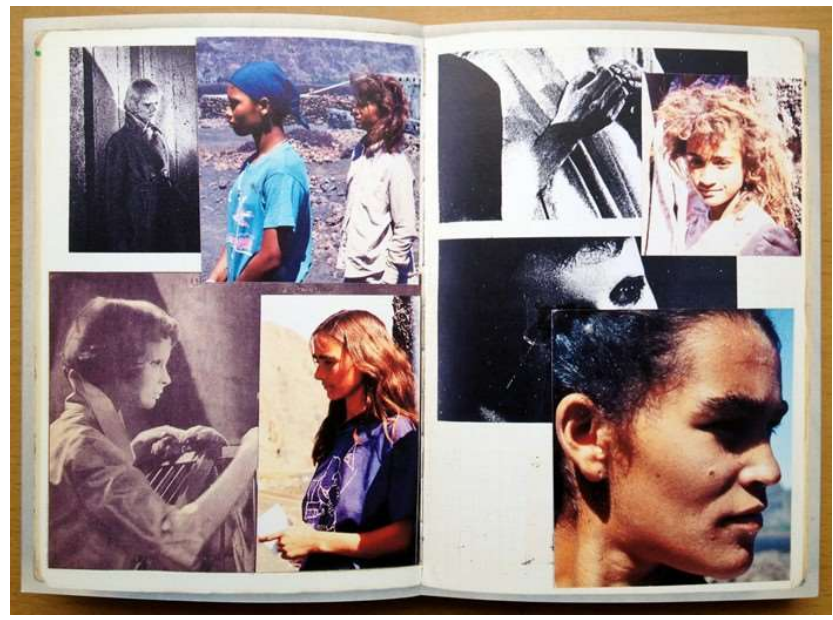

É necessário voltar aos gregos mais uma vez. No caso, ao brevíssimo entendimento segundo o qual o olhar assume uma posição ativa, a de ver, enquanto a face se coloca como o objeto da visão. ${ }^{269}$ A personagem de Franju nega o último ponto. Ao usurpar o lugar do rosto,

\footnotetext{
${ }^{268} \mathrm{O}$ acesso ao caderno foi parcial, a partir de imagens disponíveis em: http://stet-livros-fotografias.com/livros /casa-de-lava-pedro-costa/81208-7a60db8731304d36873c73347b6416b5/\#main. Acesso em: 05/02/2018.

269 O autor sinaliza que a reversibilidade é uma constante quando se trata do olhar na cultura grega. Sendo assim, por vezes o rosto pode assumir um lado ativo (aquele que vê) e, o olhar, o passivo (aquele que é visto). Françoise Frontisi-Ducroux, Op.cit.
} 
a máscara cria uma cortina brumosa, o túmulo do olhar - da câmera e do espectador. O objeto não existe para encarnar uma nova figura e nem substitui o que encobre, ${ }^{270}$ pois a todo instante o filme joga com o que ainda reside sob sua superfície. O rosto de Christiane é um interdito. Mesmo quando aparece sem máscara é diluído pelo flou. Foi privado de sua essência, já não é “o que se apresenta à vista”, e nem o medium das relações humanas. Dele restam os olhos, acuados e encarcerados pela solidez marmórea que os envolta. A reversibilidade (ver e ser visto) foi perdida e é perturbador o que Franju alcança com a mera tensão entre a natureza reveladora do close e a ocultação do rosto, entre a vivacidade dos olhos e a artificialidade da máscara. Dito isso, talvez seja redundante apontar que Costa segue um princípio similar na sequência de closes no início de Casa de Lava. Sua proposta é mais ambígua: o rosto é dado a ver, está lá sem qualquer impedimento, mas também faz as vezes de máscara, dificultando a possível transparência fisionômica, escondendo algo de quem a eles se endereça. O que a Franju serve exclusivamente ao drama, em Costa passa a compreender também a relação entre cineasta e aqueles que filma: a face só se revela no que oculta.

Fig. 200

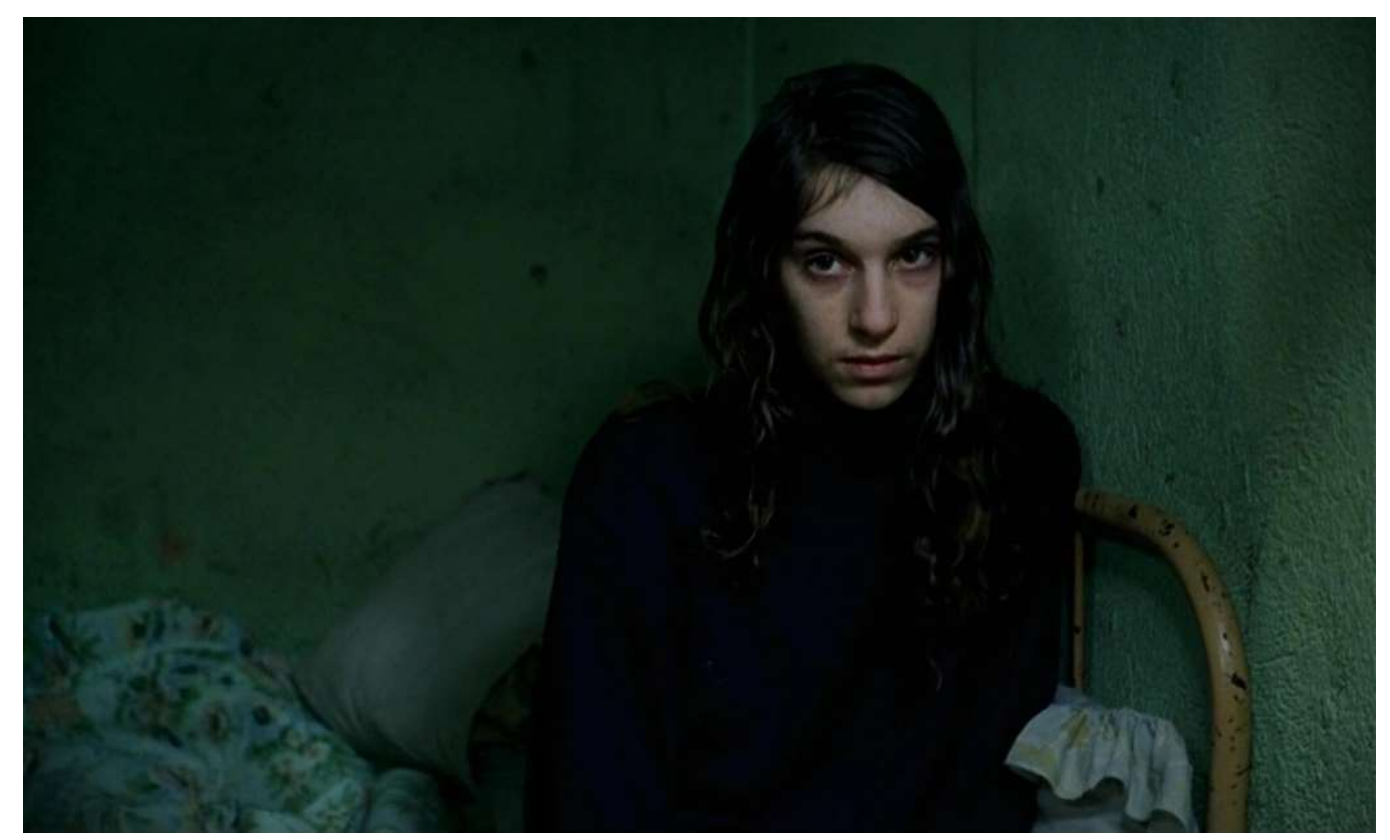

Na obra que inaugura a trilogia das Fontainhas, Ossos, uma forte ressonância com o que rege a abertura de Casa de Lava. A primeira imagem mostra em plano médio, sentada sobre

${ }^{270}$ No teatro grego, a máscara não vem esconder o rosto que recobre, mas aboli-lo e substituí-lo: “[...] sob a máscara dramática, o ator não existe, e sua individualidade, aquela que revelava seu próprio rosto, cedeu lugar àquele do personagem que encarna". Ibid., p. 79. 
uma cama, Zita Duarte (Fig. 200). A diferença é notável em relação a No quarto da Vanda, em que ela aparece nas intermináveis sessões de crack e em outros momentos com uma silhueta macilenta, cabelo desgrenhado e os olhos sempre arregalados, numa presença quase fantasmagórica. Na abertura de Ossos, o blusão folgado impede que vejamos o seu corpo, mas o rosto mais carnudo, ainda que pálido, e o aspecto juvenil dão a medida do tempo e da degradação física do corpo entre os poucos anos que separam os dois filmes. Zita encara a câmera sem nada falar. Passados alguns segundos, desvia o olhar e recosta a cabeça sobre a parede. Escuta-se o ruído da vizinhança, que invade o campo e anuncia a presença do mundo externo. Ao longo do filme, Zita reaparece quase na posição de uma figurante sobre a qual, vez ou outra, a câmera se detém, como se decidisse filmá-la e se esquecesse da história principal - um casal de adolescentes da periferia de Lisboa que acaba de ter um filho e, na falta de condições para mantê-lo, tentam inicialmente matá-lo.

Salvo engano, são seis aparições de Zita em Ossos. Em nenhuma é implicada diretamente na trama, permanecendo à margem. Sua participação tangencia os eventos principais de fora como um olhar externo. A única informação é que mora no bairro. Resumiremos os momentos que consideramos importantes para a questão do retrato, nossa preocupação principal. Além do primeiro, são outros três. Numa das vezes (Fig. 201), está no umbral de uma porta observando um baile dos moradores, enquanto bebe algo e sorri do que vê. Na outra (Fig. 202), sentada com Eduarda (Isabel Ruth), passa a maior parte do tempo a observá-la, até pedir-lhe um cigarro com um gesto. Por fim, na penúltima sequência do filme, está parada num dos corredores do bairro a interagir com outro morador, a cumprimentar quem passa e a olhar o entorno, até que vira-se de costas para a câmera e caminha em direção ao fundo da imagem. Da primeira à última vez, nada diz.

Fig. 201-202
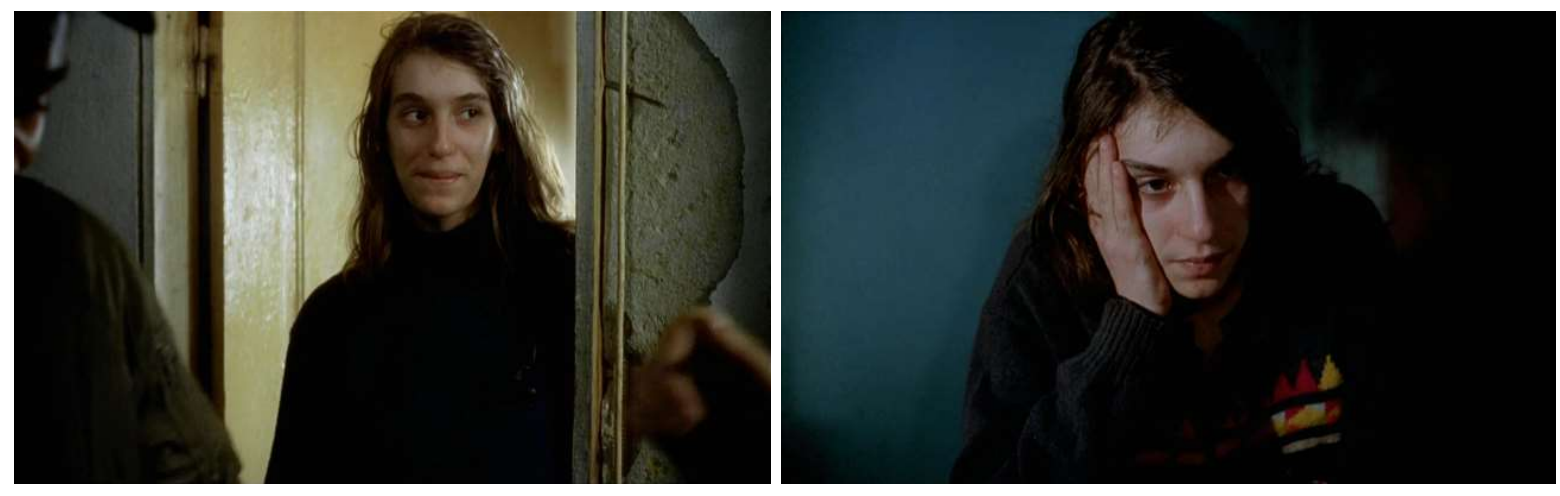
A imagem de Zita está na abertura e no encerramento do filme. No ir e vir das demais ações, seu rosto se torna um porto seguro para o qual a câmera sempre retornará. A dúvida então é por qual razão uma figura que não faz parte diretamente dos eventos principais aparece tantas vezes e, mais importante, recebe da encenação um acolhimento tão manifesto. Alimentamos duas suspeitas.

A primeira passa pela própria motivação de Costa ao escolher o bairro das Fontainhas para filmar. O projeto de Ossos, mais do que contar um drama ficcional específico, tenta acessar algo da vida dos moradores que ali vivem. É nesse sentido que a imagem de Zita se torna o elemento intrusivo dentro de uma trama orquestrada, o documento de um corpo que está ali pela sua presença, para além do que a história principal conta, uma sutil brecha pela qual algo do real se insinua em campo. Embora resultante do trabalho da mise en scène, o efeito é o de uma espontaneidade tão flagrante quanto é o sorriso que gradual e discretamente ganha o rosto de Zita durante a festa do bairro (Fig. 201). Ela carrega algo do inesperado, de uma parcial obstrução do sentido que é essencial mesma quando se tenta representar o Outro, pois sinal de uma consciência da impossibilidade de apreendê-lo integralmente.

Futuramente, em No quarto da Vanda e Juventude em marcha, Costa diminuirá a equipe e reduzirá o maquinário cinematográfico a - não só, mas principalmente - uma câmera DV. Por meio disso depurará sua encenação a fim de dar mais espaço aos moradores. Em Ossos a situação era diferente. A marca do diretor e de uma equipe é notável pelo roteiro e pela própria decupagem do drama. Nossa suspeita é a de que os planos isolados de Zita vêm flexibilizar tal encenação, demarcando uma exterioridade, uma presença que foge parcialmente do agenciamento da narrativa e do cosmo fictício. A moça está dentro da diegese e também está fora, o que se vê literalmente em cada uma das suas aparições, nas quais interage distantemente com os personagens do drama, tal qual uma visitante ou uma moradora do bairro que por ali ocasionalmente passasse num dia de filmagem. Zita é, claro, ela própria, com sua subjetividade pela qual a câmera notadamente mantém uma fixação, mas também é a manifestação do bairro das Fontainhas. Não se trata da alegoria de um espaço, tampouco de um símbolo, mas de uma pessoa cuja presença é capaz de recordar o que se esquiva ao próprio filme, tal qual a comunidade por detrás dos personagens, dos roteiros e de todo o ideário ali construído.

A segunda hipótese está diretamente vinculada à primeira - que agora se assume como uma premissa. Ao se concordar que a figura de Zita é modulada tal qual uma exterioridade esquiva, um documento e também um óbice da vida naquela comunidade, Costa, consciente ou não, reveste a imagem dela com uma moldura memorialística. Ao alijá-la parcialmente da 
fábula, acentua-se o registro de Zita para além do papel que ela cumpriria como uma personagem. Investe-se sobre sua participação enquanto (aparente) elemento do real que tangencia o universo fictício. Mencionamos registro como se diz do registro fotográfico, mas também como um filme com inflexão documental fará frente a quem filma, ou ainda como o aforisma de que toda ficção é um documentário sobre os atores etc. Documenta-se a imagem de Zita para fazê-la perdurar contra o tempo e em corolário contra o esquecimento. Há um trabalho contra a morte e em favor da memória. Se isso for verdade, de onde viria a necessidade de se fazer lembrança e o que de tão particular os planos de Zita têm se comparados com o de qualquer outro filme que, ficção ou documentário, igualmente apreende e fixa os corpos na temporalidade duradoura da imagem? Uma resposta é possível ao se refletir sobre a aparição da moça a partir de um prisma triplo e em filigrana: no filme, nas demais obras sobre as Fontainhas e no próprio universo extra diegético, ou seja, no mundo real.

Só faz algum sentido dizer que a figura de Zita em Ossos atesta uma lembrança ou se torna uma resistência se se aquiescer que ela enfrenta e se impõe contra algo que ameaça a sua existência. Nesse sentido, pode-se recordar que o filme, como os demais de Costa, desenrolase sobre uma tensão entre vida e morte, tornada evidente na diegese pela tentativa de suicídio da protagonista, que tenta matar a si e ao filho recém-nascido asfixiados com o gás de cozinha. A própria condição dos moradores do bairro, párias sociais, reverbera na aparência abatida e letárgica dos corpos, seres vivos numa vigília diária contra a morte. Por vezes, faltalhes o que comer. Zita, moradora do bairro, talvez partilhe dessa sentença comunitária. Talvez, pois o distanciamento dos eventos principais impede uma assertividade sobre sua vida. A real envergadura de sua presença em Ossos é recobrada ao cotejar o filme com as obras subsequentes da trilogia da Fontainhas. Noutras palavras, quando se analisa as imagens da moça não mais em sua duração particular, mas em seu encadeamento junto a um eixo temporal mais amplo. 
Fig. 203-204
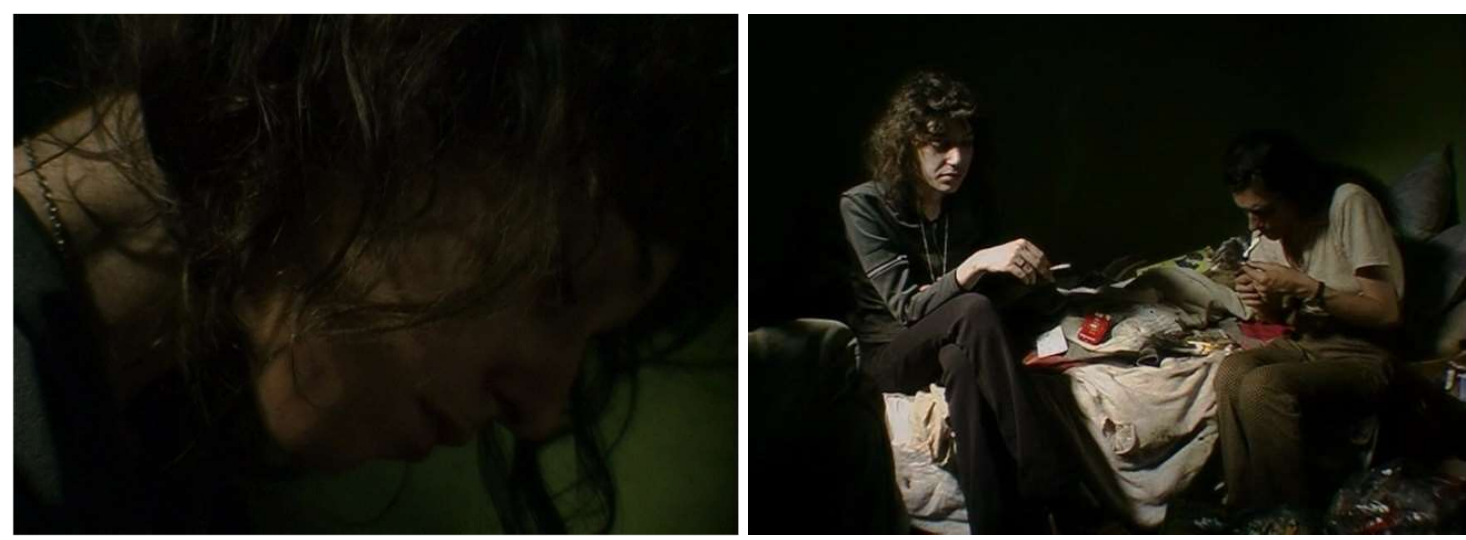

Em No Quarto da Vanda, Zita está geralmente ao lado da irmã. Algo do ar adolescente de Ossos permanece, mas agora fragilizado pelo aspecto esquálido, e nuançado pela voz, que pela primeira vez escutamos. Dela não se sabe tanto quanto a respeito de Vanda, salvo que: vez por outra rememora histórias pessoais e da comunidade das Fontainhas; já foi internada pela dependência química e pensou em se jogar da janela mas estava tão magra a ponto de mal se manter em pé; ajuda a mãe em tarefas domésticas e na vendinha que a família possui; e, como Vanda, mantém-se presa ao que no decorrer do filme, a cada cena em que usam crack, aparenta ser um destino trágico e por isso incontornável. O que em Ossos era um risco distante em No quarto da Vanda ganha contornos reais. Mas a imagem mortuária do tempo formada na passagem de um filme a outro só ganha seu aspecto final na obra subsequente, Juventude em Marcha. Nela, um plano mostra Vanda, o esposo e Ventura sentados em uma mesa sem nada falar. Vanda limpa os olhos e assoa o nariz com um lenço, enquanto os outros dois permanecem imóveis em seus silêncios. Dois minutos depois a voz dela corta a inação da imagem para nos dizer: Zita morreu. Nesse momento, a primeira imagem da então adolescente em Ossos (Fig. 200) é definitivamente revestida com a moldura memorialística que comentamos, como um documento premonitório - obviamente muito além do que o diretor poderia supor quando a filmou pela primeira vez. Agora, finalmente, iniciaremos a discussão que alinhava o que em parte foi comentado e conduz a um ponto importante para a representação do corpo.

As duas suspeitas pelas quais comentamos a importância dada a Zita em Ossos, sua exterioridade à trama como indício do real que se infiltra na diegese e a imagem como resistência ao tempo, respondem a duas características sobre as quais a tradição retratística se consolidou em alguns países da Europa: o princípio de semelhança e a vocação mnemônica. Consequentemente, são os motivos pelos quais consideramos sua primeira imagem no filme 
como um retrato cinematográfico ou mais propriamente um plano-retrato. Retomaremos sumariamente as bases do gênero pictórico tendo em vista os dois aspectos para depois realizar uma mediação em direção ao cinema e posteriormente à obra de Costa e a de realizadores que ela tangencie.

\subsubsection{Notas sobre o gênero pictórico}

A pintura retratística à qual se faz referência é a da Idade Moderna, a partir de meados do século XV, situada sobre o desejo de retratar a figura humana, de descrever uma pessoa em particular. Trata-se aí especificamente do retrato individual pintado sobre madeira e não das primeiras manifestações do gênero, que aconteceram já nos retábulos de altar e em afrescos nos quais era possível reconhecer em meio a um grupo de figuras históricas ou religiosas os traços fisionômicos de ricos devotos e doadores reais da Igreja, como por vezes em Giotto. ${ }^{271}$ $\mathrm{O}$ retrato individual surgiu um pouco mais tarde, florescendo junto à individualidade moderna dos Países Baixos e da Itália do Renascimento. Uma tradição alimentou a outra. O retrato italiano foi amplamente devedor da arte flamenga, seja pela descrição do visível, capaz de restituir a realidade a partir de um fascínio e por vezes obsessão pelo detalhe, seja pela própria cultura da região de Flandres, na qual se manifestou um mundo ao mesmo tempo espiritual e material no qual a representação isolada e temporal do indivíduo passou a ser realizada exclusivamente para a propriedade privada. ${ }^{272}$ Essa influência se faria ver, como se sabe, em um dos grandes retratistas da pintura italiana, Antonello da Messina, cujas cultura e técnica foram tributárias da escola flamenga.

No seio da nova concepção de indivíduo, a imitação do real ganha prestígio e fomenta a representação do sujeito em conformidade com a semelhança fisionômica, capaz de revelar tanto a sua história e a sua posição social quanto sua vida interior - entendida não no mesmo sentido do século XVII, mas sim das qualidades da alma (prudência, força, temperança etc.) e também de sua essência, nos termos platônicos. ${ }^{273}$ Um ponto a não perder de vista, posto que indissociável do tipo de semelhança a ser buscado, são os primeiros modelos do retrato individual. O gênero, como já se esboçava nos retábulos de altar, era dedicado inicialmente à nobreza. Pressupunha por isso um esquematismo prévio.

\footnotetext{
271 Jacob Burckhardt, "O retrato na pintura italiana do Renascimento", in Cássio Fernandes (org.). Campinas: Unicamp, 2012, pp. 51-182.

272 Jacob Burckhardt, “As origens da retratística moderna”, Ibid., pp. 187-200; Cássio Fernandes, “Apresentação: O lugar de $O$ retrato na pintura italiana do Renascimento na obra de Jacob Burckhardt", Ibid, pp. 21-50.

${ }^{273}$ Edouard Pommier, Théories du portrait, Paris: Gallimard, 1998.
} 
Os textos italianos sobre o retrato permitem entrever o equilíbrio clássico que ali se semeava em decorrência daqueles que tinham direito a serem representados. Desde pelo menos Alberti se estabelece o culto a um tipo particular de imitação em que a semelhança era subsumida não somente à natureza, mas à noção de beleza. A fórmula era válida principalmente para a realeza. Diante de um príncipe ou rei, os eventuais defeitos físicos deveriam ser minorados ou completamente corrigidos a fim de fazer jus à sua posição e consequentemente a um ideal a ela associado. Partia-se de um modelo vivo, mas de quando em quando era imprescindível ultrapassá-lo. A mestria era mensurada pela capacidade de respeitar a natureza ao mesmo tempo em que o artista deveria deter os meios para aperfeiçoála quando necessário. A imitação dependia de uma seleção, portanto, de uma idealização. ${ }^{274}$

Ao se mencionar a semelhança como um traço matricial da tradição retratística, a referência é menos o lado idealista da pintura italiana que o empirismo da flamenga, principalmente na passagem dos retratos da nobreza para os retratos da burguesia. Belting comenta a transição a partir da geração de Jan van Eyck e de Robert Campin. ${ }^{275}$ O autor elenca como novo parâmetro a possibilidade de se representar uma pessoa privada sem necessariamente matizar sua figuração, sem distorcer sua conformação visual em benefício da posição social. Na cultura da corte do mundo feudal o retrato era apanágio exclusivo da nobreza. Quando um burguês recebia o direito (o gênero portava um estatuto jurídico e um título honorífico) de ser representado era sinal de exercer uma função social na corte. Um dos diferenciais na sua representação em relação à de um príncipe era justamente a criação de uma imagem ideal, dotada de insígnias prestigiosas, dedicada a esse último e o realismo empírico pelo qual se figurava o primeiro. Com a multiplicação dos retratos burgueses, o método a eles dedicado acabou por transformar todo o gênero pictórico. Operou-se um progressivo abandono da velha gramática normativa, das regras de representação da figura humana em prol da singularidade única de uma aparência, da fidelidade aos detalhes do real, de uma verdade descritiva da pessoa. A diferença entre o retrato de um rei e o de um burguês passou a existir em procedimentos secundários e não tanto no regime de figuração. A dessacralização do mundo régio acontecia tanto na pintura como na literatura e em outros domínios no qual uma cultura material burguesa se fazia valer, pondo o sujeito no centro.

Coadunada ao realismo empírico, outra característica. Nos antípodas da pintura italiana, centrada no desenvolvimento de uma história que funcionava como eixo central das obras, a

\footnotetext{
${ }^{274}$ Ibid. Amparamo-nos também numa das aulas que Laneyrye-Dagen dedicou ao tema do retrato durante o seu seminário "Mundus Novus": l'art du XVIe siècle au regard de l'histoire?, realizado na École Normale Supérieure, em 2017.

${ }^{275}$ Hans Belting, Miroir du monde, Paris: Hanz, 2014.
} 
tradição dos Países Baixos, especificamente da Holanda, prescindia de uma linha de coesão pautada numa narrativa. ${ }^{276}$ Naturalmente os retratos individuais e de grupos, mas também as paisagens e as pinturas de gênero e históricas partilhavam uma predisposição à retratística, definida entre outros princípios pelo da supressão das ações e pela tendência à descrição. ${ }^{277}$ Quando no caso de representação da figura humana em grupo, isso poderia se dar por duas vias: pela neutralização dos efeitos da ação principal a partir da existência de episódios secundários que com ela competissem, e pela substituição de qualquer ímpeto (desejo) que pudesse resultar numa ação por um sentimento de passividade dos corpos representados - em especial pela atenção, como se verá mais tarde. O importante era preservar o foco sobre os traços de personalidade das figuras e igualmente evitar a possível distorção que o movimento produziria. $^{278}$

Como se vê, a semelhança, seja ela qual fosse, compreendia no retrato individual a possibilidade de representar visualmente os traços que denotavam uma pessoa. A afirmação é banal, mas o seu alcance é amplo. As diferenças entre os Países Baixos e a Itália também se fazem valer nesse terreno. A menção a isso não será extensa pelo risco tanto de transformar a brevidade da introdução à retratística em algo mais complexo do que se poderia aqui abordar como também de desconsiderar as minúcias existentes de um lado e de outro - até aqui, por exemplo, os Países Baixos e a Itália estão sendo trabalhados como dois blocos homogêneos, o que é uma evidente generalização de nossa parte. Feitas as ponderações, uma diferença deve ser sinalizada: para além do prestígio e da posição social, os retratos das duas regiões se afastavam pelo que permitiam evidenciar do caráter dos indivíduos.

$\mathrm{Na}$ Itália, em especial na pintura de Veneza, com Ticiano, o retrato prioriza em especial o "momento bom", quando o artista captura as formas essenciais, as libera do acidental e do particular irrelevante. ${ }^{279}$ A essa concepção idealista, anteriormente indicada, passou a se realçar a integridade moral e psíquica, atrelada ao ambiente social ao qual o modelo pertence. Essa investida não ia muito longe no que almejava apresentar da interioridade do modelo. Segundo Belting, ${ }^{280}$ naquele país, os sentimentos expostos pelo retrato compunham uma retórica da expressão e dos gestos advinda das tipologias antigas de temperamento e de

\footnotetext{
${ }^{276}$ Sobre a importância da história na pintura italiana, consultar Leon Battista Alberti, Op.cit.

${ }^{277}$ Svetlana Alpers, Op.cit.

278 Alois Riegl, The Group Portraiture of Holland, Los Angeles: Getty Research Institute for the History of Art and the Humanities, 1999. No debate sobre a especificidade do filme-retrato, Oliveira Júnior evoca a ausência de ação como um traço característico do retrato individual, também em conformidade com Alois Riegl. Consultar Luiz Carlos Oliveira Jr, "Retratos em movimento", Anais do XXIV Encontro Anual da Compós, 2015, Brasília.

${ }^{279}$ Dos grandes retratistas italianos, tomamos o caso de Ticiano porque Antonello da Messina nos parece mais próximo ao programa retratístico flamengo.

${ }^{280}$ Hans Belting, 2014.
} 
personalidade, por conseguinte, entendemos, de modelos arquetípicos. Riegl segue na mesma direção ao falar que mesmo tendo introduzido a emoção e estando interessado na representação dos estados de um ser, os retratos individuais de Ticiano e de outros por ele influenciados ainda não alcançavam uma profunda expressividade dos sentimentos uma vez que sempre lhes era introduzido um elemento de isolamento e portanto de distanciamento, uma atitude de superioridade da figura não condizente com a sua exposição emotiva. ${ }^{281}$ Quanto aos Países Baixos, a identidade se manifesta pela fisionomia e sobretudo pelo olhar. Desde Jan Van Eick, existe um aspecto de temporalidade e de subjetividade resultante da atenção aos olhos do retrato, entendidos aqui como verdadeiras janelas para o universo interior, iniciando uma transformação que só se completaria mais tarde: a do retrato como representação da subjetividade, mais do que da figura social.

Somente no século XVIII, com outra concepção de indivíduo, encontrar-se-ia o retrato plenamente condizente com a representação da vida interior, tal como a expressão é entendida na contemporaneidade, apto a apreender o estado psíquico e a experiência do sujeito. Assim, por exemplo, Diderot, a partir de um diálogo com La Tour, no Salão de 1769, entende que para além de copiar um rosto em um momento dado a retratística deve evocar a personalidade de um indivíduo. $\mathrm{O}$ bom retrato permitiria evidenciar os estados permanentes e não apenas a efemeridade de um afeto momentâneo. A noção de "bom momento" também surge, mas não mais em referência a uma ideia e sim ao que revela de definitivo sobre a natureza pessoal e psicológica do sujeito. ${ }^{282}$

Segundo alicerce de definição do retrato, o valor memorialístico é intimamente ligado à semelhança. Representar um indivíduo pela miríade de traços que permitem o seu reconhecimento é um meio de preservar duradouramente a sua imagem para as gerações vindouras. Já o retrato na Antiguidade, que aqui não é o foco, partilhava dessa vocação. Mais cedo, ao se contar o mito de Plínio sobre o nascimento da pintura e a Jovem de Corinto, foi sublinhada a função da sombra como uma imagem que por mais deficitária que fosse em seu grau de analogia frente ao real restituía algo do ser que representa. Aquele mito é uma das primeiras manifestações do rittrato enquanto figura tirada do natural que representa um ser humano. ${ }^{283}$ Ali já se reconhecia parcamente a epítome do gênero enquanto "signo de uma ausência, expressão de uma nostalgia e resposta à morte". 284

\footnotetext{
${ }^{281}$ Alois Riegl, Op.cit.

282 Edouard Pommier, Op.cit.

${ }^{283}$ Definição de Filippo Baldinucci, Ibid, p. 17.

${ }^{284}$ Definição de Charles Perraut, Ibid, p. 20.
} 
O retrato na Idade Moderna recupera o predicado memorial, mas associado a um caráter nobilitante. Membros da corte, personalidades, doadores da Igreja, indivíduos prestigiados socialmente e os primeiros burgueses: a memória era um direito restrito, assegurado por uma hierarquia social. ${ }^{285}$ Nos séculos XV e XVI, chegou-se mesmo a defender a exclusividade de representação individual a personalidades suscetíveis de interesse à posterioridade como exemplo de vida. O retrato memorial era, pois, pensado dentro de um valor social. Responde não apenas à linha familiar e à propriedade privada, mas se destina à coletividade. Somente alguns poucos poderiam perdurar no tempo e receber esse privilégio à memória. ${ }^{286} \mathrm{O}$ elitismo era tal que surgiram manifestações contra a chamada degradação e vulgarização do retrato mediante a sua popularização, com modelos considerados incultos e principalmente indignos de serem representados.

\subsection{2 $\mathrm{O}$ rosto dos marginalizados}

Retomar os dois pilares (entre outros existentes) da tradição retratística pictórica europeia à luz do cinema e em especial do de Pedro Costa impõe desde o princípio uma dificuldade. Como dar uma exclusividade à noção de semelhança frente à banalidade indexical da imagem cinematográfica? Poder-se-ia tentar responder anaforicamente a partir de uma série de negações e, pela eliminação das aparas, precisar uma afirmação. Como o intuito é menos o de uma teoria geral do retrato no cinema que o de tentar esquissar brevemente os contornos do gênero para entender sua finalidade em filmes específicos, o exercício de definição será conciso e direto. Somente um elemento, pela sua hipotética equivalência que é no limite obstrutiva para a precisão, será posto de lado a fim de um melhor entendimento do retrato, o close. Analisaremos sua definição e implicações estéticas a partir de dois teóricos: Béla Balázs e Jean Epstein.

Balázs trata o primeiro plano como um refinamento da encenação. Um fragmento da imagem é destacado do entorno, direcionando o olhar e evitando a distração do espectador. A analogia feita pelo autor é com uma espécie de lupa capaz de se aproximar das células individuais que compõem o tecido da vida, permitindo ler a partitura de sua polifonia, criando as condições para descobrir os sons vitais que se juntam numa grande sinfonia. Quando menciona o efeito do primeiro plano sobre o rosto, isto é, quando escreve sobre o close, aplica

\footnotetext{
${ }^{285}$ Jacob Burckhardt, "O retrato na pintura italiana do Renascimento", in Cássio Fernandes (org.), Op.cit.; Edouard Pommier, Op.cit.; Hans Vlieghe, Op.cit.

286 Ver os testemunhos de Pietro Aretino e de Francisco d'Olanda sobre o direito ao retrato, bem como as manifestações de Giovanni Paolo Lomazzo contra a degeneração do gênero, em Edouard Pommier, Op.cit.
} 
justamente tal lógica: cada mínima dobra da face se converte em um traço decisivo, cada contração fugaz de um músculo tem um pathos assombroso capaz de revelar os grandes acontecimentos interiores de um ser. ${ }^{287} \mathrm{O}$ todo está contido e é anunciado pela análise de suas mínimas partes.

O close criava para Balázs uma fisiognomonia cinematográfica. ${ }^{288}$ Com o enquadramento cerrado sobre o rosto, o espectador é defrontando com emoções e pensamentos da figura humana, com um drama interior que só pode surgir pela supressão mesma do espaço físico que a circunda. Quanto mais próxima a câmera está de um rosto, mais apta está a desvelar o que de profundo ele esconde. Existe uma mudança de escala: as ações são miniaturizadas e passam a existir entre os jogos de olhares e de expressões, no microdrama tornado visível pelo rosto. Assim Balázs analisava, por exemplo, A paixão de Joana d'Arc (La passion de Jeanne d'Arc, 1928), de Dreyer, no qual o embate entre vida e morte, a exposição dos espasmos da mente e das feridas da alma aconteciam exclusivamente sobre o rosto da protagonista.

Os anos 1920 são sempre generosos em suas metáforas sobre o cinema. Na análise sobre a teoria de Epstein e em especial sobre um plano de Coração Fiel (Fig. 38-39), já deparávamos com figuras de linguagens similares às de Balázs ao se mencionar o elogio feito ao plano detalhe do rosto como meio de exprimir os sentimentos das personagens. Transformado numa paisagem cujo relevo permitiria ao espectador escrutinar a vida interior das figuras, o close era discutido como dispositivo de microscopia do movimento exterior apto a revelar os movimentos do espírito e a traduzir a evolução psicológica. Desse modo, a ação cinematográfica deixava de ser composta pelo conjunto de gestualidades para se concentrar sobre as manifestações íntimas e os estados de um sujeito expostos sobre o rosto. ${ }^{289}$ Por ecos completamente casuais, tal comentário alcança e dialoga com o de Riegl sobre a anulação das ações no retrato holandês a fim de acentuar as emoções e a passividade das figuras. Existe um rearranjo de prioridades em que o fundamental é um apelo descritivo sobre o sujeito muito mais do que os eventos, os movimentos físicos e as ações exteriores ao corpo. Até aí, há uma ligação, mesmo que frouxa, entre o que Balázs e Epstein escrevem sobre close e o plano-retrato.

Uma segunda afirmação de Epstein põe as coisas em seu devido lugar. O tema é o plano detalhe em geral, e não tanto aquele do rosto. $\mathrm{O}$ autor menciona a possibilidade emancipatória

\footnotetext{
${ }^{287}$ Béla Balázs, El hombre visible, o la cultura del cine, Buenos Aires: El cuenco de plata, 2014.

${ }^{288}$ Béla Balázs, 2010.

289 Jean Epstein, 1957.
} 
e, em suas palavras, "surrealista" de um plano que pela proximidade isola do entorno um objeto para então desviar o sentido e o emprego habituais a fim de conformá-lo à ambiência sentimental e onírica do filme. ${ }^{290}$ A operação pode recordar aquela sobre a qual se falou do gesto demiúrgico do cinema burlesco e sua ressignificação dos objetos, mas para Epstein é o quadro cinematográfico que realiza a transfiguração, o desvio necessário para a nova articulação. Se se pensar que em lugar de um objeto existe um rosto, deduz-se que o isolamento do plano detalhe promove uma atenção e um novo sentido a fim de enquadrá-lo dentro de um regime distinto. Não é exatamente isso o que acontece com o close de Coração fiel, comentado no Capítulo 1? O plano detalhe sobre o rosto é o que possibilita a conversão da narrativa em estado subjetivo da personagem. Isola-se a face para então disparar e reintegrá-la a outra ordem, mesmo que temporária. A linha de raciocínio é próxima à de Balázs $^{291}$ quando este se posiciona sobre o mosaico fisiognomônico criado pela montagem cinematográfica: num filme, removem-se os closes/os rostos de seus contextos e circunstâncias originais para agrupá-los num eixo sintagmático outro que cambia seus valores emotivos e seus significados originais. Mas o que tudo isso tem a ver com o retrato?

Se o close por si só é um procedimento capaz de permitir um acesso ao universo interior de um sujeito, há vezes em que o seu potencial de desvio - próprio ao plano detalhe em geral - explora a retórica fisionômica junto ao universo fictício que se constrói. O objetivo é o de criar um novo regime representativo que possa se adequar, assemelhar-se, fortalecer e também transformar a narrativa. Configura, então, uma ferramenta dramática. É nessas condições que o close, em conformidade com Balázs e Epstein, parece perder o seu vínculo com o retrato e por isso mesmo abrir uma possibilidade de definição deste último. Pelo menos em como o identificamos em Costa e pelo que foi assimilado dos autores de história da arte citados, o plano-retrato mantém sua força numa certa autonomia diante da ação e do drama que o envelopa.

As descrições das passagens por vezes fulgurantes de Zita em Ossos preparavam o terreno. O retrato ali existe por uma série de procedimentos, entre os quais: o corpo da figura em repouso ou em mobilidade sutil na imagem, o plano fixo em close ou médio da frontalidade ou do perfil, e finalmente, essencial, um tipo de separação do modelo diante do eixo narrativo-dramático a partir de uma inclinação da encenação para a descrição interior da

\footnotetext{
${ }^{290}$ Ver Jean Epstein, "Délire d'une machine", in Jean Epstein, 1975. Num escrito anterior, "Personnalisme de la matière" (EPSTEIN, 1974), o autor já falava da possibilidade do plano detalhe criar uma dimensão autônoma à fábula. A imagem de um olho, de uma boca ou de outras partes do corpo portaria uma existência por si mesma, como se provida de uma alma particular, de uma dimensão anímica, tal qual acreditavam os vitalistas. A articulação de tais planos em um sintagma onírico, porém, ainda não está presente.

${ }^{291}$ Béla Balázs, 2010.
} 
figura mais do que para a sua ação diante do mundo. Dito isso, o entendimento da semelhança enquanto base para a retratística cinematográfica no caso de Costa existe exatamente pelo papel que se atribuiu à exterioridade de Zita, figura esquiva à continuidade dramática do filme, sinal de um mundo que está ali e só pode ser descrito, designado e mostrado, em vez de ser decifrado a partir de ações coordenadas por quem a ele não pertence (o diretor). A semelhança é uma questão de imprevisibilidade e também de opacidade, justamente ao que escapa do agenciamento e imprime uma marca do real - pensada aqui próxima ao efeito de real barthesiano. ${ }^{292}$

O close enquanto artifício dramático, portando uma retórica a partir de como responde à ação, deixa escapar o que o rosto pode fornecer em si mesmo, no sentido de algo a ser decifrado pelo conjunto dos traços e das manifestações fisionômicas, pelo espaço retratado (mesmo que mínimo), e pelos demais elementos que compõem uma tela cuja composição é suficientemente expressiva mesmo autonomamente. Esse segundo caso compreende os closes de Casa de Lava, que carregam toda uma potência da exterioridade, uma força retratística que também estará presente no plano de Zita no prólogo de Ossos. Resumindo: os efeitos retóricos elencados por Balázs e por Epstein para o plano detalhe (em especial o close) são bem-vindos ao que aqui se considera como um retrato. A diferença entre um domínio e o outro se dá no tipo de relação que esses efeitos terão com o filme: direto acolhimento dramático ou parcial apartamento dissonante.

A semelhança no retrato cinematográfico não é contra a narrativa, ela não vem alienar a figura humana. Trata-se sim de uma curta suspensão ou senão da aquiescência a um universo

\footnotetext{
${ }^{292}$ O ponto de partida de Barthes é a tensão entre o real concreto ("o que é", "o que foi”) e o significado. O primeiro pressupõe uma resistência ao segundo, na linha da oposição mítica entre o vivido e o inteligível. Fazendo referência ao contexto ideológico de sua época, Barthes afirma que o universo real é geralmente tratado como uma máquina de guerra contra o sentido, algo deslindado de um postulado oculto, de uma forma preditiva, como se o que se vive não pudesse significar. A resistência a uma estrutura que o constranja seria menor nas narrativas ficcionais e maior no discurso histórico, e existiria desde a Antiguidade, na qual o "real" era situado do lado da História, enquanto na narrativa tinha lugar a verossimilhança. Ao propor um efeito de real, um realismo moderno, ou um novo tipo de verossimilhança, Barthes discute uma narrativa capaz de simular o real concreto ao explorar a carência do significado em benefício do signo que referencia a si mesmo, à sua própria realidade, de um novo tipo de verossimilhança que se furta às "leis de gênero" para se concentrar sobre o reencontro entre um objeto e sua expressão. Ver Roland Barthes, "L'effet de réel", in Communications, 11, 1968, pp. 84-89. No cinema, a concepção barthesiana parece ter inspirado Jean-Louis Commoli. Pelo menos, há um forte ponto em comum: o real enquanto dimensão não agenciável. Comolli põe esse pressuposto na definição mesma da realidade referencial do cinema documentário. Para o autor, o real só pode surgir a partir do que foge ao controle do roteiro e da cena, provocando-lhe fissuras, cortes, brechas pelos quais algo da experiência do mundo concreto é apreendida. Poderíamos citar vários trechos de uma afinidade como o artigo de Barthes, como: "Filmar os homens reais no mundo real significa estar às voltas com a desordem das vidas, com o indecidível dos acontecimentos do mundo, com aquilo que do real se obstina em enganar as previsões. Impossibilidade do roteiro. Necessidade do documentário" (p. 176). Ou ainda: "O não-controle do documentário surge como a condição de invenção. Dela irradia a potência real deste mundo" (p. 177). Ver Jean-Louis Comolli, "Sob o risco do real", in César Guimarães (org.). Ver e poder, Belo Horizonte: UFMG, 2008, pp. 169-178.
} 
outro que a narrativa pode acabar por acolher, mas que mantém uma margem de inacessibilidade e de impossibilidade junto ao conjunto, por isso estabelece uma dissonância e um parcial apartamento. Zita faz parte da favela Fontainhas em Ossos e sua presença se soma à ambiência e ao que o drama dali irá apresentar, mas também mantém uma autonomia que ganha corpo nas perguntas que surgem quando se tenta investigar seu principal retrato (Fig. 200) e os demais (Fig. 201-202): quem é ela e por que a tristeza no olhar? Por que não se integra na festa do bairro e apenas se mantém a observar a alegria dos outros? O que pensa do que vê? Qual a sua subjetividade e como esta é devedora da condição social, do lugar em que mora e da vida que leva? Entre essas perguntas se pode tentar conhecer Zita a partir de uma tensão com o eixo dramático de Ossos: o que de similar sua vida mantém com a vida do casal de protagonistas, também jovens, que têm um filho e tentam matá-lo, vendê-lo, dá-lo? E assim por diante. O mesmo exercício pode ser feito com os rostos do início de Casa de Lava.

Saindo do universo de Costa, mas continuando com um cinema que se endereça ao cotidiano e à pobreza de moradores de periferias, encontra-se o plano-retrato no brasileiro $A$ Vizinhança do Tigre (2014), de Affonso Uchoa. Ao acompanhar algo do cotidiano de Junim, Menor, Neguim, Adilson e Eldo, jovens que moram no Bairro Nacional, em Contagem, zona metropolitana de Belo Horizonte, o filme tenta resgatar a subjetividade e os afetos de uma juventude cujo dia a dia é atravessado e definido tanto pela relação com a pobreza quanto pelo tráfico de drogas. Ao abrir mão de uma estrita análise social cujo risco seria o de redundar numa tipificação social, como o cinema brasileiro conhece tão bem, ${ }^{293}$ o filme se foca em momentos ordinários daqueles personagens. A temporalidade banal do cotidiano funciona como um tecido poroso que gradualmente é permeabilizado, permitindo entrever as marcas da identidade e da subjetividade de cada um dos jovens que ali são decalcadas. Das meninices no humor e nas brincadeiras à relação com as drogas e com o universo do trabalho, acompanham-se em planos de longa duração as marcas do contexto social. Algumas se deixam entrever no vocabulário e outras, principalmente, na cultura do tráfico e da violência: a exortação desse universo por Neguim e Menor, mais novos, e a tentativa de Junim, que já foi preso, de se afastar dele como quem foge de um vórtice que tudo tenta tragar em direção ao seu centro. As experiências se entremeiam a partir de ambiências, de cenas com um potencial descritivo, em que a ação é diluída em prol dos estados de cada um dos personagens, blocos de tempo rarefeito que nem avançam e nem retrocedem a narrativa, montados sem uma concatenação impositiva. É dentro dessa configuração, que mantém

\footnotetext{
293 A referência aqui é ao conhecido debate sobre o modelo sociológico no cinema brasileiro, feito por JeanClaude Bernardet, Cineastas e imagens do povo, São Paulo: Companhia das Letras, 2003.
} 
similaridades com a de No quarto da Vanda, que lá pelas tantas o filme é entrecortado por uma sequência de planos retratos (Fig. 205-208) de jovens sem identidade na trama.

Fig. 205-206
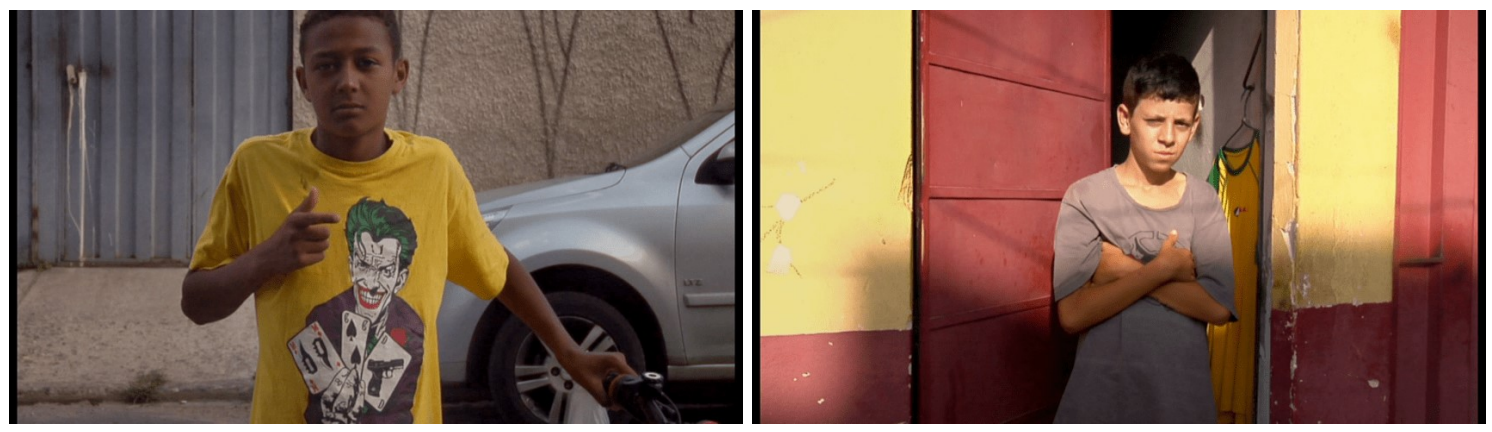

Fig. 207-208
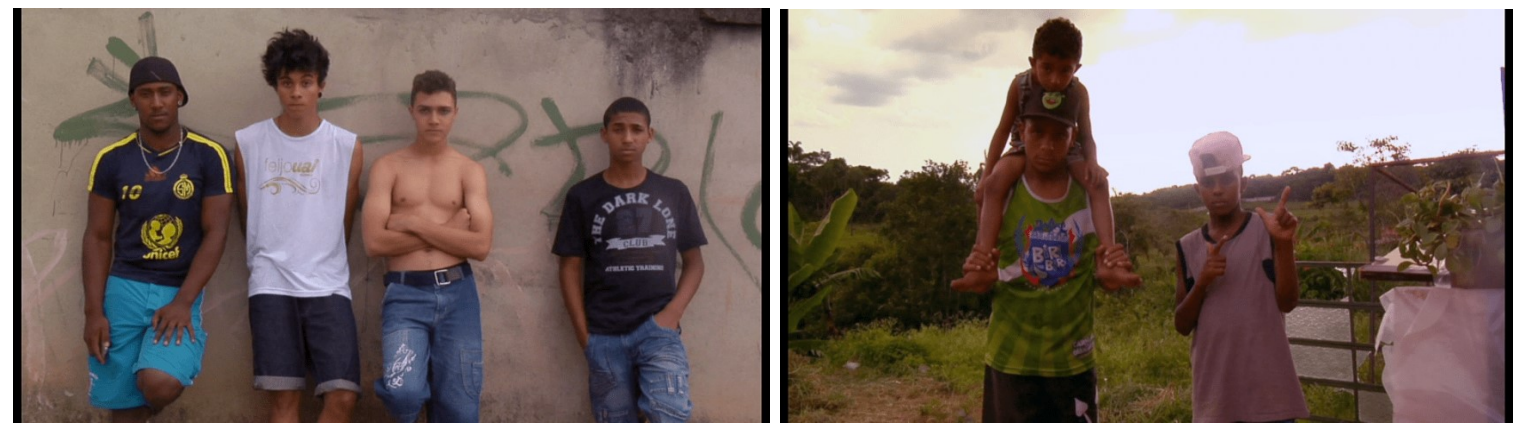

Quem são esses meninos? Por que aparecem no meio do filme e deles nada se diz? As poses de alguns apontam em direção a um imaginário de violência que perpassa e se infiltra naquele cotidiano consciente ou inconscientemente, como decisão, pela inocência ou imperativamente. Se é esse o caso, é válido o mesmo questionamento que surge na conversa entre Nhurro e Vanda: escolheram um determinado tipo de vida ou tomaram um caminho imposto a eles com tanta feridade a ponto de assemelhar-se a um destino? As demais poses não acenam para nenhum código gestual particular e podem ser simplesmente um modo do corpo de estar e de se apresentar com seu pleno direito a não ser decodificado pela instância de enunciação: o Outro em sua opacidade. ${ }^{294}$

Cada uma das figuras na série de retratos porta consigo uma experiência virtual que o espectador só pode presumir como sendo de algum modo permeada por singularidades próximas àquelas de Junim, Menor, Neguim, Adilson e Eldo, tal como em Ossos era possível cotejar a vida de Zita com a dos protagonistas. O resultado dessa comparação entre os

${ }^{294}$ Se $A$ Vizinhança do Tigre escapa a um modelo sociológico, pensando novamente no livro de Bernardet (Op.cit.), também é verdade que o filme direciona sua lente com tanta ênfase a um universo micro, à subjetividade dos personagens, que um olhar macro sobre a condição daquela favela em específico e dentro de um contexto estadual ou nacional, por isso mesmo mais amplo, escapa-lhe completamente. 
modelos dos planos retrato e os personagens principais é profícua em suas possibilidades de aproximação ou distanciamento. Por essa razão mesma o plano retrato vem criar uma tensão com o que se vê ao longo dos respectivos filmes. A Vizinhança do Tigre, contudo, tem uma estrutura muito mais flexível que a de Ossos. O agenciamento das ações cede a uma rarefação e a uma guinada em direção ao banal da vida dos personagens. Mesmo com o afrouxamento da encenação, ou com uma encenação pautada em simular um arrefecimento de seu ordenamento do plano, apela-se para uma série retratística que fortalece ainda mais as zonas de real e a consciência por parte da enunciação do que lhe escapa e do que só pode ser sugerido por uma estrutura sumária: um corpo em repouso num espaço a olhar para a câmera. O corpo fala, o espaço também, já se mostrou demasiado ao longo da tese; o problema aqui é o que se diz. Mas é realmente necessário ter tanta precisão? A ligação com o que é mostrado antes e depois no filme permite desde então conferir uma presença a essas figuras em retratos, uma vida que nos escapa pela profundidade da experiência e pela aspereza do real que nela, cremos, está presente.

Como em A vizinhança do tigre, No quarto da Vanda é estruturado sobre blocos de tempo dilatado. Os corpos ganham pregnância pela permanência em durações extensas em que pouco ou quase nada acontece, numa possível herança que o cinema de Costa talvez deva mais do que qualquer outro ao de Andy Warhol, que tanto admirava. Não existe uma linha narrativa que comece em um ponto para chegar a outro, ou mesmo uma voz off que suture os planos. A progressão mais notável, e ainda assim insuficiente, que se pode recorrer em busca de uma orientação talvez seja aquela da destruição do bairro, que avança, de modo pouco preciso. Fora isso, o filme é composto por blocos com continuidades diversas e sutis, separados em três instantes e locais principais: a casa de Vanda; a casa de Nhurro; e os corredores dos bairros, onde se veem os momentos de coletividade dos moradores e o lastro da pobreza e da destruição iminente.

É raro um uso do plano-retrato em No quarto da Vanda como o que se viu em Casa de Lava, Ossos e mesmo como no filme de Affonso Uchoa, isto é, com figuras estáticas, em pose a defrontar a câmera ou para ela viradas enviezadamente, em instantes parcial ou totalmente exteriores à fábula. Vez em quando isso acontece, como é o caso da mulher chamada Geny (Fig. 209), que só aparece uma única vez, a fumar e a encarar a câmera com seriedade enquanto algum morador fora de campo fala que sua casa foi destruída e depois flerta maliciosamente com ela. Mais pra frente, descobre-se que Geny faleceu. Para além desse momento e de alguns poucos (Fig. 210), quem recebe um tratamento retratístico são os 
próprios personagens que estão no centro do filme. Seria uma brecha no que até aqui se considerou o essencial para a delimitação do gênero, a exterioridade?

Fig. 209

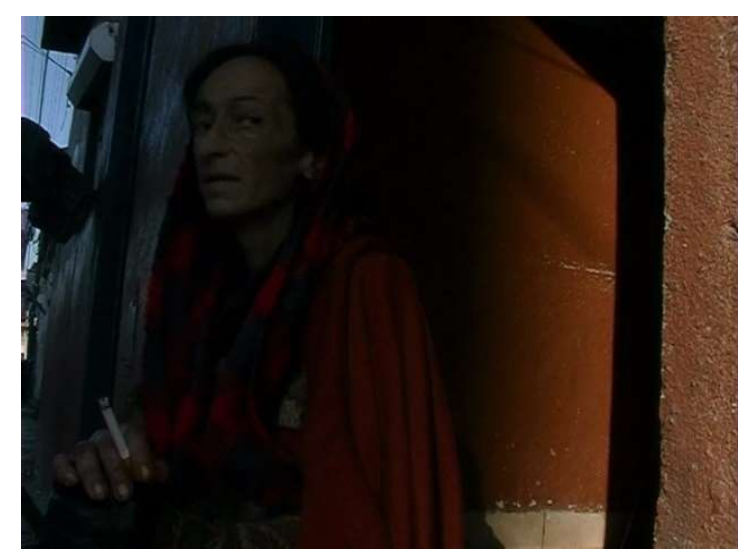

Fig. 210

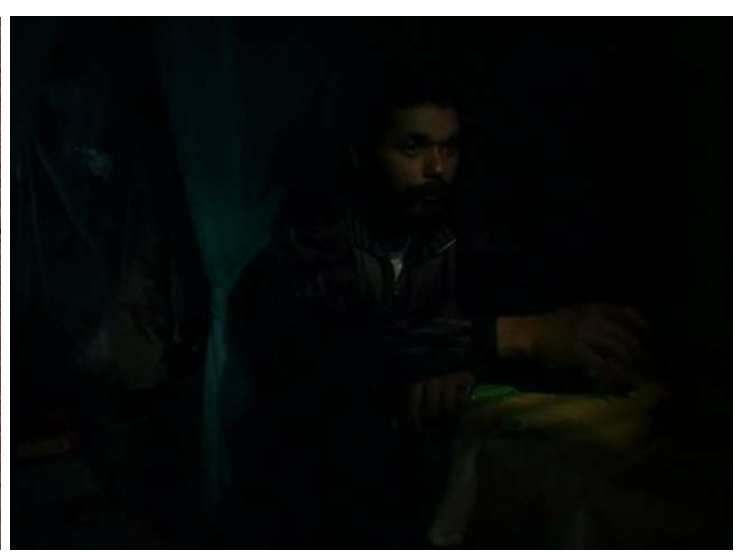

O plano-retrato em No quarto da Vanda, com as características que até o momento se definiu o procedimento, é menos recorrente porque o filme em sua integridade é impregnado e regido, como o eram os vários gêneros da pintura dos Países Baixos, por uma disposição retratística. Este programa é resultante de uma estrutura que prefere a descrição à narração. Disposta em blocos de longa duração, a figura humana realiza gestos banais que, pela incessante repetição, assumem um viés identitário. Junto a isso, o corpo deve ser interpretado pela posição no espaço, pelos objetos que o circundam e sugerem seus hábitos e suas vidas. Em vez de um momento particular, é na própria extensão do filme que se enseja extrair da imagem de um corpo, com plano fixo e parcial imobilidade - pensada relativamente, afinal estamos no cinema, sob o domínio do tempo -, algo sobre sua identidade e sobre a sua posição social.

No quarto da Vanda é contaminado por uma tendência ao retrato similar à do chinês Pais e filhos (Fu Yu Zi, 2014), de Wang Bing. Composto por planos fixos e de longa duração feitos em sua maioria de dentro de uma minúscula casa onde habitam um trabalhador de fábrica, Cai Shunhua, e seus dois filhos, Yongjin e Yonggao, o filme transforma a ação rarefeita e uma disposição retratística em experiência política. Detenhamo-nos em um dos planos de Bing, que dura pouco mais de nove minutos (Fig. 211-212) para compreender o paralelo. 
Fig. 211-212
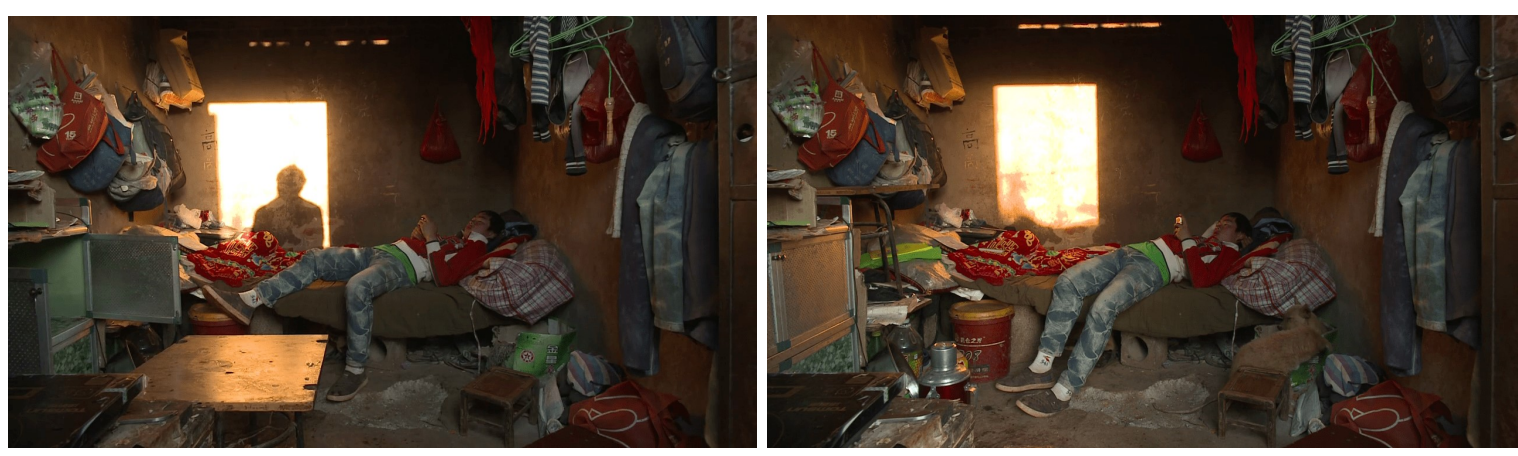

Roupas em varais, sacolas fixadas na parede, um pequeno armário, uma mesa e o único colchão, onde os três dormem, suspenso sobre tijolos, é tudo o que existe na casa. O imóvel é situado num espaço cedido pela fábrica onde Cai trabalha, em Fuming, na província de Yunnan. Um dos filhos está deitado sobre a cama a olhar o aparelho celular, enquanto se escuta o som da TV, no fora de campo. Cai entra em cena, muda a mesa de lugar, guarda um prato no armário, enxuga as mãos e sai. Depois disso e até quase o final do plano o filho permanece na maior parte do tempo com o celular nas mãos, segurando-o com fixidez próximo aos olhos. Se a figura humana fosse o único referencial, a imagem correria o risco de imobilidade dada a apatia da criança. A pobreza do ambiente é tal e a ação rarefeita a um nível em que a cena amarga uma natureza pétrea, uma falta de vida que inicia com o espaço mas inevitavelmente contamina a figura e a integridade do plano. Tudo corrobora um brutalismo da imagem, uma tendência retratística que desvela o real sem arrefecê-lo. Nada de diálogos, elipses, acontecimentos ou o que quer que pudesse minorar o peso da duração - o espectador deve vivenciá-la em toda a sua morosa densidade. ${ }^{295}$

Pela quase total ausência da palavra, o filme é ainda mais radical que No quarto da Vanda. Somente os animais a brincar no canto da casa, os insetos a atravessar o quadro e a luz rompem com o regime de estagnação. Os raios alaranjados de sol que adentram a sala pela porta e esquadrinham lentamente o cômodo lembram que o tempo não parou e que a despeito da realidade pesarosa da casa o mundo exterior existe. O contracampo, porém, é um escape imaginário e nunca realizado; a realidade é filmada como uma prisão. A lenta passagem do tempo e a mera presença dos elementos na imagem sugerem o essencial da cena. Em razão da inclinação retratística, a descrição das aparências dos objetos, do espaço e do corpo é o que permite reestabelecer suas correspondências e compreender o estado social da figura humana.

\footnotetext{
${ }^{295}$ Vale pontuar que esse é um dos filmes mais curtos de Wang Bing, cuja filmografia conta com obras com mais de 9 h de duração, a exemplo de $A$ oeste dos trilhos (Tie Xi Qu, 2003).
} 
Para além de uma estrutura que se assemelha à do retrato pelo plano fixo, imobilidade do corpo, falta de ação, tendência à descrição e flexibilização da encenação de modo a acolher as zonas do real, é de maior interesse para o nosso tema buscar como nessas condições ainda assim é possível falar em um plano-retrato. Um caminho é tornar mais fluidos os contornos da definição sem contudo perder suas bases. Em No quarto da Vanda isso acontece por um tipo de semelhança pensada não mais em relação exclusiva com a parcial exterioridade à fábula esta, como se viu, já não é tão clara, posto que cede às ambiências, ao estado dos corpos e ao cotidiano dos personagens em sua indefinição e falta de ações. A semelhança como critério da retratística nesse filme passa a existir a partir de duas vias complementares: suspensão e mundo interior.

A suspensão nada mais é que a própria exterioridade já comentada aqui, mas dessa vez a partir de outro princípio. Já não se interrompe uma lógica narrativa em prol de outra temporária e parcialmente autônoma: mantém-se o regime principal, com suas ambiências e certa liberdade do cotidiano, mas pelo crivo de uma rarefação que isola as figuras em planos suspensos. Cortam-se principalmente os diálogos para apresentar os corpos em momentos de silêncio e de absorta interioridade, isto é, de uma atividade introspectiva em que, compenetrados, dirigem-se menos ao exterior que a um mundo interior, num isolamento que em geral é o da atenção.

Fig. 213-214
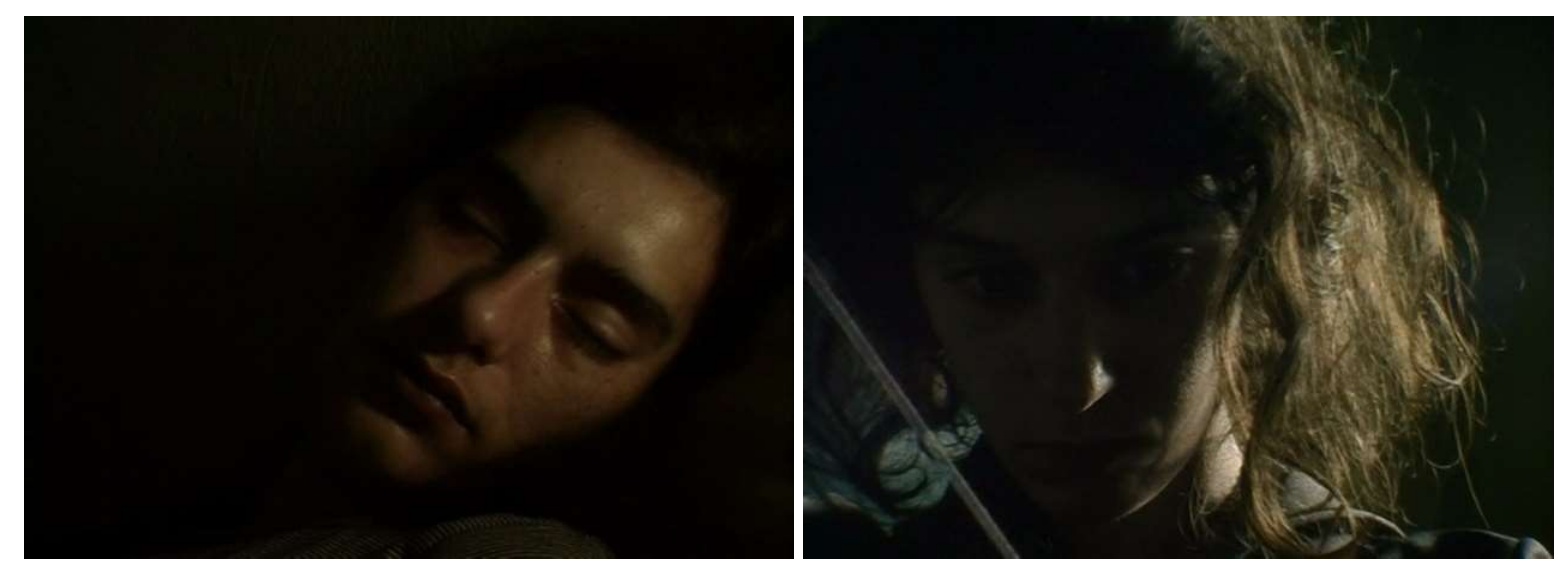


\section{Fig. 215-216}
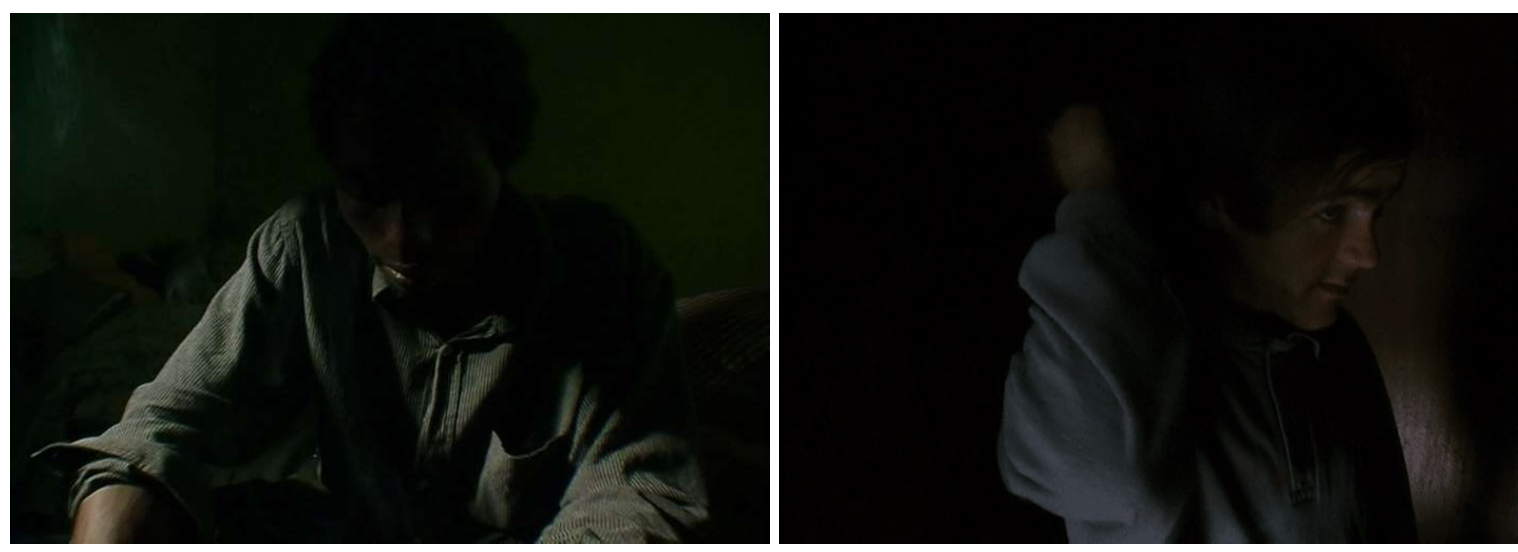

Os personagens principais recebem um retrato tal como se descreve: Vanda está dormindo (Fig. 213); Zita desentranhando um novelo (Fig. 214); Nhurro a pensar, imóvel (Fig. 215); e Russo a pentear os cabelos impecável e obsessivamente (Fig. 216). São exemplos e há outros tantos. Nos casos mencionados, cada um assume um estado de concentração e isolamento que tanto os aparta do restante do filme (em que muito se fala e se interage) como permite uma deriva pessoal, um recolhimento em relação ao cotidiano, um tom de reflexividade e mesmo de um direito a si. Existe um alheamento da miséria, da droga e da destruição do bairro que é temporário mas respeitoso com as respectivas subjetividades.

Vanda dorme, finalmente descansando dos dois principais gestos que até então forjaram sua identidade no filme: o preparo e o consumo do crack, de um lado, e a venda de verduras pelos corredores do bairro, do outro. Zita, com o olhar distante a desfiar o novelo, parece habitar um mundo à parte tão distante quanto o da irmã adormecida. O mesmo para Russo, que fica absorto num gesto repetido, como se o cabelo alinhado fosse mais importante que o seu entorno. Nhurro, que arrumava incessantemente a própria casa e se drogava, senta-se na cama e parece meditar sobre sua vida, num possível prelúdio da futura conversa que teria com Vanda (Fig. 187). Com o rosto encoberto pela penumbra, ele nos faz pensar num dos autorretratos de Rembrandt quando jovem (Fig. 217), em que a sombra repousa sobre uma parte da fisionomia. Sobre essa pintura, Max Milner pôs uma pergunta que também poderíamos endereçar ao plano de Nhurro: "por que esta estranha ocultação do olhar em um gênero onde olhos são em geral considerados como o elemento essencial do rosto?". ${ }^{296}$ A escuridão que desaparece com os olhos e parte da expressão de Nhurro the reserva uma privacidade que a frontalidade ameaça, um espaço no qual lhe é permitido mergulhar em sua

\footnotetext{
${ }^{296}$ Max Milner, Op.cit.
} 
individualidade e ponderar sobre o que o reserva o destino ("a vida que a gente é obrigado a ter"). Ele acabara de ser desalojado.

Fig. 217

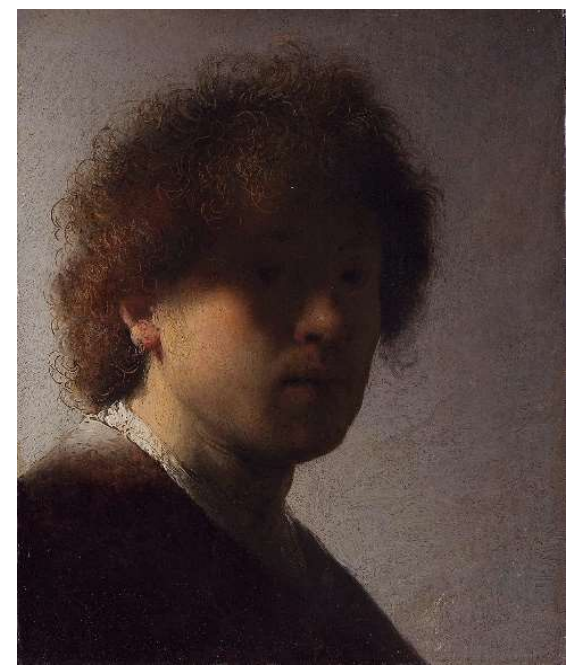

Fig.218

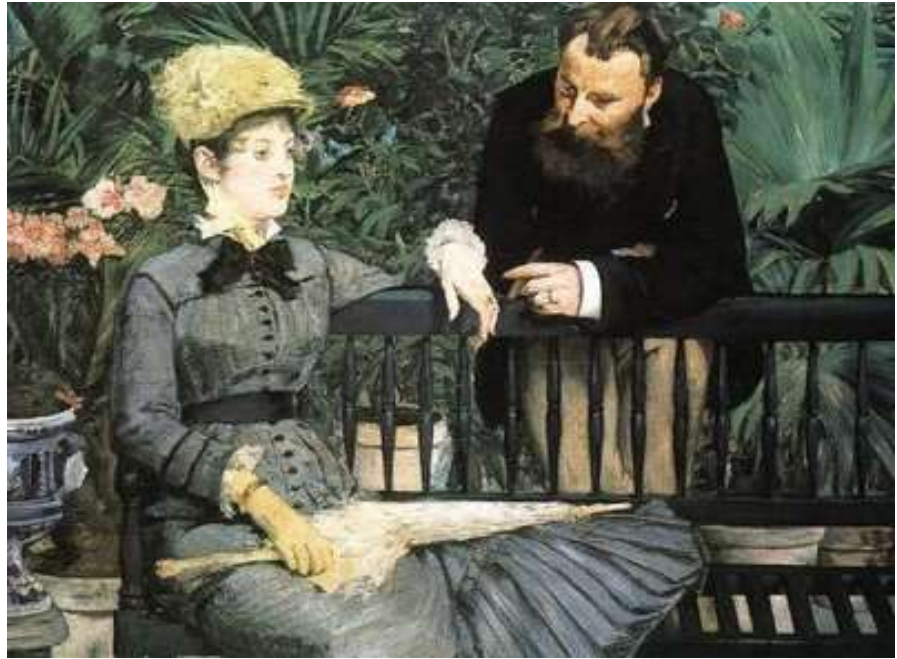

Diante desses retratos de No quarto da Vanda pode-se mencionar a análise de Crary sobre o problema da atenção em Na estufa (Dans la serre, 1879, Fig. 218), de Manet. ${ }^{297}$ O ponto de partida é a noção de visão subjetiva, desenvolvida no século XIX e referente à visão como experiência ancorada na densidade e materialidade do corpo, sensação que depende mais da constituição e do funcionamento do aparelho sensorial que de um estímulo externo. A questão inicialmente se volta para o olhar da figura feminina: ela estaria perdida em pensamento, em absorção vazia, ou mesmo numa espécie de transe? Dando seguimento à análise a partir da relação espacial das figuras, dos gestos e de uma série de signos, o autor identifica na tela uma experiência de dissociação e fratura onde aparentemente existiria uma superfície unificada. No que a princípio parecem ser duas figuras atentas, há uma série de traços que anunciam uma experiência dissociativa a partir de estados de distração que corroem a estabilidade visual. Dentro de um sistema de fixações e coerções fundado em códigos sociais e numa circularidade mercadológica, as duas figuras instauram uma errância do corpo sensorial. Entre outros meios, pelo modo de representar a atenção, que está sempre apta a deslizar para a sua dispersão, para a distração ou mais especificamente para um estado de perturbação que impede os corpos de serem plenamente coagidos pelos determinantes sociais ali existentes.

${ }^{297}$ Jonathan Crary, 2004. 
O campo de referências de Crary e da tela de Manet são outros que o do filme de Costa, mas em ambos a figura humana partilha de um estado ambivalente de atenção. Pela natureza perceptiva e sensorial, o sujeito resguarda-se e o seu corpo mantém-se parcialmente alheio a uma realidade dominante que o envolve. Esse movimento em direção a si mesmo também faz parte de um estado das figuras que, dentro de outras particularidades, Riegl observa nos retratos holandeses de grupo. Neles a atenção seria a última etapa em uma linha gradativa de representação da figura humana que inicia com o estado mais objetivo e de exterioridade, o desejo, inerente à ação diante do mundo, e segue para um grau de subjetividade e de explicitação da experiência psíquica, que primeiramente é o da emoção e por fim o da atenção.

A semelhança enquanto base para a retratística cinematográfica, em especial no nível do plano, é baseada portanto em dois tipos de exterioridade relativa. Uma em relação à fábula, com figuras que dispõem de certa autonomia. A outra, que chamamos de suspensão, em relação a um sistema dominante frente ao qual é dado aos personagens o direito de uma introspecção e um mergulho no mundo interior. A vocação memorial, por sua vez, aponta em direção a outro horizonte. O que na pintura dos Países Baixos e da Itália foi por muito tempo associado ao prestígio social que permitia a determinadas classes serem retratadas e perdurarem ao longo das gerações, por vezes assumindo uma exemplaridade de vida, Costa trabalhará numa chave essencialmente política que inverte essa tendência.

Talvez já esteja por demais evidente que o retrato em Ossos e No quarto da Vanda existe para dar uma justa figura a pessoas marginalizadas socialmente, possibilitando que tenham direito a uma imagem. Dá-se um rosto à experiência, como se antecipou mais cedo. Uma máxima benjaminiana sobremodo citada atualmente, mas que ainda preserva seu valor de origem, tem sua validade para o tema: a história oficial é a história dos vencedores; os oprimidos amargam uma derrota que entre outras é a do esquecimento. ${ }^{298}$ Alguma dúvida de que, sem a obra de Costa, Vanda, Zita, Nhurro, Russo, Muleta e outros tantos moradores das Fontainhas que aparecem em seus filmes, bem como o próprio bairro, permaneceriam no anonimato? O pobre ali recebe uma face, uma identidade e principalmente uma história. Mais que a participação por outras vias nos filmes, é pelo retrato, pela semelhança, que nada mais é do que um acesso privilegiado e menos impositivo sobre o Outro, que se garante uma imagem aos marginalizados. Numa chave similar, o mesmo acontecerá com a série de planos-retratos do filme de Affonso Uchoa e também com a disposição retratística de Wang Bing. Em

\footnotetext{
${ }^{298}$ A remissão é às "Teses sobre o Conceito de História”, em Walter Benjamin, Op.cit.
} 
diferentes medidas e com mais ou menos sucesso, os três realizadores tentam representar a figura humana pela tentativa de lhe propiciar uma espessura política, encarnando-as por um jogo de flexibilização da encenação, pela abertura ao que os corpos deixam sugerir pelo mínimo de ação.

Não custa pontuar que, em relação ao nível econômico e social de seus "modelos", os filmes mencionados acenam a um tipo de retrato executado por artistas modernos como Manet. Influenciado por Velásquez, que no século XVII pintara bobos e anões, o francês retratou moradores de rua, mendigos e outros párias sociais, a quem conferiu uma proeminência pictórica. Contudo, seu programa se distancia do dos filmes analisados na medida em que é orientado pela solidariedade a um grupo de pessoas que, como os artistas de vanguarda, também sofriam o estigma da exclusão na sociedade parisiense. ${ }^{299}$ Outro caso a ser lembrado é o dos retratos dos marginalizados na Itália do século XVII, alinhados a uma inflexão etnográfica presente em textos (dos legislativos aos literários) que ofereciam descrições taxinômicas de classes marginalizadas: mendigos, prostitutas e outros. Marcados por uma ambivalência, situam-se entre a representação objetiva e a idealização, "a meio caminho entre o materialismo da descrição e o elogio de uma pobreza digna, entre a determinação precisa e carnal de uma fisionomia bem caracterizada e a representação de um estereótipo dramático, de um topos literário ou de uma alegoria". ${ }^{300}$ Assim, possuem algo do olhar materialista-histórico dos retratos cinematográficos discutidos, mas ao mesmo tempo deles se afastam quando se inclinam para a tentativa de enquadrar o modelo num programa arquetípico.

Como na tradição pictórica, a morte assombra e mesmo garante a vocação memorial do retrato cinematográfico. Os filmes aqui analisados figuram o corpo em contextos maculados por algum tipo de precariedade existencial que é diretamente vinculado ao mundo material. A fome e a miséria motivam os protagonistas de Ossos ao suicídio e a tentarem matar o próprio filho. Quando não, estão sempre a desmaiar e a cair pelos cantos letárgicos e com o olhar moribundo. Em No Quarto da Vanda, é o processo de demolição do bairro e o depauperamento físico e moral ocasionado pela droga que se impõem contra as figuras. Os corpos esquálidos de Zita e de Vanda; a tosse e o vômito desta última; as agulhas atravessando os corpos de Nhurro, Russo e Muleta: o filme é marcado por uma fantasmagoria tão forte quanto aquela que se discutiu no Capítulo 1 sob o título de uma Síndrome de

\footnotetext{
${ }^{299}$ Meyer Schapiro, “Os personagens”, in Impressionismo, São Paulo: Cosac \& Naify, 2002, pp. 139-159.

${ }^{300}$ Francesca Cappelletti, Annick Lemoine, Les Bas-fonds du Baroque: La Rome du vice et de la misère. ParisRoma, Officina Libraria, 2014.
} 
Nosferatu - no cinema de Grandrieux, de Garrel (cuja obra é marcada pela retratística) e de outros realizadores. Com a diferença que em Costa a trama ficcional é substituída pelo risco real da droga que espolia e condena as existências. A figura humana está no limiar da vida. Existe uma aproximação com os universos de $A$ vizinhança do Tigre e Pai e filhos, nos quais os corpos são representados também pelo que os martiriza socialmente e marca sua fragilidade. Em todos estes casos, o retrato, em suas diferentes formas, sinaliza um risco e registra o esmorecimento do corpo. Sintoma de ameaça e por vezes sinal de uma ausência, será ele, paradoxalmente, a reforçar a resposta contra o tempo e a potência mnemônica das imagens.

\subsection{A representação do negro}

O retrato dos marginalizados porta consigo a problemática de representação do Outro. Se a estrutura mais livre de No quarto da Vanda demonstra a vontade de uma abordagem menos impositiva e mais digna sobre os moradores do bairro das Fontainhas a partir de estratégias de reorientação da mise en scène como o plano-retrato ou uma disposição retratística, o filme seguinte de Costa, Juventude em marcha traz uma particularidade a mais. Protagonizado por Ventura, habitante da favela das Fontainhas, a obra nos põe uma pergunta: existiria ali alguma especificidade em figurar o negro? O corpo aqui é o de um imigrante cabo-verdiano que mora numa favela na periferia de Lisboa. Ventura se mudou para Portugal para procurar emprego na construção civil como pedreiro. Do seu passado, sabe-se que se dividia entre o exílio e o trabalho enquanto o restante do país comemorava o fim da ditadura e a Revolução dos Cravos. Do seu presente, como outros moradores das Fontainhas, ou do que dela resta, vive a pobreza.

Fig. 219

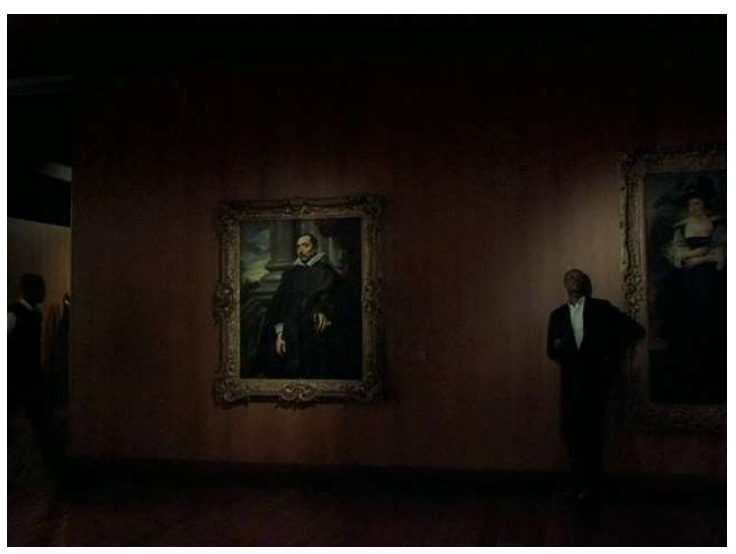

Fig. 220

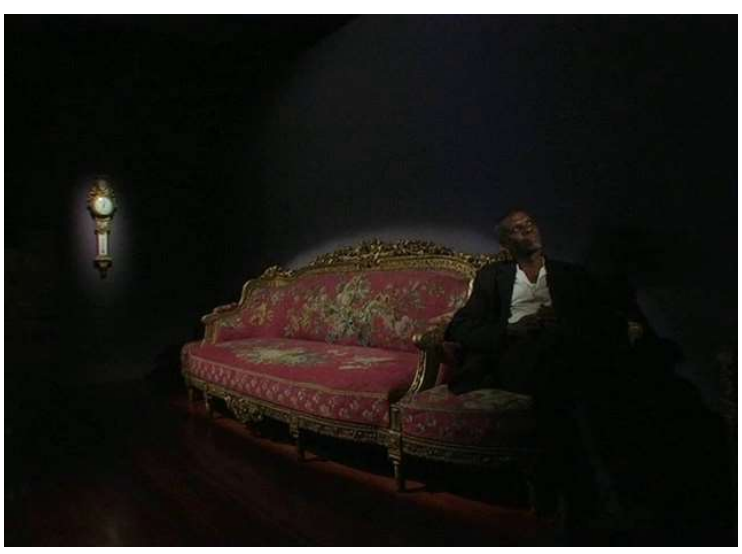


Para responder à pergunta posta, vamos nos ater à cena em que Ventura entra em um dos salões da Fundação Gulbenkian e se encosta numa das paredes. Aureolado por sombras demarcadas, fica entre o Retrato de homem (1920-1921), de Anthony Van Dyck, e o Retrato de Helena Fourment (1930-1932), de Rubens (Fig. 219). O segurança, também negro, entra em campo, fala ao seu ouvido e o personagem se retira do espaço sem muita contrariedade. Logo após sua saída, o funcionário limpa o lugar em que estava. Seu rastro precisa ser apagado. Alguns planos mais à frente, Ventura aparece sentado elegantemente, com as pernas cruzadas, sobre uma poltrona que está em exposição no museu. Com a cabeça e o olhar em direção ao fora de campo, parece confortável e tem o ar distraído. Não dura muito. O desfecho é similar: o segurança chega ao espaço, mostra o descontentamento com um gesto e dessa vez conduz Ventura até a saída do museu, pelas portas do fundo. No jardim externo, os dois conversam. Ventura comenta que foi um dos pedreiros que ajudou a construir o edifício da Fundação Gulbenkain.

Fig. 221

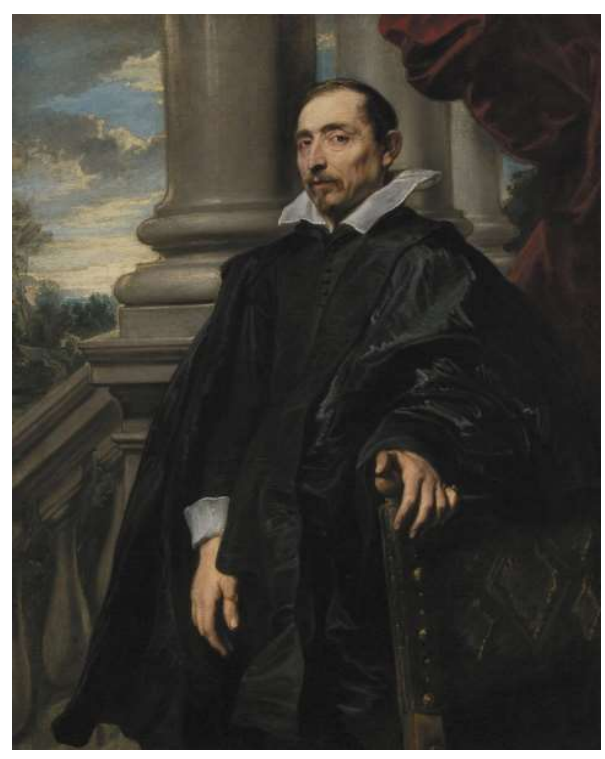

Fig. 222

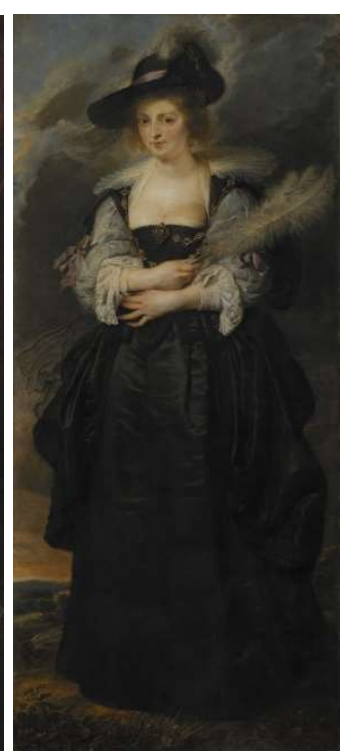

Dado o que foi desenvolvido até aqui sobre a importância que sua obra dedica ao gênero do retrato, duvidamos que tenha sido em vão a escolha de Costa em pôr Ventura justamente numa sala com uma tela de Van Dyck e outra de Rubens, dois pintores flamengos cujo prestígio foi construído entre outros meios pela tradição do retrato, principalmente da nobreza e da burguesia em ascensão. Por que Ventura é colocado ali entre os dois quadros? Uma contextualização é necessária.

Ambas as telas são posteriores a 1620, quando a pintura histórica e também os retratos flamengos foram revitalizados pelo esplendor do alto barroco, com vestimentas influenciadas 
pela moda francesa em substituição aos trajes do início do século XVII, e também por representarem o modo de vida refinado de uma burguesia recém-enriquecida que almejava a aristocracia. Os retratos solicitados naquele período portavam um caráter ostentatório, refletindo diretamente a transformação social, quer seja pelas roupas, quer seja pelo cenário com elementos arquitetônicos majestosos.

O Retrato de Helena Fourment (Fig. 222) ilustra perfeitamente o momento anunciado. A mulher representada é a esposa de Rubens. O quadro foi realizado no período em que o pintor produziu seus retratos mais íntimos, incluindo, como é o caso, os dos membros de sua família. Para além da maior descontração e da naturalidade resultante da informalidade em pintar os seus, os retratos desse período traziam outra singularidade: representavam as figuras de corpo inteiro, formato que à época era privilégio da aristocracia - aos burgueses era reservado o retrato de meio corpo. Um das razões para essa escolha ao retratar a esposa se encontra na biografia do pintor, que desde 1624 havia ascendido à condição de nobre. Os retratos de sua família estavam envoltos pelo desejo de adaptar-se ao estilo das classes superiores, personificando a vontade de reconhecimento aristocrático. Quanto a Retrato de Homem (Fig. 221), tela de seu discípulo Van Dyck, não se sabe ao certo quem é o modelo. ${ }^{301}$ Contudo, pela data da pintura, pelo tratamento elegante dado à vestimenta e mesmo pelo cenário com a cortina vermelha atrás da qual se desdobra, sugerido pelas colunas em perspectiva, um cenário em profundidade, supomos se tratar de um retrato da fase de transição entre a estética flamenga e a exuberância do estilo veneziano, cuja influência se faria valer no pintor a partir das décadas de 1920 e $1921 .{ }^{302}$ Mais do que esse tipo de suspeita, o importante é saber que o tratamento da pintura, desde o que se descreveu até a pose suntuosa, enaltecem o modelo na imagem.

Qual a relação entre Ventura e aquelas duas figuras? Sua representação ao longo do filme tem algo a ver com o que o que revelam os dos dois retratos em seus contextos originais: o enobrecimento, a afirmação social ou mais precisamente o desejo de ascensão aristocrático envolvendo os modelos. Essa operação é similar àquela que a mise en scène de Juventude em marcha realiza sobre o corpo de Ventura a partir de uma série de estratégias que se esforçam em propiciar-lhe uma dimensão monumental na imagem e ao mesmo tempo uma gestualidade distinta, elegante e mesmo elevada. Não são poucas as vezes que a câmera o enquadra de baixo para cima, acentuando sua estatura a despeito da dos outros personagens,

\footnotetext{
${ }^{301}$ Museu Calouste Gulbenkian. Disponível em: https:/gulbenkian.pt/museu/works_museu/ retrato-de-homem. Acesso em: 25/01/2018.

${ }^{302} \mathrm{O}$ comentário sobre a pintura flamenga do alto barroco, bem como a descrição dos respectivos quadros, foram baseados em: Hans Vlieghe, Op.cit.
} 
ou que os seus gestos adquirem uma potência pela economia e pelo hieratismo singular. $\mathrm{O}$ objetivo, claro, não é caracterizá-lo como figura aristocrática. A figuração de Ventura obedece a um cruzamento recorrente no filme entre uma "alta cultura", incluindo uma certa beleza presente na própria composição pictórica dos planos, e o cotidiano dos pobres. Muitos textos sobre Costa se lançaram na compreensão desse encontro entre universos aparentemente antagônicos, também presente na obra do casal Straub-Huillet. Retomaremos um para dele pontualmente discordar e, então, tentar encontrar uma via de entendimento para o hibridismo que contamina Ventura.

Partindo da cena na Fundação Gulbenkain, Rancière defende um tipo de política em Costa que surge na contramão da hipótese facilmente deduzível do episódio de expulsão de Ventura do museu, a de que "os prazeres da arte não são para os proletários, mais precisamente ainda que os museus estão fechados aos operários que os construíram". ${ }^{303} \mathrm{Ou}$ mesmo a de que ali se veria a alienação do trabalhador frente ao objeto que produziu e a serviço do prazer dos estetas. Para Rancière, o museu não é o lugar da riqueza artística em oposição à indigência do trabalhador, mas sim o espaço de uma arte ingrata ao último, avarenta diante da riqueza sensível de sua experiência. Com o progredir do texto, defende que Juventude em marcha, mais do que abrir o museu aos trabalhadores que o construíram, ensaia uma arte que provenha daquelas pessoas. O filme levaria a cabo uma política fundada na riqueza sensível da experiência, no poder da palavra e da visão oriundos de vidas precárias. Não seria preciso restituir nenhum tipo de dignidade, mas mostrá-la. A formulação é valiosa e está em consonância com outros comentários sobre a obra do diretor e também com uma entrevista $^{304}$ que o próprio concedeu a respeito de tentar resgatar uma beleza e uma verdade dos pobres que estão a se perder. No entanto, um ponto nos chama a atenção. Segundo Rancière, tal política se opõe a um esteticismo pelo qual parte da crítica acusou o cinema de Costa. ${ }^{305}$ Uma prova disso seria a de que os lugares teriam sido filmados tal como estavam

\footnotetext{
303 Jacques Rancière, "Política de Pedro Costa", in Ricardo Matos Cabo (org.), Cem mil cigarros, Lisboa: Orfeu Negro, 2009, pp. 56.

304 "Esta escolha [de António Reis] pelo campo dos humildes foi para mim fundamental, pois há no pobre uma beleza, uma riqueza, uma verdade, que se está a perder porque não é bem vista, não é bem ouvida, e [isto] só pode ser feito se se passar muito tempo com essas pessoas. [...] o cinema começa de uma maneira e vai acabar se acabar - dessa mesma maneira, com as pessoas pobres. O cinema começou a olhar para as pessoas que não tinham imagem, não começou por fazer histórias - ele é História". Costa citado por Mateus Araújo Silva, "Pedro Costa e sua poética da pobreza", in Carla Maia, Daniel Ribeiro Duarte, Patrícia Mourão, O cinema de Pedro Costa, SP: CCBB, 2010, pp. 111.

305 Talvez seja demasiado óbvio, mas tanto o uso do sufixo como o modo pejorativo com que Rancière (2009) emprega o termo levam a pensar que se trata de um estado que ultrapassa e por isso distorce a estética entendida como o momento de unidade e de adequação constatada entre a forma e o conteúdo de uma proposição, alinhamento entre o pensamento e a aparência sensorial, quando a forma se mostra o invólucro, a precisa roupagem de uma intuição da ordem do mundo, sendo capaz de restituir o signo é à sua fenomenalidade.
} 
(sem recriações a partir de cenários etc) e, especialmente, sem explorar a miséria como objeto da ficção. Até aí, sem objeções. As coisas ficam menos óbvias se se pensar que o risco de um esteticismo não está tanto em uma indiferença em relação àquele que se filma, mas em outro lugar. Para alcançar esse ponto, recobraremos à voo de pássaro uma discussão aparentemente distante, mas que tem sua importância para o debate.

Em um artigo dedicado à figuração do negro em pinturas espanholas realizadas entre o século XVI e XVII, Stoichita aborda uma dialética entre a imagem de pessoas brancas e negras que existia tanto num nível ideológico quanto no de uma expressão formal. ${ }^{306} \mathrm{~A}$ antítese estética ou o binarismo racial é verificado em quadros que de um modo mais geral vão associar a negritude à feiura e a brancura à beleza e, por conseguinte, colocarão o negro num lugar periférico. São dados como exemplos retratos de damas aristocráticas ao lado de seus servos negros, ${ }^{307}$ como Joana da Áustria com uma escrava negra (de Cristóbal de Morales, 1553, Fig. 223); imagens de batizados de negros como formas de um embranquecimento interior; e mesmo quadros de estudos fisiognomônicos, de autoria de Fray Matías de Irala, em que rostos de negros surgem em oposição aos "perfis gregos" e brancos que dominam o plano, estabelecendo um grupo paralelo que não se integra ao sistema geral, mas que demarca um deslocamento e marginalização, uma contraposição ao que ali é figurado (Fig. 224).

Fig. 223

Fig. 224
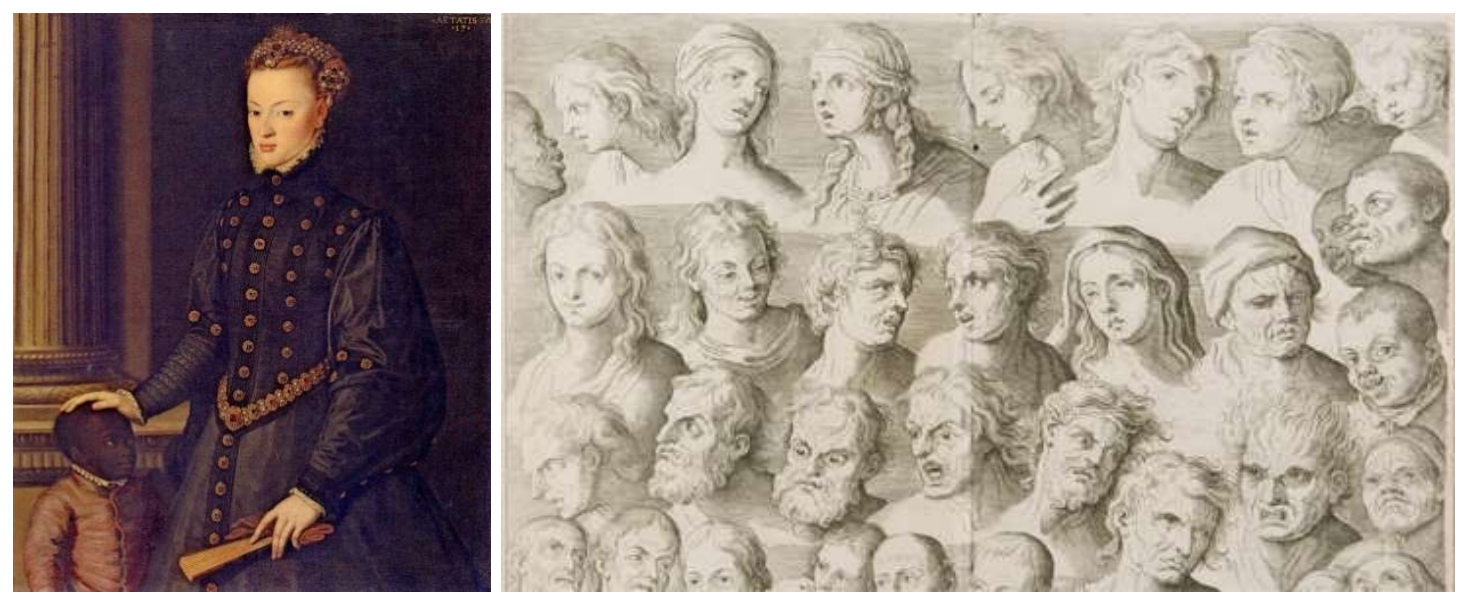

O transbordamento rumo ao esteticismo aponta, acreditamos, o formalismo que desfaz o equilíbrio entre o pensamento e a aparência sensorial, obstruindo o percurso e impedindo que o signo seja reconstituído ao mundo. Em Costa, no pior dos casos, o risco do esteticismo é criar um problema ético: aproveitar-se do pobre formalmente sem com isso implicar num engajamento político. Sobre a noção de "estética", nos baseamos num brevíssimo comentário de T.J. Clark, "Fenomenalidade e materialidade em Cézanne”, in Sônia Salzstein (org.), Modernismos, São Paulo: Cosac Naify, 2007.

${ }^{306}$ Victor I. Stoichita, “L'image du noir”. 2013.

${ }^{307}$ Como se sabe, isso não é nenhuma exclusividade da pintura espanhola, pois a mesma composição se vê, por exemplo, na pintura flamenga, na obra de Van Dyck, em Retrato de Elena Grimaldi (1623), Retrato de Henrietta de Lorena, 1634, entre outros. 
O percurso adotado pelo texto de Stoichita almeja um ponto mais além: uma certa codificação, mecanismos simbólicos da pintura ibérica por meio dos quais a figura do negro poderia ascender a um status de representação equivalente ao do branco. Uma importante iconografia nesse sentido é a da visita dos Reis magos no nascimento de Cristo, em que um dos reis, Balthazar, é negro. Nos dois quadros homônimos analisados pelo autor, Adoração dos Reis magos, um de Diego Velásquez (1619) e outro de Juan Bautista Maíno (1613-1614), Balthazar passa por um processo de conversão que o aproxima da imagem do branco, seja pelas vestimentas e pelos traços fisionômicos, seja por estratégias figurativas. Stoichita dá seguimento à questão a partir de três outros casos principais, o de São Benedito de Palermo, o de um homem de letras conhecido por Juan Latino, e o do militar Juan de Mérida. Cada um é protagonista de uma história em que suas ações o deslocam de uma condição subalterna para outra superior, permitindo então um direito à imagem. Seria a partir dessas figuras que se iniciaria um processo de abertura na cultura ibérica, incluindo a pintura, para a representação do negro.

Fig. 225

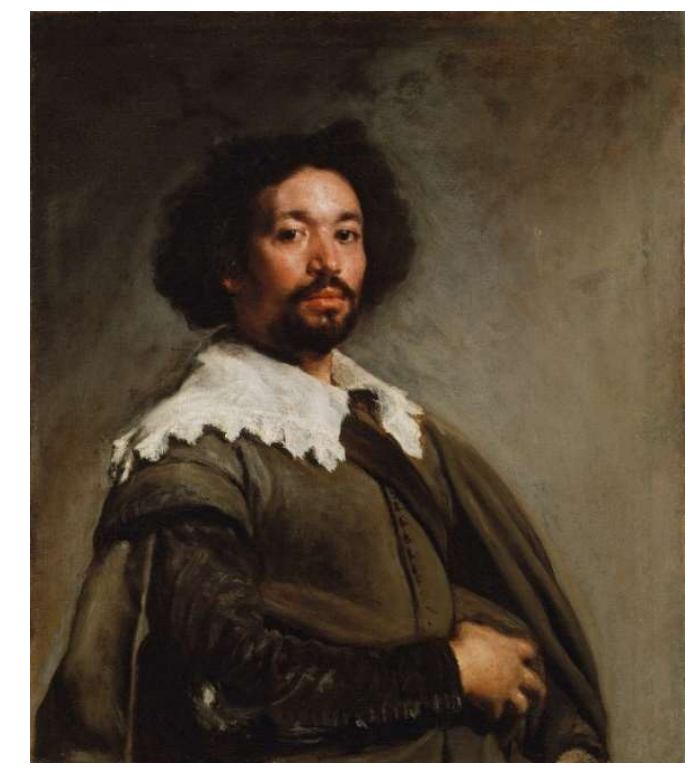

O século XVII espanhol veria, ainda como exceção, o retrato que Velásquez pintou em 1650 de seu assistente afrodescendente e também escravo, Juan de Pareja (Fig. 225). ${ }^{308}$ Para além da semelhança, que segundo biógrafos causou furor à época, a imagem continha, como se pode presumir, um aparente paradoxo. Ao fazer o retrato de um escravo, violava-se uma das bases do gênero, a sua restrição aos membros de classes abastadas. Velásquez pintou o

${ }^{308}$ Cf. Victor Stoichita, "Le Portrait de 'l'Autre”. 2013. 
seu assistente, mas para isso retirou do quadro possíveis indicações da sua posição social, realçando outras características. Juan é retratado enquanto nobre. Ele "porta, como um senhor, um rico colarinho de renda de Flandres - na Espanha, este ornamento era proibido aos homens livres e mesmo Philippe IV evitava utilizá-lo a fim de respeitar a austeridade dos costumes", ao que se acrescenta o olhar altivo dirigido ao espectador. ${ }^{309} \mathrm{O}$ gesto de modificar a classe de Juan sugere duas interpretações complementares: omiti-la para conformar (mesmo que por uma invenção) a figura às normas do retrato; realizar uma ascensão social figurativa necessária mesma para restituir uma grandeza que a condição de escravo lhe usurpava.

Essa breve visada sobre a representação do negro na pintura ibérica permite retornar o texto de Rancière. Ao defender que o cinema de Costa se exime de um esteticismo, o autor fecha os olhos para a especificidade da figuração de Ventura, que é única na obra do diretor por várias razões. Se na trilogia das Fontainhas não se recria o espaço a partir de cenários, se existe um certo realismo que tenta representar a comunidade sem recorrer a uma cosmética da miséria, mas evidenciando uma potência própria àquelas pessoas e às suas vidas, uma beleza que em nada arrefece o problema social em questão, o mesmo não se pode dizer de Ventura. Diferentemente dos demais personagens de Ossos, No quarto da Vanda e Juventude em Marcha, ele passa por uma codificação gestual, figurativa e mesmo de personalidade que tem por objetivo conferir-lhe uma imagem particular. Tentaremos ser mais precisos. No filme anterior, Vanda, Zita, Nhurro, Russo e Muleta são apresentados em situações delicadas em razão da droga e da pobreza. No entanto, pelas experiências que partilham através dos muitos diálogos e por uma empatia que se cria frente à penúria de suas vidas, existe neles uma forte dignidade. A cena de Nhurro e Vanda é um desses momentos (Fig. 187). Não há ali ou em outros planos uma estetização, uma mise en scène que sublinhe, acentue, torne patente a beleza e suavize a pobreza. A operação é quase oposta. Onde a desigualdade social teria reservado apenas a rudeza e a fealdade da miséria, encontra-se algo de muito elevado. Com Ventura, vai-se além pelo que antes se comentou sobre a monumentalidade da sua figura em razão dos planos em contraplongée (Fig. 226 e 227) e da gestualidade distinta - ao que vale acrescentar sua personalidade, difícil de ser desvendada. Se há uma cosmética em Juventude em marcha, ela é direcionada à representação do seu corpo.

\footnotetext{
${ }^{309}$ A descrição é de Julián Gállego. Ibid.
} 
Fig. 226

Fig. 227
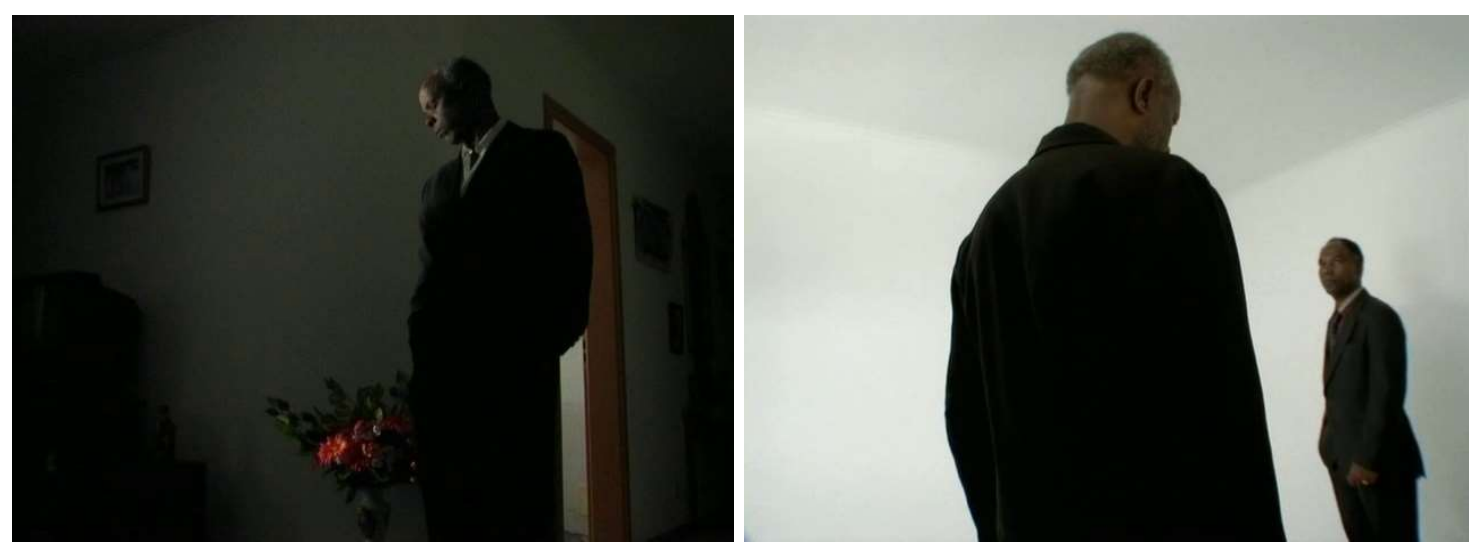

A excepcionalidade de Ventura faz pensar. De início, no esquema de Juan de Parejaque é bem diferente dos casos de "embranquecimento" do negro, de uma tentativa de representá-lo por outra raça. Tal como o quadro de Velásquez, Juventude em marcha é atravessado por um problema de alteridade tocante a uma dupla assimetria. Ali o pintor, aqui o diretor, é o sujeito que detém a propriedade dos meios de representação e ao mesmo tempo está numa posição de privilégio se comparado àquele que é retratado. Velásquez era o senhor de Juan. Costa é europeu e Ventura é um imigrante de uma ex-colônia portuguesa morando num bairro periférico de Lisboa. A ascensão conferida a Juan e a Ventura seria um modo de compensar a assimetria ao figurá-los acima mesmo daquele que os representa? Essa é uma hipótese. Se válida, o enlevo dado ao cabo-verdiano pela mise en scène seria justificado não só pela relação pessoal com o diretor ${ }^{310}$ como pelo reconhecimento de uma dupla desigualdade que não pode ser desfeita simplesmente pelo recurso a uma estética naturalista ou mesmo a um realismo social como nos filmes anteriores. Existe uma eleição simbólica que é devedora da consciência de uma horizontalidade outra, somente possível por um "esteticismo" que não vem para explorar a miséria, mas como tratamento compensatório que repara uma desigualdade.

A assimetria, vale corrigir, não é apenas dupla. Ela suplanta a posse dos meios de representação e o abismo social. É também histórica. Como isso se faz ver? Pelo modo com que o negro e o imigrante são representados no cinema português ou mundial? Pela quantidade de filmes assinados por diretores negros ou sobre populações afrodescendentes no

\footnotetext{
310 "Antes de começar cada dia de trabalho, o que mais me importava era como realmente conhecer aquele homem, aquele homem grande com quem falei e que aceitou minha proposta de fazer um filme. Então veio o momento, logo nas primeiras semanas de filmagem, em que tive que descobrir como eu poderia - as palavras não são suficientes -, como eu poderia me colocar à sua altura com minha câmera. A câmera teve que descer e descer e descer, porque eu não poderia estar à altura dele. Eu precisava estar abaixo". Pedro Costa em Carla Maia, Daniel Ribeiro Duarte (et al.), Op.cit.
} 
circuito comercial ou em festivais e outros meios de exibição alternativos? Pode-se ir ainda mais a fundo e, em vez de dirigir a atenção para fora, olhar para dentro: ${ }^{311}$ a assimetria estaria no próprio filme? Costa não assumiria a histórica posição do "artista etnógrafo" engajado, ${ }^{312}$ de um "mecenas ideológico"? ${ }^{313}$ É certo que há uma tácita identificação entre ele e aqueles que filma, como geralmente há entre o artista de esquerda diante do outro oprimido - em termos econômico, cultural ou étnico -, mas essa identificação também não deslocaria consigo o problema de uma expropriação capitalista, no real, para uma exploração póscolonialista, no nível da representação? Sabemos que por mais bem intencionada, por mais solidária que foi e que é uma arte engajada numa política da alteridade, ${ }^{314}$ na tentativa de oferecer uma imagem do outro, ela pode incorrer em riscos, desde a idealização e a consequente perda do senso crítico até a autorrestauração narcisista do artista a partir da superidentificação com o outro.

As suspeitas específicas a respeito da política de alteridade em Costa, retornaremos mais à frente. Sobre as questões anteriores a respeito do lugar do negro no cinema, reconhecemos tangenciarem o cerne de Juventude em marcha e a importância para compreender um processo de produção mais amplo no qual o filme está inserido, mas elas transbordam em muito o tema da nossa tese. Mesmo sem respondê-las, o próprio filme dá a pista sobre a disparidade histórica aventada anteriormente, exatamente na cena da Fundação Gulbenkain: onde estão os retratos dos negros no museu? Ora, não estão lá. Quando Ventura se encosta na parede, no vazio deixado entre os retratos de Van Dyck e de Rubens, ele explicita uma ausência, uma desigualdade representativa. A supressão da imagem do negro na cena é dupla, se se pensar também no gesto do segurança de apagar mesmo o rastro deixado pela presença temporária no museu. Juventude em marcha tentará responder a essa exclusão a partir de uma representação diferenciada, de um tratamento monumental dado ao

\footnotetext{
311 Se virarmos o espelho na direção de nossa tese, pode-se criticar a ausência de autores negros no presente tópico.

312 A expressão é usada por Hal Foster para definir um tipo de paradigma cujo modelo é tributário ao debate empreendido por Benjamin no seu texto "O autor como produtor". Se este último aborda a relação conflituosa entre o artista/intelectual e o proletariado, aquele desloca a discussão para a contemporaneidade ao analisar um artista/intelectual cujo outro está situado numa fronteira mais cultural e étnica do que econômica. Ver Hal Foster, O retorno do real, São Paulo: Cosac Naify, 2014.

313 O termo vem de Benjamin quando comenta o texto Saber e mudar (Wissen und Verändern), de Alfred Döblin, e remete à proximidade do intelectual junto ao proletariado em razão da solidariedade, da fraternidade e de suas convicções ideológicas. Essa posição será questionada por Benjamin em prol de outra, que defende: a do apoio do intelectual ao proletariado e à luta de classes em função do seu modo de atuação e de sua posição no processo produtivo, o que no caso do artista passa pela estética da obra. Ver Walter Benjamin, "O autor como produtor: Conferência pronunciada no Instituto para o Estudo do Fascismo, em 27 de abril de 1934", Op.cit. ${ }^{314} \mathrm{O}$ escopo é amplo e é possível falar desde a fantasia primitivista da arte surrealista dos anos 1920 e 1930 e do movimento négritude nas décadas de 1940 e 1950 (Foster, Op.cit.), até, para ficar numa escala nacional, sobre o que já se comentou sobre a representação do "povo" pelo cinema brasileiro das décadas de 1960 e 1970 (Bernardet, Op.cit.).
} 
protagonista, como se dele fizesse um retrato, uma imagem capaz de revelar sua altivez, ainda que abrindo mão de uma abordagem mais direta e realista em prol de uma estetização, de uma figuração particular necessária para resgatar um respeito talvez por outros meios inacessível.

Uma diferença é notável diante do exemplo de Juan e Velásquez, e que também ajuda a recobrar a pergunta que se fez há pouco sobre o tipo de alteridade de Costa em sua hipotética posição de "artista etnógrafo": o filme não apaga as marcas da posição social de quem representa. Miséria e nobreza (moral, não social) continuam a coexistir em uma mesma figura, a de Ventura. Ele permanece sendo o ex-pedreiro que imigrou de Cabo Verde para trabalhar em Lisboa e que é morador da favela das Fontainhas. Em nenhum momento isso é perdido. A sua codificação diferenciada existe no interior mesmo de um realismo social, como uma espécie de ponto de abertura e de tensão dentro do regime de representação. Esse dissenso talvez seja uma alerta ao espectador sobre um falso antagonismo entre a "alta cultura" e a cultura do povo, entre o enlevo moral e a pobreza material, numa continuação da política que se fazia nas obras anteriores, mas por outra via. A partir de um "esteticismo", a encenação e o comportamento de Ventura são antitéticos a um pressuposto e por isso mesmo produzem no filme uma perspectiva dialética. Corrobora essa direção tanto um certo deboche em relação à "alta cultura", como o que se vê quando o protagonista se senta na poltrona da Fundação Gulbenkain, como uma intraduzibilidade de sua personalidade. Ela é menos precisa e unívoca do que poderia ser. Por que Ventura está sempre a olhar para o fora de campo? O que vê, quem aguarda? Por que sempre fala em filhos quando aparentemente não tem nenhum? Está louco? As respostas são muitas, mas vêm sempre alimentar hipóteses e não certezas. Retoma-se com ainda mais veemência algo do princípio dos planos-retratos dos filmes anteriores de Costa, com suas figuras impenetráveis, frente às quais o olhar (da encenação e do espectador) deve renunciar a um saber totalizante e a uma tentativa de apreender o Outro numa imagem estanque. Talvez a política da alteridade esteja muito mais nesse tipo de constante negociação do que propriamente em uma imagem unilateral e enobrecedora que, como se vê, não existe, posto que é nuançada, feita, refeita e desfeita continuamente.

Uma linha complementar permite um adendo e um fechamento um pouco mais plausível sobre o tema. Para encontrá-la, é preciso retomar, muito ligeiramente, dois dos traços compositivos da figura de Ventura à luz de uma tradição cinematográfica. Nesse sentido, um exercício genealógico exclusivamente temático fracassaria. Se por um acaso se comparar as raízes de Ventura com pilares do cinema negro underground, como os personagens das crônicas sociais de Charles Brunett em O matador de ovelhas (The killer of 
sheep, 1978) e O casamento do meu irmão (My Brother's Wedding, 1983), ou com as figuras revolucionárias do etiopiano Hailé Gerima em Bush Mama (1979) e Ashes and embers (1982), pouco se avança. Mesmo frente a europeus contemporâneos com preocupações póscoloniais sobre o negro imigrante, como Nicolas Klotz e Élisabeth Perceval em A ferida (La blessure, 2003), a similaridade é limitada. A herança à qual Costa faz referência na composição de Ventura tem sua matriz nos cinemas clássico e moderno, e é tributária de uma série de nomes. O português é profícuo e no limite labiríntico para uma análise comparada, pois seu cinema se constrói sobre uma ampla rede intertextual. Contudo, dois realizadores bastam para um complemento sobre a codificação de Ventura. John Ford, sobre a escala figurativa. Jacques Tati, sobre a gestualidade.

Fig. 228

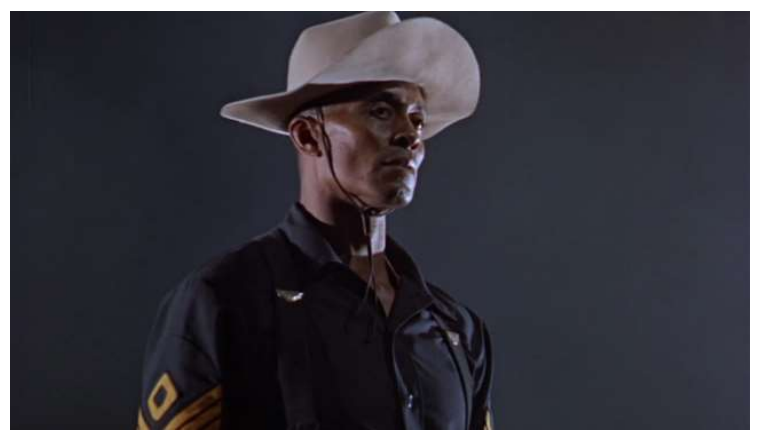

Fig. 229

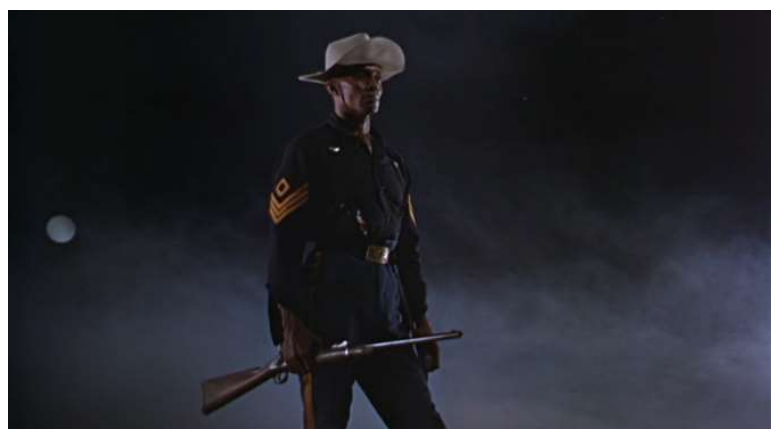

A influência de Audazes e malditos (Sargent Rutledge, 1960, de Ford) sobre Juventude em marcha já foi sugerida. ${ }^{315} \mathrm{O}$ estofo do filme é uma dúvida: a culpa ou a inocência de um soldado negro no estupro e assassinato de uma criança. A princípio, dele nada se sabe. Nada além de sua figura, dos aspectos sensíveis imediatamente reconhecíveis: seu porte físico, a severidade dos traços faciais e o olhar impassível com que responde o escarcéu que se cria durante o julgamento. Já aí se pode inferir a resposta para a questão que movimenta o drama. A relação que se estabelece entre o corpo de Rutledge, interpretado por Woody Strode, e o seu entorno é patente. A fisicalidade avantajada estabelece por si mesma uma dissonância frente ao espaço da sala de julgamento e aos demais personagens, pequenos demais para sua presença hercúlea. Ele mal cabe na cadeira em que está sentado. É mais alto e está acima de todos que ali tentam condená-lo. A estatura, claro, é literal, mas também moral. Se isso por si só não é suficiente para pressupor a inocência de Rutledge, a câmera vai acentuar a ascensão figurativa a partir de planos em contraplongée (Fig. 228-229), agigantando-o ainda mais.

315 Thom Andersen, "Histórias de Fantasmas", in Ricardo Matos Cabo (org.). Op.cit. 
Complementam essa imagem, os flashbacks e a consequente tensão com as ações do tempo presente, dialética que permite recompor com nitidez o caráter de Rutledge a partir de cada diálogo, gesto, olhar e comportamento - sempre nas situações mais decisivas possíveis. ${ }^{316}$

A encenação do filme de Ford guarda estritas correspondências com a que Juventude em marcha dedica ao corpo de Ventura. A personalidade deste último é certamente menos transparente que a de Rutledge, mas é do mesmo modo recomposta por idas e vindas entre presente e passado. Principalmente, a escala dos planos também o torna desproporcional, grande demais para a casa que a prefeitura tenta realocá-lo no novo conjunto habitacional, no bairro social Casal da Boba, para o qual foram transferidos os antigos moradores da favela das Fontainhas; ou mesmo diante do corretor que lhe apresenta o imóvel (Fig. 231). Ventura, por outro lado, perfeitamente confortável sobre o móvel luxuoso do museu Gulbenkain (Fig. 220). A grandeza do personagem guarda uma inconformidade espacial e simbólica com o que tenta enquadrá-lo. Sua aparição é um foco de insurgência. Isso conduz a Tati e ao seu personagem Monsieur Hulot, em Meu tio (Mon oncle, 1958).

Fig. 230

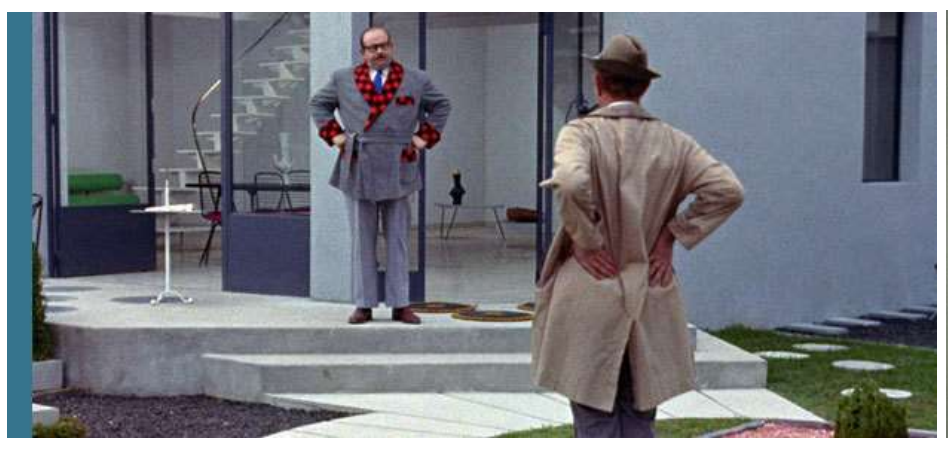

Fig. 231

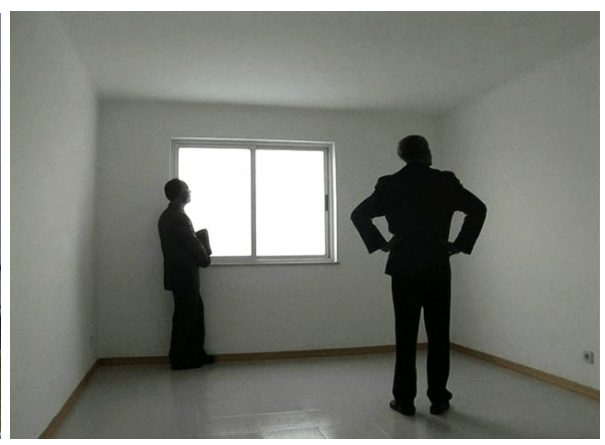

O capítulo anterior se deteve sobremaneira sobre a lógica do burlesco. Há uma série de singularidades e portanto de diferenças cruciais entre os filmes analisados de Chaplin e Keaton, da década de 1920, e os de Tati. Uma delas é o som, nuclear para as gags do último. Outra é o nível de modernização da sociedade. Estamos na década de 1950, com a invasão do design e da arquitetura moderna. A industrialização e a cultura dos objetos contra a qual

\footnotetext{
${ }^{316}$ Recordemos uma lição básica: como qualquer ficção tem um limite, de orações (literatura), de tempo (cinema e teatro), ou de qualquer outra espécie, a definição de um personagem depende das escolhas que o autor de uma obra faz para tornar seu caráter o mais claro possível. Referindo-se à literatura, Rosenfeld afirma: "o autor pode realçar aspectos essenciais pelas seleção dos aspectos que apresenta, dando às personagens um caráter mais nítido do que a observação da realidade costuma sugerir, levando-as, ademais, através de situações mais decisivas e significativas do que costuma ocorrer na vida." Ver Anatol Rosenfeld, "Literatura e personagem", in Antônio Candido, Anatol Rosenfeld, Décio de Almeida Prado, Paulo Emílio Sales Gomes, A personagem de ficção, São Paulo: Perspectiva, 1981, p. 35.
} 
Chaplin e Keaton lutavam domina o cotidiano do novo burguês como um fetiche. A figura burlesca é novamente quem se insurge, mesmo involuntariamente, contra um universo que sob a bandeira do progresso teima em ocupar e ameaçar o território humano. Desta vez, o perigo maior não se impõe exclusivamente contra o corpo, mas sobre a comunidade.

Hulot, como Ventura, vive entre dois universos explicitados por diferentes arquiteturas. Um favorece a troca e tece os fios da rede social em seus espaços desorganizados, às vezes degradados, nos quais se constrói um modo de vida popular e tradicional. Outro asséptico, permeado por vazios espaciais nos quais a figura humana parece deslocada, estabelece o isolamento dos indivíduos, a perda dos laços que os une. No filme de Tati, trata-se respectivamente do novo bairro burguês, onde está a Villa Arpel (casa ultra moderna), e a antiga parte da cidade. No de Costa, do Casal da Boba e da favela das Fontainhas.

Um gesto se repete nos respectivos filmes: as mãos sobre a cintura. A pose aparece em Meu tio para expressar o descontentamento do pai ao saber que o filho se sujou brincando no antigo bairro, na companhia de outras crianças e do tio, M. Hulot. A tensão entre os dois universos, dois modos de experiência, o antigo e o novo, o tradicional e o moderno, é sinalizada pelo gesto, que Hulot espelha e devolve ao emissor (Fig. 230). Juventude em marcha também faz daquela pose a exposição de uma fratura entre dois universos. Com uma irreverência cômica, Ventura põe as mãos sobre a cintura diante do corretor do apartamento no bairro Casal da Boba, contestando a mudança para o imóvel (Fig. 231). O remanejamento para o novo conjunto habitacional simboliza abandono de um lugar que até então formou uma comunidade e que é o relicário da memória coletiva. A mudança demarca uma espécie de segregação, uma atomização dos moradores, que perdem o território que compartilhavam e que os unia. Ventura tentará reparar este esgarçamento dos antigos habitantes, visitando-os, recebendo-os, reconectando-os a partir de sua figura e consequentemente preservando um senso de comunidade. O gesto tatiano em Juventude revela a tensão entre os dois mundos ao mesmo tempo em que estabelece a revolta diante do que o novo bairro representa. Reverbera, por isso, para além daquelas paredes.

Ainda sobre o tema, é preciso acrescentar o hieratismo. Quando põe as mãos sobre a cintura inconformado, ou quando aponta uma teia de aranha no apartamento que lhe é oferecido, o gesto de Ventura surge como um corte no plano. Existe uma contenção corporal ao longo de todo o filme (possível herança de Bresson, Straub-Huillet ou Brecht? Ou do africano em transe de $A$ morta viva, de Tourneur?) que é rompida de modo incisivo no instante em que o personagem gesticula com seus longos braços e mãos. A força expressiva é condensada em uma ação, um gesto suspenso por alguns segundos no plano. A figura humana 
parece se converter numa escultura cuja imobilidade traz consigo o próprio movimento insurgente, a subversão burlesca no interior de um espaço e de uma mise en scène austeros.

$\mathrm{O}$ realce à estatura física e moral pela codificação figurativa e gestual de Ventura tanto compensa uma série de desigualdades representativas do imigrante e negro, sem contudo cair numa idealização homogênea e acrítica, como, em diálogo com Ford e Tati, sugere uma inconformidade do personagem diante das condições vivenciadas pelos moradores e exmoradores das Fontainhas. Ventura é eleito simbolicamente pelo papel central que desempenha na trama, assumindo a figura de um porta-voz imaginário da comunidade a que pertence, um elemento nuclear encarregado de impedir, ou senão de se opor, ao contínuo processo de destruição das Fontainhas. Mais do que o espaço físico, quase inexistente, o que corre o risco de ser perdido são os laços que ali se fizeram. A figura de Ventura, cuja estatura rivaliza com as estruturas que tentam coagi-la, talvez seja referente não apenas ao corpo de um indivíduo, mas ao de uma comunidade.

\subsection{As horas sombrias: experiência e alteridade}

Portanto, voltar a olhar para as pessoas e as coisas do presente, para a vida comum e sua diferenciação indefinida. Reencontrar 'o gosto da germinação anônima inominável' e tudo o que constitui o vivo do sujeito. Ver o gelo frágil dos hábitos, o solo movediço dos partidos tomados onde se incisam circulações sociais e costumeiras, onde se descobrem atalhos. Aceitar como dignas de interesse, de análise e de registro aquelas práticas ordinárias consideradas insignificantes. Aprender a olhar esses modos de fazer, fugidios e modestos, que muitas vezes são o único lugar de inventividade possivel do sujeito: invenções precárias sem nada capaz de consolidá-las, sem línguas que possa articulá-las, sem reconhecimento para enaltecê-las; biscates sujeitos ao peso dos constrangimentos econômicos, inscritos na rede das determinações concretas.

Luce Giard, A invenção do cotidiano ${ }^{317}$

Aquiles:

- Mas quem dizia que a vida seria assim? Ó, Pátroclo, a vida é esta. Devemos enfrentar o pior.

Cesare Pavese, Diálogos com Leucó ch18 $^{18}$

\footnotetext{
${ }^{317}$ Luce Giard, Pierre Mayol, A invenção do cotidiano 2, Petrópolis: Vozes, 1996, p. 217

318 Cesare Pavese, Diálogos com Leucó, Cosac Naify, 2011, p. 85.
} 
A escolha pelo retrato como porta de entrada para o cinema de Costa enfatizou um mecanismo estético capaz de revelar a densidade existencial da figura humana sob uma perspectiva de teor materialista. Nossa atenção dada ao indivíduo, porém, ignorou um dado programático da trilogia das Fontainhas: um corpo raramente está sozinho em cena. ${ }^{319} \mathrm{~A}$ observação não é das mais inventivas, é verdade. Porém, a simplicidade da evidência não deve obscurecer a riqueza do que revela ou o aspecto difuso do que esconde. Se a renúncia a uma presença numerosa de corpos naqueles filmes e a preferência por composições em duplas seguramente tem a ver com uma depuração visual e com a importância dada aos diálogos, sua centralidade em Costa também sinaliza uma poética fundada sobre o que se constrói entre dois ou mais corpos. Tudo está ali.

Nas próximas páginas vamos retraçar de modo bastante descritivo os motivos e as circunstâncias que reúnem as figuras humanas a fim de estabelecer um primeiro e ainda que insípido mapeamento de suas disposições e efeitos. A etapa é preliminar e faz parte de um processo de interpretação que só se concluíra com o fechamento do capítulo.

Comecemos pelos pares. São muitos em No quarto da Vanda. Vanda e Nhurro. Nhurro e Muleta. Zita e Vanda. Russo e Nhurro. Vanda e o vendedor de flores. Nhurro e Zita. O mesmo arranjo continua em Juventude em marcha, com a diferença demarcada pela presença inelutável do protagonista, espécie de coeficiente fixo que diminui as variações e impõe um padrão. Ventura e Vanda. Ventura e a "filha". Ventura e Nhurro. Ventura e o "filho". Ventura e Lento. E assim por diante. Como se viu a partir do plano-retrato de Zita, é também em Ossos que Costa aparenta ter se valido de um procedimento que depois seria depurado em No quarto da Vanda e em Juventude em marcha. As duplas ali surgem como um prenúncio de suas aparições futuras. A princípio, vejamos dois momentos daquele filme.

No primeiro deles, Clotilde (Vanda Duarte) está a fumar um cigarro próximo a um ponto de ônibus, de onde descem os moradores do bairro ao fim do dia, depois da jornada de trabalho. Ela aguarda uma amiga e vizinha, Tina, a mãe que tentou matar o próprio filho e a si mesma por causa da pobreza. A espera não é tranquila, quer seja pelas últimas ações e pelo estado sorumbático de Tina, quer seja pela expressão de Clotilde, invariavelmente rígida e circunspecta em seu silêncio. Seu rosto, sob tensão vigilante, impassível, parece mais do que qualquer outro em Ossos acostumado às demandas ingratas do cotidiano. Enquanto aguarda,

\footnotetext{
319 Complementar, mas não mencionado, são também os enquadramentos e os reenquadramentos por portas e janelas que desde o primeiro longa-metragem, Sangue (1989), abundam em sua obra como molduras que sublinham a figura dos indivíduos diante do todo, tal como se vê sistematicamente em um realizador referencial para Costa, Yasujiro Ozu.
} 
uma outra vizinha (Clotilde Montron) se aproxima, tenta conversar e lhe oferece um pedaço do pão que traz consigo. Clotilde mantém-se fiel ao voto de reserva e silêncio: nada diz, recusa a oferta com o olhar e continua a fumar como se estivesse sozinha, emoldurada pelos seus pensamentos. E então, num comportamento atípico para um filme em que até então os personagens ou sofrem o amargo cotidiano com dureza ou andam pelos cantos convalescentes, a vizinha caçoa da espera. Faz isso uma vez, duas vezes, três vezes e então, inesperado até aqui, Clotilde desata a rir. A vizinha a acompanha (Fig. 232).

Fig. 232

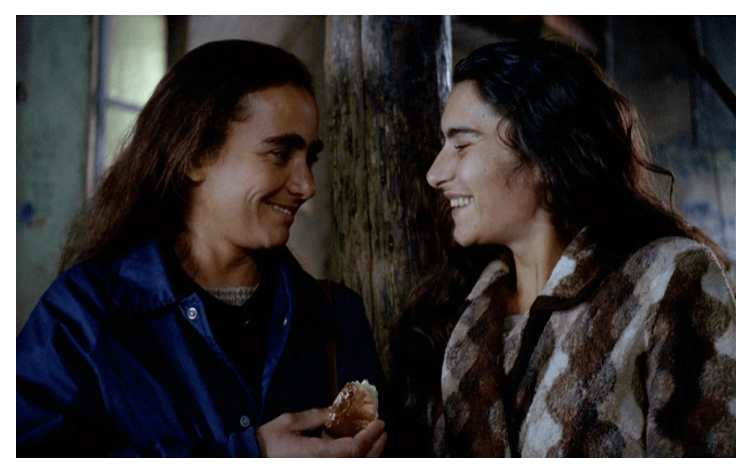

Fig. 233

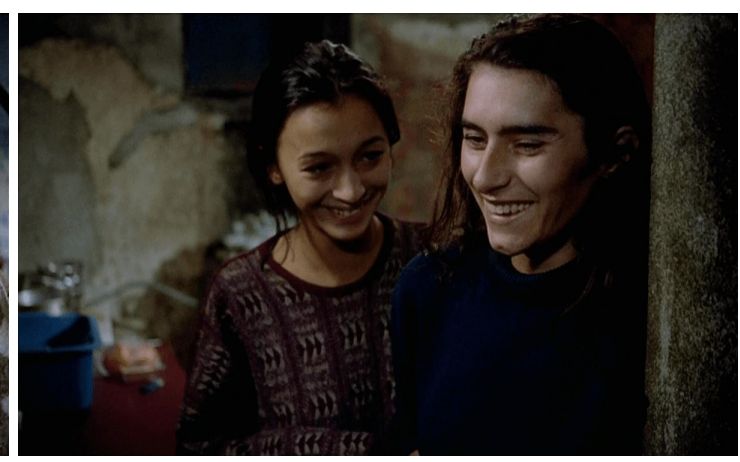

O segundo momento acontece pelo final do filme, quando Clotilde visita Tina. Ela a encontra dormindo. Acorda-a e segue para a cozinha, onde, subentende-se, prepara algo para que as duas comam. No cômodo, não trocam uma palavra. Estão de costas uma para a outra. O momento amigável é impregnado pela mesma ambiência carregada das demais cenas. Porém, algo acontece. Num movimento desajeitado de Tina ao carregar uma panela, as duas personagens acabam se chocando e a comida cai no chão. Nenhuma delas sabe como reagir. Tina passara o filme inteiro melancólica e com ares sonolentos. Clotilde, confinada em sua já descrita seriedade. São duas personalidades inaptas para responder a uma situação que em outro contexto serial natural em seu total prosaísmo. O silêncio permanece e ganha peso pelo que as cenas anteriores já alertaram: neste filme, sempre se deve esperar pelo pior. Mas as coisas ganham outro rumo. As personagens se dirigem para a soleira da porta, aproximandose da câmera. Tina olha para a amiga com um sorriso nos lábios, buscando uma cumplicidade que lhe é negada. Com um certo atraso, o sorriso vem. Clotilde desata a rir. Tina faz o mesmo (Fig. 233). A alegria não dura e elas logo retomam suas respectivas máscaras de apatia e seriedade.

Não há dificuldades em perceber a estrita correspondência tanto no desenrolar como no sentido. O início de cada cena é marcado pela ambiência sufocante de Ossos. Similar aos 
outros dois filmes na favela das Fontainhas, a asfixia é decorrente tanto da pobreza material como também da predominância de espaços fechados. O ponto de vista raramente permite ver o que há no exterior dos imóveis. Em Juventude em marcha, mesmo as janelas visíveis são de tal maneira superexpostas que circunscreverem apenas a opacidade branca. Estão mais para muros do que para um prolongamento do in-visto. ${ }^{320}$ A clausura dos demais filmes existe mesmo quando se mostram as ruelas do bairro, rodeadas por paredes e sem a visibilidade do céu. Ossos, menos radical nesse sentido, contém um ou outro planos mais aberto capaz de localizar a imagem dos corpos num todo amplo. Mas em geral, e principalmente em No quarto da Vanda e em Juventude em marcha, mergulha-se no interior tanto de uma realidade como de uma arquitetura cerradas. O plano é um cárcere, ${ }^{321}$ tal como se mencionou a respeito de Pais e filhos, de Wang Bing. Diante disso, o que as duas cenas descritas de Ossos revelam é a brecha, a principal e por vezes única abertura à qual se tem direito nos filmes de Costa: o Outro, com quem sempre se pode confiar para arrefecer a figura humana maltratada pelo cotidiano.

O diálogo de Vanda e Nhurro, no início do capítulo, sinalizava desde então o peso que o outro tem num universo em que a figura humana está desamparada materialmente. Se nos filmes das Fontainhas não se pode contar com o Estado ou com uma política exterior ao bairro, estabelece-se em compensação uma intrapolítica pela solidariedade entre os moradores. Costa irá desdobrar essa rede de amparo mútuo, sistematicamente, a partir de planos compostos por duas e três figuras em No quarto da Vanda e em Juventude em marcha. Filmados em longa duração e com a câmera fixas, os corpos são enquadrados em imagens autônomas. Estão vinculadas à trama, claro, mas carregam em si mesmas uma forte unidade, como pequenos universos independentes. Nada perturba esse tipo de composição: figuras não entram em campo, a câmera não se movimenta e não há ações que irrompam, exigindo a saída do quadro ou mesmo o rearranjo dos corpos. A austeridade compositiva certamente tem algo do que já se discutiu sobre a inflexão retratística em Costa. ${ }^{322}$ Ao mesmo tempo, acreditamos, afirma o plano como unidade mantida a partir da relação estabelecida entre dois corpos, marcado por um encerramento que é menos uma alienação ao mundo que a tentativa de recobrar no interior de cada imagem um resguardo, uma suficiência e mesmo um refúgio cimentado sobre a fraternidade. Nada deve interromper essa unidade. A montagem só

\footnotetext{
${ }^{320}$ Ver o debate sobre a janela como expansão do olhar em: Jacques Aumont, 1989.

${ }^{321}$ Sobre a realidade que se impõe como uma prisão nos filmes de Costa, ver Mateus Araújo Silva, Op.cit.

${ }^{322}$ Uma das categorias do gênero eram os retratos de duas figuras ou mesmo de um grupo. Ver Alois Riegl, Op.cit.
} 
acontece para anunciar outra cena. Dadas essas condições, os filmes de Costa apontam em direção a um realizador importante para a sua obra, Ozu.

Não vamos nos alongar no comentário, pois é preciso seguir adiante, mas cabe indicar uma composição recorrente no cinema do diretor japonês que ressoa os duplos de Costa. Trata-se do sojikei, ou figuras similares. ${ }^{323}$ Presente desde pelo menos Coral de Tóquio (Tôkyô no kôrasu, 1931), é referente a planos com dois personagens, lado a lado, parados com a mesma postura ou realizando rítmica e sincronicamente os mesmos gestos, numa espécie de arabesco cinético. Além de funcionar na composição de gags e rimas visuais, o espelhamento reflete gestualmente o entendimento que existe entre duas figuras, tal como acontece entre marido e esposa em Coral de Tóquio, entre pai e filho em Era uma vez um pai (Chichi ariki, 1942) e entre as duas irmãs de Fim de verão (Kohayagawe ke no aki, 1961).

No último dos filmes mencionados, Noriko e Akiko, respectivamente a irmã mais nova e a mais velha, são pressionadas pela família a se casarem. Se a primeira está entrando numa idade propícia ao matrimônio, a segunda é uma viúva e mãe que a família teme não conseguir mais um marido. Sob a unidade, reside uma polarização: partilham o mesmo momento, mas em posições diametralmente opostas. Em suas conversas, Akiko tentará partilhar com a irmã a importância de seguir os próprios sentimentos independentemente dos imperativos parentais e sociais. Ela mesma se recusa a aceitar os pretendentes sugeridos pela família, preferindo o direito de decidir, seja por alguém que a agrade verdadeiramente, seja pela solidão. É desse modo que em duas cenas Akiko e Noriko surgem figurativamente espelhadas. Primeiramente, durante uma viagem da família. Enquanto os parentes conchavam sobre os possíveis casamentos, ambas conversam sobre seus respectivos pretendentes (Fig. 234-235). Nenhuma parece verdadeiramente confortável com a situação imposta, identificação que será enfatizada pelo alinhamento dos corpos. Os gestos serão rigorosa e perfeitamente sincrônicos em seu desenrolar: os passos, os olhares, o sentar-se em seiza e o levantar-se.

Mais determinante para o que aqui se quer realçar é o segundo sojikei, ao final do filme, quando o chefe da família morre (Fig. 236-237). Novamente, as duas irmãs se afastam dos parentes para um instante de intimidade. $\mathrm{O}$ espelhamento gestual expressa não apenas duas personagens vivenciando a mesma situação, mas uma ligação mais sólida e longeva: a transmissão da experiência. Sob o impacto da morte e portanto sob o signo da efemeridade que se impõe, Noriko finalmente compreende a importância das palavras de Akiko em respeitar o próprio desejo, embora em contradição com a vontade familiar. Enquanto no

\footnotetext{
${ }^{323}$ Cf. David Bordwell, Ozu and the poetics of cinema, Nova Jersey: Princeton University Press, 1988.
} 
sojikei anterior a roupa demarcava uma diferença entre ambas, nesse último caso, vestidas com o luto, a horizontalidade é patente: as figuras estão em uníssono visual e gestual, mas também em suas respectivas posições sociais. Na cena, a passagem do tempo pela morte do chefe de família demarca a ruptura entre tradição e modernidade. Acompanha-se a mudança da geração passada para a atual, do rito matrimonial imposto socialmente à união pelo desejo individual. O que expõe a comunicação dos novos valores é a partilha do gesto.

Fig. 234-235
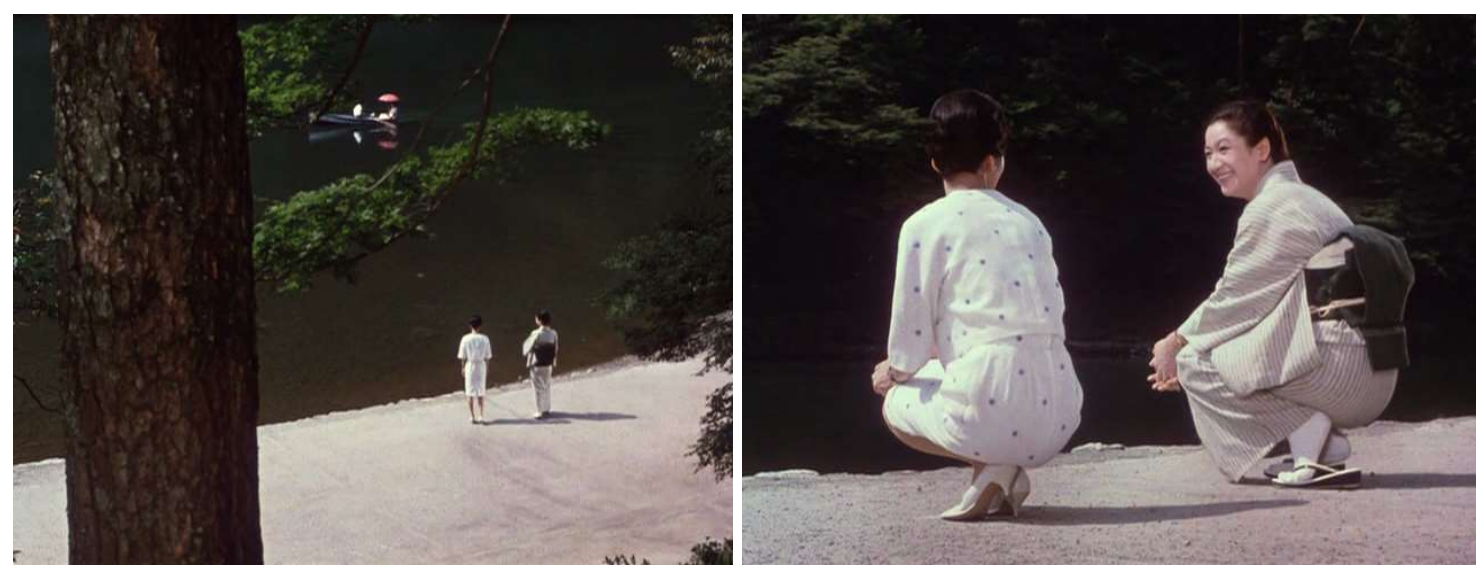

Fig. 236-237
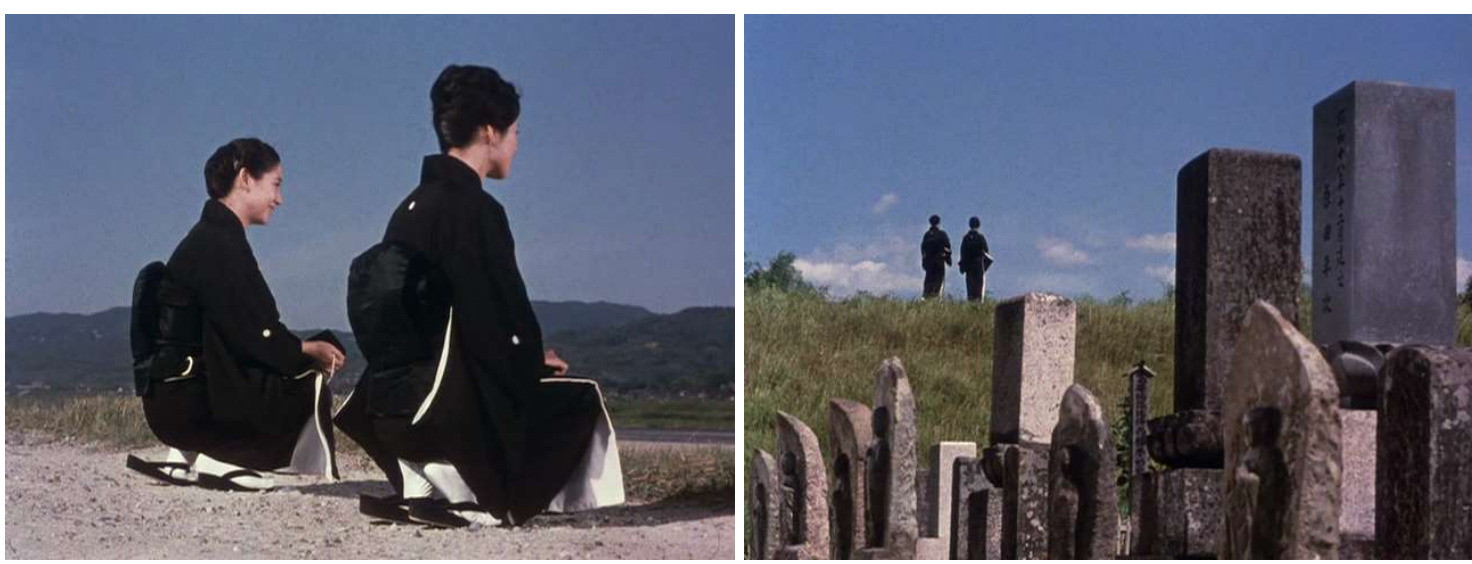

O exímio rigor compositivo de Ozu está deveras distante da obra de Costa. ${ }^{324}$ Ambos recorrem a planos fixos e a uma certa moderação da figura humana, mas o controle soberano

\footnotetext{
${ }^{324}$ Percorrendo sua filmografia, reparamos que os movimentos de câmera como travellings e panorâmicas são paulatinamente abandonados a partir dos anos 1932 e 1933, até serem extintos nos últimos filmes. Essa progressiva redução da mobilidade "coincide com a sistemática organização do quadro em unidades geométricas, em torno das quais se articula a composição” (Antonio Santos, Yasujiro Ozu, Madrid: Cátedra, 2005, p.68). Isso implica dizer que as linhas horizontais e verticais criadas pela arquitetura dos espaços internos (casas, bares e restaurantes) ou mesmo pelas paisagens tornam-se elementos cada vez mais presentes, corroborando para a fragmentação visual e os consequentes (re) enquadramentos das figuras humanas pelo cenário, como se cada personagem tivesse uma porção reservada e demarcada graficamente do quadro fílmico para si, tal como na cena final de $A$ rotina tem seu encanto. Paralelamente a esse cuidado, a mise en scène segue
} 
do primeiro sobre cada mínimo aspecto visível não serviria ao tipo de realismo proposto pelo último, em sua tentativa de trabalhar a encenação em correspondência com um certo acolhimento dos lugares e respeito à verossimilhança das pessoas que filma. $\mathrm{O}$ modo de figurar os duplos, contudo, sugere uma afinidade ética entre os realizadores. Um corpo que aparece ao lado de outro nos filmes das Fontainhas não mostra a mera presença compartilhada de um espaço e tampouco vai engendrar um evento decorrente do encontro. Existe um sentido maior. Estar junto é equiparar a experiência e, a despeito da diferença entre os corpos, encontrar o comum. O cotidiano se inventa na partilha. Próximo a Ozu, a micro-história acontece em casa e na vizinhança, entre os laços solidários que nelas se criam.

\subsection{1 À mesa}

A composição em duplas e trios evidencia um princípio de ramificação ou, se quisermos, de disjunção compositiva. No lugar da unidade corporal, passa a existir uma diluição e constante expansão do corpo individual rumo à identidade e ao pertencimento coletivos. Das duplas e trios, a dinâmica visual calcada no prolongamento corporal continua com um motivo que se alastra na obra de Costa desde Casa de Lava: sentar-se à mesa. O que se revela a partir daí complementa a disposição retratística de sublinhar o corpo a partir de seu estado social e econômico, pela realidade concreta e por uma série de fatores que conjuram a presença da figura humana no seio do mundo material.

O que poderia haver de tão expressivo em se sentar à mesa? Primeiro, é preciso reconhecer a singularidade da ação. Nos filmes de Costa, não se está em qualquer mesa, mas na mesa do pobre. Isso tem relevância para o segundo ponto: sentar-se ali não é mero acaso e nem ritual culturalmente hermético, mas uma necessidade e especialmente um prazer. Antes

um padrão rígido e minucioso, entre os quais filmar de um ângulo baixo e, tal como Robert Bresson, com lente de $50 \mathrm{~mm}$, a mais próxima da visão humana e cuja distorção do campo visual é reduzida. Experimentando uma série de combinações entre as figuras, o cenário e os objetos, Ozu prioriza o equilíbrio da composição visual a partir de arranjos simétricos, harmoniosos e geométricos. A manutenção deste equilíbrio é indispensável: se há o movimento de um personagem que possa vir perturbar o enquadramento ou a relação entre a figura humana e os demais elementos cênicos, é preferível fazer um corte a mover a câmera. Assim, quando um personagem se levanta, a câmera permanece fixa e apenas no plano seguinte, feito de outra perspectiva, a figura é enquadrada dentro de uma nova composição - tão equilibrada como a anterior. Por fim, vale dizer que o controle soberano de Ozu sobre cada detalhe da imagem compreendia desde as etapas de produção até a realização dos filmes. O realizador se ocupava da seleção dos espaços externos, supervisionava a construção dos cenários e desenhava esboços e storyboards por meios dos quais representava os planos que posteriormente seriam filmados. Ozu caminhava pelo set alinhando cada posição da câmera e, com o olho no visor, demarcava as posições dos personagens. O mesmo cuidado dedicava aos objetos, organizando-os demoradamente no espaço até encontrar o lugar ideal. Quando finalmente o plano estava pronto, ninguém podia ousar tocar na câmera, ou seja, era montado um aparato cênico que existia não em função do ator, mas de um planejamento detalhista com a composição. 
de justificar a afirmação, duas breves digressões. Uma pelo cinema de dois realizadores importantes para Costa. Ford, mais uma vez, e o amigo Paulo Rocha. Outra pela pintura de artistas até aqui não mencionados, Van Gogh e Courbet.

Fig. 238

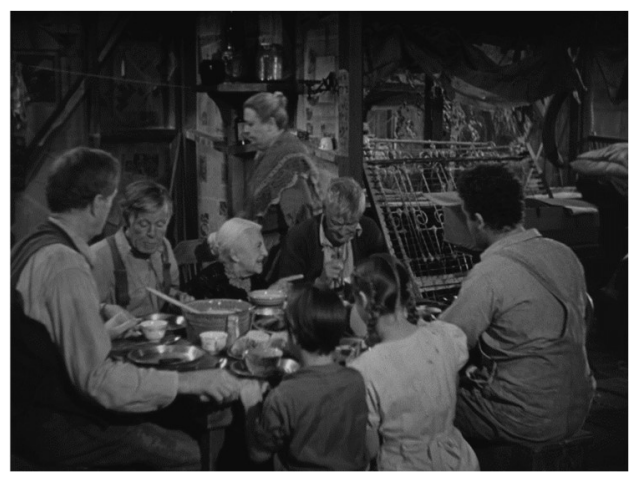

Fig.239

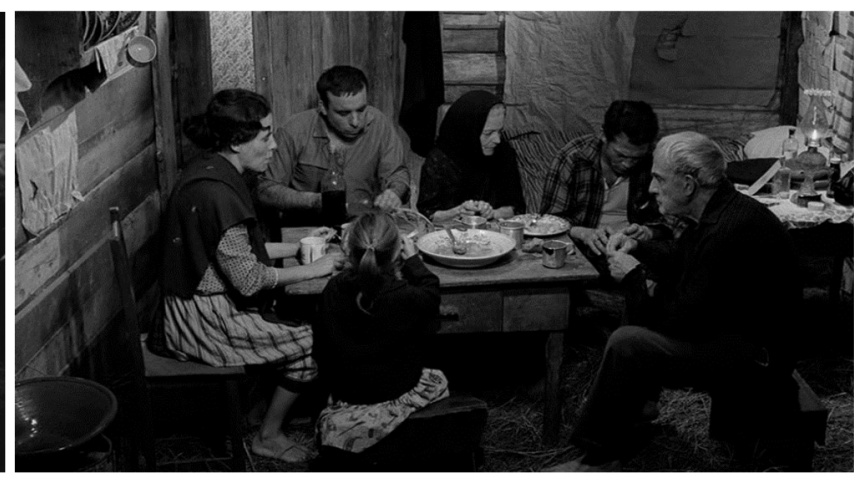

Em As vinhas da ira, obra mencionada no primeiro e segundo capítulos, Tom Joad (Henry Fonda) recebe a liberdade condicional e regressa a Oklahoma. Devido à Grande Depressão e à perda de suas terras, sua numerosa família está de partida para a Califórnia em busca de emprego e melhores condições de vida. A chegada de Tom acontece durante o café da manhã, quando os parentes estão em torno da mesa (Fig. 238). O espaço é amplo e atulhado de móveis e objetos por todos os lados. Diferentes gerações estão sentadas, das crianças aos idosos. Cadeiras para alguns, banquinhos para outros. Durante a cena, o casal de idosos começa a discutir: a mulher debocha do marido por comer às escondidas, durante a oração para o café da manhã. Inicia-se aí uma algazarra entre os dois que descontrai o ambiente. Apesar de obrigados a deixar suas terras, estão esperançosos com a mudança para a Califórnia. Fiquemos com a descrição.

Mudar de vida (1966), de Rocha, que poderia muito bem ser o título do filme de Ford, novamente mostra o retorno de um filho. Quem regressa é Adelino (Geraldo Del Rey). Não estava preso, mas servindo ao exército na África. A família, que mora na vila de pescadores nas proximidades da praia de Furadouro, não está de partida, mas uma drástica mudança se aproxima: o aceno ao mundo exterior, simbolicamente representado pela chegada de um personagem que morava fora da vila, coincide com a progressiva intrusão da modernidade no âmago da vida tradicional que ali subsiste. A cena que nos interessa está no início do filme. Com o retorno de Adelino, a família prepara um jantar para recepcioná-lo (Fig. 239). A comida não é farta e está disposta numa mesa tão pequena que mal cabe o pequeno grupo de seis pessoas. No espaço limitado, as cadeiras são privilégio. Parte da família está sentada 
sobre banquinhos, desnivelados com a altura da mesa. Se em Ford a cena era de pura amenidade, aqui a rudeza do cinema moderno, próxima à do neo-realismo italiano, e também um mal-estar dramático dificultam a descontração. A cena se arrasta com a sisudez e as poucas palavras dos personagens, que tentam conferir uma maior naturalidade ao momento, festejar o retorno: mas o que há pra comemorar? O mar está destruindo as casas da vila, a pesca não rende tanto e a companhia de pescadores acabou, a industrialização se impõe pela presença de uma fábrica nos arredores e tudo transforma. Parte do filme parece mostrar uma comunidade e uma tradição em vias de desmoronarem. Mas não nos adiantemos. O jantar é anterior a uma parte desses eventos. E, mesmo que delongue, acaba por cumprir o seu papel: lá pelas tantas surgem as piadas e a tensão se dissipa. A cena termina com um clima ameno e agradável entre a família.

O corpo individual não é acentuado pela encenação em nenhuma das duas cenas. A disposição das figuras em ações concomitantes ao redor de uma mesa certamente tem a ver com a predileção pelo plano geral. Porém, deve-se entender que o essencial suplanta o comportamento de um ou outro indivíduo, passando a subsistir no convívio social. Em regimes estéticos distintos, um clássico e um moderno, Ford e Rocha recorrem a artifícios similares: passar a comida para alguém que está do outro lado da mesa, estabelecendo pelo ato uma circularidade entre os corpos; a distribuição de trabalhos que delimita a separação entre os gêneros e associa o corpo feminino à responsabilidade por cozinhar e pelos cuidados em servir; a presença de diferentes gerações que interagem e convivem harmoniosamente; a ocasião sendo um rito social que expõe a intimidade entre os membros da família. As respectivas cenas vão ao encontro do comentário da historiadora Luce Giard a respeito da importância da alimentação em fortalecer os elos sociais: "Comer serve não só para manter a máquina biológica do nosso corpo, mas também para concretizar um dos modos de relação entre as pessoas e o mundo, desenhando assim uma de suas referências fundamentais no espaço-tempo." 325 Ou ainda do seu complemento, sobre o cozinhar: "prática elementar, humilde, obstinada, repetida no tempo e no espaço, com raízes na urdidura das relações com os outros e consigo mesmo, marcada pelo 'romance familiar' e pela história de cada uma".326

As vinhas da ira e Mudar de vida transformam o estar em torno da mesa, o reunir-se para a refeição, em rito que desdobra uma série de continuidades entre os corpos. Salvo a distinção entre os gêneros pelo papel assumido pela figura feminina, as duas cenas reúnem signos de horizontalidade que vão dos planos gerais, e portanto de uma mise en scène não

\footnotetext{
${ }^{325}$ Michel Certeau, Luce Giard, Pierre Mayol, Op.cit.

${ }^{326}$ Ibid. p. 218
} 
diferenciada para cada personagem, à disposição circular dos membros em torno da mesa; da socialização entre gerações diferentes, partilhando o mesmo ambiente e momento como iguais, ao clima de comunhão em que todos se esforçam para manter o ambiente de convivialidade e harmonia. A mesa é o espaço de recuo das respectivas individualidades em torno de um alinhamento comum da figura humana.

Fig. 240

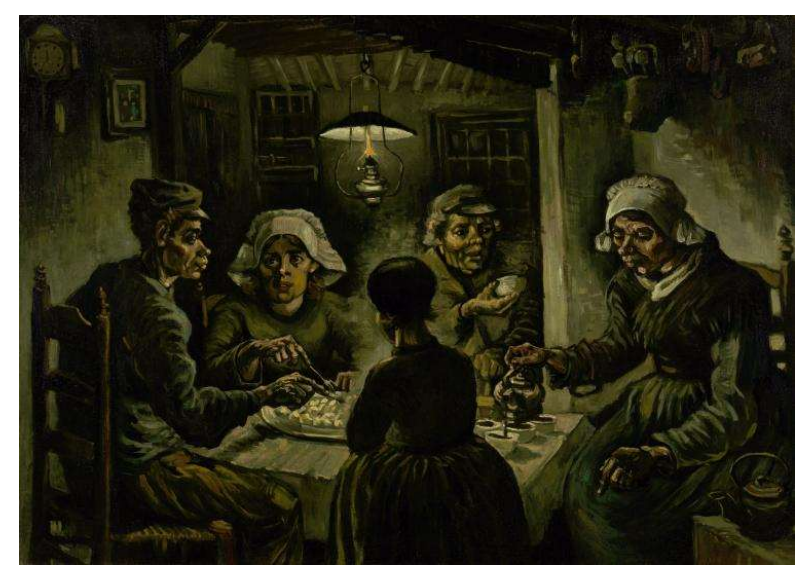

Fig. 241

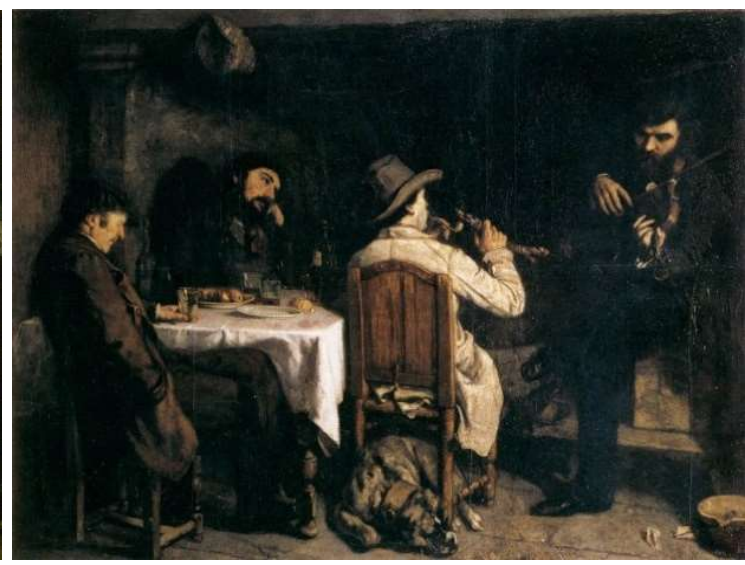

Como no filme de Ford, Os comedores de batata (Aardappeleters, 1885, Fig. 240) de Van Gogh, também focaliza uma família camponesa em torno de uma mesa. Nesta cena de gênero em Nuenen, nos Países Baixos, um dos primeiros trabalhos importantes do pintor, o contraste é flagrante com os traços comumente associados à sua obra, sobretudo a exuberância cromática. A tonalidade amarronzada quase homogênea estabelece uma continuidade entre os corpos, as batatas, as roupas e as paredes da casa, como se tudo ali fosse constituído de uma mesma matéria. É conhecida a frase de Van Gogh, inspirada em Milliet, em que diz ter tentado compor a figura dos camponeses como se pintadas com a própria terra que semeavam. ${ }^{327} \mathrm{O}$ aspecto tonal também engendra na imagem uma certa estagnação. $\mathrm{O}$ padrão cromático mergulha a imagem numa camada com poucas variações rítmicas, como se a duração fosse congelada. Ou isso viria da própria composição, a partir das roupas, da ação, dos objetos, do ritual e do que mais, dado o anacronismo do olhar presente, parece conservado na redoma da tradição, por demais longe de uma ambiência urbana para ser contaminado pela modernidade?

A cor e os demais fatores elencados certamente contribuem para a impressão tanto do tempo imóvel como de austeridade. Mas a isso é preciso pensar o outro lado da tela, o humano. O modelado rígido dos corpos e os traços fisionômicos talhados conferem uma

\footnotetext{
${ }^{327}$ Théodore Van Gogh. Cartas a Théo. São Paulo: L\&PM, 1986.
} 
solidez à imagem. As duas figuras nas extremidades, a da esquerda com uma circunspeção distante, a da direita cabisbaixa a servir o café, sugerem uma dureza que um detalhe confirma: as mãos. Seu aspecto embrutecido e rugoso expõe a relação física com o trabalho, revela a difícil experiência social. Em contraposição, estar à mesa é, como nos filmes de Ford e Rocha, encontrar um repouso da labuta e do cotidiano. O peso revelado pelos corpos e reforçado pela paleta de cores escura e tonal é amenizado pelo momento de confraternização, que compartilha com As vinhas da ira e Mudar de vida a ambiência humilde e os signos de horizontalidade.

Um último desvio, breve, é pelo quadro Depois do jantar em Ornans (Après dîner à Ornans, 1848-1849, Fig. 241), de Courbet. A imagem diverge das cenas comentadas anteriormente em razão da autonomia de cada figura, dispersas no espaço, e do sujeito da representação: não mais o camponês ou o pobre, mas burgueses - o pintor, o pais e amigos que moram no campo. O realismo, que se abstém de uma figuração do campo pastoral e de figuras arquetípicas em seu anonimato, ${ }^{328}$ é radicado na tensão entre formas banais de vida e rostos particulares, no rito social objetivado pela prática privada: "a autobiografia começa quando amigos se reúnem em torno do fogo, quando toda uma vila se encontra no cemitério; quando a experiência, sob forma banal e ancestral, se torna única". ${ }^{329}$ Dentro de uma ocasião ordinária, entre o jantar e o momento de se recolher para dormir, o despojamento de amigos em sua particular e universal intimidade.

Voltemos então aos encontros em torno de uma mesa no cinema de Costa. As similaridades com Ford, Rocha, Van Gogh e Courbet são notáveis. Um mapeamento do motivo nos filmes das Fontainhas iniciaria com Ossos, quando a enfermeira recebe os miseráveis à mesa de sua cozinha para dar-lhes de comer e ali iniciar uma tentativa de aproximação com seus respectivos universos. Juventude em marcha é ainda mais programático. Ventura surge inúmeras vezes à mesa com aqueles que acredita serem seus "filhos". Busca-os no trabalho para almoçarem juntos (Fig. 242). Com Vanda, experimenta o silêncio e a tristeza pela morte de Zita. Com Lento, nos intervalos do trabalho, escuta música, joga baralho ou recita uma carta que escreveu para a mulher que ficou em Cabo Verde. Ao lado de uma das "filhas", que depois de sucessivas recusas aceitou sua paternidade, almoça um frango (Fig. 243). Esta última cena é uma síntese do que representam tais encontros à

\footnotetext{
${ }^{328}$ Por uma perspectiva histórica e social da arte, Clark analisa como a ideia de uma sociedade rural pastoral, sem divisão de classe e sem conflitos sociais serviu de mito para demarcar e para legitimar a classe burguesa parisiense entre as décadas de 1840 e 1850. Defende o autor que telas de Courbet como Enterro em Ornans (Enterrement à Ornans, 1849-1850) expõem justamente as zonas de sombra que aquele mito tenta encobrir. Consultar T.J. Clark, Une image du peuple, Villeurbanne: Les presses du réel, 2007.

${ }^{329}$ Ibid., p. 148.
} 
mesa, pois não se sabe ao certo se realmente a "filha" acredita que Ventura seja seu pai ou se simplesmente reconhece a necessidade ou convence-se do prazer que é poder vivenciar similar partilha.

Fig. 242

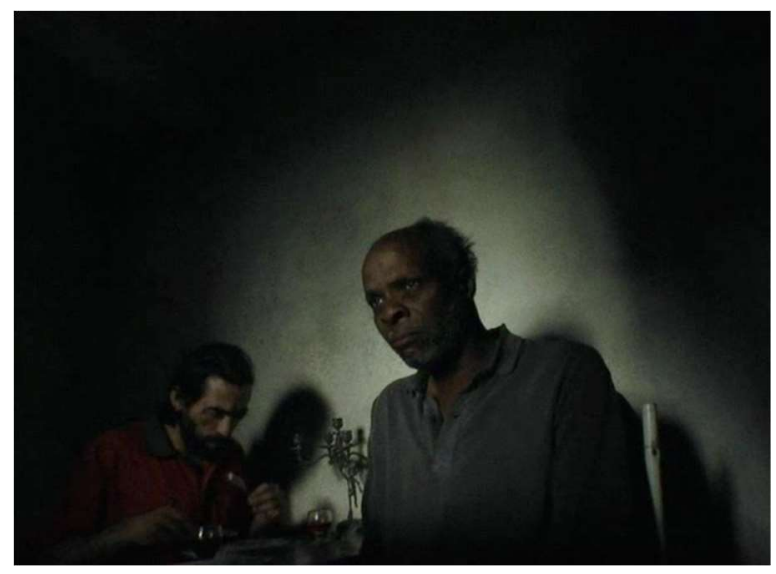

Fig. 243

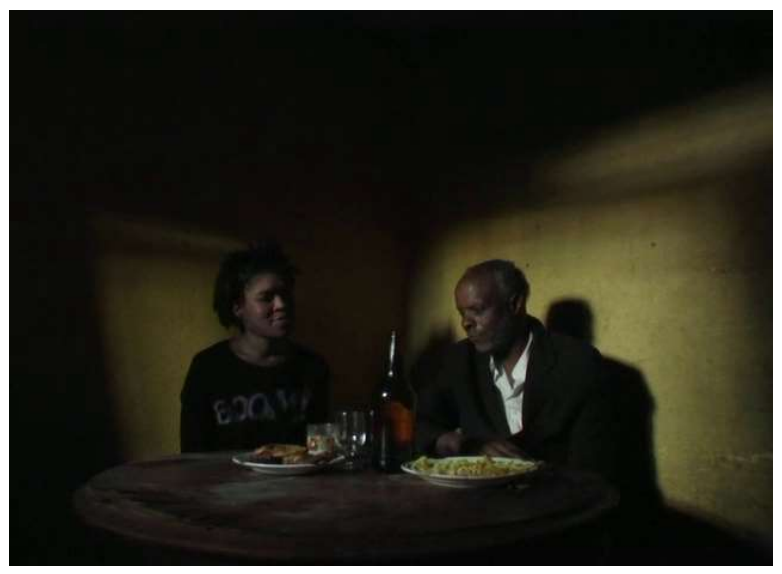

No quarto da Vanda substitui a mesa por uma cama e a refeição pela droga. A exceção é a casa de Nhurro. Ali os amigos se reúnem para usar heroína à mesa, onde rememoram histórias pessoais: episódios de roubo, mesmo quando amarguravam umas poucas moedas no bolso; dormir em abrigos que viriam a ser incendiados; o medo de morrer na pobreza ("Nós, os merdas, nunca morremos") ${ }^{330}$; a relação com as mães; a avaria de quem lhes dá esmola e assim por diante. Sempre em evidência na imagem, mesmo quando nada se passa sobre ela, a mesa perdura como relicário dos encontros. Sobre sua superfície, os rastros da droga e da pobreza: uma garrafa d'água, seringas e outros materiais de preparo e consumo da heroína. Tudo é muito tangível, como o era também sobre as mesas de Mudar de vida e de Os comedores de batata. Espécie de síntese objetal de um estado socioeconômico miserável, a mesa também acena para uma potência de natureza coletiva. Às escuras, quando fecham portas e janelas para consumirem a heroína à luz de velas, é sobre ela que acontecem as narrativas, a transmissão de uma memória oral, o adensamento da experiência coletiva em ritual. Figurativamente, tais cenas diluem os corpos individuais na penumbra. Vestígios anatômicos e o som de vozes murmurando histórias transitam e ocupam o plano fantasmagoricamente. A integridade física desaparece em prol de uma permanência coletiva emoldurada pela horizontalidade visual da escuridão - ainda mais radical que o tonalismo de

\footnotetext{
${ }^{330}$ Frase dita durante um diálogo entre Nhurro e Muletas.
} 
Van Gogh. Um tecido negro abarca conjuntamente as figuras num mesmo todo, recriando imageticamente a partilha experimentada.

Costa, como Ford, Rocha, Van Gogh e Courbet, torna o encontro em torno de uma mesa um rito de sedimentação das relações sociais. Conquanto o preparo da comida e a alimentação em si mesmas sejam quase sempre preteridos, existe um investimento afetivo ou um tipo de intimidade cujo efeito é uma urdidura entre os indivíduos similar à sugerida pelo comentário de Luce Giard. A integração depende em muito do que se falou sobre a singularidade da mesa do pobre, presente tanto em Costa como na maioria dos outros exemplos mencionados. Diante das demais expropriações, numa casa pequena, com mesas modestas e pessoas humildes, é ali que o corpo é capaz de abandonar seus próprios dramas e o de uma existência individual para, longe das horas sombrias, compartilhar um prazer coletivo.

A reunião em torno da mesa nos filmes das Fontainhas coincide com o que há de mais pessoal ou por vezes de mais doloroso para cada personagem em cena. Os signos de horizontalidade elencados em Ford, Rocha e Van Gogh também lá estão, mas de acordo com a poética de Costa: plano geral fixo a enquadrar simultaneamente dois ou três corpos, jamais os separando pelo esquema campo/contracampo, diferentes gerações à mesa, o alinhamento dos humores, a confraternização e sobretudo a intimidade fortalecida pela transmissão da experiência. Especificamente sobre a mesa de Nhurro, incorpora-se também a escuridão da imagem como manto que se sobrepõe uniformemente sobre os grupos.

Quanto a Courbet, é verdade que a classe social e o despojamento de suas figuras em nada se parece com o hieratismo e a contenção gestual dos pobres nos filmes de Costa. Evocou-se Depois do jantar em Ornans porque mais do que qualquer outro exemplo ali se vê nos rostos das figuras o prazer de um tempo em suspensão, o fruir agradável de um momento fraternal. Similar corte no real em benefício do que se passa entre dois corpos está na base mesma dos encontros de Costa. Os risos são mais raros e os gestos mais rígidos, mas o prazer pelo convívio é próximo. Também, existe na tela de Courbet uma personificação, dado o abandono de modelos arquetípicos em prol de figuras reais. Talvez seja um pouco forçoso apontar como correspondente, mas Costa faz o mesmo ao escolher pessoas reais para encenar os seus filmes, dotando situação universais de uma forte particularidade.

Uma pergunta que poderia ser dirigida ao cinema de Costa em comparação às obras dos demais artistas citados é: onde estão as famílias ou as figuras numerosas em torno da mesa? Por que se restringir sempre a duas ou no máximo três pessoas? A hipótese reside sobre uma possível perda das relações parentais: a família principal de Ossos corre o risco de se separar porque mal tem dinheiro para alimentar o filho recém-nascido; em No Quarto da Vanda, 
exceto a protagonista que mora com a mãe, o que se sabe é da dificuldade dos personagens principais de reencontrarem os pais, pois geralmente sentem vergonha de quem se tornaram e da vida difícil que levam. A essa desagregação, a família passa a ser substituída por uma irmandade, uma política comum entre os vizinhos. No lugar de uma mesa numerosa composta por parentes que moram juntos, as visitas de um morador a outro.

\subsubsection{Corpo negativo e desterro histórico-transcendental}

A reunião das figuras é a objetivação de um princípio de continuidade e expansão corporal radicado nas demandas do cotidiano das Fontainhas. Porquanto seja verdade, essa é apenas uma parte da história. $\mathrm{O}$ tom descritivo assumido até o momento se deteve sobre os encontros e suas consequências, mas pouco a respeito do que os motiva e das condições gerais do corpo antes de reunidos. Vale um olhar retrospectivo sobre as causas, dessa vez priorizando a síntese, as leis gerais, em detrimento de uma descrição extensiva.

Existe uma ampla negatividade da figura humana no cinema de Costa, sobretudo em Ossos e No quarto da Vanda. Neles o corpo é estruturado por uma série de deficiências e expropriações decorrentes da sujeição a uma miserável realidade material. Para além de identificar essa origem, é necessário analisar os pormenores. Primeiramente, deve-se reconhecer uma pulsão autodestrutiva. O sofrimento que aflige os corpos não é derivado de uma justiça redistributiva que vem penalizar um delito ou castigar um pecado a partir de uma conversão do mal ativo em mal passivo. ${ }^{331}$ A mortificação que experimentam as figuras é auto imposta, como se vê desde os suicídios de Ossos até o uso da droga em No quarto da Vanda. Um hipotético inventário da representação do corpo nos filmes das Fontainhas reuniria figuras esquálidas, tíbias, doentes e em óbito (anunciado, não mostrado, portanto, dupla morte, na vida e na imagem) em razão do que infligem a si mesmos. O instinto de auto-conservação da vida encontra o seu inverso em cada gesto reflexivo. Estamos por diversas razões no oposto do que este modo de ação humana significava no Capítulo 2, quando vinha para fornecer novas figurações a um corpo em vias de adaptação ou contestação do seu entorno. O gesto reflexivo em Costa é geralmente letal.

Por um lado, a violência auto infligida e, de modo geral, a resultante da experiência material, acabam transformando a figura humana em um repositório ou num reflexo do que a circunda. Tanto quanto a solidez das paredes sujas e dos casebres das Fontainhas, a imagem

\footnotetext{
${ }^{331}$ Ver Norberto Bobbio, "Os deuses que fracassaram (Algumas questões sobre o problema do mal), in Elogio da serenidade e outros escritos morais, São Paulo: UNESP, 2011.
} 
do corpo é uma placa sensível, um sismógrafo a anunciar a precariedade social. O sonambulismo de Tina e do pai de seu filho sugerem a realidade pétrea, estagnada e sem perspectiva de transformação em Ossos; o rosto de Clotilde, presume-se, é uma resposta à severidade do cotidiano. Em No quarto da Vanda, a injeção da droga faz pelo corpo o mesmo que as escavadeiras pelo bairro, destruindo lenta e progressivamente uma estrutura cujo estado de deterioração está a tal ponto avançado que já não pode durar muito. A figura humana duplica, emula e responde em aquiescência o que a envolve. Figura e fundo, corpo e espaço, estão num constante jogo de espelhamentos e retroalimentação.

Ainda tendo em mente o capítulo anterior e seus corpos movidos pelo desejo (sexual, nos expoentes contemporâneo; de transformação e adaptação, no burlesco), numa infatigável motivação rumo aos seus objetivos e ao lugar que almejavam no mundo, a figura humana nos filmes das Fontainhas está por demais combalida. Minguada fisicamente, a vontade lhe é estranha. O corpo parece em vias de abandonar a ação como instrumento de concreção de seus anseios. A dimensão sexual está completamente ausente e consigo retira também o afeto que poderia revitalizar o corpo, impulsioná-lo em direção a outro. A figura humana foi a tal ponto precarizada que perdeu sua natureza de agente? Se a ação é o que conduz à felicidade ou ao seu inverso, ${ }^{332}$ a apatia paira como morte simbólica do corpo, passividade diante do poder que sobre ele se faz valer. A referência continua sendo o sonambulismo de Ossos e a droga em No quarto da Vanda. O gesto mais ativo das figuras nesses filmes é, como se falou, o que anula a si mesmas.

A trilogia das Fontainhas é aclimatada a céu aberto, o corpo não tem nada acima de si, está completamente exposto ao desabrigo histórico e transcendental. Vindos de Cabo Verde, no limbo cultural, os imigrantes dos filmes estão marginalizados em outro país e o aceno mais próximo ao lugar de origem vem sacramentar o desterro: em Juventude em marcha, Ventura escutando Labanta braço, música sobre a independência de Cabo Verde, no intervalo do trabalho. A rádio toca a euforia da liberdade enquanto o cabo-verdiano imigrado para Portugal vive em condições de miséria e dispõe seu corpo e sua força de trabalho para uma exploração que revitaliza a condição de colonizado. A remissão musical à terra de origem surge como operação dialética entre passado e presente, entre o tempo em que se visava um futuro e o agora que renova, sob outro rompante, a ferida histórica. ${ }^{333}$

\footnotetext{
332 Recordamos da ação dramática, definidora de ambos os efeitos, segundo Aristóteles, Poética, São Paulo: Editora 34, 2017.

${ }^{333}$ Exceção ao exílio cultural, duas cenas de festa, duas ilhas apartadas no tetro universo em que despontam: uma em Ossos, quando os moradores dançam a música cabo-verdiana, ignorando, pela primeira vez, o duro cotidiano; e outra, bem menos efusiva, em No quarto da Vanda, quando vizinhos se reúnem na casa da protagonista e ali
} 
A ausência do que se chamou de abrigo transcendental não é a ausência dos deuses nas Fontainhas. Ou também o é. De todo modo, No quarto da Vanda e Juventude em marcha enraízam os corpos no bairro com tanto afinco a ponto de vetar a presença de uma possível transcendência. Isso implica a ausência do próprio Estado, que não existe para assegurar os moradores com garantias básicas. Sua atuação é inversa, remete às máquinas e ao processo de destruição do bairro. Extirpados da própria cultura e esquecidos por qualquer instância externa, os corpos em cena amargam também a falta da imanência de sentido. É natural que a figura humana dispense a ação e se entregue à apatia ou à autodegradação pela droga. Antes mesmo de se questionar a eficácia não se sabe contra quem lutar. A já discutida clausura nos filmes das Fontainhas é drástica em sua negação do contracampo e alheamento do mundo exterior. Ou ela é aceita e implica a letargia, ou contornada por um escapismo cuja condição é a destruição da figura humana.

A recusa do corpo a uma dimensão ativa pode ser pensada também a partir da estrutura de No quarto da Vanda. A forma fílmica não estabelece a busca por algo, a tentativa de descobrir e construir a totalidade oculta da vida a partir de objetivos e caminhos a serem descobertos na jornada dos personagens. ${ }^{334}$ No quarto da Vanda é arreigado numa anulação que impede a ação: nem há objetivos para a figura humana, pois o seu entorno se decompõe imperativamente, e nem há caminhos a seguir, pois todas as vias levam às casas do bairro, portanto a uma imersão onde se busca a saída. A princípio, o filme suprime um sentido profundo que justifique e ampare o desejo dos corpos nutrindo-os de anelos infra ou suprapessoais. Também não se vê em No quarto da Vanda e nos demais filmes da trilogia um acontecimento crucial determinante, um fenômeno que mesmo na sua contingência ofereça uma esfera de atuação para a figura humana ou que extraia da vida o que a torna essencial. A permanência extensiva no mundo propiciada pela duração dilatada dos planos, como em Pais e filhos, de Bing, e a não condução das cenas a um fim firmam a forma fílmica sobre a negação de um horizonte a ser alcançado, um esvaziamento de sentido e por conseguinte dos anseios. A possível força motriz que poderia advir dessa ausência é convertida em passividade dos corpos. A forma não resolve, mas acentua a ausência de um sentido imanente. ${ }^{335}$

confraternizam e dançam ao som do acordão, enquanto Vanda, Zita e uma terceira pessoa no fora de quadro fumam cigarros e preparam o crack. Ecos nos dois momentos da família de músicos cabo-verdianos de Casa de Lava, que sonhava e temia uma futura imigração para Portugal.

334 Caso da estrutura do romance literário, à qual o cinema não é indiferente. Ver Georg Lukács, A teoria do romance, São Paulo: Editora 34, 2008.

$335 \mathrm{O}$ filme vai além de certas obras em que a forma explicita e não resolve a incoerência própria ao universo diegético. Pensamos, tendo como exemplo a literatura, aquelas descritas por Lukács: “Toda a forma é a resolução de uma dissonância fundamental da existência, um mundo onde o contrassenso parece reconduzido a seu lugar correto, como portador, como condição necessária do sentido. Se portanto numa forma o cúmulo do 
A negatividade envolvendo a figura humana, do estado físico e ausência de ações até a presença num universo de desterro histórico-transcendental, é o que justifica a rede de expansão, o corpo enquanto uma exterioridade, a série de encontros que descrevemos mais cedo. A rede de fraternidade das duplas, das refeições conjuntas e dos rituais em torno da mesa não vêm resolver e completar com o outro o que falta a si mesmo. Diferentemente do tipo de relação que se almejava nos realizadores contemporâneos dos demais capítulos, em que o outro era visto como uma espécie de presença a preencher um vazio, a alteridade a partir dos pares e trios na trilogia das Fontainhas existe por uma via outra que a do complemento. Uma figura é acompanhada por outra não para sanar o que lhe falta, preencher um vácuo substancial. ${ }^{336} \mathrm{~A}$ imagem do corpo é completa em si mesma na sua "escolha" pela apatia ou pela droga. A necessidade de outrem existe enquanto responsabilidade que se impõe como modo de preservação da comunidade. Os filmes reivindicam essa disposição.

$\mathrm{O}$ modo de presença da figura humana nos filmes das Fontainhas não se reduz à figuração integral do corpo. Não deve soar estranho nessa reta final retomar o paradigma inicial da tese: a imagem do corpo onde sua matéria física não está presente ou pelo que a ela é exterior. Antes, em Grandrieux e realizadores correlatos, isso acontecia pela imagem e vinha como uma evocação das sensações. O horizonte agora é completamente diferente. É preciso deixar o corpo como determinante sensível do indivíduo no mundo porque, relegado ao ensimesmamento, restrito à pretensa existência una e autossuficiente, é, em sua negatividade, por demais pequeno diante das forças que o ameaçam.

contrassenso, o desaguar no vazio de profundos e autênticos anseios humanos ou a possibilidade de uma nulidade última do homem, tem de ser acolhido como fato condutor, se aquilo que é em si um contrassenso tem de ser explicado e analisado, e em decorrência inapelavelmente reconhecido como existente, então é possível que nessa forma certas correntes desemboquem no mar da satisfação, embora o desaparecimento dos objetivos evidentes e a desorientação decisiva de toda a vida tenham de ser postos como fundamento do edifício, como $a$ priori constitutivo de todos os personagens e acontecimentos". Ibid., p.62

${ }^{336}$ A lembrança é a da alteridade descrita nos termos de Levinas. O autor considera como condição essencial para o Desejo de Outro que o ser esteja completo, sem uma necessidade, que não busque um "complemento". Do contrário, tratar-se-ia de um investimento de disposição egoística, voltado para si mesmo e para o processo de identificação e de assimilação do mundo. $\mathrm{O}$ autor defende um movimento que implique o ser numa conjuntura em que originalmente não lhe é concernente e por isso frente à qual deveria ser indiferente. É somente por essa via que o Outro interrompe e coloca sob suspeita a unicidade do Eu, apresentando o que a ela escapa, o que está fora dos domínios individuais. Nesta proposta, desarticula-se a identificação primária do Eu consigo mesmo, a consciência fundada em uma interioridade. O Outro imputa sobre o si uma responsabilidade indeclinável, um movimento ético na consciência, um compromisso com o bem-estar dos demais que está na base da experiência social. Ver Emmanuel Levinas, Humanisme de l'autre homme, Paris: Fata Morgana, 1972; Emmanuel Levinas, Totalité et l'infini, Paris: Biblio Essais, 1994. 


\subsection{Comunidade na expropriação}

Totalidade do ser só é possivel quando tudo já é homogêneo, antes de ser envolvido pelas formas; quando as formas não são uma coerção, mas somente a conscientização, a vinda à tona de tudo quanto dormitava como vaga aspiração no interior daquilo a que se devia dar forma; quando o saber é virtude e a virtude, felicidade; quando a beleza põe em evidência o sentido do mundo.

Georg Lukács ${ }^{337}$

\subsubsection{A criação do espaço comum}

Num texto escrito no início da década de 1930, intitulado Aqueles que esperam, Siegfried Kracauer comenta a atomização do mundo moderno. Um grande número de pessoas que conquistaram sua parte dos bens culturais e educacionais estaria, mesmo sem se conhecer, enovelada em torno de uma profunda melancolia comum decorrente da ausência de um sentido mais elevado de suas vidas. Embora a ênfase recaia sobre o abandono espiritual que relega a vida ao esvaziamento e a poderes disformes, lá está a solidão das grandes cidades, o agravado sentimento de isolamento pela fratura das relações interpessoais. ${ }^{338}$ Especificamente sobre a individuação, o texto não está muito distante da reflexão de contemporâneos que igualmente entenderam a estética moderna do fragmento também no nível do corpo social. Seria um exercício por demais ousado tentar retraçar a espessura de tal debate nesse momento. E também não se alcançaria grande coisa: o cinema de Costa acena para o risco de um esgarçamento do tecido social e a consequente perda de sentido que lhe acompanha, é verdade, mas está muito mais preocupado com a produção de um modo de resistência. A figura humana faz parte da obstinação insurgente que ganha forma a partir de um corpo coletivo. As manifestações dos pares, trios e encontros em torno de uma mesa são um estado prematuro dessa figuração.

O cinema não tem necessidade de pôr em cena, literalmente, um exército de corpos a preencher o campo ou um enxame a forçar os limites do quadro para representar um grupo, uma comunidade, um povo ou mesmo uma nação. As alternativas são numerosas e não é mero acaso que Costa apareça como mais um nome num amplo panteão de realizadores engajados politicamente que a elas irão recorrer. Apenas para forjar uma linhagem imaginária e demasiado livre em suas escolhas, lá estariam: Sergei Eisenstein, John Ford, Glauber Rocha,

\footnotetext{
${ }^{337}$ Georg Lukács, Op.cit.

${ }^{338}$ Siegfried Kracauer, “Aqueles que esperam”, in O ornamento da massa. São Paulo: Cosac Naify, 2009.
} 
Michelangelo Antonioni, Jacques Tati, Peter Watkins, Jorge Sanjinés, os irmãos Jean-Pierre e Luc Dardenne, entre outros.

Lembremos, por exemplo, da cena em que o casal de protagonistas de Zabriskie Point (1969), de Antonioni, transa em meio a um deserto, completamente isolado. O ato de dois corpos semeia sobre o solo arenoso, numa terra que se diria improdutiva, um desdobramento figurativo, uma ressonância corporal: surgem outros casais descendo as montanhas, rolando pelo chão, engalfinhando-se alegres num deslumbre amoroso que só sublinha o contexto histórico do filme, o final da década de 1960. Diversificam-se os corpos e ramifica-se a ação numa escala numerosa de modo a propor uma dimensão coletiva e geracional. Um episódio inicialmente fechado na intimidade de dois corpos recebe um desdobramento e uma consumação coletiva. Um ano depois, Punishment Park (1971), de Watkins, mostra um grupo de militantes norte-americanos que cumpre pena num acampamento de detenção, também em um deserto. Abstendo-se a designar um protagonista que assuma e conduza o drama, o filme lida com um "personagem coletivo". As figuras são particularizadas somente a ponto de serem identificadas, mas nenhuma recebe notoriedade singular e diferenciada: a tortura de um é a tortura de todos. Como na épica, o destino só existe em sua dimensão coletiva. Do grupo de militantes que se acompanha na maior parte do tempo, nenhum sobrevive. $\mathrm{O}$ contrário seria negar o próprio imperativo que estrutura o filme. Mas esses são apenas exemplos. Voltemos a Costa.

$\mathrm{Na}$ trilogia das Fontainhas, à parte as cenas de encontros, a figuração do coletivo segue uma lógica vetorial manifesta no cinema do realizador desde Sangue. Ela implica a existência de um elemento que irá percorrer os demais personagens estreitando a distância que preservavam entre si, implicando-os numa existência coletiva, alinhavando-os em torno de um objeto ou destino comum. Quem assume o desígnio em Ossos é o recém-nascido. Corpo vivo, mas cuja existência paira sobre os pais como um espectro de morte, marca maldita a disparar a pulsão de destruição, será ele a criar um intra-espaço, um meio comum a ser partilhado pelos personagens. O bebê passa de mão em mão. Conecta, estreita e expõe a relação entre os moradores do bairro, assim como estabelece o contato dos pais com a enfermeira que a partir de então se sentirá eticamente impelida a ajudá-los, alimentando-os, tentando aconselhá-los ou tão-somente dividindo o silêncio em entendimento.

No quarto da Vanda faz da droga o vetor a atravessar os corpos em cena e a estimular a criação de um espaço imaginário e ritualístico onde o território físico está em vias de ser destruído. O mais próximo do gesto coletivo será o envolvimento conjunto no preparo pormenorizado do crack e da heroína, bem como seu subsequente consumo. A injeção e o 
trago são os modos de criar um tecido conjuntivo. Ali surgem as narrativas pelas quais a experiência e o imaginário dos indivíduos são sedimentados em memória coletiva, numa permanência, a princípio duradoura, contraposta à demolição iminente. A extensão de um corpo a outro é intrínseca ao que ameaça e nega a vida: o depauperamento das condições materiais pela pobreza e a agressão ao corpo pela droga.

Ventura talvez seja o maior emblema da lógica vetorial em Costa. Sua presença em Juventude em marcha é figurativamente a de um ser que percorre um plano a outro, vai de rua em rua, de casa em casa, conversando com os vizinhos que chama de filhos, entre eles estabelecendo um liame, uma cesura que tem como centro sua existência. A comunidade que em Ossos e em No quarto da Vanda existia por um prisma preponderantemente negativo, um extermínio dos corpos por si mesmos e pela bruta realidade que os oprime, passa a ser forjada por um gesto vivente e agregador livre da pulsão destrutiva dos filmes anteriores.

O papel de Ventura como vetor remete ao de outro filme contemporâneo que também transforma a figura humana em elemento que entremeia os demais corpos a fim de tentar restituir a comunidade num ambiente em que o instinto de sobrevivência pode engendrar uma individuação: Dois dias, uma noite (Deux jours, un jour, 2014, de Jean-Pierre e Luc Dardenne). O ponto de partida é a demissão de Sandra, funcionária de uma fábrica de painéis solares. Surge a possibilidade de manter o seu contrato, mas somente se os demais empregados perderem um bônus de 1.000 euros. O filme se estrutura, de modo bem mais esquemático que Juventude em marcha, pelas visitas de Sandra aos colegas de trabalho, a fim de convencê-los a abdicar da gratificação para mantê-la na empresa. O emprego só é possível pela renúncia comunitária: para preservar o indivíduo é necessário um esforço coletivo. $\mathrm{O}$ corpo de um é, simbolicamente, vinculado ao dos outros.

De volta a Costa, percebe-se que o vetor é conformado em três modos distintos: o corpo (o recém-nascido e Ventura), a ação (consumo da droga, refeições em torno da mesa) e o objeto (a droga). Sua operacionalidade nos filmes depende da criação de figuras espaciais de passagem que facilitem a comunicabilidade pela redução dos muros reais e simbólicos. Dito de outra maneira, o trânsito dos vetores exige a criação de uma abertura, de uma brecha que permita violar as barreiras impostas pelas estratificações espaciais/sociais e, assim, transgredir o que poderia segregar e alienar a figura humana. $O$ primeiro objeto a assumir tal função são as portas, abundante e quase obsessivamente espalhadas ao longo da filmografia de Costa. A chegada de Nhurro na casa de Vanda mostrava a detida atenção ao objeto. Não só pelo uso do plano detalhe sobre as mãos que suspendiam a tramela, mas também porque depois de "violar" o bloqueio, a figura permanecia na soleira da porta, nem dentro do quarto e nem fora 
dele (Fig. 186). O mesmo "não lugar" será assumido por Ventura quando está na casa de uma de suas filhas (Fig. 44.). A porta parece abrigar algo de inusitado ao longo da obra do português. Ainda Ventura, quando visita o apartamento no Casal da Boba, abre e fecha sucessiva e comicamente uma das portas, como se a atestar sua funcionalidade. Por que tanto interesse? Depois de ser desalojado, Nhurro aparece carregando um saco com os seus poucos pertences e ... uma porta. Comum também são corpos no interior de imóveis, geralmente de um quarto, filmados a partir de um ponto de vista externo, pela fresta da porta entreaberta.

A fim de compreender o seu uso como mecanismo ambivalente e essencial para a criação de uma comunidade, é necessário pensar as portas dos filmes de Costa à luz do cinema fantástico. A proximidade do realizador com o gênero não deve ser surpresa, tendo em vista suas constantes menções diretas, em entrevistas e nos filmes, a realizadores como Jacques Tourneur e Georges Franju. Entre outros elementos daquele gênero que se apropria, está a porta como dispositivo fronteiriço de impedimento e comunicação entre mundos. Nos filmes das Fontainhas, ela é o entre dois, o que muitas vezes simboliza o limbo social dos moradores, desprovidos de uma propriedade e sem ter para onde ir. Eles vivenciam um mundo ao mesmo tempo em que estão fora dele, às suas margens. Ao se falar da circularidade no plano pela escuridão, no Capítulo 1 , fora mencionado que certos filmes recorrem a dispositivos de travessia, como a porta. Jean-Louis Leutrat comenta a função que ela assume no cinema fantástico:

Tematicamente, a porta é ao mesmo tempo uma fronteira e um lugar de passagem. Ela define, fecha, delimita o território. Ligada à separação, ela funciona com a ponte, como percebe Georg Simmel. Ela é fechada sobre o interior, a ponte abre em direção ao exterior. A ponte, como a porta, separa, mas também sutura: na versão da história de Dr. Jekyll proposta por Rouben Mamoulian, uma passarela transpõe o espaço que separa o laboratório do doutor do seu apartamento; a porta, como a ponte, abre, mas também enclausura: além da porta, como também além da ponte, encontra-se o país dos fantasmas. ${ }^{339}$

A finalidade das portas em Costa está alinhada com a das janelas, que redobram a permeabilidade entre o que acontece no espaço privado e no espaço público. Em Ossos, pelas ruelas do bairro, são vistas as famílias que estão em casa. Pelas casas, observa-se os passantes na rua. De todos os filmes, a arquitetura é talvez a mais evidente nesse aspecto, pois compartimenta o campo em um jogo de enquadramento e re-enquadramentos que criam vasos comunicantes. Pela janela: uma das vizinhas vê a chegada do bebê que tudo irá secretar no

${ }^{339}$ Jean-Louis Leutrat, Op.cit. 
filme (Fig. 244); Tina se intromete durante o sexo de Clotilde com o marido para pedir ajuda; Ventura, da rua, fala com a "filha" que está dentro de casa (Fig. 246-247); Russo põe a mão na cozinha da casa de Vanda para perguntar se a mãe dela não quer comprar o passarinho que ele encontrou. As janelas reforçam as portas como elementos de infiltração, diluição ou flexibilização das fronteiras que deveriam separar espaços e consequentemente os corpos.

Fig. 244-245
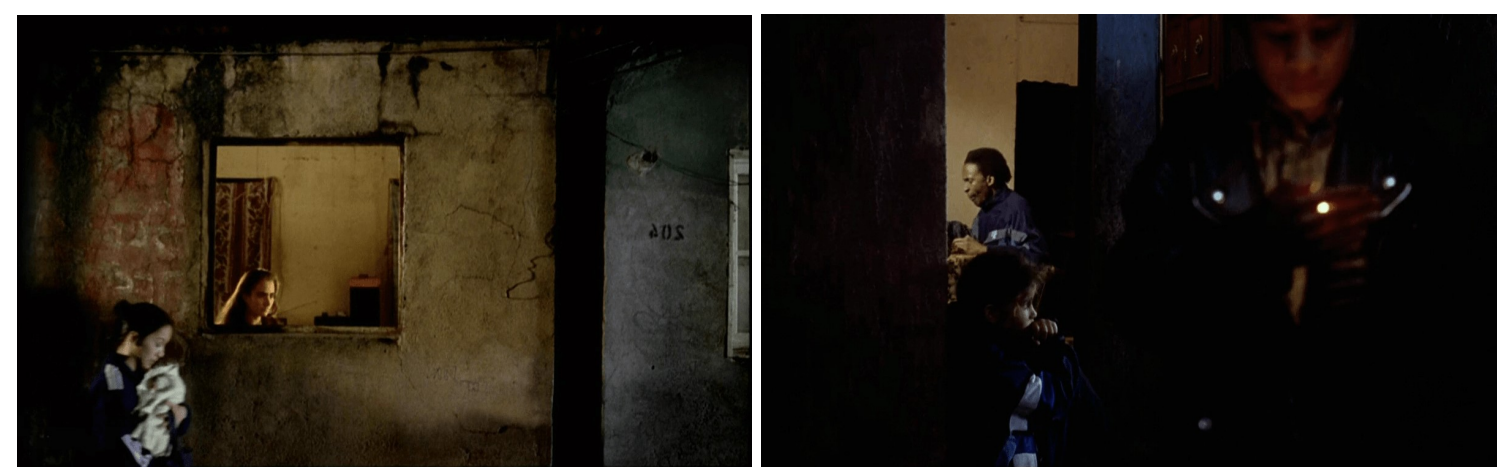

Fig. 246-247
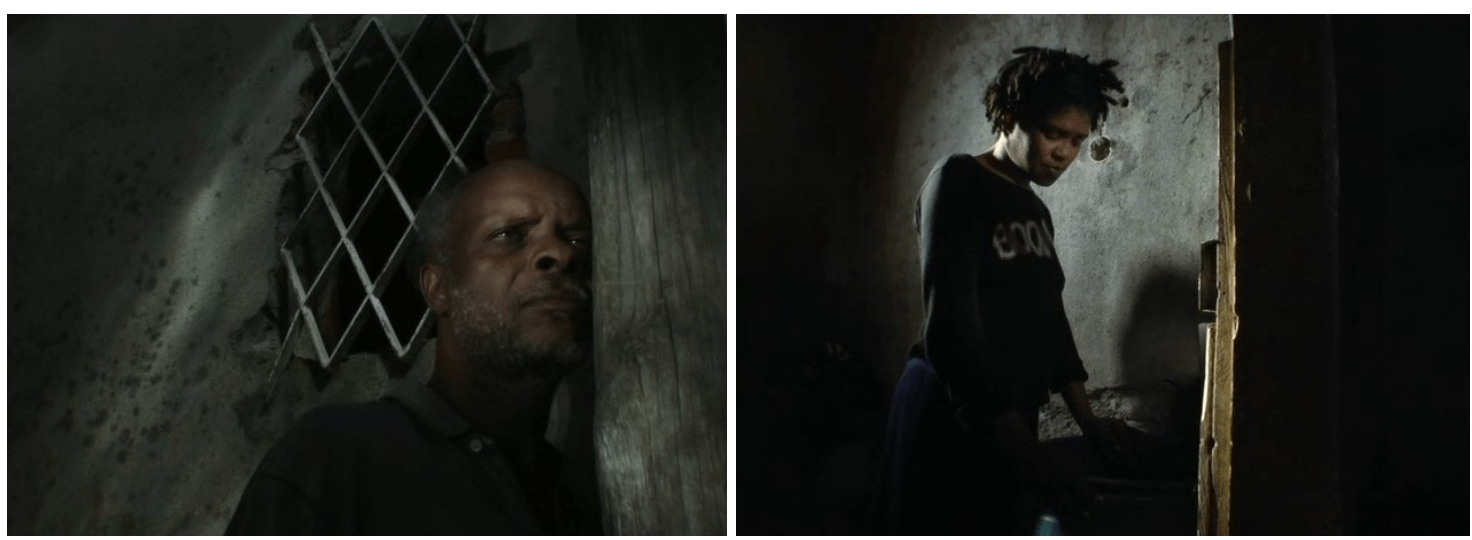

A circularidade é desencadeada também por motivos pontuais que surgem em um corpo e reaparecem ou ganham continuidade em outro. Fora da trilogia, Casa de lava antecipava a prática quando o vestido vermelho que caracterizava a protagonista aparece em outra personagem do filme. A passagem da roupa estabelece uma conexão e também uma transferência de um corpo a outro. Em Juventude, antes de Ventura, quem primeiro põe as mãos sobre a cintura em sinal de desaprovação é o segurança do museu. Ao repreender o protagonista, sentado numa poltrona (Fig. 220), o funcionário faz o gesto contestatório que Ventura futuramente repetirá - numa dinâmica de transferência gestual comum ao cinema de Jacques Tati. Já no filme anterior, Vanda tenta procurar um isqueiro para ascender o cigarro de crack. Até encontrar um que funcione, joga dezenas deles numa lixeira (Fig. 248-249). A montagem concatena a cena com o plano de uma mão mergulhada na treva a segurar um 
isqueiro aceso na casa de Nhurro (Fig. 250), estabelecendo um raccord imaginário. A continuidade entre o quarto de Vanda e a sala de Nhuro acontece tanto no nível da experiência com a droga, como também por uma ressonância e espelhamento gestuais.

Fig. 248-250
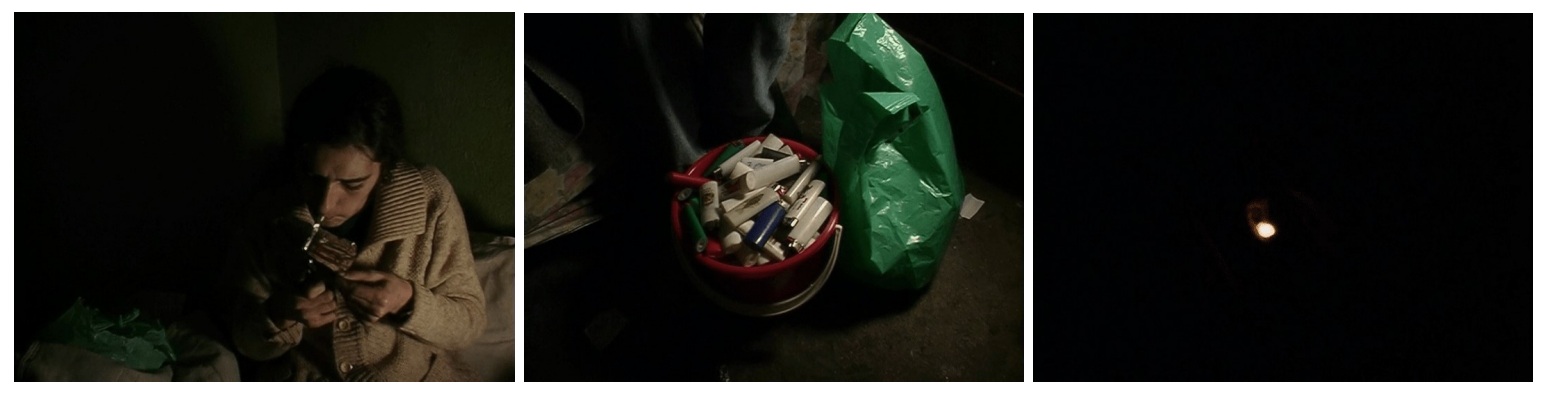

A dinâmica circular ainda depende do som ao redor, da ausência de isolamento acústico das casas, de onde sempre se escuta o que se passa no exterior, impedindo a existência de um espaço eminentemente privado. Por fim, deve-se acrescentar os corredores do bairro das Fontainhas. Não raramente eles fazem a ligadura de uma casa a outra na montagem. Ao mesmo tempo, funcionam como espaço de passagem de Ventura quando visita os filhos, ou de Vanda quando vende verduras no bairro. Juntos, os elementos listados figuram um espaço partilhado, uma topografia do outro, rede de constante interação entre figuras e sons capaz de forjar um corpo orgânico coletivo onde poderia existir apenas as ruínas e a atomização dos indivíduos em torno de suas tragédias pessoais.

Anteriormente, sinalizou-se a diluição da ação em No quarto da Vanda em decorrência de uma natureza retratística ancorada na predisposição à descrição. Os gestos de Vanda, Zita, Nhurro, Muleta e Zita redundam num aspecto identitário, particularizando-os, ou numa potência negativa, ameaçando o próprio corpo. A estrutura vetorial do filme, porém, permite recuperar um outro tipo de ação que, parece-nos, está em consonância mesmo que vaga com aquela descrita por Hannah Arendt ao distinguir o agir e o fabricar. Para a autora, enquanto o último pode ser realizado isoladamente e requer somente a circunvizinhança da natureza que fornecerá a matéria-prima, a ação é entendida pelo seu caráter coletivo, podendo existir exclusivamente na circunvizinhança de outros, rente aos atos e palavras de outros homens. Não se lida com os negócios humanos como se lida com qualquer material do mundo. "Estar isolado é estar privado da capacidade de agir". ${ }^{340}$ Desse modo, a autora recorda que o grego e o latim possuem duas palavras diferentes e correlatas para designar "agir": 1. Começar,

\footnotetext{
${ }^{340}$ Hannah Arendt, A condição humana, Rio de Janeiro: Forense Universitária, 2009, p. 201.
} 
governar (archein, em grego), por em movimento, guiar (agere, em latim); 2. Realizar, acabar (prattein, em grego), conduzir (gerere, em latim). É “como se toda ação estivesse dividida em duas partes: o começo, feito por uma só pessoa, e a realização, à qual muitos aderem para 'conduzir', 'acabar', levar a cabo o empreendimento." 341

$\mathrm{O}$ entendimento da ação como indissociável de uma coletividade permite repensar os filmes das Fontainhas, em especial No quarto da Vanda. Ao se analisar o caráter descritivo do filme, considerou-se entre outros critérios a rarefação da ação dramática. Pensando em termos políticos, parece-nos que No quarto da Vanda é permeado por um outro tipo de ação, aquela criada pela íntima interdependência entre os moradores do bairro. A estrutura vetorial do filme, organizada em torno do consumo da droga, da palavra partilhada, das visitas realizadas e dos demais elementos listados anteriormente põe em movimento, estabelece uma travessia, realiza algo. A ação existe e o seu produto é a rede dos negócios humanos. Os micro atos, os mínimos gestos dos personagens, para além da identidade que propiciam, também organizam a disposição conjuntiva do filme, criam e mantêm a comunidade.

Não nos parece descuidado pensar sobre o conjunto das estratégias enunciadas até o momento nos termos de uma esfera pública, ainda seguindo na esteira de Arendt. A autora define público segundo dois traços correlatos. Primeiramente, o que sai dos limites da existência resguardada, abandona a esfera privada e íntima para vir à luz, tornando-se passível de ser visto e ouvido por todos. Em segundo lugar, o mundo comum. Não um espaço limitado, mas o artefato, o produto das mãos humanas, o que deriva dos negócios realizados entre um conjunto de pessoas, o mundo feito pelo homem. Curioso, diante da discussão pregressa, que Arendt use como metáfora para este segundo traço a mesa: "Conviver no mundo significa essencialmente ter um mundo de coisas interposto entre os que nele habitam em comum, como uma mesa se interpõe entre os que se assentam ao seu redor". ${ }^{342}$ Como um intermediário, ela separa e promove a relação entre os homens. A perda da força e da conexão que mantém os indivíduos juntos é sinalizada pela autora, em oposição, pelo desaparecimento da mesa, o que mantém as pessoas sentadas umas em frentes às outras: já não estão separadas, mas tampouco possuem uma relação tangível entre si.

\footnotetext{
${ }^{341}$ Ibid., p. 190. As palavras que inicialmente correspondiam à segunda parte, à realização da ação (prattein, gerere) se tornaram os termos hoje utilizados para a ação em geral, enquanto as relativas ao início da ação (archein, agere) ganharam o significado, na linguagem política, de governar e liderar. Partindo dessa mudança em seus usos, Arendt investe contra o mito popular do "homem forte", cuja pujança adviria do isolamento diante dos demais. A ideia teria sua origem no mundo político e justamente na cisão comentada: quem inicia a ação passou a ser o governante e quem a executa os seus súditos. A falácia do homem forte, poderoso por estar só, surgiria de um hipotético isolamento, do ato de governar alienado da própria força que o constitui, da omissão daqueles sem cujo auxílio o líder conseguiria realizar algo.

${ }^{342}$ Ibid. p.62.
} 
A criação de um espaço comum ou de um esfera pública no cinema de Costa acontece, como se mostrou, por uma constelação entre vetores, portas, janelas, som e corredores. O que essa dinâmica arquitetônica, visual e sonora impede é o cerceamento, o isolamento dos corpos e de seus respectivos dramas no seio de um território privado. O que favorece é a criação de uma esfera comum pela conversão do interior em exterior, pela extensão do eu ao outro, pelo arranjo dos diferentes em torno de um objeto comum. ${ }^{343}$

\subsubsection{Sacrifício}

Uma comunidade, não se deve ignorar, é forjada sob um manto cujo tecido é menos uniforme e liso do que aparenta. Os acidentes, as irregularidades e os rasgões são constitutivos do que une um grupo. Organização ambivalente, os seus componentes se fortalecem ao mesmo tempo em que deles é exigido um tipo de sacrifício: desde um dever que os desapropria parcial ou inteiramente de sua subjetividade até a aceitação de um risco que em último grau pode envolver a própria vida. $\mathrm{O}$ objeto real ou simbólico que promove a coesão cobra o seu preço e, não raramente, o elemento a acolher, suportar e expor as marcas deste fardo necessário é o corpo individual.

Verdadeira ode à comunidade, o boliviano La nácion clandestina (1989, de Jorge Sanjinés) expõe com clareza o duplo regime comentado. Sebastián Mamani, camponês de origem aimará, abandonou a sua comunidade, em Willkani. Muda-se para La Paz, onde é hostilizado em razão da cor da pele e dos traços indígenas. Adota o sobrenome Maisman, filia-se ao exército e faz de tudo para dissimular sua origem mestiça, que paira como espectro discriminatório na sociedade citadina. Alcoólatra e isolado, retorna a Willkani quando o pai morre. Lá, casa-se e se torna chefe comunitário, mas aproveita-se do cargo para tomar decisões em benefício e enriquecimento próprios. Quando é descoberto que mentia e traía aqueles que representava, uma assembleia popular decide relegá-lo ao exílio, expulsá-lo de Wilkani.

Passados alguns anos, Sebastián, que revive o terror de ser alijado da pertença social, tenta reintegrar-se à comunidade. Faz uma longa peregrinação a Wilkani decidido a realizar a Jacha Tata Danzante. Trata-se de um antigo ritual, geralmente executado em anos difíceis. Quem o protagoniza deve portar uma pesada máscara de diabo e dançar até perder as forças e morrer (Fig. 251-252). Com o sacrifício, Sebastián espera reparar os danos que causou no

\footnotetext{
${ }^{343}$ A esfera comum exige a possibilidade de convivência de perspectivas distintas. Ela não é garantida pela "natureza comum" dos homens que a constituem, mas a despeito das diferenças de posição e da multiplicidade de perspectivas. Ibid.
} 
passado, reconectar-se às raízes da cultura andina e assim se reinserir na comunidade. Ao mesmo tempo, sacrifica-se pelo bem do seu povo, que naquele momento atravessa uma crise política - parte dos aimarás se junta aos mineiros na luta contra o Golpe de Estado; o cortejo ritualístico de Sebastián cruza com os camponeses que carregavam os corpos dos assassinados no combate. ${ }^{344}$ Aquele que buscou tirar proveito da coletividade, prefere ser reintegrado ao seu povo mesmo que às custas da própria vida. A morte é menor que o exílio, o indivíduo não é nada sem a comunidade, e o corpo primordial é o coletivo. Num filme cuja encenação é fundamentada em suturas entre dípticos, passado e presente, ${ }^{345}$ mortos e vivos, imanência e transcendência, tempo profano e tempo sagrado, a união mais definitiva é a que dilui e incorpora a figura humana numa organização cultural e política: o corpo na sociedade.

Fig. 251-252
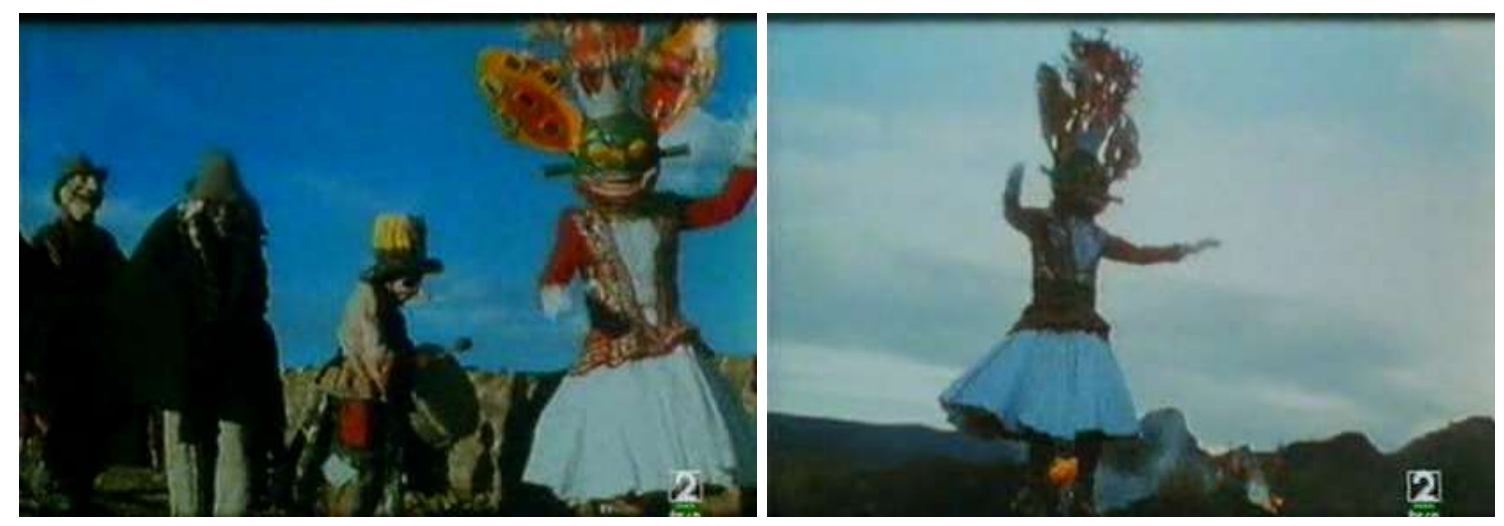

La nación clandestina justifica o sacrifício por uma perspectiva cultural. No quarto da $V a n d a$, que agora será nosso único foco na trilogia das Fontainhas, segue por outro caminho em razão do anunciado desterro histórico da figura humana. Mais perto de elucidar os meandros de sua proposta figurativa é, novamente, um filme clássico paralelo ao nosso corpus, mas amiúde citado, As Vinhas da ira. O tema sacrificial compõe o próprio estofo da

\footnotetext{
${ }^{344} \mathrm{O}$ filme é pontuado por remissões diretas ao processo histórico vivenciado na Bolívia, incluindo o apoio dos camponeses, sobretudo dos aimarás, à greve geral dos operários. O movimento contestou o golpe de Estado empreendido pelo militar Natusch Busch. Para uma análise de tais aspectos no filme, ver o capítulo dedicado a Sanjinés em: Maria Alzuguir Gutierrez, Um "momento crítico de tomada de consciência latino-americana", Tese de doutorado, São Paulo: USP, 2014.

${ }^{345}$ Como se sabe, o filme é permeado pelo que o próprio Sanjinés chama de "plano-sequência integral": "Fomos elaborando uma estética própria, uma linguagem, uma narrativa que futuramente culmina em La nácion clandestina, onde construímos o plano-sequência integral, que é uma maneira de narrar que interpreta o sentido do tempo circular do mundo andino. Entre os aimarás e quéchuas o tempo não é linear, como para os europeus, não responde à lógica cartesiana. Um espaço no qual o tempo gira e tudo regressa, isso é o que a câmera faz ao narrar cada sequência". Em outras palavras, num mesmo plano-sequência se acompanham cenas que se passam no passado e no presente, substituindo uma possível digressão temporal numa coexistência. Ver Jorge Sanjinés, "Un cine de combate junto al pueblo", Entrevista feita por Cristina Alvares Beskow, in Cinema Comparat/ive Cinema, v. 4, n. 9. 2016, pp. 22-30.
} 
filmografia de Ford, comumente relacionada a uma dinâmica paradoxal de glória pela derrota, da obrigatoriedade de uma renúncia a fim de transferir a potência vital do indivíduo em direção à sobrevivência de uma coletividade. Ou, ainda, de uma estrutura afetiva subsidiada quase inconscientemente sobre uma lógica crística. ${ }^{346}$ São recorrentes em As vinhas da ira as abdicações de um personagem em prol de outro. Raramente isso acontece como gesto isolado: em geral, a ação adquire um caráter expansivo, engendrando uma continuidade presente no interior de um plano, de uma sequência ou mesmo em momentos distantes do filme. O que inicia com uma ação individual se transforma em circuito de retroalimentação.

A renúncia pode ser simplória, como se vê quando um dos membros da família Joad tenta comprar um pedaço de pão num pequeno café de estrada. Sem dinheiro suficiente, a garçonete recusa a atendê-lo. Um outro funcionário, talvez o proprietário do estabelecimento, acompanha a cena e aceita oferecer o pão. Logo em seguida, a mesma situação se repete, com alguns doces que seriam comprados para as crianças da família. Dessa vez, a própria garçonete vende os quitutes por um preço abaixo do que valiam. Na sequência, dois motoristas de caminhão que tomavam café durante o desenrolar das duas ações pagam o que consumiram com um valor acima do cobrado, em resposta à caridade dos funcionários frente à família desamparada. Cada personagem recua diante de seus respectivos interesses em benefício de outro. De início o dono do café, depois a garçonete e por fím os clientes. O que começa com um gesto individual ganha um caráter centrífugo, transforma-se em encadeamento.

Episódios similares são sistemáticos em As vinhas da ira. Uma das cenas, no entanto, conduz tal lógica a uma dimensão definitiva. Trata-se do momento em que um fazendeiro, acompanhado do xerife, visita um terreno onde estão acampados desempregados, sem-terra e demais miseráveis, incluindo a família Joad. Ele tenta convocar trabalhadores para a colheita nas terras que arrendou. Feito o anúncio, um dos moradores do acampamento acusa o fazendeiro de tentar aplicar um conhecido golpe em que é feita uma oferta sem contrato e sem exatidão do salário. A operação é sempre a mesma: os proprietários de terra aguardam a chegada dos trabalhadores e, diante da quantidade sempre massiva dos que se apresentam, pois a mão de obra é farta em momentos de crise, decidem por um pagamento abaixo do ofertado inicialmente. Revelada a farsa, o fazendeiro pede ajuda ao xerife, que forja uma acusação e tenta prender o morador que desvelou o esquema. A cena que interessa inicia a partir de então. Nela, o xerife desce do carro e caminha em direção ao morador. Ao se

${ }^{346}$ Cf. Patrice Guillamaud, La gloire dans la défaite, Liège: Cefal, 2010. 
aproximar, leva um soco do personagem, cai no chão, saca a arma e atira (Fig. 253). Mata uma mulher que não participava da ação (Fig. 254), enquanto o alvo dispara em fuga. Tenta acertá-lo com um segundo tiro, mas é derrubado pelo protagonista, Tom Joad, e auxiliado por Jim Casy, um ex-padre que também mora no acampamento (Fig. 255). Quando o reforço policial chega ao acampamento para encontrar o culpado por nocautear o xerife, Jim assume a culpa sozinho (Fig. 256).

Fig. 253-254
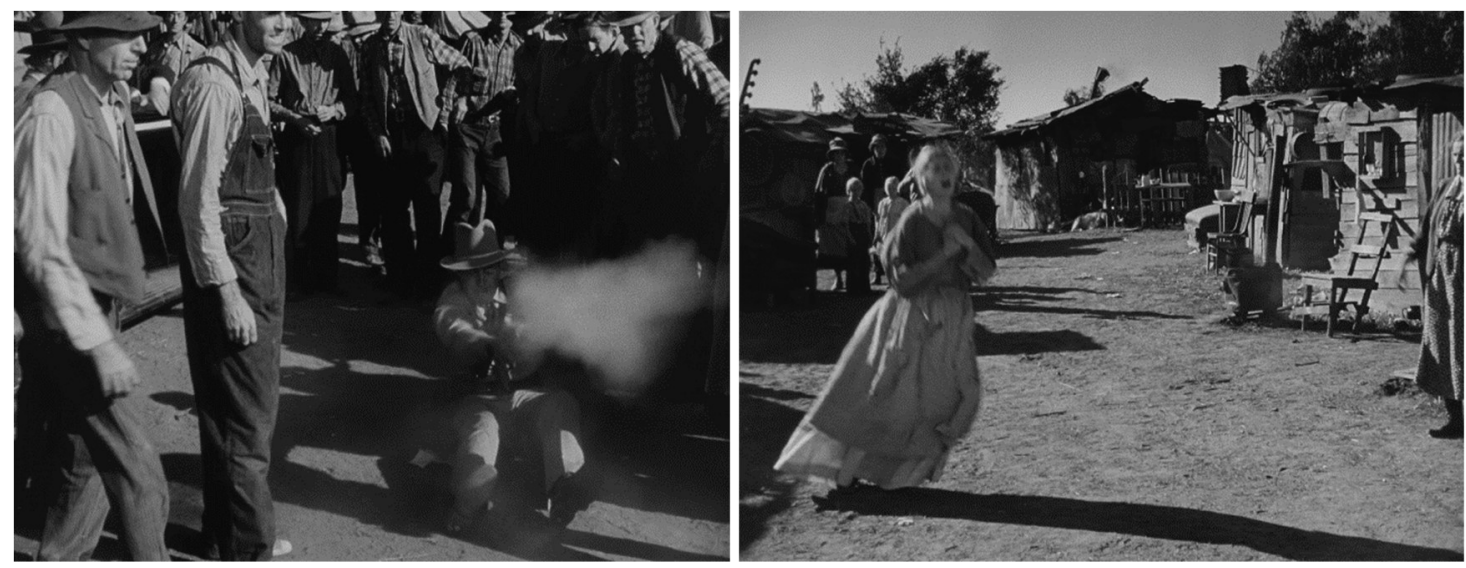

Fig. 255-256
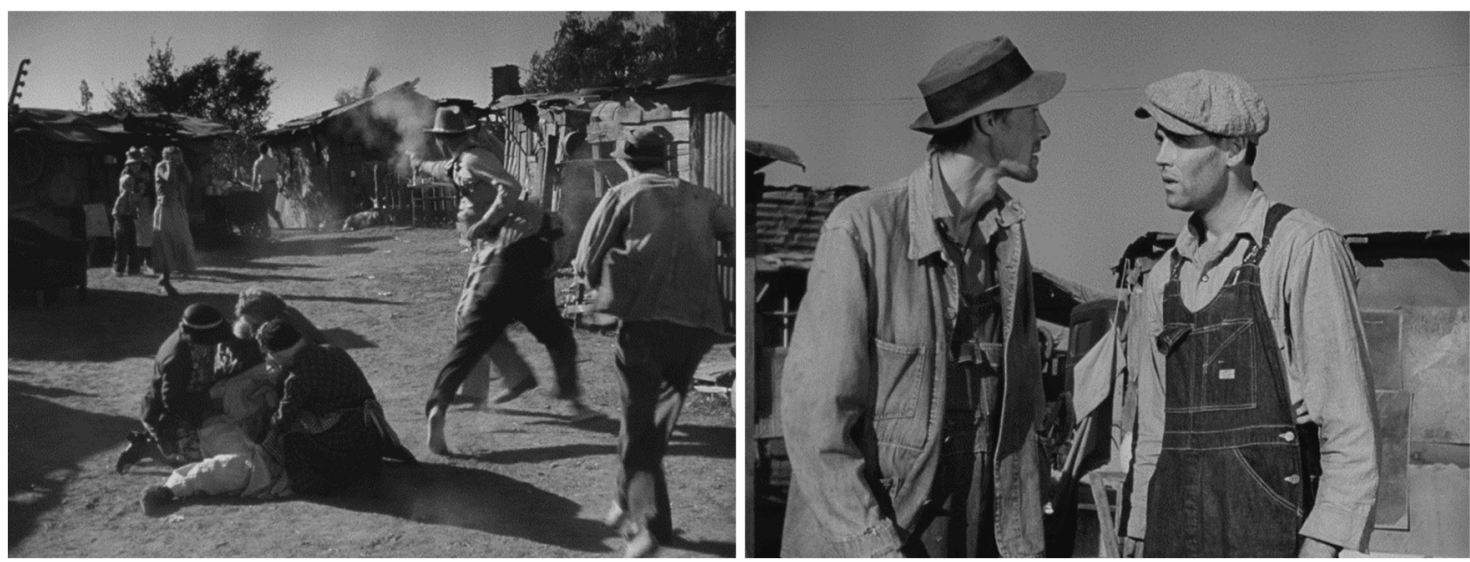

A cena explicita um gesto coletivo que se concretiza não somente por ações sequenciadas entre vários corpos, mas também por uma espécie de permuta figurativa que inicia com a mulher baleada em lugar de outro personagem. A expropriação é liminar, extrema, a do corpo e a da própria vida. Na sequência, para que o fugitivo consiga escapar, Tom Joad golpeia o policial. Para que este não seja detido, Jim assume a culpa. Tem-se então uma orquestração gestual, espontânea (pela volição dos personagens) e involuntária (pela agenciamento da mise en scène na morte da desconhecida), pautada na substituição: de início, um corpo é alvejado no lugar do outro, em seguida um personagem assume a autoria de um 
gesto que não foi o seu. A ação é realizada visando o cuidado com Outro a despeito de si mesmo. O corpo já não é meramente a unidade sensível de um indivíduo no mundo, mas o instrumento, a ferramenta de um corpo maior, o da comunidade. Para preservá-la, para resistir à força econômica e policial que ali se insinua, cria-se uma lógica sacrificial. Diante da coação, os homens são incitados a um mecanismo de defesa, que, naquelas condições de miséria, só pode se dar pela criação de um espaço e ação coletivos.

Alguma coincidência com o filme de Costa? Sabemos que o português é um entusiasta de Ford e que o universo dos dois últimos filmes das Fontainhas em muito se aproxima daquele de As vinhas da ira. A dinâmica descrita estreita seus respectivos universos a partir do interesse em construir uma esfera comum. Tanto em Ford como em No quarto da Vanda a vida é dominada pela miséria e não pela liberdade. Nessas condições, será a própria ausência, o nada, o que falta ou o que foi retirado da figura humana o eixo em torno do qual a comunidade se forma. Os personagens de Ford perderam suas terras. Os de Costa começam a ser desalojados. Para ambos, sobra como forma de poder e zona de atuação, a dimensão coletiva.

À guisa de uma sistematização, o espaço comum de As vinhas da ira e No quarto da Vanda pode ser entendido a partir de três vias. Primeiramente, em sua oposição ao universo privado/familiar. Em segundo lugar, por uma ação ou uma condição que permita a extensão de um corpo a outro. Em terceiro, pela criação de um tipo particular de comunidade fundado na expropriação.

No filme de Ford, a família constitui o âmago original do filme. A narrativa inicia com a partida do grupo para a Califórnia em busca de emprego. Por um bom tempo, o mais importante parece ser zelar pela unidade familiar. A adesão à greve dos trabalhadores, por exemplo, é a princípio recusada sob o receio de afetar a vida dos Joad: por que aderir ao movimento se ficarão sem pagamento? A resposta vem com o desenrolar do drama, pelo contínuo processo de conscientização da vulnerabilidade do indivíduo e do grupo familiar diante do poder econômico. Progressivamente, existe um abandono da esfera familiar e a aceitação de um universo comunitário - seja pelo fortalecimento que promove, seja pelo risco que implica.

$\mathrm{Na}$ trilogia das Fontainhas, comentou-se mais cedo, a fragilidade da unidade familiar logo é substituída pela efetiva fraternidade entre os vizinhos. O ápice da transferência de um âmbito a outro será mostrado em Juventude em marcha pela figura de Ventura, que assume a paternidade dos moradores e legitima uma política de solidariedade que se fazia presente nos filmes anteriores. Cria-se uma esfera comum a partir do distanciamento da existência privada, 
da transcendência da conexão exclusivamente familiar, de modo a organizar as diversidades absolutas em uma igualdade relativa. O espaço comum existe numa constante tensão em relação ao que concerne exclusivamente ao particular.

Na remissão à esfera do comum mais cedo, Arendt, alinhada a uma matriz grega, opõe a associação natural cujo centro é construído pela casa e pela família ao surgimento da cidadeestado, na qual o indivíduo possui, além de sua vida privada, uma espécie de segunda vida, o seu bios politikos. Cada cidadão passa a pertencer a duas ordens de existência. Pensados em correspondência a isso, os universo de Ford e Costa possuem uma particularidade: a separação já não é tão clara entre as vidas privada e pública, a esfera do próprio e a do comum. Seus respectivos filmes forjam uma zona que sugere a identificação entre as duas ou a sobreposição definitiva de uma sobra a outra. Resta no limite a vida pública.

O ponto fulcral, o nervo da representação do corpo na cena que abriu o capítulo, a chegada de Nhurro na casa de Vanda, é nada menos que o esboroamento das fronteiras (a porta, tão facilmente aberta pelo exterior) entre dois corpos, o Eu e o Outro, a flexibilização entre o que deveria ser privado e o que é público. O mundo particular de Vanda e o risco de encontrá-la "descomposta" ou mesmo indisposta são minorados pelo engajamento diante de quem precisa. Isso é só outra forma de designar a essencialidade de preservação do outro e do que ele representa independentemente dos embargos e das abjurações. A figura humana em si mesma, o espaço que deveria delimitar o seu território e resguardar sua subjetividade (exposta nos raros planos-retratos deste filme), é pontual, tem importância restrita.

As comunidades de As vinhas da ira e No quarto da Vanda edificam-se sobre uma contingencialidade. $\mathrm{O}$ universo partilhado não se enraíza num território, num espaço físico de durabilidade. Não se poderia aplicar aos filmes a distinção segundo a qual o espaço público é aquele criado pela presença de outros e desfeito quando a causa que os aproximou chega ao fim, enquanto o político seria assegurado por uma cidade ou outro lugar palpável capaz de sobreviver aos feitos e às ações dos homens, permanecendo de pé em direção à posterioridade e às próximas gerações. ${ }^{347}$ Como exigir dos sem-terra de Ford e dos pobres do filme de Costa

\footnotetext{
347 “O espaço público da aventura e do empreendimento desaparece assim que tudo chega a seu fim, logo que dissolvido o acampamento do exército e os 'heróis - que em Homero nada mais significam que os homens livres - retornam para suas casas. Esse espaço público só se torna político quando assegurado numa cidade, quer dizer, quando ligado a um lugar palpável que possa sobreviver tanto aos feitos memoráveis quanto aos nomes dos memoráveis autores, e possa ser transmitido à posterioridade na sequência das gerações. Essa cidade a oferecer aos homens mortais e a seus feitos e palavras passageiros um lugar duradouro constitui a polis - que é a política e, desse modo, diferente de outros povoamentos [...], porque originalmente só foi construída em tono do espaço público, em torno da praça do mercado, na qual os livres e iguais podiam encontrar-se a qualquer hora". Ver Hannah Arendt, 1993. p. 54. Numa obra anterior, a autora afirma que, no sentido estrito, a existência de um espaço tangível é relativa: "A rigor, a polis não é a cidade-estado em sua localização física; é a organização da
} 
um território duradouro, quando estão desprovidos de condições mais elementares, quando ambos os filmes abordam justamente corpos que perderam suas raízes, extirpados de suas terras e de suas casas? Uma esfera comum pautada numa rede comunitária, que no caso de Costa toma a forma de gestos e rituais do cotidiano (a droga, o sentar-se à mesa, os diálogos), seria menos política?

Não é preciso instrumentalizar ou buscar uma brecha naquela distinção para compreender que nos filmes analisados a política existe de outra maneira. A efemeridade que circunda os espaços em decorrência da miséria produz um espaço político, embora germinal e precário, existente entre os corpos, independentemente de um território ou de qualquer outra propriedade. Já se comentou mais cedo em Ford e agora estendemos o argumento a Costa: o gesto, em parceria ou em direção ao Outro, é a pedra angular. Se fortuito em sua permanência, é imprescindível em sua função. As visitas e os demais componentes do esquema vetorial de No quarto da Vanda constituem essa ação de cesura entre os corpos, engendrando uma circularidade. Facilita-se a travessia entre casas, bem como a comunicação e a dinâmica entre duas figuras. Cria-se uma existência pautada na exterioridade. A totalidade só existe a partir do Outro, a partir de uma conduta ou ética (auto) expropriativa, de caráter donativo.

$\mathrm{O}$ pertencimento à coletividade exige uma renúncia de si mesmo. Se estivermos corretos ao afirmar isso, a comunidade partilha de um paradigma anti-imunitário, na contramão de uma organização pautada na construção de limites e fronteiras, mas também de leis que conservem a vida. Uma vez que a circularidade vetorial de No quarto da Vanda reduz as barreiras que separam os indivíduos, ela também viola o resguardo, a sua proteção, deixandoos expostos. Para melhor entendê-la, somos tentados a buscar um parentesco, ligeiro e não absoluto, com o que Roberto Esposito $^{348}$ considera o projeto imunitário das sociedades modernas, em especial aquele construído nos termos hobbesianos. A passagem por sua formulação será pontualíssima. Somente um fragmento do debate nos interessa, como inspiração.

Resumindo grosseiramente, a proposta de comunidade elaborada por Hobbes depende da existência de um homem artificial, o Estado. ${ }^{349}$ Sua função primordial é preservar a

comunidade que resulta do agir e falar em conjunto, e o seu verdadeiro espaço situa-se entre as pessoas que vivem juntas com tal propósito, não importa onde estejam.” Ver Hannah Arendt, 2009. p. 211.

348 Roberto Esposito, Communitas, Paris: Essais du Collège international de philosophie, 2000; Roberto Esposito, Immunitas, Buenos Aires: Amorrortu, 2009.

${ }_{349}$ Consultamos Thomas Hobbes, "Cap. XIII - Da condição natural da Humanidade relativamente à sua Felicidade e Miséria", in Richard Tuck (org.), Leviatã, São Paulo: Martins Fontes, 2003. Para subsidiar nossa rude leitura de Hobbes e a fim de compreender a remissão que Esposito faz ao autor, buscamos apoio numa obra que Norberto Bobbio dedica ao filósofo inglês, na qual expõe de maneira clara e generosa os princípios gerais de sua obra política. Ver Norberto Bobbio, Thomas Hobbes, Rio de Janeiro: Campus, 1991. Em Hobbes, o Estado, 
integridade, conservar a vida dos membros da sociedade. Para evitar que um homem cause mal a outro, para impedir que, em seu estado de natureza, os indivíduos se entreguem às paixões e à incessante inclinação pelo poder, ${ }^{350}$ cujo perigo é o de produzir um estado permanente de guerra, ${ }^{351}$ firma-se uma instituição e uma proteção artificiais, elabora-se um contrato que os subjuga a uma autoridade. Para Esposito, a criação desse imperativo sob a forma do Estado-Leviatã "coincide com a dissociação de todo laço comunitário, com a abolição de toda relação social estrangeira à troca vertical proteção-obediência." ${ }^{" 352}$ Uma vez que a comunidade porta consigo o delito, a possibilidade de uma sobrevivência reside no "delito contra a comunidade". Recusa-se o que é produzido no seio mesmo da dimensão coletiva, erguem-se muros ante a convivência, artificializa-se a relação entre os seus membros para imunizá-los das consequências de um contágio - sinalizado pela peremptória sombra virtual que paira sobre a sociedade, a morte.

Certamente injusta em sua acentuada concisão do pensamento dos autores citados, a menção à hipótese de uma imunidade comunitária teve um único objetivo: ela ilumina um aspecto recorrente em filmes que figuram um corpo coletivo. Quer seja em La nación clandestina, quer seja em As vinhas da ira e No quarto da Vanda, a comunidade figurada é erguida justamente sobre a virtual mácula entre os seus membros, pelo eventual perigo do outro, por uma série de fraturas que residem na relação das figuras humanas, no antagonismo de qualquer política imunitária. Cria-se por vezes um ambiente que enseja a disputa ou as soluções individuais - como se vira em Dois dias, uma noite. Nessas condições, a comunidade se firma apesar de tudo o que atenta contra ela e contra a vida, o que ameaça a integridade e o ensimesmamento dos seus membros, como se fosse possível constituí-la somente por uma série de renúncias, pelo que a põe em xeque, por um viés no limite negativo.

Antes que os laços surjam ou em concomitância à existência deles, os filmes mencionados revelam os perigos intrínsecos ao viver comunitário. O protagonista de $L a$

\footnotetext{
enquanto um produto do engenho humano, artificium capaz de reparar o produto defeituoso da natureza, está em correspondência com uma das características do pensamento renascentista que marcara a filosofia de Francis Bacon, primeiro mestre de Hobbes: a transformação da relação entre natureza e arte. A segunda passa a ser concebida não apenas como imitação, mas como igual à primeira, sinalizando uma nova avaliação das coisas feitas pelo homem, de sua industriosidade. O autor explica: a natureza é então compreendida como grande máquina cujas leis e mecanismos são passíveis de serem desvendados; ao tomar conhecimento do que compõe tal "segredo", o homem é igualmente capaz de recriar e aperfeiçoar a natureza a partir de suas próprias máquinas. Uma delas é, para Hobbes, o Estado. Ver Bobbio, 1991.

${ }^{350}$ Especialmente a vanglória. Derivada da ideia de superioridade sobre o outro, e manifestação mais visível do desejo de poder, ela está na base dos conflitos sociais. Ibid.

351 Ao falar de uma "guerra permanente", Hobbes entende "não apenas o estado de conflito violento, mas também a situação na qual a calmaria é precária, sendo assegurado apenas pelo temor recíproco, como hoje se diria da 'dissuasão'; ou, em suma, como seria aquele estado no qual a paz se torna possível unicamente por causa da permanente ameaça de guerra". Ibid. p. 37.

352 Roberto Esposito, 2000, p. 29.
} 
nación clandestina aproveita a confiança que lhe é creditada para trair o povo em benefício próprio. A família Joad, de As vinhas da ira, recua diante da possibilidade de aderir à greve sob o receio de seus efeitos negativos. Quando Tom afirma que o pai e a família jamais aceitarão perder os salários e passar fome por desconhecidos, que a greve não os interessa, o amigo Jim é taxativo: terão de sofrer para aprender. Dito de outro modo, precisarão suportar uma condição ainda pior para perceber que o equilíbrio privado é ilusório em sua brevidade e ingênuo em sua soberania - a estabilidade vivenciada pela família Joad só é possível porque os proprietários de terra querem agradar os trabalhadores que furaram a greve. Apesar das épocas, do processo histórico e das figurações dessemelhantes, existe um eixo comum com o de outros filmes nos quais a figura humana é enquadrada sob a tensão indivíduo-sociedade, como o já comentado Dois dias, uma noite. ${ }^{353}$ Continuemos.

Em Costa, a famigerada fraternidade corre em via paralela a uma série de desamparos e vulnerabilidades entre os moradores das Fontainhas. O momento sensível de Vanda e Nhurro (Fig. 187) termina quando ela, cansada e em discordância com o amigo desolado, sai do quarto e o deixa lamentando sozinho. Antes, na vendinha da família, envolta por frutas, Zita nega a Nhurro um pedaço de pão. Diz não ter sobrado nada, tampouco lhe oferece algo. Com a mesma falta de solidariedade, Nhurro recusa dar abrigo a um morador do bairro que entra na sua casa pedindo um lugar para dormir. São episódios excepcionais, mas que descortinam a tensão que existe entre o Eu e o Outro. Emblema maior desse risco, claro, é o ritual de heroína. Uma figura aplica a droga em outra. A violência é explícita, não obstante consentida.

A flexibilização das fronteiras, o desenrolar das relações e a efetivação da comunidade se dá entre dois polos, fratura e união, temor e certeza, risco e resguardo. Resultante de um processo de consciência nos filmes citados de Sanjinés, Ford e Dardenne, a situação é diferente em Costa. A ambivalência comunitária se configura como uma resposta direta e quase intuitiva em sua genuína organicidade. Não se põem questões, não se reflete, vive-se a comunidade. Prevalece talvez inconscientemente a mesma lei épica que se mencionou a respeito de Punishment park: o destino de um é o destino de todos. Suporta-se o que de perverso pode existir socialmente e ao mesmo tempo se sorve a fraternidade ao lado do Outro. Sujeitar-se a um risco e aceitar um dever: dupla doação. O que no paradigma imunitário é evitado, nos filmes mencionados é condição.

Sacrifício, é verdade, talvez seja uma palavra carregada demais para descrever uma parte dessas operações de No Quarto da Vanda. Em todo caso, âmago da comunidade, a

\footnotetext{
${ }^{353}$ No contexto brasileiro, poderíamos lembrar de Eles não usam black-tie (1981, de Leon Hirszman).
} 
renúncia jamais é pueril, mesmo quando pequena, mesmo quando se trata da recepção de um amigo desabrigado. Se a expropriação acontece volitivamente pela doação, deve-se recordar que ela também preexiste à figura humana, pela paupérrima condição material. Em seu desterro histórico e transcendental, relegado a uma série de negações, sob a perda iminente do território físico, o corpo débil é representado por um único aspecto afirmativo, irredutível e imanente, sua natureza coletiva. A experiência de alteridade e doação, nesse estado, é radical em sua mera existência.

Não é de todo estranho, supomos, ter iniciado o percurso deste último capítulo a partir do retrato, tanto no nível do plano como no de uma disposição retratística que impregna No quarto da Vanda. Desde suas raízes pictóricas, o gênero é impregnado pela tensão entre ausência e presença, o que foi no mundo real e o que ainda é na imagem. Nos filmes abordados aqui, notadamente nos de Costa, essa dimensão foi o que primeiramente sinalizou a frágil condição da figura humana. Sem a hipertrofia visual do cinema de Grandrieux e igualmente distante da pujança envolvendo a existência orgânica, física e carnal, como nos filmes de Ming-liang, Denis e Rodrigues, era necessário encontrar outro método de análise. Os diferentes níveis da retratística em Costa permitiram pensar a expressividade do corpo mesmo quando sua ação se tornou pontualíssima, quase inexistente em sua discrição e morbidez. Foi preciso passar por este enquadramento sobre o indivíduo, pelo que confere um rosto à sua experiência e explicita sua difícil condição social, para então entender o que mais estava envolvido em sua representação.

A figura capital em No quarto da Vanda - nos filmes das Fontainhas de maneira geral já não é a do corpo individual, mas a do coletivo. A constituição de uma comunidade se sobrepõe num universo de espoliação da figura humana. Pobre, magro, apático e com uma gestualidade reduzida ao mínimo, o corpo está na imagem, mas também não está, ou pelo menos não se sabe até quando. A morte vigia de perto, disfarçada sob a penumbra que envolve a imagem. A forma vetorial que estabelece uma coletividade figurativa a isso se contrapõe. Ela afirma a presença. Devolve a materialidade ameaçada a partir de uma associação entre dois ou mais corpos que só se efetiva num arco mais amplo, no nível macroestrutural, o da forma fílmica. Efetiva-se um processo de recomposição, de engate de diferentes blocos a fim de descobrir a anatomia de uma figura coletiva, numa reconstrução metonímica. A figura da comunidade se articula pela série de caminhos que o filme cria para ligar e expor um corpo a outro, estabelecer um contágio, dos vetores a uma arquitetura pautada em vazamentos e infiltrações, da rede de solidariedade à parcial deposição do Eu pelo Outro. O corpo depende do que o ultrapassa. 


\section{Considerações finais}

Os vazios do homem, ainda que sintam a uma plenitude (gora mas presença), contêm nadas, contêm apenas vazios [...].

João Cabral de Melo, Os vazios do homem

Aquele que imagina uma árvore é forçado a imaginar um céu ou um fundo para vê-la sustentada.

Paul Valéry, Introdução ao método de Leonardo da Vinci

A figura humana cinematográfica é concebida sob uma série de perdas. A principal delas a acompanha desde os primeiros filmes dos Lumière, tal qual um elemento constituinte: independentemente da sua semelhança, o corpo representado é apenas a imagem de um ser filmado pela câmera em outro espaço, outro tempo. Sua carnalidade foi reduzida a uma forma bidimensional. Do mundo dos vivos para o da representação, a sentença é permanecer no eterno hiato entre ausência e presença. A evolução da linguagem e a da técnica não solucionaram essa duplicidade que corre o risco da aporia. Talvez faça parte do destino do cinema - como das demais artes visuais - portá-la consigo.

Intrigante que seja, a natureza ambivalente da imagem cinematográfica nunca impediu a crença na existência real do que é representado e tampouco a certeza de sua ausência. Vimos ao longo da tese que a definição destes dois polos é mais relativa do que aparenta ser. No mundo figurado como no mundo real, a presença tem suas leis próprias e nem de longe aceita o reducionismo que o senso comum lhe reserva quando a entende exclusivamente pelo que possui existência física em determinado tempo e espaço. Fosse esse o único viés, a representação do corpo no cinema somente poderia ser pensada sob o lamento de uma ausência, a do corpo real. A figura humana estaria condenada à existência enquanto duplo, assombrada por uma longeva carga epistemológica que lhe restringe a uma cópia. O cinema ocuparia a posição de arte mórbida, relicário dos ausentes. A oposição evidente seria com o teatro, a performance e a dança, que desfrutam da plena presença física do corpo. Felizmente, os filmes nos levam em outra direção.

O itinerário realizado até aqui reivindicou o que a fantasmagoria das imagens recusa: as formas de presença da figura humana cinematográfica. Entenda-se por isso tanto os modos de representá-la, conformando-a visualmente a partir de diferentes lógicas (figurativas, 
performáticas e sociais), como também de conferir-lhe uma espécie de pregnância, um acento que a destacasse e a tornasse evidente em comparação com os demais elementos visuais. Pela variedade de representações, a noção de presença assumiu um amplo diâmetro, passando a incorporar não apenas o corpo visível no universo da imagem, mas também a sua evocação mesmo quando ausente ou sem contornos claros. Nesse sentido, a análise do cinema de Grandrieux, como de outros realizadores experimentais, mostrou a figura humana (e a própria imagem) transformada em constructo visual, assumindo uma forma inacabada, metamórfica, em constante composição e decomposição. Sob pretexto de exprimir sensações cuja intensidade e natureza não possuem referente no mundo real, rompe-se o regime naturalista. $\mathrm{O}$ corpo passa a ser evocado pelas deformações de sua figura. A imagem cinematográfica se torna o medium a exprimir a experiência subjetiva e física atrelada à dor e ao êxtase. No lugar da visibilidade, tem-se a presença forjada pelos artifícios plásticos do cinema, especialmente pela matéria escura da imagem. As invectivas sobre os elementos visíveis produzem uma hipóstase, simbolizam ou dão concreção, quer seja a um universo interior, quer seja a uma ordem afetiva e sensorial.

No polo oposto, apesar de um interesse comum pela sensação, discutimos um cinema que se aproveita da indexicalidade da imagem cinematográfica para, a partir dela, tentar criar uma espécie de espessura do corpo, dotá-lo de uma carnalidade. A figuração exacerba o que remete à natureza física, dos gestos aos embates objetais com o mundo, da pele ao erotismo. Alinhando esses elementos e orientando o corpo, uma força intempestiva, o desejo sexual. Os filmes de Ming-liang, Rodrigues e Denis apresentam uma presença que joga com um corpo fenomenal, intimamente associado ao mundo e aos seres que o circundam. Sua existência se faz pelo toque e por todo tipo de atrito que envolve a superfície do corpo. A despeito da bidimensionalidade da imagem, tenta-se recuperar a densidade do mundo pela profundidade do espaço, pelo tempo dilatado e sobretudo pela figuração de um corpo a partir de tudo o que recorda sua existência física e orgânica. Nesse universo, a economia libidinal que envolve a figura humana dispara uma desordem que contamina os corpos e também os seres inanimados. Cria-se uma correspondência entre o humano e o inumano. A presença diz respeito a tudo o que é físico, claro, mas especialmente ao que é suscetível ao desejo.

Por fim, ao tomar como guia filmes de Costa deparamos com uma figuração pautada pela descrição das aparências visíveis, com ênfase no estado social e econômico do corpo. O universo material vivenciado é determinante para a representação. Em razão da inflexão documental, a relação entre realizador e corpo filmado ganha importância. A figuração passa a ser feita a partir de um jogo de flexibilização dos agenciamentos e imperativos da encenação 
a fim de respeitar a opacidade de quem está diante da câmera. Para isso, recorrem-se aos planos-retratos e à disposição retratística. São procedimentos que tentam resgatar o lastro da experiência real ao mesmo tempo em que aceitam a dificuldade de sondar e decodificar a interioridade do corpo. Um dos pontos desvelados por esse olhar descritivo foi a figura humana estiolada pela pobreza e pelas condições históricas, resultando em uma gestualidade mínima e, quando existente, às vezes letal para si mesma. Nesse quadro, o que permite ao corpo se afirmar é a inclusão numa coletividade. A presença depende do esboroamento das fronteiras entre dois corpos, da projeção do Eu em direção ao Outro. A comunidade é criada a partir da partilha da experiência, mas também dos riscos implicados na convivência, portanto no que fortalece e no que ameaça o corpo.

Os modos de presença analisados são dispostos em três linhas, referentes: à matéria da imagem cinematográfica, à natureza física e sexual do corpo, e à participação deste último dentro de uma organização coletiva. Embora não tenha sido um programa prévio, pensando-as retrospectivamente vê-se uma parcial correspondência com três tipos de materialismos. O primeiro se alinha ao de autores de diferentes vanguardas cinematográficas, e é referente à exploração dos elementos constitutivos do cinema (em nosso caso, da plasticidade da imagem). O segundo tende a pensar o materialismo do corpo segundo o que tem existência concreta e tangível no mundo. O terceiro mantém um diálogo mesmo que distante com o materialismo histórico, no que este último pensa o imperativo das condições sociais sobre o indivíduo. Como dito, esses possíveis paralelos são casuais. Eles só se sustentam numa abordagem superficial e de certo modo arbitrária. Não é essa a conclusão a que chegamos.

Um termo recorrente desde o primeiro capítulo evidencia mais do que qualquer esquematismo preexistente os contornos finais que a tese adquiriu: circularidade. A análise da representação do corpo ramificou-se em muitas direções, mas acabou por retornar amiúde à exigência de uma espécie de troca, comunicação ou mesmo contaminação do que é figurado. Ausente, inacabado pela série de deformidades de sua aparência ou plenamente visível, o corpo somente se efetiva quando abandona o território individual. Lembremos do rosto na antiguidade clássica, o prosopon, cuja existência pressupunha um observador. A figura humana nos filmes analisados também se mantém na constante dependência de uma reversibilidade. O corpo representado forja a sua presença pela negociação com o Outro, manifesto pelas propriedades da imagem, pela fisicalidade de seres animados ou inanimados, e pela comunidade. O cinema contemporâneo é quase obsessivo em sua predileção por criar pequenas jornadas em que corpos se projetam em direção a outros, e, nesse percurso, 
evidenciam suas necessidades, suplícios, gozos e venturas. Nesse quadro, o fracasso, a busca ou a consolidação da alteridade define a presença.

A travessia imaginária, criada pelo êxtase e pela plasticidade da imagem, entre homens e mulheres que se violentam num horizonte de eternas clivagens. O desejo como força motriz a alinhavar seres vivos e inanimados numa teia libidinal de prazeres que, consumados ou não, em nada arrefecem a angústia dos corpos. A fraternidade que finalmente estabelece uma horizontalidade possível, uma alteridade alcançada. Embora a linearidade da tese desenhe um progresso que inicia com a clivagem entre os seres e termina pela articulação deles em comunidade, um momento não vale mais do que o outro. Cada um dos filmes conduziu a uma potência ao mesmo tempo em que revelou uma fraqueza. $\mathrm{O}$ corpo - e agora assumindo o risco da generalização -, o humano, surgiu sob uma série de imperfeições. Ver nessa condição somente uma precariedade é rejeitar o que ela tem de propositiva: falível que seja, ou graças a isso, o corpo jamais se alienou. Fechar-se em si mesmo foi um gesto rejeitado antes mesmo de ser anunciado. A materialidade aconteceu sob os arcanos do Outro. A presença somente existiu como exterioridade. 


\section{Referências bibliográficas}

AGAMBEN, Giorgio. "Notas sobre o gesto". In: Artefilosofia, Ouro Preto, n.4, p. 9-14, janeiro 2018.

ALBERTI, Leon Battista. Da pintura. $2^{\text {a }}$ Edição. Tradução: Antonio da Silveira Mendonça. Campinas: Unicamp, 1999.

ALPERS, Svetlana. L'art de dépeindre: la peinture hollandaise au XVII siècle. Paris: Gallimard, 1990.

ANDERSEN, Thom. "Histórias de Fantasmas". In: CABO, Ricardo Matos (org.). Cem mil cigarros - Os filmes de Pedro Costa. Lisboa: Orfeu Negro, 2009. pp. 53-64.

ANDRIOPOULOS, Stefan. Aparições espectrais: O idealismo alemão, o romance gótico e a mídia óptica. Tradução de Vera Ribeiro. Rio de Janeiro: Contraponto, 2014.

ARASSE, Daniel; BOURG, Lionel; DAVILA, Thierry; FALGUIÈRES, Patricia; FRÉCHURET, Maurice [et. al.]. Les figures de la marche: Un siècle d'arpenteurs. Paris: Réunion des musées nationaux, 2000.

. "A carne, a graça, o sublime". In: CORBIN, Alain; COURTINE, Jean-Jacques; VIGARELLO, Georges. História do corpo: 1. Da Renascença às Luzes. Petrópolis: Editora Vozes, 2008, pp. 535-620.

ARAÚJO SILVA, Mateus. Pedro Costa e sua poética da pobreza. In: MAIA, Carla; DUAERTE, Daniel Ribeiro; MOURÃO, Patrícia. O cinema de Pedro Costa. SP: CCBB, 2010, pp. 111-134.

ARDENNE, Paul. L'image corps: figures de l'humain dans l'art du $\mathrm{XX}^{\circ}$ siècle. Paris: Éditions du regard, 2010.

ARENDT, Hannah. A condição humana. 10ª ed. Rio de Janeiro: Forense Universitária, 2009. . O que é política? Rio de Janeiro: Bertrand Brasil, 1993.

ARISTÓTELES. Poética. Trad. Paulo Pinheiro. São Paulo: Editora 34, 2017.

AUBRAL, François. "Variations figurales". In: AUBRAL, François; CHATEAU, Dominique (org.). Figure, figural. L'Harmattan: Paris, 1999, pp. 197-244.

AUERBACH, Erich. Figuras. São Paulo: Editora Ática, 1997.

AUERBACH, Jonathan. Body shots: Early cinema's incarnations. Berkeley: University of California Press, 2007

AUMONT, Jacques. A imagem. Tradução: Estela dos Santos Abreu e Cláudio C. Santoro. Campinas, SP: Papirus, 1993. 
. A quoi pensent les films? Paris: Nouvelles Éditions Séguier, 1996

. “Cinégénie, ou la machine à re-monter le temps.” In: . 1998a, pp .87-108.

. De l'esthétique au présent. Bruxelas: De Boeck, 1998b.

. Le montreur d'ombre: essai sur le cinéma. Paris: J.VRIN, 2012.

. L'oeil interminable: cinéma et peinture. Toulouse: Séguier, 1989.

. O cinema e a encenação. Lisboa: Texto e grafia, 2011.

BALÁZS, Béla. El hombre visible, o la cultura del cine. Buenos Aires: El cuenco de plata, 2014.

. "The spirit of film". In: CARTER, Erica (ed.). Early film theory. Nova York: Berghahn Books, 2010.

BANU, Georges. Nocturnes: peindre la nuit, jouer dans le noir. Cahors: Biro, 2005.

BARTHES, Roland. O óbvio e o obtuso: ensaios sobre fotografia, cinema, pintura, teatro e música. Rio de Janeiro: Editora Nova Fronteira, 1990.

. “L'effet de réel”. In: Communications, 11, 1968, pp. 84-89.

BATAILLE, Georges. Documents. Éditions Gallimard : Paris, 1968.

. "L’Érotisme". In: . Euvres complètes - X. Paris: Gallimard, 1987.

BAUDELAIRE, Charles. Escritos sobre a arte. Organização e tradução de Plínio Augusto Coêlho. São Paulo: Hedra, 2011.

. La Fanfarlo. Paris: Boucher, 2002.

BAZIN, André. O que é o cinema? São Paulo: Cosac Naify, 2014.

BELTING, Hans. Miroir du monde: L'invention du tableau dans les pays-bas. Paris: Hanz, 2014.

. Pour une anthropologie des images. Paris: Gallimard, 2004.

BENJAMIN, Walter. Magia e técnica, arte e politica. Tradução de Sergio Paulo Rouanet. São Paulo: Brasiliense, 1994.

BERGSON, Henri. O riso: ensaio sobre a significação do cômico. $2^{\text {a }}$ edição. Rio de Janeiro: Zahar Editores, 1983.

BERNARDET, Jean-Claude. Cineastas e imagens do povo. São Paulo: Companhia das Letras, 2003. 
BOBBIO, Norberto. "Os deuses que fracassaram (Algumas questões sobre o problema do mal)". In: UNESP, 2011. . Elogio da serenidade e outros escritos morais. $2^{\mathrm{a}}$ ed. São Paulo: Editora Thomas Hobbes. Rio de Janeiro: Campus, 1991.

BOIS, Yve-Alain ; KRAUSS, Rosalind. L'informe: mode d'emploi. Paris: Centre Georges Pompidou, 1996.

BORDWELL, David. Figuras traçadas na luz. Campinas: Papirus, 2008. . Ozu and the poetics of cinema. Nova Jersey: Princeton University Press, 1988.

BORGES, Cristian. "Mais perto do coração selvagem (do cinema)". In: GONÇALVES, Osmar (org.). Narrativas sensoriais. Rio de Janeiro: Editora Circuito, 2014, pp. 41-60.

BOUQUET, Stéphane, "Les flux sans visage”, Cahiers du Cinéma, n.569, 2002a. . "Plan contre flux". Cahiers du Cinéma, n. 566, março, $2002 \mathrm{~b}$.

BRAKHAGE, Stan. "Metáforas da visão". In: XAVIER, Ismail (org.). A experiência do cinema: antologia. Rio de Janeiro: Edições Graal: Embrafilme, 1983.

BRENEZ, Nicole, De la figure en général et du corps en particulier: l'invention figurative au cinéma. Bruxelas : De Boeck Université, 1998.

BURCH, Noel. La lucarne de l'infini: Naissance du langage cinématographique. Paris: Nathan, 1991.

BURCKHARDT, Jacob. "As origens da retratística moderna". In: FERNANDES, Cássio (org.). Jacob Burckhardt: O retrato na pintura italiana do Renascimento. Campinas, SP: Editora da Unicamp; São Paulo: Fap-Unifesp, 2012, pp. 187-200.

. "O retrato na pintura italiana do Renascimento". In: FERNANDES, Cássio (org.). Jacob Burckhardt: O retrato na pintura italiana do Renascimento. Campinas, SP: Editora da Unicamp; São Paulo: Fap-Unifesp, 2012, pp. 51-182.

BURKE, Peter. O renascimento. $2^{\text {a }}$ edição. Lisboa: Edições texto e grafia, 2014.

BUTLER, Judith. Ces corps qui comptent: de la matérialité et des limites discursives du "sexe". Paris: Amsterdam, 2009.

CALDAS, Paulo. "Poéticas do Movimento: Interfaces." In: BONITO, Eduardo; LEVY Regina (Orgs). A dança na tela. Dança em Foco, Volume 4. Rio de Janeiro: Contra Capa Livraria/Oi Futuro, 2009.

CANDIDO, Antonio; ROSENFELD, Anatol; PRADO, Decio de Almeida; GOMES, Paulo Emilio Salles. A personagem de ficção. $6^{\mathrm{a}}$ edição. São Paulo: Editora Perspectiva, 1981. 
CANUDO, Ricciotto. In: MOREL, Jean-Paul (org.). L'usine aux images: Ricciotto Canudo, L'homme qui inventa le Septième Art. Paris: Arte Éditions, 1995.

CAPPELLETTI, Francesca; LEMOINE, Annick. Les Bas-fonds du Baroque: La Rome du vice et de la misère. Paris-Roma: Officina Libraria Editions, 2014.

CARONE, Modesto. "Um roteiro do conceito de figura". In: AUERBACH, Erich. Figuras. São Paulo: Editora Ática, 1997.

CASTRO, Eduardo Viveiros. "Perspectivismo e multinaturalismo na América indígena". In: O que nos faz pensar, n. 18, setembro de 2004.

CENNINI, Cennino. "O livro da arte". In: LICHTENSTEIN, Jacqueline. A pintura - Vol.6: A figura humana. São Paulo: Editora 34, 2004, p. 21-24.

CERTEAU, Michel; GIARD, Luce; MAYOL, Pierre. A invenção do cotidiano: 2. Morar, cozinhar. Petrópolis, RJ: Vozes, 1996.

CHARBONNAT, Pascal. Histoire des philosophies matérialistes. Paris: Éditions Kimé, 2013.

CHARNEY, Leo. "Num instante: o cinema e a filosofia da modernidade". In:

SCHWARTZ, Vanessa. O cinema e a invenção da vida moderna. São Paulo: Cosac Naify, 2004, pp. 317-336.

CHION, Michel. "L'homme qui marche”. In: AUMONT, Jacques (org.). L'invention de la figure humaine: le cinéma, l'humain et l'inhumain. Paris: Cinémathèque française, 1995, pp. 36-51.

CLAIR, Jean. "Freud, biologiste". In: DEBRAY, Cécile. Lucian Freud: l'atelier. Paris: Centre Pompidou, 2010.

CLARK, T.J. "Fenomenalidade e materialidade em Cézanne”. In: SALZSTEIN, Sônia (org.). Modernismos. São Paulo: Cosac Naify, 2007a.

. Une image du peuple: Gustave Courbet et la révolution de 1848.Villeurbanne: Les $\overline{\text { presses }}$ du réel, $2007 \mathrm{~b}$.

COHEN, Renato. Performance como linguagem. São Paulo: Perspectiva, 2007.

COLI, Jorge. O corpo da liberdade. São Paulo: Cosac Naify, 2010.

COMOLLI, Jean-Louis. "Sob o risco do real". In: GUIMARÃES, César (org.). Ver e poder. A inocência perdida: cinema, televisão, ficção, documentário. Belo Horizonte: Editora UFMG, 2008, pp. 169-178.

COSTA, Flávia Cesarino. O primeiro cinema. São Paulo: Scritta, 1995.

COURTINE, Jean-Jacques. Decifrar o corpo: Pensar com Foucault. Tradução de Francisco Morás. Petrópolis: Vozes, 2013. 
CRARY, Jonathan. "A visão que se desprende: Manet e o observador atento no fim do século XIX". In: CHARNEY, Leo; SCHWARTZ, Vanessa (org.). O cinema e a invenção da vida moderna. São Paulo: Cosac Naify, 2004, pp. 67-94.

Técnicas do observador. Visão e modernidade no século XIX. Tradução de Verrah Chamma. Organização de Tadeu Capistrano. Rio de Janeiro: Contraponto, 2012.

DA VINCI, Leonardo. In: PÉLADAN, Joséphin (org.). Les Manuscrits de Léonard de Vinci: les 14 manuscrits de l'Institut de France. Paris: E.Sansot, 1910.

DASTON, Lorraine. "Objectivity and the Escape from Perspective". In: Social Studies of Science - An International Review of Research in the Social Dimensions of Science and Technology. Vol 22, N. 4, Novembro, 1992.

DELEUZE, Gilles. Espinosa: filosofia prática. São Paulo: Escuta, 2002.

. Francis Bacon: Lógica da sensação. Rio de Janeiro: Jorge Zahar, 2007.

DENIS, Claire. "Ce poids d'ici-bas": entrevista concedida a Jean-Philippe Renouard e Lise Wajeman. In: Vacarme 14, 2 de janeiro, 2001.

DENIS, Claire. "Corps d'armée": entrevista a Anne-Laure Chanel. In: France culture, 8 de março, 2013. Programa de rádio.

DESCOLA, Philippe. Par-delà nature et culture. Paris: Gallimard, 2005.

DIDEROT, Denis. Lettre sur les aveugles - à l'usage de ceux qui voient. Paris: Gallimard, 2015.

DIDI-HUBERMAN, Georges. Diante da imagem. São Paulo: Editora 34, 2013.

DOUCHET, Jean. "Le visage comme révélation, le geste comme signe, le corps découpé comme figure, le corps plein comme opacité". In: AUMONT, Jacques (org.). L'invention de la figure humaine: le cinéma, l'humain et l'inhumain. Paris: Cinémathèque française. 1995a, pp. 113-121.

.'L'ombre portée de la réalité". In: AUMONT, Jacques (org.). L'invention de la figure humaine: le cinéma, l'humain et l'inhumain. Paris: Cinémathèque française, 1995b, pp. 247258

DREUX, Emmanuel. Le cinéma burlesque ou la subversion par le geste. Paris: L'Harmattan, 2007.

DUBOIS, Philippe. O ato fotográfico e outros ensaios. Campinas, SP: Papirus, 2008.

. "La question des Figures à travers les champs du savoir: Le savoir de la lexicologie: note sur Figura d'Erich Auerbach". In: AUBRAL, François; CHATEAU, Dominique (org.). Figure, figural. L'Harmattan: Paris, 1999, pp. 11-24. 
. "La tempête et la matière-temps, ou le sublime et le figural dans l'œuvre de Jean Epstein". In: AUMONT, Jacques (org.). Jean Epstein: cinéaste, poète, philosophe. Paris: Éditions de la Cinémathèque Française, 1998, pp. 267-324.

D'ALLONES, Fabrice Revault. "L'homme burlesque du cinéma (de Chaplin à Keaton et Langdon)". In: AUMONT, Jacques (org.). L'invention de la figure humaine: le cinéma, l'humain et l'inhumain. 1995, p. 53-73.

ELCOTT, Noam M. Artificial darkness: An obscure history of modern art and media. Chicago: The University of Chicago Press, 2016.

EPSTEIN, Jean. Écrits sur le cinéma 1: 1921-1947. Paris: Seghers, 1974.

. Écrits sur le cinéma 2: 1946-1953. Paris: Seghers, 1975.

. La essencia del cine. Tradução de Elena Lerner. Buenos Aires: Galatea Nueva

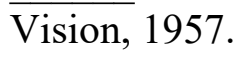

ESPOSITO, Roberto. Communitas: origine et destin de la communauté. Paris: Essais du Collège international de philosophie, 2000.

. Immunitas: Protección y negación de la vida. Buenos Aires: Amorrortu, 2009.

FABRIS, Annateresa. “A captação do movimento: do instantâneo ao fotodinamismo". In: Ars, v.2, n.4, São Paulo, 2004, p. 50-77.

FAURE, Élie. A arte moderna. São Paulo: Livraria Martins Fontes Editora, 1991. . A arte renascentista. São Paulo: Livraria Martins Fontes Editora, 1990. . Função do cinema e das outras artes. Lisboa: Texto \& Grafia, 2010.

FÉRAL, Josette. Além dos limites: teoria e prática do teatro. Tradução: J. Guinsburg [et.al]. São Paulo: Perspectiva, 2015.

FERNANDES, Cássio. "Apresentação: O lugar de $O$ retrato na pintura italiana do Renascimento na obra de Jacob Burckhardt". In: Jacob Burckhardt: O retrato na pintura italiana do Renascimento. Campinas, SP: Editora da Unicamp; São Paulo: FapUnifesp, 2012, pp. 21-50.

FOSTER, Hal. O retorno do real: A vanguarda no final do século XX. São Paulo: Cosac Naify, 2014.

FOUCAULT, Michel. Histoire de la sexualité II: l'usage des plaisirs. Paris: Gallimard, 2013.

FRANCASTEL, Pierre. A realidade figurativa. São Paulo: Perspectiva, 1993. . Pintura e sociedade. São Paulo: Martins Fontes, 1990. 
FRÉCHURET, Maurice. "Le pied arpenteur". In : ARASSE, Daniel; BOURG, Lionel; DAVILA, Thierry; FALGUIÈRES, Patricia; [et. al.]. Les figures de la marche: Un siècle d'arpenteurs. Paris: Réunion des musées nationaux, 2000a, pp. 157-224.

. "Un siècle d'arpenteurs, les figures de la marche". In: ARASSE, Daniel; BOURG, Lionel; DAVILA, Thierry; FALGUIÈRES, Patricia; [et. al.]. Les figures de la marche: Un siècle d'arpenteurs. Paris: Réunion des musées nationaux, 2000b, pp. 9-34.

FREUD, Sigmund. A interpretação dos sonhos. Rio de Janeiro: Imago Ed., 2001.

FRIEDLAENDER, Walter. De David a Delacroix. São Paulo: Cosac \& Naify, 2001.

FROMENTIN, Eugène. Les maîtres d'autrefois, Belgique-Hollande. $8^{\mathrm{a}}$ edição. Paris: Librairie Plon, 1896.

FRONTISI-DUCROUX, Françoise. Du masque au visage. Aspects de l'identité en Grèce ancienne. Paris: Flammarion, 2012.

GALARD, Jean. A beleza do gesto: Uma estética das condutas. São Paulo: Editora da Universidade de São Paulo, 2008.

GAME, Jérôme (org.). Images des corps/corps des images au cinéma. Lyon: Ens Éditions, 2010 .

GARB, Tamar. Bodies of modernity. Londres: Thames and Hudson, 1998.

. The body in time: figures of femininity in late 19th century France. Seattle: University of Washington Press, 2008.

. "Visuality and sexuality in Cézanne's Late Bathers", The Oxford Art Journal, Vol. 19, No. 2, 1996, pp. 46-60.

GARIN, Manuel. El gag visual: de Buster Keaton a Super Mario. Madrid: Cátedra, 2014.

GLAZER, Jonathan. "Under the skin: Scarlett est envoûtante, comme son personnage". Entrevista a Frédéric Strauss, Télérama, 23/06/2014. Disponível em: http://www.telerama.fr/cinema/jonathan-glazer-under-the-skin-scarlett-est-envoutantecommeson-personnage, 114007.php. Acesso em: 02/08/2017.

GLUSBERG, Jorge. A arte da performance. Tradução de Renato Cohen. São Paulo: Perspectiva, 2013.

GODARD, Hubert. "Gesto e percepção”. In: PEREIRA, R.; SOTER, S. (org.). Lições de dança. Rio de Janeiro: UniverCidade, v. 3, 1999.

GORKI, Máximo. "No país dos espectros". In: PRIEUR, Jérôme. O espectador noturno. Os escritores e o cinema. Tradução de Roberto Paulino e Fernanda Borges. Rio de Janeiro: Nova Fronteira, 1995, pp. 28-31. 
GREENBERG, Clement. Arte e cultura: ensaios críticos. São Paulo: Cosacnaify, 2013.

- "Rumo a um mais novo Laocoonte". In: FERREIRA, Glória. \& COTRIM, Cecília (orgs.). Clement Greenberg e o debate crítico. Rio de Janeiro: Jorge Zahar, 2001.

GUILLAMAUD, Patrice. La gloire dans la défaite: essai sur le sacrifice et la renonciation dans l'oeuvre de John Ford. Liège: Éditions du Cefal, 2010.

GUMBRECH, Hans Ulrich. Produção de presença: o que o sentido não consegue transmitir. Tradução de Ana Isabel Soares. Rio de Janeiro: Contraponto: Ed. PUC-Rio, 2010.

GUNNING, Tom. "Body, light, eletricity and the origins of cinema". In: ALLEN, Richard; TURVEY, Malcolm (org.). Camera obscura, camera lucide: Essays in honor of Annette Michelson. Amsterdã: Amsterdam University Press, 2003, p. 75-90.

. "The cinema of attractions: early film, its spectator and the avant-garde". In: ELSAESSER, Thomas (org.). Early cinema: space, frame, narrative. Londres: BIF, 1990, pp. 56-62.

GUTIERREZ, Maria Alzuguir. Um "momento crítico de tomada de consciência latinoamericana": o cinema moderno da América Latina e as letras. Tese de doutorado. São Paulo: USP, 2014.

HOBBES, Thomas. "Cap. XIII - Da condição natural da Humanidade relativamente à sua Felicidade e Miséria”. In: TUCK, Richard (org.). Leviatã. São Paulo: Martins Fontes, 2003.

HUBERT, Marie-Claude. As grandes teorias do teatro. Tradução de Eduardo Brandão. São Paulo: Editora WMF Martins Fontes, 2013.

HUCHET, Stéphane. "Do ver ao mostrar". In: ___ : Fragmentos de uma Teoria da Arte. São Paulo: Editora da Universidade de São Paulo, 2012, pp. 217-262.

JEANNERET. Michel. Perpetuum mobile Métamorphoses des corps et des œuvres de Vinci à Montaigne. $2^{\circ}$ édition revue et complétée d'une postface. Genebra: Droz S.A, 2016.

JOSELIT, David; LAMBERT-BEATTY, Carrie; FOSTER, Hal (org.), October, n.155, inverno de 2016.

KRACAUER, Siegfried. "Aqueles que esperam". In: O ornamento da massa. Tradução de Carlos Eduardo J. Machado e Marlene Holzhausen. São Paulo: Cosac Naify, 2009.

KLEIST, Heinrich von. Sur le théâtre de marionnette. Paris: Editions Millet et une nuits, 1998.

LABAN, Rudolf. Domínio do movimento. São Paulo: Summus, 1978.

LANERYE-DAGEN, Nadeije. L'invention du corps. Paris: Flammarion, 1997. 
LARDEAU, Yann. "Le sexe froid". In: Théories du cinéma. Quétigny: Petite anthologie des Cahiers du cinéma, 2004.

LE GRICE, Malcolm, "Material, Materiality, Materialism [1978]". In: . Experimental

Cinema in the Digital Age. Londres: BFI, 2001.

LEHMANN, Hans-Thies. O teatro pós-dramático. São Paulo: Cosac Naify, 2007.

LEPPERT, Richard. The Nude: The cultural rhetoric of the body in the art of western modernity. Boulder, Colorado: Westview Press, 2007.

LEUTRAT, Jean-Louis: Vie des fantômes: le fantastique au cinéma. Paris: Cahiers du Cinéma, L’Étoile, 1995.

LEVINAS, Emmanuel. Humanisme de l'autre homme. Paris: Fata Morgana, 1972. Totalité et l'infini. Essai sur l'extériorité. Paris : Biblio Essais, 1994.

LOUPPE, Laurence. "Le corps comme poéthique". In: MACEL, Christine; LAVIGNE, Emma (ed.). Danser sa vie : écrits sur la danse. Paris: Centre Pompidou, 2011, p. 211-230.

LYOTARD, Jean-François. Discours, figure. Paris: Klincksieck, 1985.

LUKÁCS, Georg. A teoria do romance. Um ensaio histórico-filosófico sobre as formas da grande épica. São Paulo: Editora 34, 2008.

MACHADO, Arlindo. Pré-cinemas e pós-cinemas. $6^{\mathrm{a}}$ edição. Campinas, SP: Papirus, 2011.

MASOTTA, Cloe. "La plástica del deseo: entrevista a Philippe Grandrieux", Transit, março de 2010. Disponível em: <http://cinentransit.com/entrevista-a-philippe-grandrieux/>. Acesso em: 2 outubro de 2015.

MATOS, Franklin. O filósofo e o comediante: ensaios sobre literatura e filosofia na Ilustração. Belo Horizonte: UFMG, 2001.

MARTIN, Adrian. Last day every day. Nova York: Punctum Books, 2012.

MARTIN, André. "Le mécano de la pantomime”, Cahiers du cinéma, n. 86, agosto, 1958, pp. 18-30.

MARX, Karl. Prefácio. In: . Contribuição à Crítica da Economia Política. Tradução e Introdução de Florestan Fernandes. $2^{\mathrm{a}}$ edição. São Paulo: Editoria Expressão Popular, 2008, p. 45-50.

. Manuscritos Econômicos-Filosóficos. Tradução, apresentação e notas: Jesus Ranieri. São Paulo: Boitempo Editorial, 2004.

MERLEAU-PONTY, Maurice. O olho e o espírito. São Paulo: Cosac Naify, 2004.

. Sens et non-sens. $5^{\mathrm{a}}$ édition. Paris: Les Éditions Nagel, 1966. 
MICHAUD, Philippe-Alain. Sur le film. Paris: Éditions Macula, 2016.

MILNER, Max. L'envers du visible: essai sur l'ombre. Paris: Éditions du seuil, 2005.

MIRANDA, José Bragança de. Corpo e imagem. São Paulo: Annablume, 2011.

MONZANI, Luiz Roberto. Desejo e prazer na idade moderna. $2^{\text {a }}$ ed. Curitiba: Champagnat, 2011.

MORAES, Eliane Robert. O corpo impossível: a decomposição da figura humana de Lautréamont a Bataille. São Paulo: Iluminuras, 2012.

MULVEY, Laura. "Prazer visual e cinema narrativo". In: XAVIER, Ismail (org.). $A$ experiência do cinema: antologia. Rio de Janeiro: Edições Graal; Embrafilme, 1983, p. 437453.

NACHACHE, Jacqueline. $O$ ator de cinema. Lisboa: Texto e grafia, 2012.

NEALE, Steve. "Masculinity as spectacle - Reflections on men and mainstream cinema". Screen, Vol. 24, N. 6, novembro, 1983, pp. 2-17.

NOCHLIN, Linda. Realism. Nova York: Penguin Books, 1984.

. The body in Pieces: metaphor of modernity. Nova York: Thames \& Hudson, 1994.

OLIVEIRA JR, Luiz Carlos. O cinema de fluxo e a mise en scène. Campinas: Papirus, 2013. 2015. . "Retratos em movimento". Anais do XXIV Encontro Anual da Compós, Brasília,

ORTEGA Y GASSET, José. A desumanização da arte. 6ª edição. São Paulo: Cortez, 2008.

OSTERWEIL, Ara. Flesh cinema: the corporeal turn in American avant-garde film: Manchester: Manchester University Press, 2014.

PAINI, Dominique. L'attrait de l'ombre: Brakhage, Dreyer, Godard, Lang, Tourneur. Paris: Yellow now, 2007.

PANOFSKY, Erwin. "L'histoire de la théorie des proportions humaines, conçue comme un miroir de l'histoire des styles". In: L'œuvre d'art et ses significations: essais sur les "arts visuels". Paris: Gallimard, 1969.

. La perspective comme forme symbolique et autres essais. Paris: Minuit, 1975.

PASTOUREAU, Michel. Black: the history of a color. Nova Jérsia: Princeton University Press, 2008. . Bleu: histoire d'une couleur. Paris : Éditions du Seuil, 2000. 
PAVESE, Cesare. Diálogos com Leucó. Tradução de Nilson Moulin. Cosac Naify, 2011.

PAVIS, Patrice. "Le personnage romanesque, théâtral, filmique". In: Iris: Revue de Théorie de l'image et du son : Le personnage au cinéma, n. 24, Outono, 1997, pp. 171-184.

PEARSON, Roberta E. Eloquent gestures: the transformation of performance style in the Griffith Biograph Films. Berkeley: University of California Press, 1992.

POMMIER, Edouard. Théories $d u$ portrait. De la Renaissance aux Lumières. Paris: Gallimard, 1998.

RANCIÈRE, Jacques. “A estética como Política”. In: Devires, v. 7, n.2, 2010, p. 14-36, $\mathrm{jul} / \mathrm{dez}, 2010$.

. "Política de Pedro Costa". In: CABO, Ricardo Matos (org.). Cem mil cigarros - Os filmes de Pedro Costa. Lisboa: Orfeu Negro, 2009. pp. 53-64.

REHM, Jean-Pierre, JOYARD, Olivier, RIVIÈRE, Danièle. Tsai Ming-liang. Paris: Éditions Dis Voir, 1999.

RIEGL, Alois. The Group Portraiture of Holland. Los Angeles: Getty Research Institute for the History of Art and the Humanities, 1999.

RILKE, Rainer Maria. Auguste Rodin. São Paulo: Nova Alexandria, 2003.

RODIN, Auguste. L'Art: entretiens réunis par Paul Gsell. Paris: Bernard Grasse, 1911.

ROMANO, Lúcia. O teatro do corpo manifesto: Teatro físico. São Paulo: Perspectiva, 2013.

RUBENS, Peter Paul. "Teoria da figura humana, considerada em seus princípios, seja em repouso ou em movimento". In: LICHTENSTEIN, Jacqueline. A pintura - Vol.6: A figura humana. São Paulo: Editora 34, 2004, pp. 63-68.

SALZSTEIN, Sônia. "Uma pintura de interiores". In: erotismo, visão decorativa. São Paulo: Cosac Naify, 2009, pp. 150-163.

(org.). Matisse: Imaginação,

SANJINÉS, Jorge. "Un cine de combate junto al pueblo". Entrevista feita por Cristina Alvares Beskow. In: Cinema Comparat/ive Cinema, v. 4, n. 9. 2016, pp. 22-30.

SANTOS, Antonio. Yasujiro Ozu: Elogio del silencio. Madrid: Cátedra, 2005.

SCHAPIRO, Meyer. A arte moderna: Séculos XIX e XX. São Paulo: Editora da Universidade de São Paulo, 2010.

. "Os personagens". In:

$\overline{\operatorname{Cosac}} \&$ Naify, 2002, pp. 139-159.

Impressionismo: reflexões e percepções. São Paulo:

SCHELling, F.W.J. Filosofia da arte. São Paulo: Editora da Universidade de São Paulo, 2010. 
SELIGMANN-SILVA, Márcio. "Apresentação da questão: A literatura do trauma". In: . História, memória, literatura: o testemunho na era das catástrofes. Campinas: Editora Unicamp, 2003, pp. 45-58.

SEIJA-VERGEZ, Sarah (org.). La peau: un continent à explorer. Paris: Éditions Autrement, 2005.

SIETY, Emmanuel. Ficctions d'images: essai sur l'attribution de propriétés fictives aux images de films. Rennes: Presses universitaires de Rennes, 2009.

SILBERSTEIN, Marc. "L' 'unité plurielle' du matérialisme". In: __. Matériaux philosophiques et scientifiques pour un matérialisme contemporain. Paris: Éditions Matériologiques, 2013.

SINGER, Ben. "Modernidade, hiperestímulo e o início do sensacionalismo popular". In: CHARNEY, Leo; SCHWARTZ, Vanessa. O cinema e a invenção da vida moderna. São Paulo: Cosac Naify, 2004, pp. 95-123.

SOHN, Anne-Marie. "O corpo sexuado". In: Alain; COURTINE, Jean-Jacques; VIGARELLO, Georges. Petrópolis (org.). História do corpo: 3. As mutações do olhar. O século XX. RJ: Vozes, 2011.

SONTAG, Susan. “A imaginação pornográfica”. In: Companhia das Letras, 1987. . A vontade radical. São Paulo:

SOULIER, Noé. Actions, Mouvements, Gestes. Pantin: Centre national de la danse, 2016.

SOURIAU, Paul. L'esthétique du mouvement. Paris: Elibron Classics, 2006.

SPINOZA, Benedictus de. Ética. 2a edição. Belo Horizonte: Autêntica Editora, 2013.

STEINBERG, Leo. Outros critérios. São Paulo: Cosac Naify, 2008.

STOICHITA, Victor I. Breve história da sombra. Lisboa: KKYM, 2016.

. Caillebotte et l'intrigue visuelle. In: Degrés, no 69-70, 1992, pp. 1-11.

. Figures de la transgression. Genebra: Droz, 2013.

SUQUET, Annie. "O corpo dançante: um laboratório da percepção". In: Alain; COURTINE, Jean-Jacques; VIGARELLO, Georges. Petrópolis (org.). História do corpo: 3. As mutações do olhar. O século XX. RJ: Vozes, 2011.

SZONDI, Peter. Teoria do drama moderno (1880-1950). Tradução de Raquel Imanishi Rodrigues. São Paulo: Cosac Naify, 2011.

TODOROV, Tzvetan. Éloge du quotidien: essai sur la peinture hollandaise du XVII siècle. Paris: Société nouvelle Adam Biro, 1993.

VALÉRY, Paul. Degas, dança, desenho. São Paulo: Cosac Naify, 2003. 
"Introdução ao método de Leonardo da Vinci". In: BARBOSA, João Alexandre (org.). Variedades/Paul Valéry. São Paulo: Iluminuras, 2011, pp. 141-171.

VANCHERI, Luc. "Le nu, le cru et le monstrueux: les trois manières du corps pornographique". In: Admiranda. n.4, 1998, p. 31.

Les pensées figurales de l'image. Paris: Armand Colin, 2011.

VAN GOGH, Théodore. Cartas a Théo. São Paulo: L\&PM, 1986.

VASARI, Giorgio. The lives of the artists. Nova York: Oxford University Press, 1991.

VERNET, Marc. Figures de l'absence: De l'invisible au cinéma. Paris : L'Étoile, 1988.

VLIEGHE, Hans. Arte e arquitetura flamenga 1585-1700. São Paulo: Cosac Naify, 2001.

WOLFF, Francis. Nossa humanidade: de Aristóteles às neurociências. Tradução de Roberto Leal Ferreira. São Paulo: Editora Unesp, 2012.

WÖLFFLIN, Heinrich. Conceitos fundamentais da história da arte: o problema da evolução dos estilos na arte mais recente. $4^{\mathrm{a}}$ ed. São Paulo: Martins Fontes, 2000.

WOLLEN, Peter. “'Ontology' and 'Materialism' in Film”, in Screen, vol. 17, n. 1, março de 1976, pp. 7-25.

XAVIER, Ismail. Sétima Arte: Um culto moderno. São Paulo: Perspectiva, 1978. 